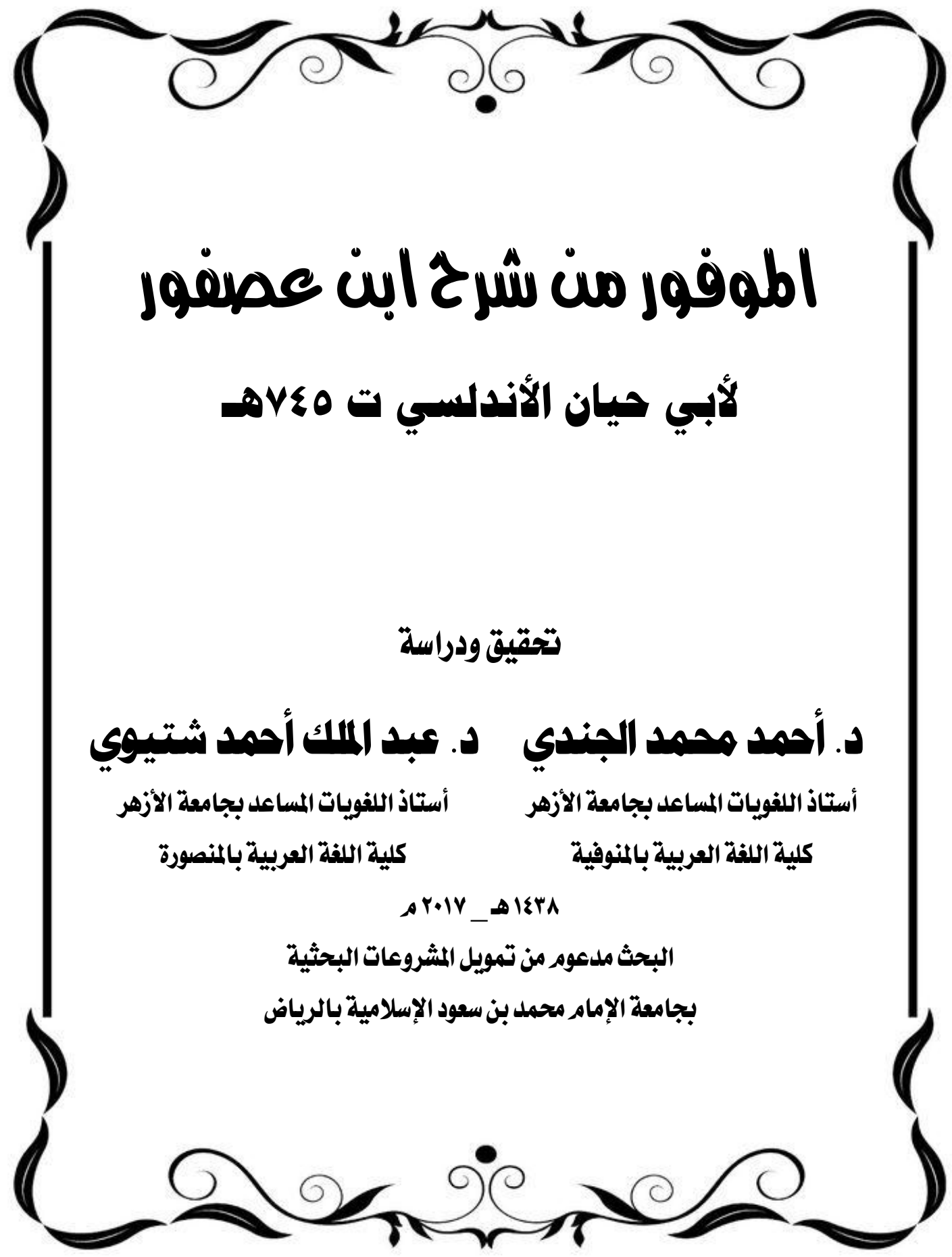




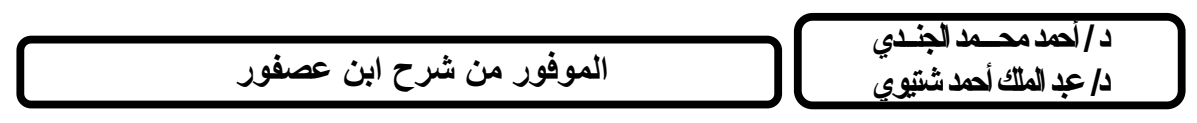

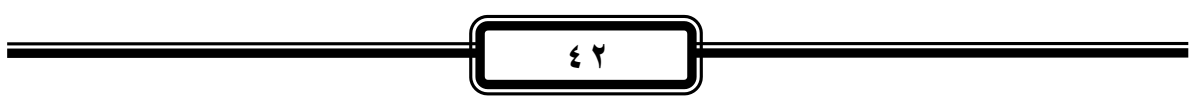




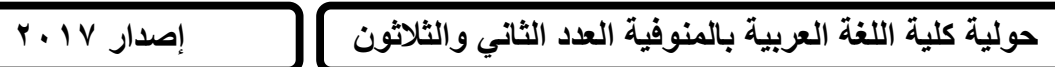

Ч๋

@iตn
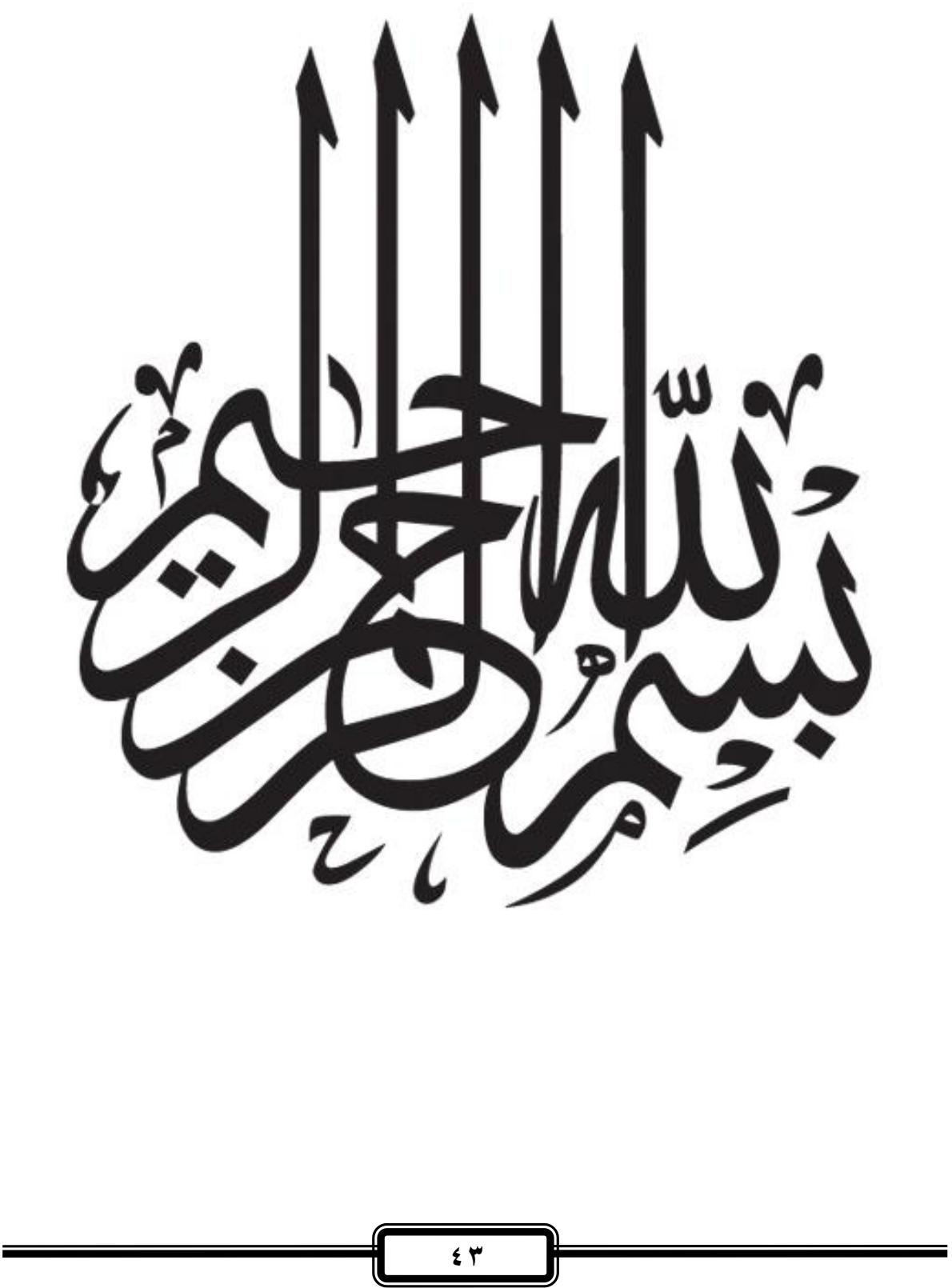


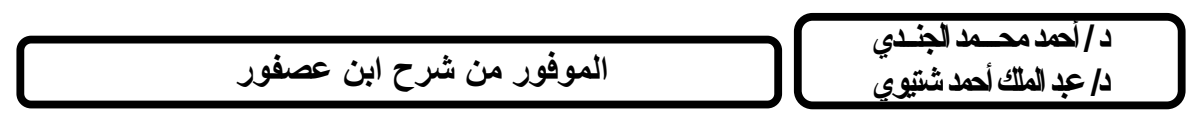

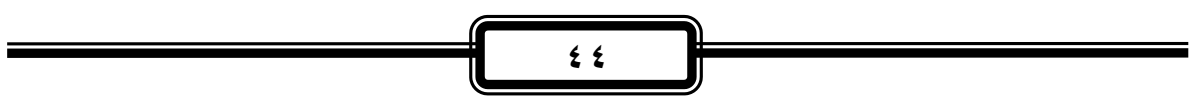




\section{المقدهة}

الحمد لله رَبِّ العالمين ، والصلاة والسلام على خاتم النبيين، وعلى آله

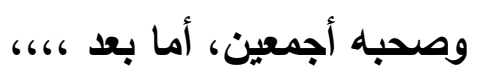

فإن أبا إسحاق الزجاجيَّ يُعدُّ أحد الأئمة الذين أسسوا المدرسة البغدادية في التحو العربي، وقد حظي كتابه (الجُمَل) بشهرة كبيرة لاى التحويين المشارقة والمغاربة، فشرحوه، وعلقوا عليه، حتى قيل: إن شروحه بلغت

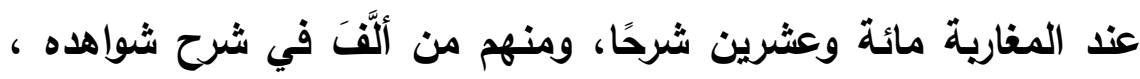
ومنهم من تعقبه.

وقد اهتم ابن عصفور بكتاب (الجمل)، فشرحه شروحًا متعددة، منها شرحه المُسمى (شرح الجمل الكبير )، وقد اختصر أبو حيان هذا الشرح، وبسى هذا المختصر (الموفور من شرح ابن عصفور). ويتناول هذا البحث تحقيق هذا الكتاب ودراسته على نسخة خطية مودعة في دار الكتب المصرية، وهي بخط أبي حيان نفسه، وتقع في إحدى وستين لوحة.

ومن هنا تبدو أهمية تحقيق هذا المخطوط الفريد؛ لأنه لعالم مُبرٍِِّ، هو أبو حيان، ولأنه اختصار لكتاب لعالم مُبَرٍِّ آخَرَ، هو ابن عصفور، فكان هذا وذاك من أهم الأسباب التي دفعتنا إلى تحقيق هذا المخطوط، ولكن أكبر الصعاب التي واجهتنا في تحقيقه تمثلث في وجود نسخة وحيدة له، تعرضت في عدة مواضع للرطوية أو الطمس، وهي قليلة جدَّا، وقد بذلنا جهنا لإخراج هذا الأثر النفيس على الصورة التي أرادها مؤلف الكتاب أبو حيان -رحمه الله-. 
ويعد البحث تبين لنا عدم تحقيق هذا المخطوط من قبل، كما أن أحدًا لم يتناول هذا المخطوط على أي وجه من الوجوه في دراسات سابقة. وقد قسَّمنا كتاب "الموفور" فيما بينتا نصفين، فحقق الباحث الأول الاكتور/ أحمد محمد الجندي نصفه من أول الكتاب إلى نهاية باب

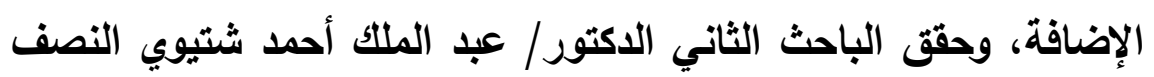
الثاني من أول باب التوابع إلى نهاية الكتاب، وأما الدراسة والفهارس فهي مشتركة بينتا. هذا وقد جاء تحقيق الكتاب في مقدمة، وتمهيد، وقسمين، وفهارس فنية: - التمهيد وفيه ثلاثة مباحث: - المبحث الأول: ابن عصفور حياته، وآثاره. - المبحث الثاني : الجمل وشروحه. - المبحث الثالث : أبو حيان حياته ، وآثاره. - القسم الأول: ( دراسة المخطوط ) وفيه ثلاثة مباحث: - المبحث الأول : شرح الجمل الكبير لابن عصفور. - المبحث الثاني: منهج أبي حيان في الموفور: (الغرض من تأليف الكتاب، منهجه في تقسيم الكتاب، مصادره، من تأثروا به أو نقلوا عنه، موققه من ابن عصفور، والنحويين قبله). - المبحث الثالث: أصول النحو عند أبي حيان من خلال (الموفور). - أولاً: استدلاله بالسماع. - ثانياً: استدلاله بالقياس. - ثالثاً: استدلاله بييان العلة.

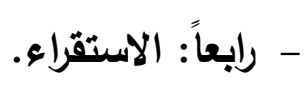

- القسم الثاني: التحقيق، وإثتمل على ما يأتي: 


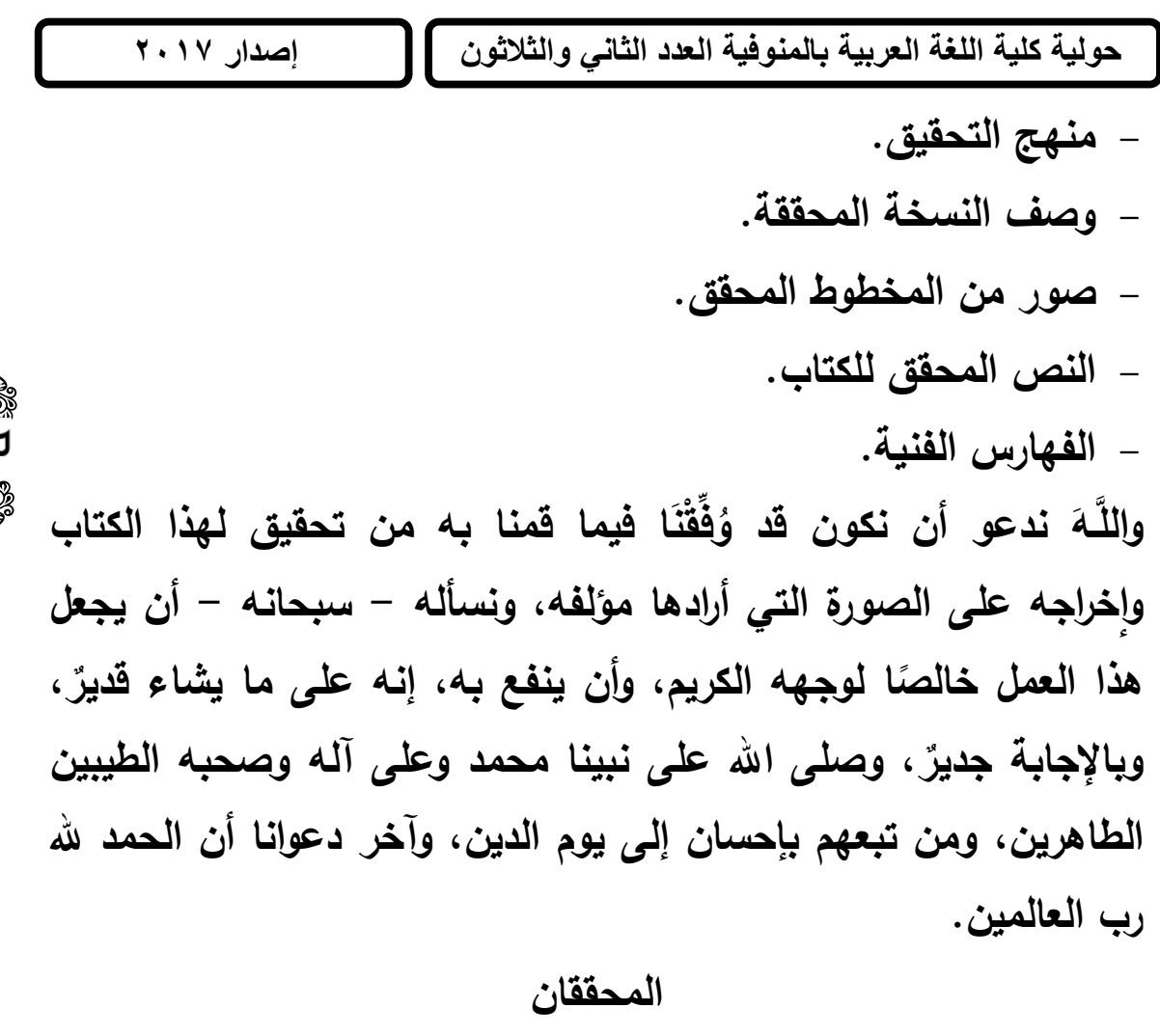




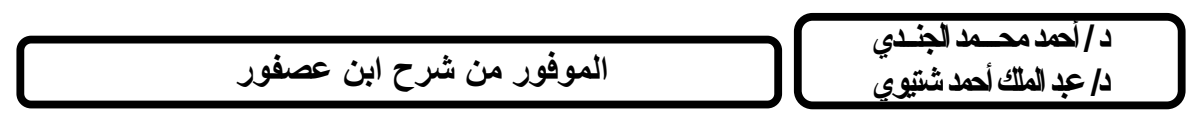

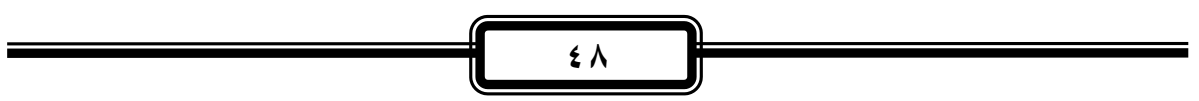


المبــث الأول : ابـن عصفور هياته، وآثاره . المبـشث الثاني : الجمل وشروهـ. المبـشث الثنالث : أبو صيان هياته، وآثناره. 


\section{الموفور من شرح ابن عصفور}

\section{المبحث الأول}

\section{ابـن عصفور صياته، وآثاره (1)}

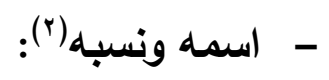

هو أبو الحسن علي بن مؤمن بن محمد بن علي بن أحمد بن محمد بن

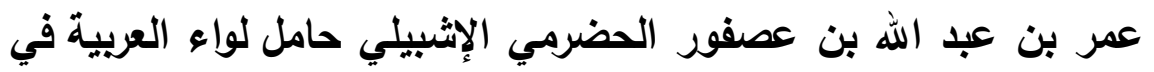
زمانه بالأندلس.

وقيل(ّ): علي بن أبي الحسين بن مؤمن بن محمد بن علي بن أحمد بن محمد بن أحمد بن عمر بن عبد الله بن منظور بن عصفور الحضرمي.

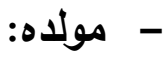
ولد ابن عصفور في إثبيلية سنة وهـ خهلال عصر دولة الموحدين

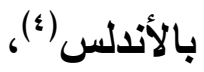

(1) انظر: الوافي بالوفيات للصفدي r/ 10/1 1، وتاريخ الإسلام للذهبي

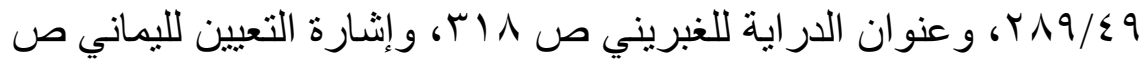

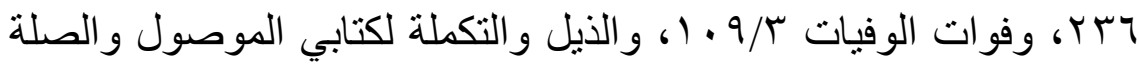

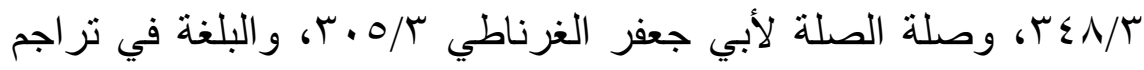

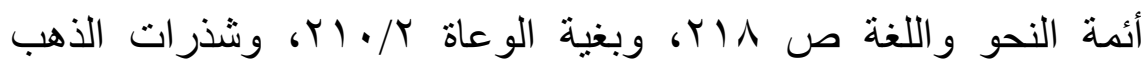

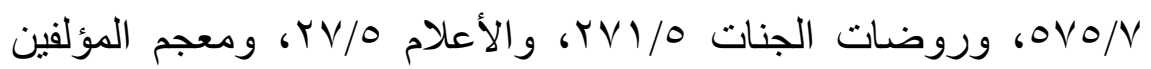
$. r 01 / V$

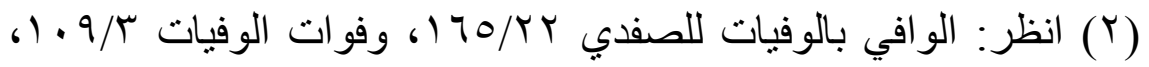

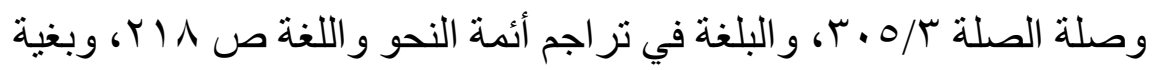

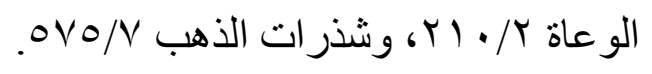

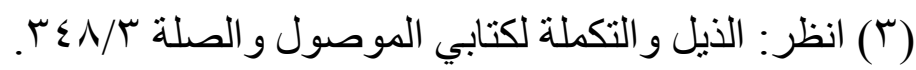

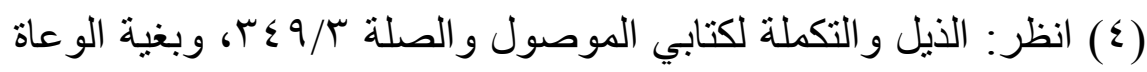
. $1 \cdot / r$ 
وَصَفَهُ مَنْ ترجموا له بأنه حامل لواء العربية في الأندلس في زمانه، وأنه

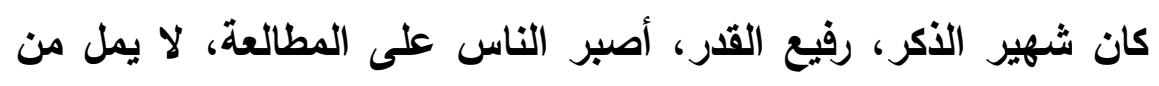

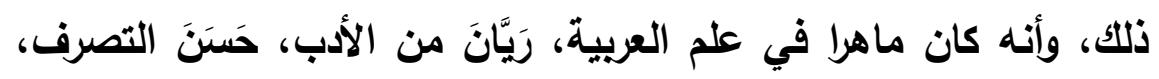
من أبرع من تخرج على أبي علي الشلويين، وأحسنهم تصنيفًا في علوم اللسان.

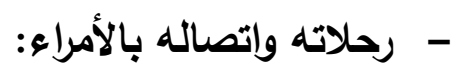
طاف المغرب كله، وأقام بتونس شاغلا للطلبة، وكان يملي من صدره، وكان له اختصاص بالأمير أبي عبد الله بن زكريا بن أبي حفص، وكان يخدم الأمير أبا عبد الله محمد بن أبي بكر الهنتاني (َّ).

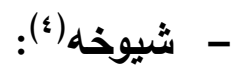
أخذ العربية والأدب عن خلق كثير، ولكن المصادر لم تذكر منهم إلا

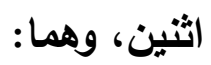

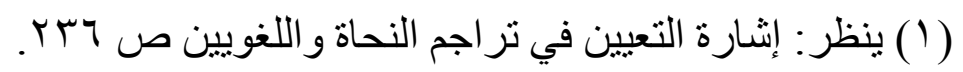

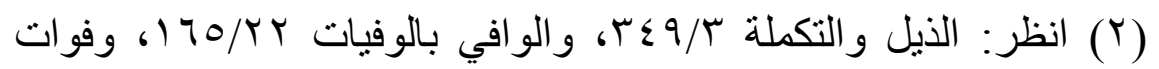

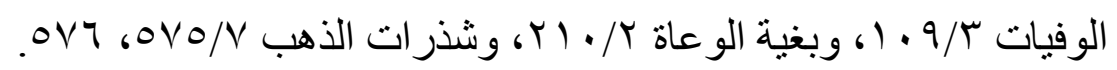

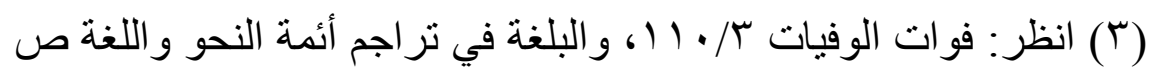
. 19

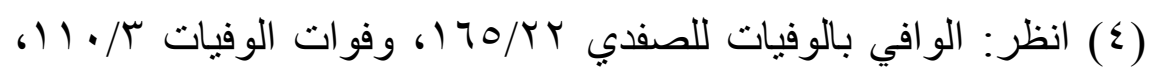

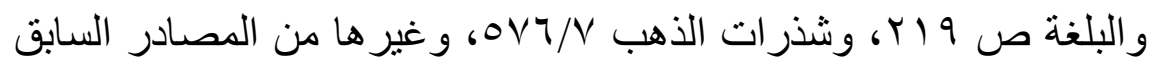
ذكر ها في أول الترجمة. 
ا. أبو علي الثلويين عمر بن محمد بن عمر بن عبد الله الأزدي (ت أبل ه \ آه)، واختص به كثيرا، لازمه عشر سنين إلى أن ختم عليه كتاب سيبويه في نحو السبعين طالبا، وكان من أبرع من تخرج على الثلوبين، وكان أحنهم تصنيفا في علوم اللسان، ثم كانت بينهما منافرة ومقاطعة. r. أبو الحسن الدََّّاجُ علي بن جابر بن علي بن يحيى اللخمي المقرئ

$$
\begin{aligned}
& \text { (ت } \\
& \text { - تلاميذه(1) }
\end{aligned}
$$

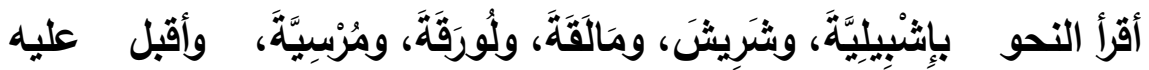
الطلبة، وعلا ذكره، وصار له مجلسُ عِلْم يختلف إليه الطلاب والعلماء يأخذون عنه، ويفيدون منه، فقد روى عنه الحسن بن عبد الرحمن بن

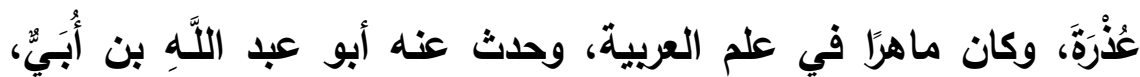

وأبو محمد مولى سعيد بن حكم (؟).

$$
\text { ومن تلاميذه-أيضًا- }
$$

- أبو الحسن علي بن موسى بن سعيد العنسي (ז).

- الثلويين الصغير أبو عبد الله محمد بن علي بن محمد الأنصاري المالقي (•).

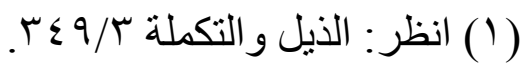

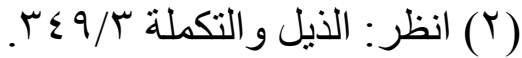

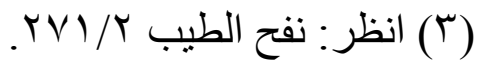

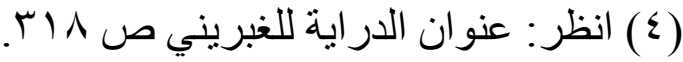

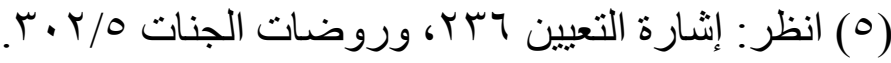




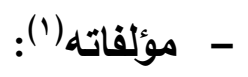

لابن عصفور كتب في مختلف الأجناس الأدبية وكل ما يتعلق باللغة، فهو لم يقتصر على مجال واحد، فتراه يكتب في التحو والصرف ويشرح دواوين شعرية، كديوان المتنبي، وشرح الأثعار الستة الجاهلية. كما تدل تآليفه النحوية على أن له مشاركة في علم المنطق، ولأجل ذلك حسن إيراده فيها تقسيما وحدودا، باستعمال حجة ثابتة ودامغة، فيليق كلامه مقدما على كلام غيره من المعبرين من النحاة، وقال الغبريني في

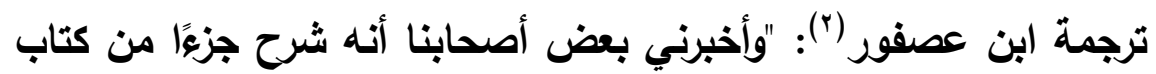
الله العزيز، وسلك فيه مسلكا لم يسبق إليه من الإيراد والإصدار والإعذار بما يتعلق باللفاظ ثم بالمعاني، ثم بإيراد الأمثلة الأدبية على أنحاء مستحسنة، وقال: لو أعانتي الوقت، وأمدني الله بالمعونة منه، وأكمل هذا الشرح على هذا المنزع لكان ذخيرة العالم، وهو اولى الناس بشرح كتاب

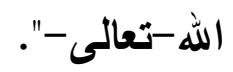
وهذه بعض مؤلفاته مرتبة ألفبائيًا: - - سرقات الشعراء، ولم يكمله. - شرح أبيات الإيضاح.

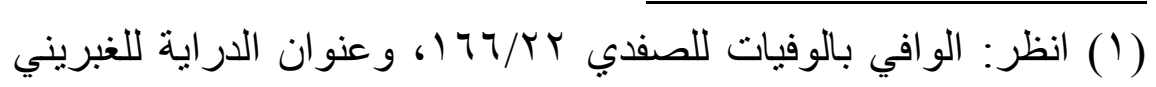

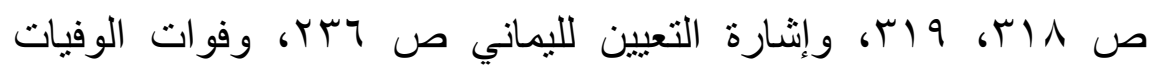

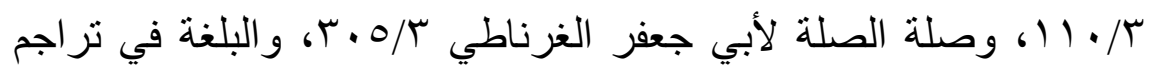

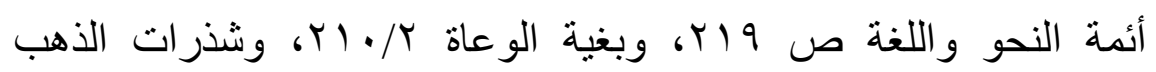
TV/V

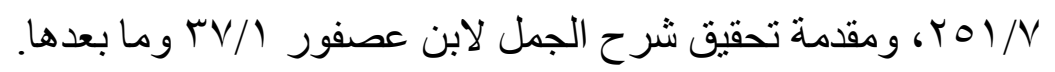

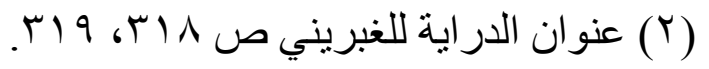




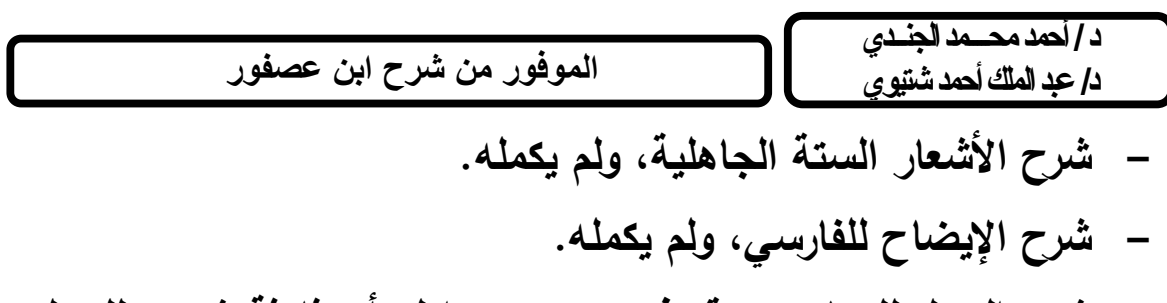

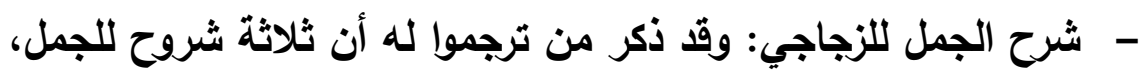
والذي وصل إلينا شرحان فقط، وهما محققان ومنشوران. - شرح ديوان المتنبي، ولم يكمله. - مرح كتاب سييويه. - - شرح المقدمة الجزولية، ولم يكمله. - ضرائر الشعر، وهو محقق ومنشور. - مختصر الغرة.

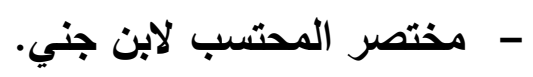
- المقرب في النحو، وهو محقق ومنشور، وله لهن عليه شرحان. - المتع في التصريف، وهو محقق ومنشور. - أقوال العلماء فيه: ذكر بعض المؤرخين أن ابن عصفور لم يبرع في غير علوم العربية، فقد

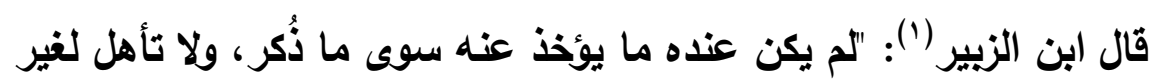
ذذلك". ولكن نص الغبريني السابق عن أنه شرح جزيًا من كتاب الله العزيز ، وما

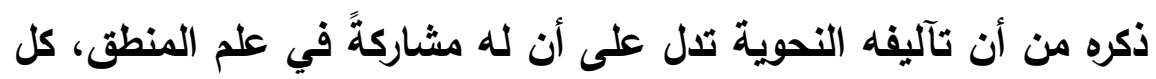
هذا ياحض هذا الزعم.

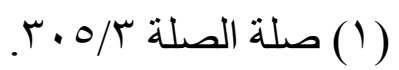


وقال عنه المراكشي('): "وكان ماهرًا في علم العريية، ريان من الأدب، حسن التصرف، من أبرع من تخرج على أبي علي بن الثلويين وأحسنِهم تصنيفًا في علوم اللسان". وقال عنه الاهبي(؟): "وكان إماما بالنحو لا يُشَثَُّ غُباره، ولا يُجارى"،

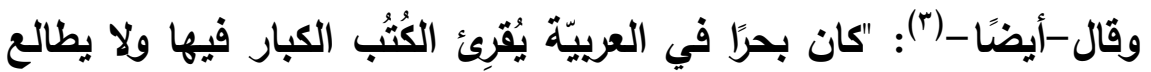
عليها، وكان في خدمة أمير، أقرأ بعدّة مدائن". ولكنه قال -أيضًا -(؛): "ولا تَعَلُّقَ له بعلم القراءات ولا بالققه ولا رواية

$$
\text { - الحديث". }
$$

تضاريت الروايات في تحديد السنة التي توفي فيها، واختلف الرواة في تحديلها، حتى وصلت إلى خمس روايات: 1-قيل: سنة وه 7ه، ققد قال المراكثي(ْ): "وتوفي بدار سكناه من قصبة تونس، بعد ظهر يوم السبت، لست بقين من ذي قعدةٍ تسعِ وخمسين وستمائة، ودفن عقب العصر من يوم وفاته". ץ-قيل(؟): في عثر السبعين، دون تحديد السنة.

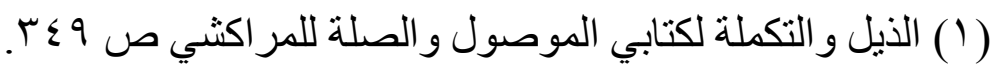

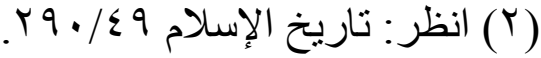

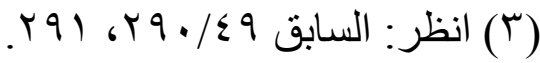

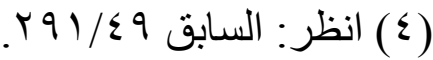

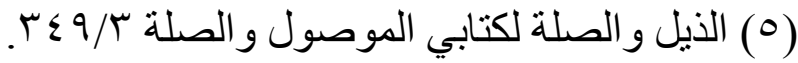

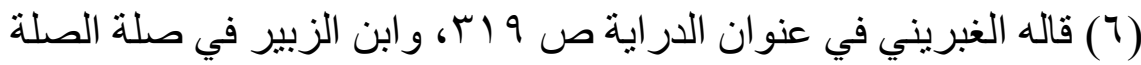
. $0 / \mu$ 


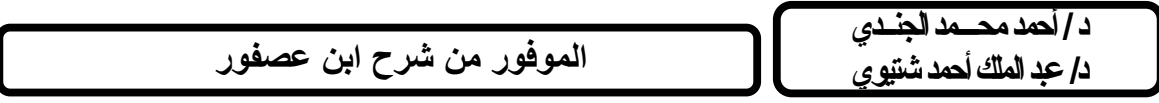

r-قيل: في الرابع والعشرين من ذي القعدة سنة بآ آهـ، قاله

الصفدي)(')

ـ-نقل الزركلي عن وفيات ابن قنف أن ابن عصفور توفي سنة

V V 74

ه- أغلب المصادر تذكر أنه توفي سنة 977 هـ 7 هـ").

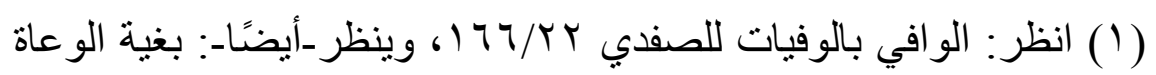

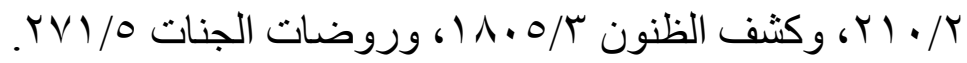

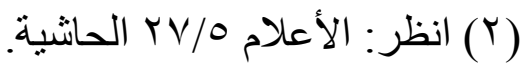

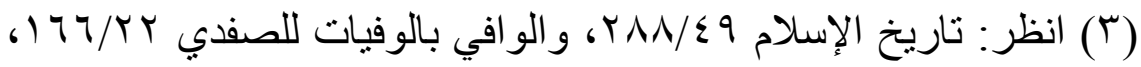
و إثشارة التعبين ص TrV

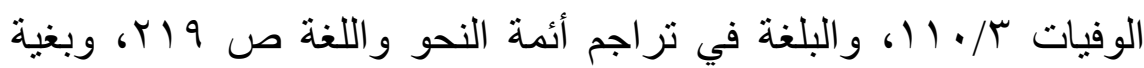

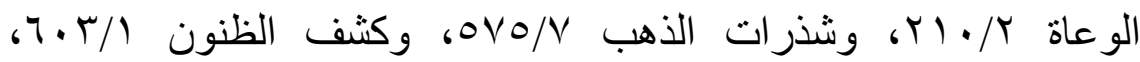

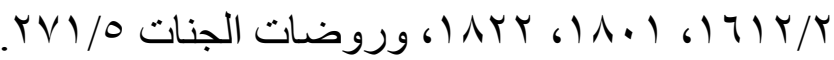




$$
\text { r. IV Rدار }
$$

حولية كلية اللغة العربية بالمنوفية العدد الثاني والثلاثون

\section{المبــث الثنانـي}

\section{الجمل ونشروصه}

كتاب الجمل طارت شهرته في الآفاق، وتعددت طبعاته ، وكثرت شروحه، صنَّهه أبو القاسم الزجاجي بمكة(')، ويعد كتاب الجمل من كتب النحو الجامعة مع يسر وسهولة في منهجه، وقدر جيد من الشواهد ، والأمثلة التوضيحية، وهو على رأس مؤلفات الزجاجي النحوية، ومن أهميته أنه كان كتابًا اشتخل به أهل مصر والمغرب والحجاز واليمن والثام، فهو كتاب إنهاب عظم النفع به؛ لوضوح عبارته، وكثرة أمثلته(؟). والحق أنه كاتت لهذا الكتاب قيمة علمية كبيرة في عصره حتى انشغل به به وهنه الناس، وجعلوا حِفْظَهُ هَمَّهُمْ، وطار في الآقاق كل مطار، وقيمة الكتاب هذه هي التي تفسر لنا ازدحامهم على الكتابة عنه، وإن كان كتاب سيبويه وأمثاله يصلح للثيوخ المتعمقين في العلم، الواقفين على دقائقه وأسراره، فإن كتاب الزجاجي نافع للمبتدئين في النحو، والمتطلعين إلى تعلمه، وذلك لأن طريقته متوسطة، وتصانيفه يقصد بها الإقادة(؟).

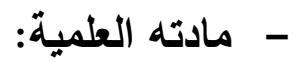

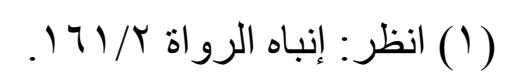

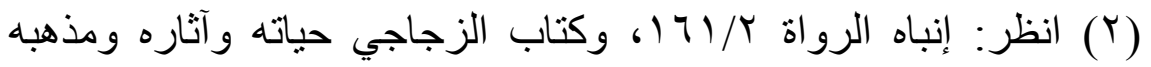

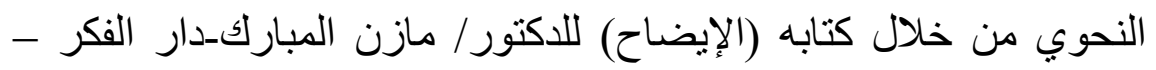

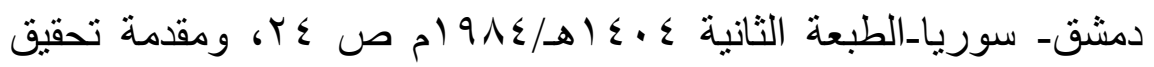
الجمل.

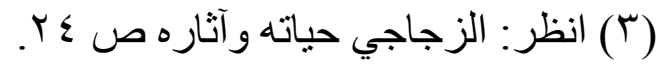


1 - هو كتاب لغة بما تضمنه من نقول عن قبائل العرب، وعلماء اللغة، فقد نقل عن ست لهجات عربية، وهي: "أزد السراة(')، وأسد(؟)، وينو

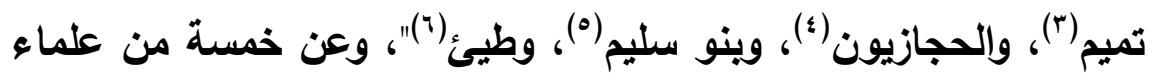

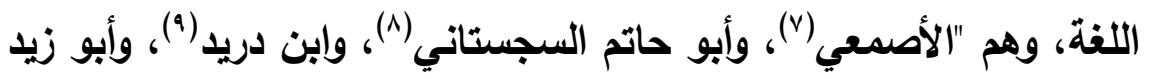

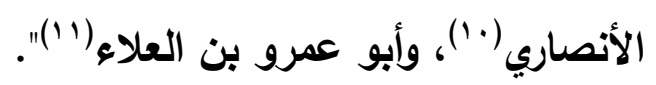
كما تضمن الكتاب أبوابًا وثيقة الصلة بعلم اللغة والأصوات ك"باب ألف بلف الوصل وألف القطع، والهجاء وأحكام الهمزة، والمقصور والممدود، والإدغام، والحروف المهموزة والمجهورة". r-وهو كتاب نحو وصرف من أهم المختصرات بما احتواه من نقول عن نحويين هم أئمة الفن، وأبواب ومسائل خلافية، وشواهد متنوعة، فقد نقل

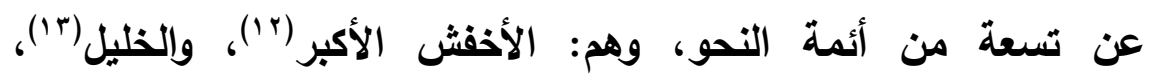

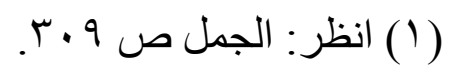

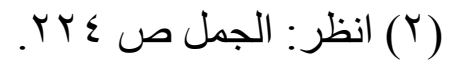

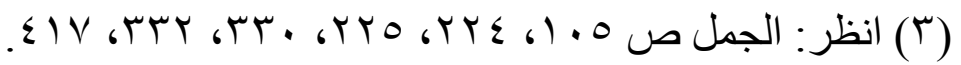

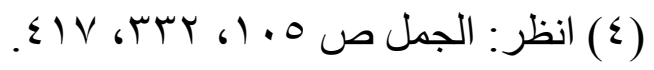

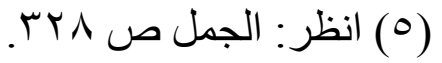

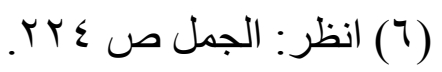

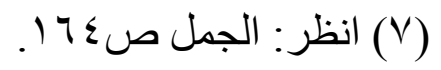

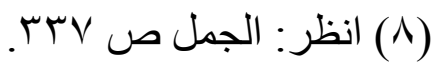

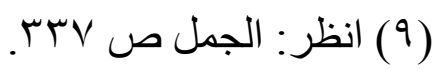

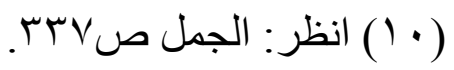

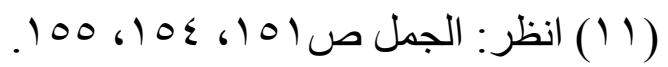

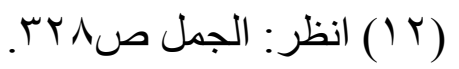

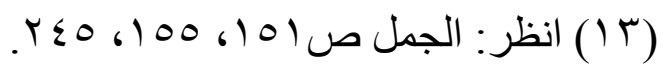




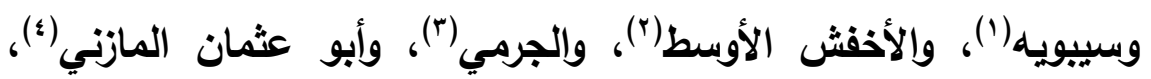

$$
\text { والقراء(")، والكسائي ("). }
$$

r-ضم الكتاب خمسةً وأربعين ومائةَ بابٍ، هي أبواب نحو وتصريف

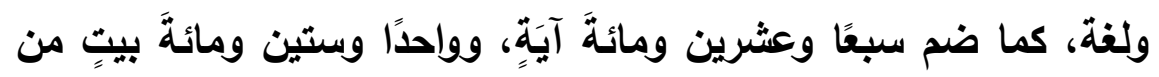
الثُعر والرجز، وعشرة من الأقوال والأمثال العربية، أما الحديث النبوي الثريف فلم يكثر أبو القاسم الزجاجي-رحمه الله-في الاستشهاد به، فلم

$$
\begin{aligned}
& \text { يرد في جمله إلا حديثان. }
\end{aligned}
$$

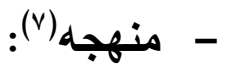

لمنهج أبي القاسم-رحمه الله-في جمله خصائص عدة يمكن إيجازها فيما

1-أن الزجاجي لم يقدم بمقدمة لجمله، متبعا في ذلك نهج أسلافه كسيبويه في الكتاب، والمبرد في المقتضب، فقد بدأوا كتبهم بعرض أبوابها

$$
\begin{aligned}
& \text { (1) انظر: الجمل ص VYr، 00، سYV، و غيرها. }
\end{aligned}
$$

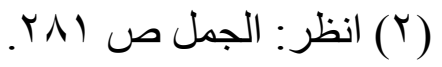

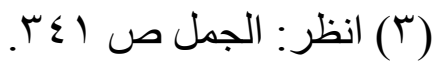

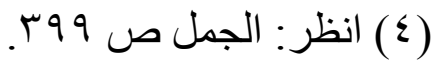

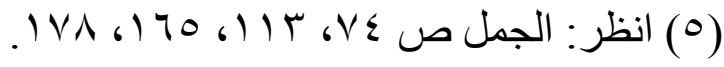

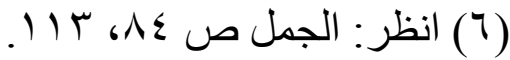

أكثر ما أوردناه هنا اعتمدنا فيه على مقدمة تحقيق كتاب الجمل للاكتور (V)

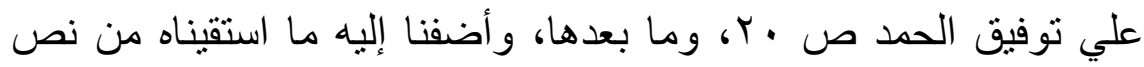
الجمل مباثرة. 
مباشرة دون مقدمة، فقد بدأ الزجاجي كتابه مباشرة بتقسيم الكلام إلى اسم

وفعل وحرف جاء لمعنى (').

r-أن الكتاب جاء موجزًا بالنسبة للمعلومات التي تناولها، وقد جاء بلغة عربية فصيحة واضحة حتى إن القارئ لا يرى فيه من الكلمات التي لا يقوى على فهمها إلا ما نلدر.

r-أن الزجاجي قسم كتابه إلى مجموعة من الأبواب النحوية التي تعالج قضية العامل، ثم عرض مجموعة من الأبواب الصرفية، ثم مجموعة أبواب

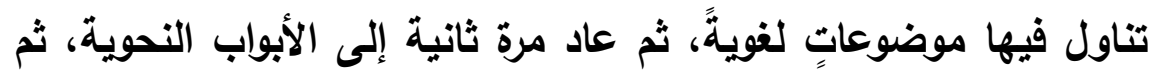
عاد ثانية إلى الأبواب الصرفية، ثم عرج على بعض الأبواب اللغوية التي تلور حول الإدغام، والحروف المهموسة والمجهورة، وما إلى ذلك. فقد سار في ترتيب كتابه على أساس تناول مجاميع أو طوائف نحوية وصرفية وصوتية، وخلط بين المجاميع النحوية والصرفية، وأخر الموضوعات الصوتية، وجمعها في آخر الكتاب، لكنه كان ياخل بين الموضوعات اللغوية المختلفة "الأصوات والصرف والنحو"؛ لتوضيح موضوعه الرئيس الأي يكون بصدد عرضه، وليس بين أيدينا من كتب

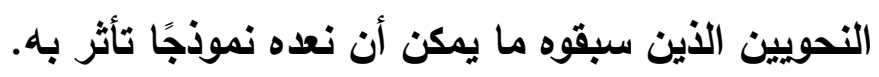

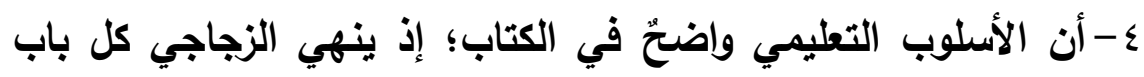
تقريبًا بما يفيد ذلك، كقوله: "فافهم تُصِبْ إن شاء الله"(†)، وقوله: "فقس

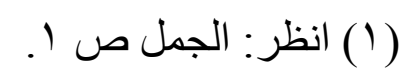

(Y) انظر: الجمل ص 7 في آخر باب معرفة علامات الإعراب، ص 1 في آخر باب الأفعال، ص آنط 11 آفي آخر باب النعت، وغير ها. 


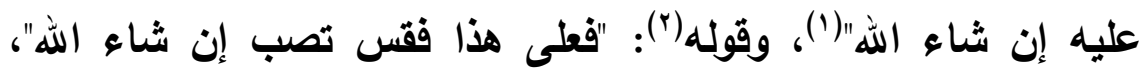
وغيرها من العبارات.

0-من مظاهر الأسلوب التعليمي في الجمل-أيضًا-: كثرة الأمثلة المصنوعة، فقد كان يكثر منها بقصد التعليم، ويقصد الاختصار للشرح، ومن ذلك أنه في باب العطف أورد واحدًا وعشرين مثالًا(ّ)، رغم أنه جاء في ثلاثِ صفحات ونَيَّفٍ، كما أنه في باب الحروف التي تتصب الأفعال المستقبلة أورد سبعة عشر مثالًا، بخلاف الثواهد من القرآن والثعر، رغم

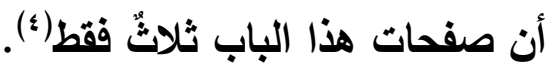
צ-أنه أورد آراءً لنحويين مشهورين من أعلام المدرستين: البصرية والكوفية، وأسندها إلى أصحابها، وكان يناقثها، فيوافث بعضها، ويخالف بعضها الآخر. V- أنه سلك منهج غيره من المصنفين في الاستشهاد، فقد يستشهد من القرآن بالآية، أو بعضها حسب ما يقتضيه الثاهد، ومن الآيات المستشهر بها خمسُ وعشرون قراءةً، ما بين منسوب وغير منسوب، ومتواتر وشاذًّ، وموجَّهِ وغيرِ موجَّهٍ، ويستشهُ من الشعر بالبيت، والثطر منه، وتَسَبَ كثيرًا من الأبيات المستثهـد بها إلى أصحابها، فعدد الأبيات

(1) انظر: الجمل ص (1) (1) في آخر باب الفاعل و المفعول به.

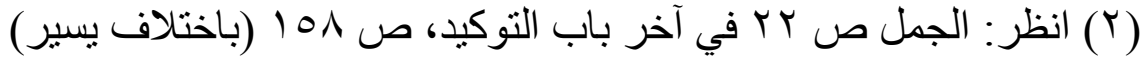

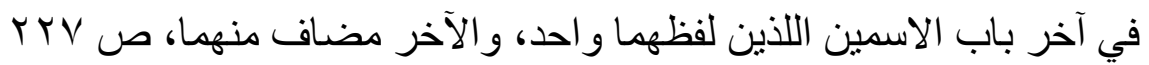
في آخر باب أسماء القبائل و الأحياء و السور و البلدان.

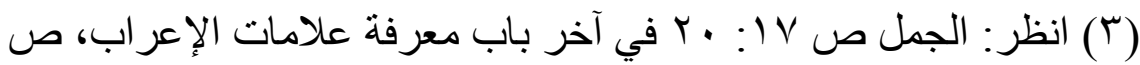

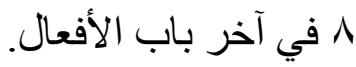

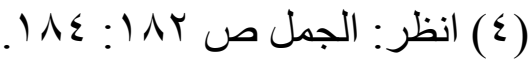


المستشهر بها واحد وستون ومائة بيت، نسب منها ثلاثةً وسبعين بيتًا، وأما الأقوال والأمثال فقد اشتمل الكتاب على ثثلاثة من أقوال العرب، وسبعة من أمثالهم، نَبَّة على شذوذ واحد منها، وهو قولهم: "عليه رجلًا

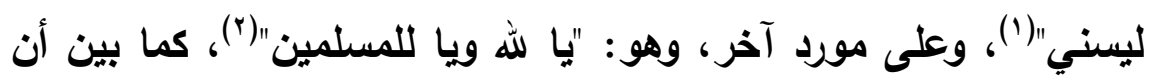
الأمثال يمكن أن تجري على الأصل، وذلك فيما جاء في المثل: "هالك في الهوا لك" (").

وأما الحديث فلم يرد في الكتاب إلا حديثان: أحدهما: لإثبات قاعدة نحوية، وهي أمر المخاطب باللام، وهو قوله-استشهد به على معنى لغوي، حيث قال(0): "ومعنى الإعراب هو البيان، يقال: أعرب الرجل: إذا أبان عن حاجته، ومنه الحديث: (البكر تستأمر، والثيب تعرب عن نفسها)".

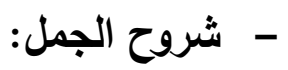
تنوعت شروح الجمل في الطريقة، والمادة، والحجم فمنها ما زاد على مجلاين، أو ثثلاثة، ومنها ما كان شرحاً قصيراً، ومنها ما كان تعليقات، وتعقيبات على الكتاب، وإصلاح ما وقع فيه من الخلل، ومنها ما كان

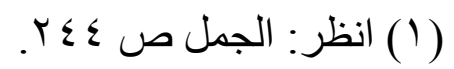

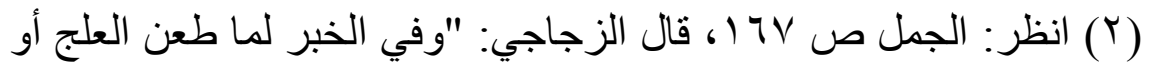
العبد عمر بن الخطاب-رحمه الله، ورضي عنه-صاح: يا لله للمسلمين، مستغيثنا بهما".

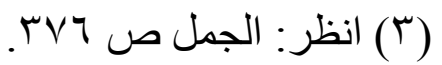

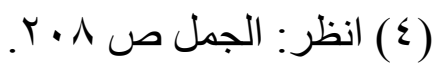

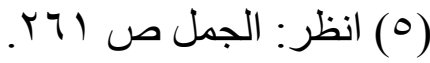




\section{r. IV إصدار}

حولية كلية اللغة العربية بالمنوفية العدد الثاني والثلاثون

شرحًا لشواهده الشعرية، وقا ذكر من ترجم لأبي القاسم الزجاجي أن لجمله شروحًا تصل إلى مائة وعشرين شرحًا.

وق ذكر الاكتور علي توفيق الحمد(') في مقدمة تحقيقه لكتاب الجمل واحدًا وأربعين شرحًا له، وثماتية عشر شرحًا لشواهده، كما ذكر الدكتور عياد الثبيتي(r) منها تسعة وسبعين شرحًا إجمالًا. فمن هذه الثروح:

ا ـ شرح الجمل لابن العريف: وهو أبو القاسم الحسين بن الوليد بن نصر

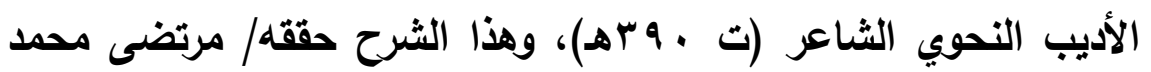
تقي الأيرواني في رسالة دكتوراه بكلية دار العلوم جامعة القاهرة سنة

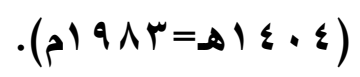

r. شرح الجمل لأبي العلاء المعري أحمد بن عبد الله بن سليمان (ت أن

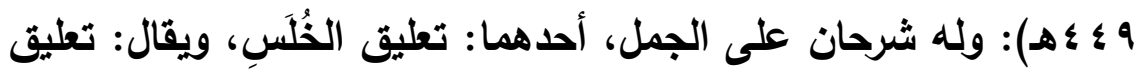

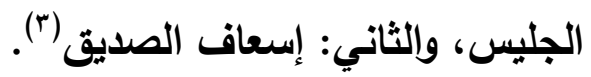
r. شرح الجمل لابن بابشاذ: وهو أبو الحسن طاهر بن أحمد بن داود بن سليمان بن إبراهيم المصري الجوهري (ت 9 ج \هـ)، وله على الجمل ثلاثة شروح(؛) أحدها: صغير، وقد حققه مصطقى إمام في رسالة دكتوراه بكلية

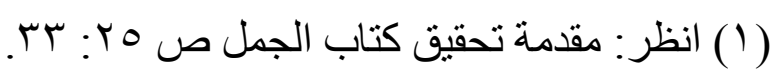

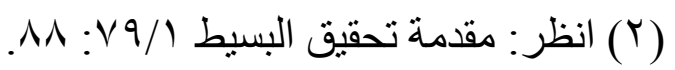

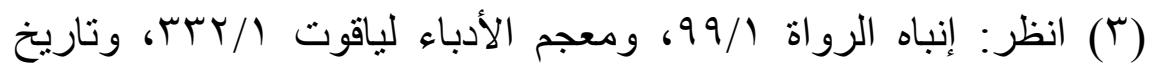

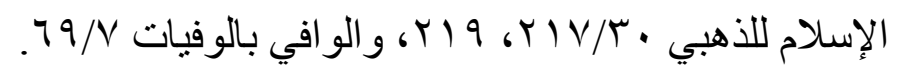

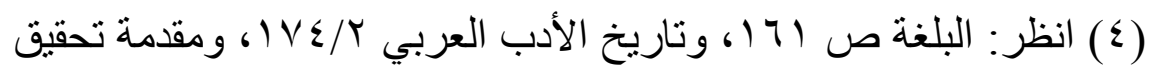

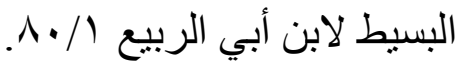




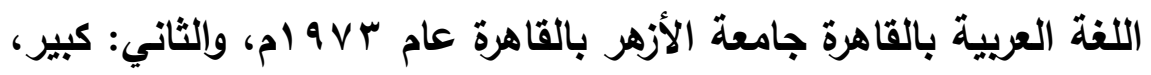
والثالث: فيه إكمال ما بين الثرحين، وهذا الشرحان مفقودان. ـ. إصلاح الخلل الواقع في الجمل لابن السيد البطليوسي (ت ابץهـ): حققه الدكتور/ حمزة النشرتي، ونشرته دار المريخ بالرياض سنة .p) $9 \vee 9$

هـ شرح الجمل لابن خروف: وهو أبو الحسن علي بن محمد بن علي بن محمد الحضرمي الأندلسي الإثبيلي (ت 9 . 7هـ): حققته الاكتورة/ سلوى محمد عمر عرب، طبع في جامعة أم القرى عام ^ أـ الهـ في مجلدين، من أول الكتاب إلى نهاية باب "المخاطبة"، وحققتُ بقيته في جزأين بمركز

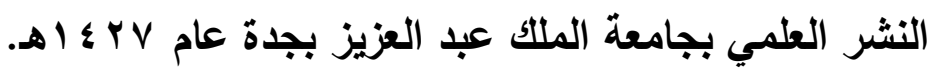
צ. شرح الجمل لابن بزيزة: وهو أبو محمد عبد العزيز بن إبراهيم بن أحمد القرشي التميمي التونسي (ت ب r 7هـ)، واسم كتابه "غاية الأمل في شرح الجمل"، وقد حققه محمد غالب عبد الرحمن في رسالة دكتوراه بكلية

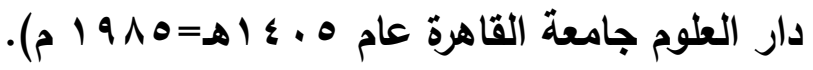
V. شرح الجمل لابن عصفور: وهو أبو الحسن علي بن مؤمن بن علي الخضراوي الإثبيلي المعروف بابن عصفور (ت 79 74ه)، ولابن عصفور ثلاثة شروح على الجمل: صغير، وأوسط، وكبير. فأما الصغير فحققته/ قمر أحمد القصاص في رسالة دكتوراه في كلية الدراسات الإسلامية وإلعربية للبنات بجامعة الأزهر سنة ج 9 ام، بعنوان: (شرح ابن عصفور الصغير على جمل الزجاجي -تحقيق ودراسة). وأما الشرح الأوسط فهو مفقود، لم يصل إلينا. وأما الشرح الكبير فحقَّه الدكتور/ صاحب أبو جناح ، ونشر في مجلدين، وشرح فيه ابن عصفور كتاب الجمل من أوله وحتى باب "الإمالة"، ويبدوا 
أنه لم يتمه، فقد ترك منه باب "أبنية الأفعال"، والتصريف، ويابًا منه آخرَ، والإدغام، وهذا الشرح هو الأي اختصره أبو حيان في كتابه (الموفور) الأي نقدمه محققًا. قال المحقق (1): "والذي وصل إلينا من شروح الجمل اثنان، أحدهما: يقع في مائة وستين ورقة، ومنه نسخة في المكتبة التيمورية بدار الكتب

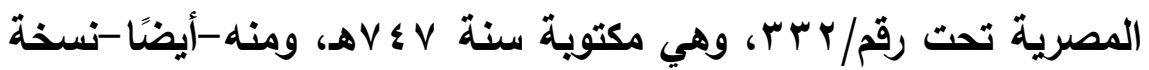
أخرى في ليدن بهولندا تحت رقم/ بـ، وقد استحصلت منها مصورة فوجدتها مطابقة للنسخة التيمورية". ويعد الكتاب من أهم شروح الجمل؛ لِمَا تضمَّنَهُ من شواهدَ نحويةٍ متنوعةٍ،

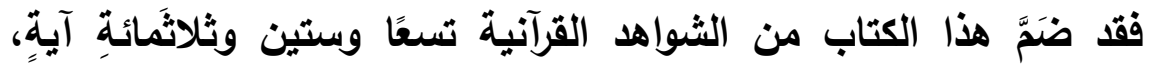
تضمنت ثلاثًا وأربعين قراءةًَ، ما بين متواتر وشاذ، وثمانيةَ أحاديثَ نبويةٍة، وستةً وستين وتسعَمائةة بيتٍ من الشعر، وقد انتهج فيه ابن عصفور منهجا يجعل القارئ يقول حين يتجاوز الأبواب الأولى منه: إنه لا يقرأ شرحًا على كتاب الجمل، بل يظن أن أمامه مؤلفًا في النحو مبتكرًا، وليس شرحًا لكتاب الجمل. وليس هذا في طريقة العرض فقط، بل تجاوزه إلى تصنيف الأبواب والفصول، فقد سار ابن عصفور في ترتيب أبوابه على نهج ترتيب أبواب كتاب الجمل غير أنه زاد فيها أبواب عطف البيان، وما رخمت الشعراء في غير النداء اضطرارا، والاستثناء المقدم، وفصلاً في شواذ النسب، كما أورد في باب "ما ينصرف وما لا ينصرف" طائفة من المسائل تتعلق بالتشمية التي تمنع الصرف في الاسم، وأحكامها، كما وَحَََّ أبواب جمع التكسير -

$$
\text { ( ( ) انظر : مقدمة شرح الجمل الكبير لابن عصفور / ب/ . . }
$$


وهي في كتاب الجمل ثمانية أبواب-تحت عنوان واحد، وهو "باب جمع المكسر"، وأهمل أبوابيًا، فلم يشرحها، وهي: "أبنية المصدر، واشثتقاق اسم المصدر والمكان، وأبنية الأسماء"، ولإسهاب ابن عصفور في شرحه قسم أبواب الجمل إلى فصول، تناول في كل فصل منها جانبًا من جوانب الباب، علمًا بأنه لم يعمد إلى وضع فواصل أو عناوين بين هذه الفصول (1). ^. شرح الجمل لابن أبي الربيع: وهو أبو الحسين عبيد الله بن أحمد بن

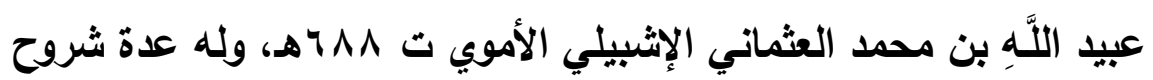
على الجمل(r)، والذي وصل إلينا جزع من شرحه الكبيز على الجمل المسمى ب"البسبط"، وق حققه الدكتور عياد الثبيتي، وطبعته دار الغرب

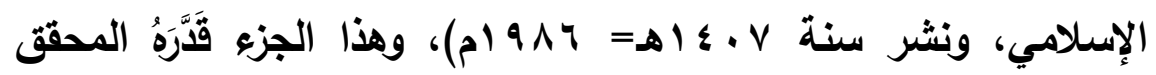
بريع الكتاب(")؛ إذْ يبدأ بأول كتاب الجمل، وينتهي بباب "الصفة المشبهة

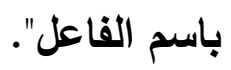

9. شرح الجمل لابن الفخار وهو أبو عبد الله محمد بن علي بن أحمد الخولاني الإلبيري (ت \&هـه): وهو ينتهي بباب التصريف، وأظنه آخر ما وقف عنده هذا الشرح، وق حققه خليفة محمد خليفة بديري في كلية دار العلوم بالقاهرة، سنة 919 ام، ونشرته دار الكتب العلمية

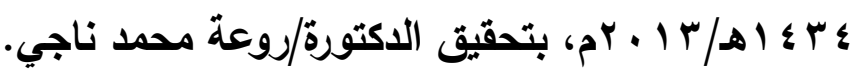

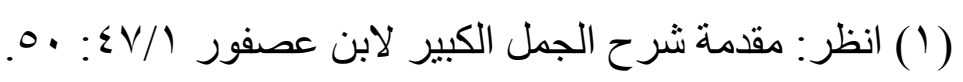

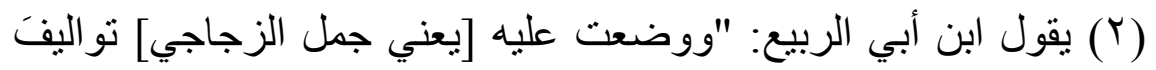

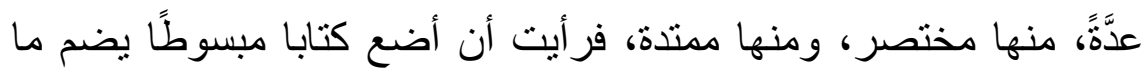

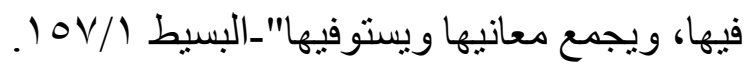

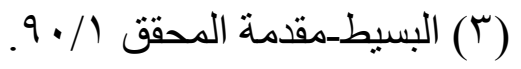




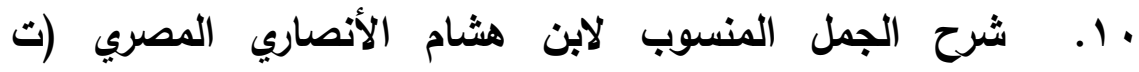
I IVI): وقا حققه الاكتور/ علي محسن عيسى المدرس بكلية الثريعة بجامعة بغداد، وقد قام بطباعته مكتبة النهضة العربية. وأما شروح شواهد الجمل فهي كثيرة-أيضًا-، ومنها: ا ـ شرح شواهد الجمل لأبي العلاء المعري أحمد بن عبد الله بن سليمان

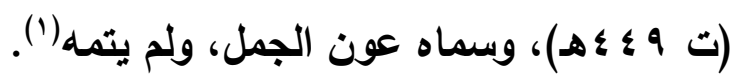
r. شرح أبيات الجمل لابن سيده (ت ^هـهـ): حققه/ محمود أحمد العامودي في رسالة ماجستير في جامعة عين شمس سنة . إـ اهـ| .99 ام، عنوانها: (شروح الشواهد النحوية دراسة لغوية تحليلية، مع كع. تحقيق شرح أبيات الجمل لابن سيده). r. العلل في شرح أبيات الجمل لابن السيد البطليوسي (ت ابوهـ): حققه الاكتور/ مصطفى إمام، وطبعته مكتبة المتببي بالقاهرة سنة - $19 \vee 9$

ع. الفصول والجمل في شرح أبيات الجمل لابن هشام اللخمي (ت أمهام هـVV ه. وشي الحلل في شرح أبيات الجمل لأبي جعفر أحمد بن يوسف الفهري

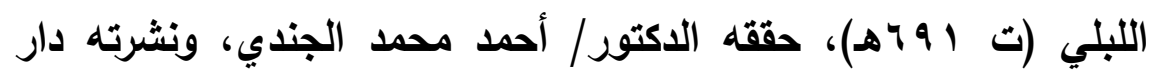

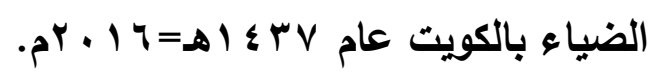

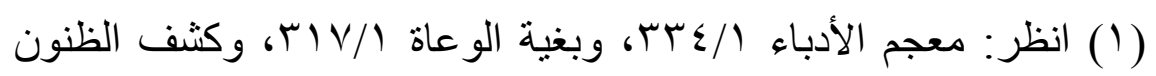
$7.5 / 1$ 


\title{
المبـهث الثالث
}

\section{أبو صيان: صياته وآثناره(انئه}

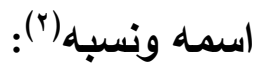

هو محمد بن يوسف بن علي بن يوسف بن حيان، أثير الدين، أبو حيان

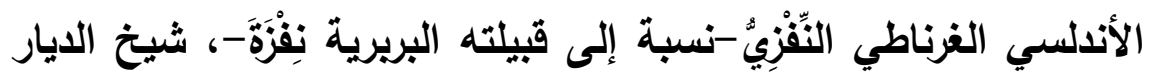
المصرية، وشيخ المحدثين بالمدرسة المنصورية.

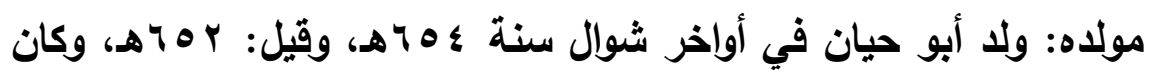

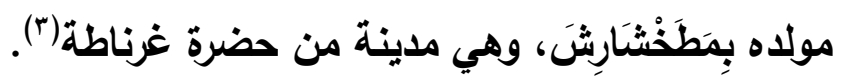

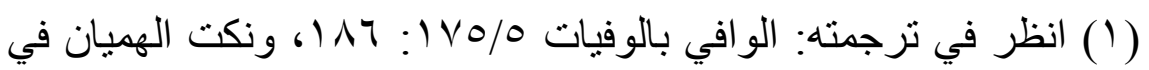

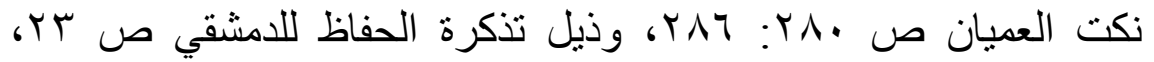

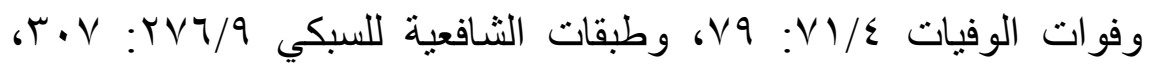

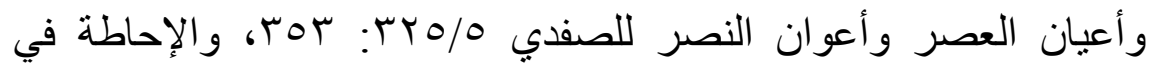

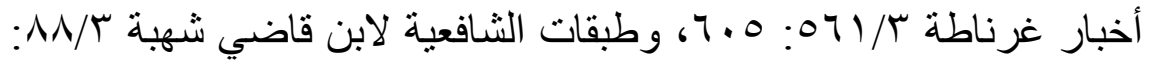
Y

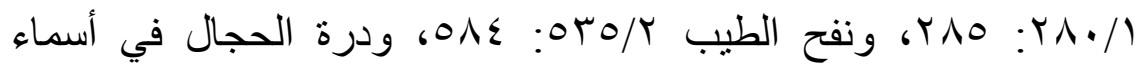

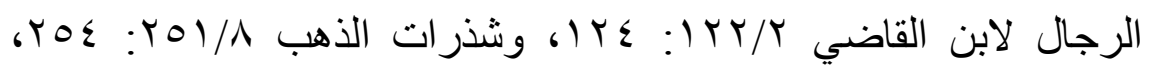

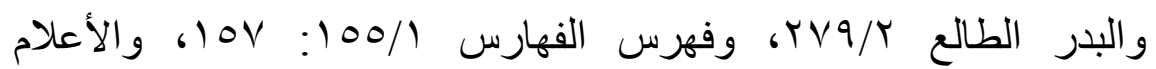

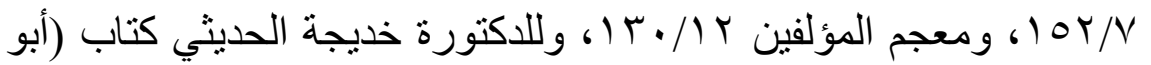

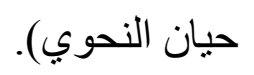

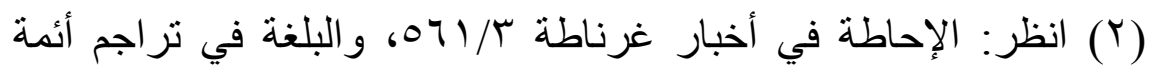

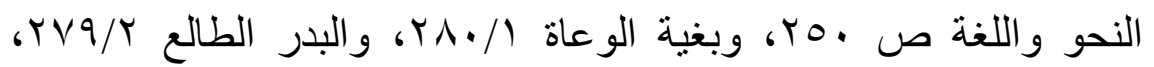
و غير ها من مصادر ترجمة أبي حيان السابق ذكر ها.

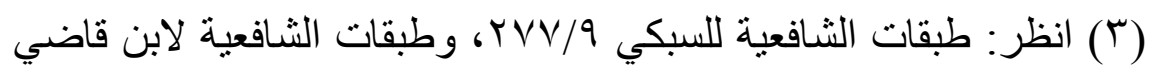

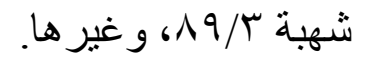


ولكن الراجح هو الأول؛ لأن أكثر من ترجموا له ذكروا ذلك، بل إن أبا حيان ذكر ذلك عن نفسه في إجازته التي أرسل بها إلى تلميذه الصفدي، وجاء في آخرها قوله('): "قاله وكتبه أبو حيان محمد بن يوسف بن علي بن يوسف بن حيان، ومولاي بغرناطة في أخريات شوال سنة أربع وخمسين وستمائة".

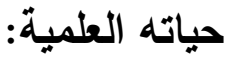
تلقى أبو حيان علومه في أول حياته في الأندلس، ثم لم يلبث أن تركها وارتحل عنها، واختلف في سبب رحلته، فيقال: كان سبب رحلته أنه حملته حدة الثبيبة على التعرض للأستاذ أبي جعفر بن الطبََّّاع، وقد وقعت بينه ويين أستاذه أبي جعفر بن الزبير واقعة، فنال منه، وتصدى للتأليف في الرد عليه وتكذيب روايته، فرفع أمره إلى السلطان، فأمر بإحضاره وتتكيله

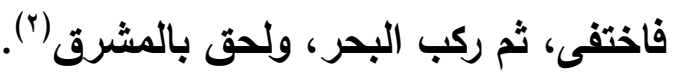
ونقل بعض المؤرخين عن أبي حيان أنه ذكر في كتاب النضار "أن مما قوى عزمه على الرحلة عن غرناطة أن بعض العلماء بالمنطق والقلسفة والرياضي والطبيعي قال للسلطان: إني ق كبرت، وأخاف أن أموت، فأرى أن ترتب لي طلبة أعلمهم هذه العلوم؛ لينفعوا السلطان من بعدي، قال أبو حيان: فأثثير إلى أن أكون من أولئك" (").

(1) انظر: طبقات الثافعية للسبكي rVV/9، وطبقات الثافعية لابن قاضي

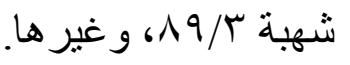

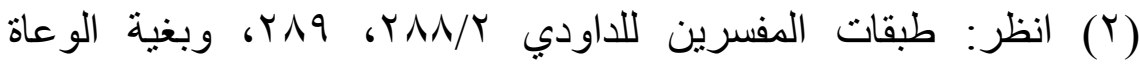

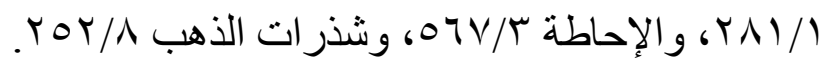

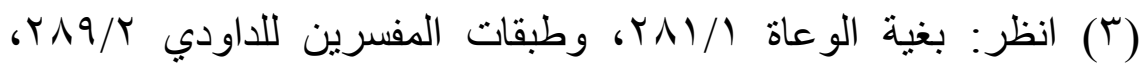

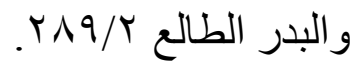


فرحل عن غرناطة خوفًا من أن يكره على تعلم المنطق والقلسفة، وقد استقر به المقام في مصر، فألف كتبا كثيرة في مختلف العلوم، وتولى

تدريس التفسير بالمنصورية والإقراء بجامع الأقمر (1).

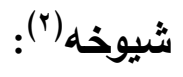

كثر شيوخ أبي حيان، فبلغوا نحو أربعمائة وخمسين شيخًا، فقد أخذ بغرناطة عن أبي جعفر أحمد بن إبراهيم بن الزبير الثقفي الحافظ، والمقرئ أبي جعفر أحمد بن علي بن الطباع الرعيني وغيرهما، وقرأ القراعات بالإسكندرية، على عبد النصير المريوطي، صاحب الصفراوي، ويالقاهرة على أبي طاهر إسماعيل بن هبة الله المَّليجِيّ، صاحب أبي الجود. وقرأ التيسير سنة إحدى وسبعين وستمائة على أبي عليٍ الحسينٍ بنِ أبي الأحوص، وقرأ الموطأ سنة ثلاث وسبعين على ابن الطباع، وأخذ علم الحديث عن الامياطي وغيره، وسمع من عبد العزيز بن الصيقل، وغازي الحلاوي وطبقتهما، ومع براعته الكاملة في العربية، والإمام بهاء الدين محمد بن إبراهيم بن محمد بن أبي نصر بن النحاس الشافعي، قرأ عليه جميع كتاب سيبويه في سنة ثمان وثمانين وستمائة ، وقال له عند ختمه، لم يقرأه علي أحد غيره.

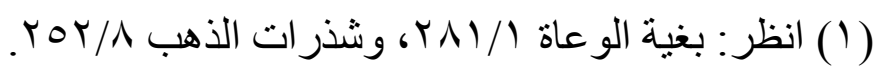

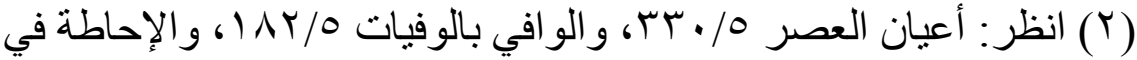

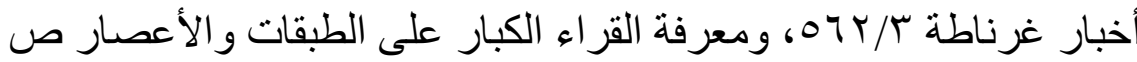
TrV

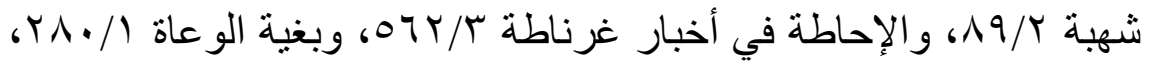
وذيل التقييد في رواة السنن والأسانيد للفاسي / / /

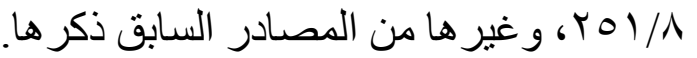


تلاميذه(')

له يا طولى في الفقه والآثار، والقراءات، وله مصنفات في القراءات والنحو، وكان مفخرة أهل مصر في وقته في العلم، تخرج به عدة أئمة،

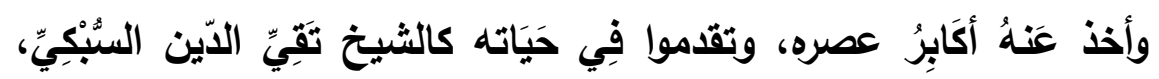
وولايه، وَالجمال الإسنْنَوِيّ، وَابِن قََاسم، وَابِن عقيل، والسمين الحلبي،

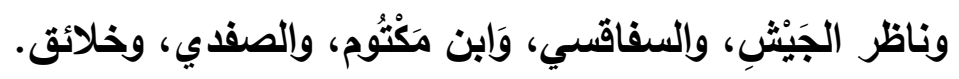
أقوال العلماء فيه:

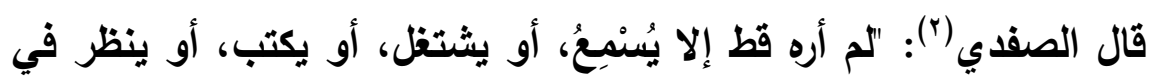

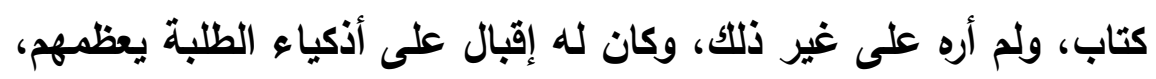
وينوه بقرهم، وكان كثير النظم، ثبتا فيما ينقله عارفا باللغة، وأما النحو والتصريف فهو الإمام المطلق فيهما، خدم هذا الفن أكثر عمره حتى صار لا يذكر أحد في أقطار الأرض فيها غيره، وله اليد الطولى في التفسير والحديث وتراجم الناس ومعرفة طبقاتهم خصوصا المغاربة، وله التصانيف التي سارت في آفاق الأرض، واشتهرت في حياته، وأخذ الناس عنه طبقة بعد طبقة حتى صار تلاميذه أئمة وأشياخا في حياته، وهو الأي رغب الناس إلى قراءة كتب ابن مالك، وشرح لهم غامضها، وكان يقول: إن مقدمة ابن الحاجب نحو الفقهاء، وألزم نفسه ألا يقرئ أحدا إلا في كتاب

(1) انظر: الوافي بالوفيات V7/0 أ، ومعرفة القراء الكبار على الطبقات

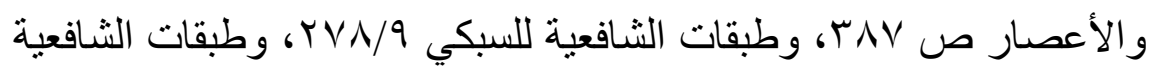

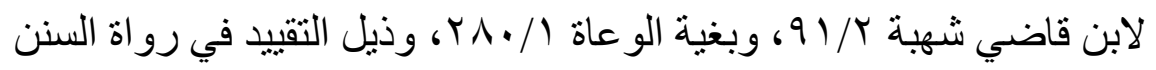

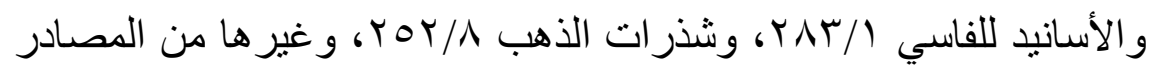
السابق ذكر ها.

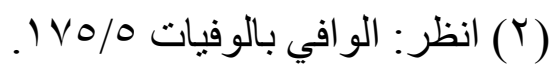


الموفور من شرح ابن عصفور

سيبويه، أو في التسهيل، أو في مصنفاته، وكان هذا دأبه في آخر

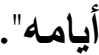

وقال عنه السبكي('): "ثثيخ النحاة، العلم الفرد، والبحر الذي لم يعرف الجزر بل المد، سيبويه الزمان، والمبرد إذا حمي الوطيس بتشاجر الأقران، وإمام النحو الأي لِقَّاصِدِهِ منه ما يشاء، ولسنان العرب الأي لكل سمع لايه الإصغاء، كعبة علم تحج ولا تحج، ويقصد من كل فج، تضرب إليه الإبل آباطها، وتفد عليه كل طائفة سفرا لا يعرف إلا نمارق البيد بساطها". - آثاره(ז): كثرت مصنفات أبي حيان في علوم اللغة والتفسير والقراعات والحديث والفقه، ولغات الفرس والحبش والترك، ومن هذه المصنفات: البحر المحيط في التفسير، والتهر الماد في التفسير، وهو مختصر البحر المحيط، وغريب القرآن، والإسفار الملخص من شرح كتاب سيبويه للصفار، وشرح التسهيل، والتذكرة، والموفور، والمباع، والتقريب، والتدريب، وغاية الإحسان، وشرحه المعروف بالنكت الحسان، وارتثاف الضرب من لسان العرب، والثذا في مسألة كذا، والوهاج مختصر المنهاج، والأنور الأجلى في اختصار المحلى، والإعلام بأركان الإسلام، وتحفة الندس في نحاة الأندلس، والإدراك للسان الأتراك، ومنطق الخرس

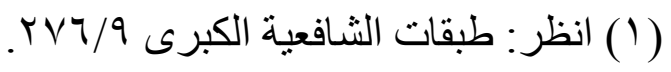

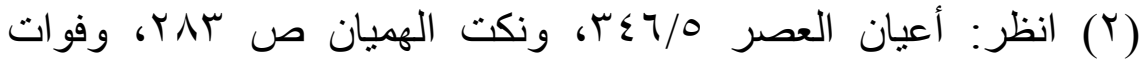

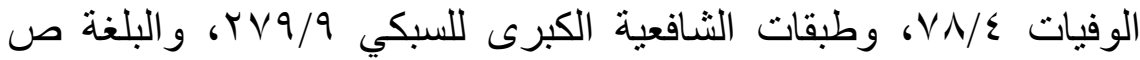

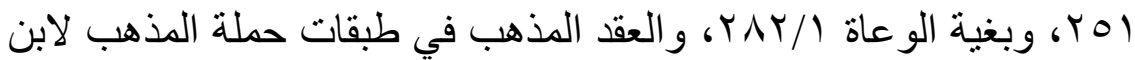

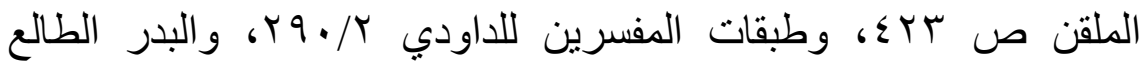




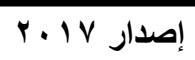

حولية كلية اللغة العربية بالمنوفية العدد الثاني والثلاثون

في لسان الفرس، ونور الغبش في لسان الحبش، ومسلك الرشد في تجريد مسائل نهاية ابن رشد، ومنهج السالك في الكلام على ألفية ابن مالكك، وخلاصة البيان في علمي البديع والبيان، وغير ذلك كثير .

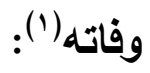

توفي أبو حيان عشية يوم السبت الثامن والعثرين من صفر سنة خمس لضّن وأريعين وسبعمائة بمنزله بظاهر القاهرة، ودفن بمقابر الصوفية، وكانت جنازته حافلة.

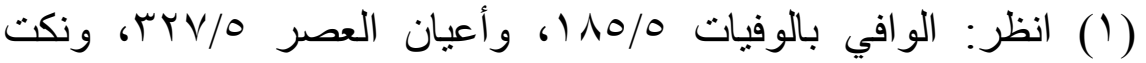

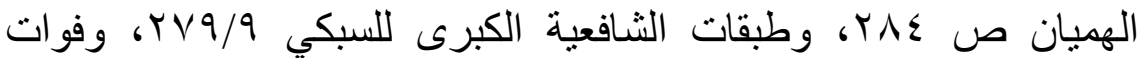

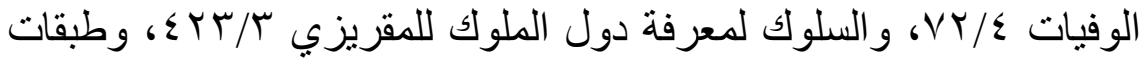

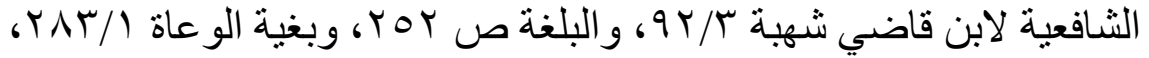

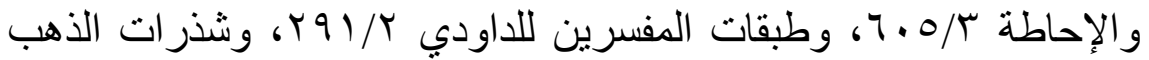
ros/A 


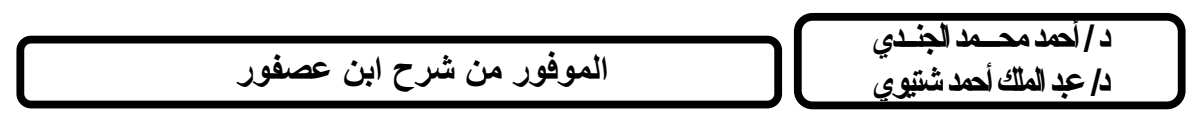

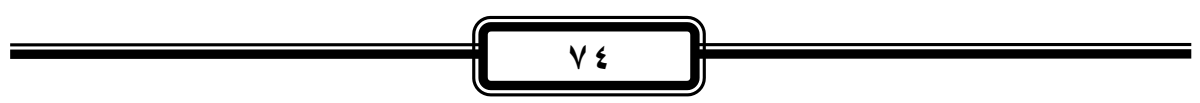




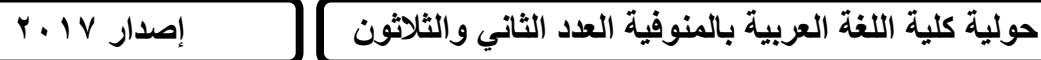

\section{القسم الأول \\ دراسة الموفهر}

المبـمث الأول : شُرم الجمل الكبير لابـن عصفور.

المبحث الثانبي : منسمج أببي هبان فيى الموفور:

(الغرض من تأليف الكتاب ، منهجه في تقسيم الكتاب ، مصادره ، من تأثروا به أو نقلوا عنه ، موقفه من ابن عصفور، والنحويين قبله). المبـهذ النفالث : أصول النهو عنـد أببي هبان من خلال (الموفور). أولاً: استثلاله بالسماع. ثانيًا: استدلاله بالقياس.

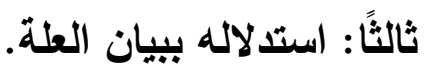

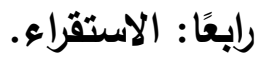




\section{الموفور من شرح ابن عصفور}

\section{المبحث الأول}

\section{شُرم الجمل الكببير لابـن عصفور}

يُعدُ كتاب (الجمل في النحو) للزجاجي من أهم المتون التي حظيت باهتمام العلماء حتى صار كتاباً للمصريين، وأهل المغرب، والحجاز، واليمن، والثشام ، وقام عدد كبير من العلماء بشرحه، والتعليق عليه. ومن بين أهم الثروح عليه شرح ابن عصفور ، كما أنه أشهر كتب ابن عصفور.

وقد سار فيه ابن عصفور وفق منهج الزجاجي ، فقد أخذ يشرح أبواب الجمل وفق النسث الذي ألفه صاحبه، حيث قسم الزجاجي كتابه إلى مجاميع أو طوائف نحوية وصرفية ولغوية، بادئًا بالأبواب التحوية التي

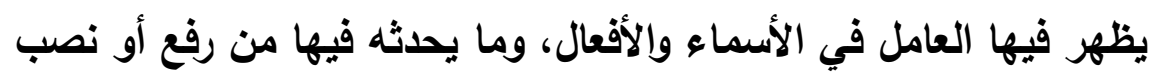
أو جزم أو خفض، ومنتهيًا بمسائلَ تدور حول الإدغام، والحروف المهموسة والمجهورة ونحوها. وقد سار ابن عصفور وفق هذا الترتيب، بلا تقديم ولا تأخير، لكنه زاد بعض المسائل، وحذف بعضها الآخر، وأدمج في شرحه بعضَ أبواب الجمل، وذلك على النحو الآتي (1): - أفأما الأبواب التي زادها على الجمل فهي: - - باب عطف البيان. - باب. - باب ما رخمت الشعراء في غير النداء اضراب.

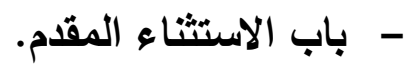

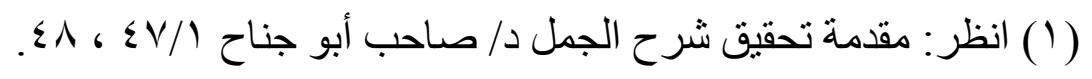




\section{r.IV إصدار}

حولية كلية اللغة العربية بالمنوفية العدد الثاني والثلاثون

- - أورد طائفة من المسائل التي تتعلق بالتسمية التي تمنع من الصرف ن في الاسم r- وأما الأبواب التي حذفها، ولم بشرحها فهي:

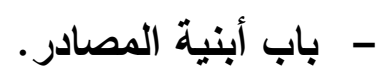
- - باب اشثقاق اسم المصدر.

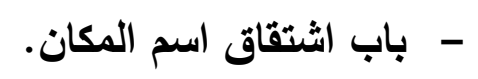

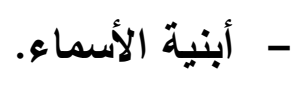

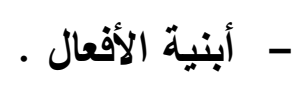
- - التصريف

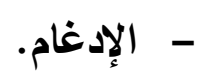
- الحروف المهموسة والحروف المجهورة، وحروف الإطباق - - باب من شواذ الإد غام (1). ب- وأما الأبواب التي أدمجها فهي: - أبواب جمع التكسير جاءت عنده تحث عنوان واحد، وهي في الجمل في ثمانية أبواب. - عرض الموصولات في باب واحد، وهي عند الزجاجي في موضعين. هذا وقد تمتع ابن عصفور بقدر كبيز من القدرة على التقسيم والعرض والتبويب في مؤلفاته جميعها، ومنها شرحه على الجمل فقد قسم الجمل إلى فصول أو أقسام كلما تراعى لله ذلك، فقد قسم التثنية إلى ثلاثية أقسام: تثثية في اللفظ والمعنى، وتثنية في اللفظ لا في المعنى، وتثنية في المعنى لا في اللفظ، مع التمثيل لكل منها بمثال.

(1) وقد أفرد لها كتاب (الممتع في التصريف). 
كما قسم المثنى قسمين: منقوص، وغير منقوص، ممثلاً ومستشهدًا، وقسم الجمع إلى أربعة أقسام: جمع السلامة، وجمع التكسير، واسم الجنس، واسم الجمع، ثم عرض للجمع السالم بنوعيه: المذكر والمؤنث. وق كانت طبيعة ابن عصفور أنه لم يكن يعرض كلام الزجاجي ثم يتبعه بالشرح كعادة شراح المتنون فيما عدا الأبواب الثلاثة الأولى، وإنما أهمل عبارة الزجاجي، ولم يوردها إلا في معرض مخالفته له في رأي أو مسألة، ومن يطالعْ شرحه يجذ أنه جعله مصنفًا مبتكرًا، وليس شرحًا لمتن

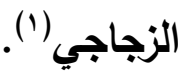

(1) انظر : مقدمة تحقيق شرح الجمل د/ صاحب أبو جناح / / • بتصرف. 


\section{المبـهذ الثناني}

منـهمج الموفور

1-الغرض من تأليف الكتاب:

نالت مؤلفات ابن عصفور اهتمامًا كبيرا عند أبي حيان، فقد لخص

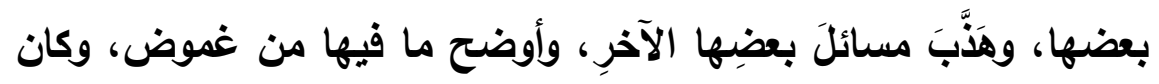
ذلك في أكثر من مؤلف.

فقد اختصر المقرب والممتع، وذكر ذلك في مقدمة الموفور، فقال('): "فإني لَمَّا اختصرت المُقََرَبِ للأستاذ أبي الحسن بن عصفور في كتاب سميته بالتقريب، وأردفته بشرح لطيف، وسميته بالتدريب، واختصرثُ في

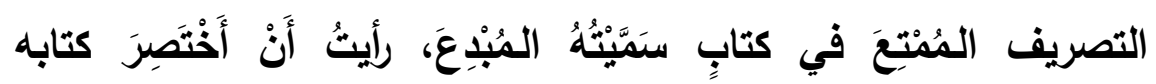
المُسنََّى عند الناس بالشرح الكبير". ثم جاء أبو حيان إلى شرح الجمل الكبير لابن عصفور، فرغب في أن يختصره دون المبالغة في الإيجاز؛ نظرا لما حواه من معارفتَ وعلومٍ

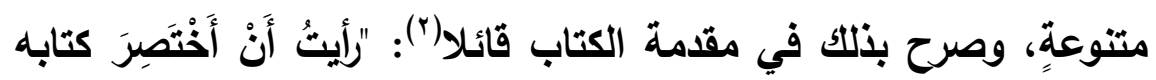
المسُسَمَى عند الناس بالثرح الكبير، وكان قد حَوَى من الفن العربِيِّ قَوَاعِدَ

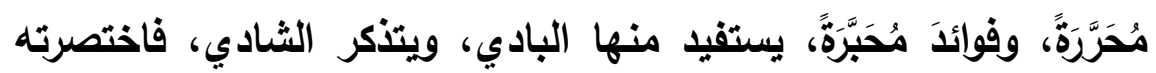

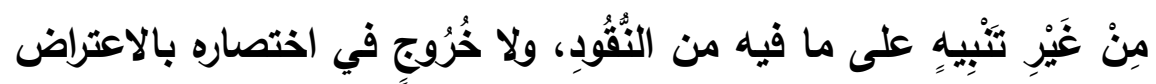

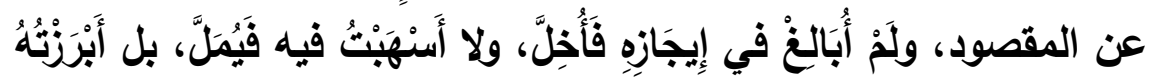

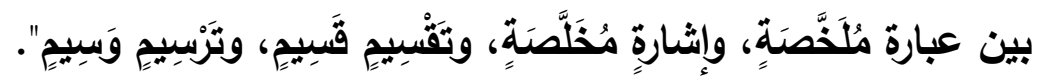
r - rنهجه في تقسيم الكتاب:

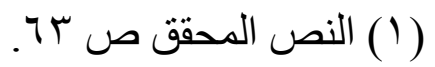

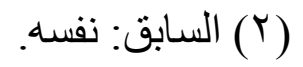


كان لأبي حيان منهج ذو خصائص عدة يمكن إيجازها فيما يلي:

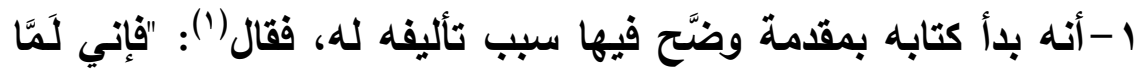
اختصرت المُقَرَبِّب للأستاذ أبي الحسن بن عصفور .....، رأيتُ أَنْ أَخْتَصِرَ كتابه المسُسَسَّى عند الناس بالثرح الكبير، وكان قد حَوَى من الفن العربِيّ

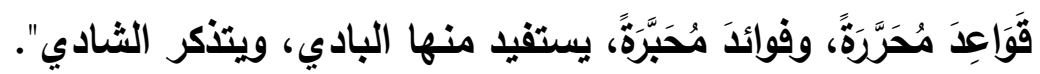
r-أنه قَسَََّ كتابه إلى عدرد من الأبواب النحوية، وسار في ترتيب كتابه على منهاج المقرب لابن عصفور، وذكر هذا الأمر في مقدمته بقوله:

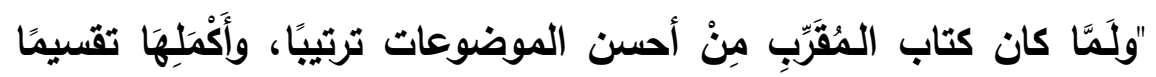

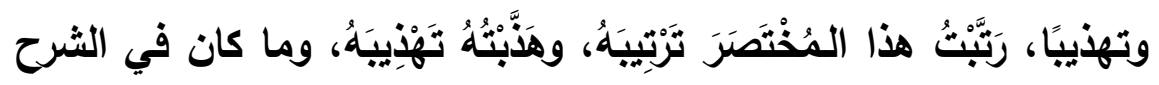

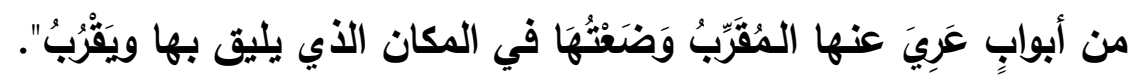
وكتاب المقرب أصاب شهرة واسعة وصيتا بعيدا، فعنْيَ به كثير من النحاة، وتناولوه بالشرح والتعليق والنقا والتهذيب، ومنهم -كما تقدم-: أبو حيان الأي وضع له شروحًا ومختصراتٍ، منها: تقريب المقرب، والتدريب في تمثيل التقريب. ويمتاز منهج المقرب بأنه يخالف ما اعتاده النحاة، فبدأ بعد أقسام الكلم بذكر أحكامها حين التركيب، وأرجأ الكلام على أحكامها مفردة، وأول الأحكام الإعراب، وأول ألقابه الرفع وأول المرفوعات الفاعل، ويتميز الكتاب بالبراعة والدقة في التعاريف، وغلبة المنطق عليه، وتتبع المعاني اللغوية لكلأدوات واستعمالاتها. 
ومن أهم مزاياه: أنه لا يجعل الإعراب ديدنه بل إنه يحتكم إلى المعنى والاستعمال، ويستقصي وجوه الاستعمال ولو لم تلخل في باب الإعراب،

ويتميز أيضا بابتكار العلل (').

ب-أنه ذكر في مقدمة الكتاب سبب تسميته له بهذا الاسم بقوله(ب): "ولََمَّا

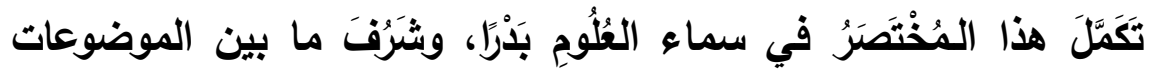

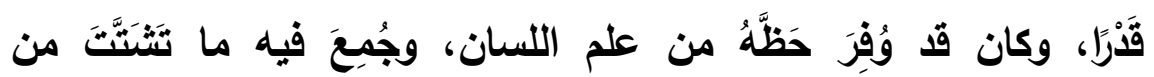
الإحسان، سَمَّيَتُهُ بالموفور من شرح ابن عصفور".

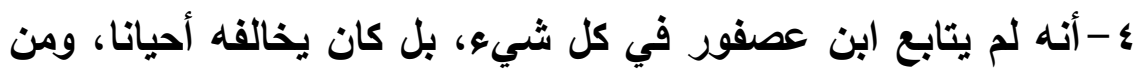
ذلك ما ورد في باب المنادى المضاف إلى ياء المتكلم، حيث قال أبو حيان(ّ): "وأحسنها: يا غلام، ثم: يا غلامَا، ثم: يا غلامِيَ، ثم: يا غلامِيْ،

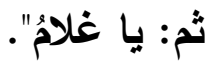
بينما ترتيبها مختلف عند ابن عصفور، حيث قال(\&): "وهذه اللغات المتقدمة على مراتب في الفصاحة، فأفصحها: يا غلام، لأنَّ المنادى كثير الاستعمال فهو في موضع الحذف، وهذه الياء-أيضًا-معاقبة للتنوين، فجاز حذفها مع أنَّ ثََّّ ما يدلُّ عليها، ويليه في الفصاحة: يا غلامِي؛ لأنَّه متوسط، ألا ترى أنّه قد خَفّف ما يستثقل لاوره، ولم يحذف شيئًا، ثُ يليه:

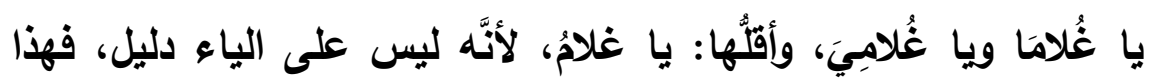
حكم إضافة المنادى إلى المتكلم".

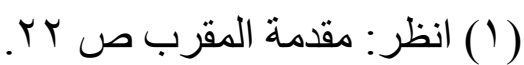

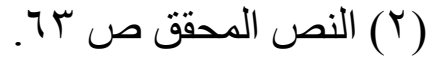

$$
\begin{aligned}
& \text { (ז) انظر : النص المحقق ص (1) } 107 .
\end{aligned}
$$

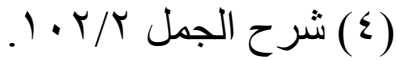


ه- أنه لم يقتصر على اختصار شرح الجمل لابن عصفور، بل زاد عليه مسائل ليست فيه، ومن ذلك: مسألة الخلاف في"ايمن" في القسم، حيث قال (1): "ومذهب (س) أن "ايمن" مفرد، همزته وصل، مشتق من اليُمْنِ، ومذهب الفراء أنه جمع يمين، وهمزته قطع، وُصِلَتْ شذوذًَا". צ-أنتا رأينا في هذا المختصر على صغر حجمه أبا حيان -كعادته في مصنفاته-قد حشد فيه آراءً لأعلام المدرستين: البصرية والكوفية، وكثير من المتأخرين، وأسندها إلى أصحابها، وكان يناقشها، فيوافق بعضها، الاعله ويخالف بعضها الآخر. V- أنه سار على نهج المصنفين في الاستشهاد، فقا يستشهد من القرآن بالآية، أو بعضها حسب ما يقتضيه الشاهد، ويستشهر من الثعر بالبيث، أو شطر منه، ونسب كثيرًا من الأبيات المستشهد بها إلى أصحابها، وأما الأقوال والأمثال فقد اثتثمل الكتاب على مجموعة من أقوال العرب وأمثالهم، وقد نَبَّة على شذوذذ بعضها، ومنها قولهه: عليه رجلًا ليسني، وقولهم: لا نَوْلَكََ أن تفعل، وقولهم: قضية ولا أبا حسن لها. وأما الحديث فقد استشهر بجملة من حديث، وهي "لا ها اللَّهِهِ ذا"، وذلك ونه

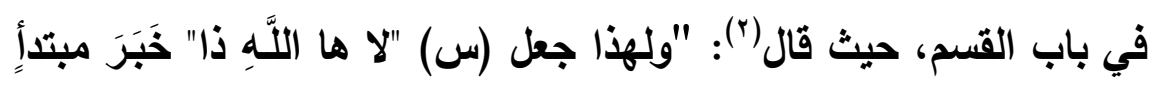

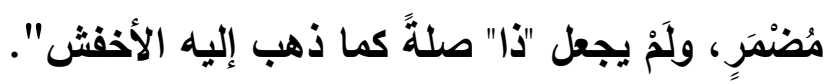

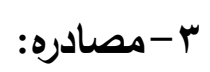

تنوعت مصادر أبي حيان في الموفور، فأفاد من كتب النحو، لكنه لم

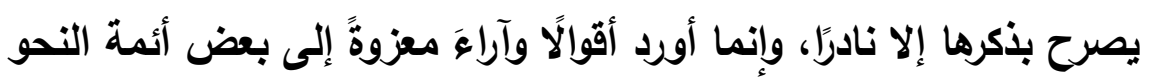

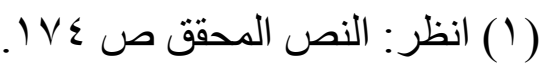

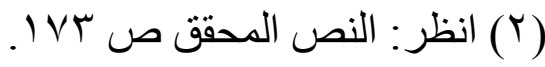




$$
\text { r. IV Rدار }
$$

حولية كلية اللغة العربية بالمنوفية العدد الثاني والثلاثون

كسيبويه، والخليل، والكسائي، والأخفش، والفراء، والمبرد، وغيرهم، وتارة يورد هذه الأقوال دون أن يعزوها إلى أحد بعينه، بل يكتفي بقوله:

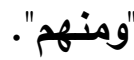

ويمكنا أن نذكر هنا أهم المصادر التي اعتمدها أبو حيان في الموفور، ف:

- الكتاب: عَوَّلَ أبو حيان كثيرًا على كتاب سيبويه وإن لم يصرح باسم

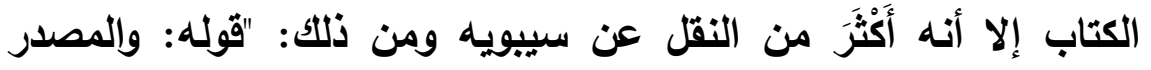
أَصنل"، والفعل مأخوذ منه" (1). وهذا معنى قول سيبويه: "وأما الفعل فأمثلة أُخذثن من لفظ أحداث الأسماء"، وأحداث الأسماء المصادر (r). - معاني القرآن للإزاء: -

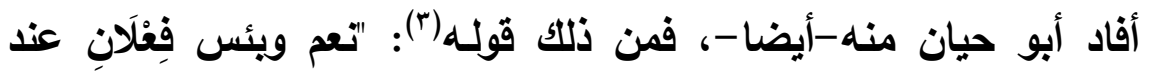
البصرينين، واسمان عند الفراء(؛)وكثيرٍ من الكوفينين". - الكبير لأخفقش: صرح أبو حيان بنقله من هذا الكتاب بقوله(ه): "وحكى الأخفش في الكبير لله أن من العرب من يقول: نعما ونعموا". -

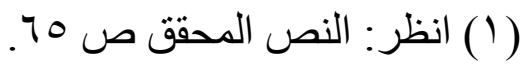

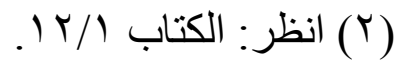

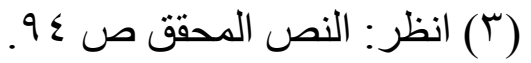

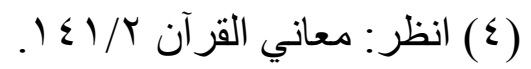

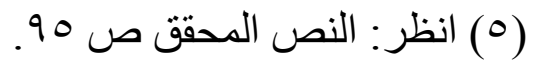




$$
\text { الموفور من شرح ابن عصفور }
$$

نقل عنه أبو حيان في قوله('): "وعند (س) : ابن أَوْيَرَ معرفةٌٌ، وعند

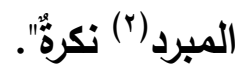

$$
\text { - الإيضاح للفارسي: - }
$$

نقل أبو حيان عن الفارسي وإن لَّْ يصرح بالنقل عنه في بعض المواضع، ومن ذلك قوله في تعريف الإعراب اصطلاحا(ّ): "تغيير أواخر الكَلمٍ؛

لاختلاف العوامل الاخلة عليها لفظًا أو تقديرًا". وهذا هو حد الإعراب عند الفارسي في الإيضاح(؛). - الحجة للقراء السبعة للقارسي: نقل عنه أبو حيان قوله: "وعند الفارسي(•): من قبيل ما عُرِّفَ بعهد الصلة"(7) (4)

\section{- شرح الجمل لابن خروف:} أفاد منه أبو حيان، ومن ذلك قوله(V): "قلب الإعراب لا يجوز إلا حيث

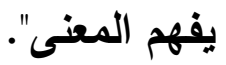

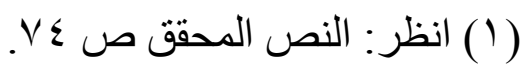

(Y) (Y)

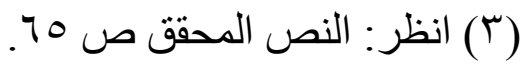

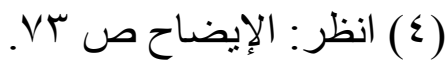

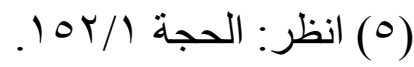

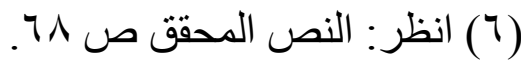

(N) انظر : النص المحقق ص (V) 
أخذه من قول ابن خروف(1): "المفعول المحمول على المعنى من باب الاتساع والمجاز؛ لفهم المعني، وهو كثير جدا؛ ومنه: خرق الثوبُ المسمارَ، وأدخلت القلنسوة في رأسي". ع -من تأثروا به أو نقلوا عنه:

لم أقف على نقلٍ عن الموفور في كتب النحويين الأين جاعوا بعد أبي لُّلَّ حيان، ولعل هذا راجعٌ إلى وجود الأصل الذي اختصره أبو حيان، وهو شرح الجمل لابن عصفور، ولكن هذا لا يغمط الموفور حقه؛ إذْ إن أبا حيان لم يقتصر على اختصار شرح الجمل، بل كاتت له شخصيته البارزة في هذا المختصر، وخاصة في ترتيب أبواب الكتاب، وهذا ما تكلمنا عنه في بداية هذا المبحث عند حديثنا عن منهج الموفور. ه-موقفه من ابن عصفور: - لم نقف في الموفور إلا على موضعين خالف فيهما أبو حيان ابنَ

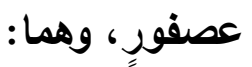
أ- أحدهما: في باب المنادى المضاف إلى ياء المتكلم، حيث قال أبو

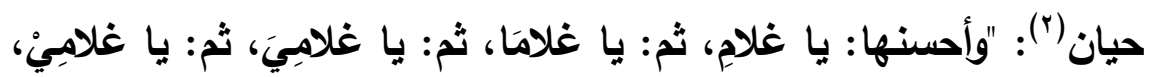
ثم: يا غلامُ". بينما جاء ترتيبها مختلفًا عند ابن عصفور، على نحو ما أشرنا إليه في ذاكو الموضع.

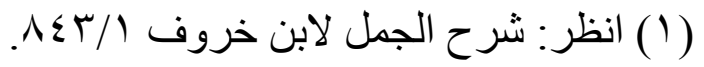

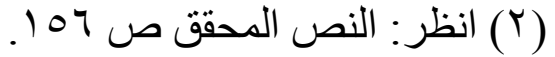


ب-والثاني في باب التعجب، حيث أجاز أبو حيان التعجب مما كان على أنى وزن "أفعل" إذا كانت همزته لغير النقل، حيث قال('): "فلا يتعجب من جامد، ولا ناقص، ولا مزيد، إلا إن كان موازن "أَفْلَّ"، فمانعُ، ومجيزّ، ومُفَصَّلْ بين أن نكون الهمزة للنقل فيمنع، أو لغيره فيجيز، وهو الصحيح".

أما ابن عصفور فمنعه، ولم يجز التعجب منه إلا فيما شذ(؟). كما أن أبا حيان-كما أسلقنا-لم يلتزم ترتيب ابن عصفور في شرح الجمل، بل التزم ترتيب المقرب، وهذا ما أشار إليه في مقدمته، حيث

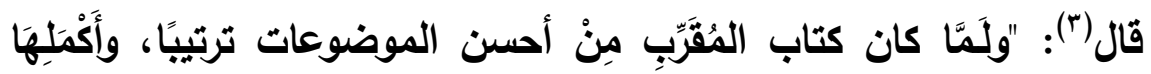

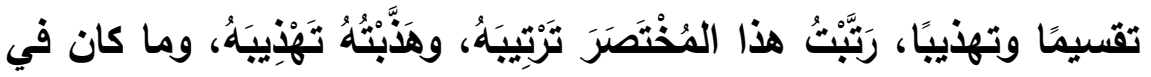
الشرح من أبوابِ عَرِيَ عنها المُقَرَبُِّ وَضَعْتُهَا في المكان الأي يليق بها

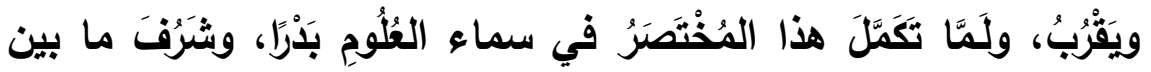

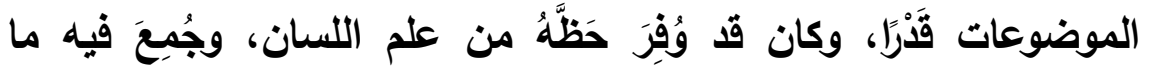

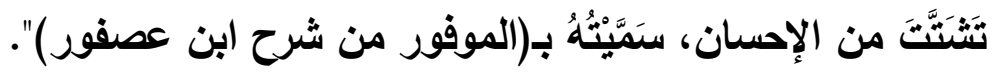
צ-موقفه من النحويين قبل ابن عصفور: جاء أبو حيان وقد أُرسيث قواعد النحو، وأحكمت معاييره، وتوطدت أركانه، ووضحت معالمه، فكان من السهل عليه أن يعرض المذاهب والآراء النحوية على بساط البحث والنقد، وأن يعرض القواعد والأصول التي قامت مات عليها هذه المذاهب ليتعرف مقدار هذه القواعد من الصحة والضعف، ولألك فإنه لم يخرج في اتجاهه النحوي عن منهج التحويين الأين جاءوا

$$
\begin{aligned}
& \text { (1) انظر : النص المحقق ص } 91 \text { (1). }
\end{aligned}
$$

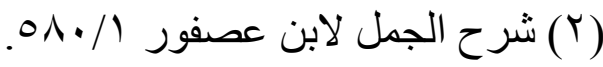

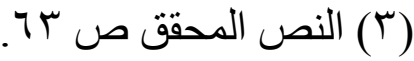




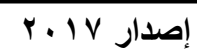

حولية كلية اللغة العربية بالمنوفية العدد الثاني والثلاثون

من بعد القرن الرابع، والأين قامت مذاهبهم على الاختيار من المذهبين: البصري والكوفي.

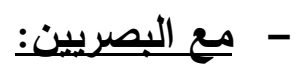

بصرية أبي حيان تبدو واضحة في اتجاهه النحوي، فقد سلك سبيل البصريين في آرائه النحوية، وتتحلى هذه النزعة فيما بلية: ا ـ أنه صرح بمذهب البصريين أكثر من مرة. r. أنه دأب على تقديم مذهب البصريين على مذهب الكوفيين، سواء صرح بنسبة الرأي إليهم أم لا، وفي هذا إثارة إلى أن مذهبهم هو الأصل .

r. أنه وافق جمهور البصريين في جل آرائهم في المسائل المختلفة. - موقفه من أعلام المدرسة البصرية: -

لهج أبو حيان به كثيرا، فوافق سييويه في جلّّ ما ذهب إليه، ومن ذلك:

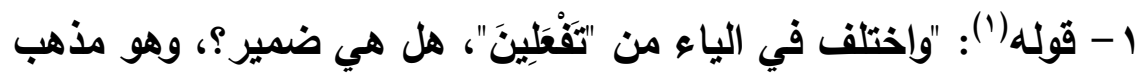
(س)، أو علامة تأنيث؟، وهو مذهب الأخفش، والصحيح الأول". r - قوله في أفعال المقارية(؟): "وإذا اتصل بها ضمير نصب فالأخفش يقول: هي في موضع رفع، و"أن يقوم" في موضع نصب، و(س) يعكس، وهو الصحيح". - الأخفش: -

$$
\begin{aligned}
& \text { ( ) انظر : النص المحقق ص IV. } \\
& \text { r) انظر : النص المحقق ص r Y I . }
\end{aligned}
$$


وافق أبو حيان الأخفش في مواضع، وخالفه أحيانًا في مواضع، وسكت عنه في مواضع أخرى، ومن ذلك: - قوله('): "ومذهب أبي الحسن أن الموصول من قبيل ما عُرِّنَ بـ"أل"،

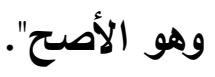
- وقوله في الكلام على شروط جملة الخبر اسمية كانت أم فعلية(؟): "وشرطهما: أن يكون فيهما ضمير المبتدأ، أو تكراره بلفظه لا بمعناه؛ خلافًا للأخفش، أو إثارة إليه، أو عموم، إلا أن تكون نفس المبتدأ في المعنى، فلا يحتاج إلى رابط. - وقوله(َّ): "وحكى الأخفش في الكبير له أن من العرب من يقول: نعما ونعموا". - المازنـي: أغلب المواضع التي صرح فيها أبو حيان بالمازنـي خالفه فيها، ومن ذلك:

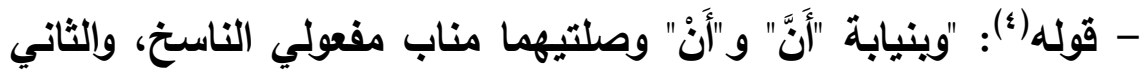
والثثالث في "أَعْلَمَ"، لا بنيابة ذابك مناب مفعولي الناستخ، خلافَا للمازني".

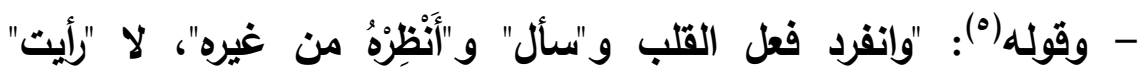
البصرية-خلافا للمازنـي-بالتعليق".

( ) (انظر : النص المحقق ص 1^؟.

r) انظر : النص المحقق ص 0 . 1. r) انظر : النص المحقق ص 90. ع) انظر : النص المحقق ص آ| . 0) انظر : النص المحقق ص rr ا. 


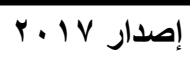$$
\text { حولية كلية اللغة العربية بالمنوفية العدد الثاني والثلاثون }
$$

- وقوله في الاستثناء المنقطع|": "والمنقطع يجب نصبه، فإن أمكن اتصاله مجازًا وَجَبَ عند الحجازيين، وجاز عند التميميين هو والبََّلُ، وليس من تغليب العاقل على غيره، خلافا للمازني".

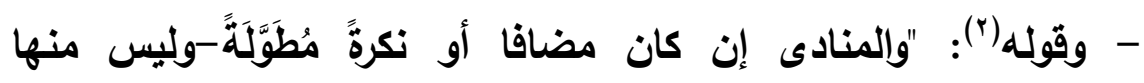
الموصوفةُ خلافًا لبعضهم، أو غَيْرَ مُقْبَلِ عليها عند الجمهور، خلافًا لمن

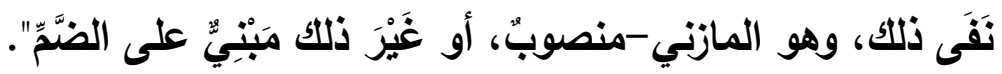
- وقوله في المنادى (): "أو مفردٌ، فهذان الوجهان، والأحسن على اللفظ، إلا أن تلزم الصفة، فالصحيح وجوب الرفع، والمازني يُجيزُ الوجهين". - المبرد: صرح أبو حيان بمخالقته للمبرد في قوله(؛): "وكل فعل ثثلاثي يجوز أن يبنى على "فَفُلَ"، ويراد به معنى المدح أو الأم، وحكمه فاعلا وتمييزا ومخصوصا حكم "تِعْمَ"، ولا يكون فَاعله كُلَّ اسنِْ، خلافَا للمبرد". إين السراج: عارضه أبو حيان في موضعين، وسكت عنه في موضع واحد في هذا المختصر:

() انظر : النص المحقق ص 9 § ا.

Y) انظر: النص المحقق ص 101.

r) انظر: النص المحقق ص ror

؟) انظر : النص المحقق ص 97. 


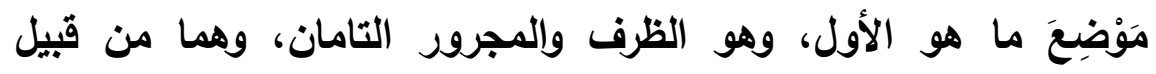

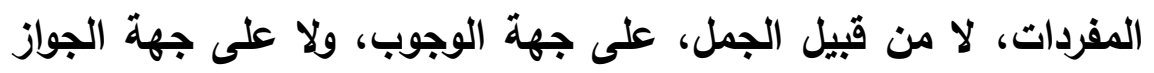

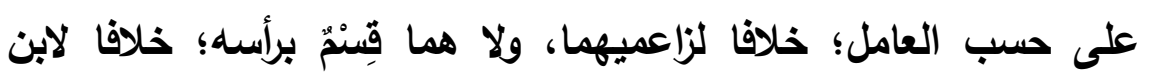
السراج".

- والثثاني قوله في الكلام على الخبر الجملة|(') "وجملة، ولا يشترط أن تكون خبريةً؛ خلافا لابن السراج".

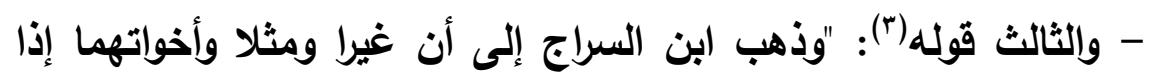

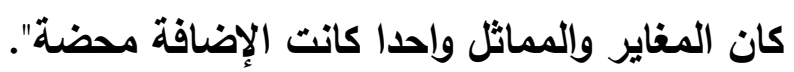
- ميع الكوفين: المغايز والمياتي إذا كان أبو حيان قد وافق البصريين غالبًا، واحتج لهم، فإنه قد خالف الكوفيين غالبا، ومن ذلك: - قوله(|): "والواو في "هو"، والياء في "هي" أصلٌ خلافًا للكوفيين، وما بعد الهاء في "هُمَا" وفرعه زوائد".

() انظر : النص المحقق ص ؟ ـ 1.

r) انظر : النص المحقق ص 0 • 1.

r) انظر : النص الدحقق ص VOI

§) انظر : النص المحقق ص •v. 


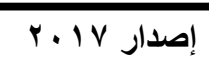

حولية كلية اللغة العربية بالمنوفية العدد الثاني والثُلاثون

- وقوله(1) " "والألف في "أنا" زائدة خلافًا للكوفيين".

-وقوله(ץ): "ولا يتقدم الفاعل إلا ضرورةً، خلافا للكوفيين في جواز ذلك".

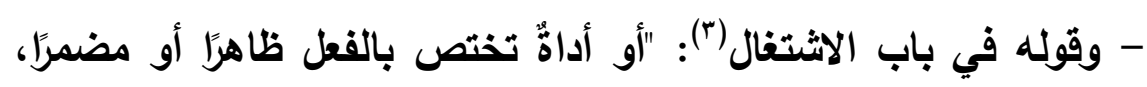
وهي أدوات الشرط وأدوات التحضيض؛ خلافا لبعض الكوفيين، فإنهم أجازوا بعدها المبتدأ والخبر".

- وقوله في "كان" الناقصةُ(؛): "إنْ بَقِيَ بعدها مرفوعان فقيها ضمير الأمر أو القصة اسمًا لها، والجملة في موضع الخبر، وتلحق علامة التأنيث

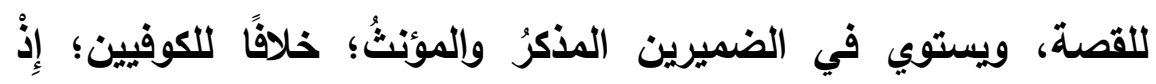
طابَقُوا بين الضمير والمخبر عنه لزومًا". - وقوله(•): "واسم "كان" وأخواتها مرفوع بها، لا بالابتداء خلافًا للكوفيين". - موقفه من أعلام مدرسة الكوفة: - الكسائي: الغالب على موقف أبي حيان من الكسائي هو مخالفته، ولكنه قد يحكي قوله دون مخالفة له أو تأييد، ومن ذلكي هوني هن

( ) انظر : النص المحقق ص IV.

ץ ( انظر : النص المحقق ص 99

r) انظر : النص المحقق ص • 11.

ع) انظر : النص المحقق ص 1111.

0) انظر : النص المحقق ص • ب I. 


\section{الموفور من شرح ابن عصفور}

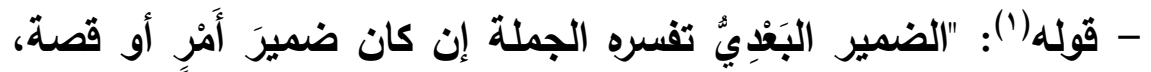
خلافًا للكسائي في إجازة تفسيره بمفرد". - وقوله(؟) "ولا يجوز : الذي ضريتُ زيدًا أنا؛ خلافًا للكسائي". - وقوله(َ): "وإذا عُطفَ على الخبر أو الاسم قبل ذكر الخبر فالمطابقة في الإعراب، إلا فيما شذ من اعتبار موضع اسم "إِنَّ"، وقاسه الكسائي في

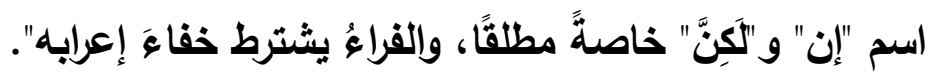
- وقوله (؛) : "ولا تكون "رئَّ" اسمًا، خلافًا للكسائي". - الفراء: كذلك الغالب على موقف أبي حيان من الفراء مخالقته، ومن ذلك:

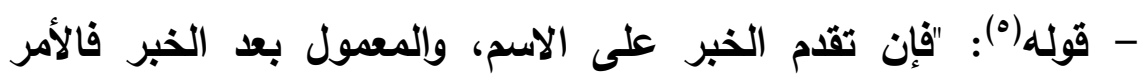
عندهم على ما كان عليه لو لم يكن له معمول، أو قَبَّلَهُ فكذلك، إلا أنه لا يجوز أن يكون خلفًا عند الكسائي، كان المعمول ظرفًا أو غيره، والفراء يُفَصِّلُ، فَإن كان معموله ظرفًا أو مجرورًا جاز أن يكون خلقًا، أو غَيَرَهُمَا فلا، والصحيح عند البصريين في جميع ذلك أنه خبر مقدم لم يخلف

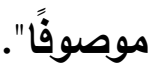

( ) (انظر: النص المحقق ص Yr.

r) (انظر: النص المحقق ص r9

r) انظر: النص المحقق ص 0ץ ا.

ع) انظر : النص المحقق ص ع 1 ا.

0) انظر : النص المحقق ص س II. 
- وقوله|") "إن كان الاستثناء من معدود، نحو: عندي عشرةٌ إلا واحدًا إلا ثلاثةً فالصحيح أنها مستثناة من العدد الأول، ومذهب الفراء أن الأول مستثنى من العدد الأول، وليس الثاني كذلك". - وقوله (ץ): "ولا يرخم إلا ما بُنِيَ في النداء، فإن كان نكرةً مُقْبَلَا عليها بهاء التأنيث فتحذفها، أو دونها لم ترخم إلا صاحبًا أو شاذَّا، ولا ينقاس، ولاس،

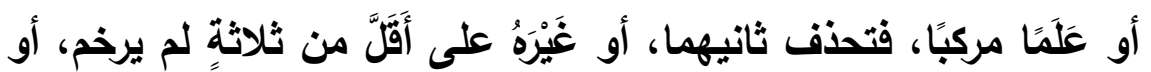
ثُلاثيَّا باللهاء فتحذفها، أو عاريًا عنها ساكِنَ الوسط لم يرخم، أو مُتَحَرِكَهُ فكذلك خلافًا للفراء فيه". - وقوله("): "ومذهب (س) أن "(يمن" مفرد، همتته وصل، مشتق من اليُمْنِ، ومذهب الفراء أنه جمع يمين، وهمزتهه قطع، وُصِلَتْ شذَوذًا". وقد يذكر رأي الفراء ولا يعقب عليه بقبول أو رد، ومن ذلك: - قوله(؛): "تعم ويئس فعلان عند البصريين، واسمان عند الفراء وكثير

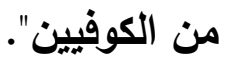
- وقوله في العطف على اسم "إِنَّ"(0):"وإذا عُطِفَ على الخبر أو الاسم قبل ذكر الخبر فالمطابقة في الإعراب، إلا فيما شذ من اعتبار موضع اسم

() انظر : النص المحقق ص V \& I.

Y) انظر : النص المحقق ص 109.

r) انظر: النص المحقق ص ع V . .

§) انظر : النص المحقق ص ؟9.

0) انظر : النص المحقق ص 0ץ ا. 


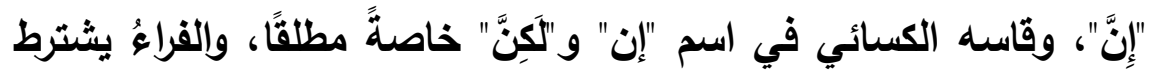

$$
\text { خفاعَ إعرابه". }
$$

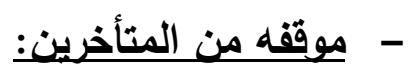

اخْتُفَفَ في تحديد المتأخرين، وإن كان بعض العلماء يرى أن السيرافي

والثارسي وابن خالويه من متقدمي المتأخرين ('). ويؤيد هذا قول ابن عطية(؟): "ومن المبرزين في المتأخرين: أبو إسحاق هي الزجاج وأبو علي الفارسي"، فهولاء متأخرون بالنسبة لزمن ابن عطية.

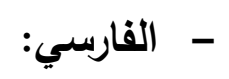

لم يرتض أبو حيان قول الفارسي في تعريف الموصول بأنه من قبيل ما

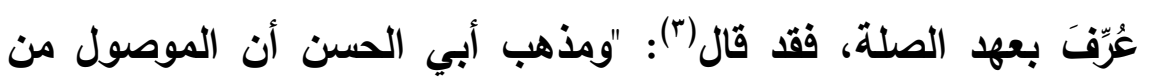
قبيل ما عُرِّتَ بِ"أل"، وهو الأصح، وعند الفارسي: من قبيل ما عُرِّفَ بعهد

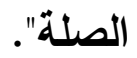

- كذلك عارضه في بناء "كان" للمفعول، فقال(؛): "والفعل الأي يُنَْى شرطه أن يكون متصرفا، واختلف في "كان" وأخواتها، فالفارسي مَنَعَ، والفراء أجاز على حذف الاسم وإقامة الخبر، والسبرافي أجاز على على على حذفهما، وإقامة ضمير المصدر، و(س) أجاز، ولم يبين على أي وجه،

()) ينظر : نشأة النحو (9) (6 19 19.

$$
\text { r) المحرر الوجيز / }
$$

ץ) انظر : النص المحقق ص 7 ا، 79.

ع) انظر : النص المحقق ص r • 1. 


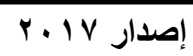

حولية كلية اللغة العربية بالمنوفية العدد الثثاني والثلاثون

والصحيح الجواز على إقامة ظرف أو مجرور -إن كان في الكلام-مُقََّمَ

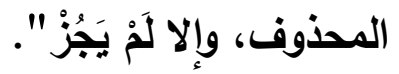

- وقال -أيضًا-(1): "ويجوز دخول "إلَّا" على خبر ما نُفِيَ جوازًا، أو كان معناه النفيَ، إن أوجبت، إلا إن كان الخبر لا يستعمل إلا منفيَّا فلا ،

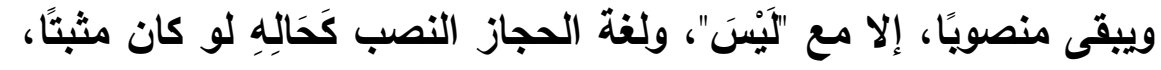

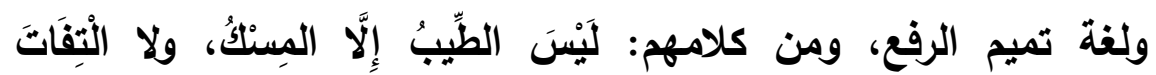

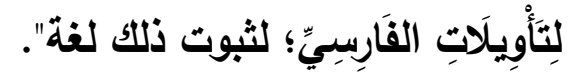
- - ابن الطراوة: لم يرد ذكر ابن الطراوة كثيرًا في الموفور، وقد خالفه أبو حيان دائمًا، ومن ذلك: -قوله في باب "كان" وأخواتها(ץ): "وإذا اجتمع معرفتان فالاسم المقدر

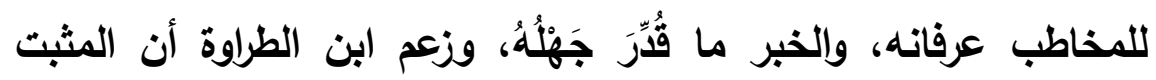
الخبر، وغير المثبت الاسم".

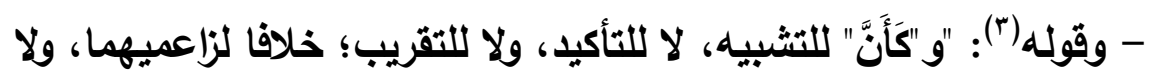
بمعنى الظن؛ خلافا لابن الطراوة".

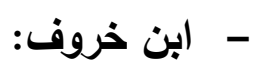
ذكر أبو حيان أبا الحسن بن خروف في موضعين فقط في الموفور، وخالفه فيهما:

1) انظر : النص المحقق ص ع 111 110 . r) انظر : النص المحقق ص 110. ץ) انظر : النص المحقق ص هץ |. 
- فالموضع الأول قوله(1): "ويعمل القول عمل الظن بلا شرط عند سليم،

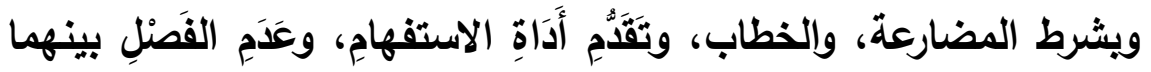
بغير ظرف أو مجرور، عند غيرهم، وإذا أُعْمِلَ عَمَلَهُ فمعناه معناه؛ خلافًا

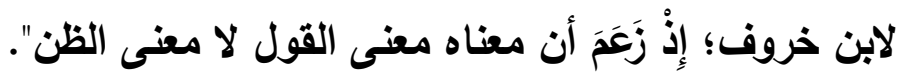

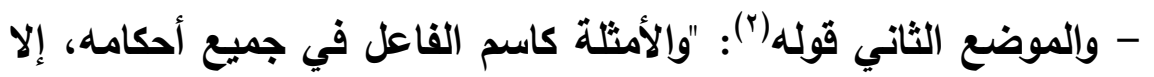
ما ذهب إليه ابن خروف من جواز إعمالها ماضية مطلقًا".

\section{- عرضه للخلاف دون ترحيح: -}

سبق في كلامنا على موقف أبي حيان من نحاة المدرستين: البصرية والكوفية، ومن المتأخرين أن بعض المواضع كان أبو حيان يحكي فيها بعض الأقوال دون ترجيح أو رَدِّ، وهذه سمة بارزة عنده في الموفور، وريما كان السبب في هذا أن الكتاب اختصار لشرح الجمل لابن عصفور. وسنذكر فيما يأتي أمثلة أخرى من هذه المواضع التي كان أبو حيان يأكر فيها أقوال العلماء دون ترجيح. ا ـ قوله(ז): "ثم الضمير -كما تقدم-مرفوع ومنصوب ومجرور، وكلها متصلة إلا ما حُكِيَ شاذَّا من المخفوض: ما أنا كَأَنْتَ، ولا أنت كأنا، وإلا أن يَفْصِلَ بين المرفوع أو المنصوب وبينَ عامليهما حَرْفُ عَطْفِ، أو "إِلَّاَ، أو ما في معناه، على خلاف في هذا، (س) جعله ضرورة، والزَََّّّاجُ قَاسَهُة".

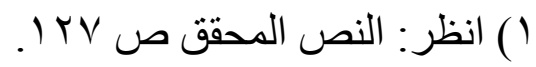

Y) انظر : النص المحقق ص بr I . r) انظر: النص المحقق ص Yr، س VY. 


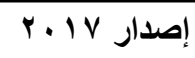

حولية كلية اللفة العربية بالمنوفية العدد الثاني والثلاثون

r r. وقوله (1): "وعند (س) : ابن أَوْيَرَ معرفةُة، وعند المبرد نكرة".

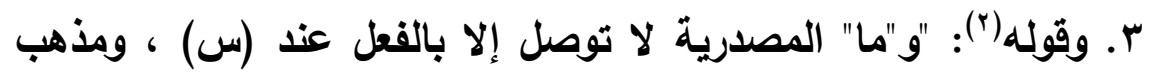

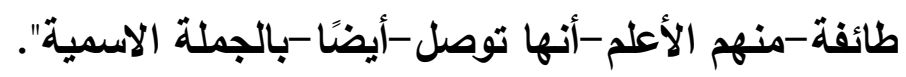
ع. وقوله("): "تعم ويئس فعلان عند البصريين، واسمان عند الفراء وكثير

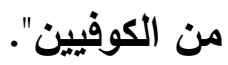

ه. وقوله(؛): "والفعل الأي يُبنَّى شرطه أن يكون متصرقًا، وإختلف في "كان" وأخواتها، فالفارسي مَنَعَ، والفراء أجاز على حذَ الاسم وإقامة الخبر، والسيرافي أجاز على حذفهما، وإقامة ضمير المصدر، و(س) أجاز، ولم يبين على أي وجه". צ. وقوله(•): "إلا كيف، فمذهب (س) انتصابها ظرفًا، ومذهب الأخفش أنها اسم في موضع نصب على الحال". V. وقوله("): "و"كان" تامة وناقصة وزائدة بين المتلازمين، كالعامل

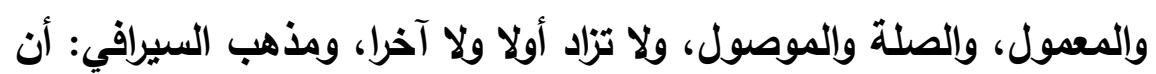
فيها ضمير المصدر فاعلا بها، ومذهب الفارسي أنها فارغة".

( ) انظر: النص المحقق ص ع V. ץ) انظر: النص المحقق ص 10.

r) انظر : النص المحقق ص ؟9.

ع) انظر : النص المحقق ص r • 1.

0) انظر : النص المحقق ص V • I.

7) انظر : النص المحقق ص VIV 


\section{الموفور من شرح ابن عصفور}

^. وقوله (1): "وإذا عُطِفَ على الخبر أو الاسم قبل ذكر الخبر فالمطابقة في الإعراب، إلا فيما شذذ من اعتبار موضع اسم "إنَّ"، وقاسه الكسائي في

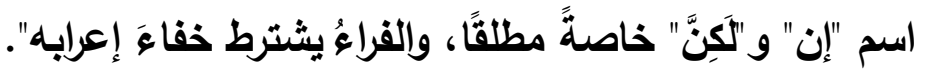

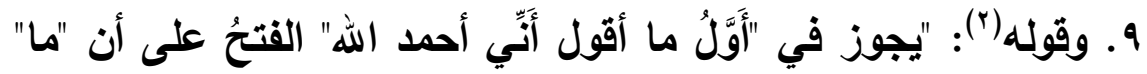

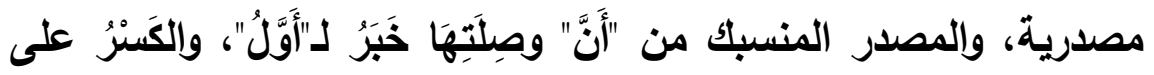

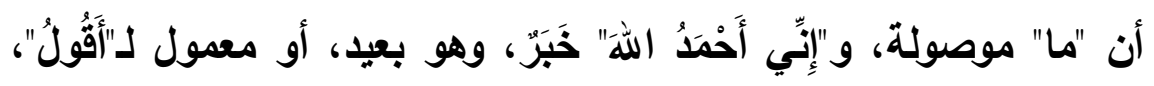

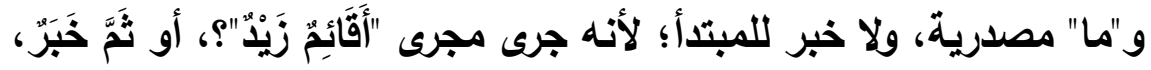
لكنه لا يمكن تقديره، أو يمكن، وهو "ثابت" أو "موجود"، وهذا مذهب الفارسي، وحكي عن عضد الدولة أنه أجاز أن يكون "إنِّي أحمد الله" لهونه معمولا لقول مضمر".

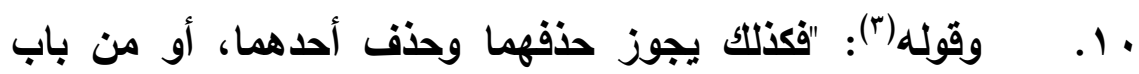
"ظن" جاز حذفهما اختصارا أو اقتصارا، خلافا للأخفش في منعه حذقهما اقتصارا مطلقا، وللأعلم في منعه في "علمت" وما في معناها، لا في "ظنتت" وما في معناها".

() انظر : النص المحقق ص 0با .

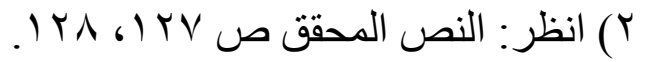

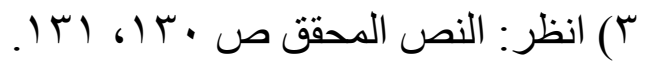




\section{r. IV Rدار}

حولية كلية اللغة العربية بالمنوفية العدد الثاني و الثثلاثون

\section{المبــث الغنالث}

أصول النهو عنــ أبيى هبان من خلال (الموفور)

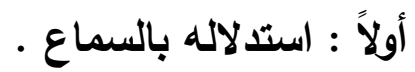

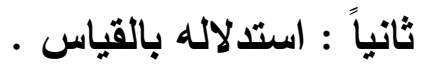

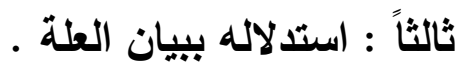

رابعاً : الاستقراء .

أولاً : استدلاله بالسماع: : الاصلاع

لم يعتمد (أبو حيان) كثيرًا على السماع في كتابه ( الموفور)، فقد استتد إليه قليلا، لكنه كان يقدمه على القياس، فقال في معرض حديثه عن المعدول في العدد(1): "المعدول في العدد لا يكون إلا موازن (مَفْمَل أو أو

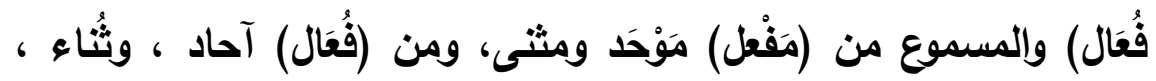

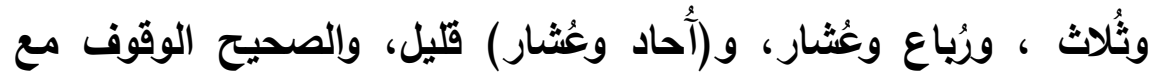

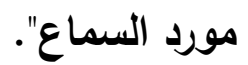

ومن أمثلة اعتماده على السماع:

ا. أنه ذهب إلى أنَّ من المصادر والصفات ما ينصب بفعل مضمر، ومنه

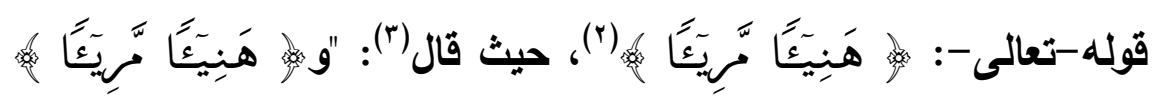
صفتان منصويتان بفعل مضمر على أنهما حالان، فإذا قلت لمن هو في حال التنعم: هنيئًا لك ، فكأنك قلت: أدام الله للك من النعيم ما أنت فيه

\footnotetext{
() انظر: النص المحقق ص سY (Y)

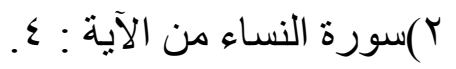

ب) انظر : النص المحقق صن صن الابه : 197.
} 
هنيئًا، وكذلك (مريئًا) إلا أنه لا يستعمل إلا بعد (هنينًا)، وقيل يستعل وحده ولا يحفظ ذللك".

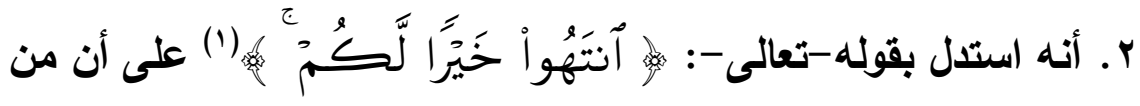
الأسماء التي تنصب بفعل مضمر ما لا يجوز إظهاره لالالة ما قبله عليه، حيث قال(r): "كلّ اسم ينتصب بمضمر على معنى الأمر قد تقدم النهي

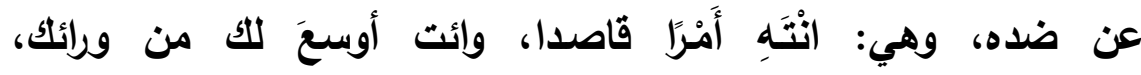

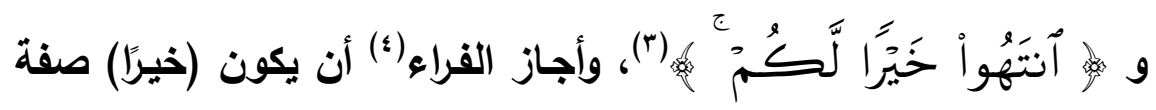
مصدر محذوف، أي انتهاءً خيراً لكم".

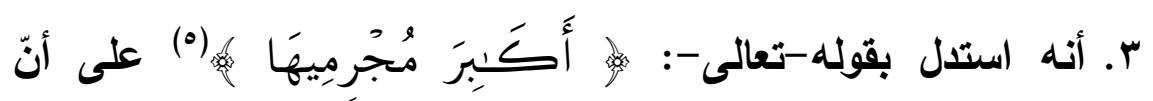
(أفعل) إذا كان للمفاضلة، وكان مضافًا جاز فيه وجهان: الإفراد والتثنية

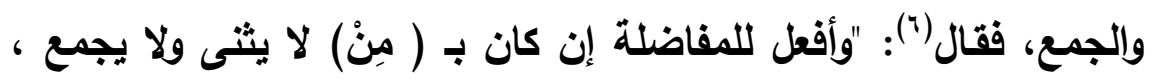
أو بـ (أل) فالأفاضل، أو مضافًا وجهان: أن يكون مفردًا، والتثية

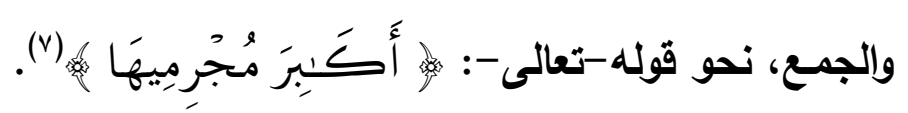

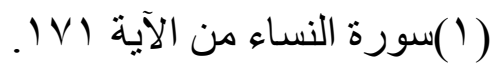

$$
\begin{aligned}
& \text { (Y) انظر : النص المحقق ص (Y) 191. }
\end{aligned}
$$

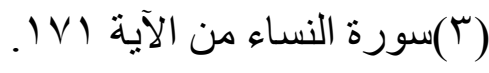

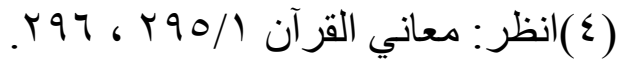

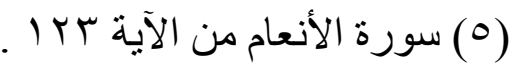

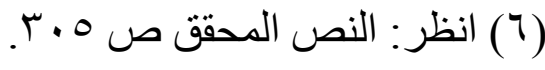

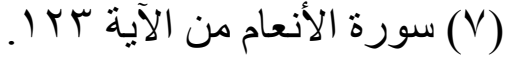




\section{r. TV إصدار}

حولية كلية اللغة العربية بالمنوفية العدد الثاني والثلاثون

وأما عن استدلاله بالسماع الشعري فقليل-أيضاً - ومن ذلك :

ا-كلامه عن الترتيب بين (أكتع) و(أجمع)، حيث قال('): "وترتيبها إذا بال اجتمعت كهو في مفردها إلا أبصع وأبتع فمن زادها لا يبالي أيهما قدم فإن لم تأت بالنفس أتيث بالباقي على الترتيب وهكا إلى أجمع، فإن لم تأت إتى به لم تأت بما بعده وقوله:

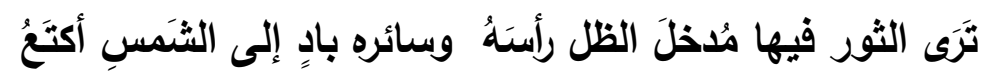

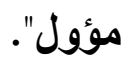

r-ومن ذلك قوله في باب التنازع(؟): "ويتصور في بعض المسائل عود

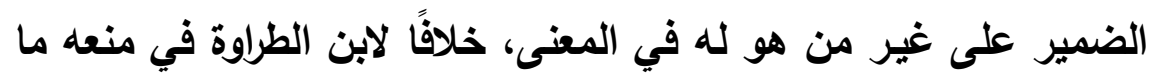
أدى إلى ذلك، وقول امرئ القيس: *كفاني ولم أطلب قليل من المال

ليس من الإعمال خلافا لأبي إسحاق بن ملكون". ثانيًا : استدلاله بالقياس: استخدم أبو حيان القياس في إثبات الأحكام النحوية، لكنه كان دائمًا يقدم

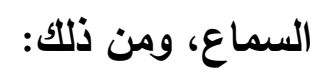
ا-قوله في ذلك في باب (ما ينصرف ومالا ينصرف)(ॅ): "المعدول في العدد لا يكون إلا موازن (مَفْعَل أو فُعَال)، والمسموع من (مَفْعل): مَوْحَد

() انظر : النص المحقق ص 111 ). r) انظر : النص المحقق ص س9 19.

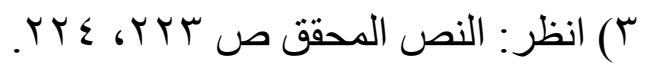




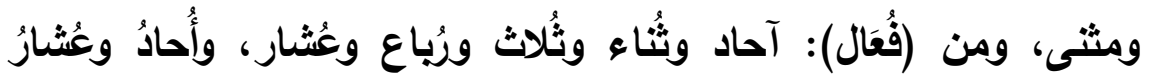

قليل، والصحيح الوقوف مع مورد السماع".

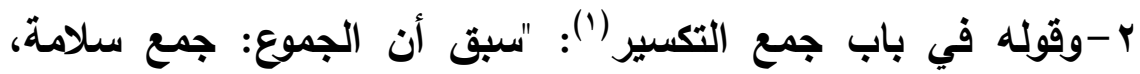

وسبق حكمه، واسم جمع ولا يدرك بالقياس، إنما هو محفوظ". - ومن استعماله للقياس:

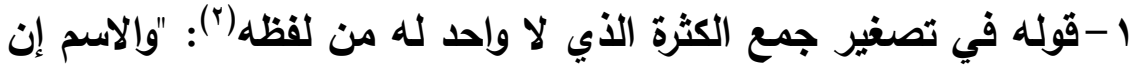

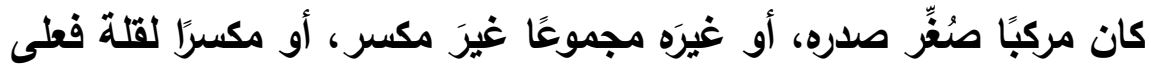

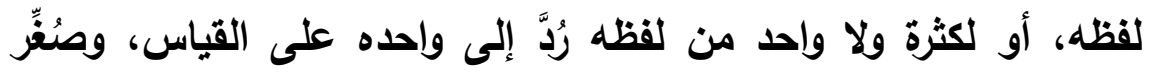

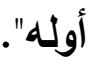
- وكان يستخدم القياس للتدليل على صحة ما يقول متأثرًا في ذللك بابن

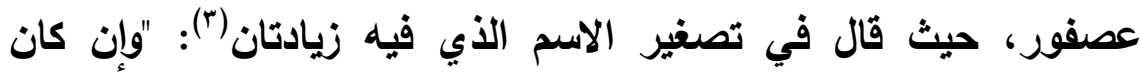

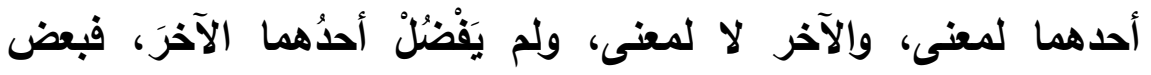
النحويين لا يحذف إلا ما ليس له معنى، وهو القياس، وتحذف ولهن أيهما

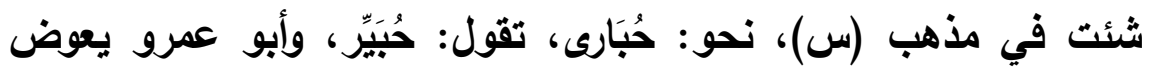

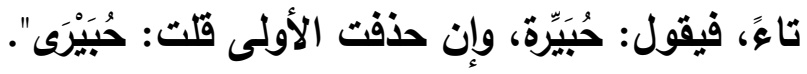
- ثالثاً : استدلاله ببيان العلة:

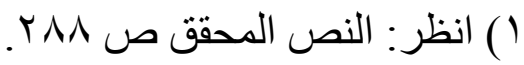

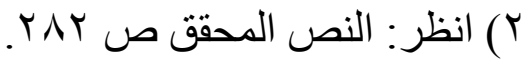

r) انظر : النص المحقق ص سرץ؟. 


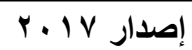

حولية كلية اللغة العربية بالمنوفية العدد الثاني والثلاثون

استخدم أبو حيان العلة، وجعلها أداةً لتصحيح ما يريد قوله وتأكيده، وكان ينطلق في تعليلاته من تعليل ابن عصفور، وق وردت عنده أنواع عدة من العلل في كتابه (الموفور)، ومنها: ا - علة التسمية: ومن أمثلة ورودها عنده:

- في حديثه عن ألف التأنيث المانعة للاسم من الصرف، حيث قال (1):

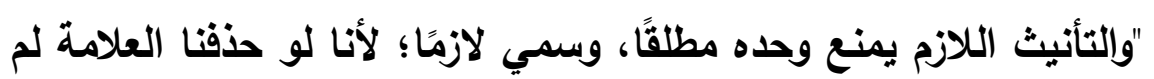
تبق كلمة تامة، وقيل: لأنها بمنزلة حرف من نفس الكلمة، وهو الصحيح". - (الصيح

- وقوله-أيضا-في الجمع الأي لا نظير له في الآحاد(ץ): " والجمع سمي جمعًا لا نظير له في الآحاد لأنه ليس فيها ما يوافقه حركاتٍ وبكناتٍ وعددَ حروف، وسراويل أعجمي، ويتقدير أنه عريي فجمع سروالة، وقد نطق بها، وحَضاجر جمع، وتغاز: تقاعل، ويمان ألفه بلا، وقيل: سمي بذلك لأن كل جمع يجمع، فيصير مفردا بالنظر إلى الجمع الثاني، وهذا لا يجمع، ولهذا سمي المتناهي، وقيل: لعدم جمعيتِه ونظيرِه في المفردات، فإن سميت به امتتع، فإن نكَّرته فخلاف (أحمر) ، هذا ما لم تعتل لامه، فإن تعرَّف باللام أو بالإضافة انصرف مطلقًا، فإن كان نكرة

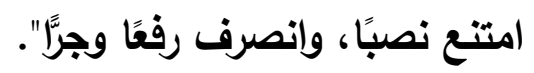

() انظر : النص المحقق ص r Y r. Y) انظر: النص المحقق ص r Y 
الموفور من شرح ابن عصفور

- قوله في باب المقصور (1): "المقصور سئمِي بذلك لأنه قصر عن

الإعراب أو عن الغاية التي للمد". لوعاب.

r - بلة تسويغ الابتداء بالنكرة :

- ومن ذلك: حديثه عن (مَنْ) في باب حكاية الأسماء الأعلام بـ (مَنْ) حيث قال(r): "ومَنْ في هذا الباب خبر مقدم والاسم العلم بعدها مبتدأ، وقد

يجوز عكس ذلك".

ب - علة الاستغناء:

- ومن أمثلتها عنده: ما ورد في باب "تعم" و"بئس"، حيث قال("): "وإذا كان الفاعل ضميرا لم يثن ولم يجمع؛ استغتاء بتثنية الممدوح أو المذموم وجمعd".

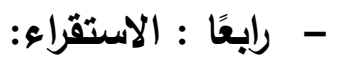

استدل أبو حيان بالاستقراء في موضع واحد، وذلك في باب العلم، حينما تكلم عن أعرف الأعلام، حيث قال (؛): "العلم: ما عُلِّقَ في أول أحواله على هلى

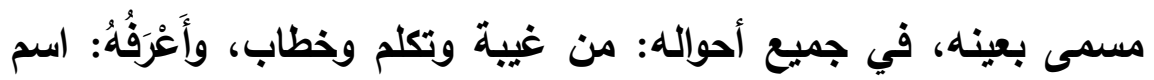

الأماكن، ثم الأناسي، ثم اسم الجنس، ولا يعرف هذا إلا بالاستقراء".

() انظر : النص المحقق ص س آ.

r) انظر : النص المحقق ص VTr.

() انظر : النص المحقق ص 90.

؟) انظر : النص المحقق ص ؟ V. 


\section{القسم الثاني \\ التحقيق}

- - وصف النسخة المحققة. - توثيق نسبة الموفور لأبي حيان. - منهج التحقيق. - - صور من المخطوط المحقق. - - النص المحقق للكتاب. 
اعتمدنا في تحقيق هذا الكتاب على نسخة واحدة، وهي النسخة المحفوظة في دار الكتب المصرية ضمن مجموع فيه عدة رسائل، ورقم التصوير (

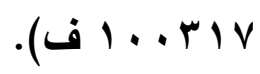

وقد نسخت بخط مؤلفها أبي حيان في القرن السابع الهجري، وخطها

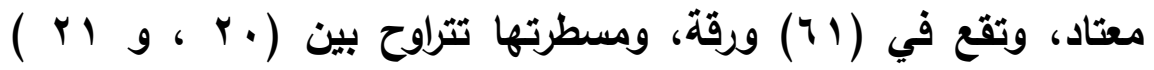

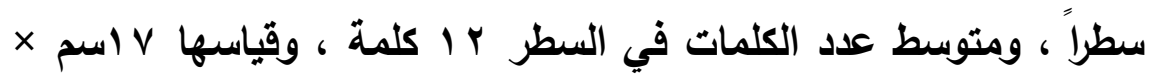

$$
\text { - بايته سما: }
$$

تبدأ هذه النسخة بقوله(1): "بسم الله الرحمن الرحيم، قال أبو حيان محمد بن يوسف بن حيان: ويعد، فإني لَمَّا اختصرت المُقَرَبَِ للأستاذ أبي الحسن بن عصفور في كتاب سميته بالتقريب ، وأردفته بشرح لطيف، وسميته بالتدريب، واختصرتُ في التصريف المُمْتِعَ في كتابٍ سَمَّنْيُهُ

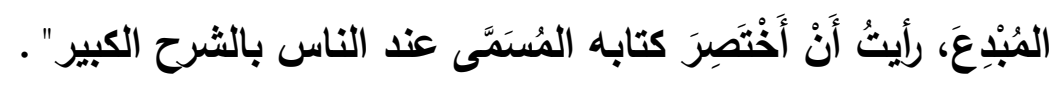

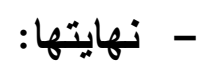
تنتهي المخطوطة بقوله في باب الإمالة(؟): "قيل: أو بثلاثة أولها ساكن ويذلك الشرط، ولانقلاب عن ياء، وللشبه بذلك، ولانقلاب عن واو وتطرفت

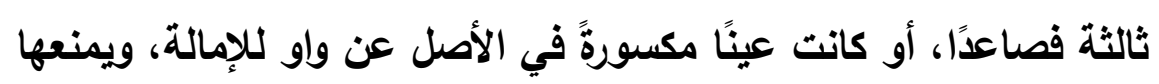
مستقل إن كانت الكسرة".

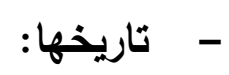

$$
\text { (Y) (1) انظر : الموفر : الموفور لوحة (Y/I ). }
$$


ليس على هذه النسخة ما يشير إلى تاريخ تأليفها أو كتابتها، ولكن الاكتورة خديجة الحديثي ترجح أن أبا حيان ألَّف الموفور بعد انتهائه من من

تأليف المبدع الذي انتهى منه سنة 99 7هـ (1).

هذه النسخة كتبها أبو حيان بخطه، كما هو مثبت على الصفحة الأولى لتّل من المخطوط، ويلاحظ على هذه النسخة ما يلي: 1-أن عنوانات الأبواب كتبت بخط عريض. r - أنه ليس فيها نظام التعقيبة. r-بعض الفقرات والعبارات الساقطة كان يكتبها أبو حيان في الحواشي، ويشير إليها بـ(صح). ع - يوجد بها ضبط لبعض الكلمات.

ه-كتب على الصفحة اليمنى من اللوحة الأولى بقلم مغاير لخط المخطوط: "كتاب الموفور من شرح ابن عصفور، المؤلف أبو حيان محمد بن يوسف الغرناطي (ته \& Vه) بخط المؤلف". צ-بعض صفحات المخطوط طمست فيها بعض الكلمات، وخاصة في المواضع التي استدرك فيها أبو حيان ما سقط من المتن في الحاشية. V أن أبا حيان كان يرمز لسيبويه غالبا بـ(س).

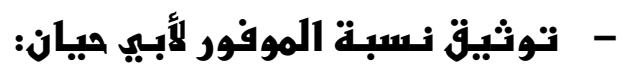
كتاب الموفور لأبي حيان، ولا شك في ذلك، وقد ذكره أبو حيان مع جملة مؤلقاته في إجازته التي أرسل بها للصفدي حين أرسل إليه الصفدي 
يسأله الإجازة بما قرأه عليه، ومما جاء في هذه الإجازة قول أبي حيان ('): "وأما ما صنفتُ فمن ذلك: البحر المحيط في تفسير القرآن العظيم، إتحاف الأريب بما في القرآن من الغريب ..... كتاب الموفور". يضاف إلى ذلك قول أبي حيان في مقدمة الموفور ()" "فإني لَمَّا اختصرت المُقَرَبَِ للأستاذ أبي الحسن بن عصفور في كتاب سميته بالتقريب، وأردفته بشرح لطيف، وسميته بالتدريب، واختصرتُ في التصريف المُمتّعَ

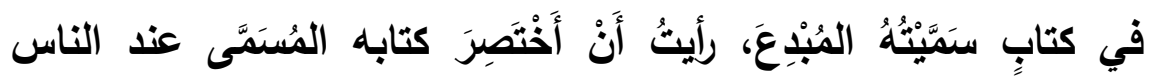
بالشرح الكبير ....، ولَمَّا كان كتاب المُقَرَبٍِّ مِنْ أحسن الموضوعات

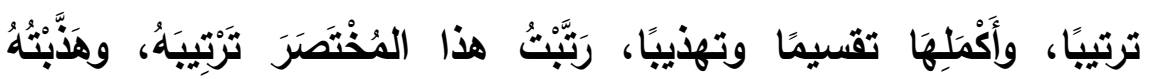

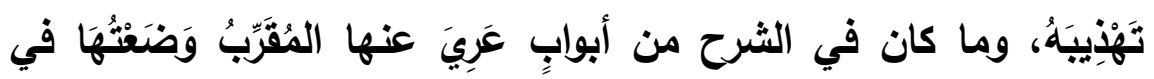

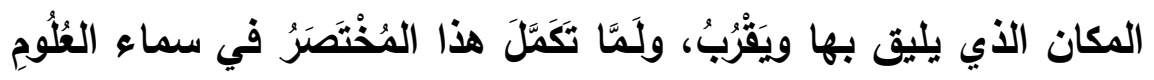

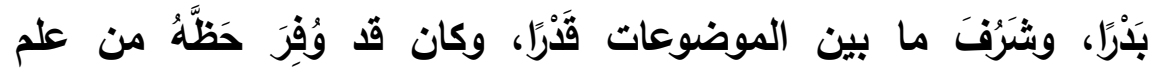

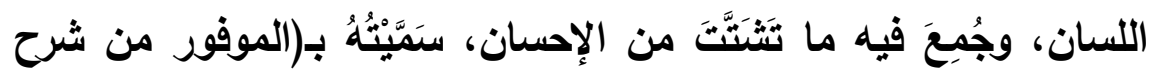
(ابن عصفور)". ويهذا العنوان الذي وضعه أبو حيان ذكره الفيروزابادي(").

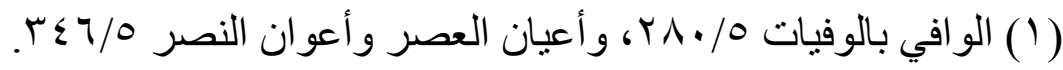

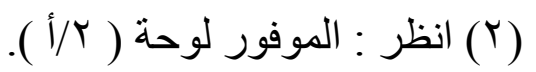

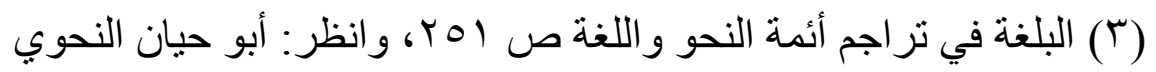
للاكتورة خديجة الحديثي. 
كما أن عددا من الأين ترجموا لأبي حيان ذكروا الموفور ضمن مؤلفاته،

ومنهم: الصفدي، وإبن شاكر الكتبي، والمَقَّرِيُّ، وإلشوكاني (').

ولكن الحاج خليفة ذكر عنوانه هكا(ץ): "الموفور في تحريز أحكام ابن عصفور لأبي حيان محمد بن يوسف الأندلسي"، وكذا ذكره إسماعيل باثـا

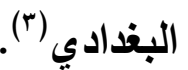

وقد اعتمدنا العنوان الأي نص عليه أبو حيان في مقدمته للكتاب، وهو (الموفور من شرح ابن عصفور). - تنبيه:

وَهِمَ محقق شرح الجمل لابن عصفور، فظن أن الموفور اختصارٌ للمقرب، فقال(؛): "والذي يظهر أن لابن عصفور شرحين على المقرب، أحدهما كبيز، وهو الأي اختصره أبو حيان في كتاب سماه الموفور من شرح ابن

عصفور".

وهذا غير صحيح؛ لأن الموفور اختصار لشرح الجمل، كما ذكر أبو حيان في مقدمته، وكما ذكر عدد من المترجمين لله، وكما هو واضتح من مادة الكتاب.

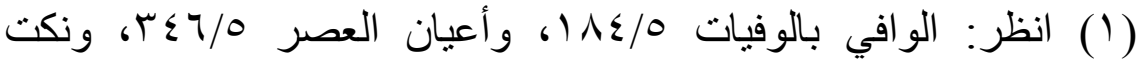

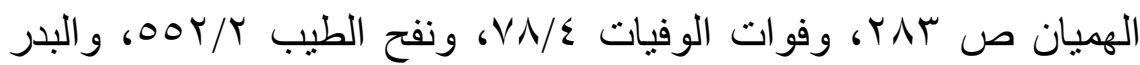

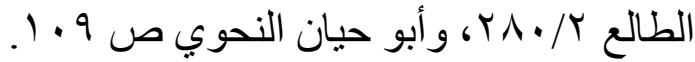

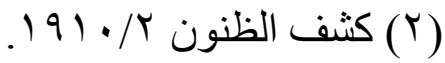

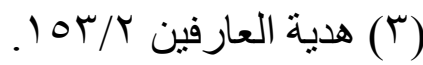

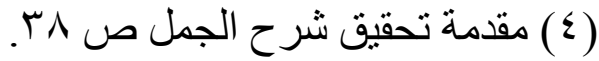




\section{- منـمج التهقيــة :}

من أهداف تحقيق المخطوطات إخراجها على الصورة التي أرادها مؤلفوها، ولا شك أن الوصول إلى هذه الغاية يحتاج إلى جه مُضْنِ، ووقت طويل، وحرصًا منا على إخراج هذا الكتاب (الموفور من شرح ابن عصفور) في صورة سليمة وجيدة، وعلى تسهيل الاطلاع عليه، والانتفاع به، اتبعنا الخطوات الآتية:

1-كتابة النص وفق القواعد الإملائية المتبعة اليوم، مع مراعاة علامات

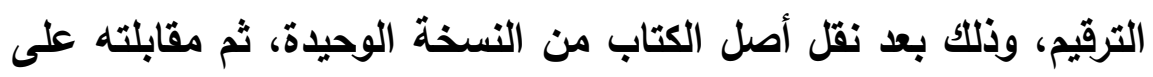
هذه النسخة. r-تقويم النص وتصويب ما وقع فيه من تصحيفات وتحريفات وأخطاء، مع الإثارة إلى ذلك كله في الحاشيـة. r-اعتمدنا (شرح الجمل لابن عصفور) بتحقيق الاكتور/ صاحب أبي جناح في توضيح بعض النصوص، وإكمال ما انطمس من نسخة الموفور - أن ـ - وضعنا ما يحتاج إليه النص من زيادة بين هذين المعقوفين [ ]؛؛ وذلك حسبما يقتضي السياق، وقد تكون الزيادة من شرح الجمل لابن عصفور، أو من عندنا.

ه-عزونا الآيات القرآنية إلى سورها مع ذكر أرقامها، ووضعها بين قوسين مزهزين هكا ( ) مع كتابتها بالرسم العثماني. צ-خرَّنا الشواهد الشعرية، وذلك بضبط ألفاظها، وذكر بحرها، ونسبتها إلى أصحابها ما أمكن، ثم الإحالة على دواوين أصحابها إن وجدت، مع ذكر عدد من كتب النحو واللغة والأدب والمعاجم، التي ورد فيها الثاهد، وإكمال البيث في التعليق إن كان ناقصًا في الأصل. 
V-وثَّتا نقول أبي حيان عن الأعلام الأين ورد ذكرهم في الثرح بالرجوع إلى مؤلفاتهم إن وجدت، أو مؤلفات غيرهم إن لم يكن لهم كتب متداولة. ^- علقتا على بعض المسائل التي تحتاج إلى التعليق، كاختلاف الآراء في المسألة، أو وجود أراءٍ أخرى مغايرة لرأي أبي حيان، حتى يتبين رأيه من الآراء الأخرى، وكي يتحدد موقفه واتجاهه النحوي، مع بيان ما نراه راجحًا ومختارًا باختصار . 9-ترجمنا للأعلام الواردة في الشرح بإيجاز عند ورودها أول مرة. • - أشرنا إلى نهاية كل لوحة من لوحات الأصل، وذلك بوضع خط

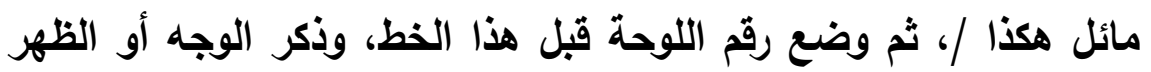
بعدهذا الخط، مع الإشارة إلى وجه الورقة بالحرف ( أ )، وإلى ظهرها

$$
\text { بالحرف (ب). }
$$

11- استتنينا عن ذكر بيانات المصادر والمراجع في الحاشية اعتمادًا على ذكرها في قائمة المراجع. r ا - ذيلنا التحقيق بفهارسَ فنيةٍ تفصيلية، تشمل: فهرسيًا للآيات القرآنية، وللأشعار، وللأعلام، وللكتب، وللمصادر والمراجع، وللموضوعات. ويالتَّه التوفيق 

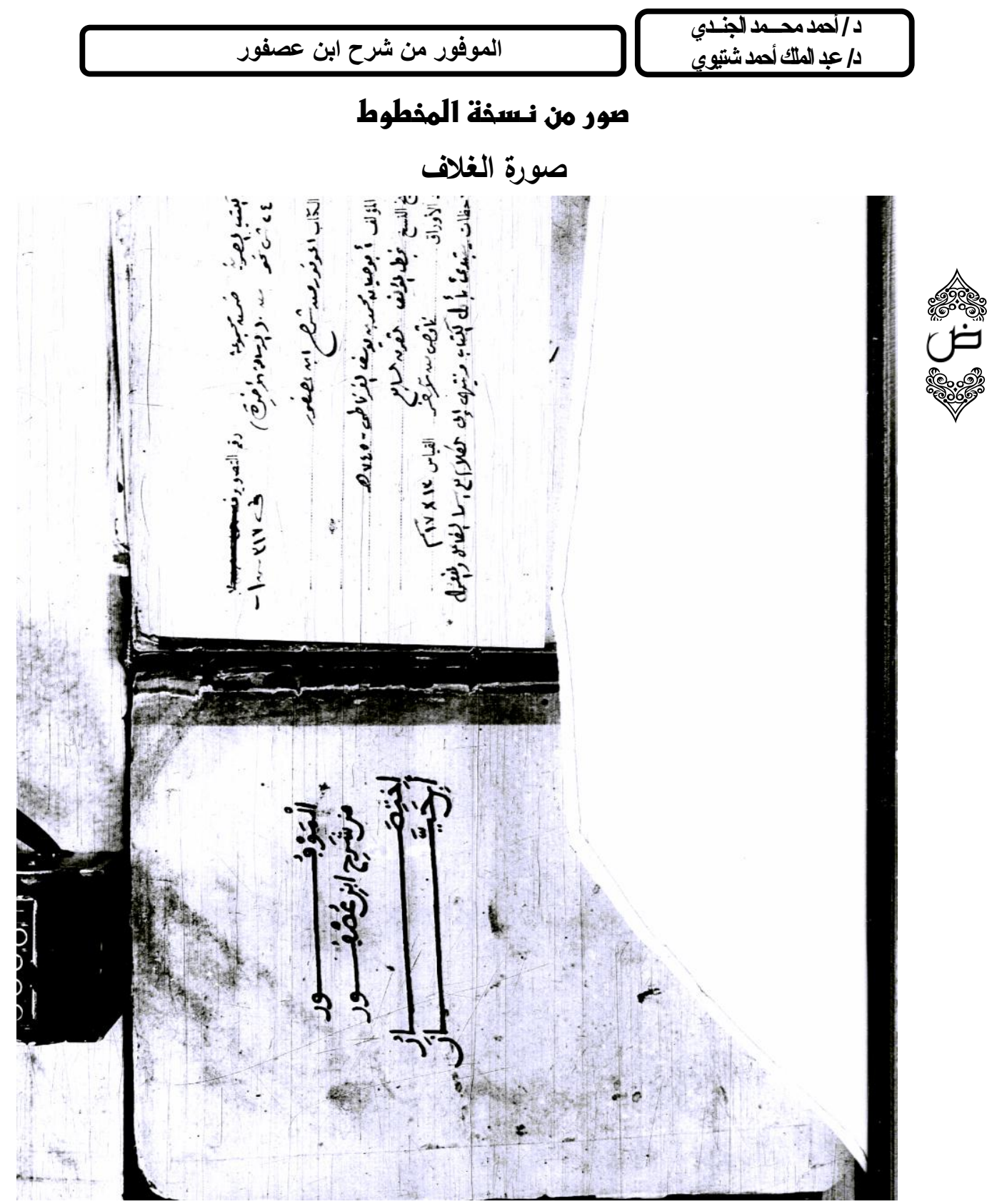

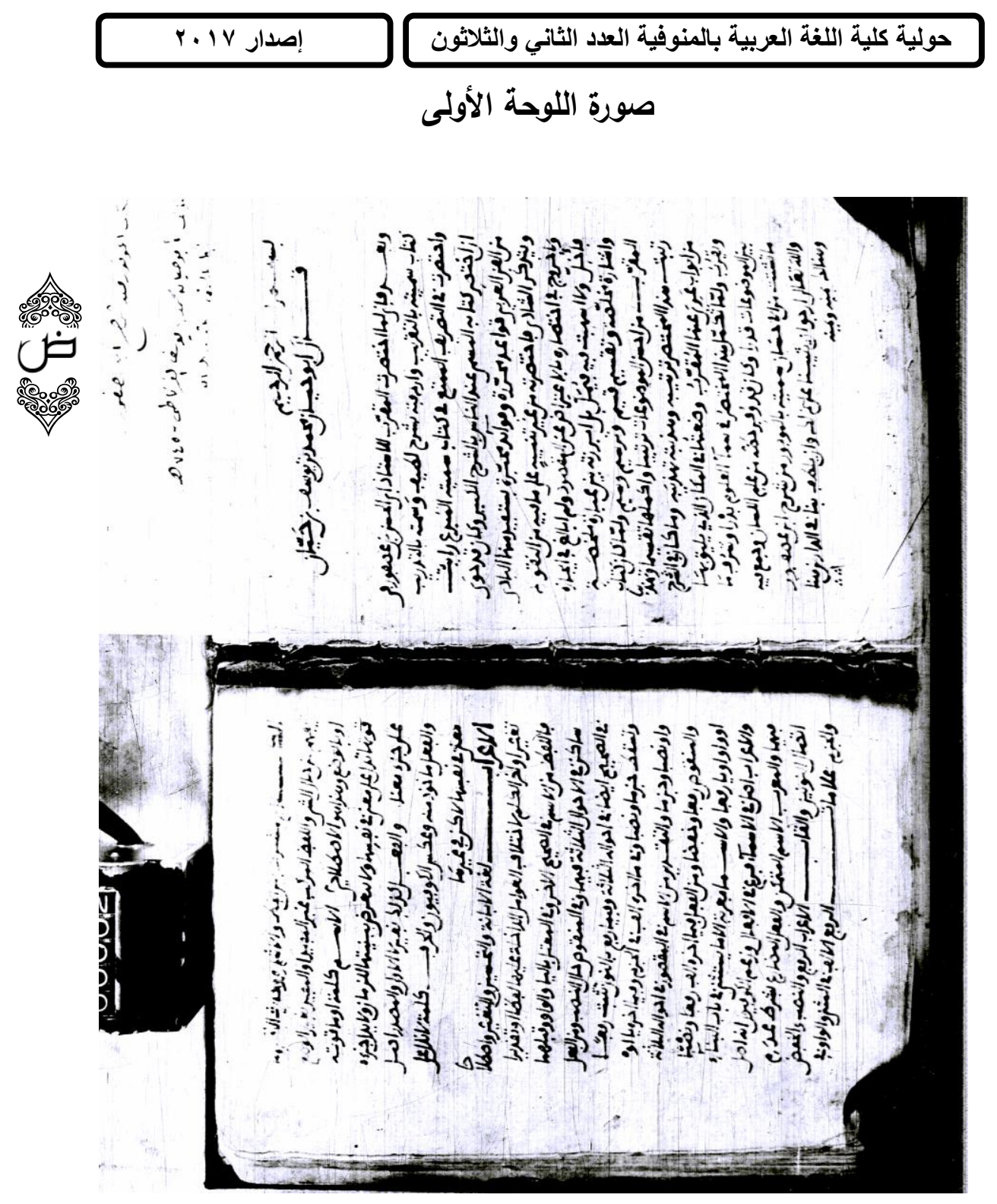

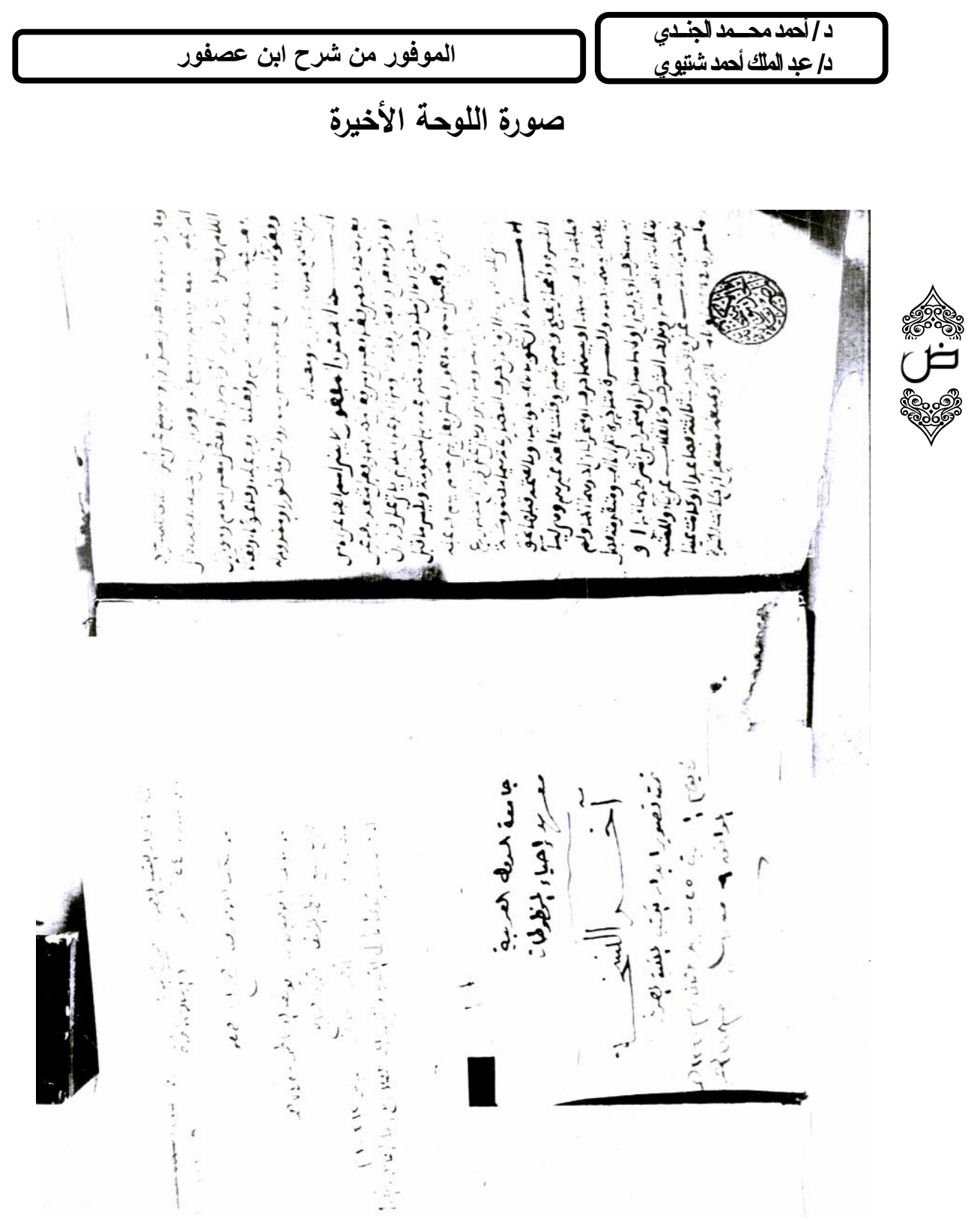


$$
\text { حولية كلية اللغة العربية بالمنوفية العدد الثاني والثلاثون }
$$

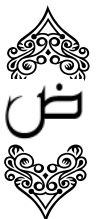

النص الامقت

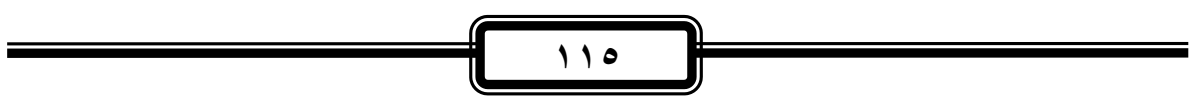




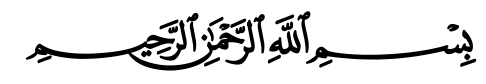

قال أبو حيان محمد بن يوسف بن حيان:

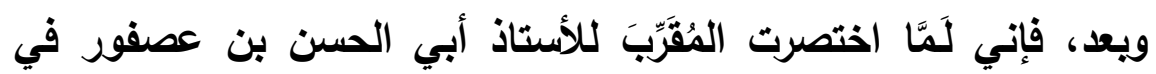
كتاب سميته بالتقريب(1)، وأردفته بشرح لطيف، وسميته بالتدريب(؟)،

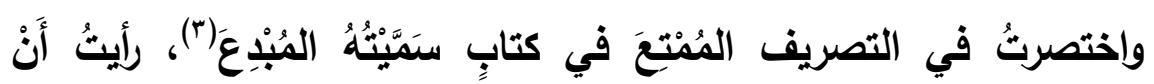

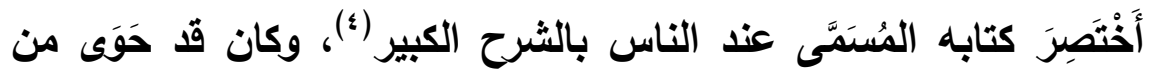

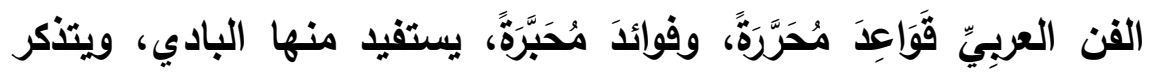

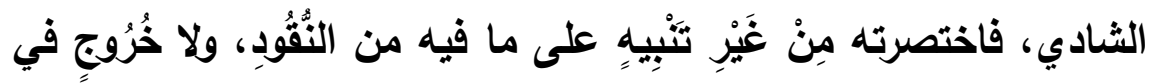

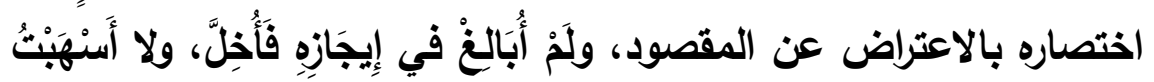

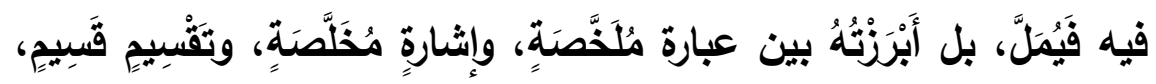

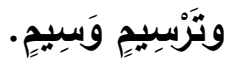

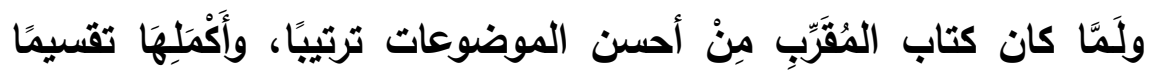

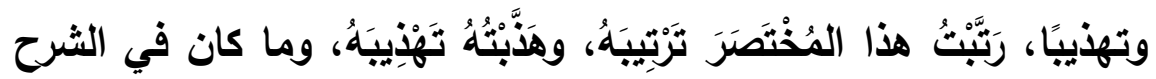

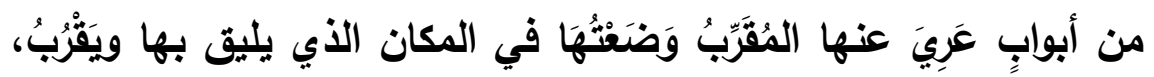

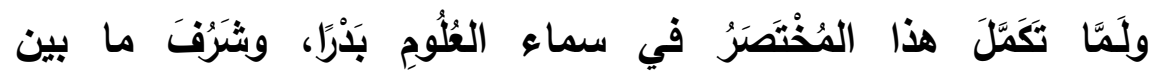

(1) تقريب المقرب، حققه الدكتور/عفيف عبد الرحمن، ونشرته دار

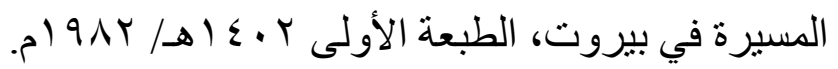

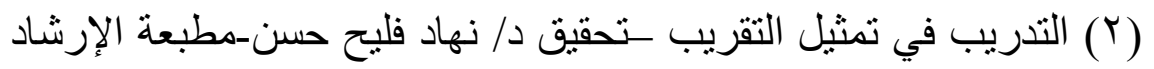
بيغداد-9 (Y) حققه الدكتور/ عبد الحميد السيد طلب، ونشرته مكتبة دار العروبة

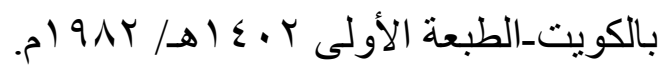

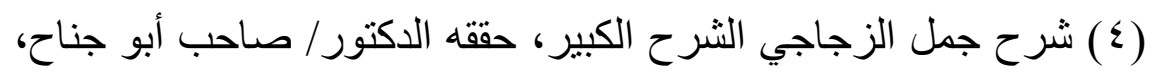

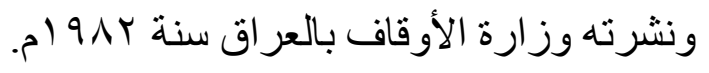


الموضوعات قََْرًا، وكان قد وُفِرَ حَظَّهُ من علم اللسان، وجُمِعَ فيه ما

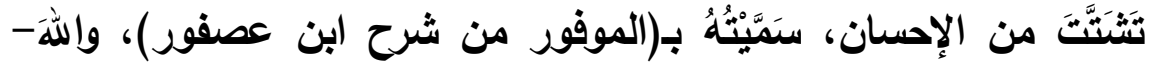

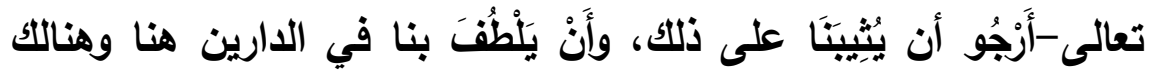

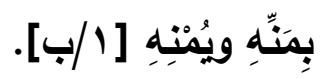

****** $* *$

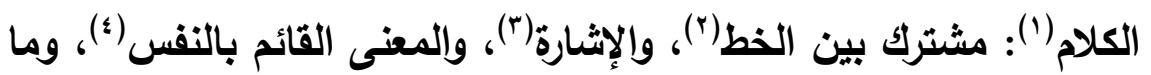

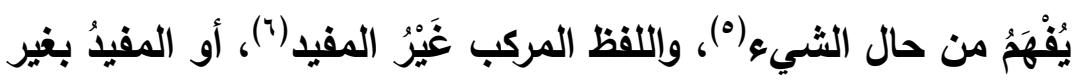

(1) انظر: شرح الجمل لابن عصفور 10/1، وشرح الجمل لابن الفخار

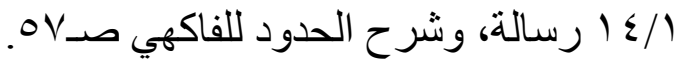
(Y) يقولون للرسوم التي بين الدفتين: هذا كلام الله، انظر : التذييل والتكميل $. r 0 / 1$ (ب) و أنشدو ا على ذللك:

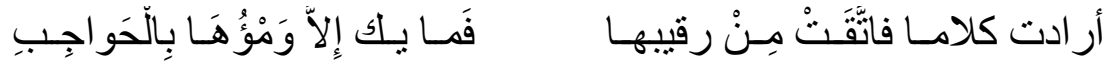

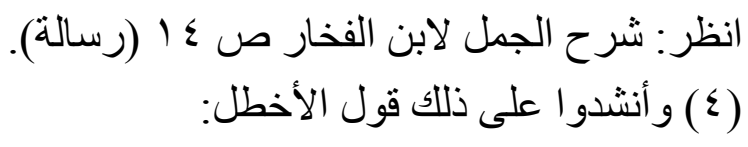

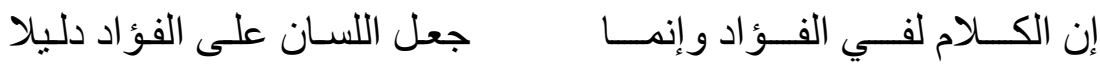

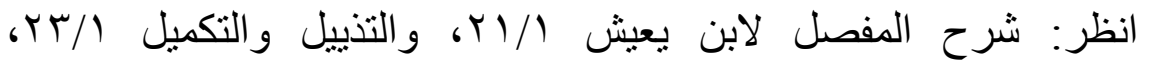

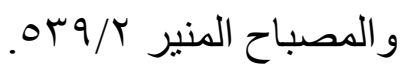

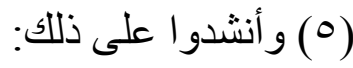

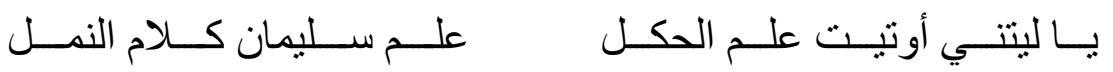

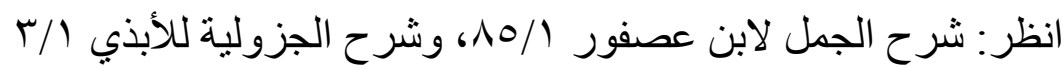
(رسالة). (7) يقال: تكلم، و إن لم يفد. 


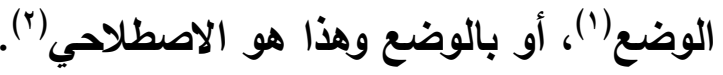

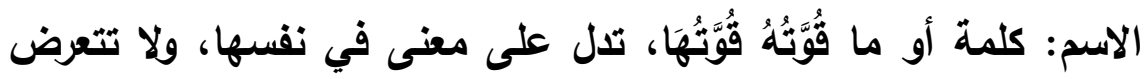

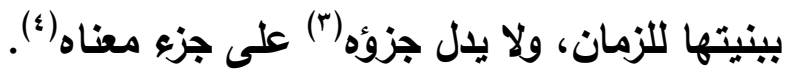
والفعل كذلك بغير "لا" الأولى (•).

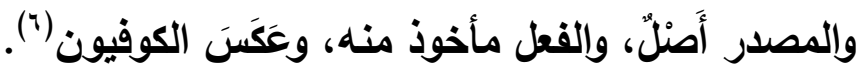

(1) يقال: تكلم ساهيا و نائما، ومعلوم أن الساهي و النائم لم يضعا لفظهما

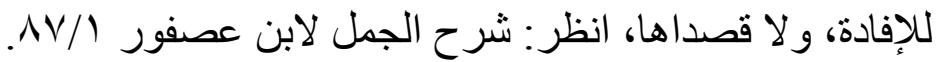

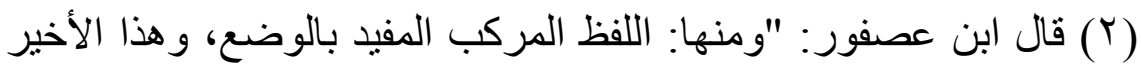
الذي أراد أبو القاسم بالكلام؛ لأن هذا الذي اصطلح النحان النحويون على تسميته

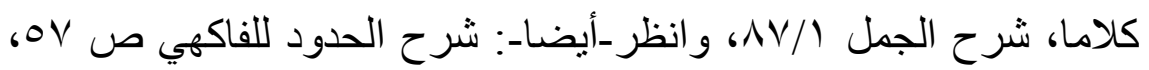

$$
\begin{aligned}
& \text { وشرح الحدود لابن قاسم ص آ آ. } \\
& \text { (؟) في الأصل: "جز أعه". }
\end{aligned}
$$

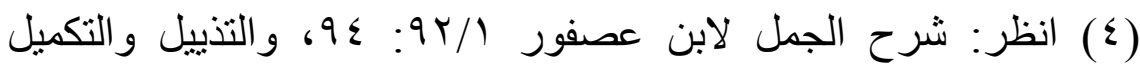

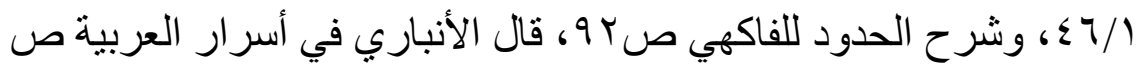

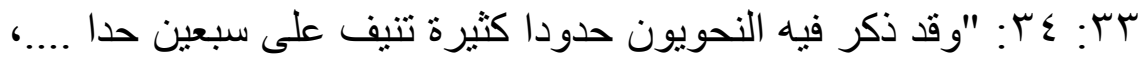

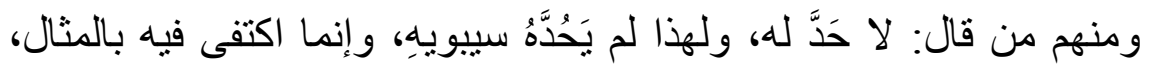

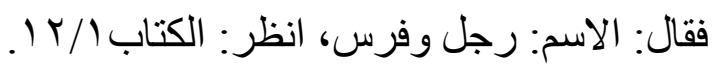

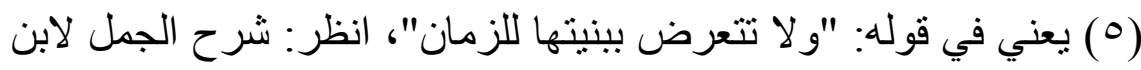

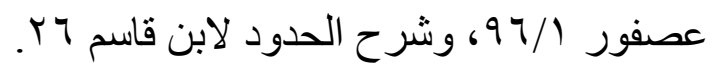

(T) الأول قول جمهور البصريين، وهذا معنى قول سيبويه: "وأما الفعل

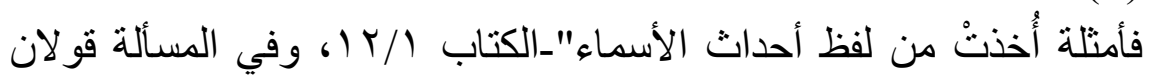

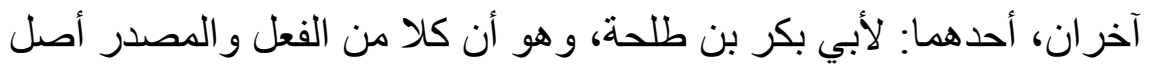

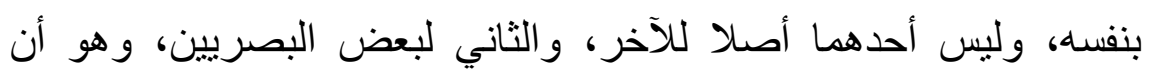

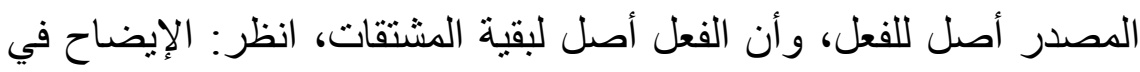

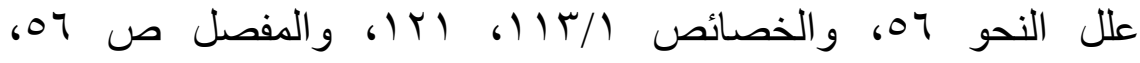




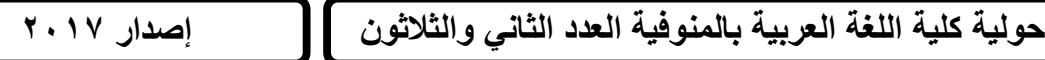

والحرف: كلمة لا تلال على معنَى في نفسها، لَكِنْ في غيرهما(').

الإعراب لغةً: الإبانة والتحسين والتغيير (؟).

واصطلاحا: تغيير أواخر العَلم؛ لاختلاف العوامل الداخلة عليها لفظًا أو

تقديرًا (")

فاللفظ من الاسم في الصحيح الآخر، وفي المعتل بالياء والواو وقبلهما ساكن في الأحوال الثلاثة فيهما، وفي المنقوص حال النصب، ومن الفعل في الصحيح-أيضًا-في أحواله الثلاثة، وفيما رُفِعَ بالنون تثبت رفمًا، وتسقط جزمًا ونصبًا، وفيما آخره ألف في الجزم وفيما آخره ياء أو واو نصبًا وجزمًا.

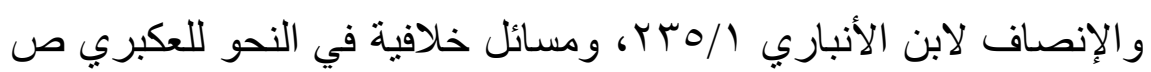

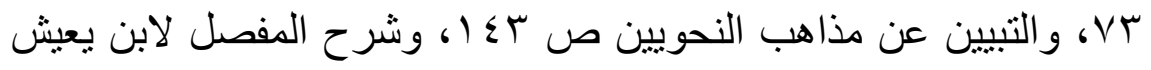

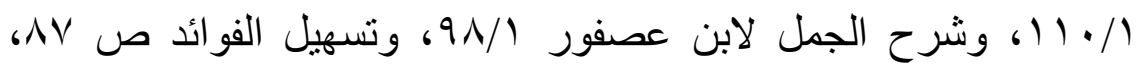

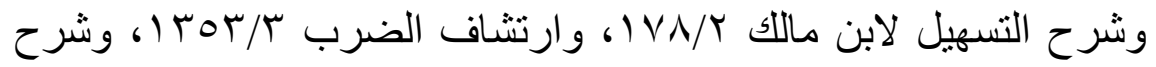

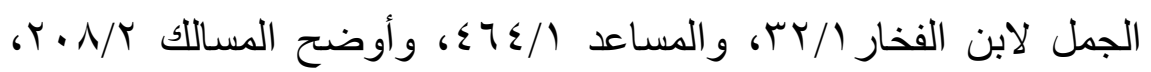

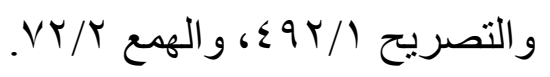

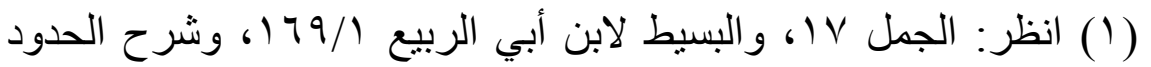

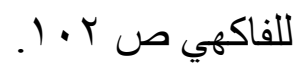

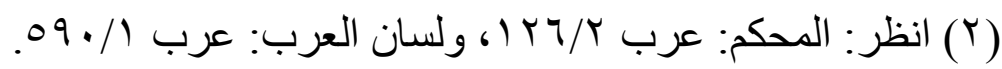

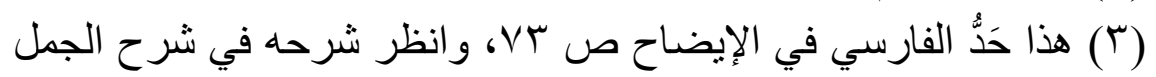

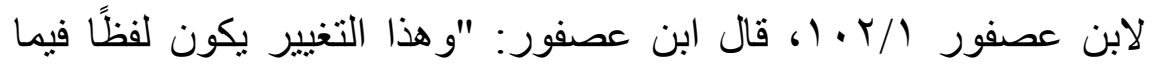

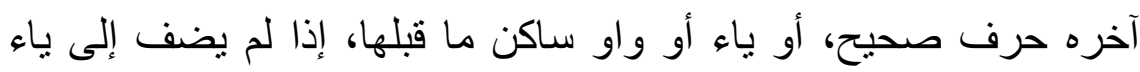

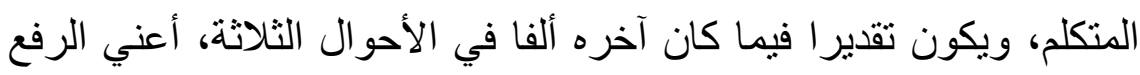

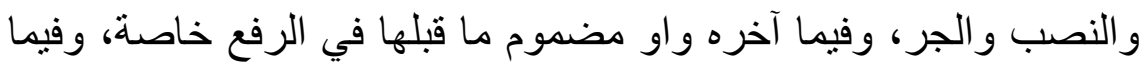

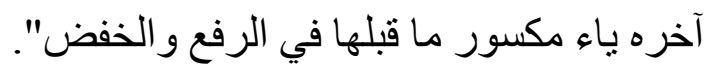


والتقاير من الاسم في المقصور في أحواله الثُلاثة، والمنقوص رفمًا وخفضًا، ومن الفعل فيما آخره ألف رفعًا ونصبًا، أو واو أو ياء رفِعًا.

والأسماء معربة إلا ما يستثنى في باب البناء.

والإعراب أصل في الأسماء، فرع في الأفعال، وزعم الكوفيون أنه أصل

فيهما (1)

والمعرب: الاسم المتمكن(؟)، والفعل المضارع بشرط عدم اتصال النونين(؟).

وألقاب الإعراب: الرفع والتصب والخفض والجزم (ء).

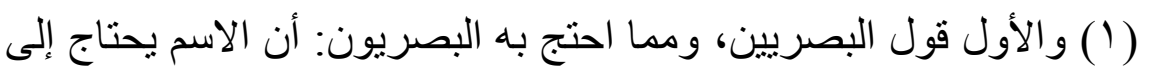

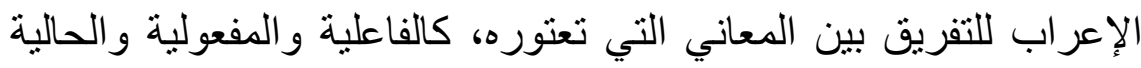

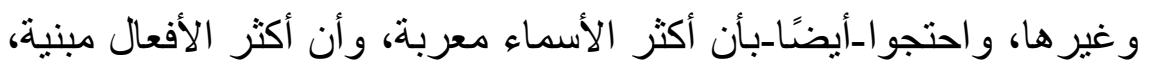

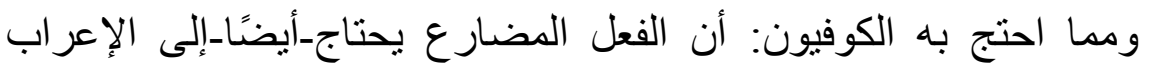

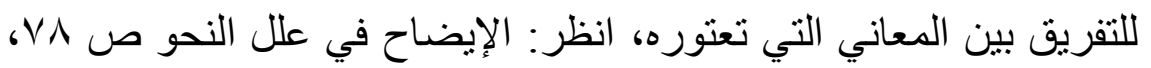

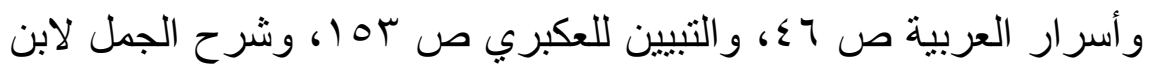

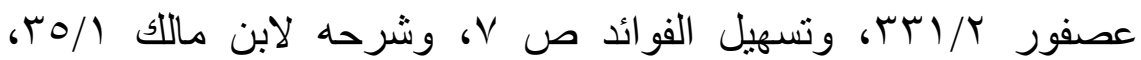

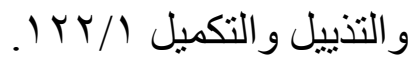

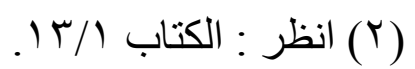

(r) قال ابن أبي الربيع: "اعلم أن المعرب من الأفعال: الفعل المضار ع إذا

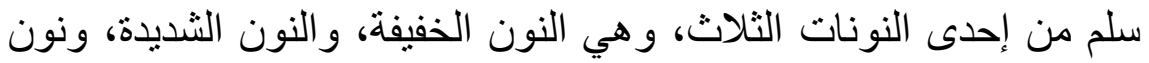

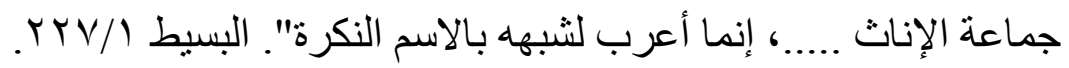

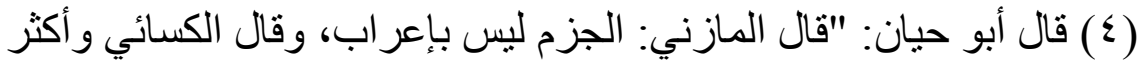

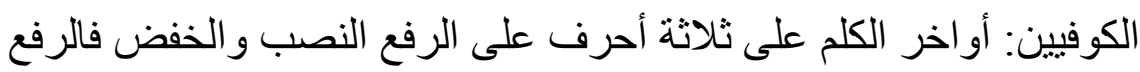

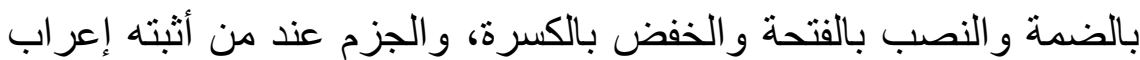

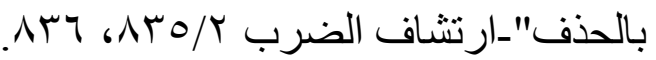


علامات الرفع: الألف في المثنى، والواو في [ب/أ] مُستَّمِ المذكر، وفي

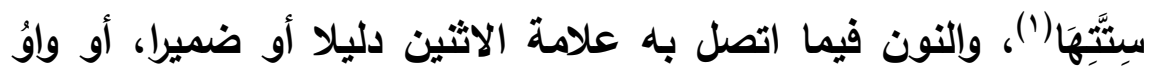
الجميع كذلك، أو ياءُ المخاطبة، والضمة فيما بقي من معرب الاسمِ

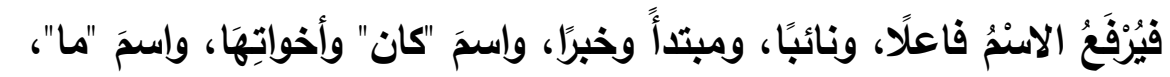

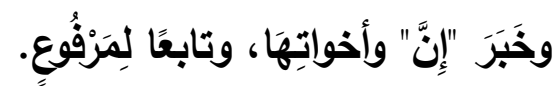

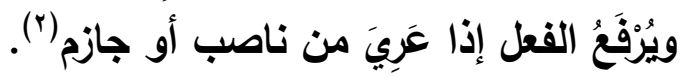

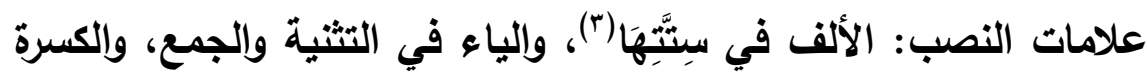
في مُستلَّم المؤنتث، وحَذْفُ النون فيما رُفِعَ باءثباتها، والقتحة فيما بَقِيَ من معربيهما.

فَيَنْصَبُ الاسمُ مفعولًا بها، وفيه، ومعه، وله، ومطلقًا، وتمييزًا، وحالًا،

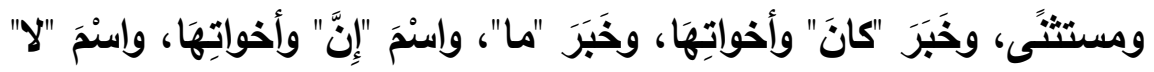

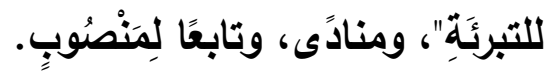

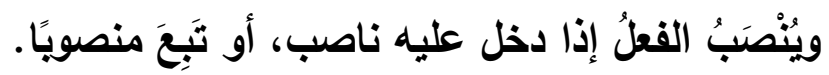
علامات الخفض: القتحة فيما لا ينصرف، والياء في سِتِّنهِا(؛)، وفي التثنية والجمع، والكسرةُ فيما بَقِيَ من مُعْرَبِ الاسم، فيُخْفَضُ بِحَرْفِ ويإضافة وتَبَعِيَّةٍ

$$
\text { (1) (1) بعني الأسماء الستة. }
$$

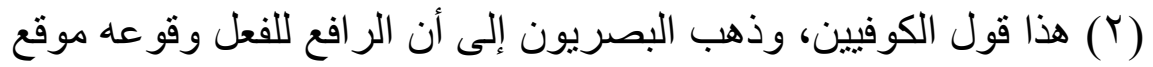

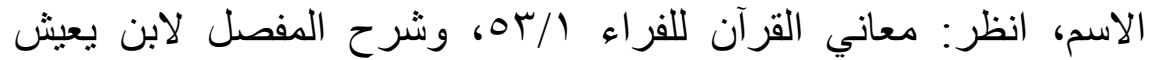

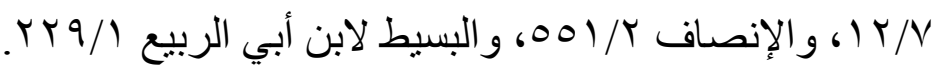

$$
\begin{aligned}
& \text { ( ) بعني الأسماء الستة. } \\
& \text { (ع) بعني الأسماء الستة. }
\end{aligned}
$$




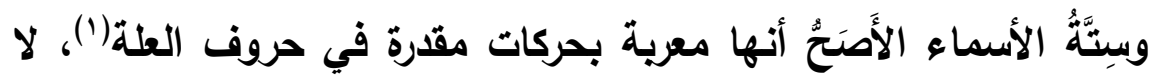
بالحروف(ז)، ولا بها ويالحركات(ז)، ولا بالحركات قبلها وهي إثباع(๕)، ولا

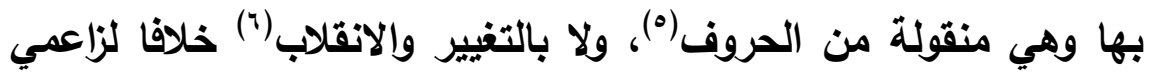
ذلك.

والتثنية والجمع الأصح أنها معربة بالتغيير والانقلاب(v)، لا بالحروف(^)،

(1) هذا مذهب سيبويه والفارسي وجمهور البصريين، انظر: ارتشاف

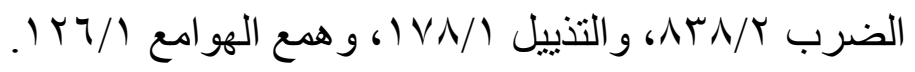

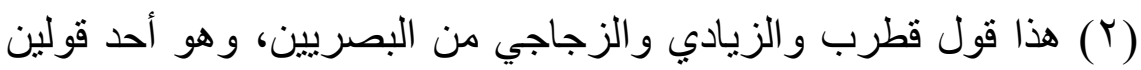

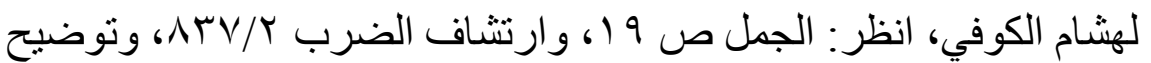

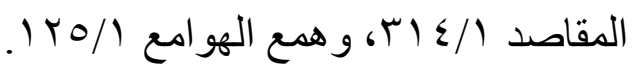

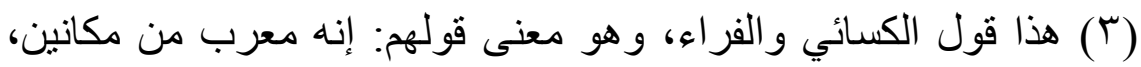

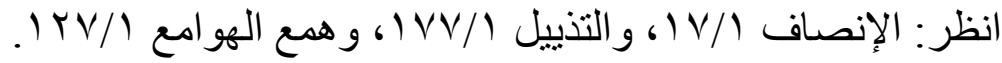

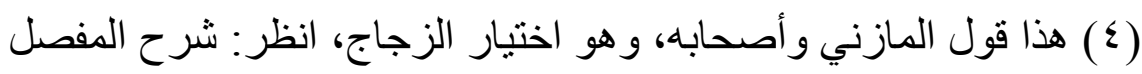

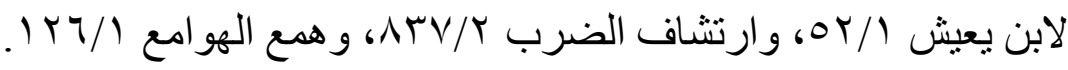

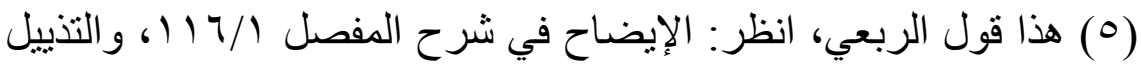

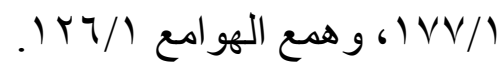

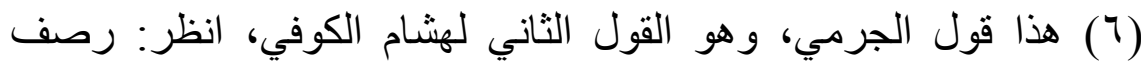

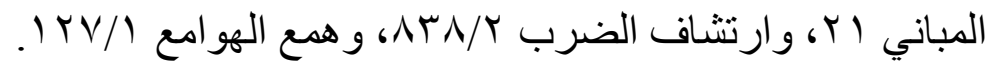

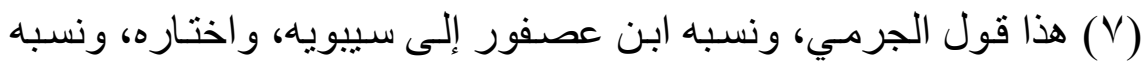

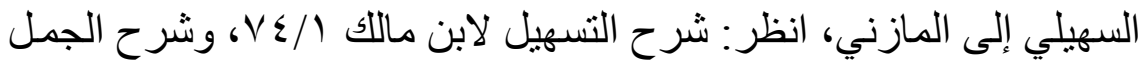

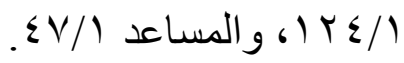

(^) هذا قول الكوفيين وقطرب و الزجاجي، وطائفة من المتأخرين، انظر :

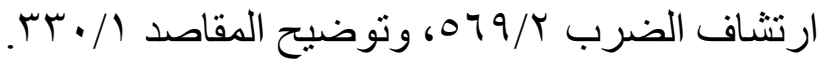


ولا بالحركات المقدرة فيها')، خلافا لزاعميهما.

علامة الجزم: الحذف في المعتل، وفيما رُفِعَ بالنون، والسكونُ فيما رفع بالضمة الظاهرة، فيجزم إذا دخل عليه جازم، أو تبع مجزوما.

\section{الباب الأول \\ باب النكرة والمعرفة}

ما عُلِّق في أول أحواله على الشياع [ץ/ب] في مدلوله نكرة(ץ)، وكل نكرة ياخل تحتها غيرها ولا ينعكس فهي أنكر النكرات، وإن دخلت تحت غيرها وغيرها تحتها فهي بالإضافة إلى الأول أَخَصُّ، وإلى الثَاني أَعَمُّ(َ).

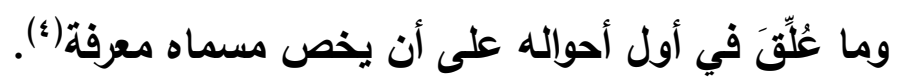
والمعارف: مضمر، وعلم، واسم إثارة، ومعرف ب"أل"، وما أضيف إلى واحد منها، إلا ما اسنتُثْيَ في باب الإضافة. ومذهب أبي الحسن(ه)

(1) هذا قول الخليل وسيبويه، واختاره الأعلم والسهيلي، انظر: الكتاب

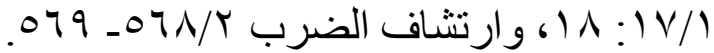

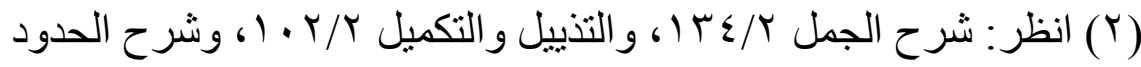
للفاكهي سب ان.

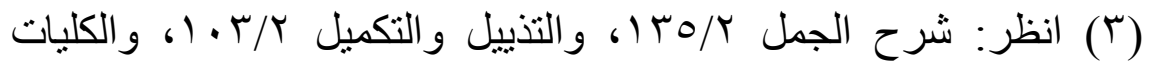

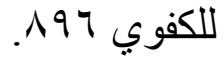

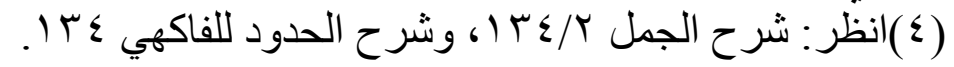

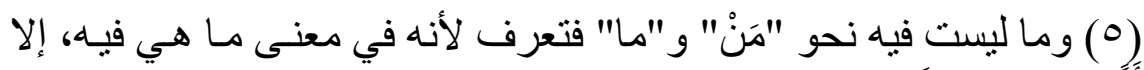

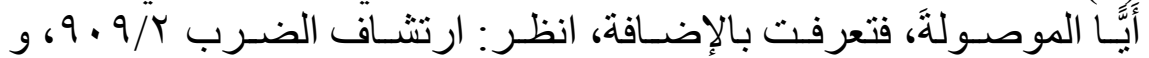

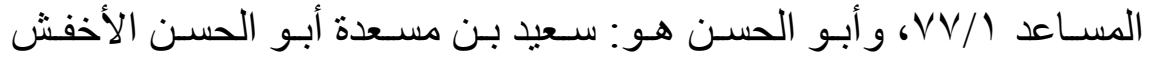

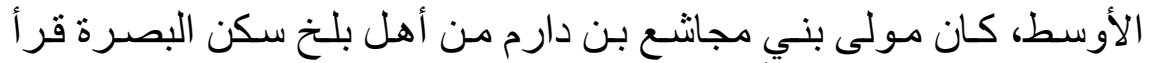

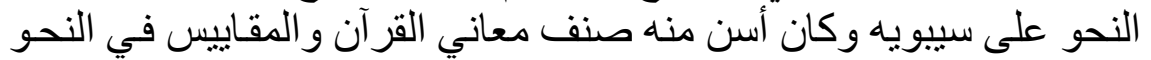

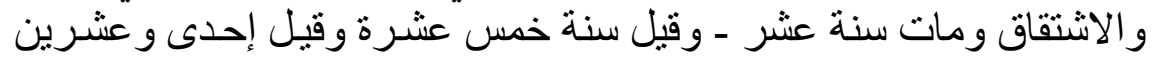

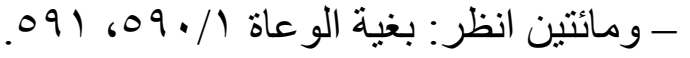


أن الموصول من قبيل ما عُرِّتَ بَ"أل"، وهو الأصح.

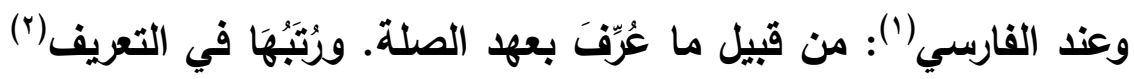
كَسَرْدهَا إلا المضافَ، فرتبته رتبة ما أضيف إليه، إلا المضاف للمضمر فكالعلم(")، وقال المبرد(؛): ما أضيف إلى واحد منها فهو أقل منه تعريفا؛ قياسا على المضاف للمضمر.

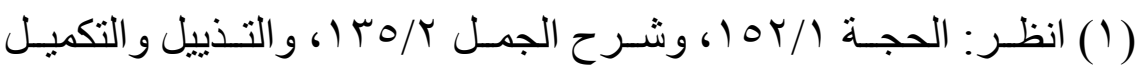

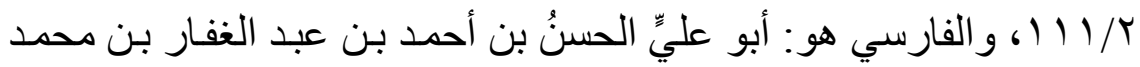

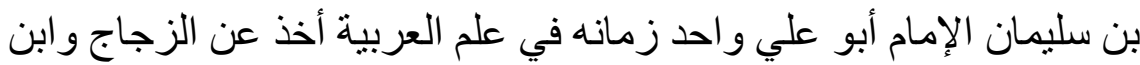

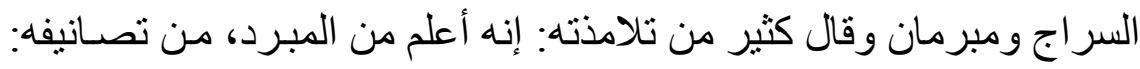

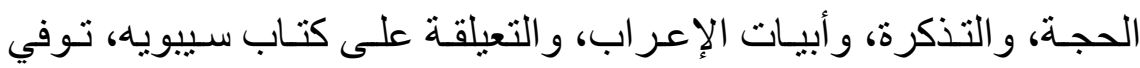

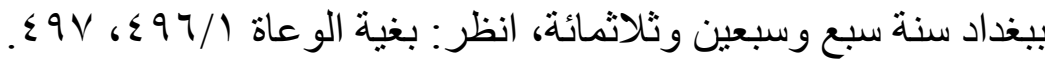

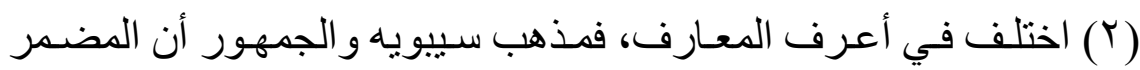

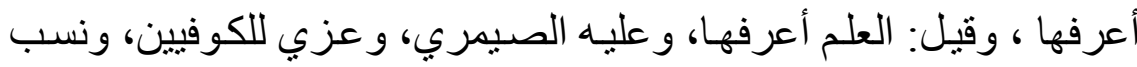

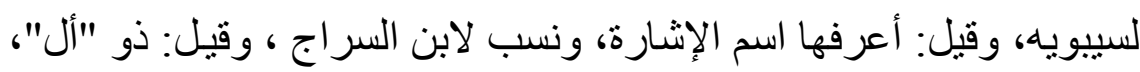

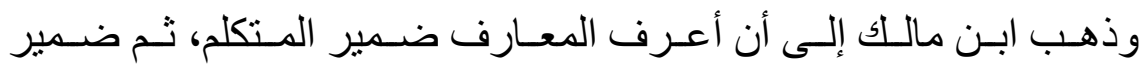

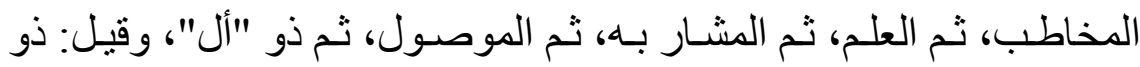

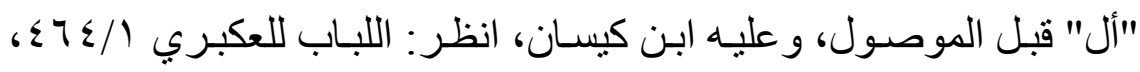

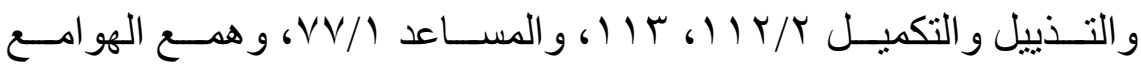
$.119: 111 \mathrm{~V} / 1$

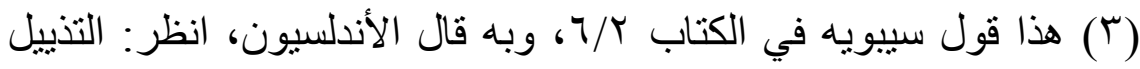

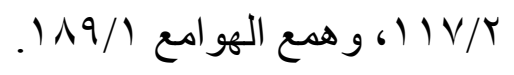

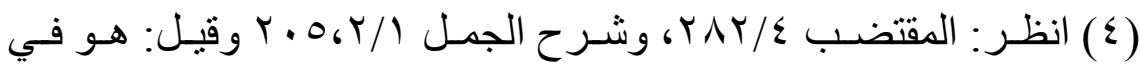

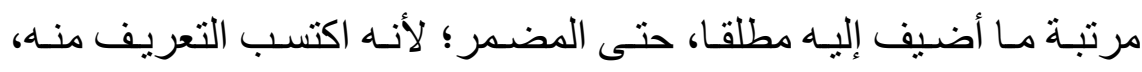

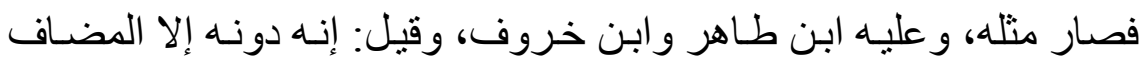

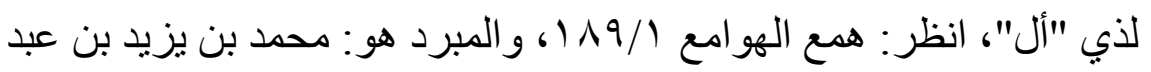


المضمر (ז): لمتكلم ومخاطب وغائب، وكُلٌّ مرفوعٌ ومنصوبٌ ومخفوضُّ. المرفوع الغائب منفصل: هو، هي، هما، هم، هن، والواو في "هو"، والياء

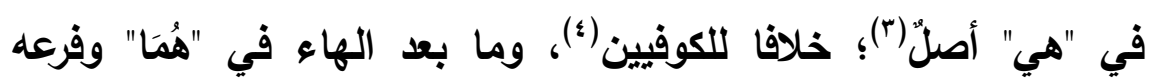
زوائد (०).

الأكبر الثمالي، إمام في العربية غزير الحفظ والمادة تصانيفه كثيرة مشهورة

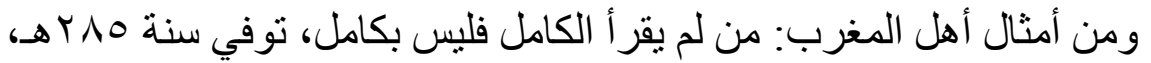

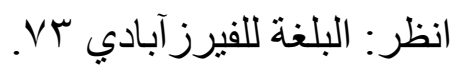

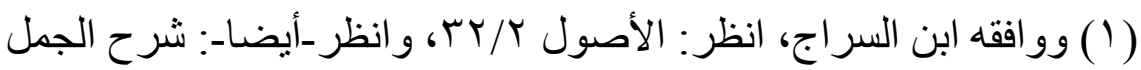

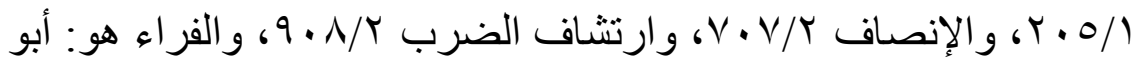

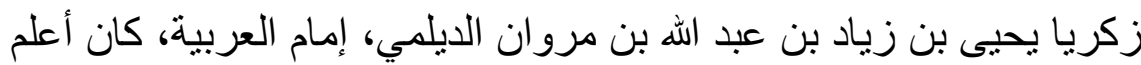
الكوفيين بالنحو بعد الكسائي، أخذ عنه و وعليه اعتمد، صنّف دئ معاني القرآن

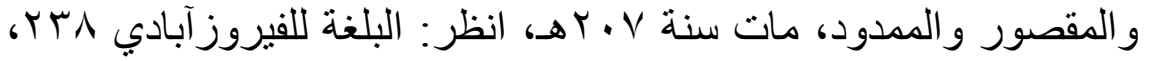

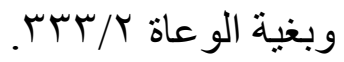

(Y) هذه تسمية البصريين، والكوفيون يسمونه الكناية والمكنى، انظر:

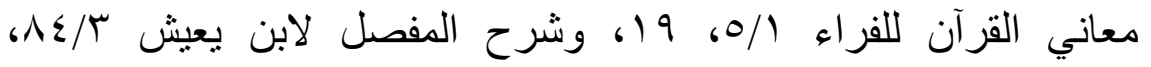

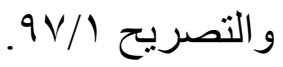

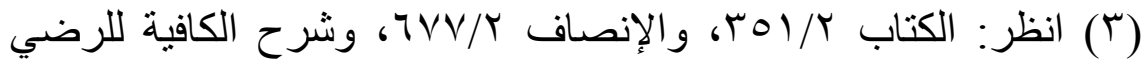
. $11 / T$ (§) وهو قول الزجاج وابن كيسان، واختاره السيوطي، انظر: شرح

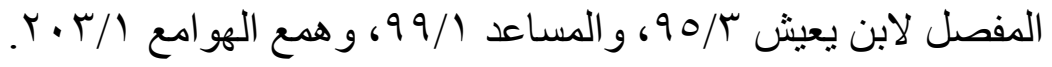

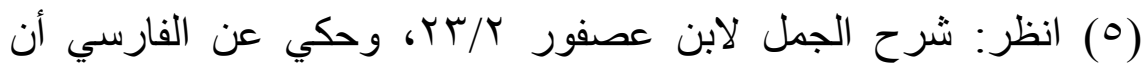

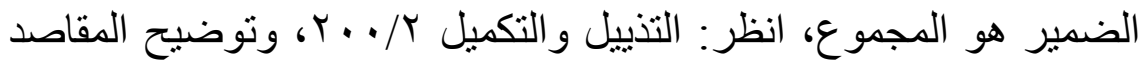

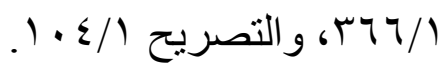




$$
\text { الموفور من شرح ابن عصفور }
$$

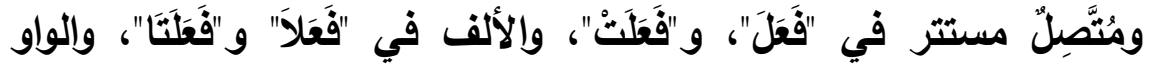

$$
\text { واللنون في "فَعَلُوا" و "فَعَلْنَ". }
$$

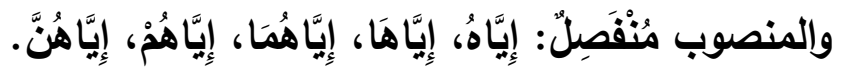

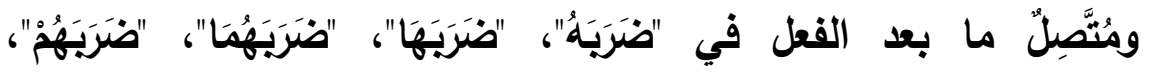

"ضَرَبَهُنُنَّ".

والمجرور كله مُتَّهِلٌ ما بعد الخافض في "بِهِ"، "بِهَا"، "بِهِمَا"، "بِهِهْ"،

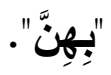

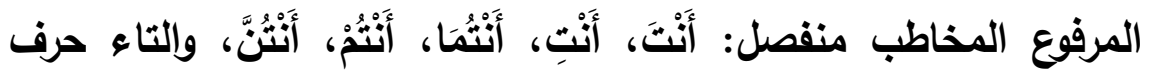
خطابٍ (')، فليست أصلًا، وكذا ما بعدها في فروعه.

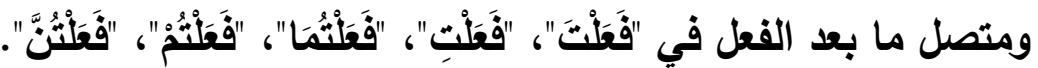
والمنصوب منفصل: إِيَّاكَ، إِيَّاكِك، إِيَّاكُمَا، إِيَّاكُمْ، إِيَّاكُنَّ، و"إِيَّا" هي الضمير، والكاف للخطاب(ץ)، لا مجموعهما(َ)، خلافًا لزاعمي ذلك.

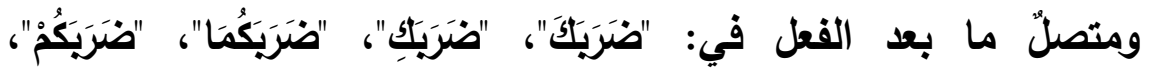

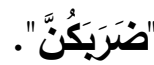

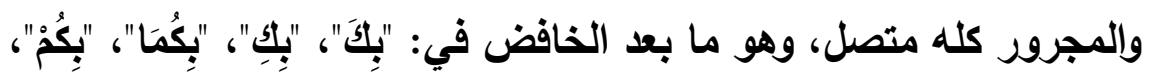

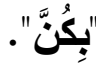

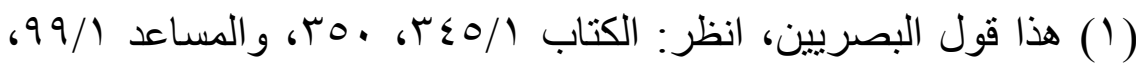
وذهب الفراء إلى أنه بكماله هو الاسم، وذهب ابن كيسان إلى أن التاء وما

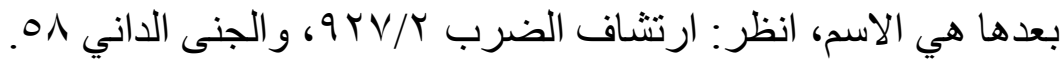

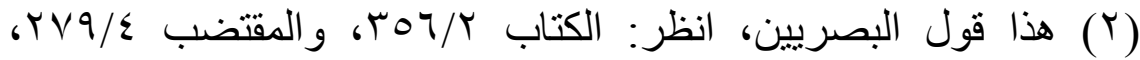

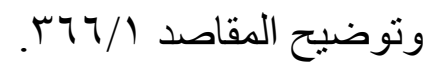

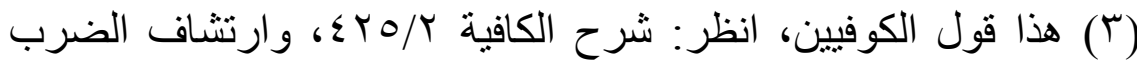

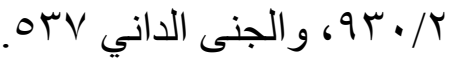


المرفوع المتكلم منفصلٌ: أَنَا، نَحْنُ، والأفَصح في "أَنَا" حَذْفُْ الألف وصلاً،

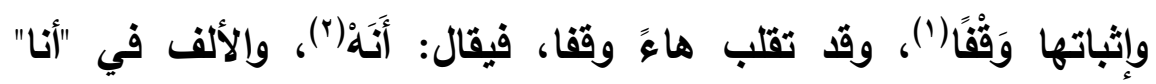

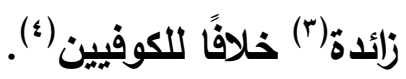
ومتصل ما بعد الفعل في "فعلتهُهَ"، "فَفَلْنَا". والمنصوب منفصلٌ: إِيَّايَ، إِيَّانَا، ومتصل ما بعد الفعل في: "ضَرَيَبِي"،

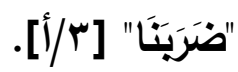

والمجرور كله متصلّ، وهو ما بعد الخافض في "بي" ونحوه(•).

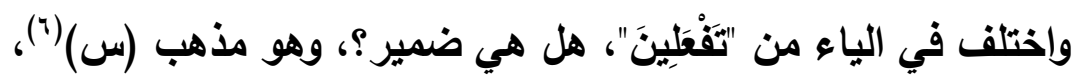

(1) وهي لغة أهل الحجاز، وأما تميم وبعض قيس وربيعة فيثبتونها وقفا

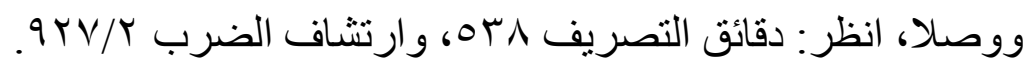

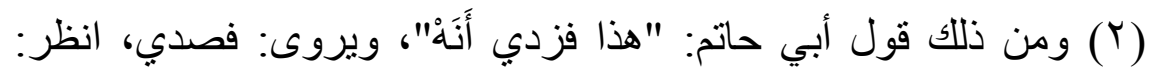

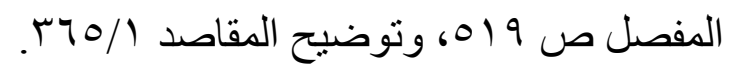

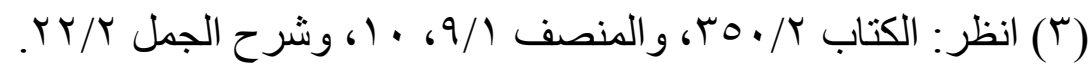

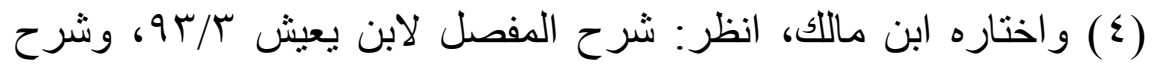

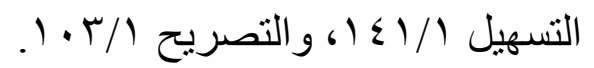
(0) هذه العبارة تقدمت قبل قليل، و أعيدت هنا.

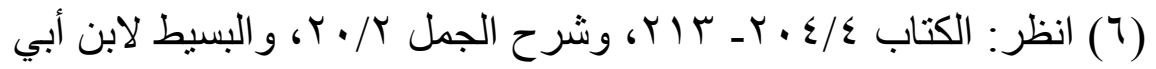

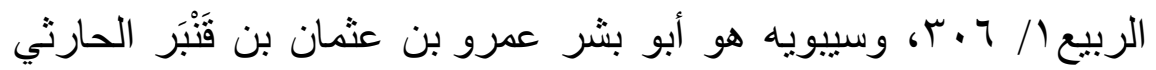

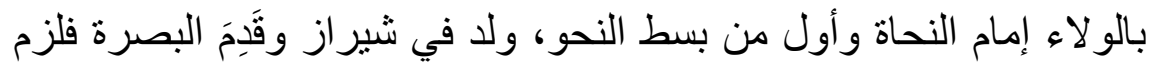

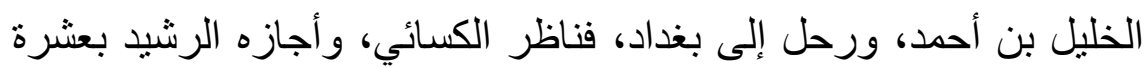

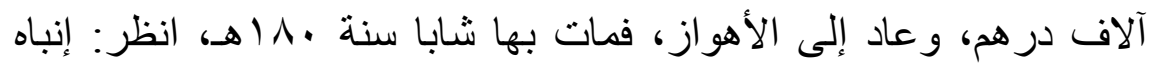

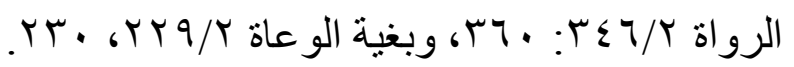


الموفور من شرح ابن عصفور

أو علامة تأنيث؟، وهو مذهب الأخفش (')، والصحيح الأول.

وأعرف المضمرات المتكلم ثم المخاطب، ولا يحتاجان إلى تفسير(؟)، وأما الغائب فمنه ما لا يحتاج إلى تفسير، ومنه ما يحتاجه، وهو قبلي ويعدي، البَعْدِيٌُ تفسره الجملة إن كان ضميرَ أَمْرٍ أو قصة، خلافا للكسائي(َ) في إجازة تفسيره بمفرد.

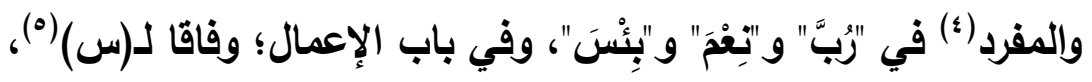

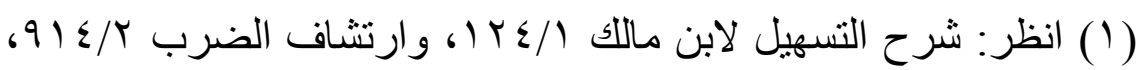

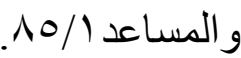

(Y) لأن المشاهدة تفسر هما، انظر : التذييل و التكميل / / TOY وشرح شذور

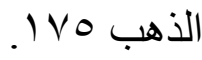

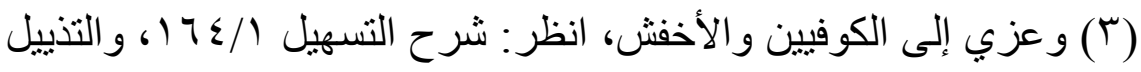

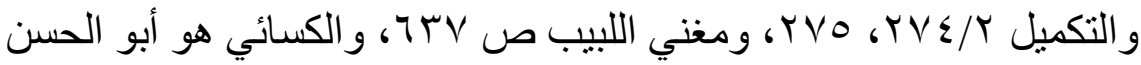

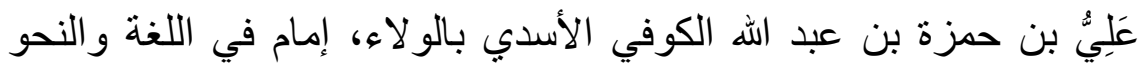

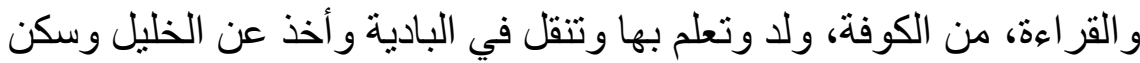

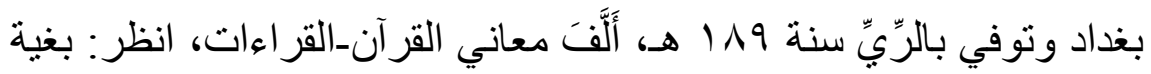

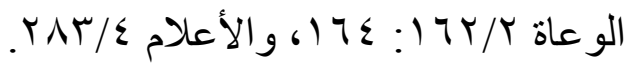

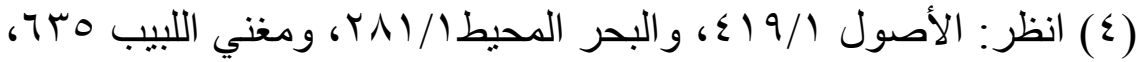

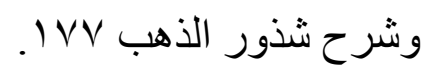

(0) الكتاب (VT/ المحيط//1) 
وفي باب البل؛؛ وفاقا للأخفش(')، لا في باب القاعل والمفعول إذا اتصل

به، وتقدم ضمير المفعول؛ خلافا للكوفيين(؟). والفََبْلِيُ إما لفظا أو معنى أو كليهما، وهذا إما متقدم لفظا أو مرتبة أو كليهما، فلا بل من معرفة المراتب، فالاسمان متفقا الإعراب ومختلفاه، ومختلفاه يقدم فيه المرفوع على قسيمه، والمنصوب على المخفوض، ومتفقاه: مرفوعان مبتدأ أو متبوعا وخبرا أو تابعا، وهما قبلهما، ومنصويان، ويقدم المبتدأ أصلا، والفاعل معنى، ومخفوضان، ويقدم منهما ما كان في موضع رفع، وإلا فمرتبة كل واحد منهما حيث وقع.

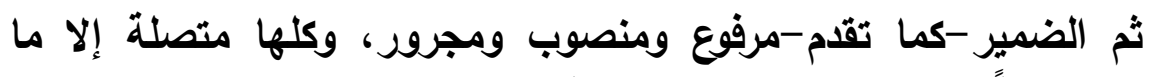

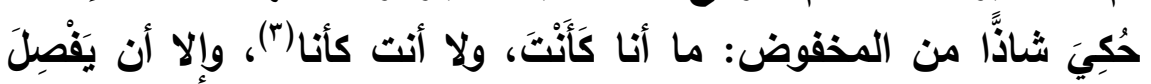

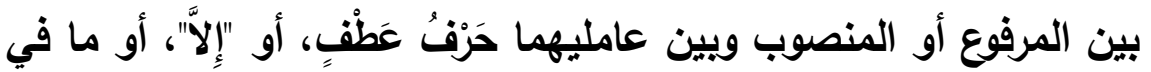

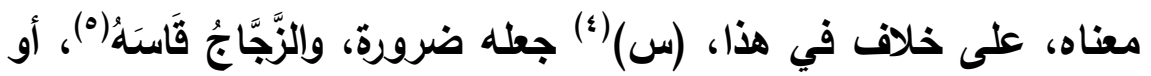

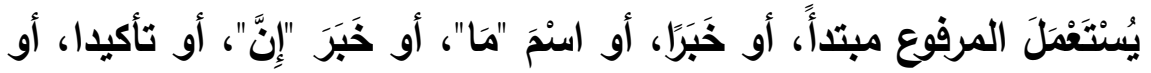

(1) نحو: اللهم صنلّ عليه الرؤوف الرحيم، وصححه ابن مالك و أبو حيان،

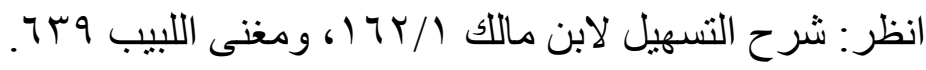

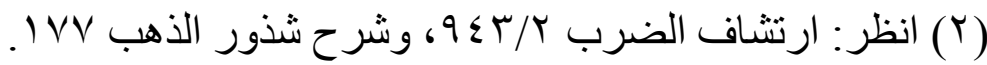

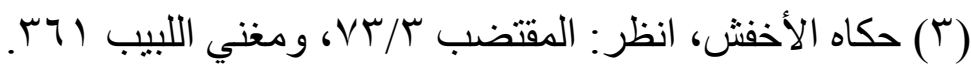

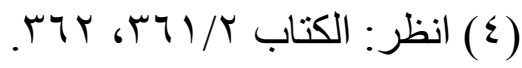

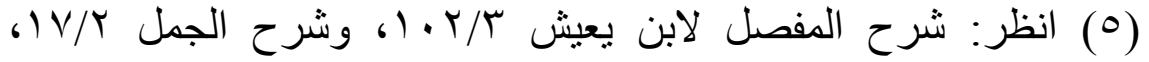

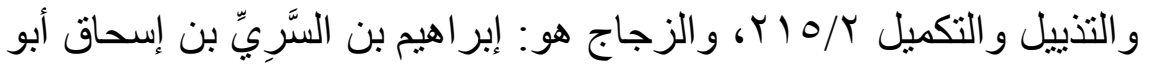

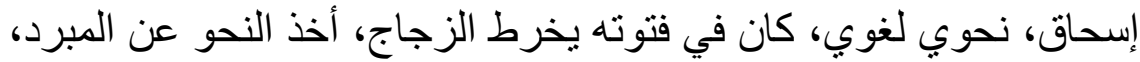

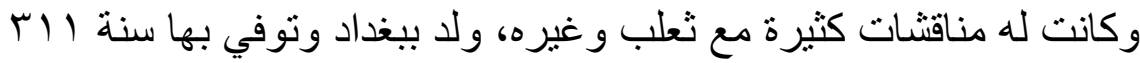

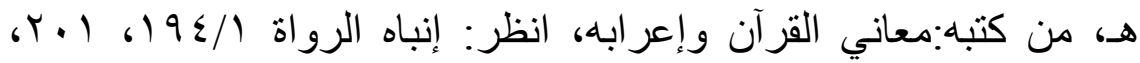

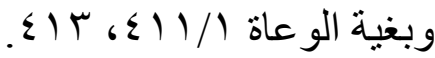




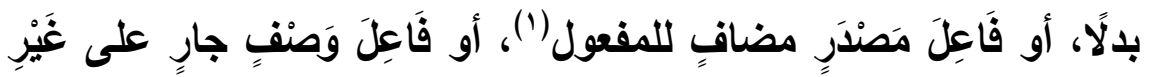

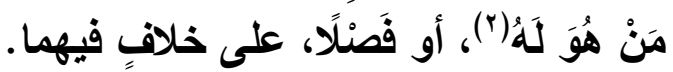

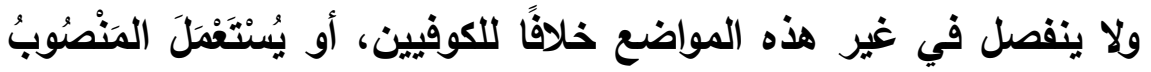

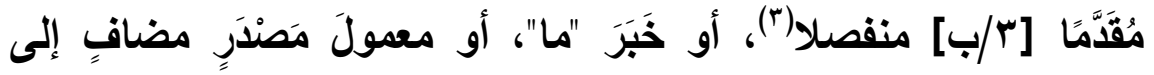

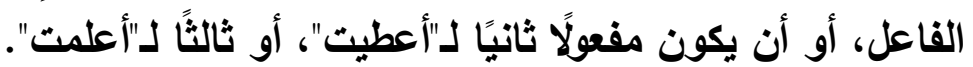
والذي يجيء متصلًا ومنفصلًا: ثاني "أعطيث"، واتصاله أحسن (๕) وثناني "ظنتت"، وخبر "كان"، ومفعول مصدر مضاف إلى فاعل مضمر، وإنفصاله

أحسن (0).

(1) نحو: زيد عجبت من ضربك هو، مطلقا عند البصريين وبشرط خوف

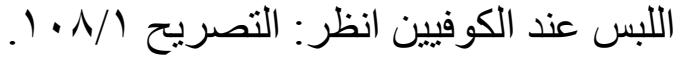

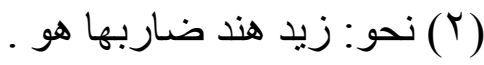

$$
\begin{aligned}
& \text { (ץ) كقول ذي الإصبع العدواني: }
\end{aligned}
$$

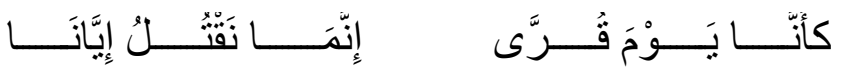

وفيه الخلاف السابق بين سيبويه والزجاج، انظر: الكتاب ك/r Tش، وشرح

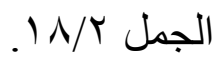
( ) علل أبو حيان لذلك بأن الثاني مفعول في الأصل، وبأن اتصاله أكثر من

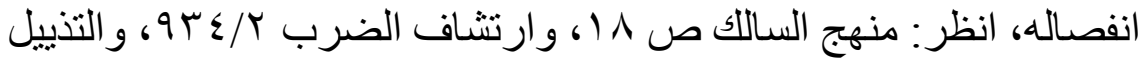

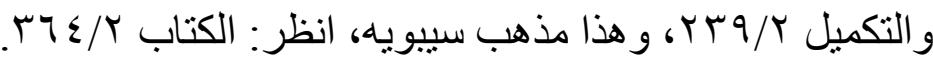

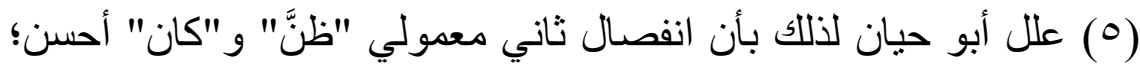

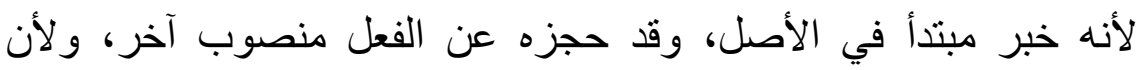

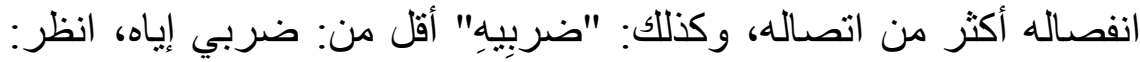

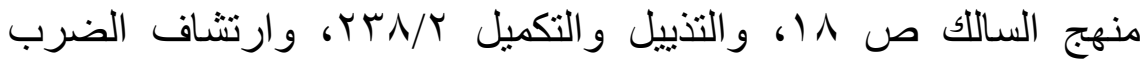
 


\section{إصدار Y r P}

حولية كلية اللغة العربية بالمنوفية العدد الثاني والثلاثون

العلم: ما عُلِّقَ في أول أحواله على مسمى بعينه، في جميع أحواله: من

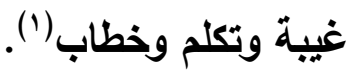

وأَعْرَفُهُ: اسم الأماكن، ثم الأناسي، ثم اسم الجنس، ولا يعرف هذا إلا

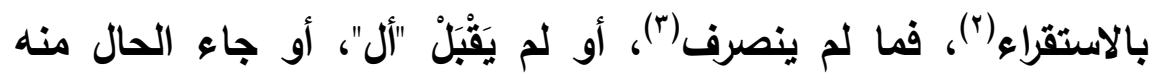
معرفةٌ بالعلمية، وما وصف به النكرة، أو قبل "أل" نكرة(أ)، وريما سُمِعَ التنكير والتعريف في اسم وإحد، كابن عرس(ه)، وعند (س) (؟): ابن أَوْيَرَ

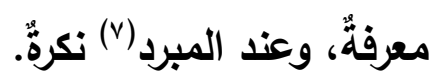

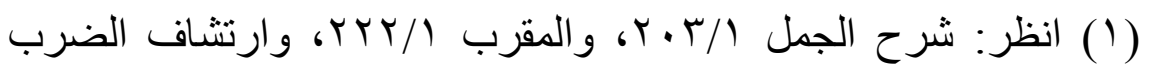

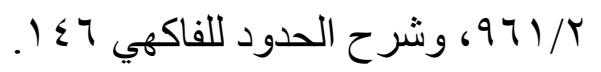

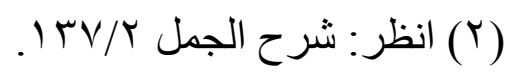

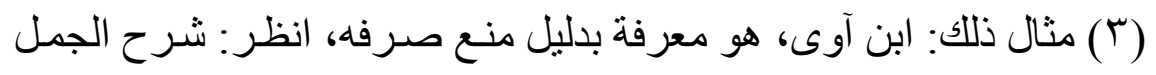
$.1 T V / r$ ( ) مثال ذللك: ابن لبون و ابن مخـاض، همـا نكرتان، بدليل قبو لهمـا الألف

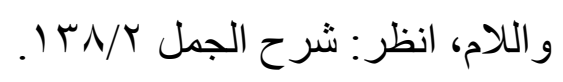

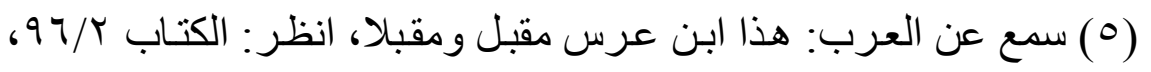

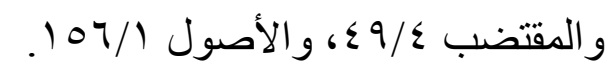

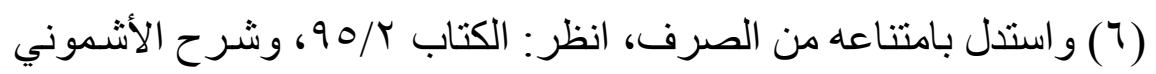
$r 9 \cdot / 1$

(V) و الذي حمله على ذلك وجود "أل" فيه في الثنّعر، فلو كان ابنُ أوْبَر

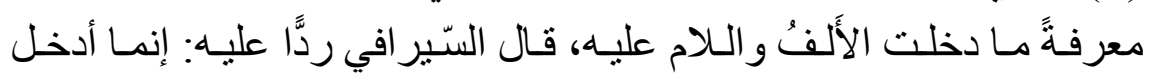

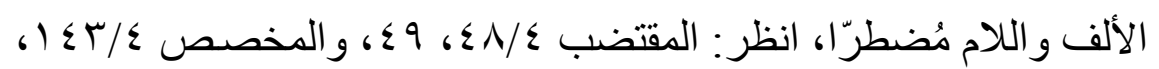

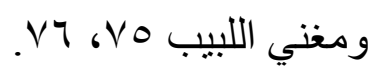




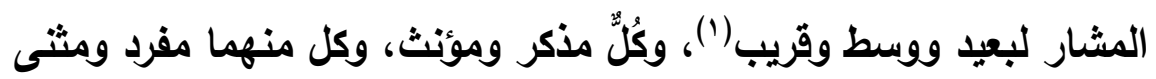
ومجموع، فلواحدٍ مذكرٍ: ذا(ץ) وهذا، ولمثناه: ذانِ وهذان، ولجمعه: أولاع(ب)

وهؤلاء.

ولواحدةٍ قريبةٍة: ذي وتي وتا وهذي وهاتي وهاتا، وهذه في الوصل، وذِهْ

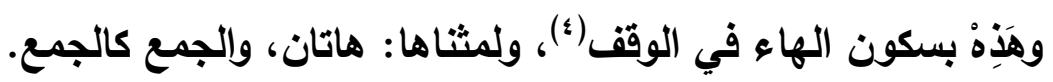

(1) ذكر ابن مالك مذهبين للنحويين في أسـاء الإشـارة، أحدهما: أن لها

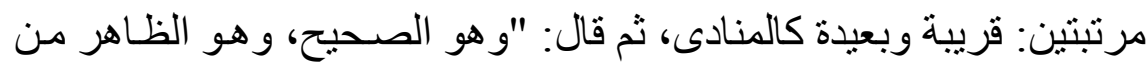

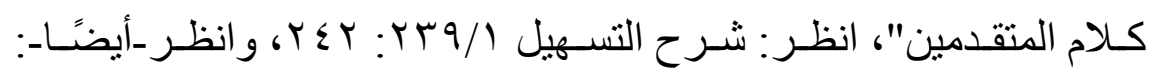

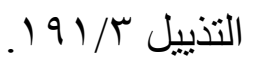

(Y) ذهب الكوفيون و السهيلي إلى أن الاسم في "ذا " الذال وحدها، وأن ما

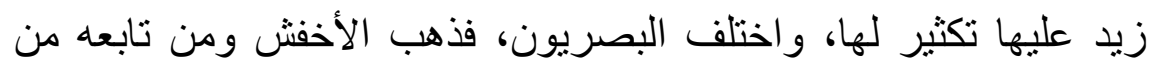

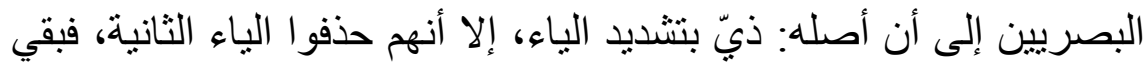

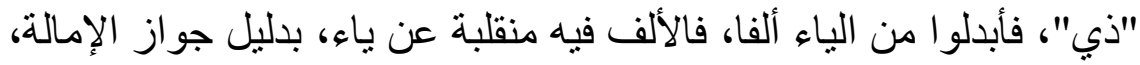

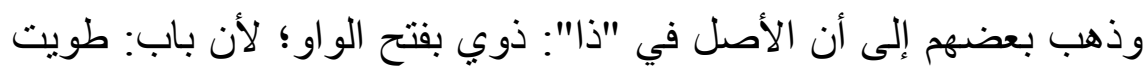

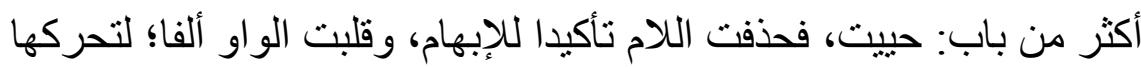

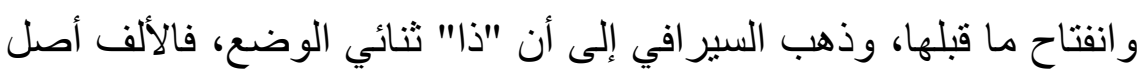

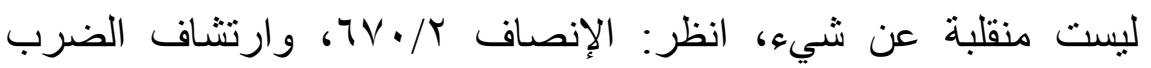

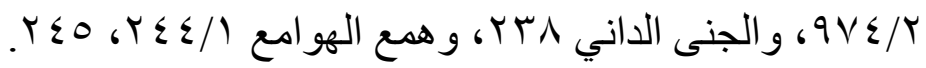

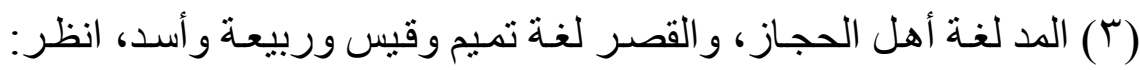

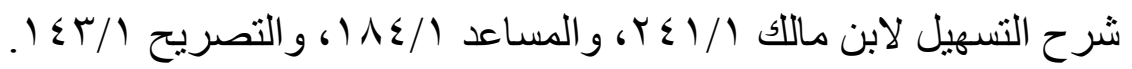
( ) ومن العرب من يسكن وصلا ووقفا، انظر: المقاصد الثافية / 90/ بـ. 
ولواحٍِ وَسنطِ: ذاك، ولمثناه: ذانك، وللجميع: أُلَّكَكَ وأُلَكَكَ بتثديد اللام وتخفيفها (')، وأولئك، وقيل: أولئك للبعيد.

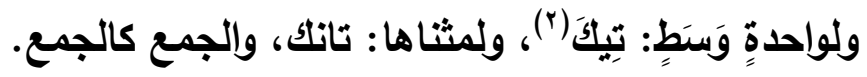

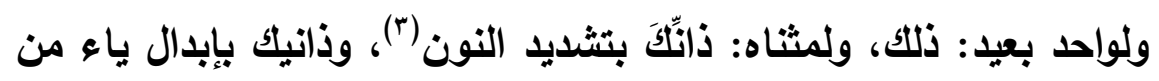
إحدى النونين (؛)، وفي الجميع: أولالك (ه).

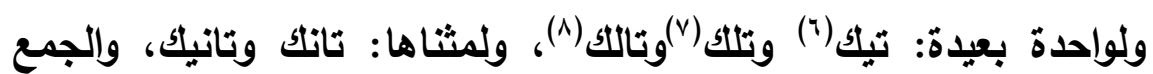
كالجمع.

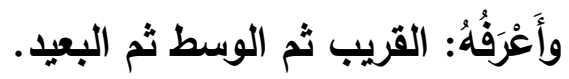

(1) حكاها ابن الأعر ابي، انظر : المقاصد الثـافية /90/1 ه، والبسيط لابن

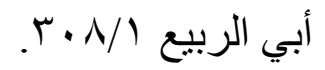

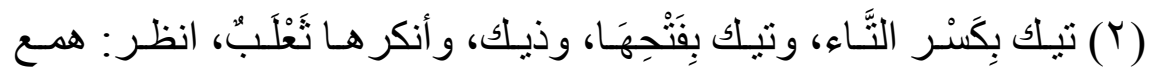

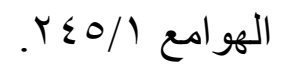

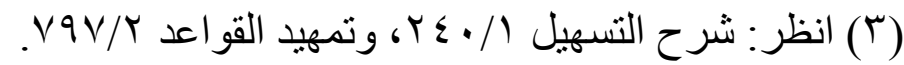

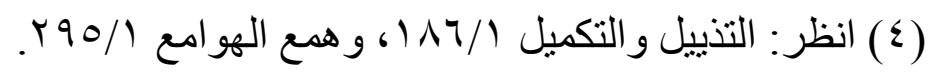

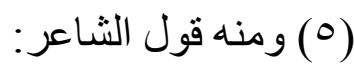

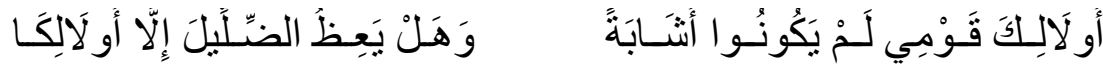

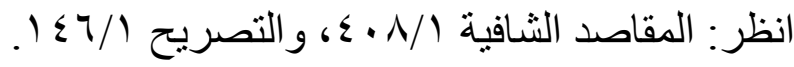
(7) في الأصل: "تلكلك".

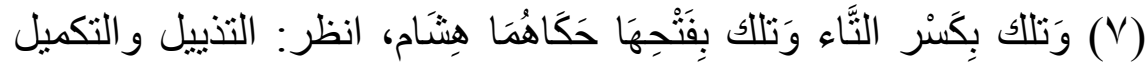

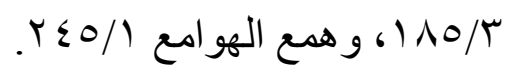

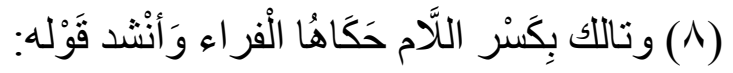

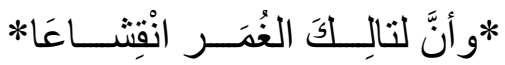

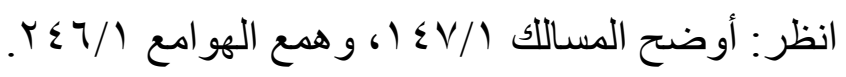


الموفور من شرح ابن عصفور

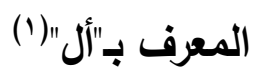

هو الاسم الذي يكون معرفة بهما، فإذا زالت عنه صار نكرةً(؟).

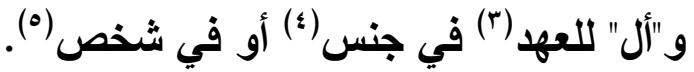
وللحضور بعد اسم الإثشارة، ويعد "أَيِّ" في النداء، ويعد "إذا" الفجائية،

(1) وَمَا ذكره أبو حيان هنا من تَقْبِيم "أل" إِلَى عهدية وجنسية هُوَ مَذْهَب

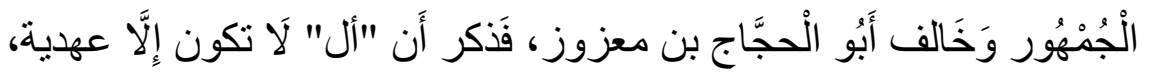

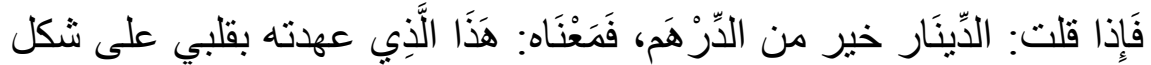

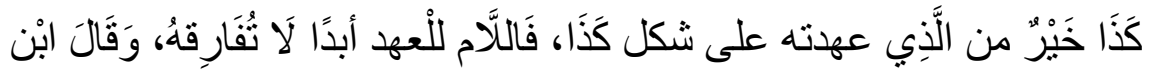

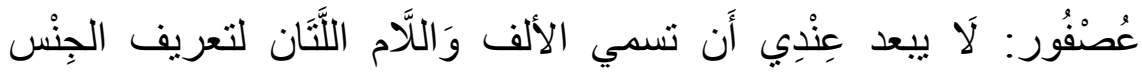

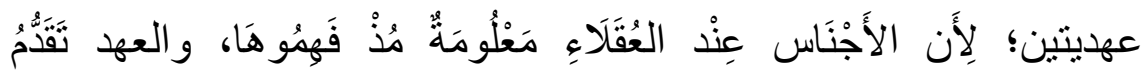

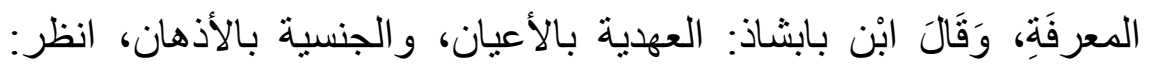

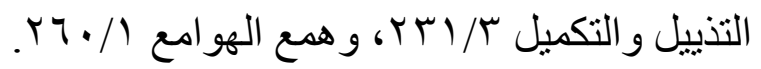

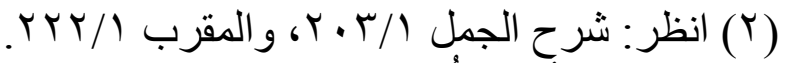

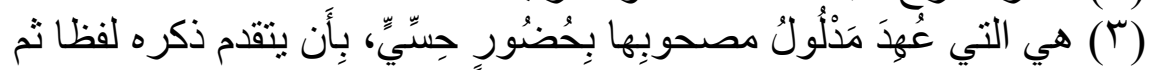

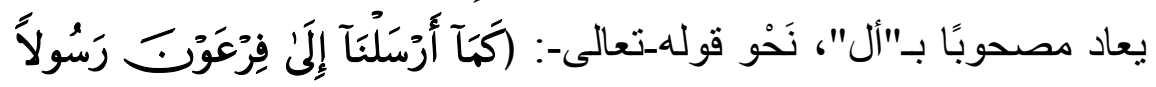

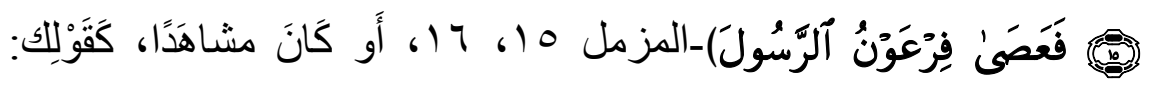

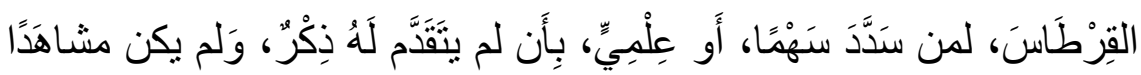

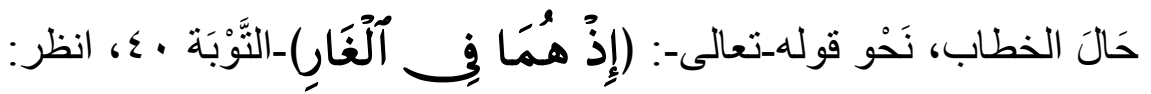

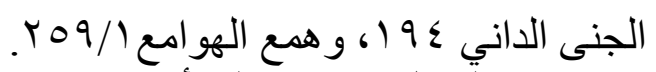
( ) نحو: الرجل خير من المر أة، يريد هذا الجنس خير من هذا الجنس،

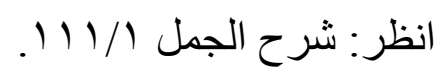
(0) نحو: جاءني الرجل الذي جاءك، إذا دخلت على معهود، شرح الجمل 


\section{r. IV إصدار}

حولية كلية اللغة العربية بالمنوفية العدد الثاني والثلاثون

والتي في "الآن" وما في معناه(')، وفي غير ذلك بقرينة.

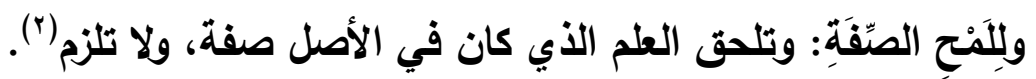

وللغلبة [ـ/أ]: وتلحق النكرة للتعريف، ثم تغلب عليه.

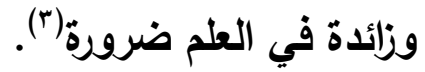

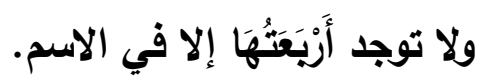

وموصولة: وتأتي في الموصولات ما توصل به.

وأعرف ما كاتت فيه "أل" التعريف: الأي كاتت فيه للحضور، ثم للعهد في شخص، ثم للعهد في جنس.

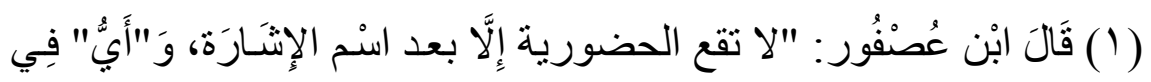

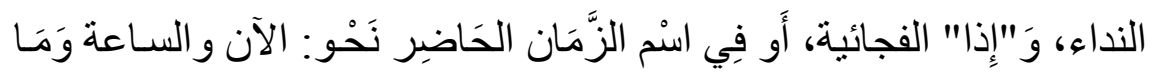

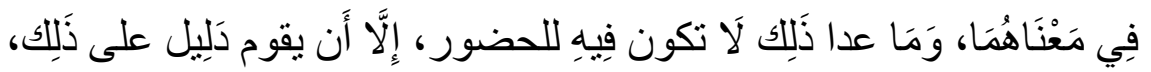

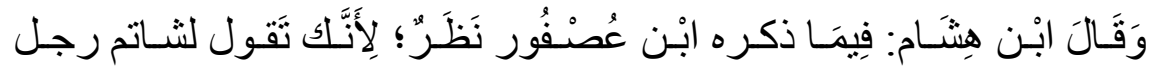

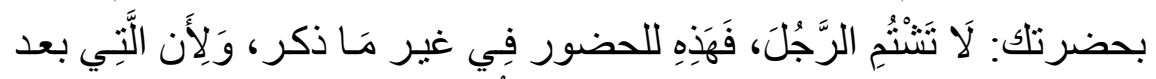

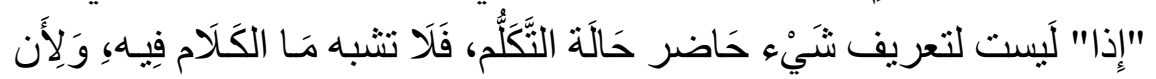

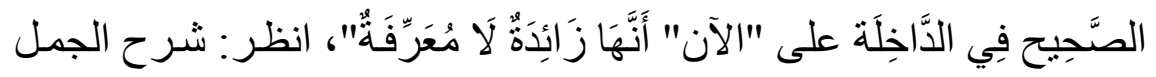

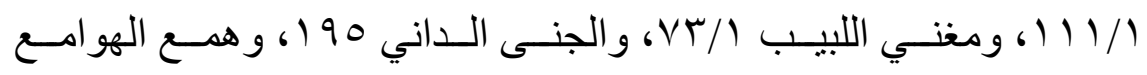
ז./1

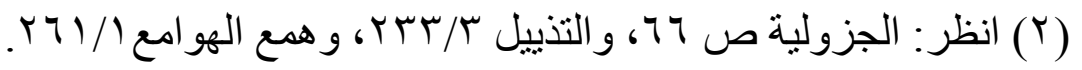

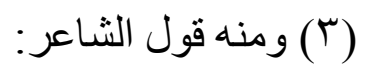

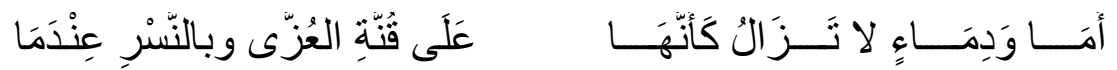
فأدخل الألف واللام على نسر، وهو علم، انظر: سر صناعة الإعراب

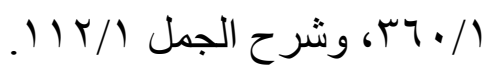




\section{الموفور من شرح ابن عصفور}

\section{المعرف بالإضافة}

ما أضيف إلى معرفة من هذه المعارف إضافته محضة، وستأتي الإضافة المحضة وغير المحضة. وأما الموصولات وأحكامها فتأتي في الباب بعد هذا. ****** $* *$

\section{(1) (المخاطبة)}

جَعْلُ اسنم الإثارة على حسب المسؤول عنه، من إفراد أو تثنية أو جمع، أو تذكير أو تأنيث(؟).

وحرف الخطاب على حسب المسؤول، فتكون جملة المسائل سِتًّا وثلاثين مسألة(זّ)، وذلك أن المسؤول عنه مفرد ومثنى ومجموع، وكل منهما مذكر

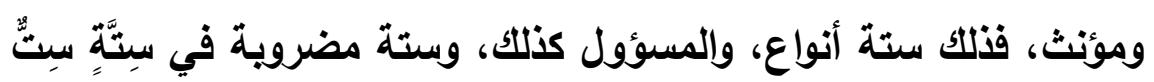
وثُلاثون، هذا إذا استعمل اسم الإشارة وحرف الخطاب على اللغة الفصيحة

فيهما (๕)

فإن جعلت اسم الإثارة على لغة من يجعلها في كل حالٍ كما يكون للواحد المذكر، وحرفَ الخطاب على كل حال كما يكون للواحد المذكر، أو يفتحها

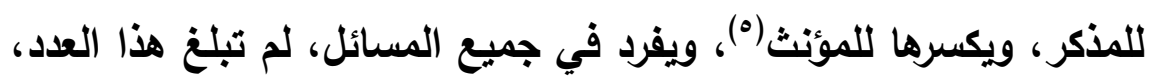

$$
\text { (1 ) شرح الجمل لا بن عصفور ب/ وسب. }
$$

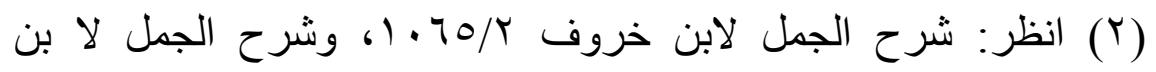

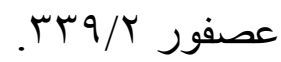

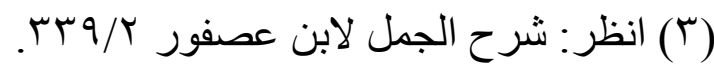

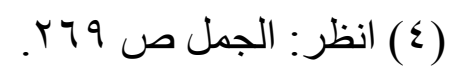

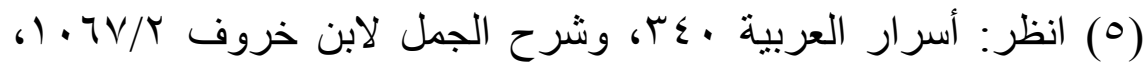

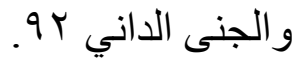


بل تكون كلها على لفظ واحد، أو على لفظين في لغةِ مَنْ فَتَحَح للمُذَكَّرِ،

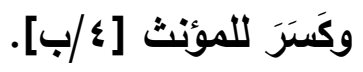

*******

(الفاعل (1) - (اعل)

كل اسم أو مقدر به، أُسنتِدَ إليه فعل أو ما جرى مجراه، وقُدِّمَ عليه لفظا أو

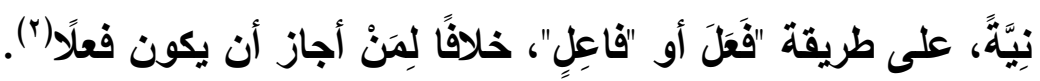

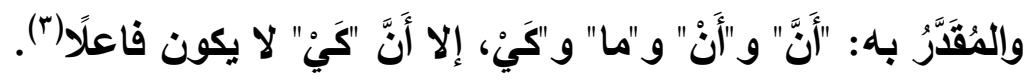
والجاري مَجْرَاهُ: اسم الفاعل، واسم المفعول، والصفة المشبهة وغير

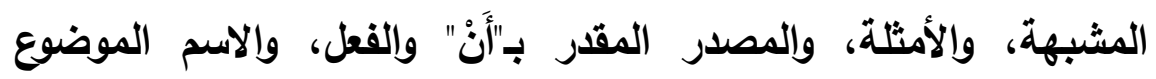
موضع الفعل، مصدرًا أو غَيْرَهُ، وأسماءُ الأفعال، والظرف والمجرور حالاً أو

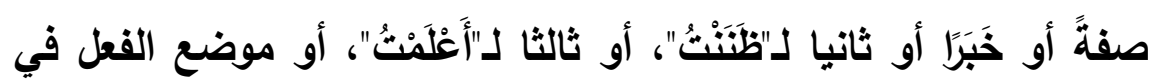
الإغراء، خلافا للأخفش في إطلاقه جريانَهُهَا مَجْرَى الفعل (؛).

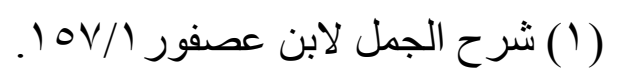

(Y) هذا قول هثام الكوفي وثعلب وجماعة من الكوفيين، وذهب الفراء وجماعة إلى جواز ذللك بشرط أن يكون العامل فعلا قلبيَّا، و العامل معلقًا

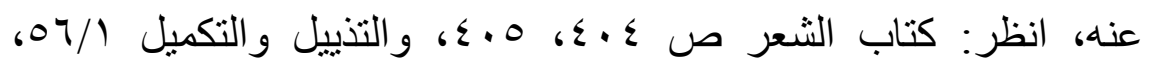

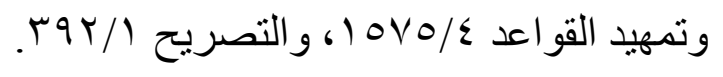

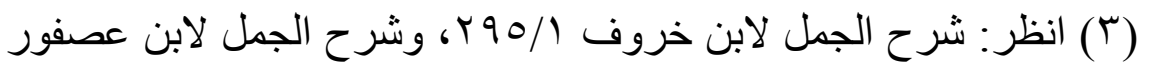

$$
.10 \mathrm{~V} / 1
$$

( (ع) في رفع الفاعل على الإطلاق قويت فيه الفعلية أو لم تَقْوَ، نقل هذا القول

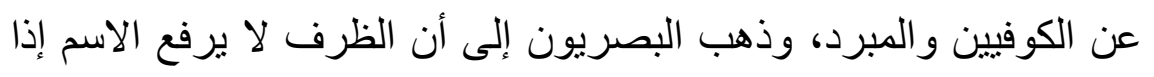

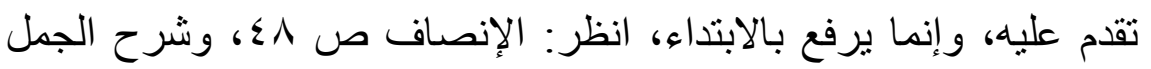

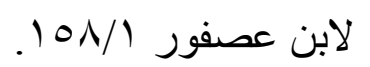


الموفور من شرح ابن عصفور

د/ لحمدمحسمد الجنــي

دا عب الملك أممد شتيوي

ولا يتقدم الفاعل إلا ضرورةً(')، خلافا للكوفيين(؟) في جواز ذلك.

\section{****** \\ المفعول}

كل فضلة انتصبث بعد تمام الكلام مَحَلَّا لفعل الفاعل خاصةًَ("). ويَلَزْمَ تقديمه إن اتصل ضميرا والفاعل ظاهر، أو أضيف إليه المصدر أو اسم الفاعل، أو قُرِنَ الفاعل بِ"إلَّا" أو بما في معناها، أو اتصل بهله ضميره،

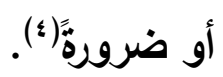

ويلزم تأخيره إن اتصل الفاعل، أو أضيف إلى المصدر، أو قُرِنَ المفعول

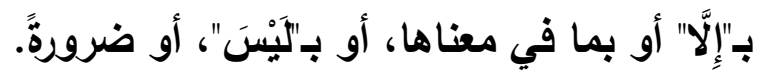
وفي غير ذلك أنت بالخيار.

ويلزم تقديمه على العامل إن كان منفصلاً، أو اسَّ شَرْطِ أو استفهامِ(•)

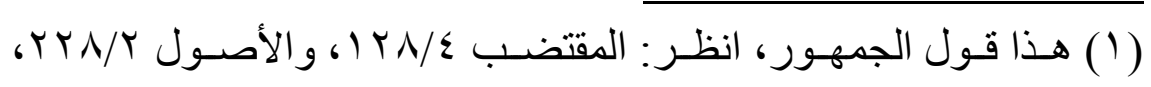

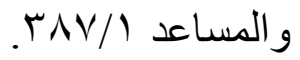

(Y) وو افقهم الأخفش، انظر: شرح التسـهيل لابن مالك r/ 1 • (، و التذييل

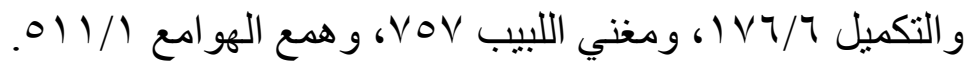

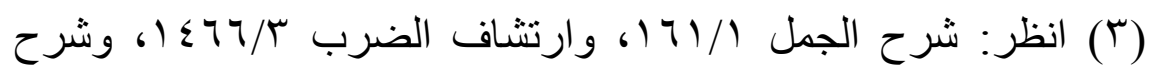

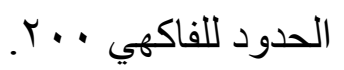
( ) (ع ) نحو قول النابغة:

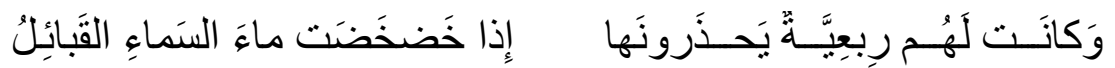

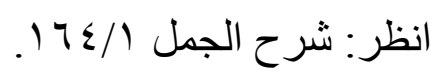

(0) نحو: أي رجل تضرب؟، وحكى الكوفيون أن العرب تقدم العامل على أنى

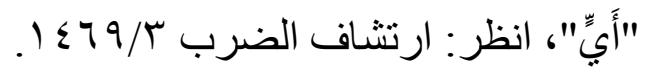




$$
\text { أو "كم" الخبرية(1)، أو ضرورةً. }
$$

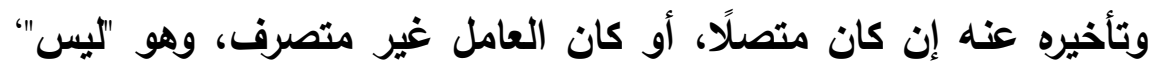

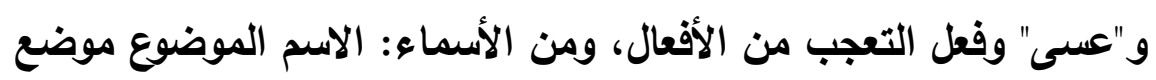
الفعل غير المصدر واسم الفعل والظرف والمجرور.

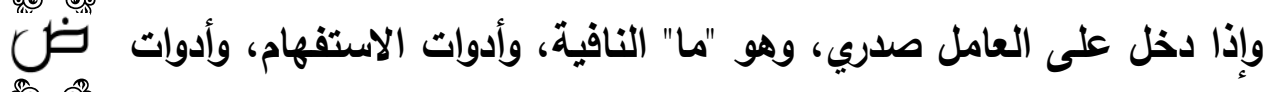

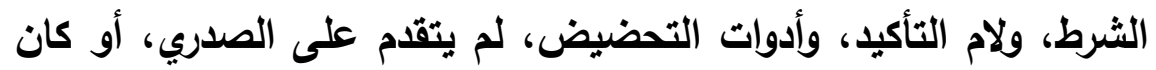

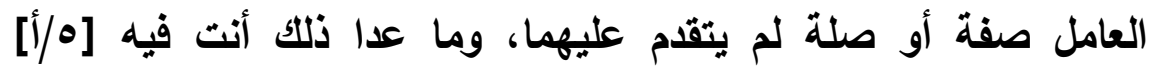

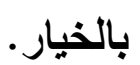

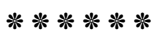

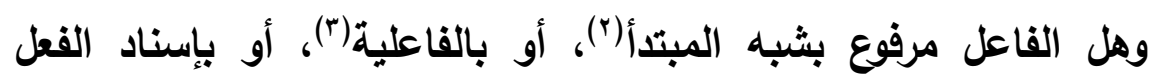
إليه(") أو بالتفريغ هرع

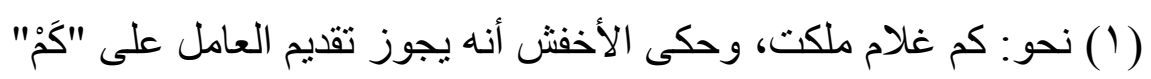

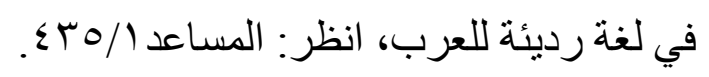

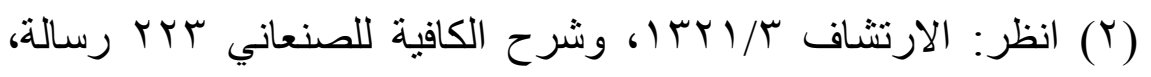

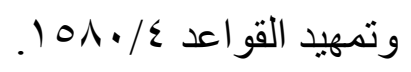

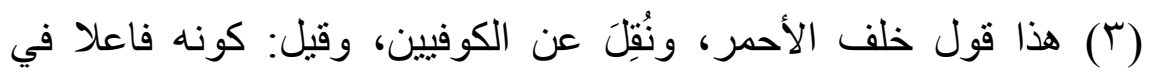

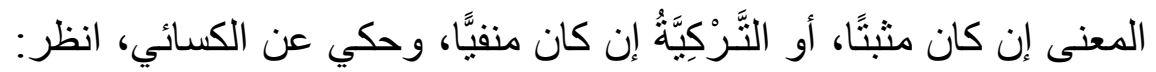

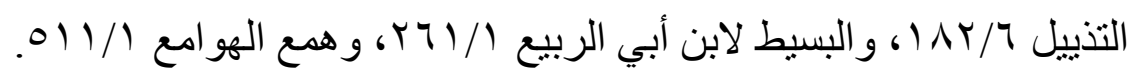

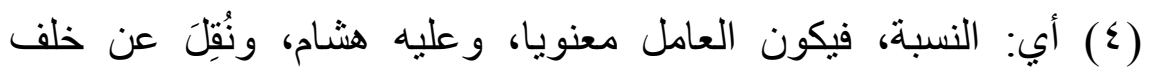

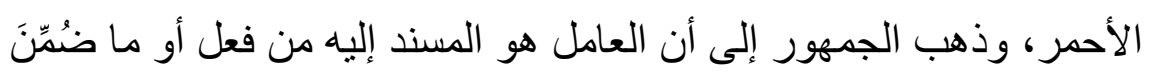

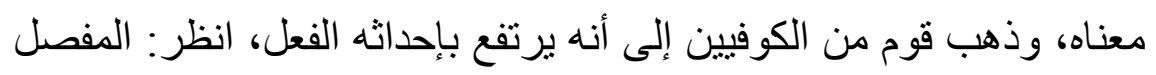

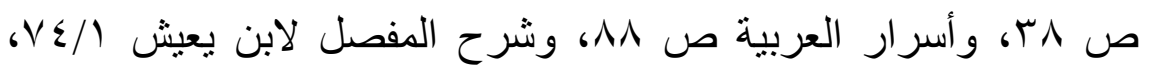

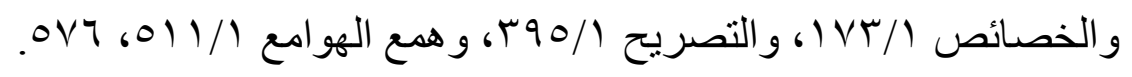


أقوال، أصحها الأخيز (') وهل المفعول منصوب بالفاعل(؟)، أو به مع الفعل(ז)، أو بالمفعولية(๕)، أو بالفعل وما جرى مجراه؟ أقوال، أصحها الأخير(•). وإذا تأخر الفعل عن الأسم كان على حسبه من إفراد وتثية وجمع، وإذا

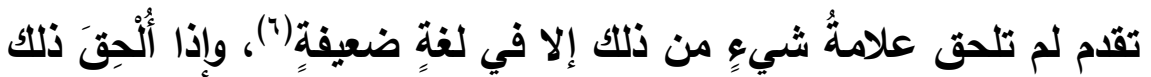

(1) هذا القول الأخير الذي صححه أبو حيان هو ظاهر كلام سيبويه في

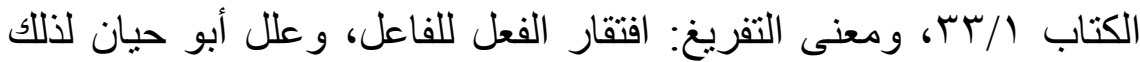
بأن الفعل طالبُ أبدًا للفاعل، لا يستقل منه مع المفعول كلام حتى يُذْكَرَ

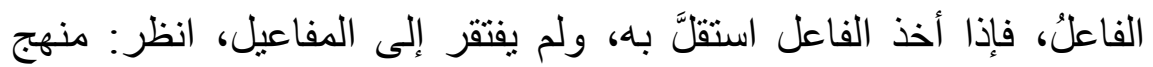

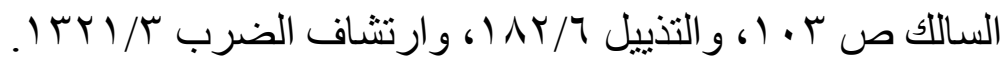
(Y) هذا قول هثام بن معاوية الضرير، انظر: شرح الكافية للرضي

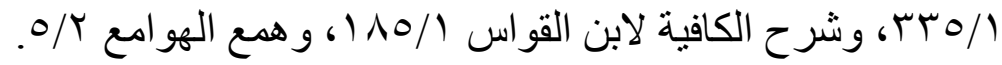

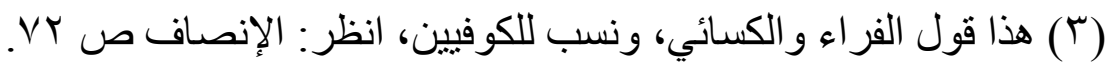

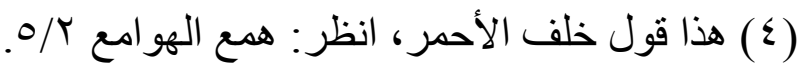

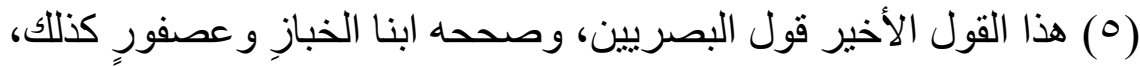

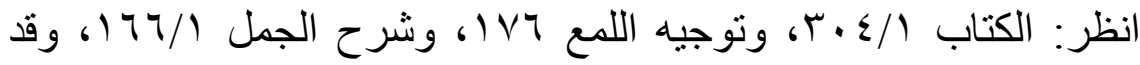

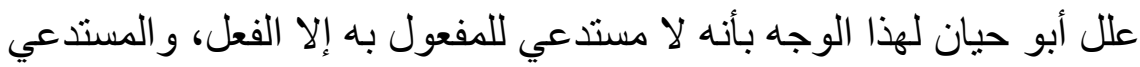

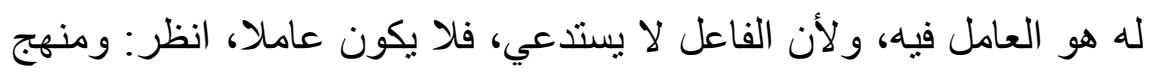

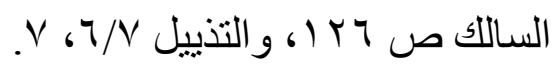

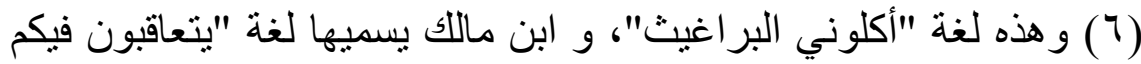

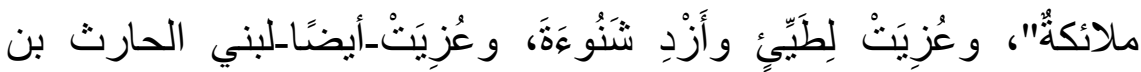

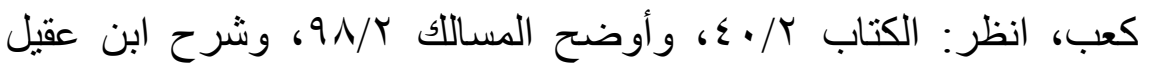

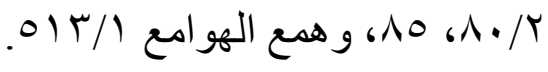


فقيل: اللاحق ضمير فاعل، وما بعده مبتدأ، والجملة قبله في موضع الخبر (')، وقيل: ما بعده بلدل منه(؟).

والصحيح: أنه علامة تلال على ما بعده من تثنية وجمع(ّ). ****** $* *$

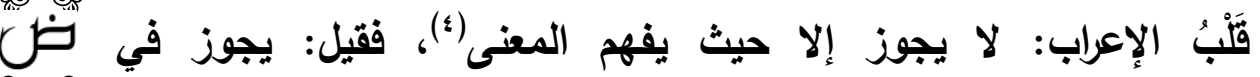

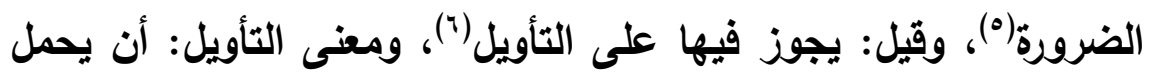
على المعنى، فيصح الإعراب عليه، وقيل: يجوز في الكلام اتساعا واتكالًا على فهم المعنى (v) ( )

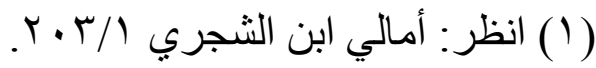

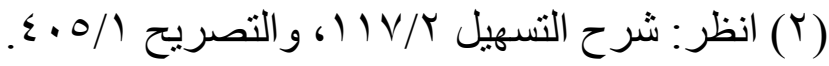

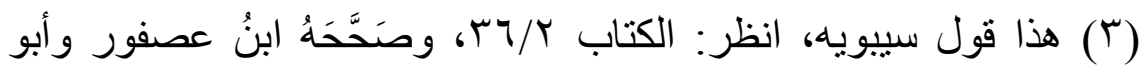

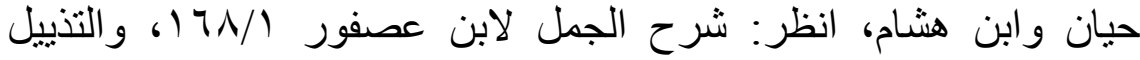

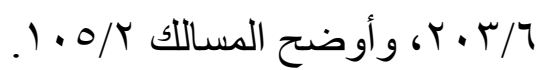
(§) قال ابن خروف: "المفعول المحمول على المعنى من باب الاتساع و المجاز؛ لفهم المعني، و هو كثير جدا؛ ومنه: خرق الثوبُ المسمارَ، وأدخلت

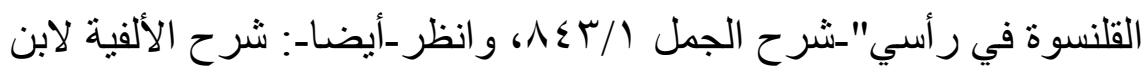

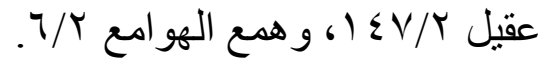
(0) كقول الشاعر : (0)

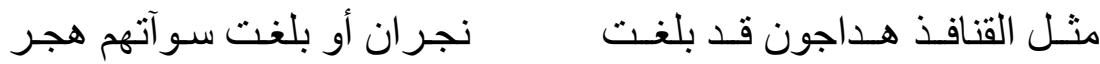
قال ابن خروف: "فقوله: (وقد جاء في الثعر) غير سديد؛ لأنه قصره على

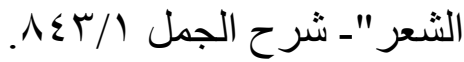
(T) هذا قول الزجاجي في الجمل || آب، وانظر : شرح الجمل لابن عصفور $.111 / 4$

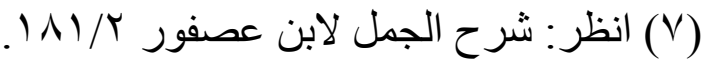


الموصول: حَرْفتُ واسنْمُ، الحرف: "أَنْ" و"ما" و"أَنَّ" و"كَيْ"(1) المَصندَرِيَّاتُ، والاسم: "مَنْ" و"ما" و"الأي" و والتي" و"أَيٌْ" بمعناهما، والألف واللام

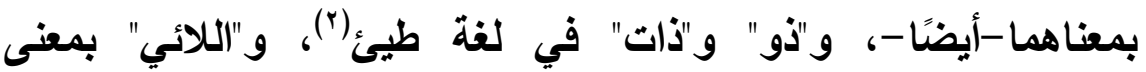

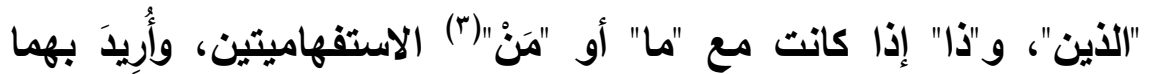
معنى "الأي" و "التي". وأجاز الكوفيون (๕) في أسماء الإشارة كُلِّهَا، وفي الأسماء الجوامد المُعَرَّفَةِ بالألف والكلام أن تستعمل موصولاتٍ. وفي "الأي" و"التي" لغات(•): تسكين الياء، وتثثديدها مع جريها بوجوه

(1) قال أبو حيان: "المتفق على حرفيته ومصدريته: "أَنْ" و "أَنَّ" و "كَيْي"،

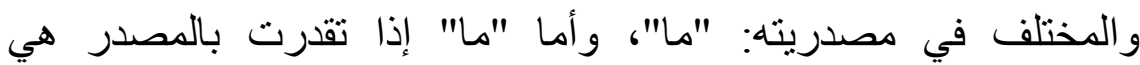
وصلتها، فذهب الجمهور إلى أنها حرف، وذهب الأخفش و المبرد و والمازني و السهيلي وابن السراج وجماعة من الكوفيين إلى أنها اسم، انظر : الكتهاب 

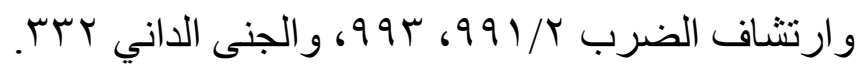

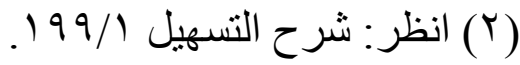

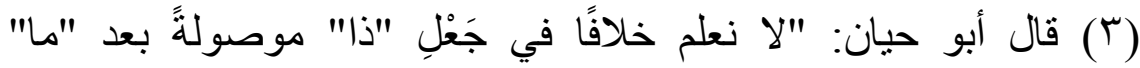

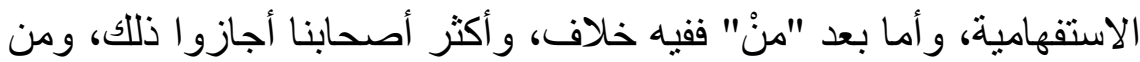
النحويين من لا يجيز ذلك"_التذييل و التكميل س/ بـ .

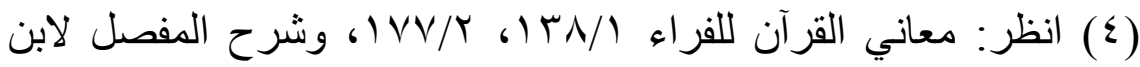

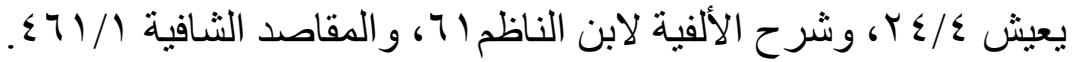

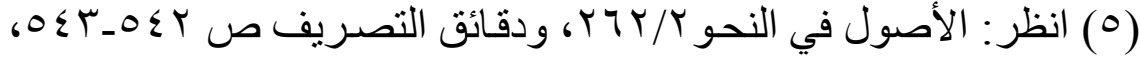
ومنهم من أنكر أن تكون هذه لغات، وقال: إنها ضـرورة، ومنهم: الثـلوبين

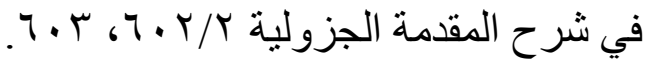


الإعراب، أو كسرها على حال(')، وحذف الياء والاستغتاء بالكسرة عنها،

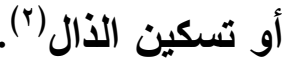

ولا يستعمل منها صيفة تثنية وجمع إلا "الأي" و"التي"، فيقال(): اللأن

رفعا، واللأين نصبا وجر.

و"الذين" في جمع "الأي" رفعا ونصبا وجَرًا، ومنهم من يقول(|): اللَُّونَ رفعًا، واللاذين نصبًا وجَرًا، وهذيل تقول: اللائين رفعا ونصبا وجرا، ويعض

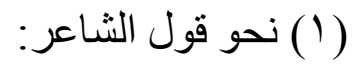

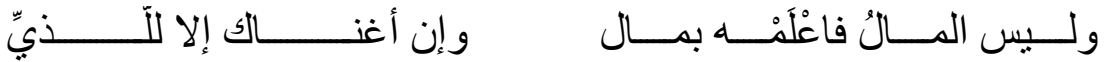

انظر: أمالي ابن الثجري س/ع 0، و الإنصاف ص إهـ، ورصف المباني

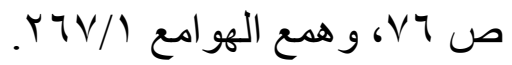

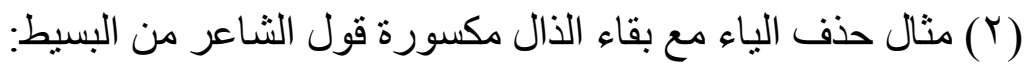

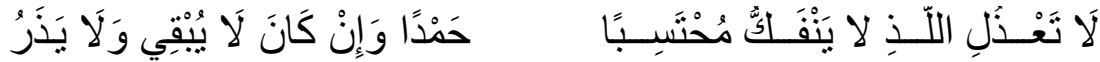
ومثال حذف الياء وتسكين الذال قول الثناعر من الطويل:

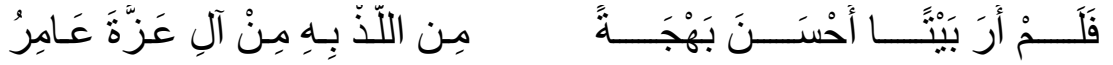

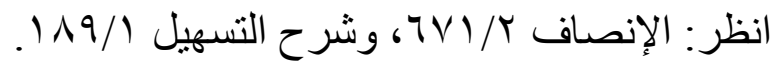

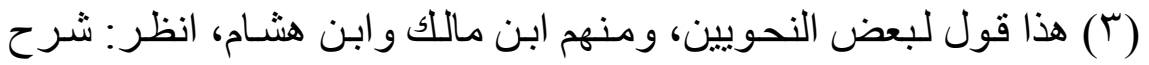

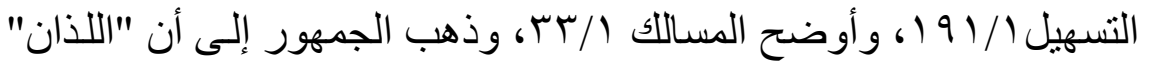

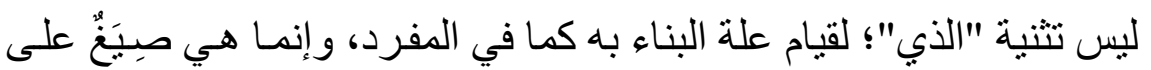

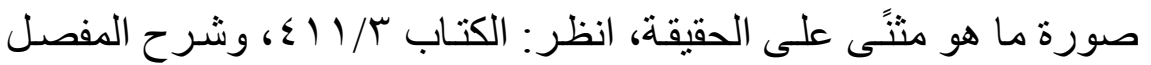

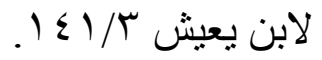

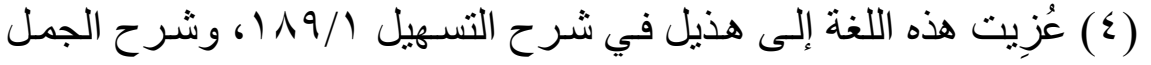

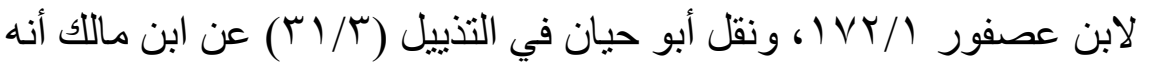

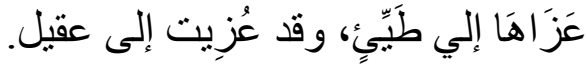


هذيل(') يقول: اللاؤون رفعا، والتلائين نصبا وجرا، ويجوز حذف النون في كل ذلك.

وتقول في جمع "التي": اللائي والتلاتي واللواتي، ويجوز حذف الياء في جميع ذلك، و "الكلاتِ" بتاءع مكسورة، و "الكلاتُ"(؟) بتسكينها. و"ما" تقع على ما لا يعقل، وعلى أنواع مَنْ يعقل من المذكرين

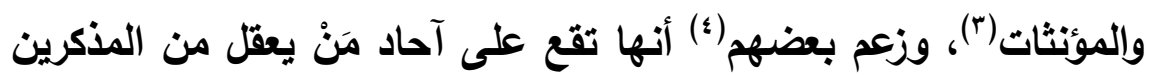
والموئثات.

و"مَنْ" تقع على مَنْ يعقل، وعلى ما لا يعقل إذا اختلط بِمَنْ يعقل فيما

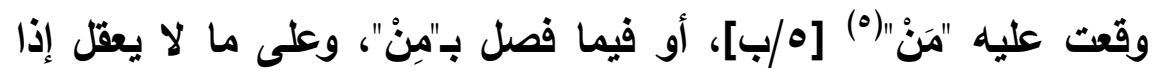

$$
\text { (1) (1) ومنه قول الثاعر: }
$$

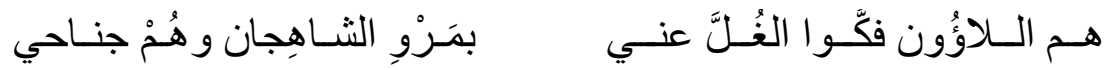

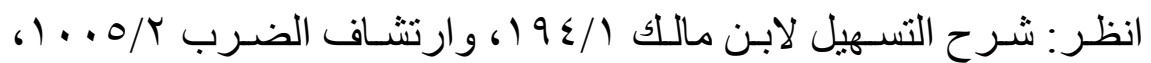

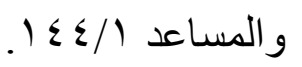

(Y) في الأصل: و "اللائي" بياء مكسورة، و "اللايْي"، و انظر : ابن عصفور .IVT/1

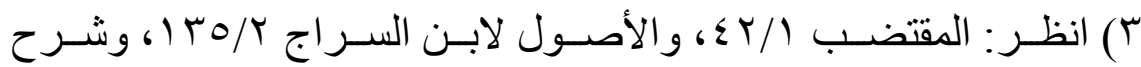

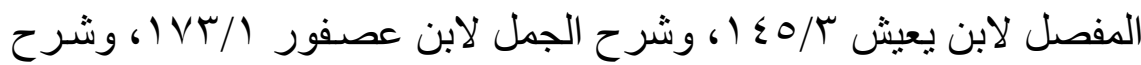

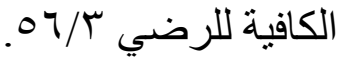

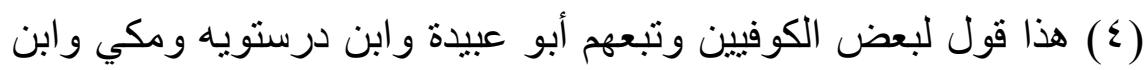

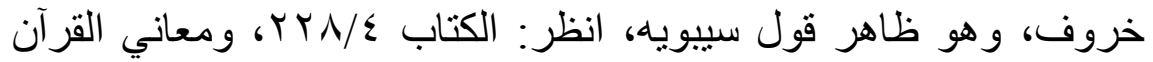

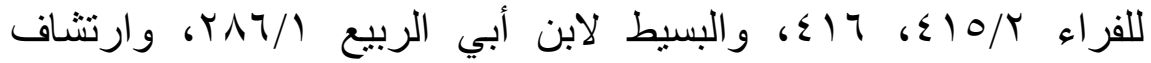

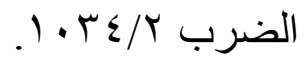

$$
\begin{aligned}
& \text { (0) في ابن عصفور 1/ 1) 1 "ما". }
\end{aligned}
$$


عومل معاملة مَنْ يعقل مِن المذكرين والمؤنثات(')، وزعم بعضهم(؟) أنها تقع على ما لا يعقل عموما.

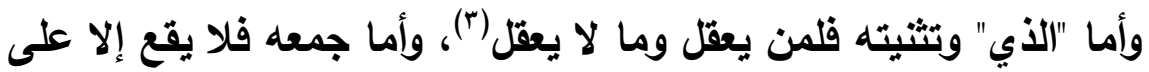
مَنْ يعقل (؛)، وأما "التي" وتثثيتها وجمعها فلمن يعقل ولما لا يعقل. والألف واللام لمن يعقل ولما لا يعقل من المذكرين والمؤنثات.

و"أَيٌْ" لمن يعقل ولما لا يعقل من المذكرين والمؤنثات، ويعض العرب(هن

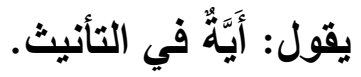

و"ذو" لمن يعقل ولما لا يعقل من المذكرين، وزعم بعضهم(") أنها تقع على المؤنث. و "ذات" لمن يعقل ولما لا يعقل من المؤنثات.

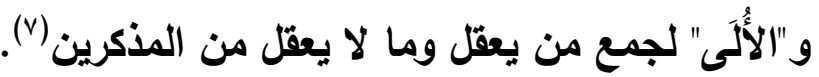

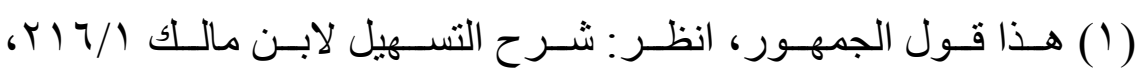
و الارتشاف آع ז • 1.

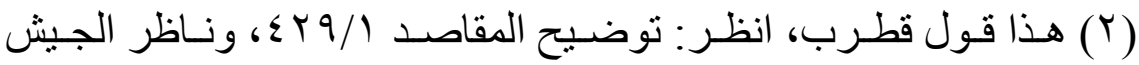

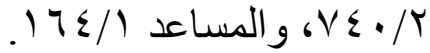

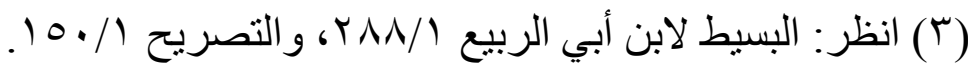

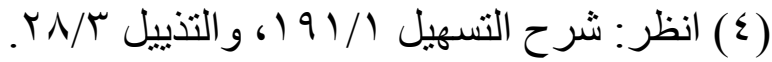

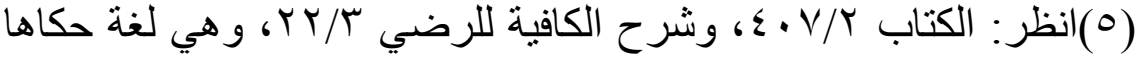

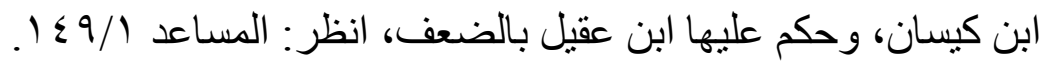

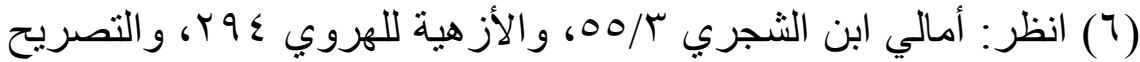
$171 / 1$ قال أبو حيان: "والمشهور أنها للعقلاء"، انظر: شرح التسهيل لابن

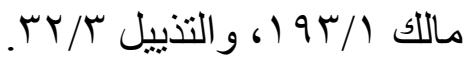


و"ذا" مـع "مَنْ" لمن يعقل من المذكرين وإلمؤنثات، ومـع "ما" لِمَا لا يعقل

منهما.

ومذهب الجمهور(') أن الألف واللام اسم، وقال غيرهم(؟): حرف. ولا بُدَّ من صِلَاتِ، فتوصل الألف والتلام باسم الفاعل واسم المفعول، ولا توصل بالجمل إلا ضرورةًَّ)، وغيرها لا يوصل إلا بظرف أو مجرور بشرط

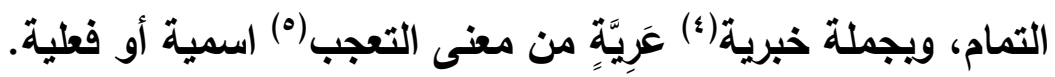

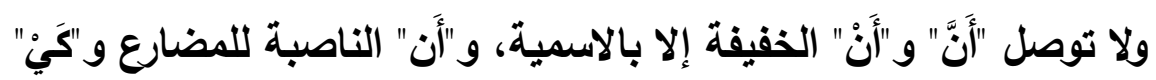

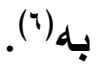

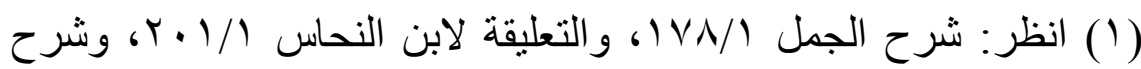

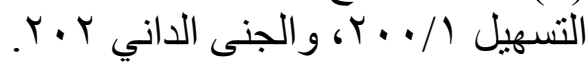

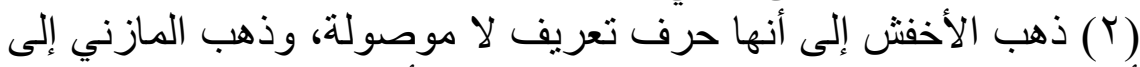

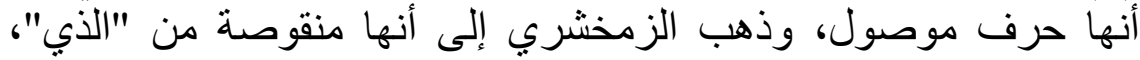

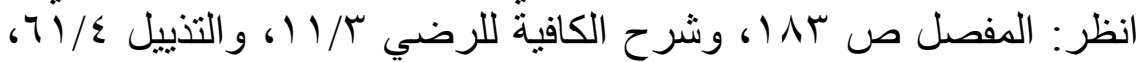

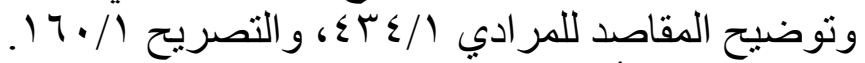

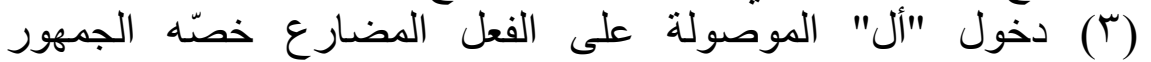

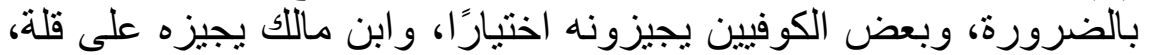

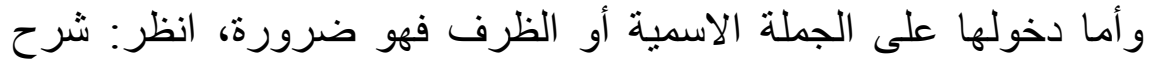

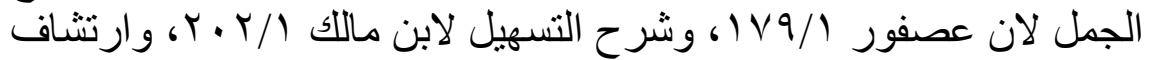

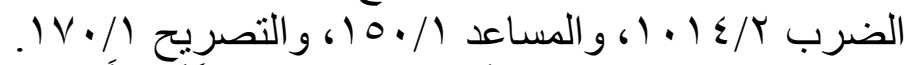

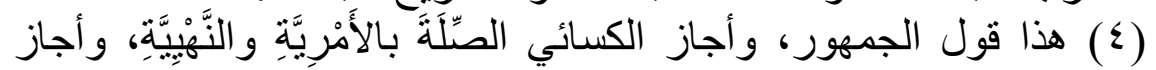

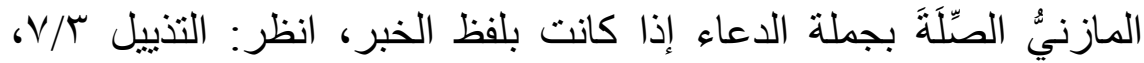

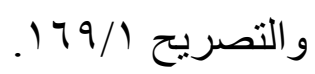

(0) هذا قول الجمهور، وأجاز ابن خروف الصلة بالتعجبية، انظر: شرح

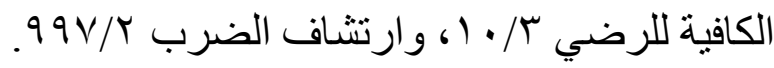

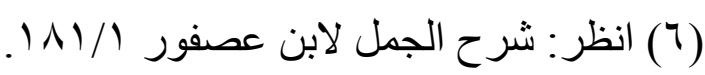




\section{إصدار V r T}

حولية كلية اللغة العربية بالمنوفية العدد الثاني والثُلاثون

و"ما" المصدرية لا توصل إلا بالفعل عند (س)(')، ومذهب طائفة-منهم الأعلم (†)-أنها توصل -أيضًا -بالجملة الاسمية.

ولا بـ في الجملة من ضمير الموصول، وقد يغنى عنه ظاهر هو هو في

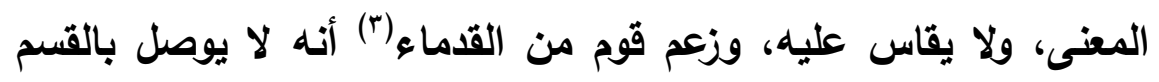
وجوابه، ولا بالشرط وجوابه، إذا عَرِيَتْ جملة القسم من ضمير الموصول، وإحدى جملتي الشرط والجزاء منه. والضمير إن كان مرفوعا لم يحذَف إلا إن كان مبتداً أَحَدَ جُزْاي الجملة الواقعة صلة، فإذ ذإك إن كان في صلة "أَيٍّ"، أو في صلة غيرها، وفي إن إن الكلام طول، جاز حذفه(؛)، والطول بأن يكون للخبر معمول واحد أو أكثر، ولا يحذف بـلا طُولٍ إلا حيث سُمِعَ.

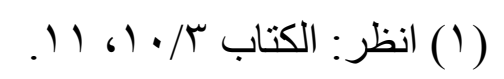

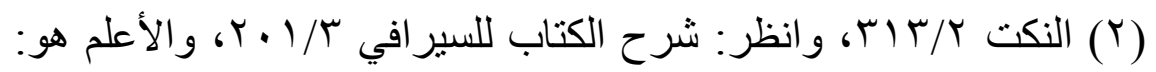

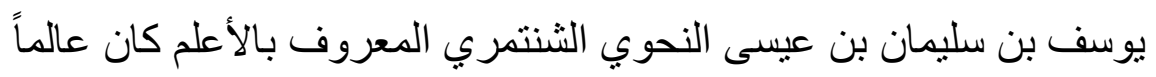
بالعربية واللغة ومعاني الأشعار، حافظاً لها، حسن الضبط لها، لها، مشهوراً

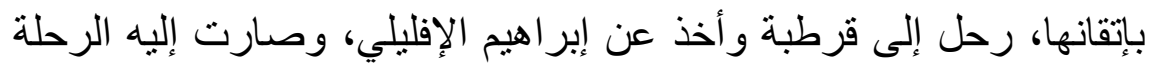

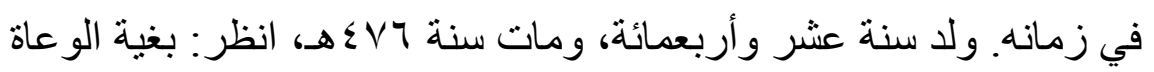
r $r \leqslant / T$

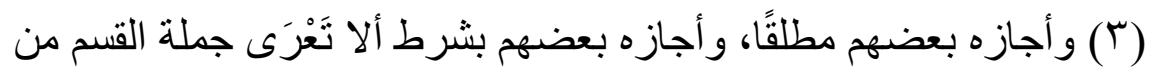

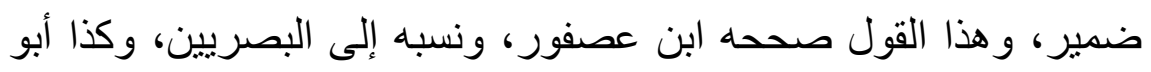

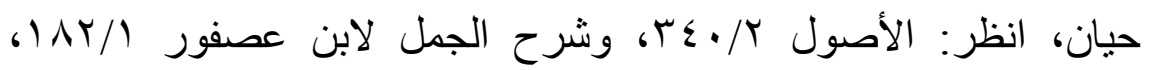

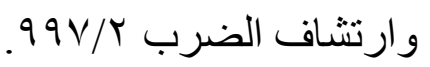

(ع) هذا قول البصريين، وأجاز الكوفيون حذف العائد المرفوع إذا كان مبتدأ طالت الصلة أو قصرت، في صلة "أَيِّ" أو غير ها، وذهب ابن مالك إلى إلى أنهـ

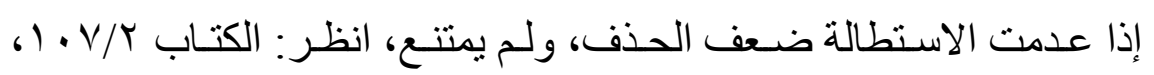




\section{الموفور من شرح ابن عصفور}

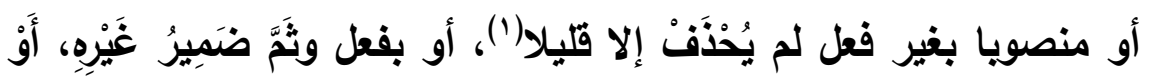

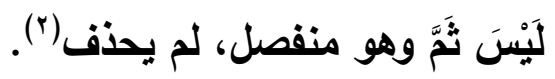

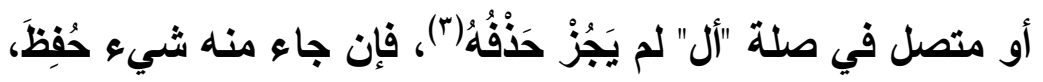

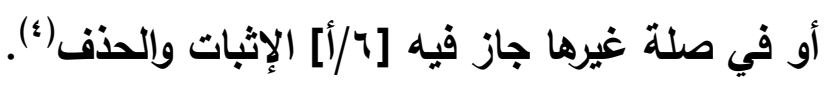

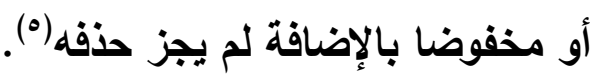

وقد يجوز في الثعر حذف الاسم والضمير لاليل(")، ولا يقاس عليه.

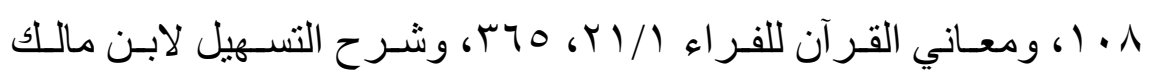

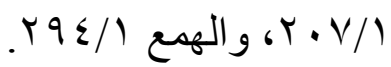

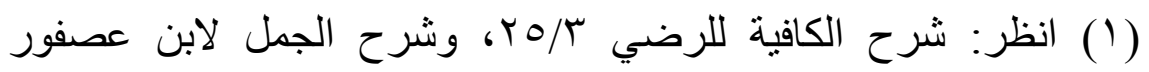

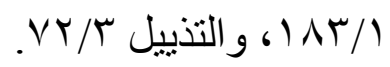

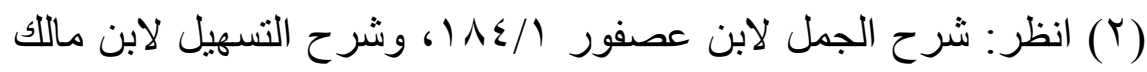

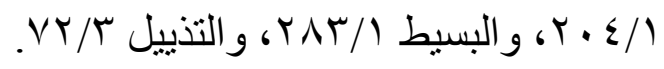

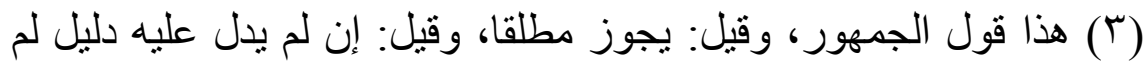

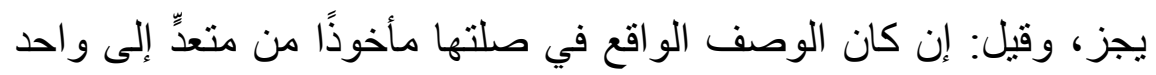

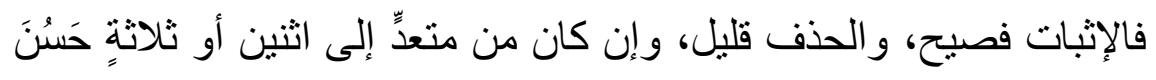

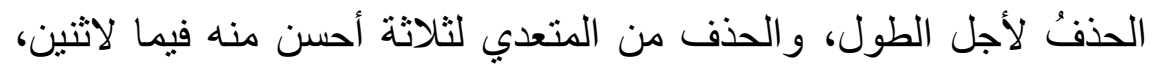

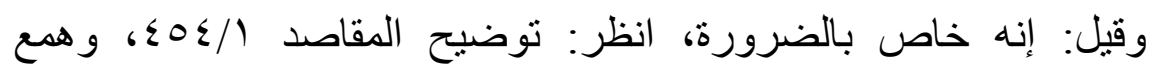

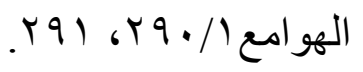

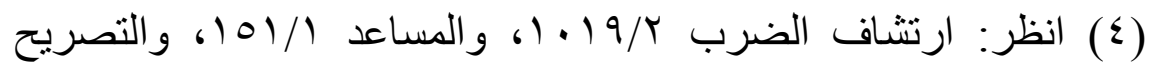
$. \quad V T / 1$

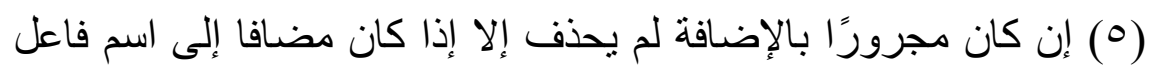

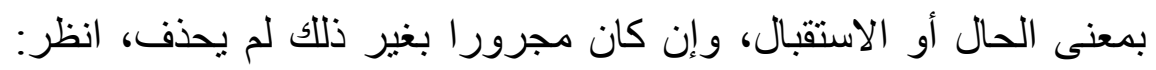

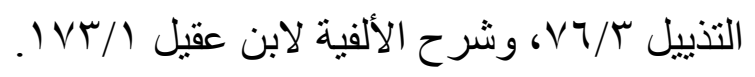

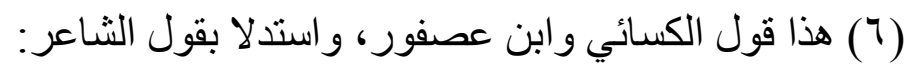


أو بحرف جر في موضع رفع فلا يجوز حذفه، أو لا في موضعه وفي الصلة ضمير غيره لم يحذف، أو لا ولم ياخل على الموصول حرف من جنس ما دخل على الضمير، فلا يحذف إلا حيث سُمِع، أو دخل فيجوز إثباته وحذفه، إلا إن تعلقا بمختلفي المعنى لم يجز حذفه(').

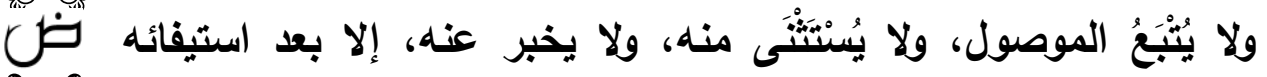
صلته.

ولا يُفْصَلُ بين الصلة والموصول بأجنبي، أعني بما ليس من الصلة، إلا إِنْ فُصِلَ بجملة اعتراضِ (r). ولا يجوز تقديم الصلة على الموصول(")، ولا يجوز حذف الصلة إلا إن كان في الكلام ما يدل عليه(؛).

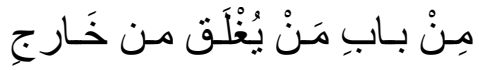

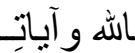
بـ أعُـ

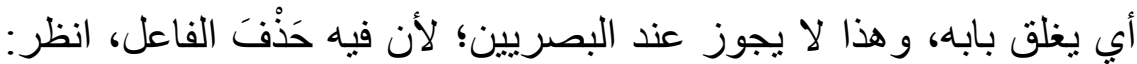

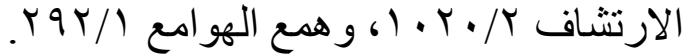

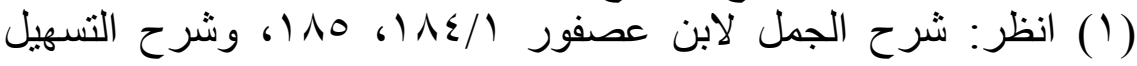
Y. T. T. T/1

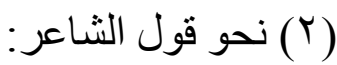

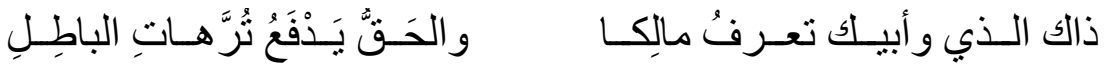

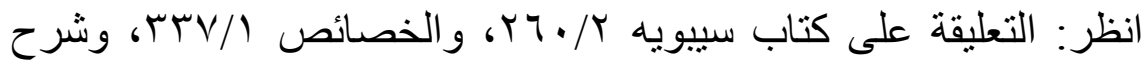

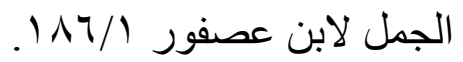
(r) لأن الصلة من كمال الموصول، ومنزلة منزلة جزئه المتأخر، انظر:

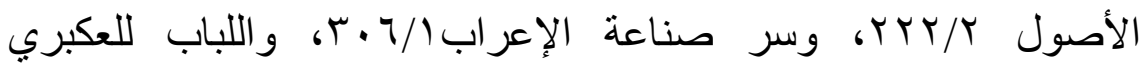
. I TN/T ( ) نحو قول عبيد بن الأبرص:

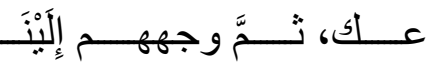

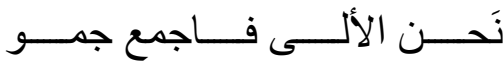


ويجوز فيما كان من الموصولات للواحد والاثنين والجمع بلفظ وإحد الحمل على اللفظ في حال التثية والجمع فيفرد، وعلى المعنى فيثى ويجمع(')، وفيما كان منها للمذكر والمؤتث بلفظ واحد أن يحمل إذا وقع على المؤنث على لفظه فيذكر ، أو على معناه فيؤنتث. ويجوز في جميعها إذا وقعت بعد ضمير متكلم أو مخاطب أن تعيد الضمير عليها كما تعيده على الاسم الظاهر إذا وقعت بعده، أعني ضمير غيبة، وأن تعامله معاملة ضمير المتكلم أو المخاطب، وإذا حملت على إلى اللفظ وإلمعنى في كلام واحد فالأحسن أن يتقدم الحمل على اللفظ، ثم يحمل بعد ذاك على المعنى()، وقد يجوز أن يتقدم الحمل على المعنى

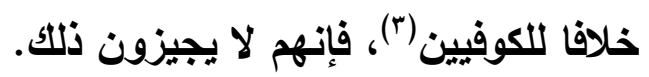

أو قصد الإبهام ولم تكن صلة أل، انظر : مغني اللبيب ص 911 (1، والتصريح

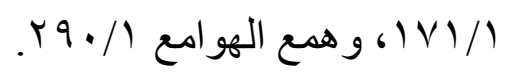

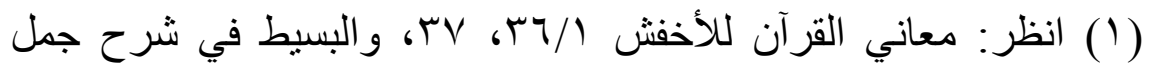

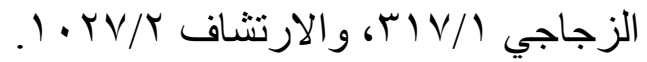

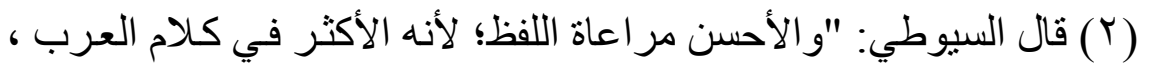

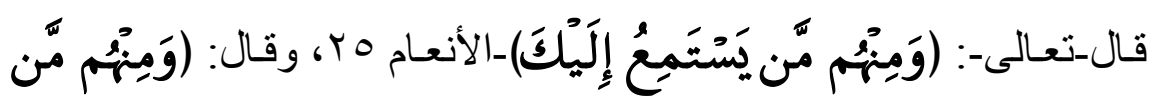

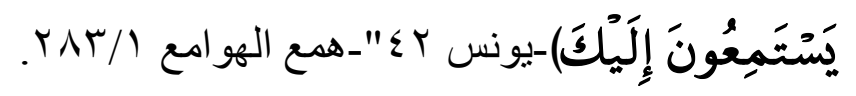

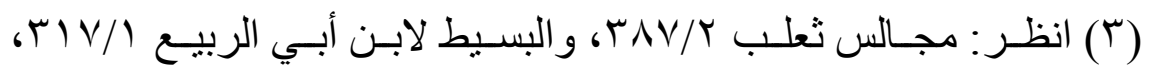

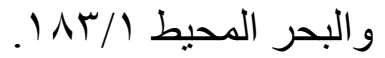


إصدار IV R حولية كلية اللغة العربية بالمنوفية العدد الثاني والثلاثون

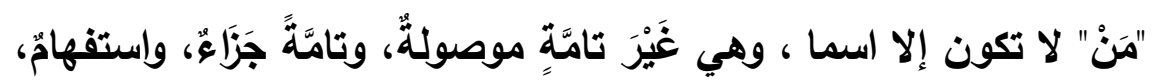

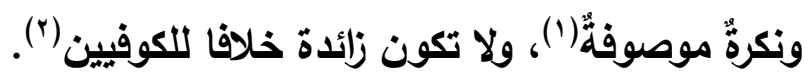
"ما" حرفية واسمية، الاسمية غير تامة، وهي الموصولة(ب)، وتامة نكرة موصوفة(؛)، وصفة، ونكرة غير موصوفة، شرطا واستفهامًا

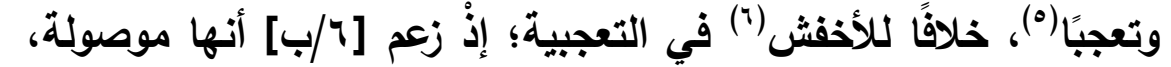

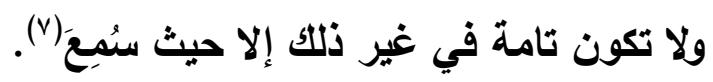

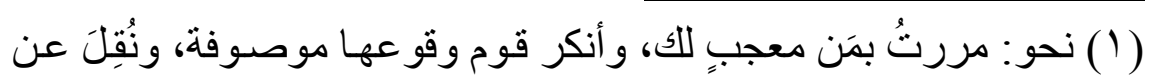

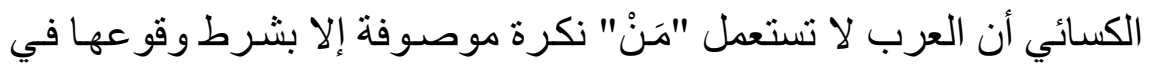

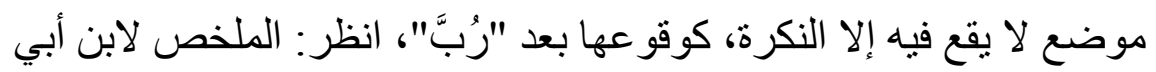

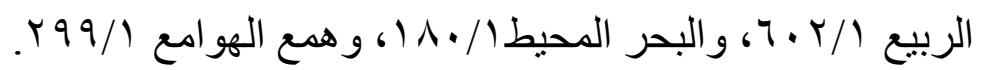

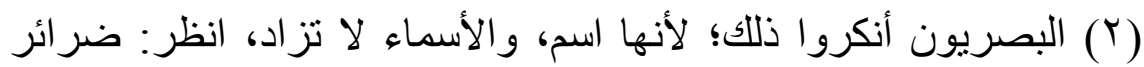

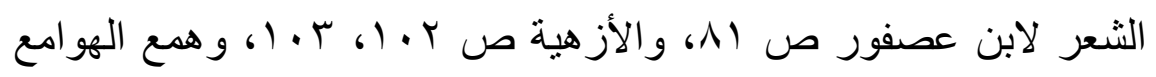
. 1/1

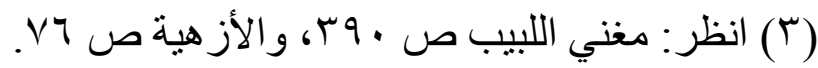

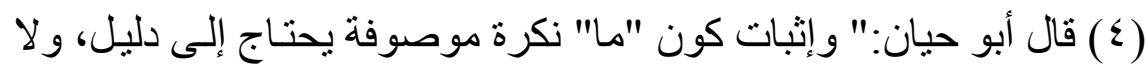

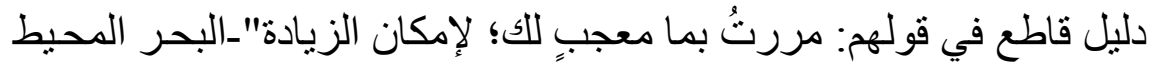

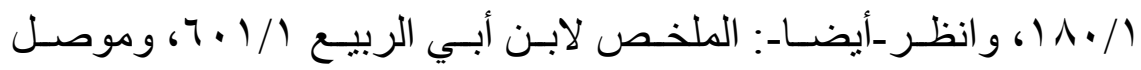

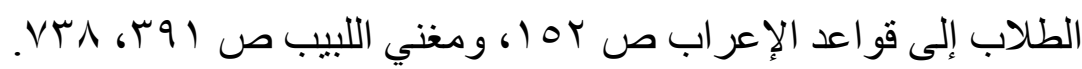

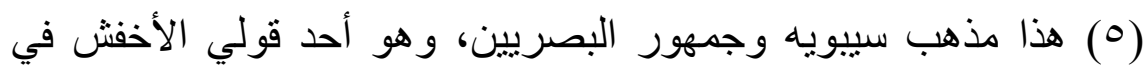

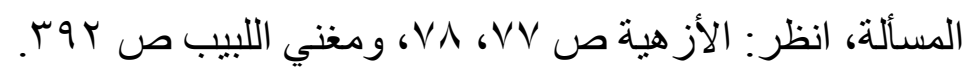

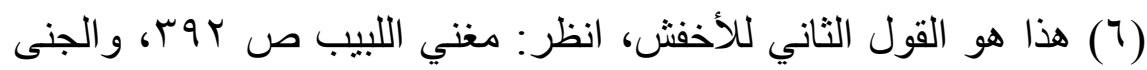

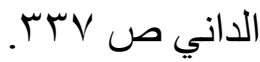
(V)

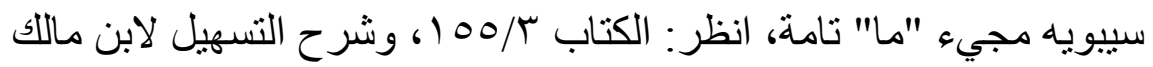

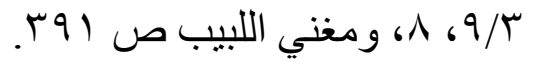


الموفور من شرح ابن عصفور

والحرفية غير زائدة مصدرية، ونافية لماض ومستقبل، وتخلص المضارع للحال(')، ولا تدخل المصدرية على جملة اسمية أصلا(r)، وهي عند

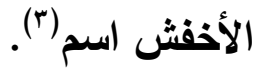

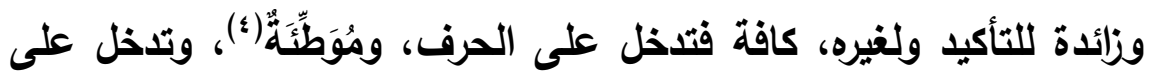
اللفظ، فتسوغ له الاخول على خلاف ما كان ياخل عليه. ****** $* *$

"أَيّْ": شرط، ويأني حكم أسماء الشرط، وموصولة(•)، ولا تخالف الموصولات إلا في شيئين، أحدهما: جواز حذف الضمير المبتدأ، وإبقاء خبره وإن لم يكن في الصلة طول، وإن جاء في غير "أَيِّ" حُفِظَ، والآخر:

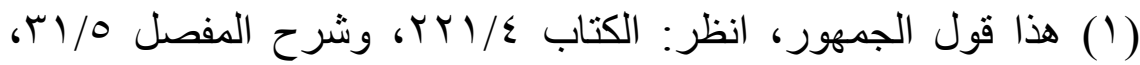

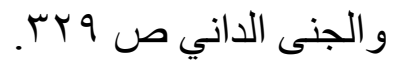

(Y) هذا قول سيبويه و الجمهور، وذهب قوم منهم السير افي والأعلم و ابن

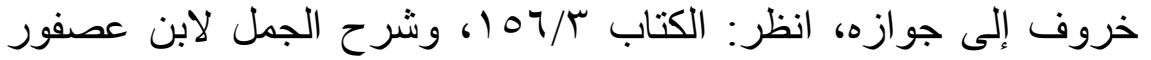

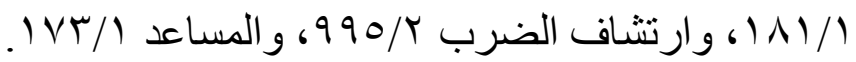

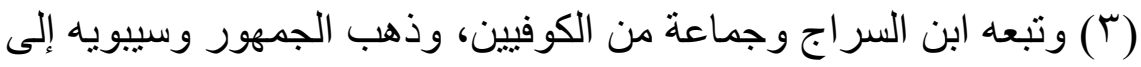

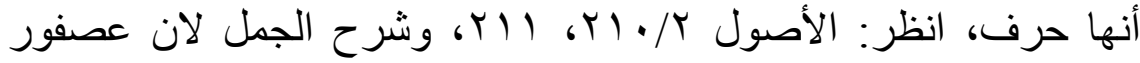
§OV/T

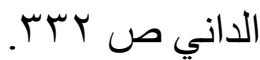

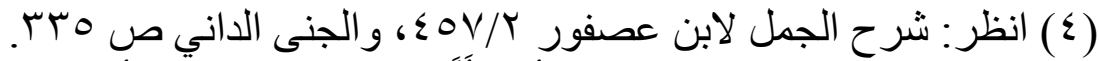

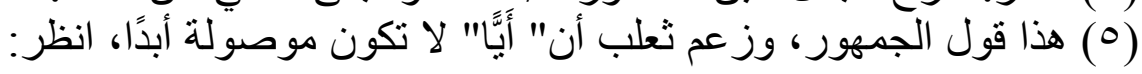

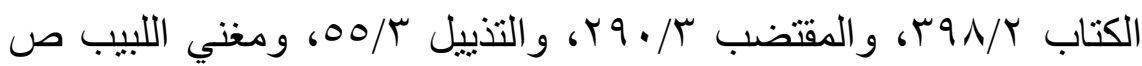

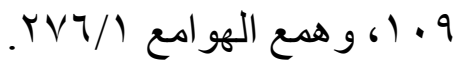


أنها لا ياخل عليها إلا المضارع(')، والموصول غيرها ياخل عليه الماضي والمضارع.

ووصلة إلى نداء ما فيه "أل"، فيلزمها النعت، ولا يقع بعدها إلا ما فيه "أل"، إلا في الشعر، فإنها قد يليها اسم الإثارة(؟). وصفة، ولا يكون الاسم بعدها إلا ما يعطي معنى الصفة التي قصد الثناء لُّلَّل بها. واستفهام، وتضاف أبدا لفظا أو نية()، فإن أضيفت إلى معرفة كانت واقعة على بعض ما أضيفت إليه، ولا يكون المفرد بعدها في معنى جمع، بل يكون واقعا على ما كان يقع عليه قبل دخولها، من إفراد وتثنية وجمع، وإن أضيفت إلى نكرة مفردة كاتت في معنى جميع، وإن كانت مثناة أو مجموعة فالمثنى واقع على جميع الجنس، مفصلا: اثثين اثثين، والجمع واقع على جميع الجنس، مفصلا: جماعاتٍ جماعاتٍ، ولا يمكن أن يكون الاسم على هذا المعنى معرفة (؛). ****** $* *$

"ذا": إذا كانت مع "ما" الاستفهامية إن بقيث كل واحدة على بابها، فلا

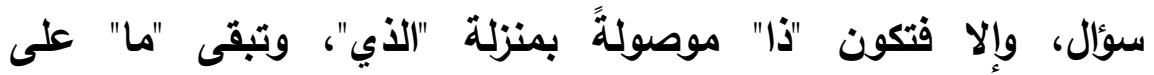

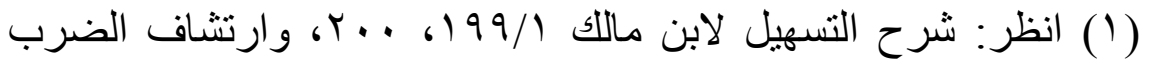
ا

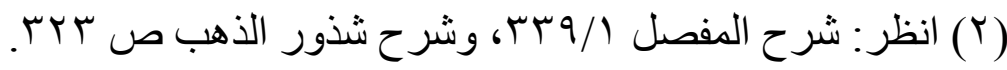

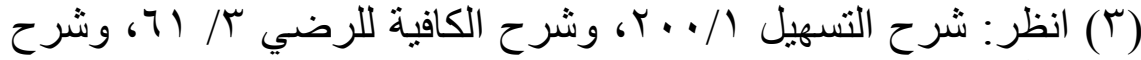

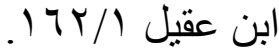

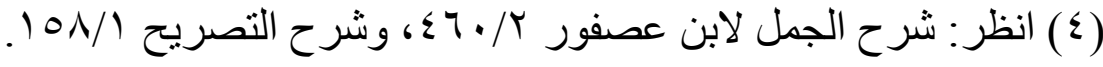


استفهاميتها، والإعراب: مبتدأ وخبره، ويكون "ماذا" كله بمنزلة اسم واحد،

ويكون معنى "ماذا" و"ما" واحدا، فيكون إعرابها على حسب ما بعدها(').

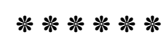

و"ما": سؤال يستدعي جوابا، ويختار فيه أن يوافق اسم المسؤول من رفع أو نصب [l/ly] أو خفض، وقد يجوز أن يكون مرفوعا على كل حال، أو منصويا على المعنى، إلا أنه قليل جدًّا. ****** $* *$

الإخبار: إلحاق أول الكلام "أل" أو "الأي" مبتدأين، وتأخير المخبر عنه إلى آخره خبرا، معوضا عنه ضمير مطابق له في الإعراب، رابط للصلة (؟). و"الذي" أعم من "أل"؛ لاخول "الذي" على الجملة الاسمية والفعلية، و"أل"

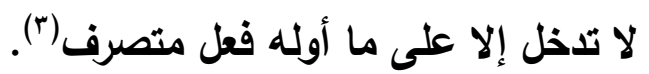

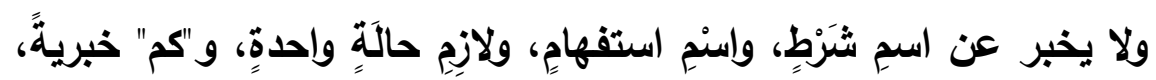

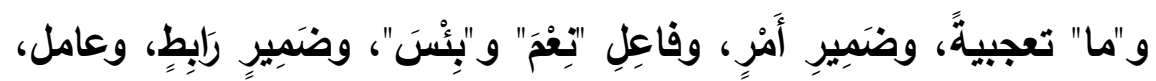
ومنعوت دون نعته، وعكسه، ومضاف دون مضاف إليه، وتأكيد، وتمييز،

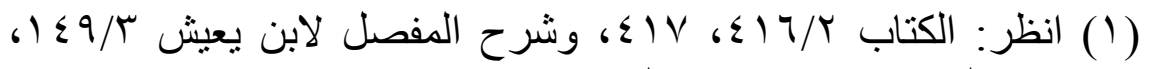

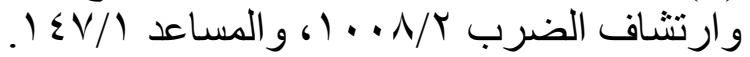

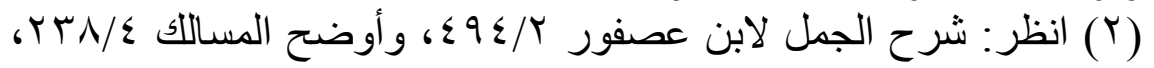

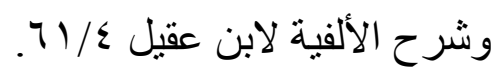

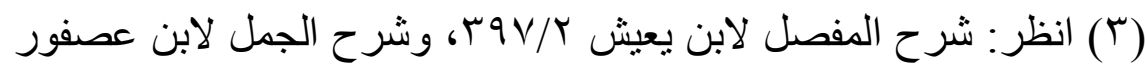
( 


\section{r.IV إصدار}

حولية كلية اللغة العربية بالمنوفية العدد الثاني والثلاثون

وحال، ومجرور "رُبََّ"، ومُخْتَصِّ بنفي، وكذا اسْمُ لا معنى تحته على

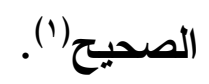

ونحو "رَيْدُ هِنْدُ الضَّارِتَتُهُ" إما أن تكون "أل" والصفة لهند، أو لزيد، أو "أل " لزيد، والصفة لهند، أو عكسه.

فالأول: يستتر فيه ضمير الفاعل، وإلثاني: إن وَلِيَ اسنمَ الفاعل ضميرُ زيلٍ

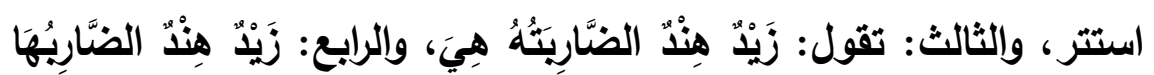

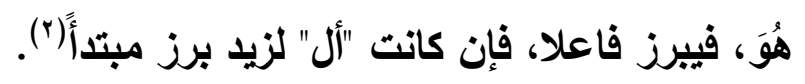
والمخبر عنه إما أن يكون مرفوعا أو منصويا أو مجرورا، إن كان مرفوعا

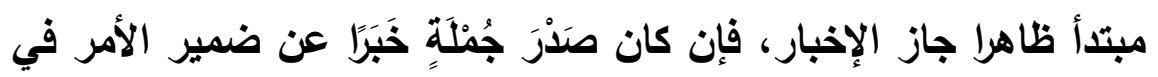

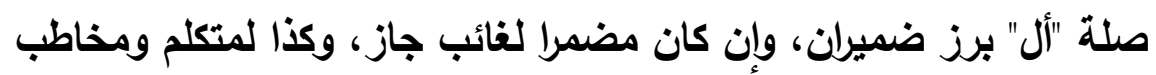

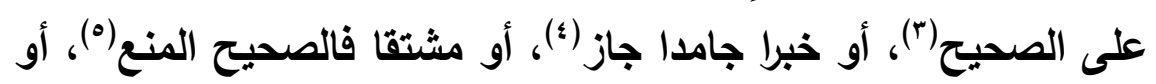
فاعلا فكالمبتأ إظهارا وإضمارا وخلافا، ويصير ذكره غالبا في نحو:

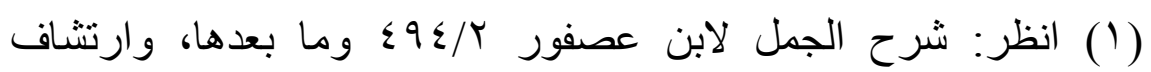

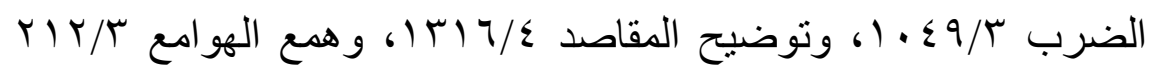
و وما بعدها.

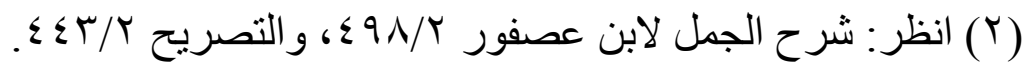

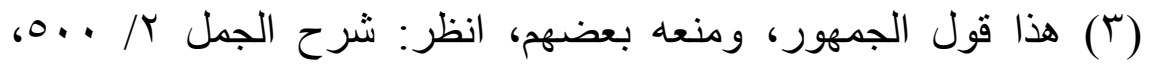

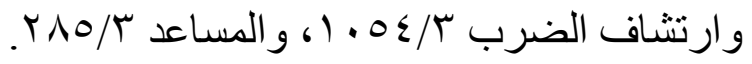

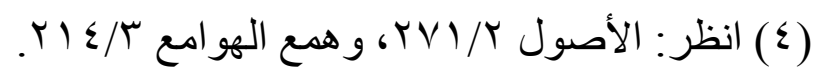

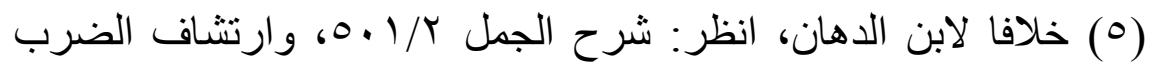

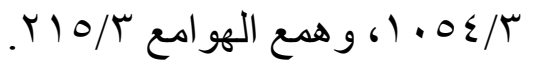


"ضربت زيدا"، فتقول: الأي ضرَبَ زَيْدًا أنا، ولا يجوز : الأي ضريتُ زيدًا أنا؛ خلافا للكسائي (') فإن عطقت عليه جملةً فاعلُها غَيْرُ الأول، والحرف الفاء أو الواو بمعنى "مَعَ"، والإخبار بـ"الذي"، فيجوز على كلا فَاعِلَّي الجملتين، أو الواو المشتركة أو حرف غير ذلك، فالإخبار عن فاعل أولاهما لا يجوز، أو الإخبار ب"أل" فكالحكم [V/ب] مع "الأي".

فإن عطفت على الفاعل الأول اسْمَ فاعِلِ، والإخبارُ بـ"الذي" وجب تنكيره،

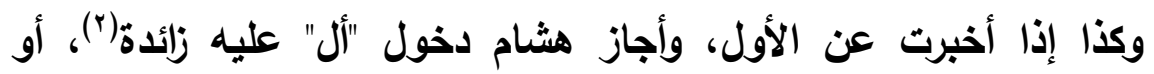
الإخبار ب"أل" واسم الفاعل نكرة، أخبرت عن الأول أو الثاني، وأجاز هشام دخول "أل" زائدةً(ّ)، ويجوز في هذه المسائل ما بجوز في المتقدمة، ويمتنع ما يمتتع.

وإن كان الفاعل الثاني هو الأول جاز للك الإخبار عن أيهما شئت، بأيهما شئت، بما شئت من حروف العطف، فإذا أخبرت عن الثاني كفى ضمير واحد. وإن عطفت على الفاعل مفردا أخبرت عن الأول بالواو فقط، و"أل" و"الذي" سواء، أو مشبها بالفاعل فكهو اتفاقا واختلافا، إلا في ضمير المرفوع بالحرف فينفصل، وفي خبر "إنَّ" المشتقِّ خلافُ الخَبَرِ عن المبتدأ إذا كان مشتقا.

(1) انظر: شرح الجمل لابن عصفور //1/.0،، وارتشاف الضرب r^

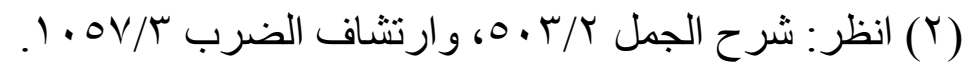
(ץ) انظر : المصدرين السابقين. 
أو نائبا فكهو، إلا أنه يُينَى من الفعل اسنُْ مفعولٍ، أو مبدلا منه، فقيل: يبلز منه ضمير، ويؤخر إلى آخر الكلام، ويجعل بالا منه كما قَّبْلَ الإخبارِ، وقيل: يخبر عن كل منهما على انفراده. وفي الببل تقول في "قام زيد أخوك": الأي قام زيد هو أخوك، والصحيح في المذهب الأخير منع الإخبار عن البدل، وجوازه عن المبدل منه، فتقول: الأي قام هو أخوك زيال' ('). وإن كان منصويا مفعولا فيه غير متسع فيه وصل الفعل إلى ضميره ب"في"، ولا تحذف ولا يحذف، وق يحذقان إن كان في الكلام حرف من جنس المحذوف يال عليه، أو مُتََّتًَا فيه فلا يصل، ويجوز حذفه لا في صلة "أل "(r).

ومفعولا معه ومفعولا من أجله(")، فالصحيح أنه لا يخبر عنهما، أو مفعولا مطلقا، فالصحيح الإخبار عنه بشرط الفائدة(؛ (). أو مفعولا به، والفعل يتعدى إليه فقط، جاز، وجاز حذف العائد لا في صلة "أل"(•) أو إلى اثثين من باب "أعطى"، وأخبرت عن الأول أو عن الثاني،

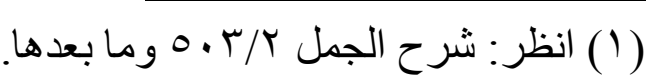

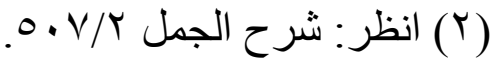

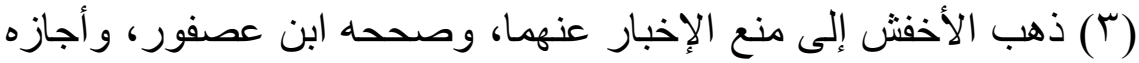

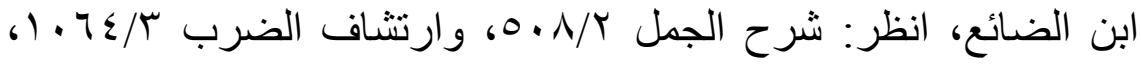

$$
\text { .1. } 10
$$

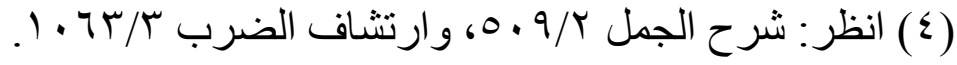

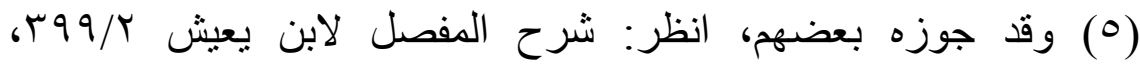

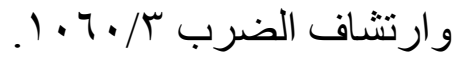


فيجوز حذف العائد لا في صلة "أل"، وفي الإخبار عن الثاني تقدمه على

الأول إن لم يلبس، فإن ألبس لم تقدمه ولم [//أ] تصله بالفعل (1). أو من باب "ظَنَّ"، فإن أخبرت عن الأول أضمرته، والصحيح جواز حذفه(؟)، وقا يحذف في صلة "أل" قليلا، أو عن الثاني بـ"أل"، ففي المشتق خلاف(ץ)، وأما الجامد فتضمره، ويجوز حذفه، ولا يجوز تقديمه على الأول ووصله بالفعل، إلا أن عُدِمَ لَبَسْ. أو إلى ثلاثة، فإن أخبرت عن الأول أضمرته، ولم يجز حذفه، أو عن بأن الثاني بـ"الأي"، وَسَّطْتَ ضميره منفصلا، ولا يجوز حذفه، فإن عدم اللبس إنس جاز أن يتصل بالفعل، أو عن الثالث فلا يتصل، ولا يحذف، وإن كان

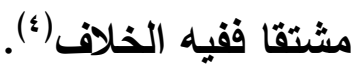
*******

نعم ويئس: فعلان عند البصريين(॰)، واسمان عند الفراء(؟) وكثير من

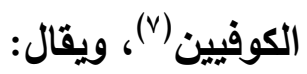

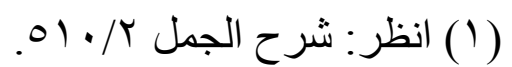

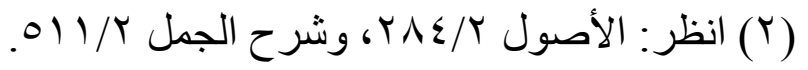

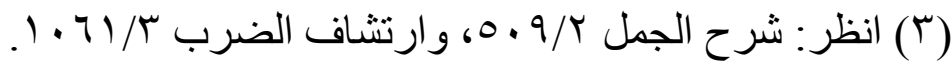

( ) (انظر : المصدرين السابقين.

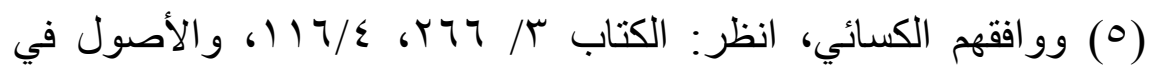

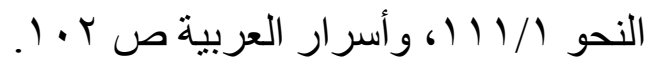

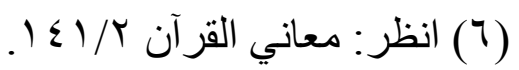

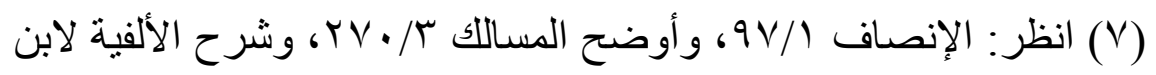

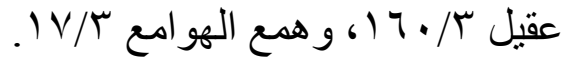




\section{إصدار Y r T}

حولية كلية اللغة العربية بالمنوفية العدد الثاني والثلاثون

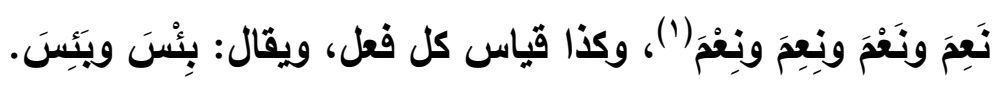
ولا يكون فاعلهما(؟) إلا ما فيه "أل"، أو مضافا إليه، أو مضمرا على ونى

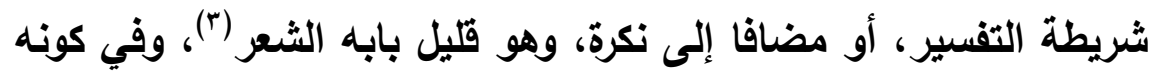
"مَنْ" و"ما" الموصولتين وما أضيف إليهما خلاف، وإلمختار المنعع(ء). ويجب ذكر اسم الممدوح أو المذموم، والتمييز إن كان الفاعل مضمرا،

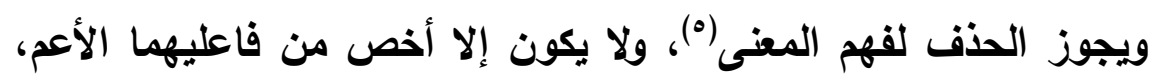
ولا مساويًًا.

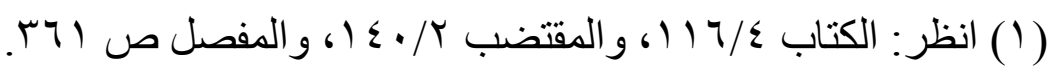

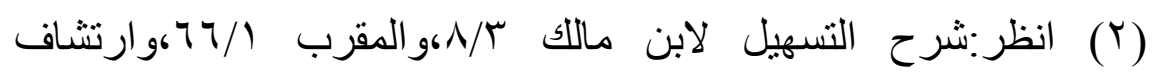

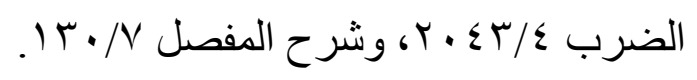

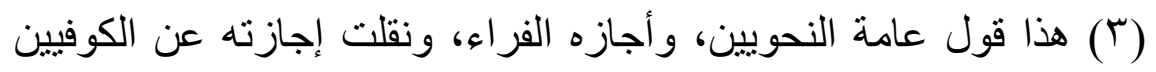

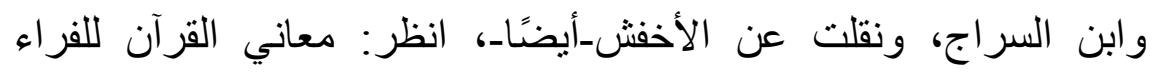

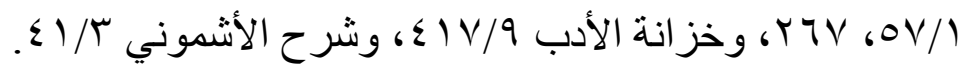

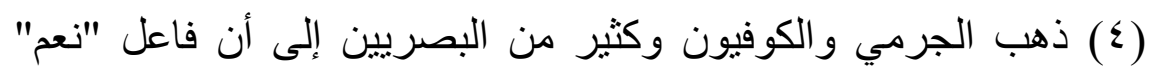

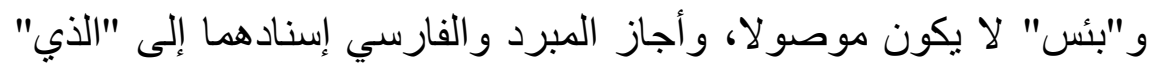

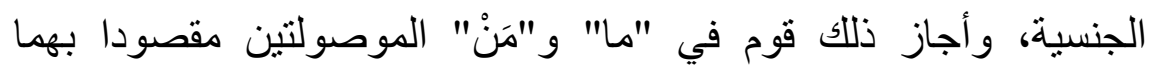
الجنس، و عليه جرى ابن العلج و ابن مالك، وظاهر قول الأخفش أنه لا يجيز

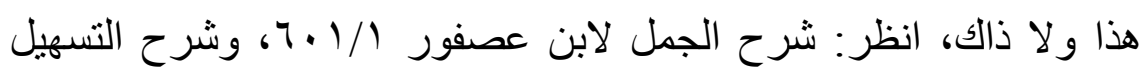

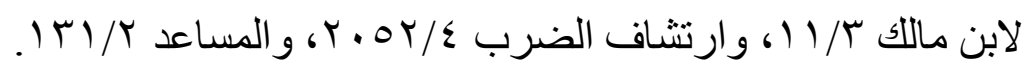

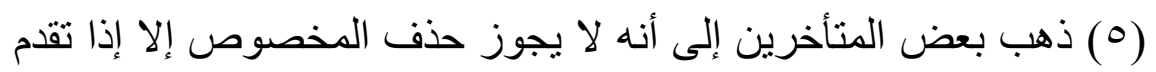

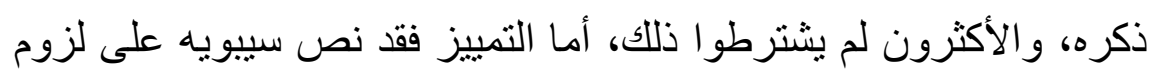

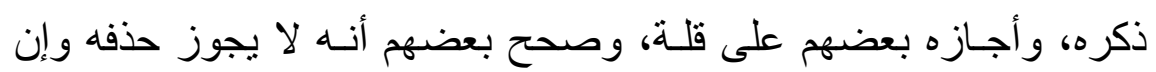

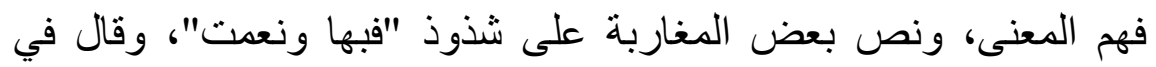

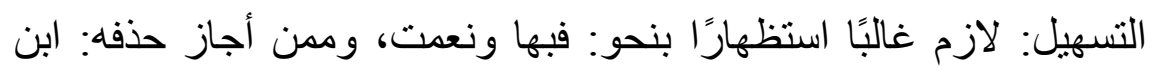


وإن قدمت الممدوح أو المذموم (') فمن قال باسمية "تعم" و"بئس" أعريهما مبتدأ، وما بعده الخبر، أو خبرا وما بعده مبتدأ، ومن قال بفعليتهما

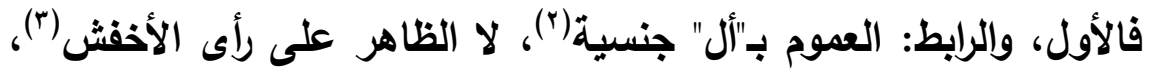
ولا لامُ عهدية، خلافا لأبي إسحاق بن ملكون (؛)، ولا مبتدأ مضمر قبلهما، خلافًا لأبي محمد بن السيِّدِ(ه).

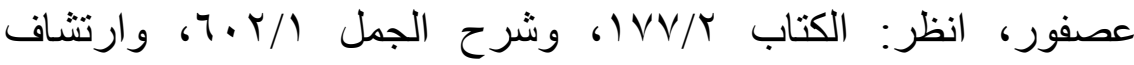

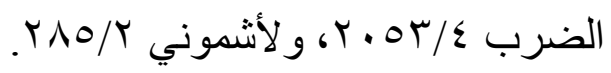

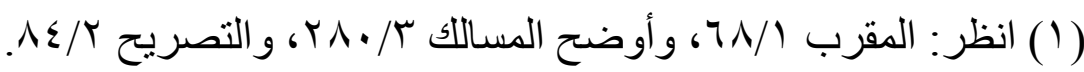

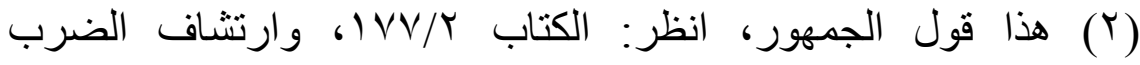

$$
r \cdot \leq r / \varepsilon
$$

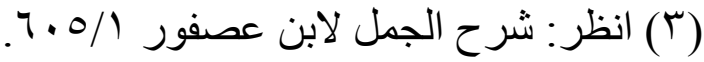

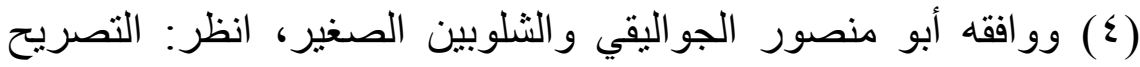

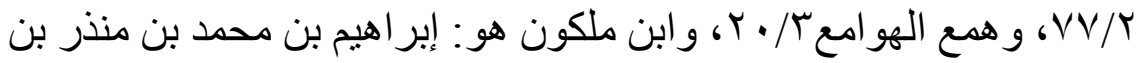
سعيد بن ملكون الحضرمي الإشبيلي، أبو إسحاق قال ابن الزبئ إنير : أستاذ

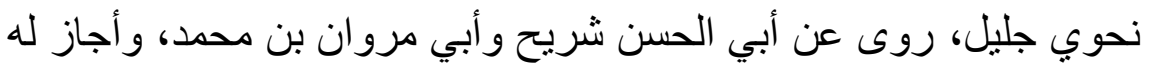

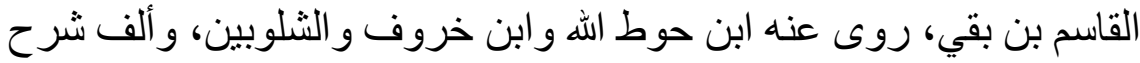

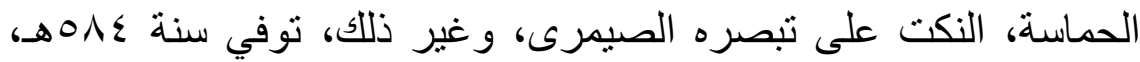

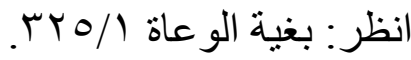

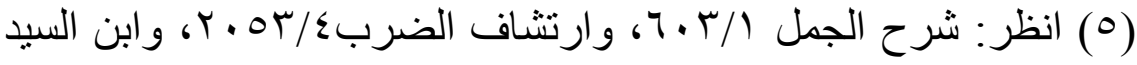

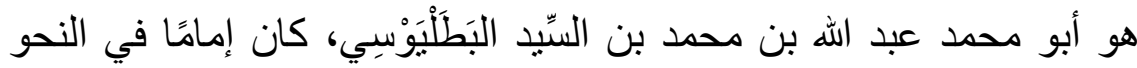

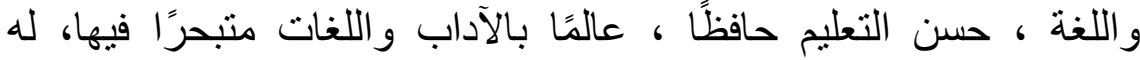

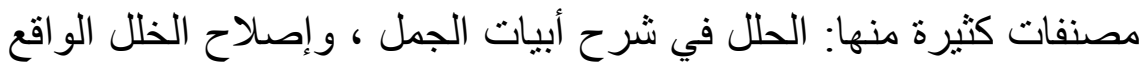
في الجمل، وشرح سقط الزند لأبي العلاء المعري، توفي في بلنسية سنة

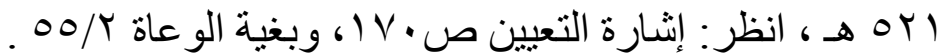




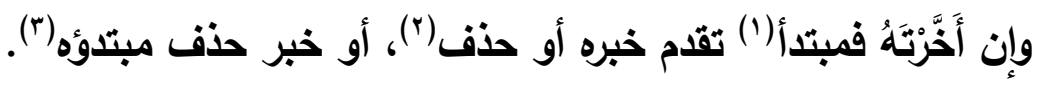
وإذا كان الفاعل ضميرا لم يثن ولم يجمع؛ استغتاء بتثية الممدوح أو المذموم وجمعه(؛)، وحكى الأخفش(ه) في الكبيز لله أن من العرب من لن لن يقول: نعما ونعموا.

ولا يجمع بين الفاعل الظاهر والتمييز(؟)، ولا تذخل [^/ب] "مِنْ" على التمييز، ولا يُمَيَُّْ بمتوغلٍ في الإبهام، كشيء و"مَنْ" و"ما" إلا أن يخصص بالوصف.

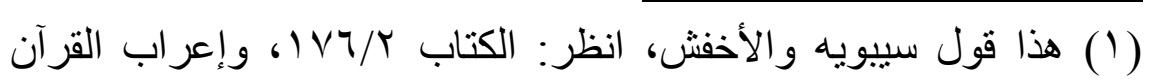
للنحاس

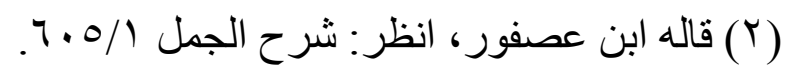

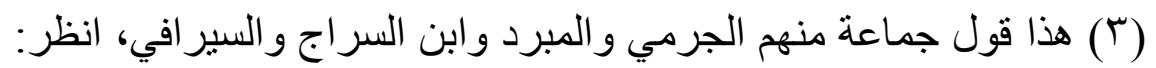

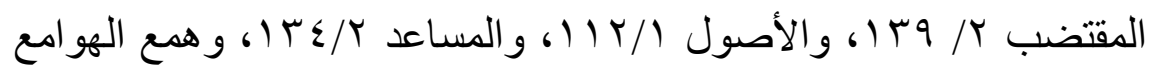
זT/ (ع) هذا قول سيبويه وجمهور البصريين، وأجاز قوم من الكوفيين تثنيته

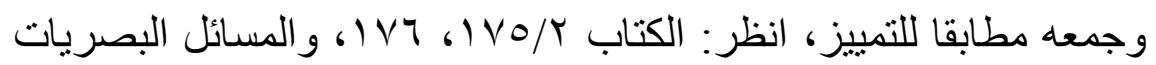

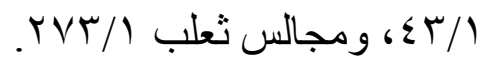

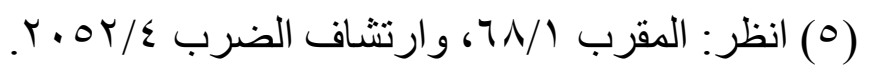

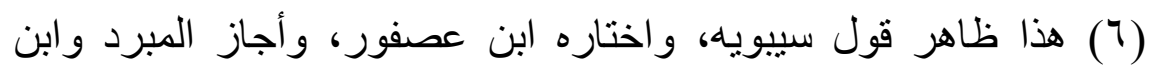

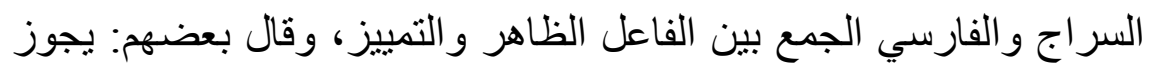

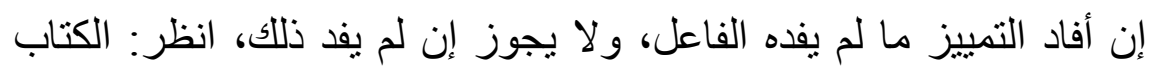

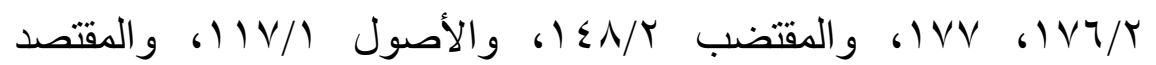
每 
وإن كان الفاعل مذكرا لم تلحق التاء، إلا إن كان مكنيا به عن مؤنث، أو مؤنثا فتلحق جوازا(')، إلا إن كني به عن مذكر فلان الن يلحق.

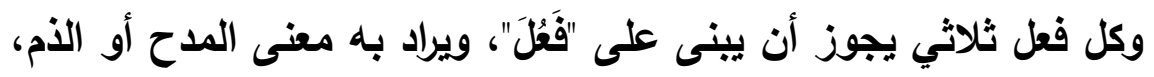

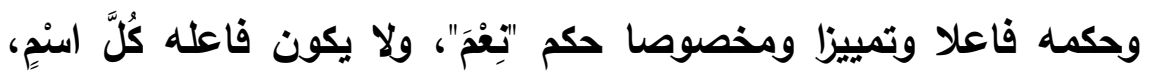
خلافا للمبرد (r)

****** $* *$

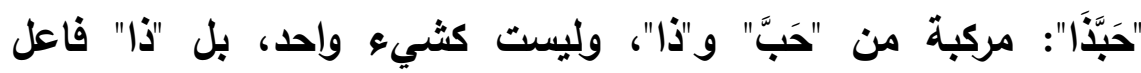

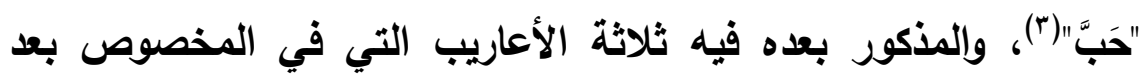

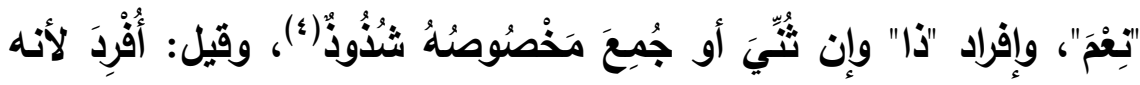
إثارة إلى مفرد مضاف إليه المثنى والمجموعُ، وهذا مذهب ابن كيسان (॰)،

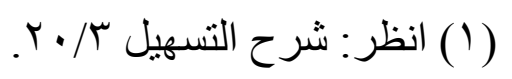

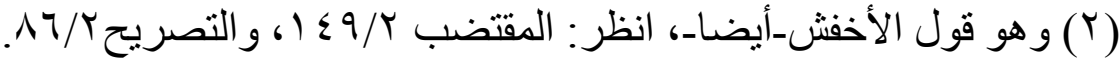

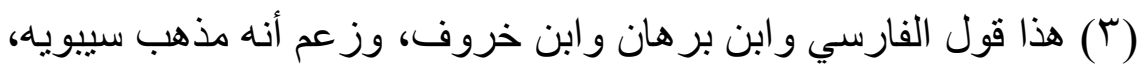

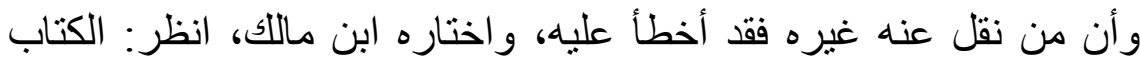

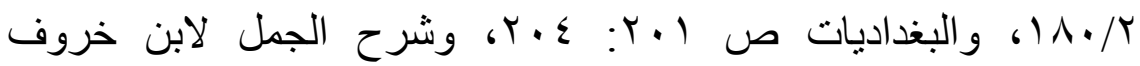

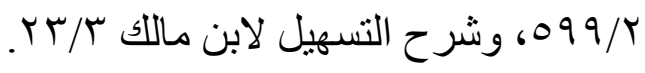

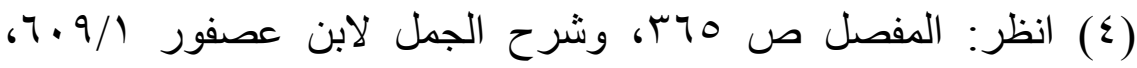

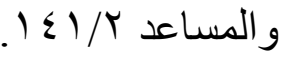

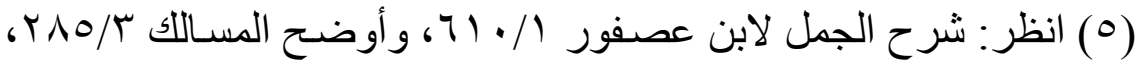

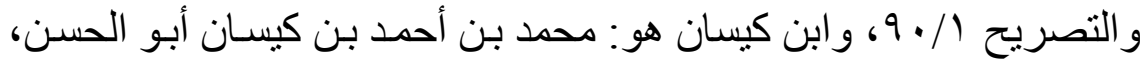

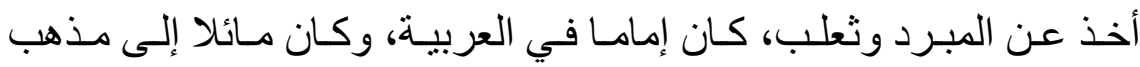

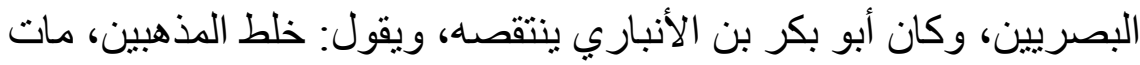

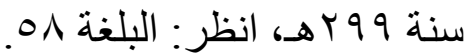


وقيل: هما كشيء واحد، وهي فعل؛ تغليبا للأسبق، فالمخصوص فاعله(')، وقيل: اسم تظليبا للاسم(ז)، وهو الأصح، فهو إما مبتأ ما بعده خبره، أو

عكسه.

ويشارك "تِعْمَ" في المدح، ومن لَمْ يَرَ التركيب قال: يشاركه في أن فاعله ليس كُلَّ اسنمٍ، ويخالفه في أن فاعله لا يكون إلا "ذا"، وفاعل "تِعْمَ" سَبَقَ، وفي الجمع بين فاعله وتمييزه وإن كان الفاعل ظاهرا، وجوازِ دخول "مِنْ" عليه. والمنصوب بعده إن كان جامدًا فتمييز(")، أو مشتقا فكنلك، وهو مذهب أبي عمرو (؛)،

(1) هذا قول الأخفش وخطاب الماردي وابن درستويه، انظر: توضيح

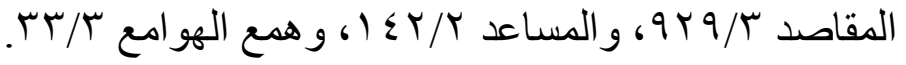

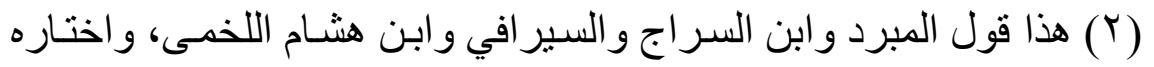

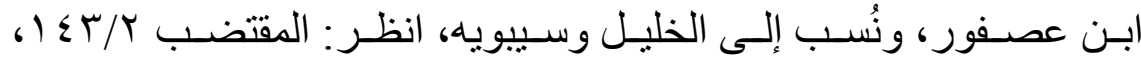

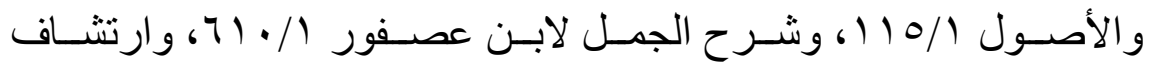

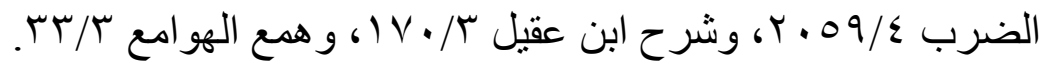

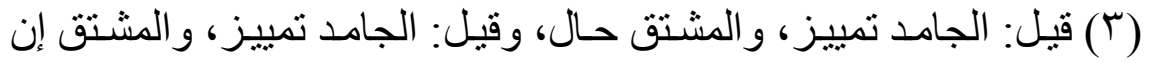

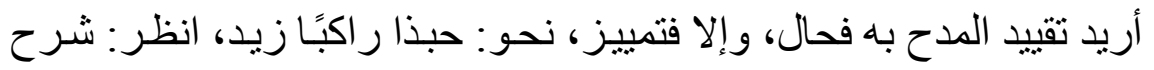

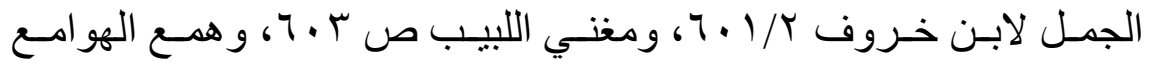
r/

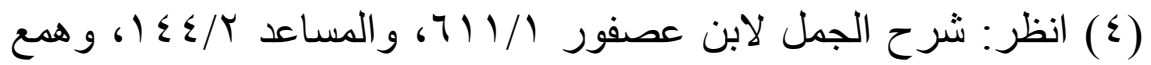
الهو امع ب/Tس، و أبو عمرو هو: أبو عمرو بن العلاء بن عمار بن العريان

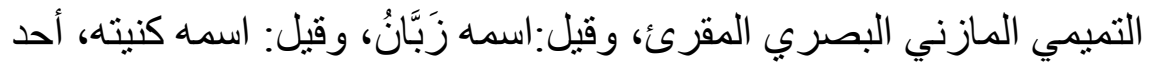

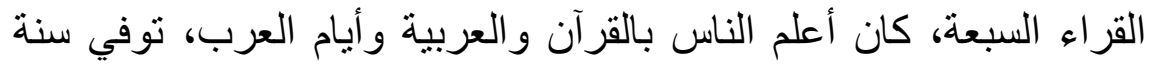

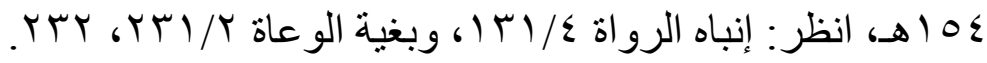


الموفور من شرح ابن عصفور
دا عب الملك أحمد شنتيوي

وقيل ('): إنه حال.

ونتيض "حَبََّّا": "لا حبذا".

\section{التصعجب!}

استعظام زيادة في وصف الفاعل، خَفِيَ سَبَبَهَا، وخَرَجَ بها عن نظائره(؟). فلا يَرِدُ من الله-تعالى -، ولا مما لا يزيد ولا ينقص، إلا ما شَذََّّ(َ)، وهو:

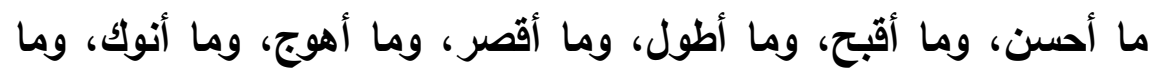
أحمق، وما أشنع.

ولا مِنْ وَصنفِ المفعول إلا فيما سُمِعَ، وهو: ما أثنغل، وما أَجَنَّ، وما

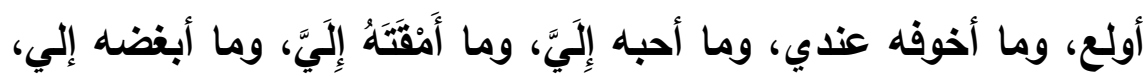

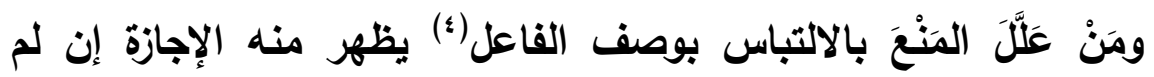
يلبس [i/9].

(1) هذا قول الأخفش و الفارسي والربعي وخطاب وجمع من البصريين،

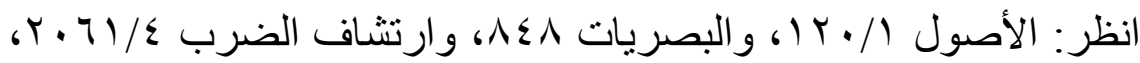

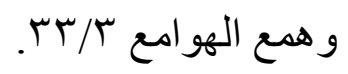

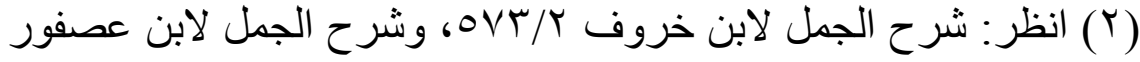


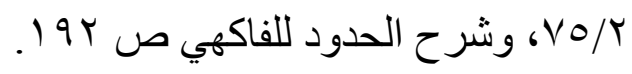

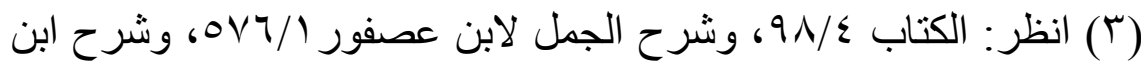

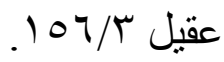
(ع) هذا قول خطاب الماردي، وتبعه ابن ماللك، وأكثر المغاربة عَدُّوا هذا

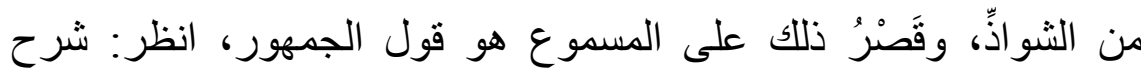

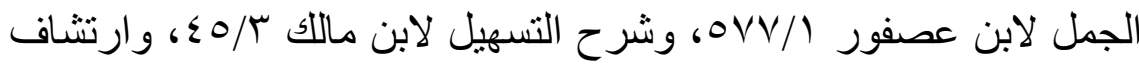

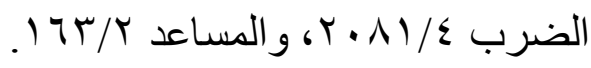


ولا من ظاهر العيب كالعاهات والألوان إلا ضرورة، خلافا للكوفيين في السواد والبياض خاصة، ولا مما لا نظير له، فإن ورد فمجاز، وألفاظ

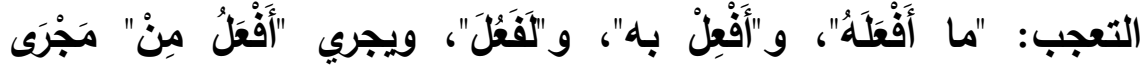
التعجب وإن لم يكن تعجبًا في أنه لا يُنْنَى إلا مما يُبنَْى منه. وشرط الفعل: التصرف، والتمام، والتجرد، وعدم الاستغتاء.

فُلا يتعجب من جامد، ولا ناقص، ولا مزيد، إلا إن كان موازن "أَفْعَلَ، فمانعٌ، ومجيزٌ، ومُفَصِّلٌ بين أن تكون الهمزة للنقل فيمنع، أو لغيره فيجيز،

وهو الصحيح' (1)

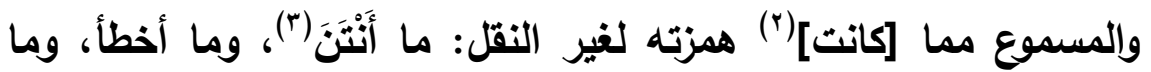
أصوب، وما آتى، وما أعطى، وما أولى، وما أضيع.

(1) أبو حيان هنا خالف ابن عصفور، فأجاز التعجب مما كان على وزن

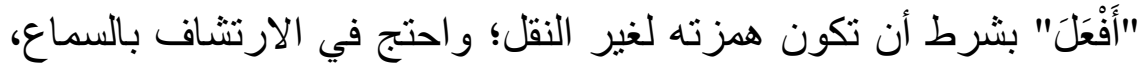

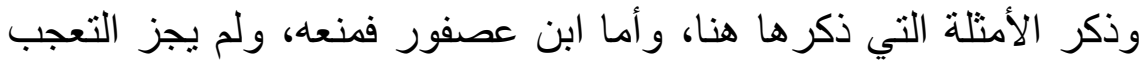

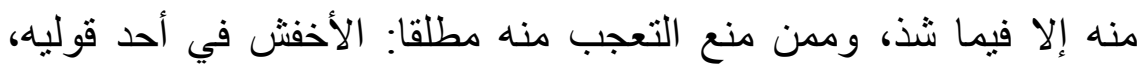

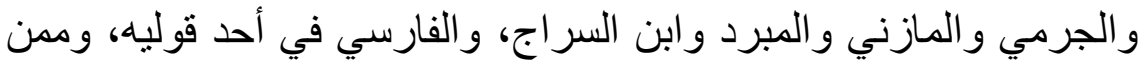

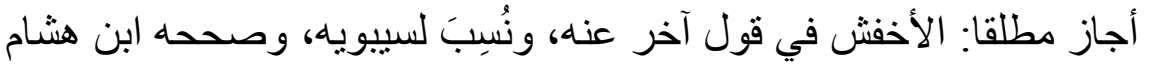

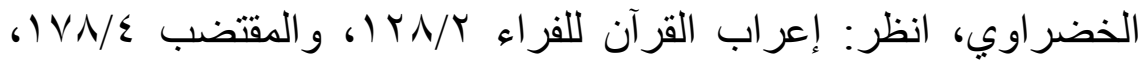

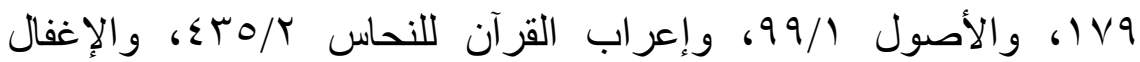

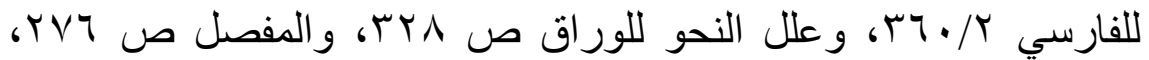

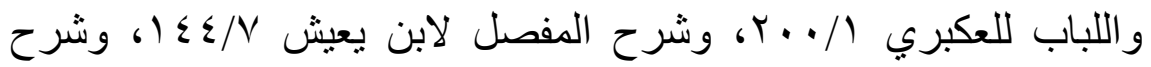

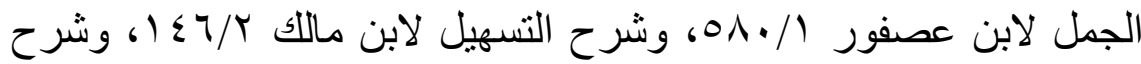

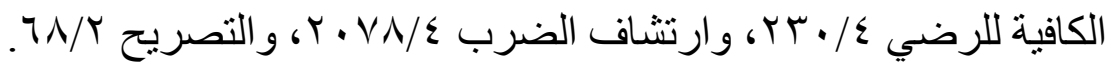

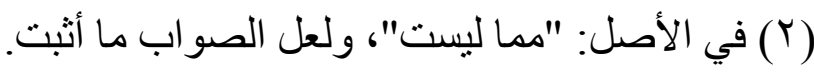

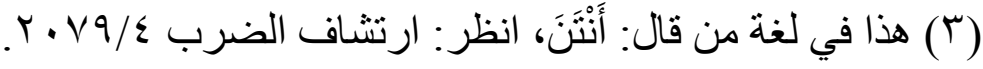


وشثذ من المزيدِ غيرِ الموازنِ "أَفْعَلَ": ما أفقرَ، وما أغنى، وما أَثقى، وما

والمستغنى عنه: قام، وقعد، ونام، وسكر، وغضب، وجلس، وقال من

القائلة.

وما لا يجوز التعجب منه يتوصل إلى التعجب منه بما يجوز فيه ذلك،

$$
\text { وتتصب مصدر ما لا يتعجب منه. }
$$

ثم الفعل الأي يجوز التعجب منه إن وازن "فَفَلَ" دخلت عليه همزة النقل،

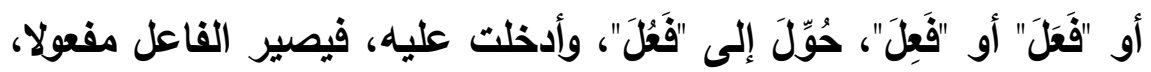
فإن تعدى قبل النقل لواحد عديته بعده إليه باللام، أو لاثنين من باب

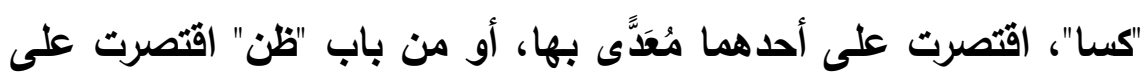

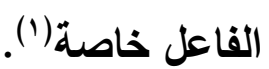
و"ما" مبتدأ عند (س)، اسم تام، والفعل خبره، وعند الأخفش موصولة، صلته الفعل، والخبر محذوف. و"أفعل" فعل، وعند الكوفيين اسمٌ، ولا مصدر له، ويصغر، وهو حالِيٌّ المعنى، ماضي اللفظ، فإن أردت مُضِيَّ المعنى أدخلت "كان". والأولى أنه بمعنى المضي، إلا أنه يال على الزمان المتصل بالحال، فيحصل الحال بحكم الانجرار، فأن أردت المنقطع أتيت ب"كان". ولا يتعجب من صفة فيما [9/ب] يستقبل إلا أن يكون في الحال ما يدل على أنه ينتهي إلى صفة يجوز التعجب من مثلها. وإذا أتيث بـ"كان" قبل الفعل فقي قولٍ: ناقصة، واسمها ضمير "ما"، والجملة بعدها خبرها، وهي ومعمولاتها في موضع خبر المتبدأ، والأصح 
زيادتها، فمذهب السيرافي أن لها فاعلا، وهو ضمير المصدر، والفارسي قال : إنها فارغة.

أو بعده فلا بـ من إدخال "ما" المصدرية، وترفع ما بعدها فاعلا بها، و"ما" بعدها في موضع المفعول، وقيل: يجوز نصب ما بعدها على أن تكون ناقصة، فإن تكررت "كان" كانت كل واحدة منهما على ما استقر فيها قبل التكرار -

ولا يزاد هنا إلا "كان"، وقاس الكوفيون سائر أخواتها، ما لم يناقض معناه معنى التعجب، وحكوا: ما أصبح أبردها، وما أمسى أدفأها، وأجاز بعضهم زيادة كل فعل لا يتعدى، نحو: ما قام أحسن زيلً، إذا أردت: ما أحسن قيام زيا فيما مضى. ولا يتقدم المعمول على "ما" ولا على الفعل، ولا يفصل بينهما إلا بظرف أو مجرور، على خلاف، والصحيح الجواز . و"أفعل به" في معنى "ما أفعله"، والمجرور في موضع رفع فاعل بالفعل، وقال الكوفيون: في موضع نصب، فيكون الفاعل ضمير المخاطب، وقيل: ضمير الحسن. ويجوز التعجب من كل فعل ثلاثي تنقله إلى "فَعُلَ" مضموم العين، فيصير لازمًا، ويجوز دخول الباء على فاعله زائدةً، ولا يلزم فاعلَه "أل". وإذا بنيتهه من معتل اللام بالياء قُقِبَتْ واوًا. ويَعْرِضُ هنا اللبس بين التعجب والنفي والاستفهام مع كل فعل إذا اتصل به ضمير المتكلم، فيؤمن اللبس أنه في التعجب يتصل به ضمير نصب، وقبلها نون الوقاية في حالة الإفراد، وفي الاستفهام لا تلحق، وفي النفي يتصل به ضمير رفع، فيسكن آخر الفعل. 
وكل فعل اتصل ضمير المتكلم المنصوب لزمته نون الوقاية إلا فعل

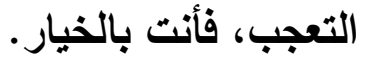

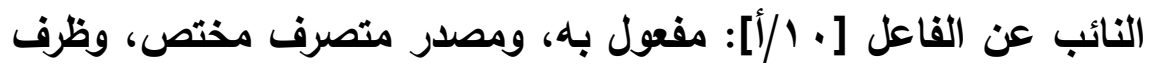
متصرف، ومجرور، خلافا للسهيلي فيه(')، وعند (س)(r) يجوز إقامتهما المصدر المختص تقديرًا، ويجواز نيابة صفته.

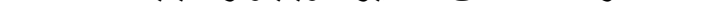
ومتى انفرد واحد منها أقيم، وإن اجتمعت أقيم الصريح، فإن لم يكن فالمصدر (ז)، فإن لم يكن فبالخيار في الظرف والمجرور، ولا يقام المجرور

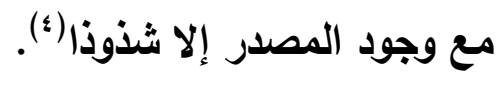

(1) ذهب ابن درستويه إلى أن المجرور لا ينوب عن الفاعل، و إنما النائب

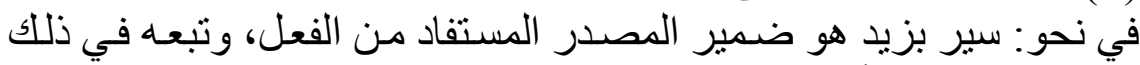

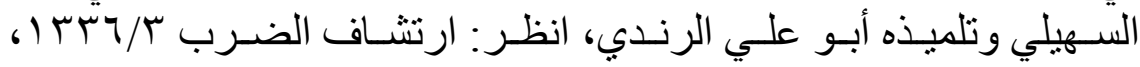

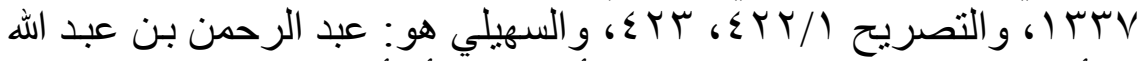

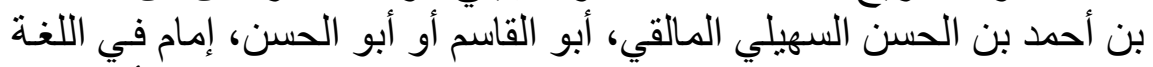

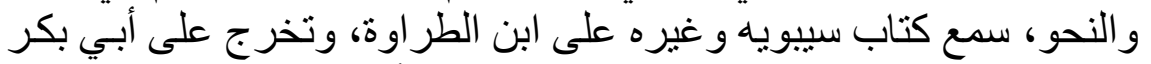

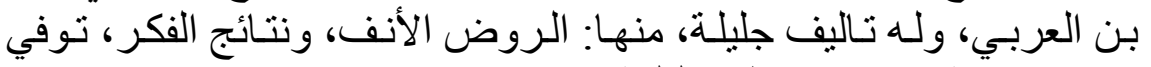

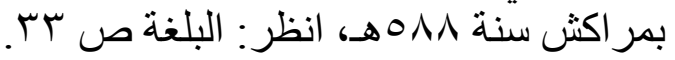

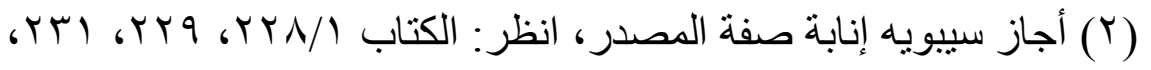

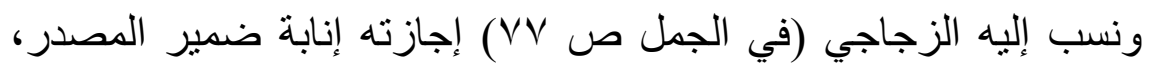

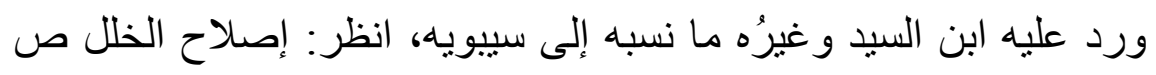

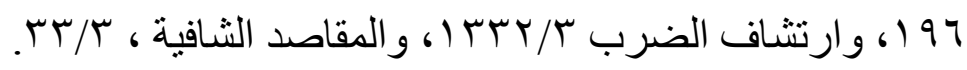

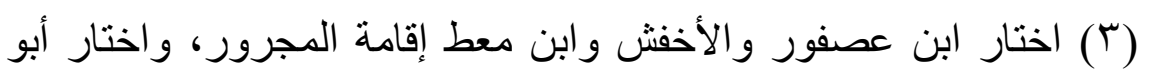

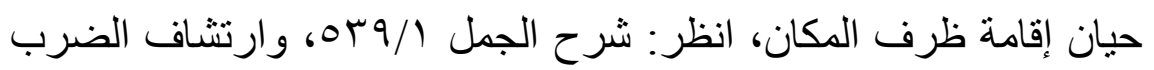
( ) ( ) انظر: شرح الجمل / / وسه. 
وإن كان للفعل مفعولاتُ صِرَّحُ أقمت الصريح لفظًا وتقديرًا، فإن كانت

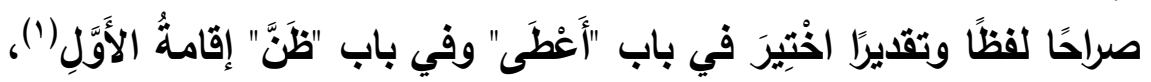
ويجوز إقامة الثاني ما لَمْ يُوَدِّ إلى اللبس في في باب "أعطى"(؟)، أو يكون الثاني جملة أو شبهها في باب "ظَنَّن"، فلا يجوز (َّ).

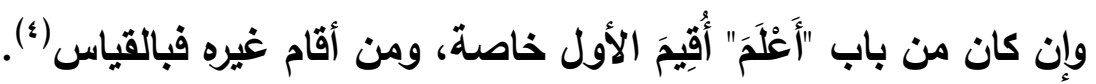

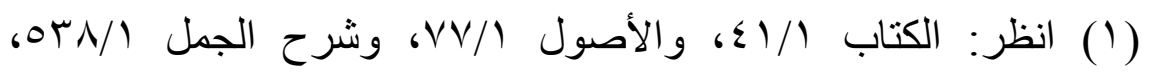

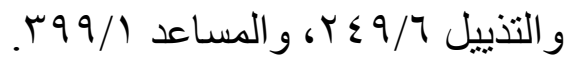
(Y) هذا قول الجمهور، وحكى الخشني عن الفارسي أنه لا يجيز إقامة الثاني

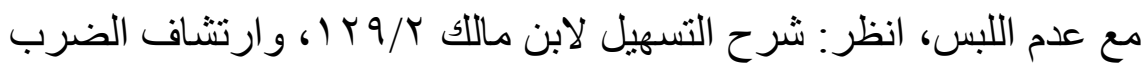
( (r) هذا قول أبي بكر بن طلحة والسيرافي وابن عصفور وابن مالك

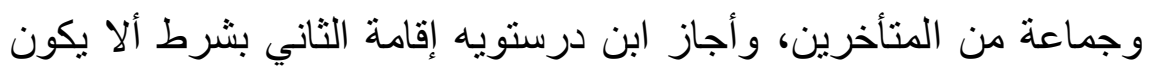

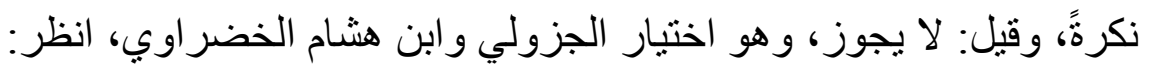

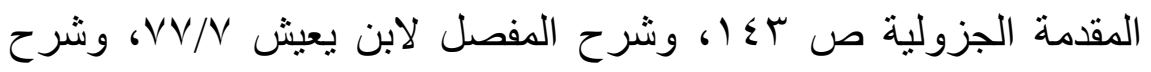

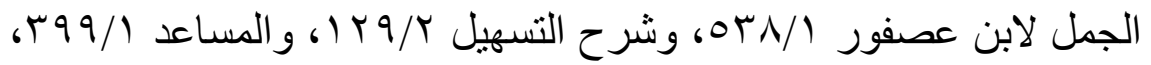

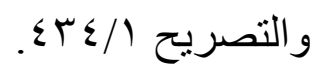
( ) ثاني مفعولي "أعلم" اختلف فيه إذا لم يُلْبِسن، فأجازه الجزولي

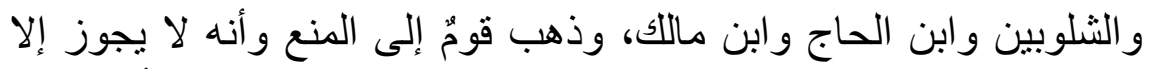

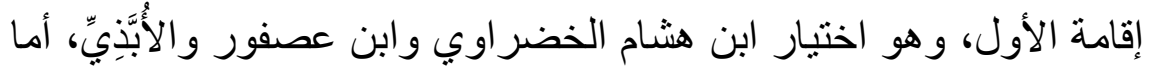
الثالث فقيل: لا يجوز، وذكر ابن هثام الاتفاق على عدم جوازه، وارئ وتعقبه أبو

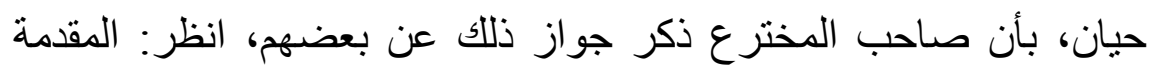

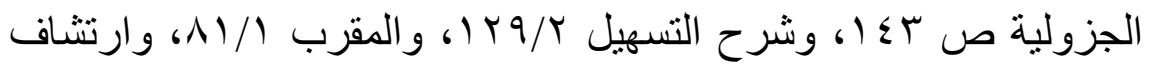

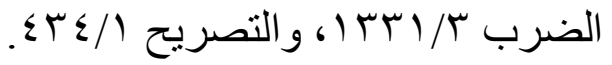


والفعل الأي يُبنَْى شرطه أن يكون متصرفا، واختلف في "كان" وأخواتها، فالفارسي مَنَعَ(')، والفراء أجاز على حذَ الاسم وإقامة الخبر (Y)، والسيرافي أجاز على حذفهما، وإقامة ضمير المصدر ()، و(س) أجاز (؛)، ولم يبين على أي وجه. والصحيح الجواز على إقامة ظرف أو مجرور -إن كان في الكلام-مُقََّم المحذوف، وإلا لَمْ يَجُزْ (ه)

وكيفية البناء إن كان صحيحا ثلاثيا ضَمُ أوله، وكُسِرَ ما قبل آخره ماضيا،

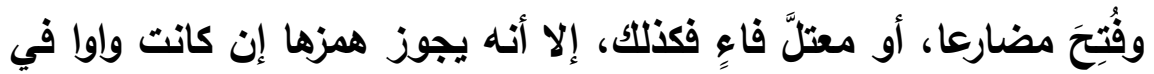
الماضي، وتقلب الياء الساكنة واوا في المضارع.

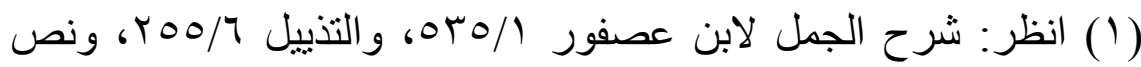

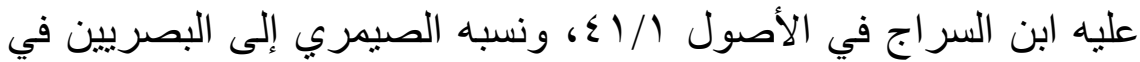

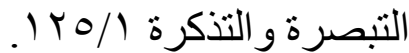

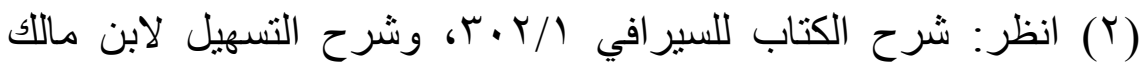

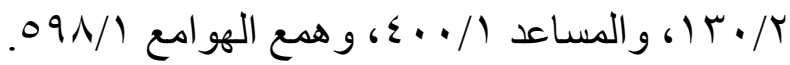

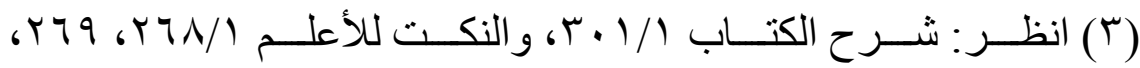
و السير افي هو: الحسن بن عبد الله بن المرزبان القاضي، أبو سعيد السير افي

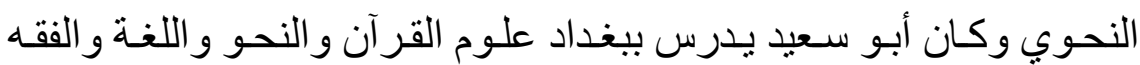

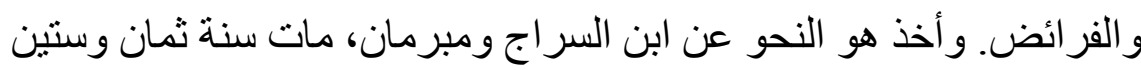
وثلاثمائة.انظر : بغية الوعاة / /

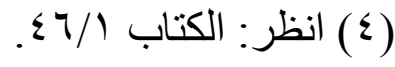

(0) هذا قول ابن عصفور، أما أبو حيان فقد اختار مذهب الفارسي، انظر:

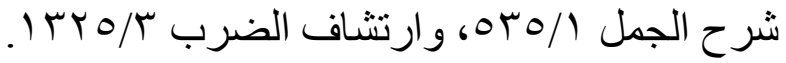




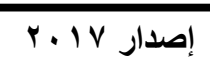

حولية كلية اللغة العربية بالمنوفية العدد الثاني والثلاثون

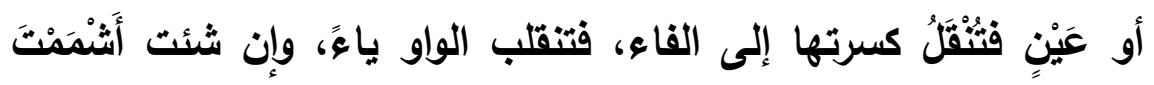
الضََّّة، أو تحذف الكسرة، فتنقلب الياء واوا، وفي المضارع تنقل حركة حرف العلة لِمَا قبلهه، فينقلب ألفا. أو لامٍ فكالصحيح، إلا أنك تقلب الواو ياءً في الماضي، وأما في المضارع فتقلب حرف العلة ألفا. والمزيد صحيحه كصحيح الثلاثي، ومزيده كزيده، إلا أن الألف أو الياء الساكنة تقلب واوا بعد ضمة. وإن اعتل ما قبل الآخر في ماض أو مضارع نقل حركته [ـ إب] إلى الساكن قبله إن كان حرفا صحيحا. والسبب الذي لأجله حذف الفاعل هو العلم به، أو جهله، أو تعظيمه، أو أو أو أوله

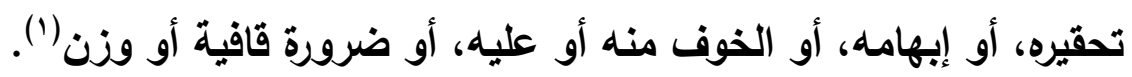
$* * * * * *$

\section{المبتدأ والخبر}

المبتدأ: هو الاسم المجعول أَوََّ الكلام لفظًا أو تقديرًا، مُعَرَّى من العوامل اللفظية غير الزائدة؛ لتخبر عنه(r). والخبر: هو الجزء المستفاد من الجملة(َّ).

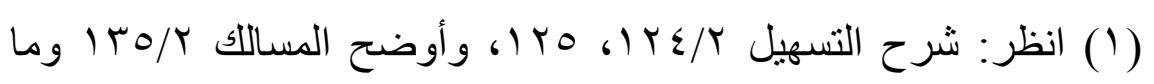

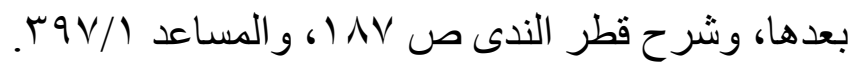

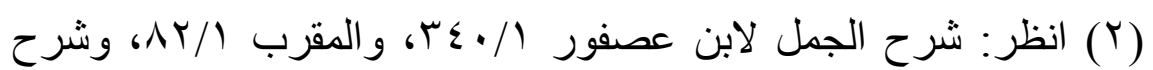

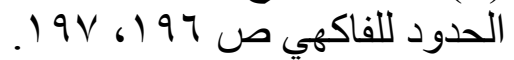

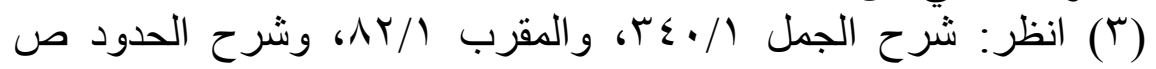
.199 .191 
والمبتدأ معرفة، ولا يكون نكرة إلا موصوفًا، أو مُقَارِبَ معرفِة، أو تقدمته

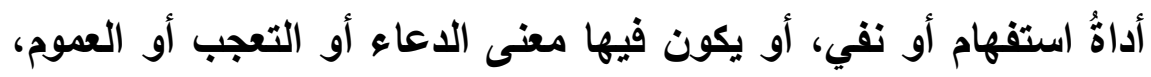
أو يكون الكلام بها في معنى كلام آخر، أو يكون الخبر ظرفا أو مجرورا مصححا، أو يكون في جواب من سأل بالهززة و"أَم"، أو في موضع تفصيل، أو لا تراد لعينها. وزاد الكوفيون: أن تكون خلفا من موصوف(1)، والأخفشُ: أن تكون في معنى فِفْعْلِ (r).

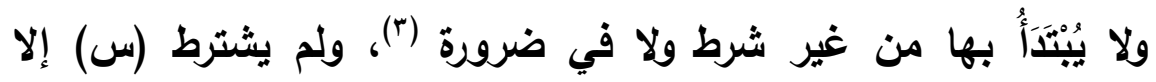

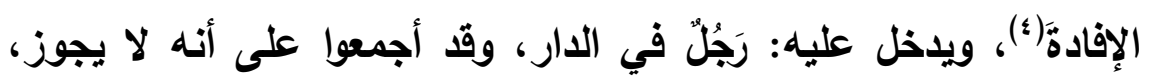
وأنه ليس بمسموع(•). والخبِر مفرد، هو الأول، أو مُنَزَّلٌ مَنْزَلَتَهُ، أو موضوعُ مَوْضِعَ ما هو

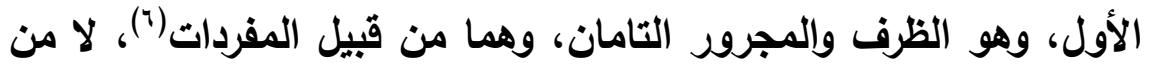
قبيل الجمل، على جهة الوجوب(v)، ولا على جهة الجواز على حسب

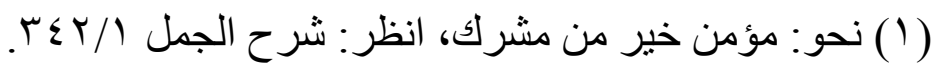

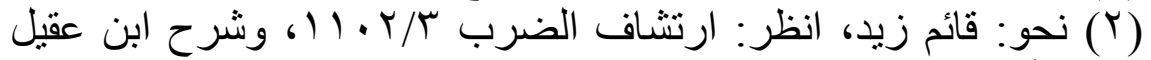

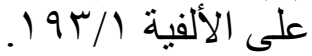

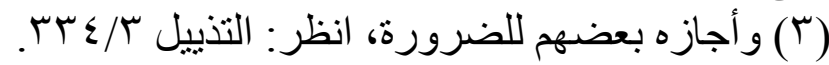

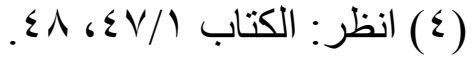

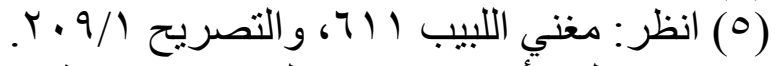

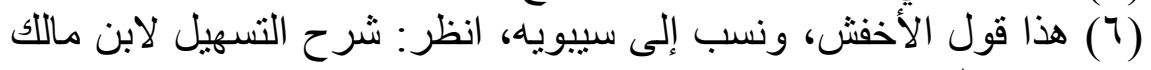

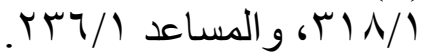
نسب هذا القول إلى جمهور البصريين و إلى سيبويه-أيضًا-، انظر: (V)

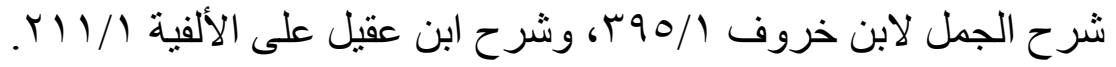




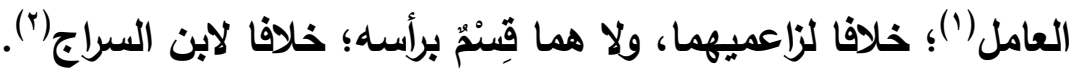
وجملة، ولا يشترط أن تكون خبريةً؛ خلافا لابن السرج(َ)، وهي اسمية،

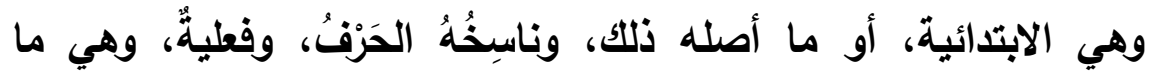
صَدْرْهَا الفِعْلُ.

وشرطهما: أن يكون فيهما ضمير المبتدأ، أو تكراره بلفظه لا بمعناه؛ لظّ خلافًا للأخفش(؛) أو إثارة إليه، أو عموم، إلا أن تكون نفس المبتدأ في المعنى، فلا يحتاج إلى لابط.

(1) يجوز أن يجعلا من قبيل المفرد، فيكون المقدر مستقر ا ونحوه، وأن يُجْعَلَا من قبيل الجملة، فيكون التقدير : استقر ونحوه، وهذا ظاهر قول ابن ماللك: * ناوين معنى كائن أو استقر

$$
\text { انظر: شرح ابن عقيل /11/ آن. }
$$

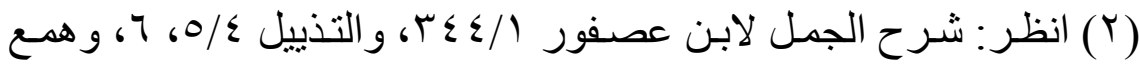

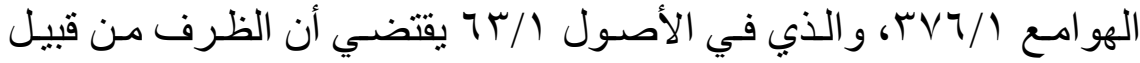

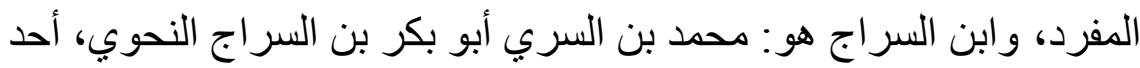

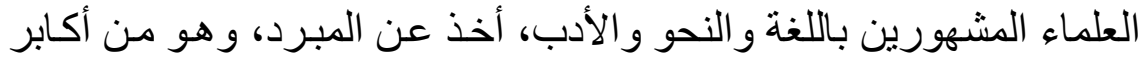

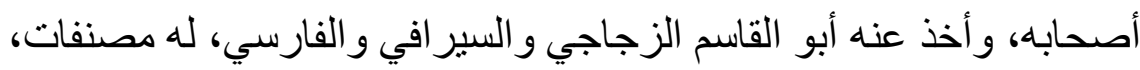

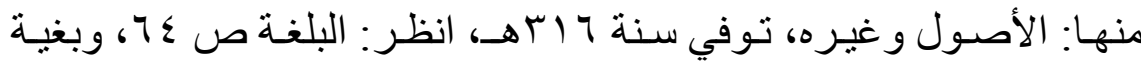

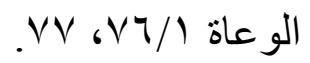

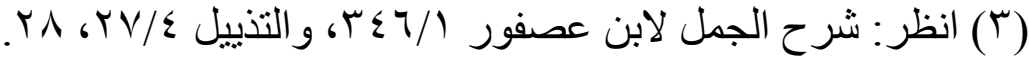

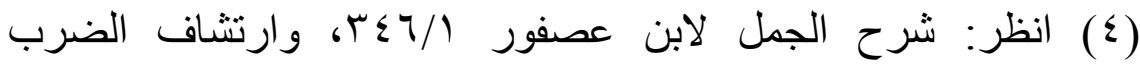


وإلظرف الزماني لا يخبر به عن عَيْنِ، اختص أو لَّْ يختص، وما جاء

من ذلك مؤول (').

والضمير الذي في الخبر لا يجوز حذفه، إلا أن ازْتَفَعَ مُبْتَاًَ، أو انخفض

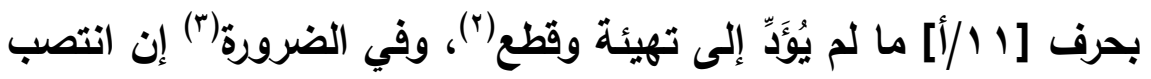
بفعل أو ما يجري مجراه، فيأتي الحذف فيها. ويجب حذف الخبر بعد "لولا"، وإذا سدت الحال مسده، ويجب إثبات المبتدأ والخبر إذا لم يدل على حذفهما دليل، أو كان المبتدأ "ما" التعجبيةَ، أو الخَبَرُ خَبَرَهَا، ويجوز في الباقي منهما.

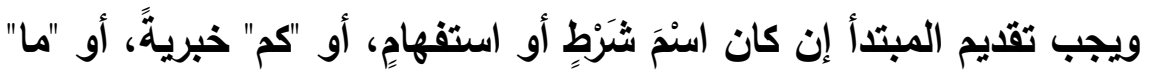
تعجبيةً، أو مشبهًا بالخبر، أو مُسَاوِيَهُ في التعريف، أو ضَمِيرَ أَمْرِ، أو أو

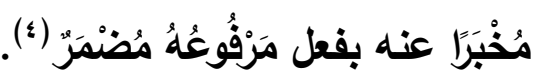
وتأخيرُهُ إن كان الخبر اسْمَ استفهامٍ، أو مصححا، أو متصلا ضميرٌ يعود

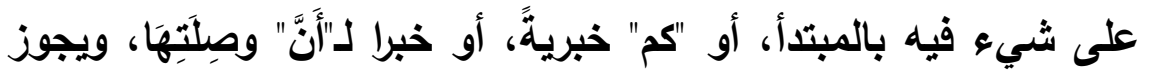
في غير ذلك.

$$
\begin{aligned}
& \text { (1) في الأصل: "مأول". }
\end{aligned}
$$

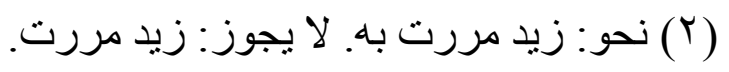

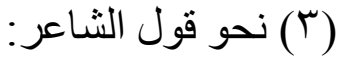

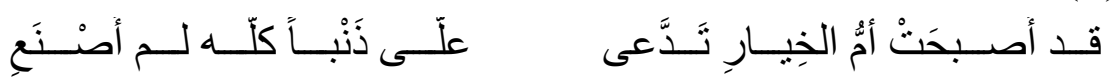

يريد: لم أصنعه، انظر: الكتاب 10/1، والخصائص ب// آح، ومغني اللبيب

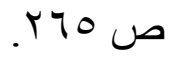

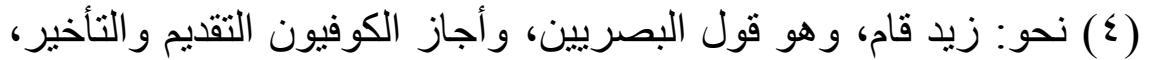

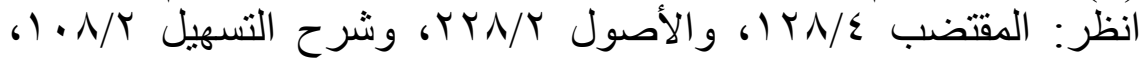

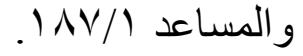


وإن كان المبتدأ والخبر معرفتين، فالمقدر للمخاطب عِلْمَهُ المبتدأ، أو

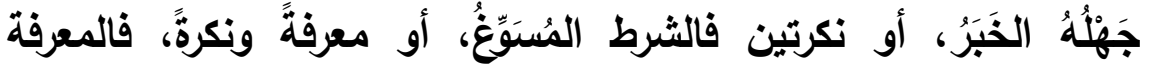

المبتدأ، والنكرة الخبر، والعكس ضرورة، وهو عندي على القلب(').

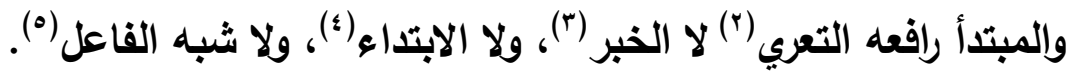

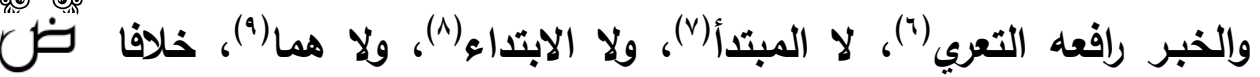
لزاعمي ذلك.

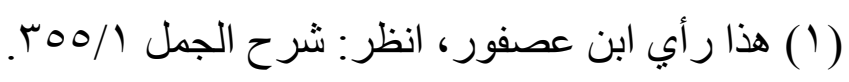

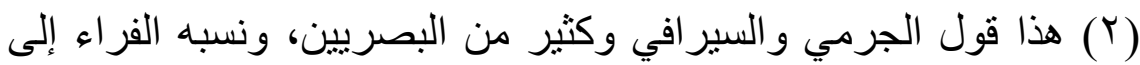

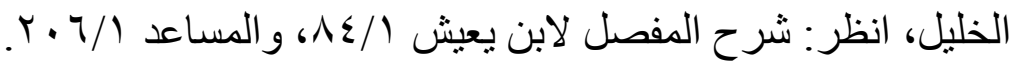

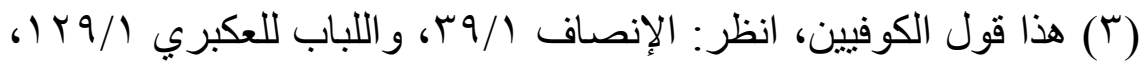

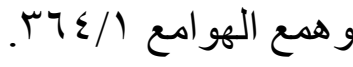

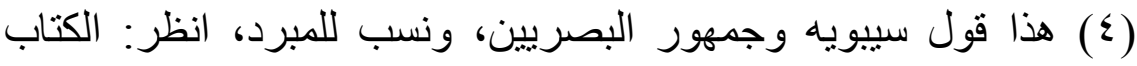

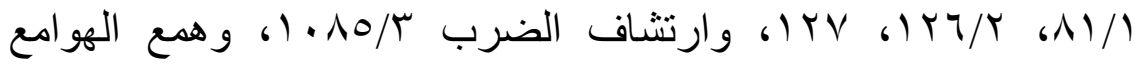
(1) (0) هذا قول الزجاجي وصاحب التخمير، انظر: الجمل ص حس، وشرح

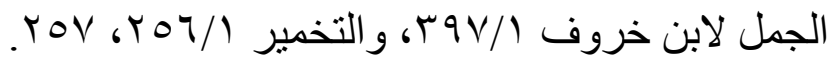

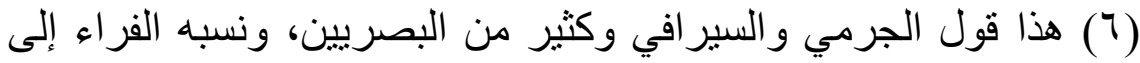

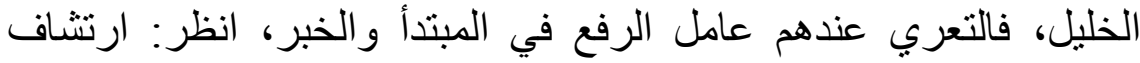

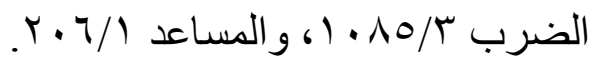

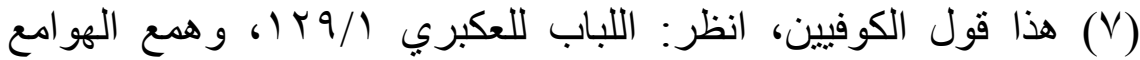
T

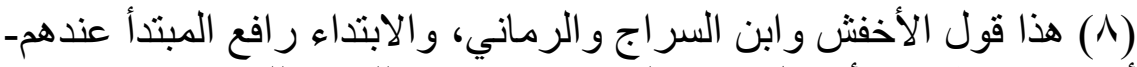

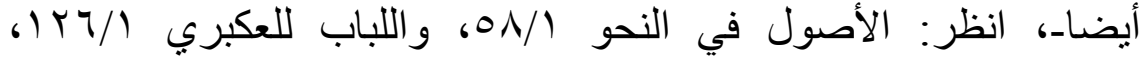

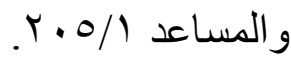
(9) هذا قول المبرد و ابن السر اج و أبي إسحاق وأصحابه، انظر : المقتضب

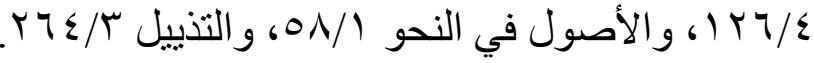


وقد يعرض في هذا الباب كثرة المبتدآت، وذلك على وجهين، أحدهما: أن تكون الضمائر في الأخبار، فيكون المتأخر للمتقدم، وما يَلِيهِِ لِمَا يَلِيهِ، إلى أن تفرغ، والآخر: أن تكون الضمائر في المبتدآت الواقعة في صدر الجملة الواقعة خبرًا. ولا يقتضي المبتدأ أَزْيَدَ من خَبَرٍ وإحد إلا بالعطف (1)، إلا إن كانا أو كانت في معنى خبر واحد، فيجوز.

$$
\text { أدوات الابتداع(r) قهمان: }
$$

قسم يقع بعده المفرد والجملة، وذلك: "متى" و"أين" و"كيف" و"بينا"، فإن وقع بعدها مفرد كانت في موضع الخبر، أو جملة كانت في موضع نصب

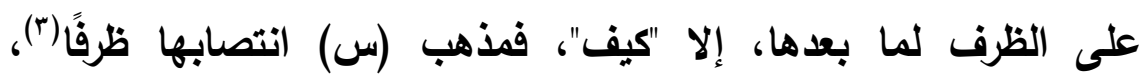
ومذهب الأخفش أنها اسم في موضع نصب على الحال(؛).

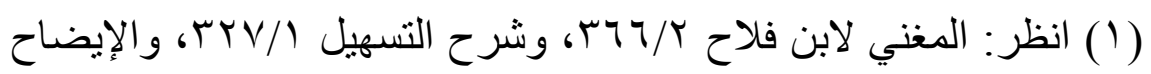

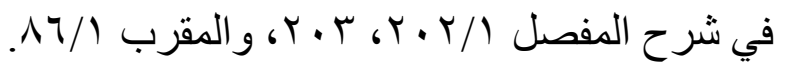
(Y) هذا الفصل ورد في حاثنية الأصل بخط أبي حيان.

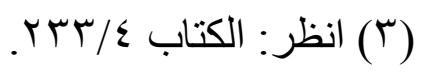

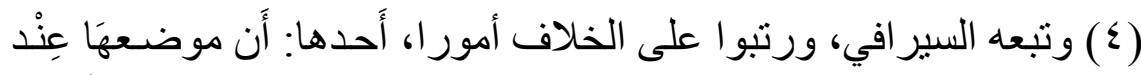

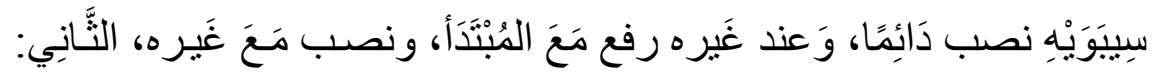

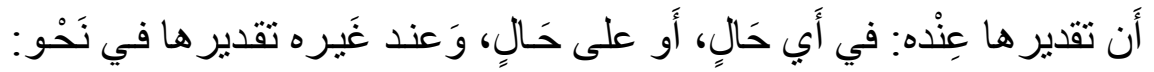

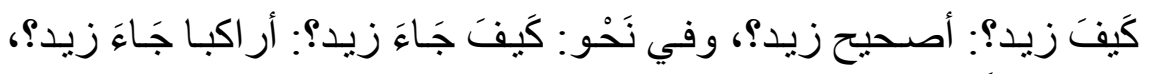

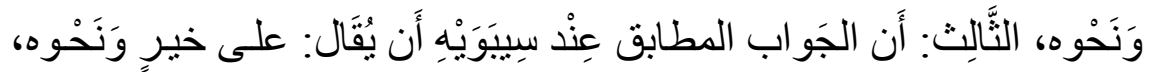

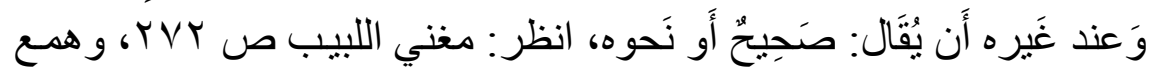

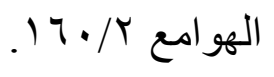


وقسم لا يقع بعده إلا الجملة، ولا موضع لها من الإعراب؛ لأنها حروف،

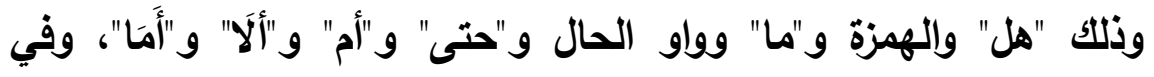
"بينما" خلاف، قيل: من قبيل ما لا يليه إلا الجملة، وقيل: من قبيل ما

يليه المفرد والجملة (1).

والعامل في "بينما" و"بينا" جوابهما(؟) [.....]"(ّ) "إذ" الواقعة في جملة

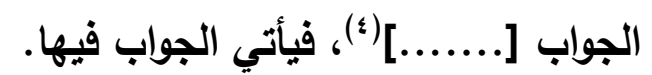
******

الاشتغال: أن يتقدم اسم، ويتأخر عنه فعل متصرف أو ما جرى مجراه، قد عمل في ضميره، أو الملابس لضميره، ولولا ذلك لعمل في الاسم الأول،

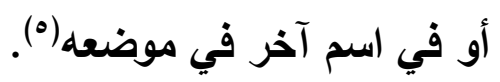
والملابس مضاف لضميره مباشرة، أو بواسطة، أو موصوف بما فيه ضمير الأول، أو معطوف عليه اسم قد اتصل به ضمير الأول.

(1) الـذي عليـه جمهـور النـــوبين أن "بينهـا" لا تضـاف إلا إلـى الجملـة،

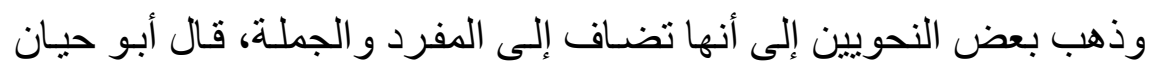

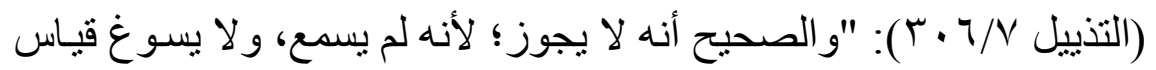

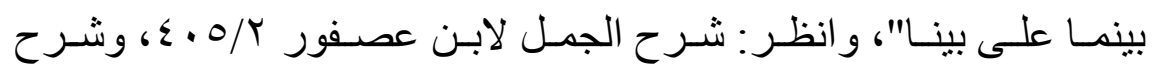

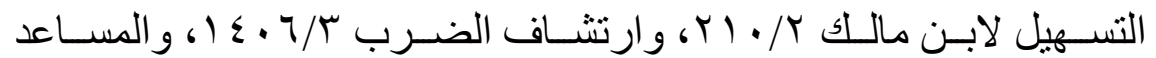
$0 . \leqslant / 1$

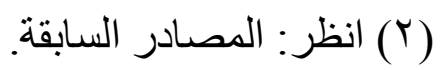

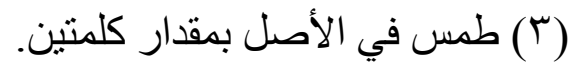
( ( ) طمس في الأصل بمقدار ثلاث كلمات.

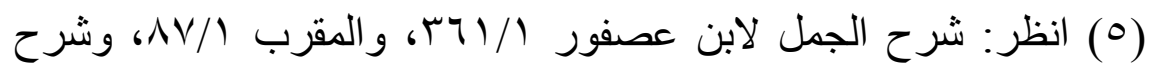

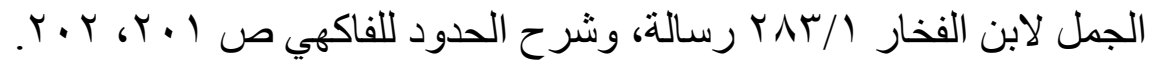


والمشتغل عنه إن تصدر والعامل [1//ب] في الضمير الرفع لفظا أو محلا، فالرفع على الابتداء، أو منصويا أو مخفوضا، فالرفع على الابتداء، والنصب على الإضمار(')؛ خلافا لمن أجاز الخفض(ז) في نحو: بزيد مررت به، ويزيد مررث بأخيه.

والنصب مع الضمير المنصوب أحسن منه مع السنَبَبِيّ، ومع السببي أحسن منه مـع المجرور، والنصب مـع الضمير المجرور أحسن منه مع السببي المجرور • هذا ما لم يقع العامل صلة أو صفة أو مصدرا بأداة استقهام أو شرط أو تحضيض(َ) أو "ما" أو "إنَّ" أو لام الابتداء أو لام القسم، فيجب الرفع

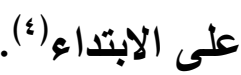

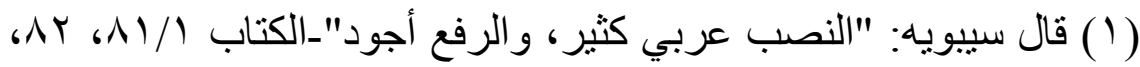
وقال ابن هشام: "الأصل أن ذلك الاسم يجوز فيه وجهان، أحدهما راجح

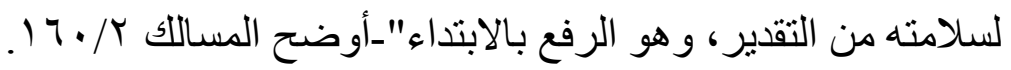

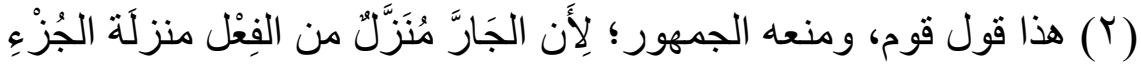

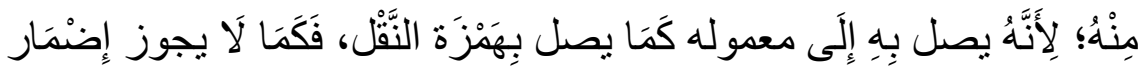

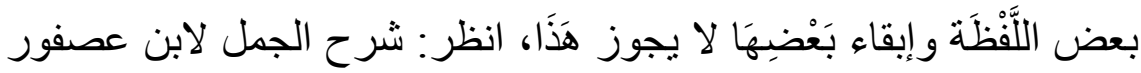

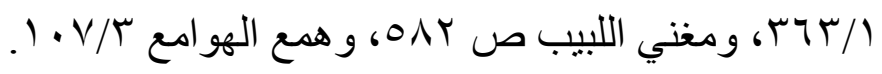

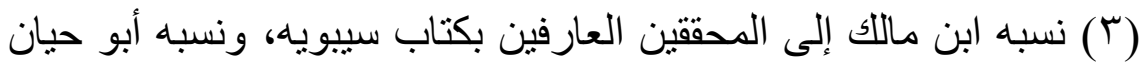

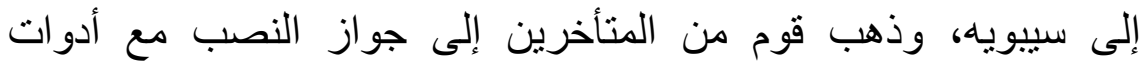

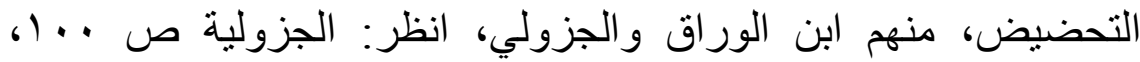

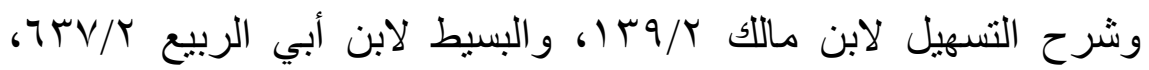

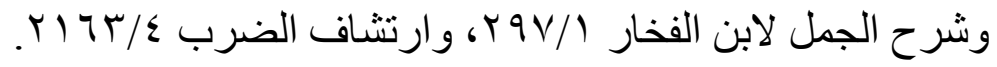

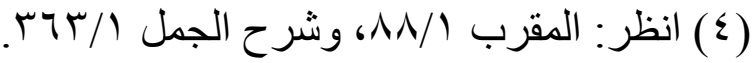


أو غير خبر، وهو الأمر والنهي والاعاء بفعل أو اسم في معناه، فإنْ طَبََه الرفعُ فهو باعتبارين، أو النصب والخفض، فالرفع والنصب، والحمل

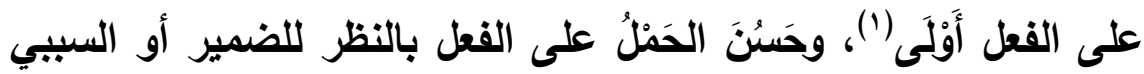
كصنـه في الخبر ·

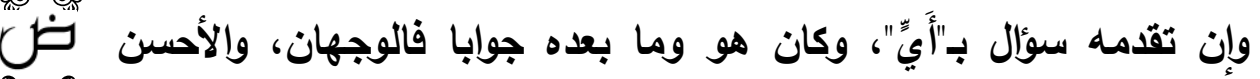
مطابقته للمسؤول به في الإعراب(r)، أو حرف عطف قبله جملة اسمية، فالأحسن الرفع ابتداء(ّ)، أو فعلية فالأحسن على الحمل الإضمار، أو ذات وجهين فالوجهان، مشروطًا في الحمل على الإضمار فيها: ضميرٌ عند

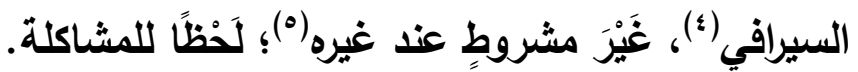
وإن لم يكن عطف، لا تكون الواو بمعنى "مع"، فيخص بمعطوفها خلافا

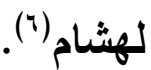
ما لم يكن بعد حرف العطف "أََّّا"، فإن كان فكما لم يتقدمه شيء، أو

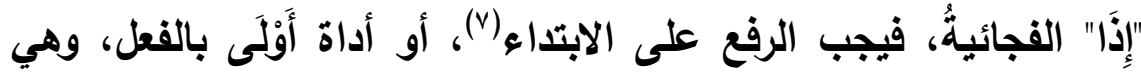
(1) انظر: شرح الجمل //؟ جس.

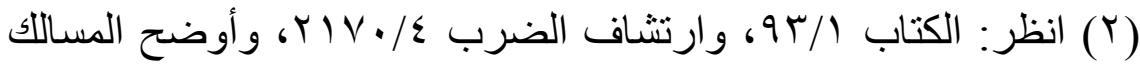

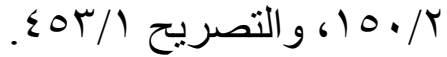

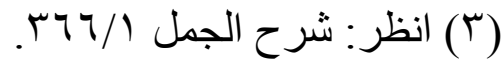

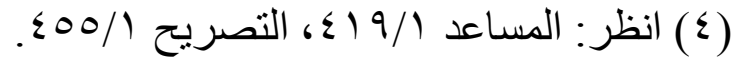

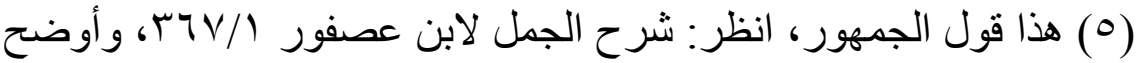
المسالك 101/ 101 (T) يعني هثام بن معاوية الضرير، انظر قوله في ارنثاف الضرب

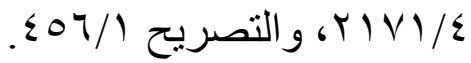
وقيل: يجوز فيه الاشتغال، وذهب فريق إلى التفصيل بين أن يكون

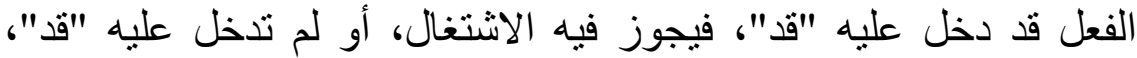


أدوات الاستفهام، و"ما" و"لا" النافيتان، فالوجهان، وهما اختيار الحمل على الفعل(')، ف"ما" و"لا" واللهمزة يليها الاسم جوازا، و"هل و و"أَمْ" ضرورة(ץ)، وحكمه مفصولا بينه وبين الأداة بمبتدأ كحكمه لو لم يتقدمه

أو أداةٌ تختص بالفعل ظاهرا أو مضمرا، وهي أدوات الشرط وأدوات التحضيض؛ خلافا لبعض الكوفيين(ّ)، فإنهم أجازوا بعدها المبتدأ والخبر

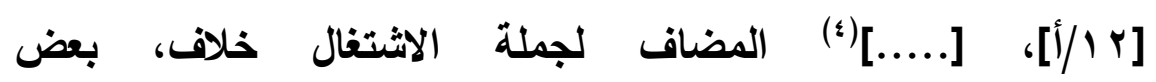

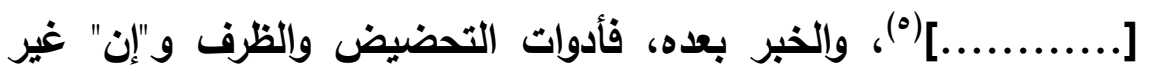
الجازمة يليها الاسم، فيكون من هذا الباب، وياقي أدوات الشرط و"إن" الجازمة لا يليها إلا ضرورة. أو غير ذلك فكما لم يتقدمه شيء، خلافا للقراء في اختيار النصب. ولا يجوز تعدي فعل المضمر المتصل إلى ظاهره مطلقا، ولا عكسه، ولا فعل المضمر المتصل إلى مضمره المتصل، إلا في باب "ظن" و"فقد"

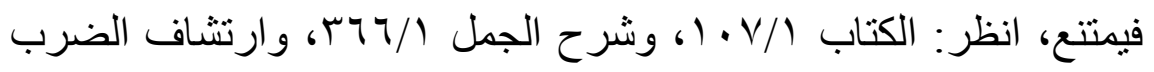
. r) $7 \varepsilon / \varepsilon$

(1) هذا قول الجمهور، واختاره ابن عصفور وابن ماللك، وظاهر قول سييويه اختيار الرفع، وذهب ابن الباذش وابن خروف إلى أنهما مستويان،

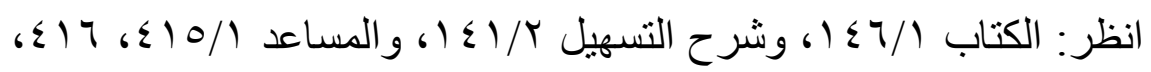

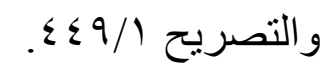

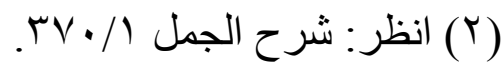

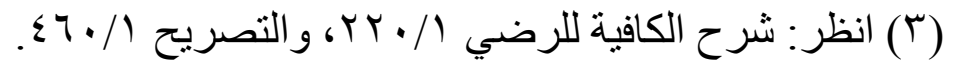
( ) طمس في الأصل بمقدار كلمتين. (0) طمس في الأصل بمقدار خمس كلمات. 


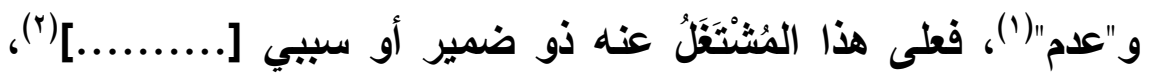
أو سَبَبِيَّنِ أو سببِي، منفصل او منفصلين، فُلى ما شئت منهما، أو متصلين فيمتع، إلا في ذلك الباب فعلى المرفوع، أو منفصل ومتصل،

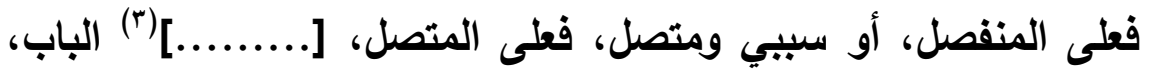
فإن كانا مع السببي، أو مع المتصل مرفوعا فعليه، أو منصويا فعليهما ****** $* *$

النواستخ: "كان" و"أصبح" و"أضحى" و "غدا" و "ظل" و"راح" و"أمسى" و"بات" و"صار" و"آض" و"ليس" و"ما زال" و"ما انقك" و"ما فتئ" و"ما برح" و"ما دام"، و"قعد" و"جاء" مقصورَيْنِ على مورد السماع، وذلك: شحذ شفرته حتى قعدت كأنها حربة، وما جاءت حاجتَك. وزاد بعضهم: "عاد" بمعنى "صار"، وزاد بعض البغداذيين: "ما وَنْيَ"، والكوفيون: "مَرَّ" لا لانتقال الخُطَى، والفعلَ المكرر في نحو: للئن ضريتَهه

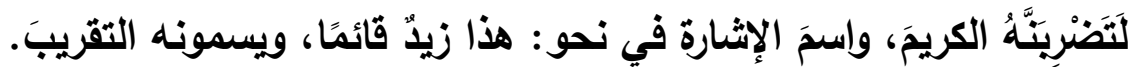
وكلها أفعال خلافًا للقارسي في "ليس"؛ إذ زعم أنها حرف. والمبتدأ اسم لهذه الأفعال، إلا اسمَ الشرط، والاستفهامِ، و"كم" الخبرية، و"ما" التعجبية، و(ايمن) في القسم، والخبر خبرها، إلا الجملة [الطلبية] (؛) وقوله:

$$
\begin{aligned}
& \text { (Y) شرح الجمل لابن عصفور / (Y) (Y) } \\
& \text { (Y) طمس في الأصل بمقدار كلمتين. } \\
& \text { (Y) طمس في الأصل بمقدار كلمتين. }
\end{aligned}
$$

(ع) في الأصل: "إلا الجملة الخبرية"، وهو وهم، ولاين، و وانظر : شرح الجمل لابن

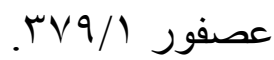


فإن صدرت الجملة بماضٍ جاز ذلتك في (ليس) باتفاق، وامتنع فيما صدر

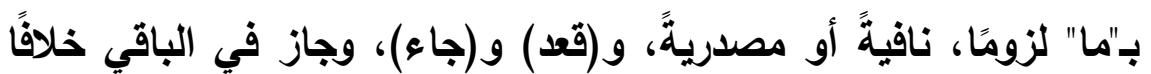

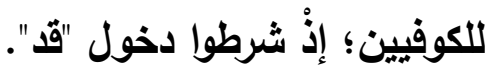
و "ليس" و"ما دام" و"جاء" و"قعد" لا يدخل عليها أداة نفي، و "ما زال" و"ما

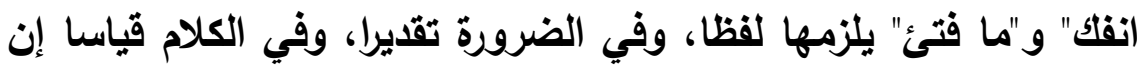
وقع مضارعٌ منفيُّ بـ"الا" جوابَ قسمِّ.

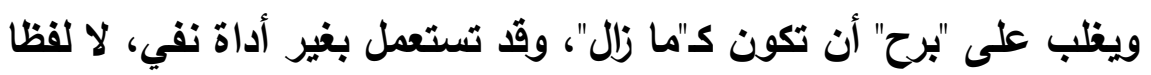

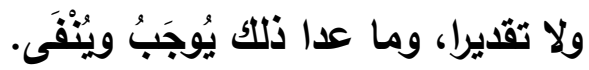

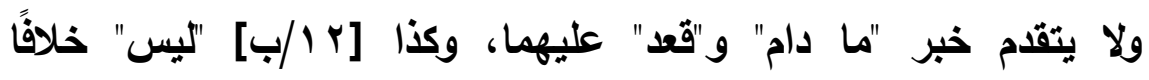
لسيبوية، ولا خبر "ما زال" و"ما انفك" و"ما فتئ" و"ما برح"، خلافا لابن ولان

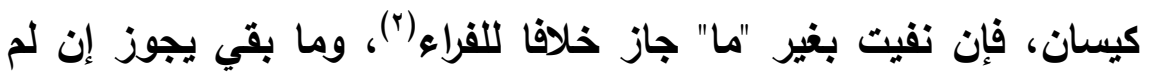
يباشزه حرف صدري.

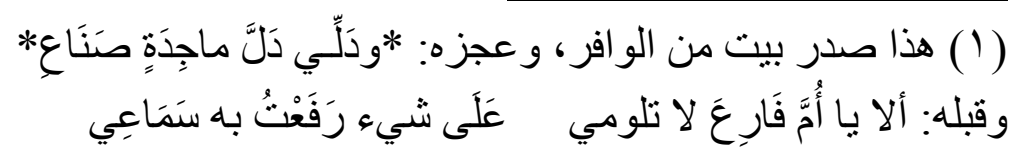

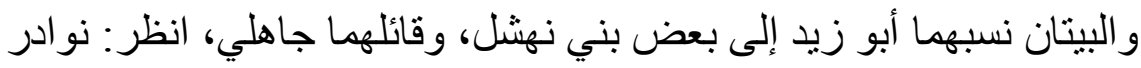

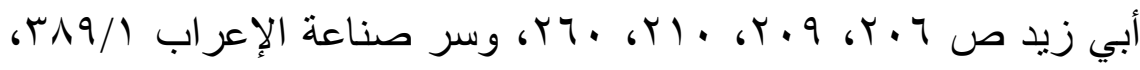

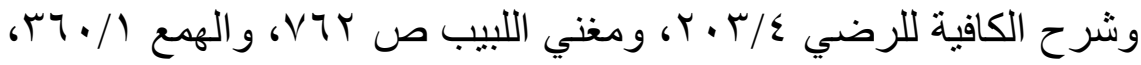

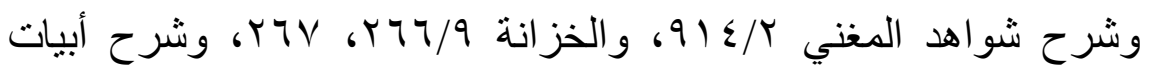

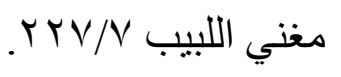

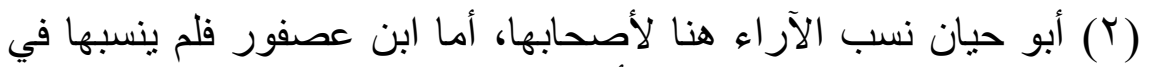

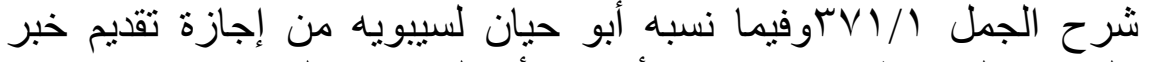

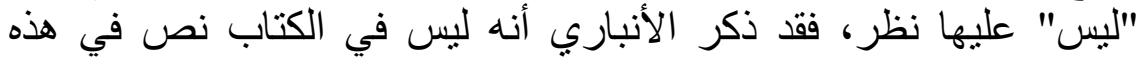


وقد يجب تقديمه على الفعل، كأن يكون اسمَ شرط أو استفهام، أو مضافًا

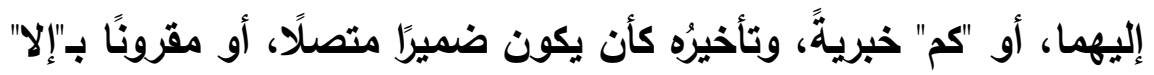
أو في معناه، أو يقع الفعل صلة أو صفةً، أو يأتي شرطا لأداة الشرط، أو أو اله

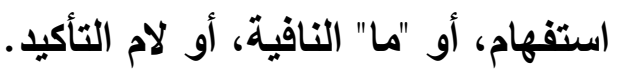

ويجوز تقدمه عليه إن حيل بينه ويين الصدري، أو بينه ويين الموصول لُّل والموصوف، إلا إن كان الصدري أداةَ شرط، أو لام تأكيد، والموصول حرف، فلا يجوز، إلا في أداة الثرط، فيجوز ضرورة. وما عدا ذلك يجوز تقدمه وتأخيره. ويجب تقدم الخبر على الاسم إن كان ضميرًا متصلًا، والاسم ظاهرًا، أو

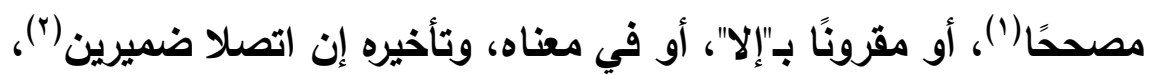

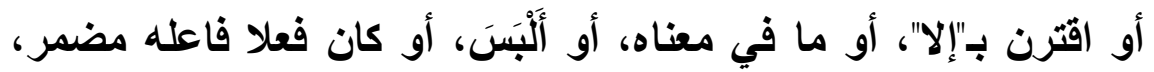
على خلاف فيه، والأصح الجواز، وما عدا ذلك فالخيار. ومعمول الخبر الظرف والمجرور يجوز تقديمه على الاسم، لا غيرهما إن قدمته وحده، خلافا للكوفيين؛ إذْ أجازوا ذلك، وتقديمه عليه مع الخبر لا

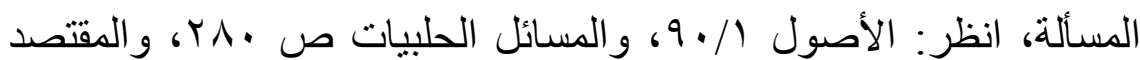

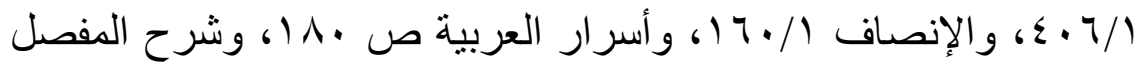

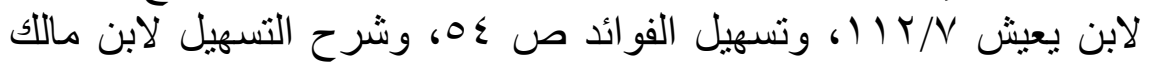

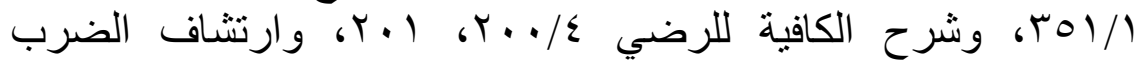

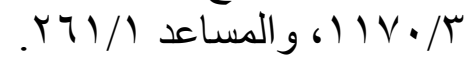

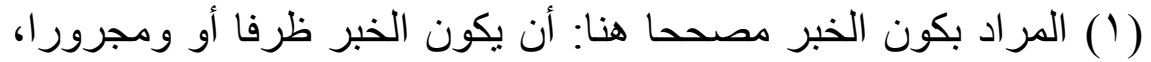

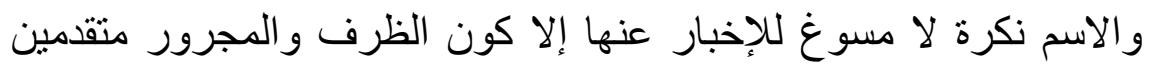

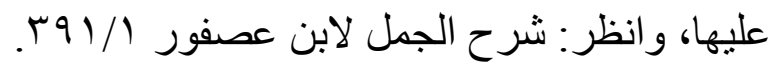
(Y) يعني: أن يكون الاسم و الخبر ضميرين متصلين. 
يجوز وفاقا لسيبويه، ومعه على الفعل يجوز فيما جاز فيه تقديم الخبر،

$$
\text { ووحده لا يجوز مطلقا. }
$$

ولا يجيز الكوفيون: كان قائما زيد، ولا: قائما كان زيد، على أن يكون في قائم ضمير اسم "كان"، بل على رفع زيد بهه، وإضمار الأمر اسمًا لـ"كان" في مذهب الكسائي، ورفعه بهما على مذهب الفراء إن لم يتوسط، ولا يثنى ولا يجمع على مذهبيهما، وإن توسط ثَنَّاهُ الفراء وجمعه، فإن جعلت قائما خلفَ موصوفٍ جاز أن يتقدم ويتوسط خبرًا، ويثنى إذْ ذاك ويجمع ('). فإن اتصل بالخبر [r/1/1/] معمول، فإن تقدم الخبر على الاسم، والمعمول بعد الخبر(r) فالأمر عندهم على ما كان عليه لو لم يكن له معمول، أو له

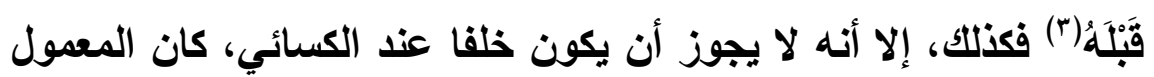

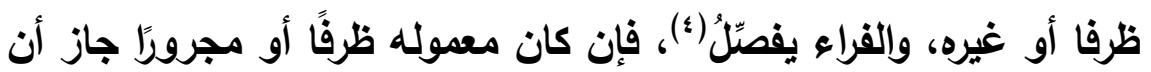
يكون خلفًا، أو غَيْرَهُمَا فِلا، والصحيح عند البصريين في جميع ذلك أنه خبر مقدم لم يخلف موصوفًا، فهو يثنى ويجمع، فإن قدمت الخبر،

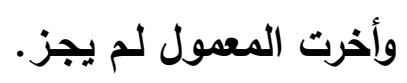

(1) هذا الجواز على مذهب الكسائي والفراء، انظر: شرح الجمل لابن

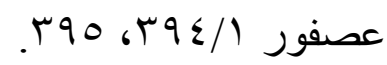

(Y) نحو: قائما في الدار كان زيد، أو كان قائما في الدار زيد.

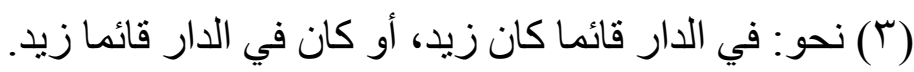

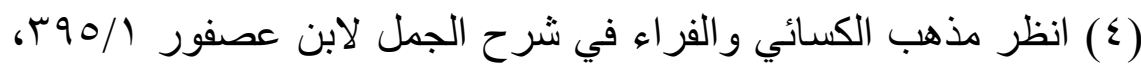

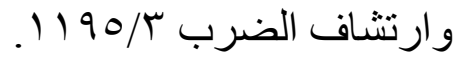


وهذا الذي فعلوه مقتضى مذهب البصريين (1)، إلا إن جعلته معمولا لمضمر يفسره المتقدم، جاز على كل مذهب، فإن قلت: كان كائنا زيد قائما، ففي "كان" ضمير الأمر على مذهب الكسائي، و"كائنا" خبر "كان"، و"زيد" اسم "كائن"، و"قائما" خبره، والفراء يجعل "كائنا" خبر "كان"، و"زيدا"، مرفوعا

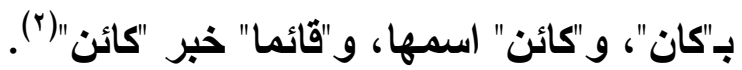
وحكمه تقديما وتأخيرا حكم ما تقدم، إلا أنه لا يجوز عندهم تقديم "كائن" على "كان"، ولا حمله على مضمر كما كان فيما تقدم.

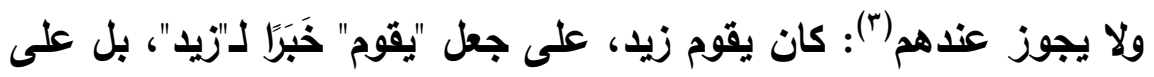
رفع "زيد" ب"يقوم"، وفي "كان" ضمير الأمر، و"يقوم" في موضع الخبر، أو على رفعه ب"كان"، و"يقوم" في موضع الخبر.

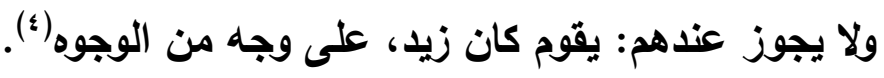

فإن كان الخبر اسما لا يتحمل ضميرا جاز توسيطه وتقديمه عندهم (॰). ويجوز دخول "إلَّا" على خبر ما نُفِيَ جوازًا، أو كان معناه النفيَ، إن لن أوجبت، إلا إن كان الخبر لا يستعمل إلا منفيا فلا ، ويبقى منصويا، إلا مع جع

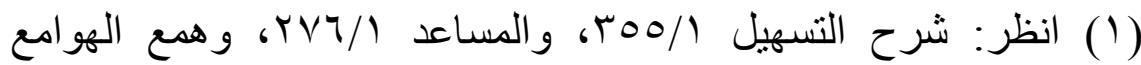
rvo/l

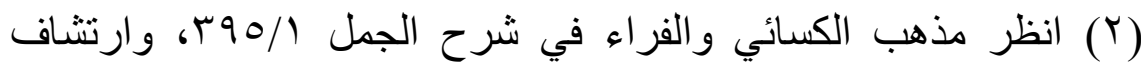

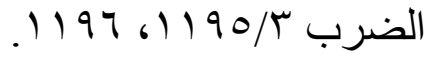

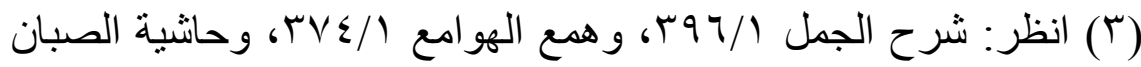
$.1 T V / r$

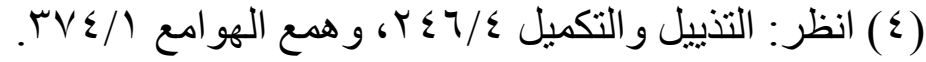

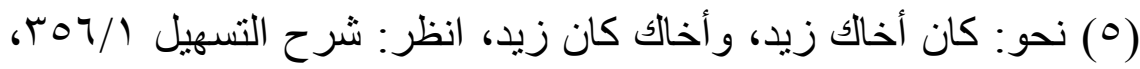

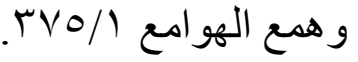




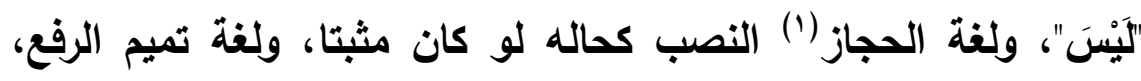

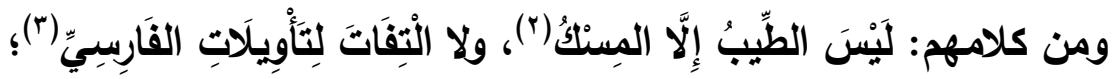

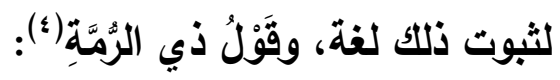

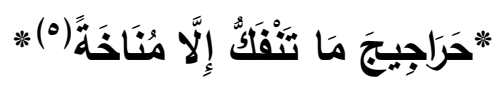

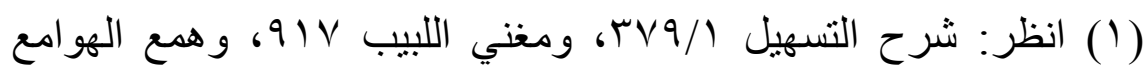
rvq/1

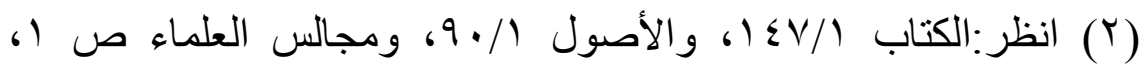

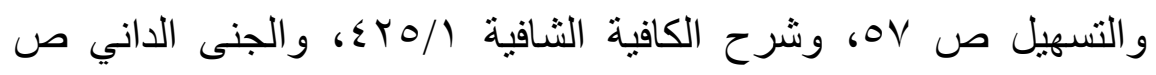

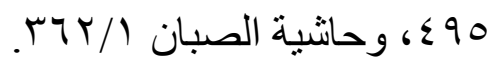

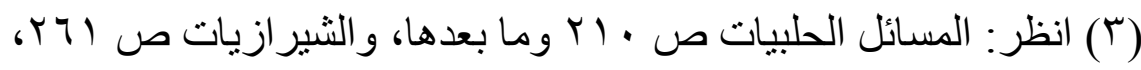

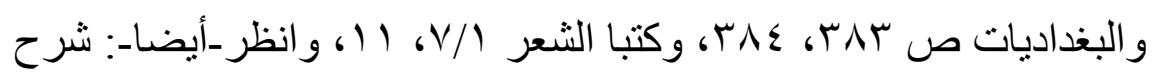

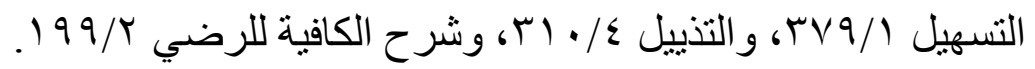

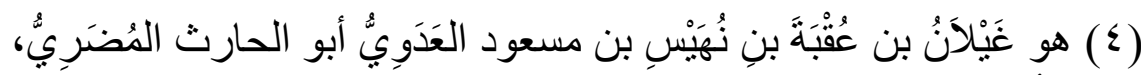

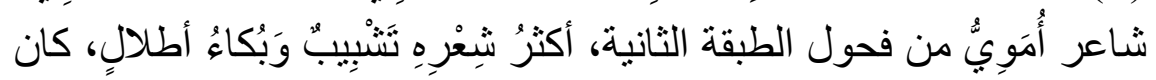

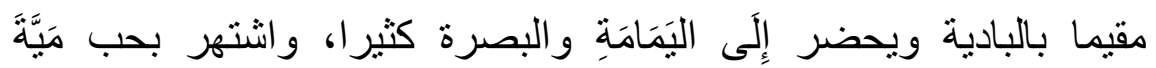

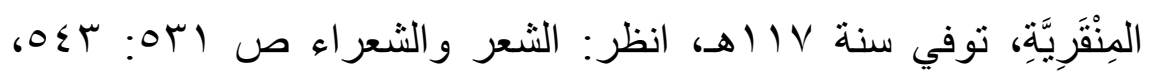

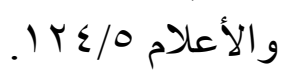

(0) هذا صدر بيت من الطويل، و وعجزه

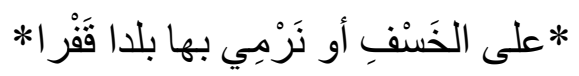

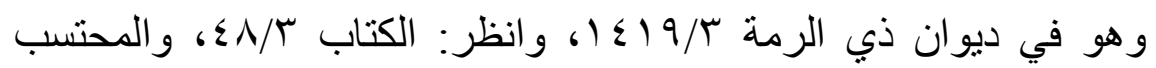

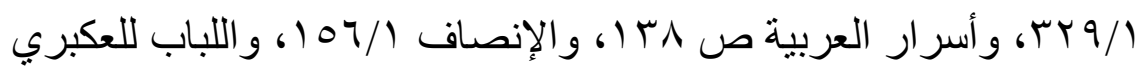

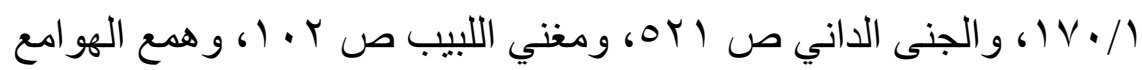


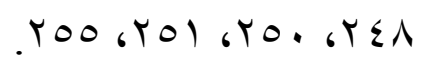


وإذا اجتمع معرفتان فالاسم المقدر للمخاطب عرفاته [ب //ب]، والخبر ما

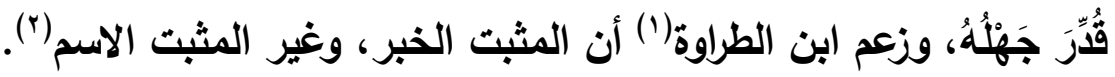

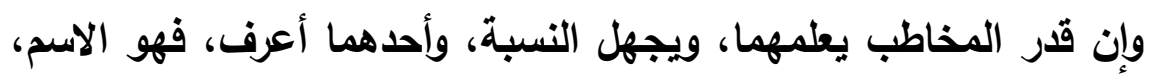
ويجوز العكس، إلا المشار فهو الاسم، وغيره من المعارف الخبر، ولا يجوز العكس إلا مع المضمرات، فهو أفصح. أو استويا تعريفا أو تنكيرا، ولكل واحد منهما مسوغ للابتداء، فالخيار، أو لأحدهما فهو الاسم، ولا يجوز العكس(ّ).

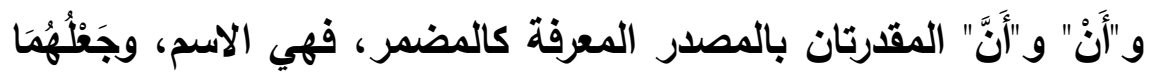
خَبَرًا يَضْعُفُُْ. أو معرفة ونكرة، فالمعرفة الاسم، ولا يعكس إلا في الشعر(๕)، ولا يخلو حينئذ أن يكون لها مسوغ أو لا، إن لم يكن أو كان، وينيت على الإخبار

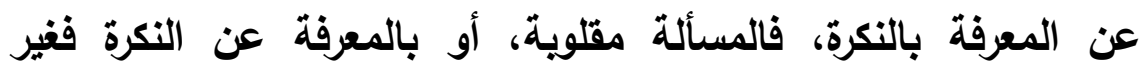
مقلوية، والقلب للضرورة جائز باتفاق (•)، والخلاف في جوازه في الكلام.

(1) هو سليمان بن محمد ين عبدالله السبائي النحوي، من أهل مالقة، أبو الهب

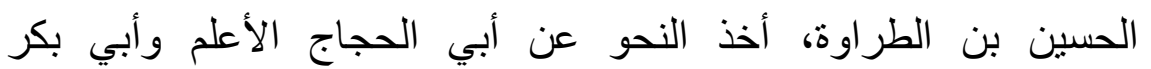

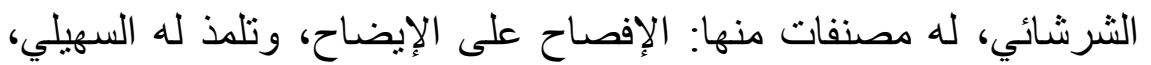

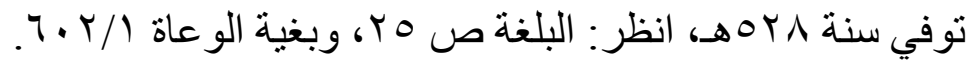

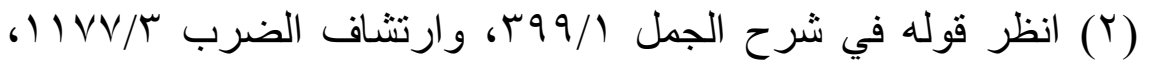

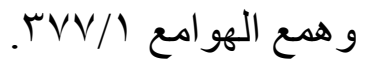

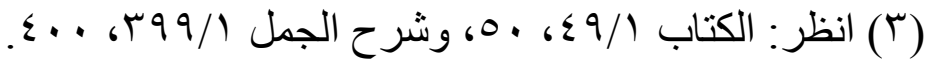

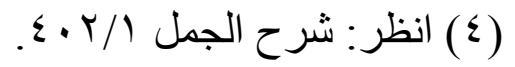

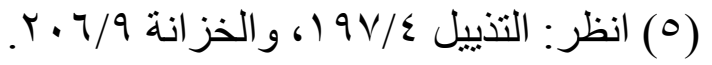


وضمير النكرة كهي في باب الإخبار، فإن أخبر عنه بمعرفة فبابه الثعر (')، والمختصة تتنزل من غير المختصة منزلة المعرفة من النكرة. هذا حكم النكرة مع المعرفة إذا اجتمعا، ما لم تكن النكرة اسنمَ استفهامٍا، فيجوز الإخبار عنها بالمعرفة(r). ويتصل الضميز إذا كان خبرا، وينفصل، وهو الأفصح(ّ)؛ خلافا لابن الطراوة(๕)؛ إذ زعم أن اتصاله أفصح. والخبر إن كان جملة أو ظرفا أو مجرورا فموضعه نصب، أو مفردا النصب، ولا يجوز رفعه على خبر مبتدأ مضمر (•)، وقول زياد (؟):

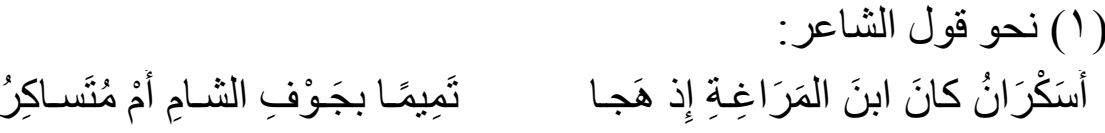

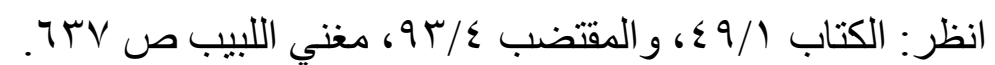

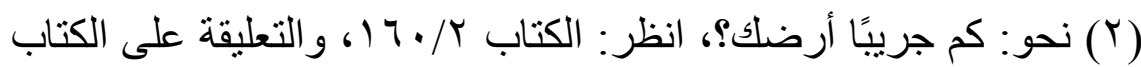
$r \cdot r / 1$

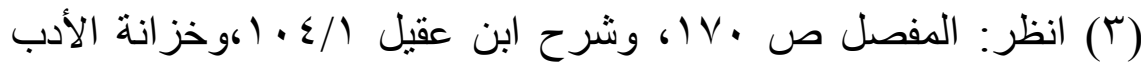
. 0/0

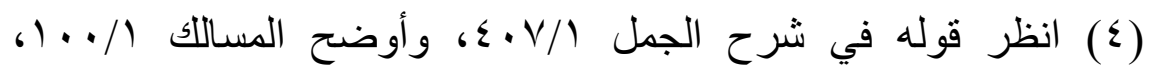

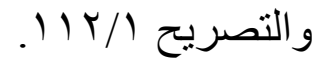

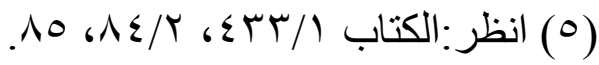

(7) يعني زيادًا الأعجمَ، وهو زياد بن سليمان، وقيل: زياد بن سليم، وقيل غير ذلك، مولى عبد القيس، نزل إصطخر، فغلبت العجمة عليه، فقيل له:

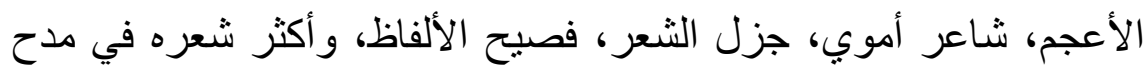

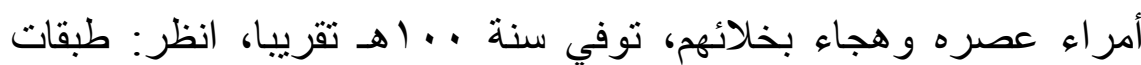

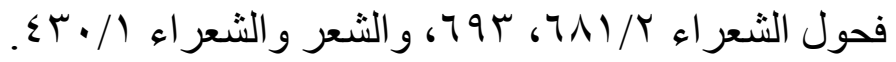




\section{r. IV Rدار}

حولية كلية اللغة العربية بالمنوفية العدد الثاني والثُلاثون

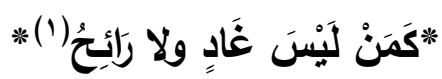

لحن، إلا في المتصل فيجوز.

و "كان" تامة وناقصة وزائدة بين المتلازمين، كالعامل والمعمول(؟)، والصلة والموصول(")، ولا تزاد أولا ولا آخرا، ومذهب السيرافي (؛): أن فيها ضمير

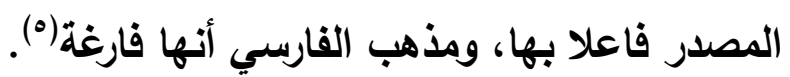
والناقصة: إن بقي بعدها مرفوعان فقيها ضمير الأمر أو القصة اسمًا لها، والجملة في موضع الخبر، وتلحق علامة [ع ا/أ] التأنيث للقصة، ويستوي

$$
\text { * (1) هذا عجز بيت لزياد الأعجم، وصدره: }
$$

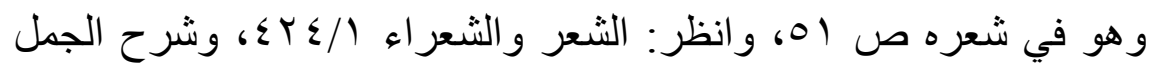


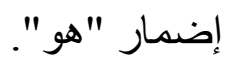

$$
\begin{aligned}
& \text { (Y) نحو: لم يوجد كان مثلك. } \\
& \text { (؟) نحو: جاء الذي كان أكرمته. }
\end{aligned}
$$

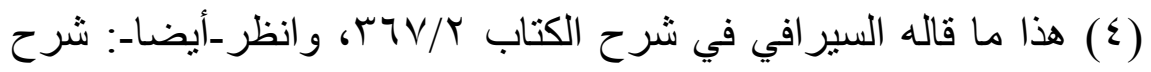

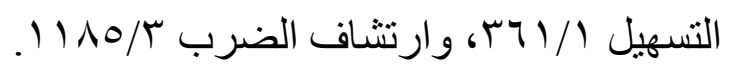

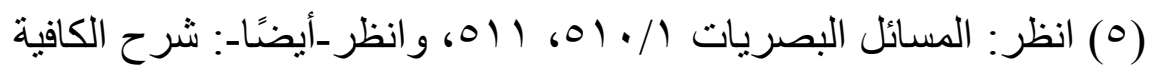

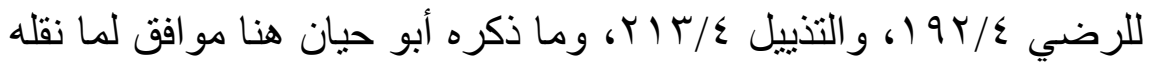

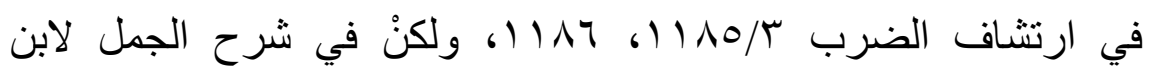

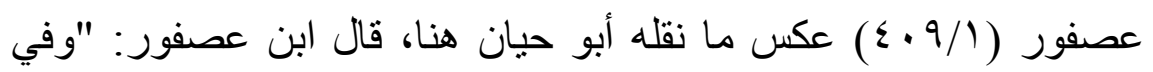

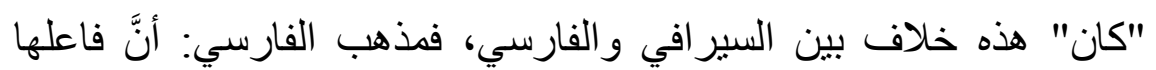
مضمر فيها، وهو ضمير المصدر الدال عليه الفعل الذي هو "كان"، كأنّك قلت: كان هو، أي كان الكونُ، ويعني بالكون كون الجملة التي تزاد فيها،

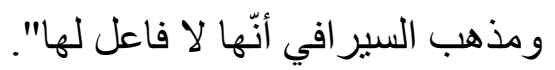


في الضميرين المذكر والمؤتث؛ خلافا للكوفيين (')؛ إذ طابقوا بين الضمير والمخبر عنه لزوما.

أو ارتفع الاسم، وإنتب الخبر، فتكون بمعنى "صار"(ץ)، أو تكون لمجرد الالالة على الزمان. وماضيها يقتضي الانقطاع على قول الأكثر (). والتامة: تكتفي بالمرفوع، وهي بمعنى "حَدَثَ"، ويمعنى "حَضَرَ" (؛)، وحُكِيَ

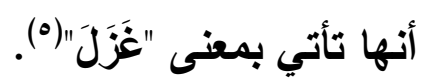

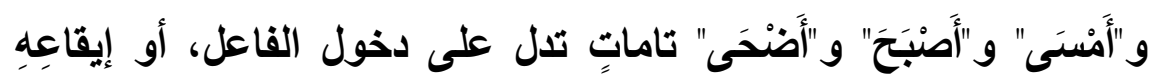

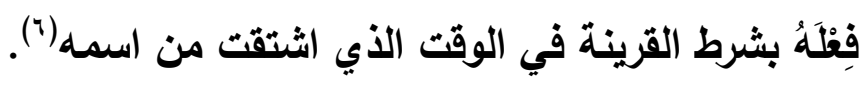

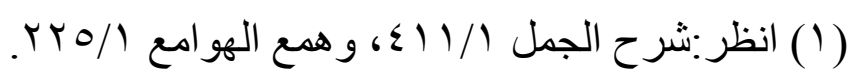

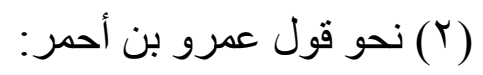

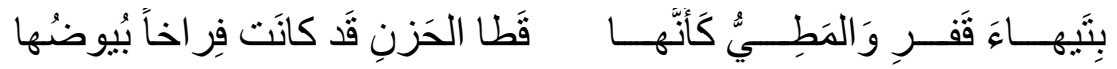

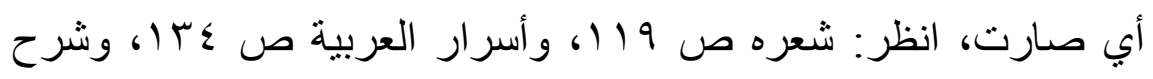

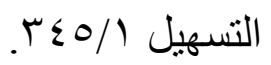

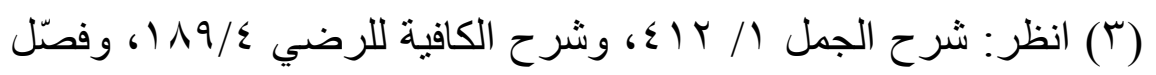
ابن ماللك في هذا بقوله: "والأصل في "كان" الدلالة على دَوَاجِ مضمون

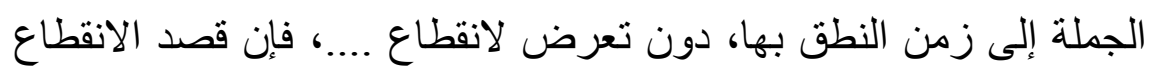

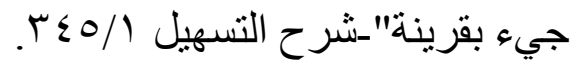

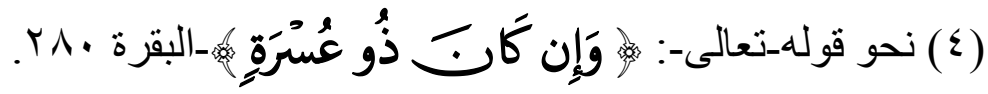

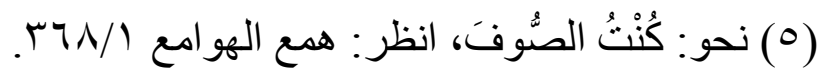

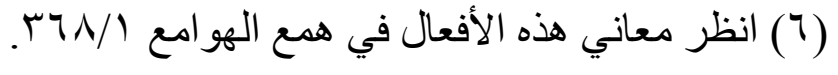


ونواقِصَ مُضْمَرًا فيها الأمَرْ إن ارتفع الجزَآنِ، وإلا ارتفع أحدهما، وإنتصب الآخر، وفي الوجهين تلال على اقتران مضمون الجملة بالزمان المشتقة منه، وقد تأتي بمعنى "صارَ"، فلا تتعرض لله

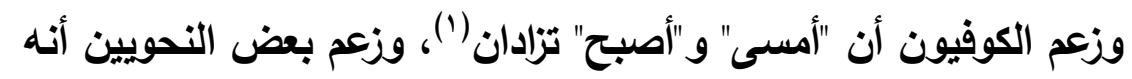

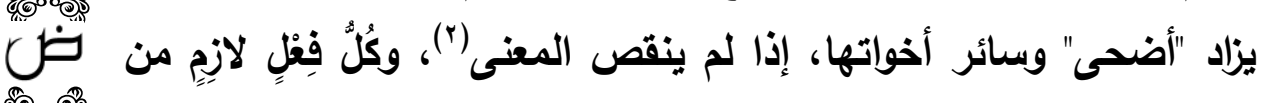
غير هذا الباب. و"غدا" و"راح" تامان دالان على دخول الفاعل في الغُدُوِّ واليَّوَاحِ، وناقصان(汭 فيهما ضمير الأمر وغَيْرْهُ كما تقدم في أخواتها، ويمعنى

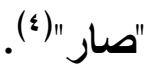
و"آض" تامة بمعنى "رجع"، وناقصة بمعنى "صار "(•).

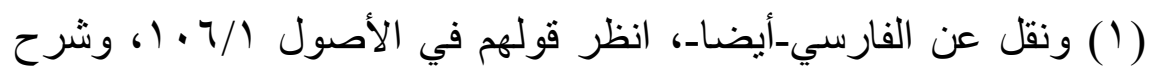

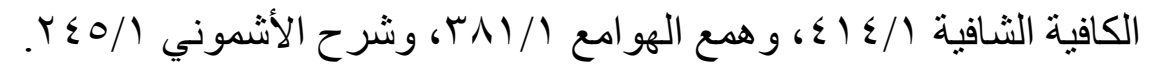

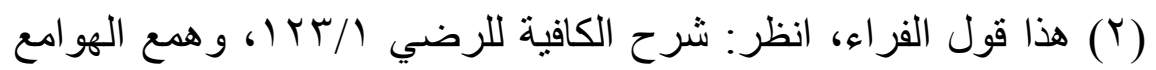
אונו

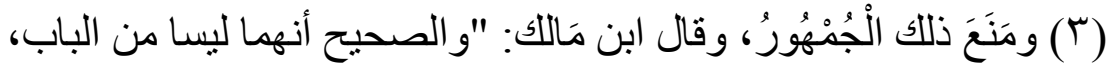

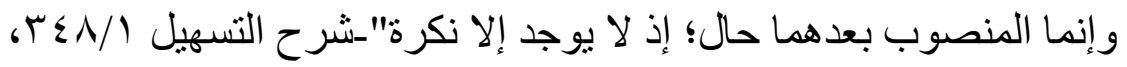

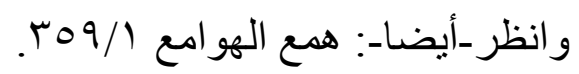

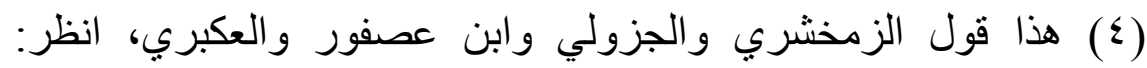

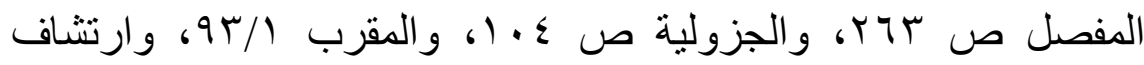

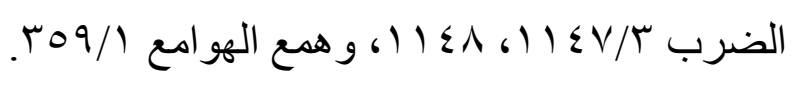

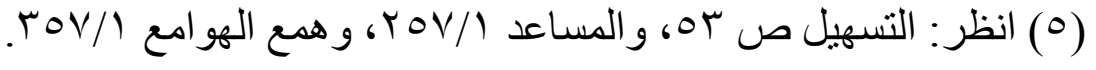


و"صار" تامة بمعنى "(نتقل"، فتتعدى ب"إلىى"(1)، وناقصة لانتقال الثيء

من حالة إلى حالة لم يكن عليها (ץ). و"قعد" و"جاء" تامان، فُ"قعد" بمعنى "جلس"، وجاء بمعنى "أتى"، وناقصان

بمعنى "صار "(") و (") و"بات" و"ظل" تامان(؛)، فتل "ظل" على إقامة الفاعل نهاره، و"بات" على إقامته لَيََْهُ، وناقصان فيكون فيهما ضمير الأمر، أو لا يكون، وتدل "ظل" على وقوع مضمون الجملة في النهار، و"بات" في الليل، ويكونان بمعنى

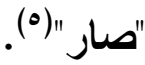

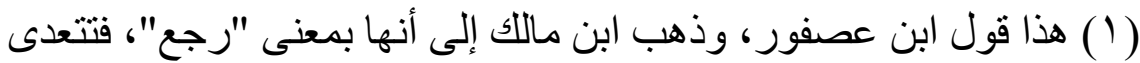

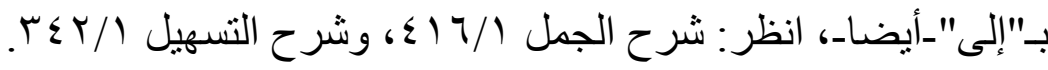

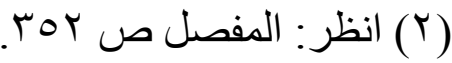

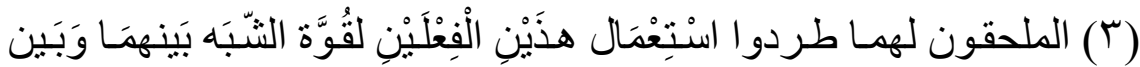

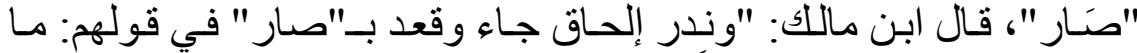

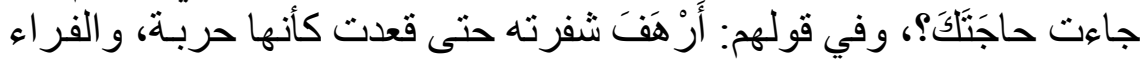

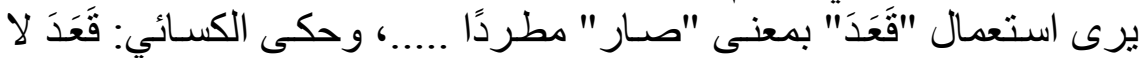

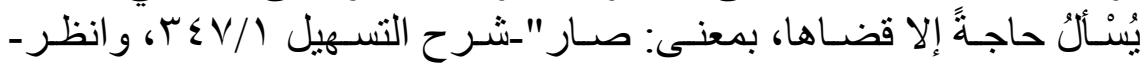

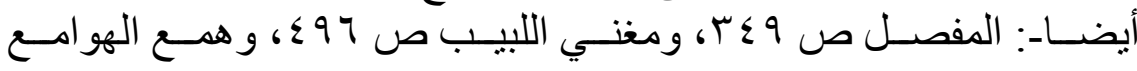
ro9 6 r0N/1

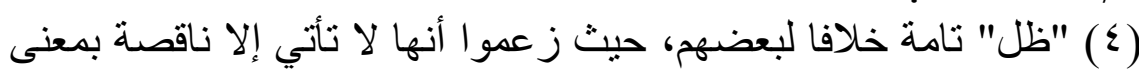

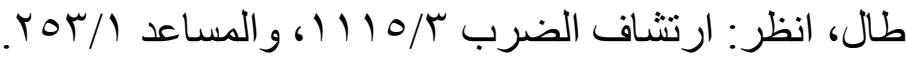

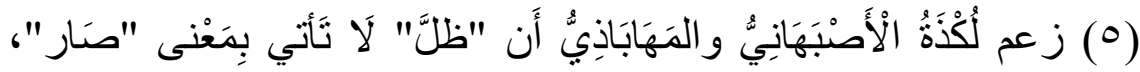

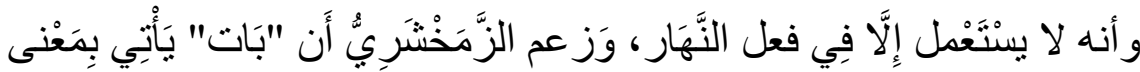

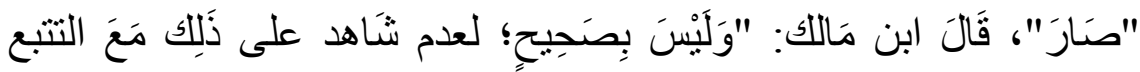

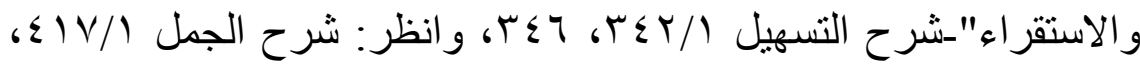

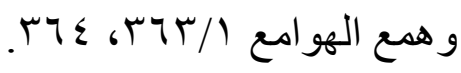


و"ما زال" و"ما انقك" و"ما فتئ" و"ما برح" تامات ، تذل على عدم انتقال الفاعل عن أمر ما، ولا تدل "ما برح" على نفي انتقال الفاعل عن مكانه؛

خلافا لبعض النُّنَّرِ (1). و"ما دام" تامة(ץ) تدل على اتصال ما قبلها [ـ ا/ب] مدة بقاء القاعل، وناقصة يكون فيها ضمير الأمر، وقد لا يكون، وتدل في الحالتين على اتصال ما قبلها مدة بقاء الصفة للموصوف. و"ليس" لا تكون إلا ناقصة، ويكون فيها ضمير الأمر، وقد لا يكون، وهي لنفي الخبر، فإن اختص بزمان نَفَتْهُ على حسب الاختصاص، وإن احتمل خلصته للحال (). واسم "كان" وأخواتها مرفوع بها(؛)، لا بالابتداء خلافا للكوفيين(•). ولا يجوز حذف الاسم ولا الخبر لا اقتصارًا ولا اختصارًا، وقد يحذف الخبر ضرورة لفهم المعنى("). $* * * * * *$

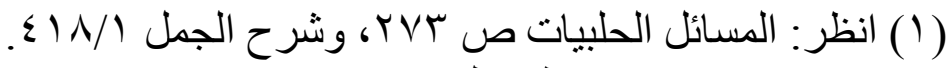

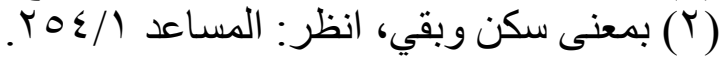

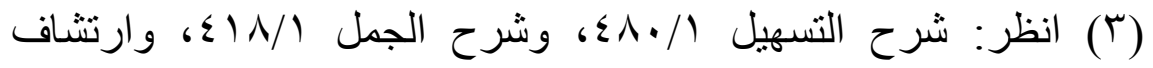

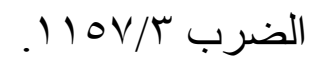

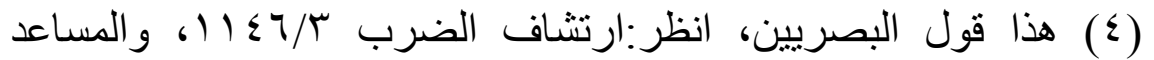
$r \leqslant \wedge / 1$ (0) وذهب الفراء إلى إنه ارتفع لشبهه بالفاعل، انظر: معاني القرآن

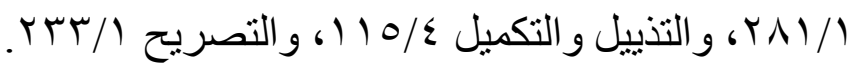

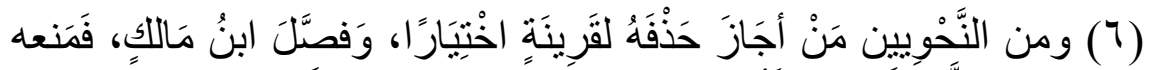

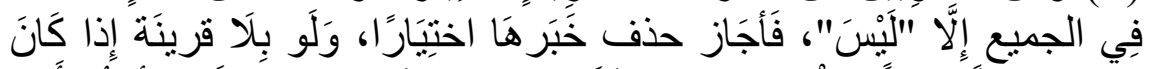

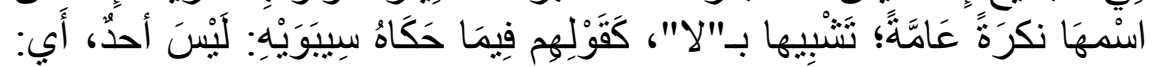

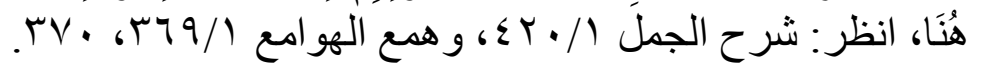




\section{أفعال المقارية}

"أخذ" و"طفق" و"جعل" و"أنثأ" للأخذ في الفعل، و"كاد" و "كرب" و "قارب"

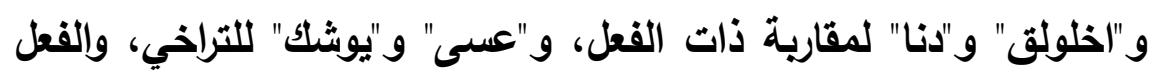

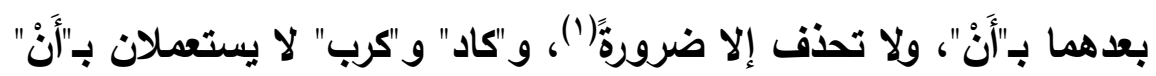

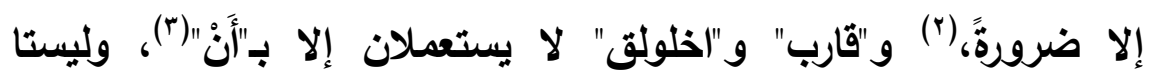
بداخلتين على المبتأ والخبر، ويجيء مفعول "قارب" اسمًا في فصيح الكلام (q). وهذه الأفعال متصرفة إلا "عسى"، وفيها لغتان: عَسَى وعَسِيَ إذا كان

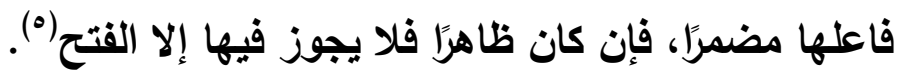

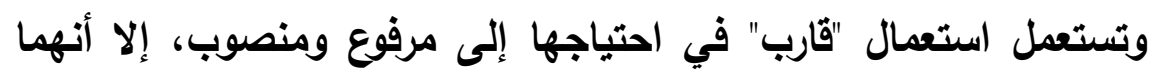

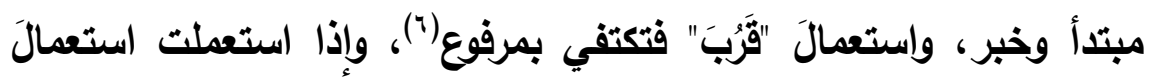

(1 (1) هذا مذهب جمهور البصريين وظاهر كلام سيبويه أنه جائز في الكلام،

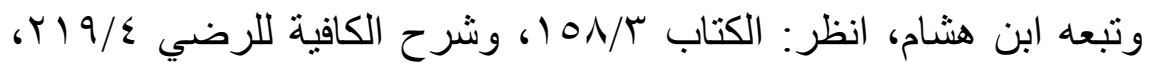

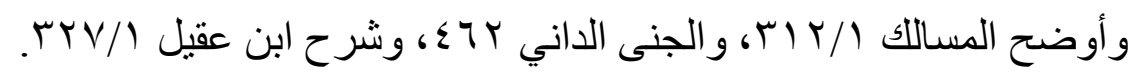

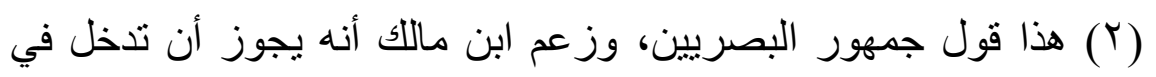

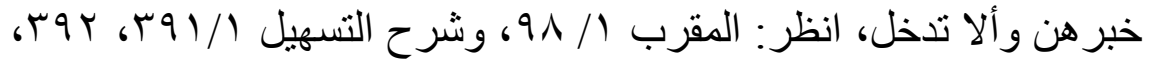

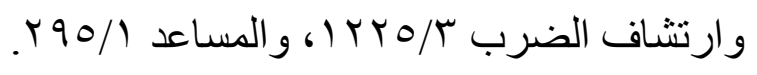

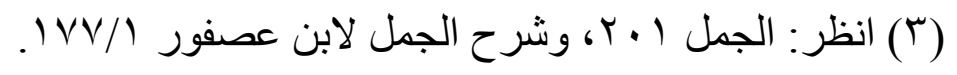

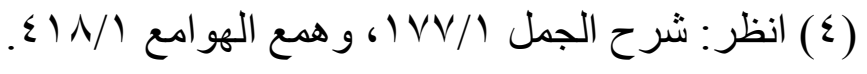

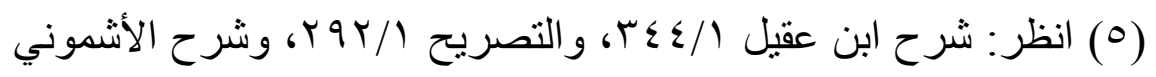
$r 94 / 1$

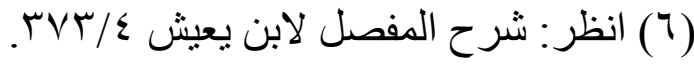


"قارَبَ" فمرفوعها اسم "عسى" و"أن يقوم" في موضع الخبر (')، وعند المبرد مرفوعها فاعل "عَسَى"، و"أَنْ يقوم" في موضع المفعول بهَ(َ). ولا يكون فاعل الفعل الذي بعد هذه الأفعال إلا ضَمِيرَ الاسم الأول، هوصل وفاعلها إن كان مضمرا استتر في حال الإفراد، ويرز في حال التثنية والجمع، إلا "عسى"، فيجوز أن يستتر، ويجوز أن ييرز. وإذا اتصل بها ضمير نصب فالأخفش يقول: هو في موضع رفع، و"أن يقوم" في موضع نصب(")، و(س) يعكس(؛)، وهو الصحيح(•). ****** $*$

ما النافية: لا تختص، ولها شبهان: عامٌٌ، وراعاه بنو تميم، فلم [1/10] يُعْمِوُوهَا، وخاصُّ، وهو شبهها ب"ليس" في النفي، وفي دخولها على (1) هذا قول الجمهور، وصححه ابن عصفور، انظر: شرح الجمل

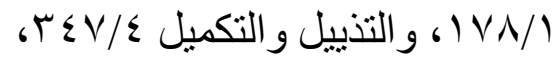

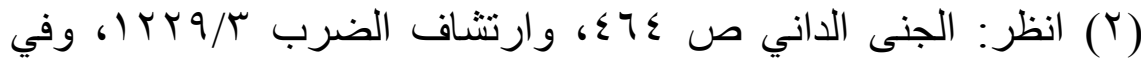

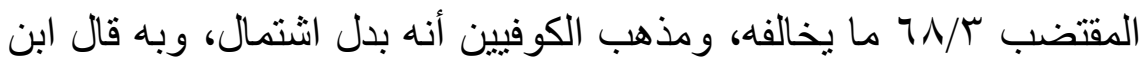

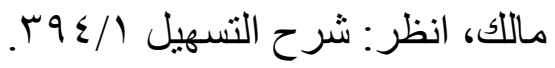

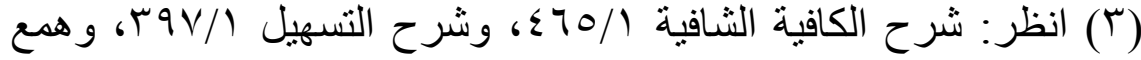

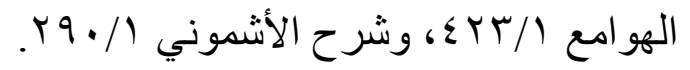

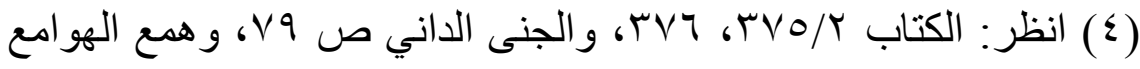
ETr/

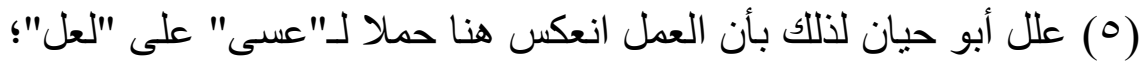

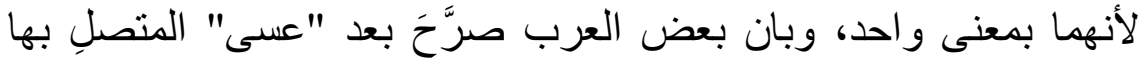

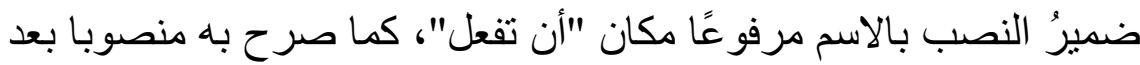

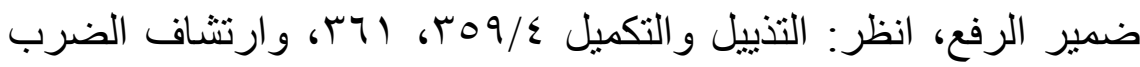


المبتأ والخبر، وفي تخليصها المضارع للحال، فأعملوها بشرط: ألا تزاد "إِنْ" بعدها، وألا تدخل "إلا" على خبرها، وألا يتوسط، إلا أن يكون ظرفا أو

مجرورا فخلافُ، الأخفش مانعُ، وغيره من البصريين مجيزٌ.

وتجوز زيادة "مِنْ" على ما [باشرته]] (1) النكرة في اللغتين.

والصحيح جواز زيادة الباء في الخبر فيهما، تقدم أو تأخر، ومنهم من لا يجيز ذلك إلا مع التأخر.

وإذا عطفت على الخبر المرفوع أو المنصوب أو المخفوض، وحرف العطف موجب فالرفع، أو غير موجب، وهو على منصوب فالنصب، وحكى (س) الخفض على التوهم، وهو قبيج، أو على مخفوض فالخفض، ويجوز النصب إن قدرت "ما" حجازية، والرفع إن قدرتها تميمية، أو على الاسم رفعت، أو عليهما والخبر مرفوع أو منصوب أو مخفوض، وحرف العطف موجب رفعت، أو غير موجب، وهو منصوب نصبت الخبر، أو مخفوض والعطف على الموضع، نصبث الخبر في لغة أهل الحجاز، ورفعته في لغة

وإذا ذكرث مع المعطوف على الخبر اسما غير سببي متقما على الخبر، جاز عطفهما على الاسمين المتقدمين، ورفعهما مبتدأ وخبرا، والجملة

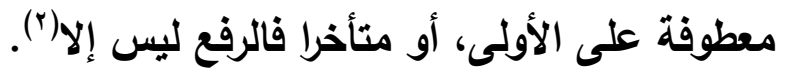
****** $* *$

( ( ) لم أستطع قر اءة هذه الكلمة إلا على هذا الوجه.

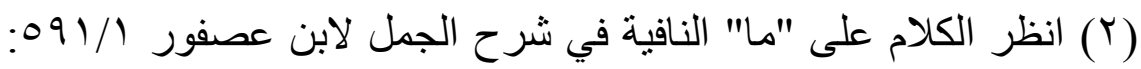


"إن" و"أن" و"لكن" و "كأن" و"ليت" و "لعل": يـخلن على المبتدأ غَيَرِ اسم الشرط والاستفهام و"كم" الخبرية و"ما" التعجبية و"ايمن"، فينصبنه، وعلى ولى خبره غير اسم الاستفهام و"كم" الخبرية والجملة غير الخبرية، فيعملن فيه رفعًا، خلافا للكوفيين أنه الرفع الأي كان فيه قبل دخولها، والرفع واجب

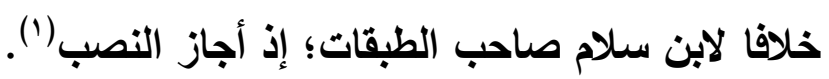
وتنفرد [0/ب] "إنَّ" بلخول اللام في اسمها متأخرا عن الخبر، وفي خبرها اسما، أو مضارعا، أو غير متصرف، أو اسمية قليلا، أو ظرفا أو

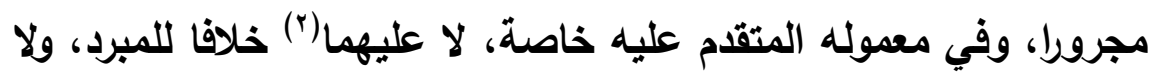
تلحق "لكنَّ" خلافا للكوفيين. وعليها(")، فتبدل همزتها هاءً، خلافا لبعضهم؛ إذ زعم أنها لا تدخل عليها. وإذا لحق "ما" هذه الحروف فمجيز الإلغاء والإعمال، وهو الزجاجي، ومانع الإعمال إلا في "ليت"، وهو الأخفش، وملحق ب"ليت": "لعل" و"كأن"، وهو ابن السراج والزجاج. وإذا كان اسمها ياءَ متكلم وجبث نون الوقاية في "ليث"، إلا في الثعر، وجازت في غيرها.

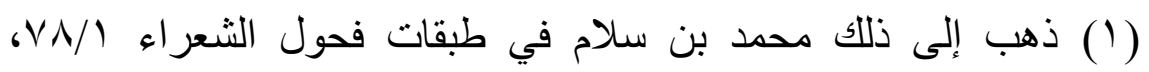

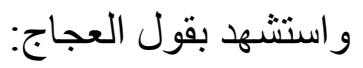

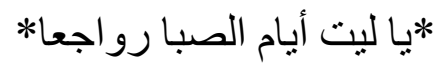

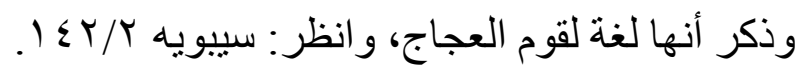

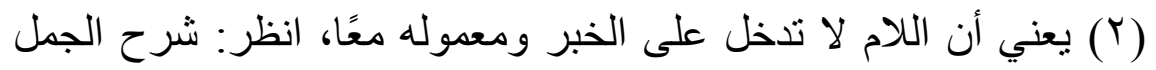
ह $₹ 9 / 1$

(T) يعني أن اللام قد تدخل على "إنَّ"، فتقلب همزتها هاءً، فيقال: لَهِيَّكَ،

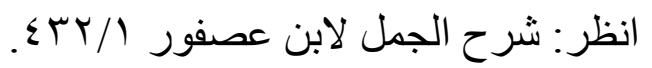


ويجوز تخفيف مضاعفها، إلا "لعل"، فَ"لكنْ" يجب إلغاؤها، و"أنْ" وكأنْ" يجب إعمالهما، إلا أن اسمهما [لا][') يكون إلا ظاهرا أو مضمرا محذوفا، و"إنْ" فالإعمال وإفلغاء، إلا أن اسمها لا يكون مضمرا إلا ضرورة، وإذا الغيت لزمت اللام، ولا تلخل إلا على المبتدأ والخبر أو ناسخه الفعل لا غير الناست، خلافا للكوفيين.

ولا يقدم عليها شيء من معمولاتها إلا إن كان الخبر ظرفا أو مجرورا، فيجوز تقديمه على الاسم، غير "أن" وصلتها، لا معمولين له، خلافا لبعضهم، ويؤول ما ظاهره ذلك، ويجب إن كان "أنَّ" وصلتها. وشرط الظرف والمجرور الواقعين خبرا: التمامُ، فإن اجتمع تامٌٌ وناقص فالتامُّ الخبر، ولا يجوز العكسُ وجَعْلُ التامِّ حالا خلافًا للقراء. ويجوز حذف الاسم فصيحًا لاليل، إلا إن كان ضميرَ الأمر، فحذفه ضرورة، لا جائز على قلة، خلافًا لبعضهم، ولا يجوز حذف الاسم والخبر الإل إلا في "إنَّ" على خلاف فيه. ويجوز حذف الخبر لاليل، وليس شرطه تنكير الاسم، وإن كان أكثر حذفه

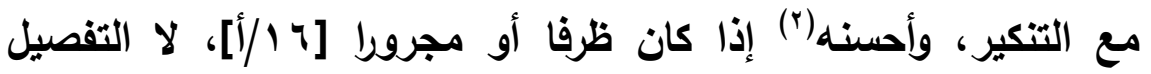
خلافًا للكوفيين (ז). ولا يجوز حذف الاسم والخبر إلا في "إنَّ" على خلاف فيه(؛).

(1) (1) (1) زيادة يقتضيها السياق. (Y) في الأصل: "و أحسن حذفه"، ثم صوب في الحاثية بخط أبي حيان نفساه.

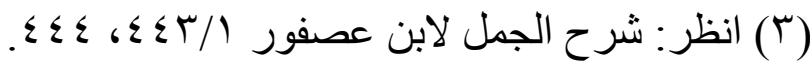
(乏) هذه العبارة ذكر ها أبو حيان قبل سطرين، ثم أعادها هنا. 
r.IV إصدار

حولية كلية اللفة العربية بالمنوفية العدد الثاني والثلاثون

ويقال في لعل: عَلَّ، ولَعَنَّ، وعَنَّ، ولَغَنَّ، وغَنَّ، وأَنَّ (')، وهي مركبة من اللام و"عَلَّ"(ז)، ومعناها الترجي في محبوب، والتوقع في محذور.

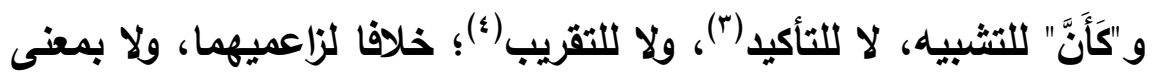

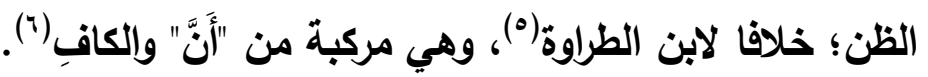
وإذا عُطفَ على الخبر أو الاسم قبل ذكر الخبر فالمطابقة في الإعراب، إلا

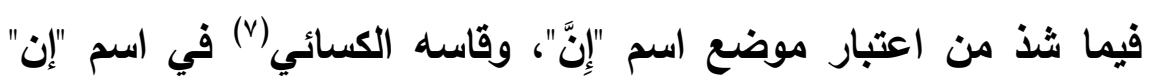

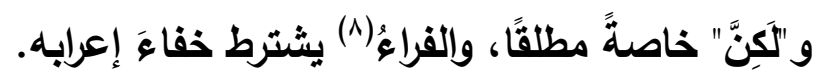

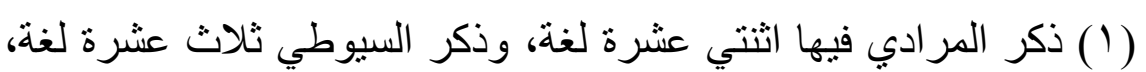

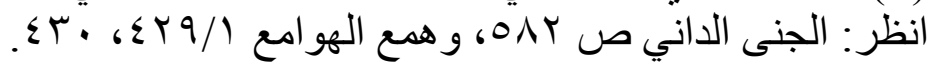

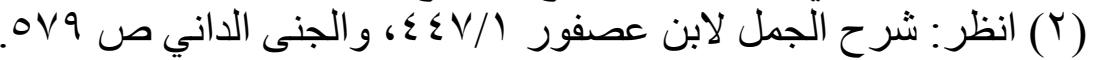

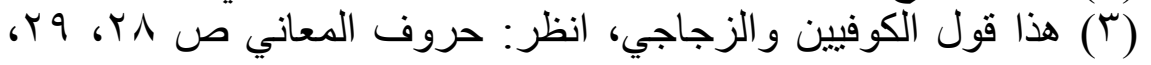

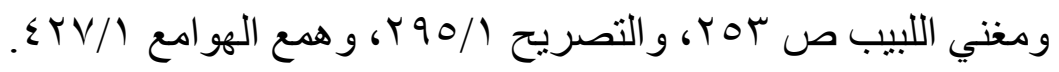

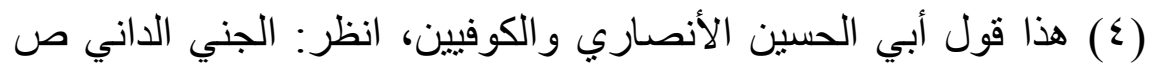

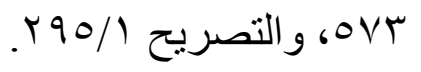

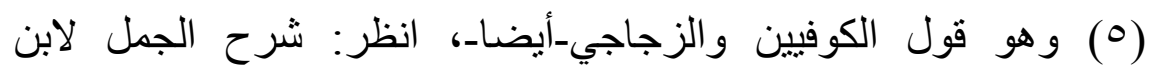

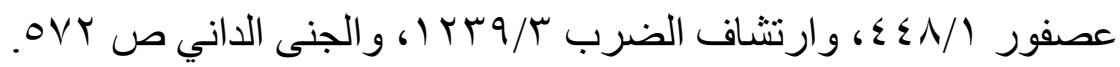
(7) هذا قول الخليل وسيبويه و الأخفش وجمهور البصريين و الفراء، وقال

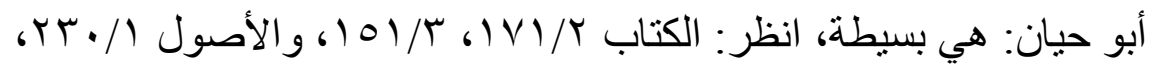

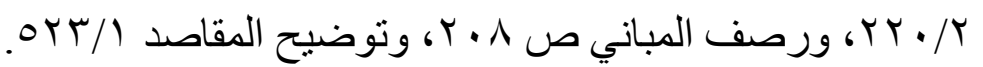

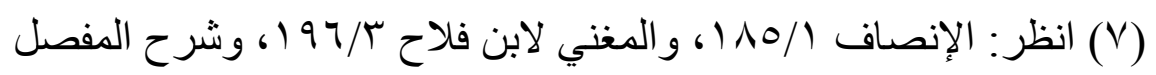
لابن يعيش

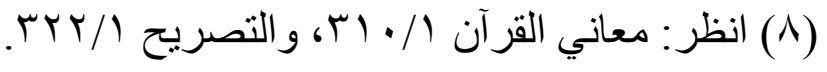


وتجب مطابقة الخبر لهما، ولا يفرد إلا حيث سُمعِع، وليس على معنى "مع"

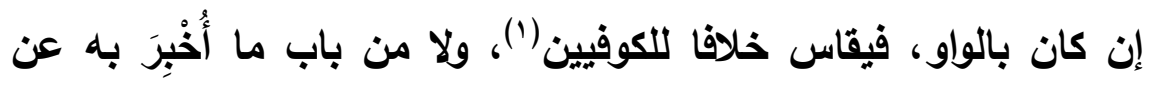

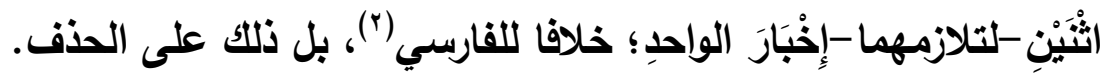
أو بعده، والحرف "إنَّ" و "لكنَّ"، فالنصب على اللفظ، والرفع على الابتداء، والخبر محذوف، أو على الضمير في الخبر إن كان يتحمله، ولا بـ من الفصل إلا ضرورةً، أو على الموضع على مذهب الكوفيين وطائفةٍ من البصريين، وأباه محققوهم (r). أو غَيْرَهُمَا، فلا يجوز إلا النصب على اللفظ خاصة، أو الرفع على الضمير في الخبر إن تَحَمَََُّْ بشرطه.

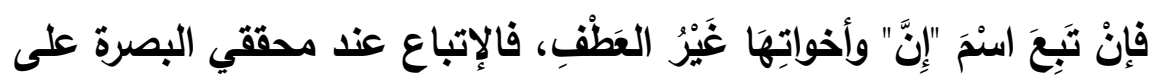
اللفظ(๕)، ولا يجوز غيره، إلا أن يسمع فيحفظ ولا يقاس، وأما الكوفيون

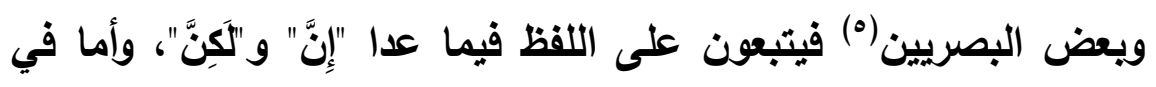
هذين فكالعطف عندهم.

(1) انظر: شرح الجمل لابن عصفور / / (1)؛، وارتشاف الضرب Ir

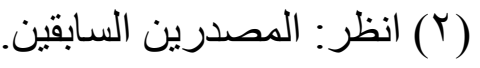
(r) انظر: الكتاب 110/1)

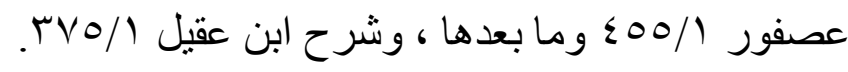

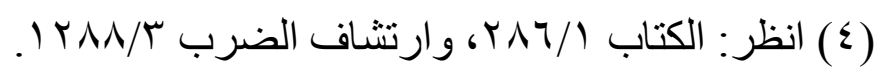

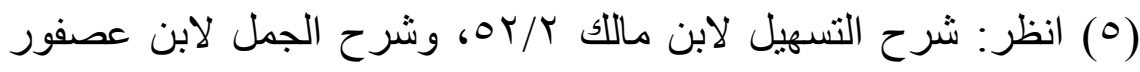
| 
وما تَعَاقَبَ عليه الاسم والفعل تُكْسَرُ فيه "إِنَّ"، وما انفرد بأحدهما تفتح فيها")، وينكسر هذا القانونُ بَ"إذَاً" الفجائيةِ.

وقيل(ץ): ما كان للجملة فتكسر [ד //ب] فيه، وللمفرد تفتح فيه، وينكسر

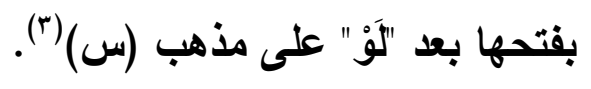

ضُبطِطَ ذلك بالتفصيل، فنقول: تكسر ابتداء، وفي خبرها اللام، ويعد واو

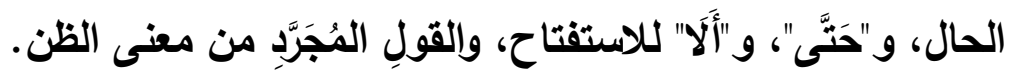

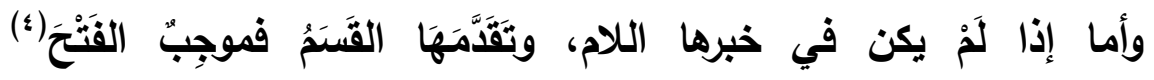

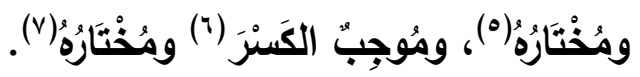

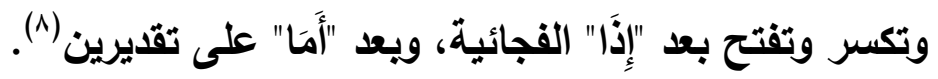

(1) هذا الضنابط قاله الفارسي في الإيضاح ص V Y I ا ، وانظر: شرح الجمل

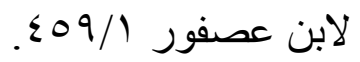

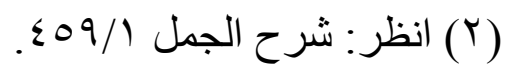

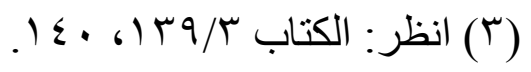

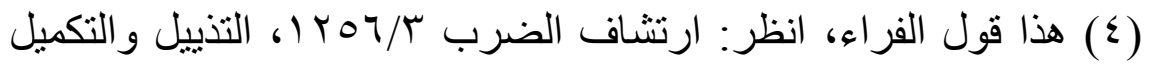
$\mathrm{V} \cdot \mathrm{/O}$

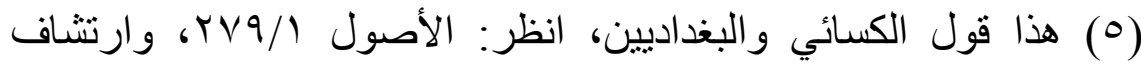

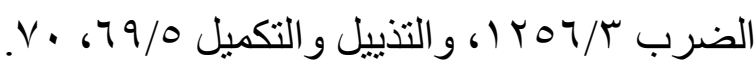

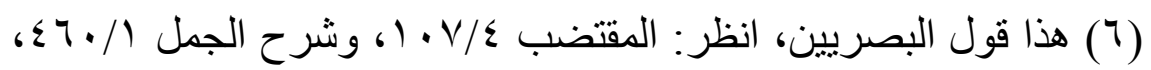

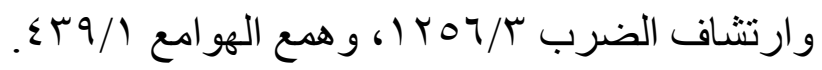

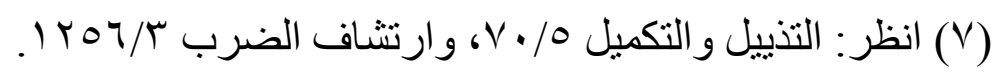

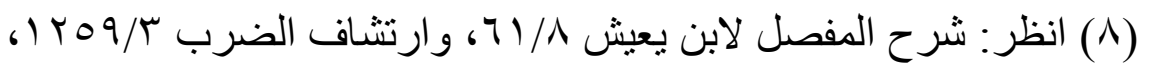

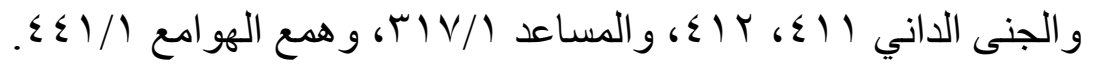


ويعمل القول عمل الظن بلا شرط عند سليم، ويشرط المضارعة، والخطاب، وتَقَدَّم أَدَاةِ الاستفهام، وعَدَمِ الفَصْلِ بينهِما بغير ظرف أو مجرور، عند

غيرهم (1)

وإِذا أُعْمِلَ عَمَلَهُ فمعناه معناه؛ خلافًا لابن خروف (َ)؛ إذْ زَعَمَ أن معناه معنى القول لا معنى الظن. ويجوز في "أَََّلُ ما أقول أَتِّي أحمد الله"(") القتحُ على أن "ما" مصدرية،

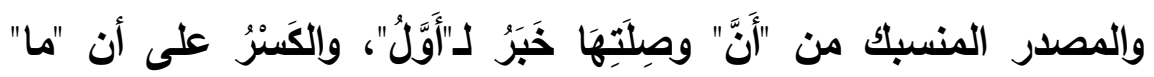

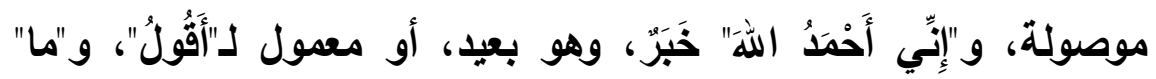

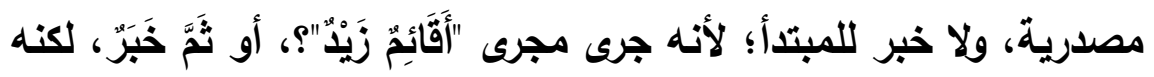

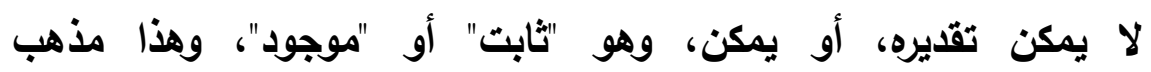

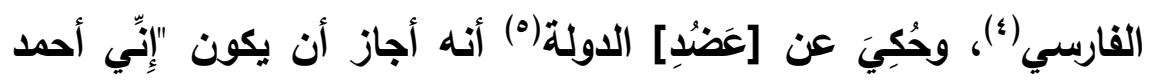
الله" معمولا لقول مضمر.

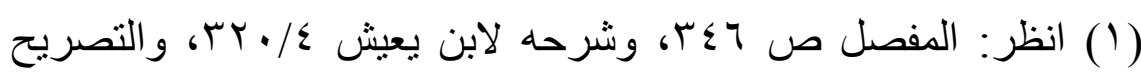

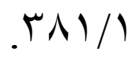

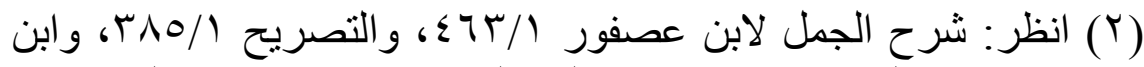

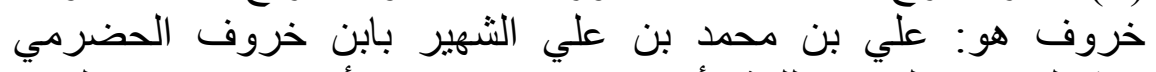

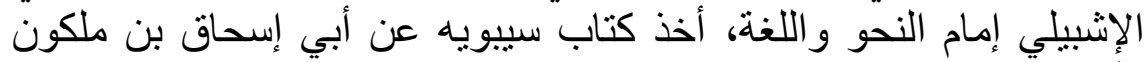

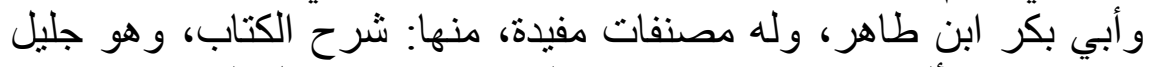

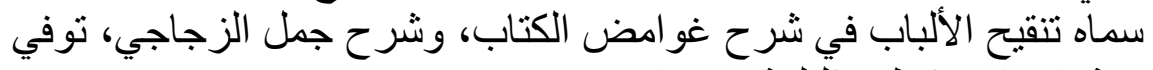

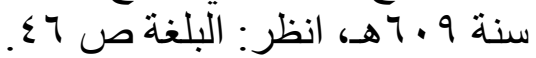

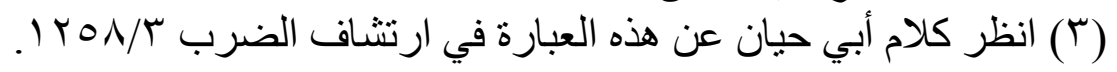

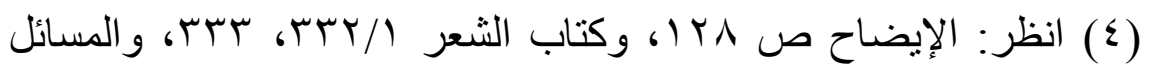

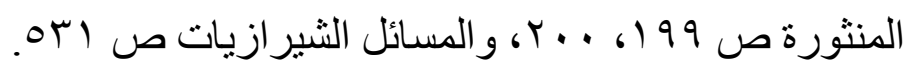

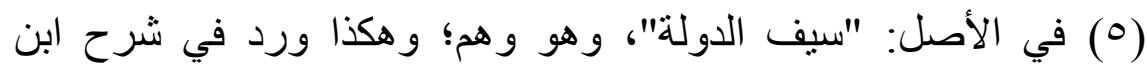
عصفور IV/ 


\section{الأفعال المتعدية}

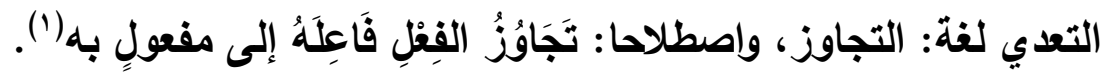

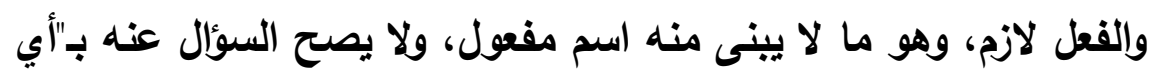
شيء وقع"؟(").

ومُنََّدَّ، وهو عكسه، ويتعدى إلى واحد بنفسه، أو بحرف جَرًّ، أو بهما، ولا

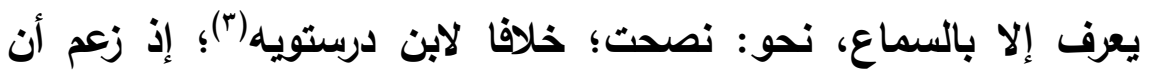

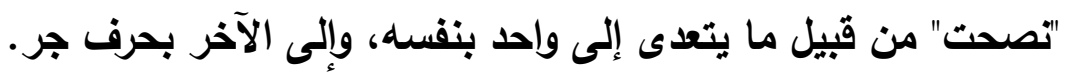

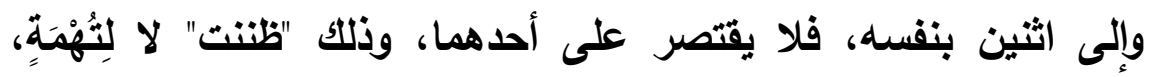

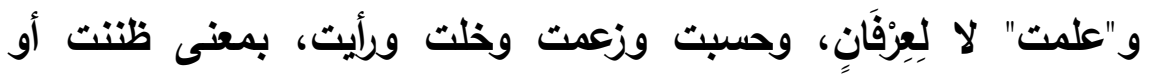

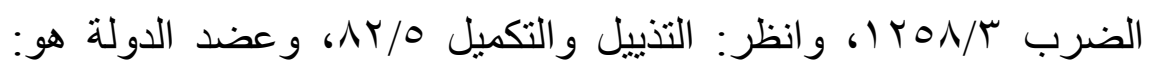

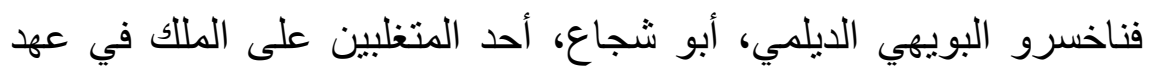

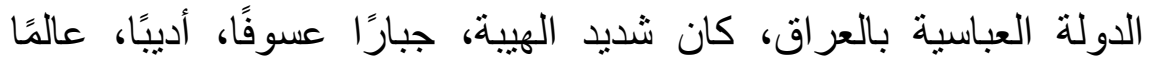
بالعربية، وكان شيعيًا، وصنف له أبو عليٍ الفارسيُّ (الايضاح) و و(التكملة)،

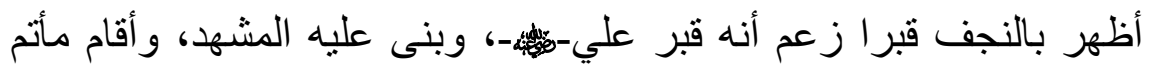

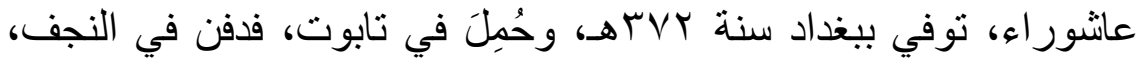

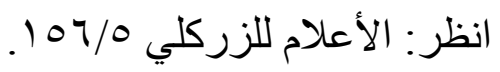

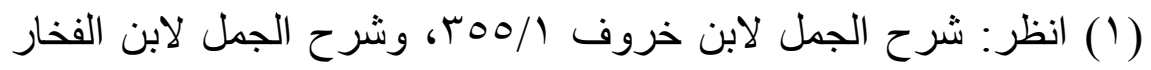
. r) $9 / 1$

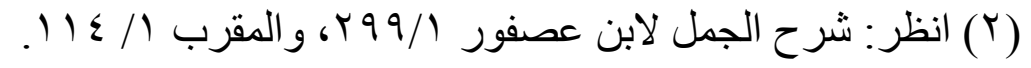

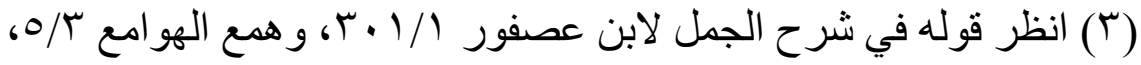

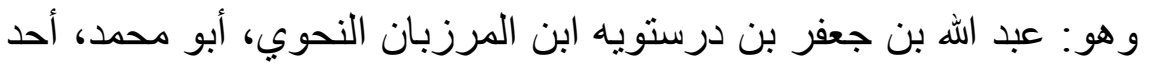

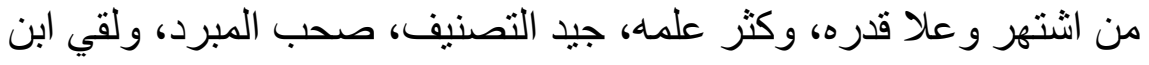

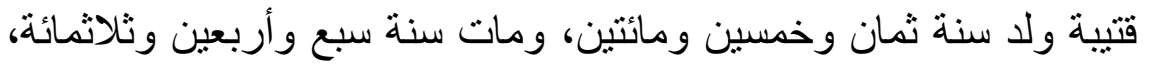

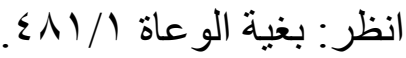




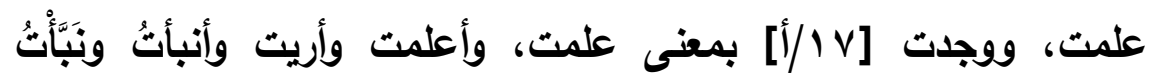
وأخبرت وخبرت وحَََّتُتُ، إذا كُنَّ بمعنى أعلمت.

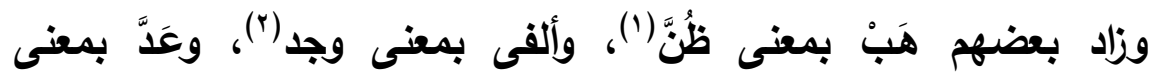
حسب(")، وسمع إن دخلت على غير مسموع(๕).

(1) أثتته الكوفيون وابن عصفور وابن ماللك انظر: شرح الجمل لابن

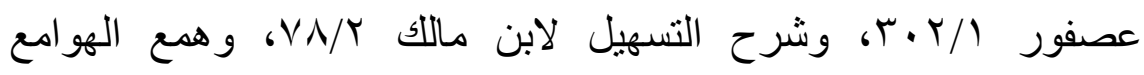
$\varepsilon \vee 9 / 1$

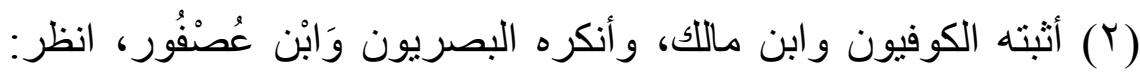

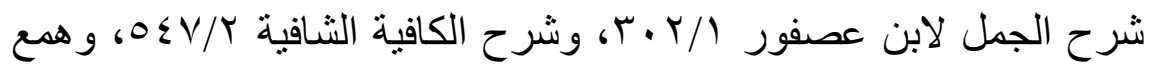

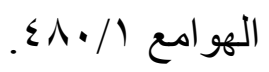

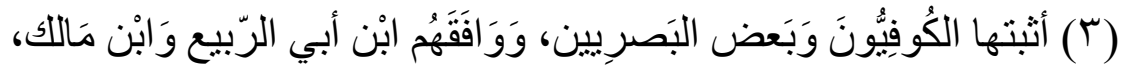
كَقَوْلِه:

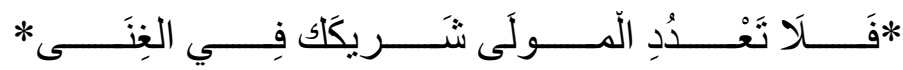

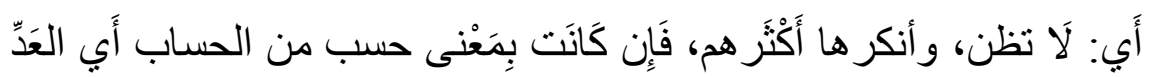

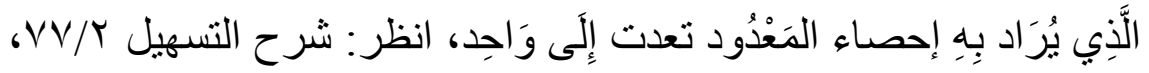

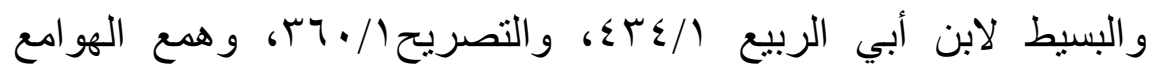
. $\leqslant \vee \vee$ ، $\leqslant \vee T / 1$

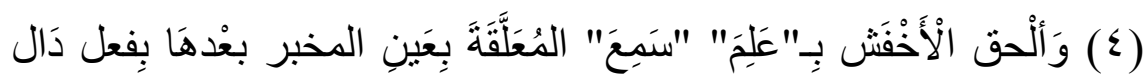

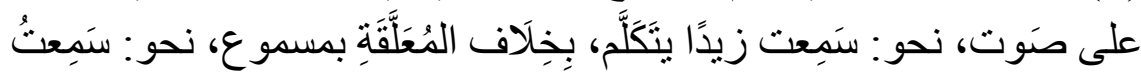

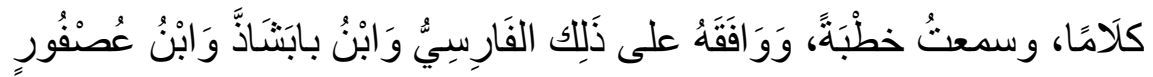

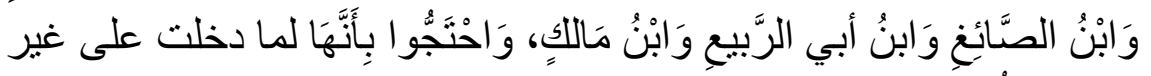

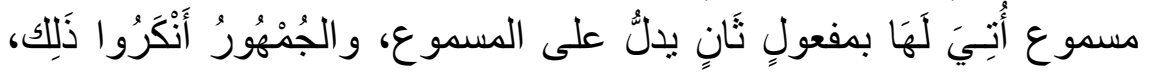

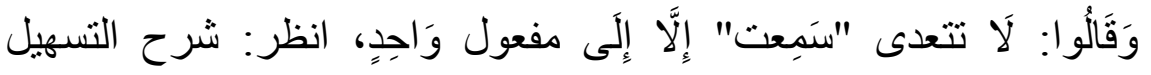

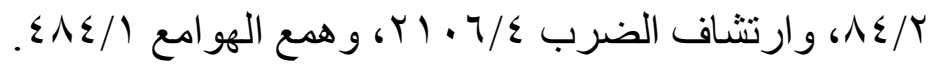


أو تقتصر، وهو كل فعل يتعدى لمفعولين، الأول فاعل في المعنى، نحو "أعطى" و"كسا"، أو إلى أحدهما بنفسه، ولِلآخر بحرف جر، هُ نحو: "أَمَرَ". أو إلى ثلاثة، وذلكا: "أَعْلَمَ" و"أرى" المنقولين من "علم" و"رأى" المتعديين

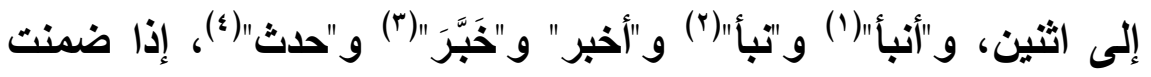

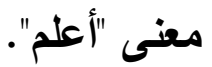

وزاد الأخفش (•) ما بقي من أخوات "علمت" و"رأيت" إذا نقلت بالهمزة. والمتعدي بِحَرْفِ جَرِ لا يجوز حذف الحرف من مفعوله، ووصول الفعل

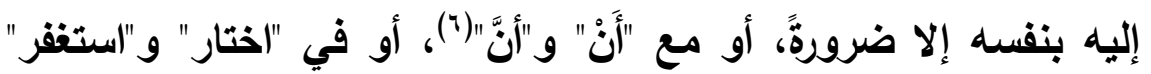

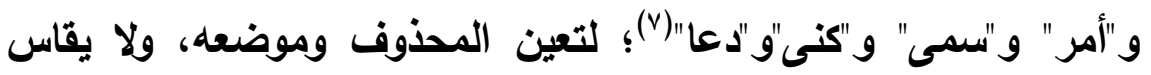
غيرها عليها وإن شارك في العلة؛ خلافا للأخفش الأصغر (^).

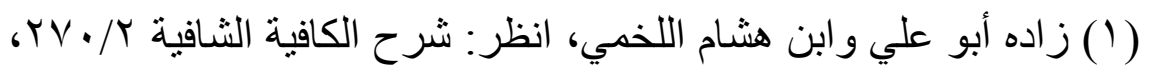

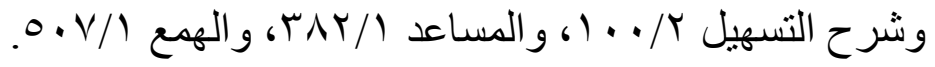

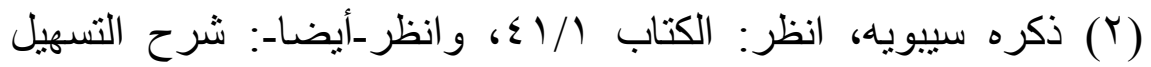
(

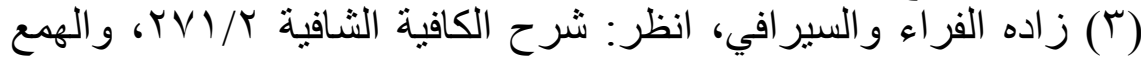
$0 \cdot 1 / 1$

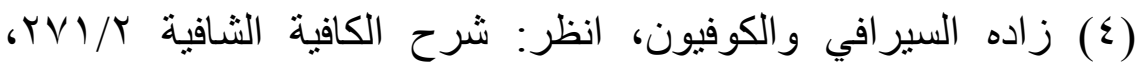

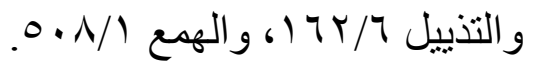

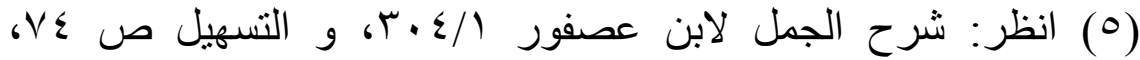

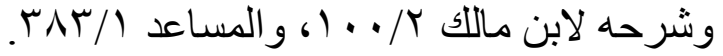

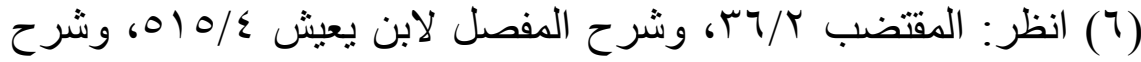

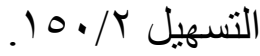

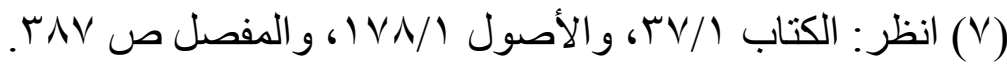

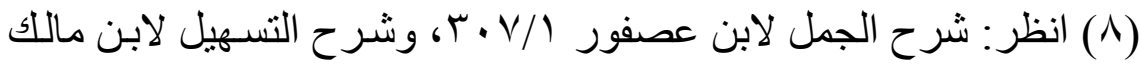

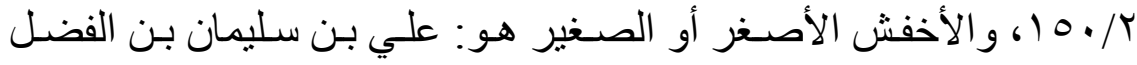


ويجوز دخول اللام على مفعول الفعل المتعدي لواحد إن تقدم، فإن تأخر

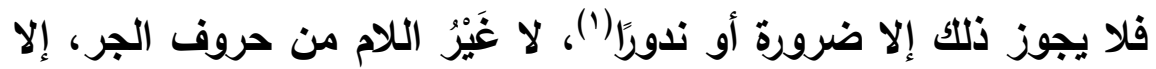

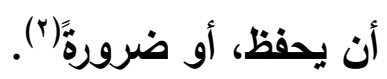
فإن تعدى لأكثر لم يجز دخول اللام، تقدم المفعول أو تأخر، إلا في باب "ظن"، فيجوز أن تلخل على الأول الباء بمعنى "في"، وتصيره كأنه ظرف لإن لهي

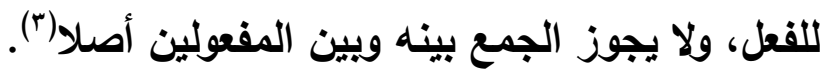
ومعمول المتعدي لواحد يجوز حذفه اختصارا، وهو الحذف لاليل، واقتصارا، وهو الحذف لغير دليل(؛) أو لاثثين من باب "أعطى" فكذلك يجوز حذفهما وحذف أحدهما، أو من باب "ظن" جاز حذفهما اختصارا أو لاب لون اقتصارا، خلافا للأخفش (•) في منعه حذفهما اقتصارًا مطلقًا، وللأعلم (؟) في

النحوي، أبو الحسن الأخفش الأصغر ، أحد الأخافشة الثلاثة المشهورين، قرأ

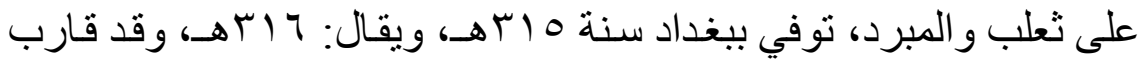

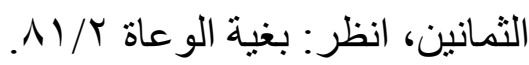

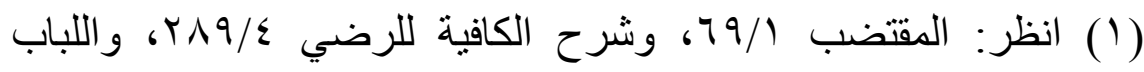

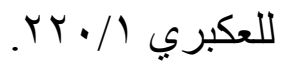

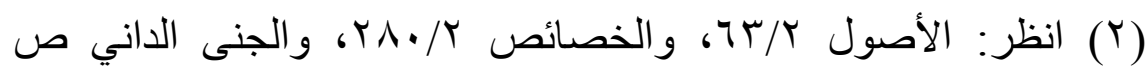
YIV

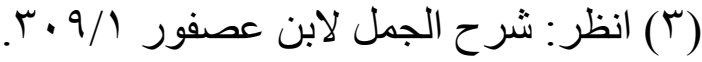

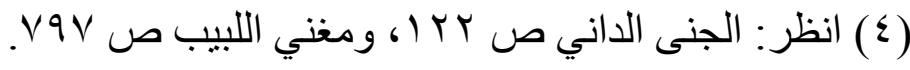

(0) وهو قول الجرمي وابن خروف وشيخه ابن طاهر و الثلوبين، انظر:

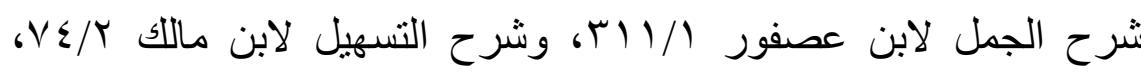

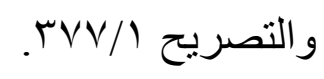

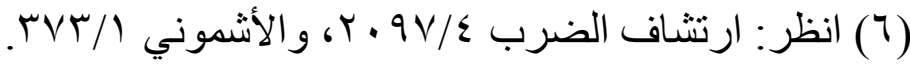


منعه في "علمت" وما في معناها، لا في "ظنتت" وما في معناها، وحذف أحدهما اختصارا قليل، أو اقتصارًا ممتتع (').

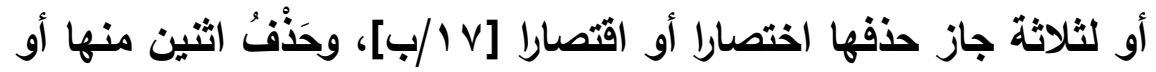
واحدٍ اختصارًا، وأما في الاقتصار فلا، هذا مذهب (س)(؟)، وأجاز غيره ذلك(َ) ما لم يؤد إلى بقاء المخبر عنه بلا خبر أو العكس. وانفردت نواست الابتداء من هذه الأفعال غير المبنية للمفعول متوسطة

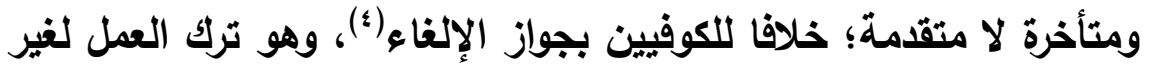
مانع، وهو أحسن مع التأخير، والإعمال أحسن مع التوسط، والتوسط ألا

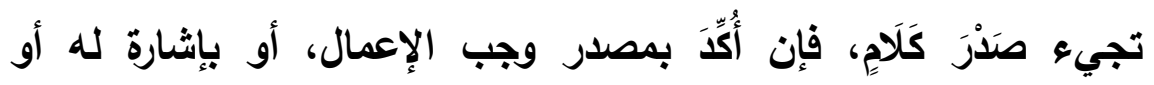
بضميره فالإعمال، ولا تلغى إلا قليلا، والإلغاء أقوى مع الإثارة منه مع الضمير ويوقوع الظرف والمجرور والجملة الخبرية موقع الثاني، و"أَعْلَمَ" وأخواتها بوقوع ذلك موقع الثالث.

(1) هذا قول الجمهور، ومنعه ابن ملكون، انظر: التذييل ج/ ع (، وهمع

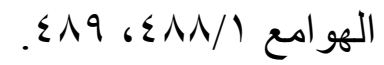

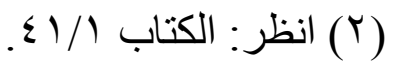

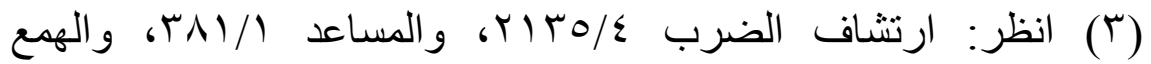
$0.7 / 1$ ( () ووافقهم الأخفش، انظر:شرح ابن عقيل /9/9؛،وشرح الأشموني

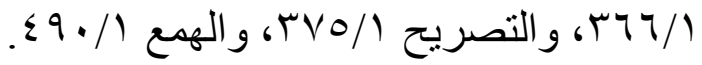


وينيابة "أَنَّ" و"أَنْ" وصلتيهما مناب مفعولي الناستخ، والثثاني والثالث في "أَعْلَهَ"، لا بنيابة ذابك مناب مفعولي الناستخ، خلافًا للمازني (')، ولا يسدان في غيرهما إلا مسد مفرد. وإنفرد فعل القلب و"سأل" و"أَنْظِهُهُ من غيره"، لا "رأيت" البصرية-خلافًا

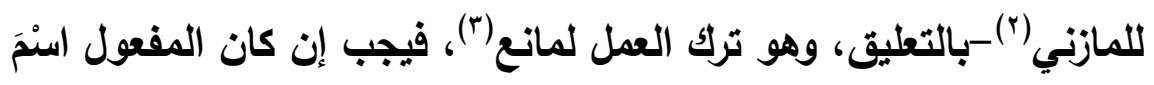
استفهامٍ، أو مضافًا إليه، أو دخلت عليه أداته، أو لام الابتداء، أو "إنَّ" وفي خبرها اللام.

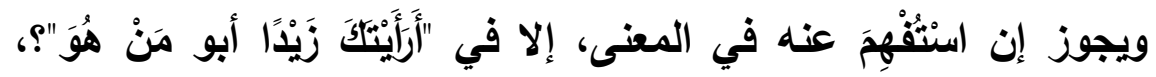

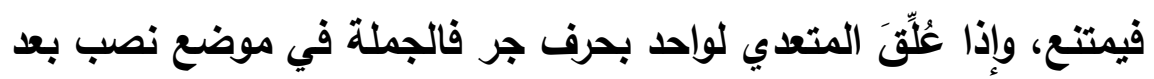
تقدير إسقاطه، أو بنفسه فهي في موضع المفعول، أو إلى اثنين سدت الجملة.

وإذا كان الفعل جائز التعليق، وكان متعديا إلى اثنين، فأعملته في الأول، وعلقته عن الثاني، فالجملة تسد مسده، أو لواحد فالواحد معمول لله، والجملة بعده بذل من المعمول(؛)، على حذف مضاف، لا في موضع

(1) انظر : شرح الجمل لابن عصفور 1/1 اس، و المازني هو: بكر بن محمد بن بقية، وقيل: ابن عدي بن حبيب، أبو عثمان المازني، روى عن عن أبي عبيدة و الأصمعي وأبي زيد الأنصاري، له كتاب التصريف، وكن وكتاب الديباج، توفي الني

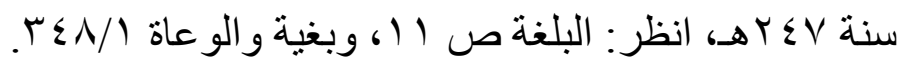

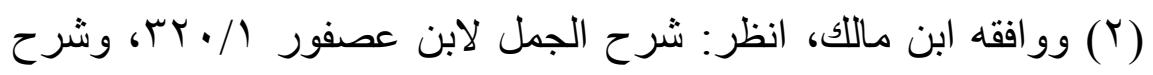

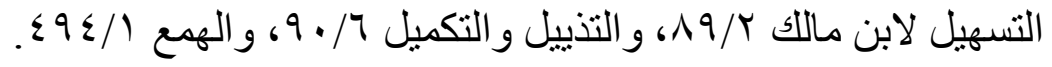

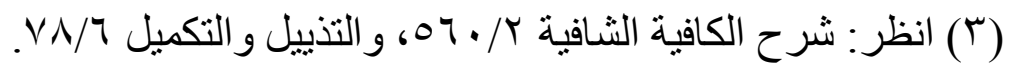

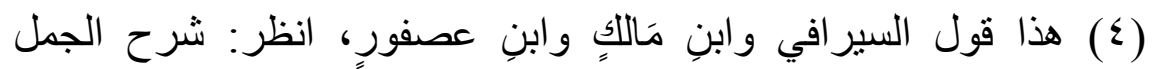
 
إصدار IV Th

حولية كلية اللغة العربية بالمنوفية العدد الثاني والثلاثون

الثاني على جهة التضمين(')، ولا في موضع الحال(r) [1 /أ]] خلافا

لزاعميهما.

ويجوز أن يضمن فعل القلب معنى "أقسم"، فيتلقى بما يتلقى به، فإن كان الفعل غير متعد فلا موضع لجملة الجواب، أو متعديا فكذلك؛ خلافا لمن جعل لها موضعا، فجعلها في موضع مفعول إن كان يتعدى إلى واحد، وفي موضع مفعولين إن كان يتعدى إليهما (ّ). ****** $* *$

الفصل: وَضْعُ ضمير الرفع المنفصل بين المبتدأ والخبر، أو ما هما أصله،

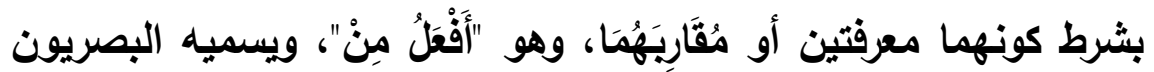

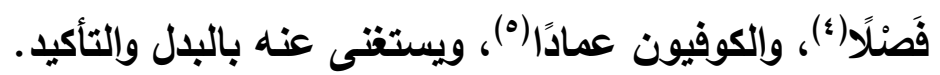
ومذهب الأكثرين أنها حروف(؟)، وزعم الخليل أنها أسماء، ولا موضع لها والضمير إن وقع في غير هذا الباب بعد اسم مضمر جاز فيه البلل،

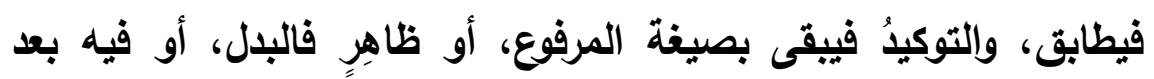
(1) هذا قول الفارسي وابن أبي العافية، واختاره أبو حيان، انظر : المسائل

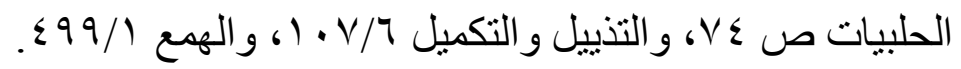

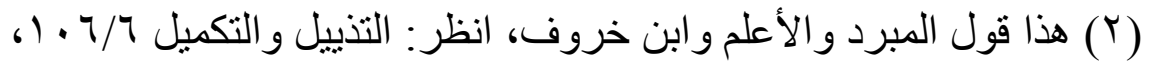

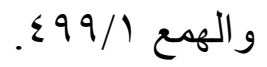

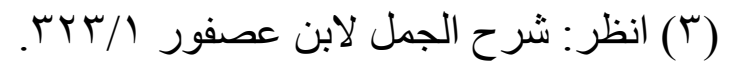

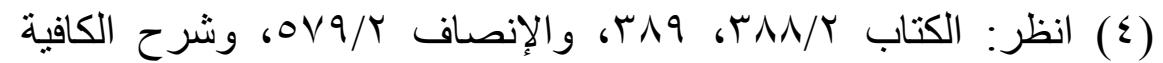

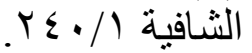

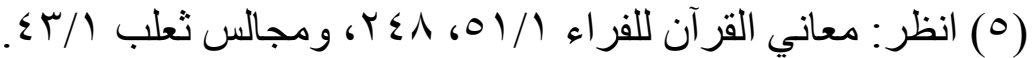

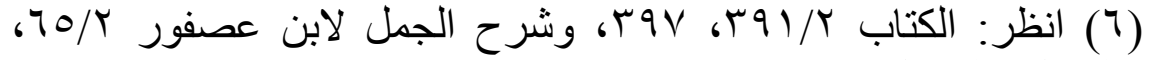

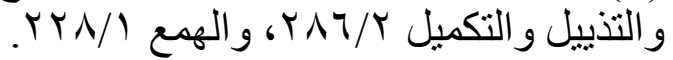

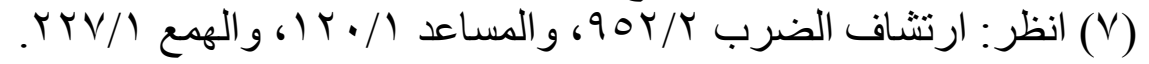


مضمر فكهو في غيره، ويجوز الفصل، أو ظاهٍِ فكهو في غيره، ويجوز الفصل.

والضمير إن سبقه مبتدأ ظاهر جاز أن يكون فصلا ومبتدأ ويدلا، أو

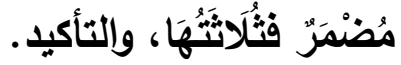

وإن وقع بين اسم "كانَ" وخَبَرِهَا بعد ظاهر ففصل أو بدل، أو بعد مضمر فهما وإلتأكيدُ، أو بين مفعولَيْ "ظَنَّ" بعد مضمر فَصل وتأكيد، أو مُظْهَرِ

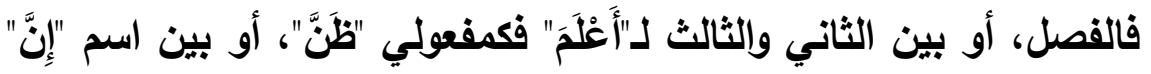
وأخواتها بعد ظاهر ففصل، أو مبتدأ أو مضمر فهما أو تأكيد. والضمير في الفصل يطابق الأول غيبة أو تكلما أو خطابا، وما أوهم

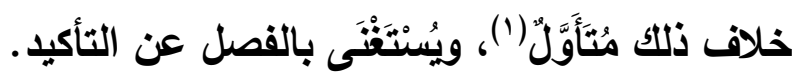

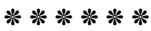

اسم الفاعل: ذو "أل" يعمل مطلقًا، ودونَها ماضيًا، وهو متعدٍٍ لواحد،

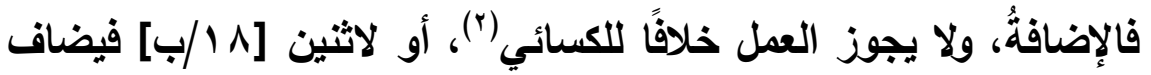

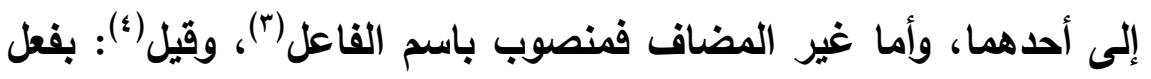
مضمر يفسره اسم القاعل.

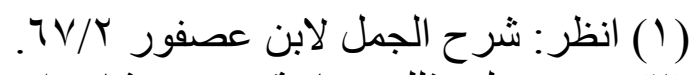

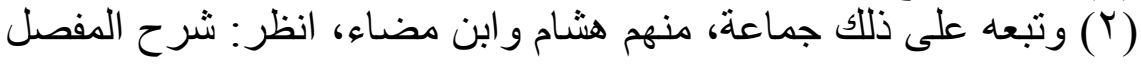

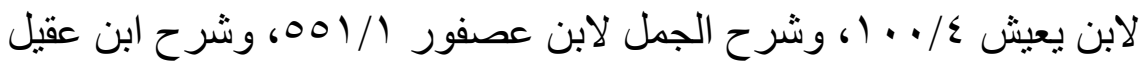

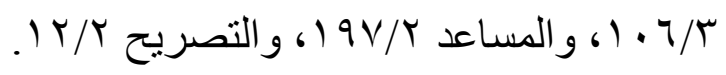

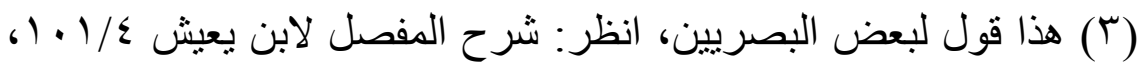

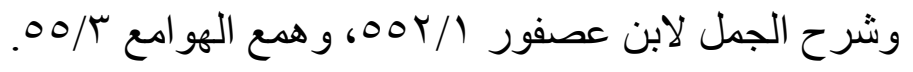

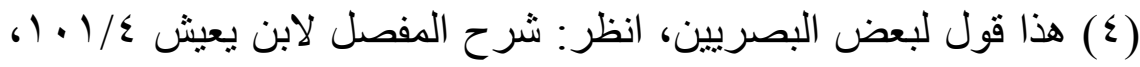

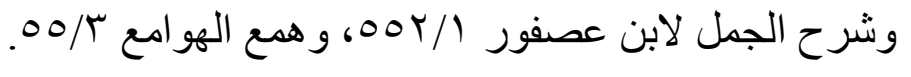


أو حالا أو مستقبلا فالعمل والإضافة، وذو "أل" إن كان مفردا أو مكسرا، ومعموله ذو "أل" أو مضاف لِمَا هو فيه، أو لضمير ما هو فيه، فالجر والنصب، ومَنَعَ المبرد الجَرَّ في المضاف لضمير ما هو فيه(')، أو دون "أل" فالنصب، وأجاز الفراء الجَرَّ (؟).

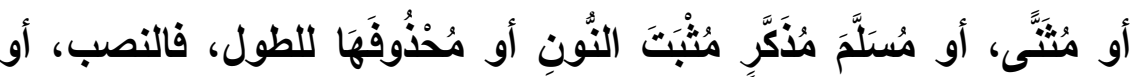
للإضافةة، فالجَرُّ. وشرط العمل: ألا يوصف قبل المعمول، وألا يصغر؛ خلافا للكوفيين فيهما(")، وأن يعتمد على أداة نفي أو استفهام، أو وقوعه خبرا، أو صلة،

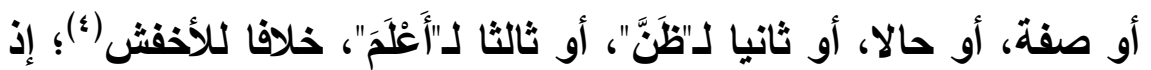
أجاز أن بعمل غَيْرَ معتمِدٍ. ويجوز تقايم معموله، إلا إن وقع صلة أو صفة فلا، إلا إن كان المعمول

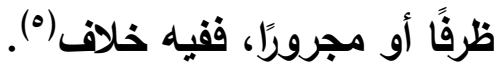

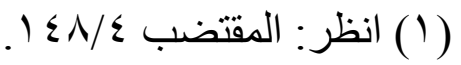

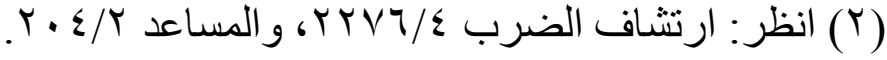

(r) ووافقه أبو جعفر النحاس الكوفيين في جواز إعماله مصغرا، انظر:

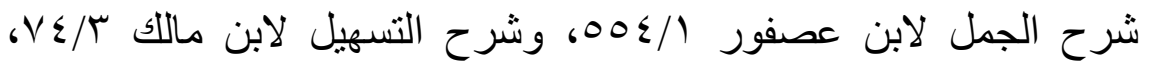

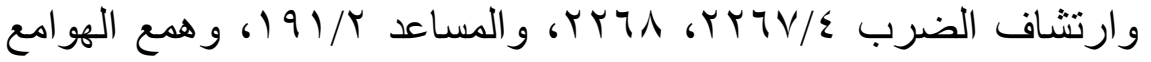

$$
0 \leqslant / \%
$$

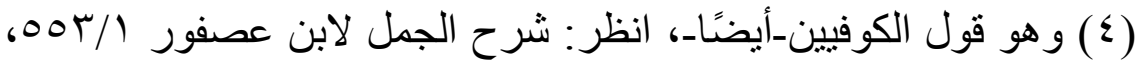

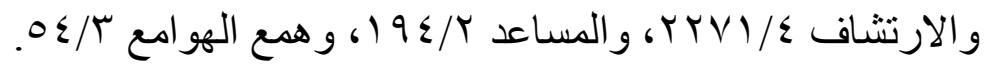

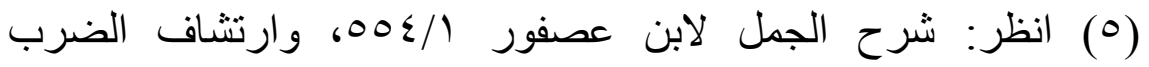
( 
وإذا أتبعت المعمول بنعتٍ أو تأكياٍ تَبِعَ على اللفظ فقط، وقيل: يجوز على

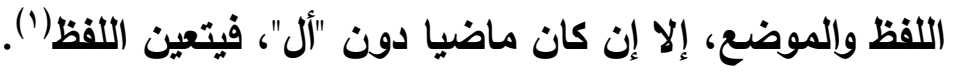

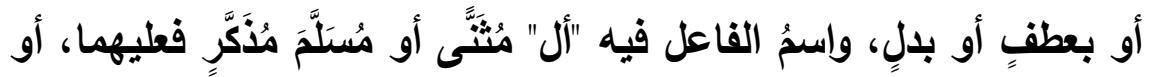
مفردًا وفي التابع "أل"، أو هو مضاف لِّمَا هي فيه، أو لضمير ما هي فيه اوله

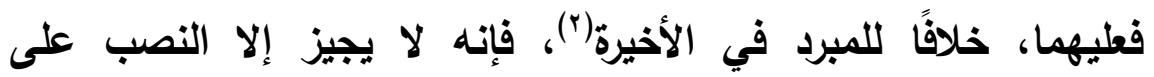
الموضع. أو ليست فيه، وعَرِيَ عن تلك الإضافة فالنصب، أو عَرِيَ عنها، وهو

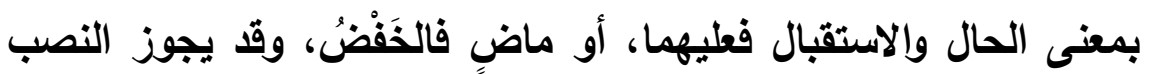
بإضمار فعل. وعطف البيان كالنعت في جميع أحكامه هنا. وإذا اتصل الضمير باسم الفاعل فموضعه جَرُّ، إلا إن اتصل بمفرد أو مُكَسَّرٍ وفيه "أل" فينصب، وقيل: نصب [9/1/أ] أبدًا، إلا إن كان ماضيا

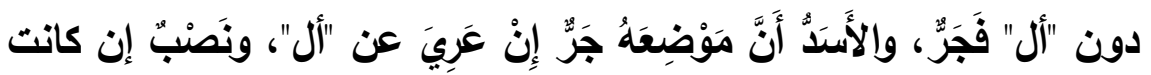

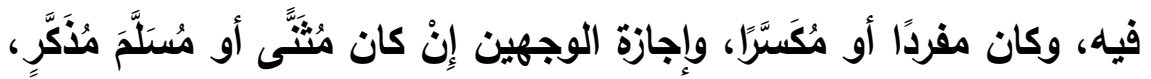

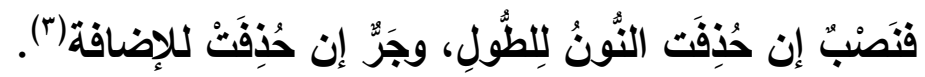
ولا تثبث النون ولا التتوين مع الضمير إلا ضرورة. $* * * * * *$

(1) انظر: شرح الجمل لابن عصفور 000/1، وارتشاف الضرب

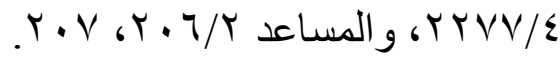

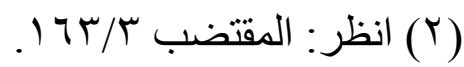

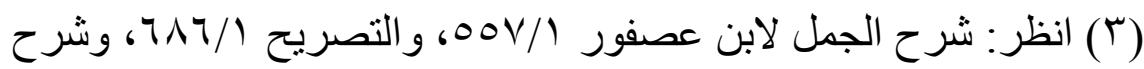

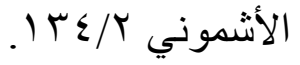




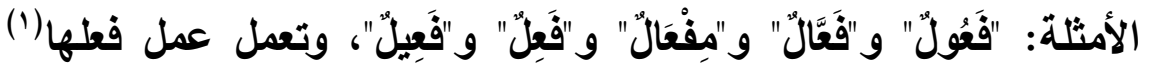

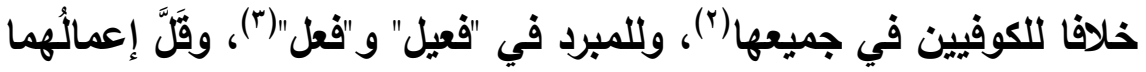
عند غيره(๕)

والأمثلة كاسم الفاعل في جميع أحكامه، إلا ما ذهب إليه ابن خروف(•) من جواز إعمالها ماضيةً مطلقًا.

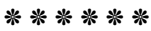

المصدر: مؤكد، ولا بعمل، وموضوع موضع الفعل، ومقدر بهه ويـ"أَنْ"،

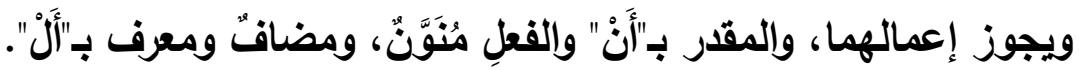

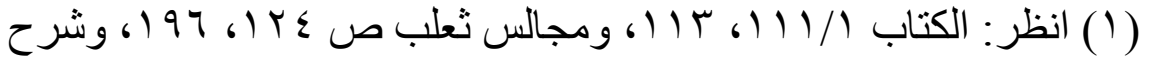

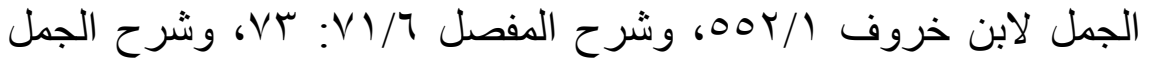

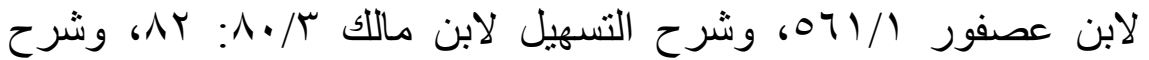

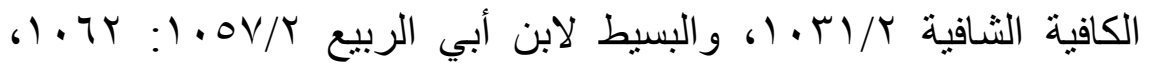

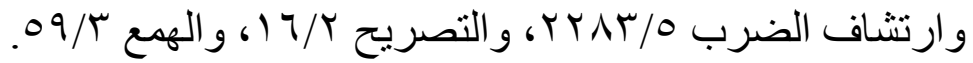

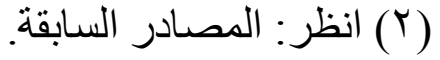

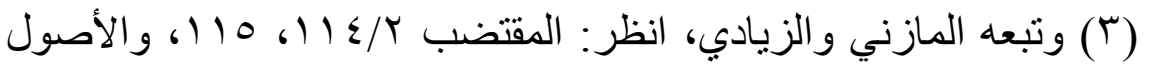

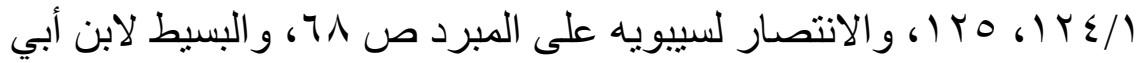

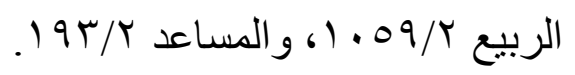

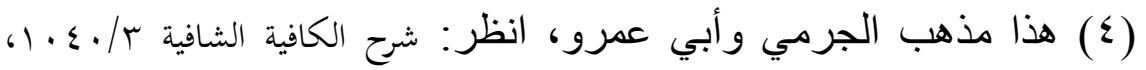

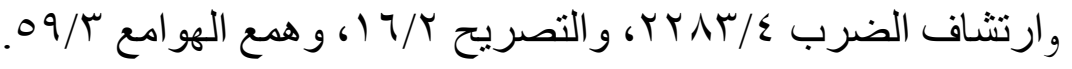
(0) شرح الجمل لابن خروف / /00، وقد وسبقه إلى ذلك شيخه ابن

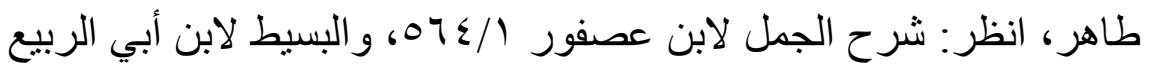

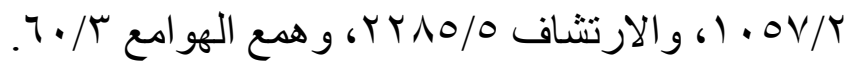


المنون يذكر الفاعل بعده، ويجوز حذفه لاليل، خلافا للفراء؛ إذ زعم أنه لا

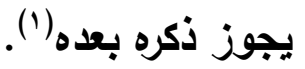
ويجوز حذف مفعول المنون والمضاف، إن أضفته إلى أحدهما بقي الآخر على إعرابه، ويجوز حذف ما لم تضف. والمعرف بـ"أل" كالمنون في رفع الفاعل ونصب المفعول(؟)، ومنع بعضهم إعماله (r) (") ولا يعمل اسْمُ في معنى المصدر إلا حيث سُمِحَ، والكوفيون يقيسونها(؛)، ولا ضمير المصدر خلافا لهم. ويخالف اسنمَ الفاعل في إعماله مُطُلَقَ الزمان، وفي منع تقديم معموله عليه، وفي تَمَحُّلِ إضافته(ْ).

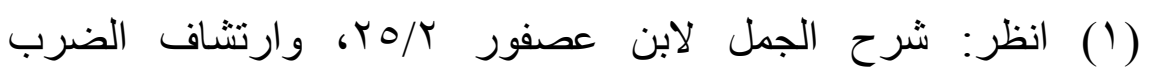

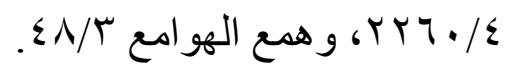

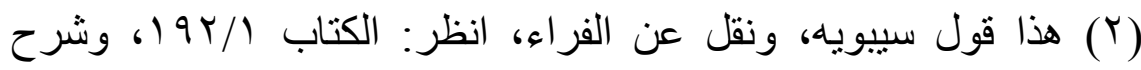

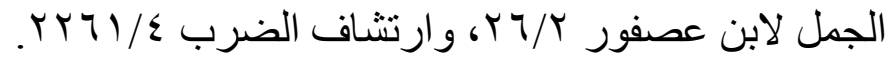

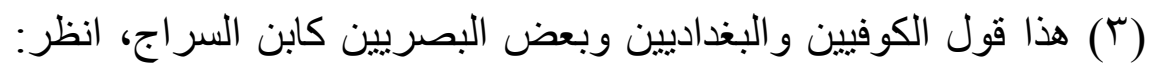

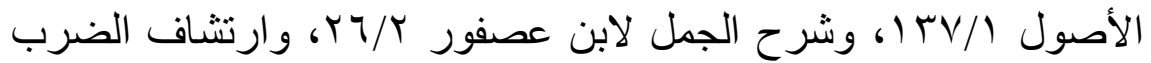

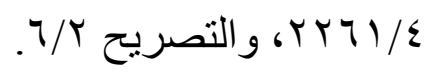

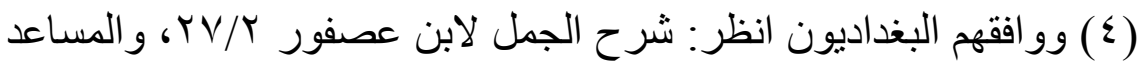
 $r \cdot \varepsilon / r$

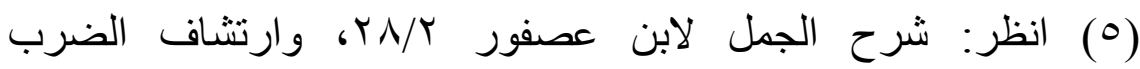

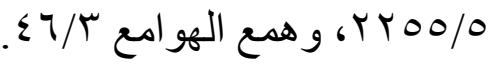


وإذا أتبعت مخفوضه على اللفظ طابَقَ، أو على الموضع فُانَ كان رَفْعًا

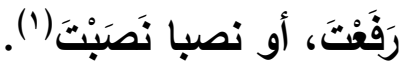

\section{$* * * * * *$}

الإغراء: لغة: التسليط، واصطلاحا: وضع الظروف [9 /ب] والمجرورات

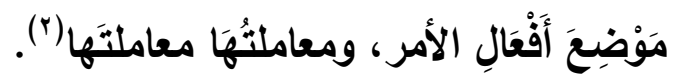
ومورد السماع: عندك، ودونك، وعليك، وإليك.

والصحيح: القصر على السماع، خلافا لمجيز القياس بشرط كونه على

أَزْيَََ من حرف، وهو الكسائي (").

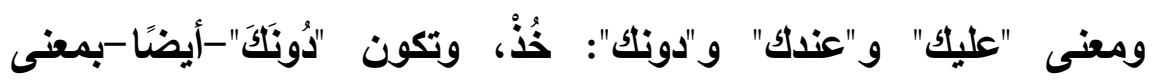

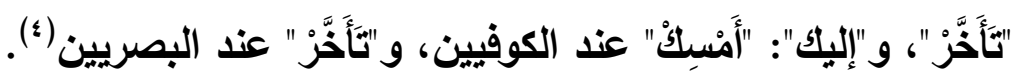
وهي في التعدي واللزوم كهذه الأفعال.

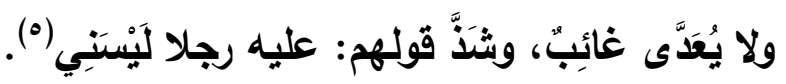

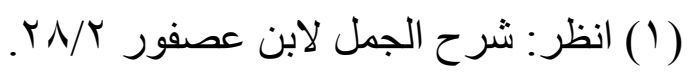

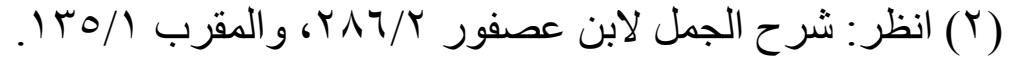

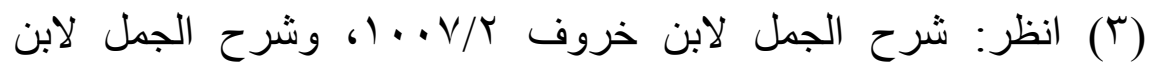

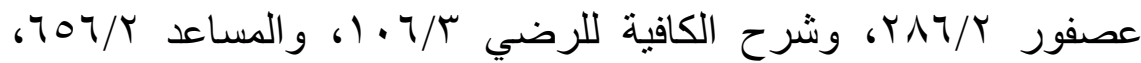

$$
\text { وشرح الألفية للأشموني و }
$$

( ( ) انظر الخلاف بين البصريين والكوفيين في شرح الجمل لابن الابن عصفور

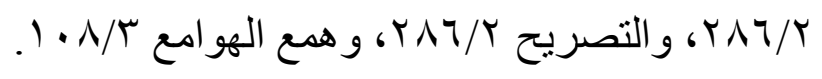

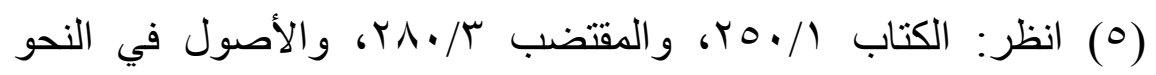

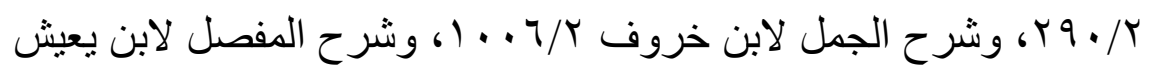

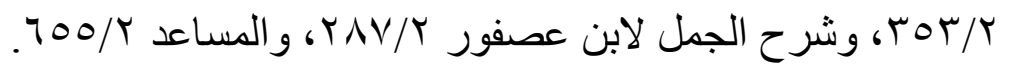




\section{الموفور من شرح ابن عصفور}

د/ لحمدمحسمد الجنــي

دا عبد الملك أحمد شئيوي

ولا يجوز تقديم معمولها، خلافا للكوفيين (').

ولا ينجزم الفعل جوابا لها إلا ضرورة، ولا ينتصب بعد الفاء والواو في الجواب أصلا.

****** $* *$

الصفة المشبهة باسم الفاعل: هي المأخوذة من فعل قاصر، المشبهة باسم الفاعل، فتتصب(ז) ووجه الشبه: الاشتراك في الوصفية، وتَحَمُّلُ الضمير، والاقتضاء لاسنْ

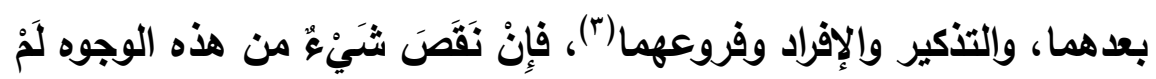

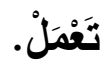
وما صلح من الصفات لمذكر ومؤنتث لفظا ومعنى شُبِّةَ عُمُومًا، أو لأحدهما فِلمَا صلح، أو لهما لفظا، والمعنى يخص أحدهما فلا يُشَبَّهُ، خلافا للأخفش؛ إذ أجاز ذلك عموما(؛). ولا تكون الصفة مشبهةً حتى تنصب أو تجر، والجر من النصب لا من

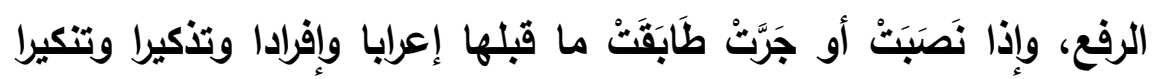

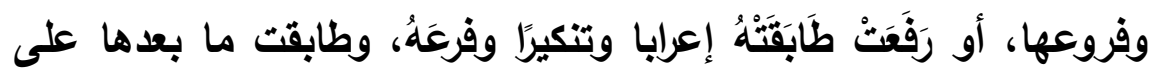

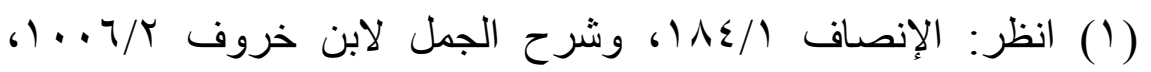

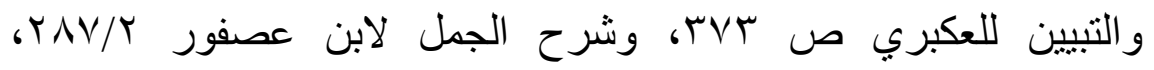

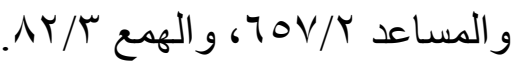

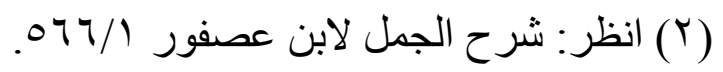

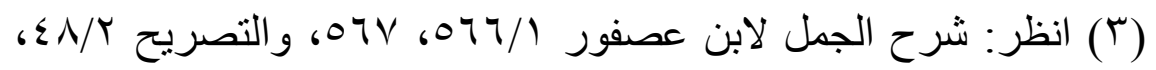

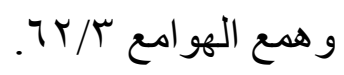

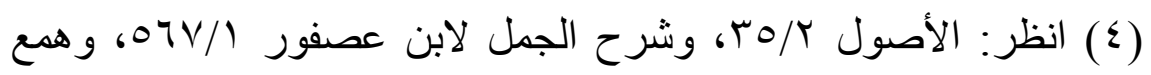

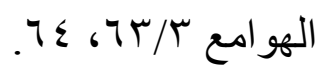


لغة "أَكَتَنْيِي البَرَاغِيثُ" في التذكير أو التأنيث، وعلى لغة "أَكَلْونِي" في التذكير والإفراد وفروعهما، ولا تعمل إلا في السببي نكرةً أو بَ"أَّْ"، أو

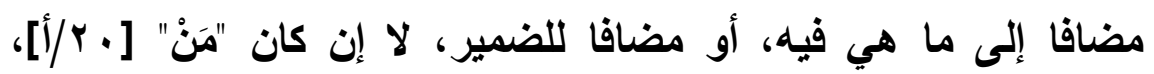
خلافا لبعضهم (1).

والصفة شُبَِِّتهْ أو لَمْ تُشَبََّهْ إن كانت نكرةً، ومعمولها نكرة، جاز فيه النصب، ثم الجر، ثم الرفع، أو فيه "أل"، أو أضيف لما هي فيه، فالجر،

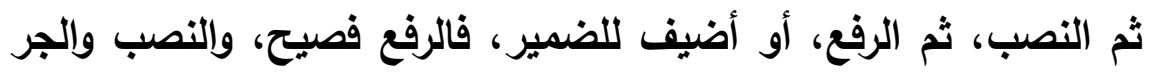

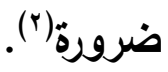
أو معرفةً، وهو فيه "أل"، أو أضيف لما هما فيه، فالنصب، ثم الجر، ثم الرفع، أو للضمير، فالرفع فصيح، والنصب ضرورة، والجر ممنوع(). أو نكرةً، فالنصب فصيع، والرفع قليل، والجر ممنوع(ء). وإذا جررتَّ فبالإضافة، أو نصبت معرفة فعلى التثبيه بالمفعول به، أو نكرةً فالأجود على التمبيز، ويجوز على التشبيه، أو رفعت مضافا إلى له الضمير، فعلى القاعلية، أو ذا "أل" فعليها في مذهب (س)(•)، وعلى البدل

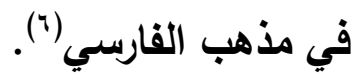

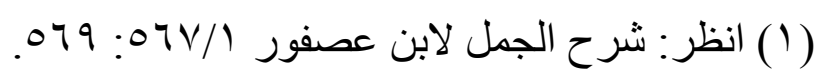

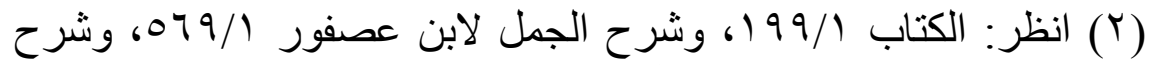

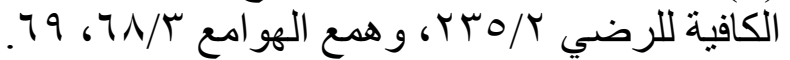

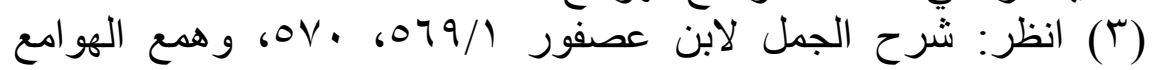
$.79671 / 4$

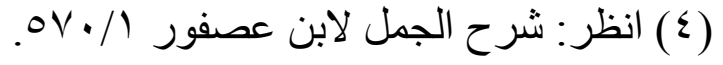

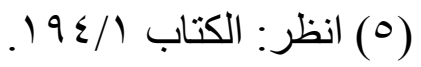

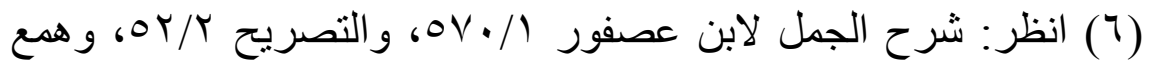

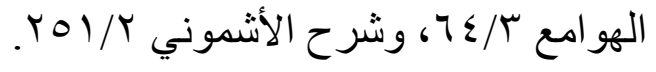


الموفور من شرح ابن عصفور

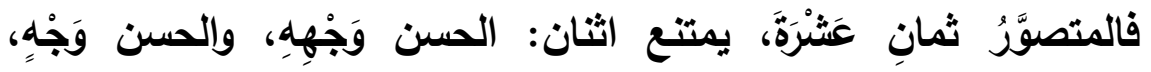
والضرورة ثُلاث: حسن وَجْهَهِهُ بالنصب والجر، والحسن وَجْهَهُ بالنصب، والباقي فصيح، ويعضه أَقْوَى على ما بُيِّنَ. وإذا كان المعمول ب"أل" فالضمير محذوف، وليست "أل" عوضا منه؛ خلافا للكوفيين (') والرفع أحسن في هذا الباب، ثم الجر، ثم النصب، إلا إن كان على التمييز، ففي رتبة الرفع، والأصل الرفع ما لم يؤد لحذف الضمير. والأصل في المعمول إضافته للضمير، ثم كونه بـ"أل"، ثم التنكير. ****** $*$

المفعول المطلق والظرفان وإلحال والتمييز والاستثناء والمفعول معه والمفعول لله

جميعها يتعدى إليها الفعل اللازم والتواقع. المصدر: اسنْمُ الفعل، أو قائم مقامه آلّةً أو وصفا أو عددا أو مضافا إليه، إما هو هو في المعنى، أو بَعْضُهُ. ومبهمه: ما وقع على [·r/ب] القليل والكثير. ومختصه: اسم لنوعه، أو مضاف، أو ب"أل"، أو موصوف. لـ ومعدوده: اسم عدد، أو ذو تاء التأنيث الدالة على الإفراد. وضمير المصدر كهو، يصل إليه الفعل بنفسه. ولا يعمل في المصدر معنى الفعل، بل هو، أو الجاري مجراه ظاهرا أو مقدرا.

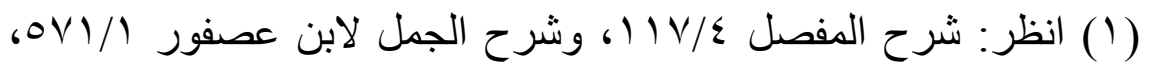
.OVY 


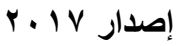

حولية كلية اللغة العربية بالمنوفية العدد الثاني والثلاثون

والمصدر الأي لا ينصرف ولا يتصرف: "سبحان" عَلَمَا غَيْرَ مضاف(1). والذي ينصرف ولا يتصرف: "سبحان الله"، و"معاذ الله"، و"ريحان الله" أي:

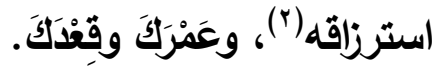

وعكسه: ما كان مؤنثا بالألف أو بالهمزة، أو علما مؤنثا بالتاء، والباقي منصرف متصرف.

****** $* *$

ظرف الزمان: هو اسم الزمان، أو قائمٌ مقامه مصدرًا أو وصفًا، وهو قليل،

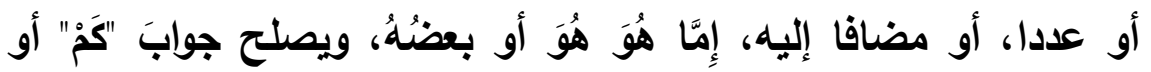

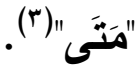

ومبههُهُ: ما وقع على غير مُعَيَّنِ، ومختصُّهُ: أسماء الشَهور والأيام، أو أو

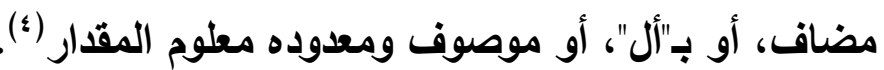

وما لا ينصرف ولا يتصرف: سَحَرُ مُعَيَّا، وما ينصرف ولا يتصرف: بعيدات

بين، وذات مرة، وذات ليلة، وذا صباح، وذا مساء، وعثاءً وعتمةً وليلا

ونهارا معينات، وخثعم تصرف ذا وذات.

وعكسه: ضحوة ويكرة وغدوة لأيام معينة، وما بقي منصرف متصرف.

ومن ظروف الزمان: أمس، فينى على الكسر إن كان ظرفا، وله معنيان،

أحدهما:

أن يكون لليوم الذي يليه يومُك.

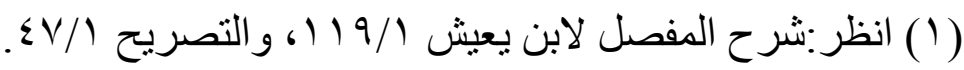

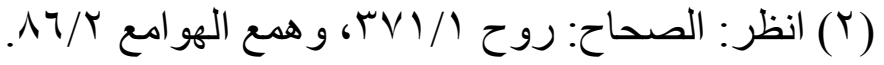

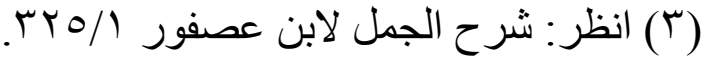

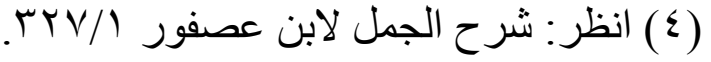


الموفور من شرح ابن عصفور

دالحمد محسمد الجندي

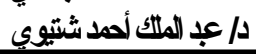

والآخر: أن يكون لما تََََّمَ يومَك مما يقرب منه، ولا يكون ذاك إلا

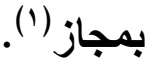

فإِنْ كان غَيْرَ ظَرْفِ فالحجاز تبينه على الكسر(؟)، وتميم تعربه إعراب ما

لا بنصرف (r)

وزعم الزجاج(؛) وأبو القاسم(ه) أنه إذا كان ظرفا جاز بناؤه على القتح، وإذا كان غير ظرف في موضع نصب أو جَرِ لَمْ يَجُزْ فيه عندهما إلا البناء على القتح أو الكسر، أو في موضع رفع فيجوز عندهما البناء. ******

ظرف المكان: اسم المكان، أو قائم مقامه وصفًا أو عددًا أو مضافًا إليه، إما هو هو أو بعضُه ("). وشرطه: أن يصلح جوابَ "كَمْ" أو "أَيْنَ".

ومبهمه: ما ليس لله أقطار تحصره، ومختصه: عكسه، ومعدوده معلوم (المقدار (v)

(1) انظر : شرح الجمل لابن عصفور / / . . ع، و المساعد /9/9 (1).

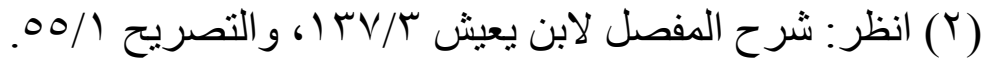

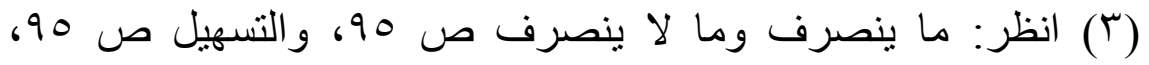
والمساعد //. •r.

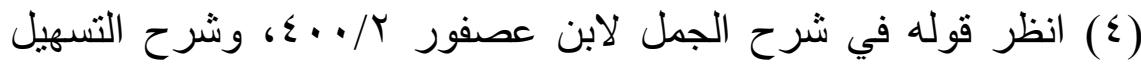
 $.1 T V / T$

(0) انظر : الجمل ص 99 9، و المصادر الواردة في الحاثية السابقة.

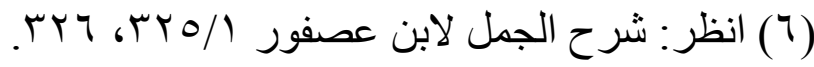
انظر : شرح الجمل لابن عصفور (V) 
وما ينصرف ولا يتصرف: سَوَاءُ وبسوَى وسئوَى، ووسنطه، ودونك، وقد

$$
\text { يتصرفن فيها ضرورة إلا "دونك". }
$$

وعكسه: ما كان صفةً في الأصل على وزن "أفعل"، وما بقي منصرف متصرف(1)، ومقابله مفقود [1/أl] والتصرف: أن يستعمل الاسم مرفوعا

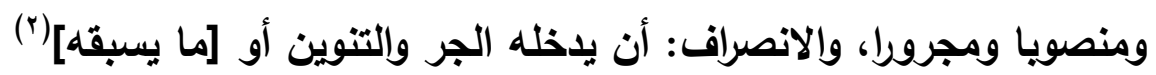
من إضافة أو "أل".

وكل فعل يتعدى إلى أضرب الزمان والمكان بنفسه إلا ضميرهما ومختص المكان فب"في"، إلا ضرورة، إلا مع "دخلت" مطلقا، ومع "ذهبت" مقيدا بالثام، لا مطلقا في أسماء الأماكن، خلافا للقراء، وإلمنصوب بعد "دخلت ظرف لا مفعول به، خلافا لأبي الحسن، و"ذهبت الشامَ" شاذ، فلا يقاس عليه: ذهبت اليمن، خلافا لبعضهم.

ويجوز في الظروف أن يتسع فيها، فتنتصب على التشبيه بالمفعول به مع أي عامل كان، ناقصِ أو تامِّ، إلا الحرفَ، وإذا أضمر بعد التجوُّز

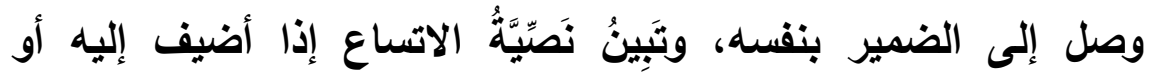
أضمر.

ويتسع مع اللازم ومع المتعدي لواحد، لا مع المتعدي لاثنين، ولا مـع المتعدي لثثلاثة، خلافا لزاعميهما.

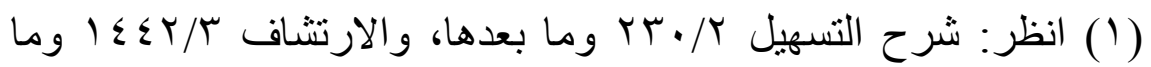

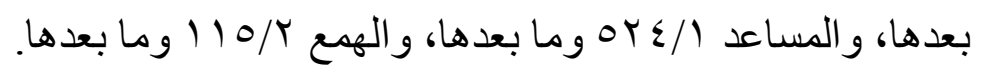
(Y) لم أستطع قر اعتها إلا على هذا الوجاهـ 
الحال: اسم منتصب على معنى "فَي" تفسيرا لمُنْبَهِِِ هَيْيَةٍة، أو تأكيدًا، فهي مبينة ومؤكدة، ولا تضمر . مان

ويعمل فيها وفي الظرفالمعنى، ولا يجوز تقديم الحال إذ ذاك، خلافا لأبي الحسن(')، ويجوز تقديم الظرف، فإن عمل فيهما غير المعنى جاز

تقدمهما إلا لمانع.

وشرط الحال: تنكير، واشتقاق، وتمام، وكونها من معرفةة، أو مقاربِها إن أتت بعدها، وقَلَّ ورودها بعد مقارب، وأما بعد غيرهما فموقوف على

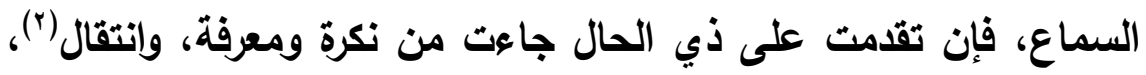
أو محكوم له بذلك، إلا من المؤكدة فلا يشترط الانتقال، وكذا في المبينة عند بعض النحويين. ولا يعمل في الحال إلا العامل في صاحبها. وتقع الجملة الخبرية حالا، فإن عريت الاسمية من ضميرِ ذي الحال

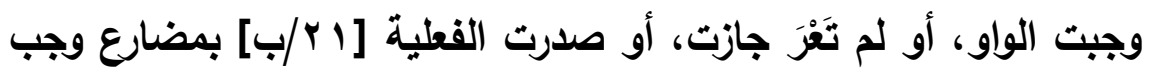

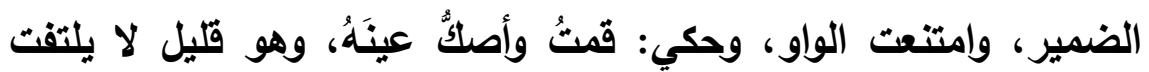
إليه، أو بماض موجب فلا با من "قد" ظاهرة أو مقدرة، أو منفي فالأولى

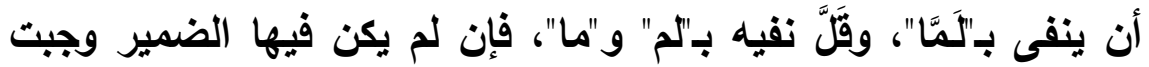

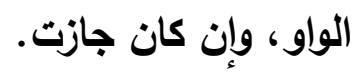
ولا يقتضي العاملُ من مصدر أو ظرف أو حال أزيدَ من واحد إلا بحرف

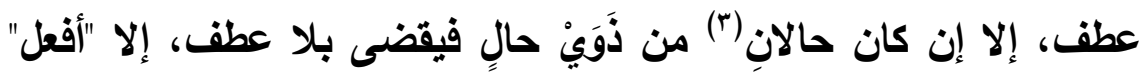

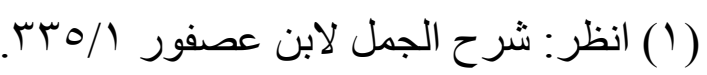

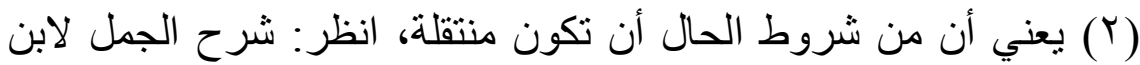

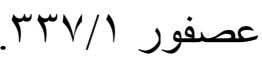

(r) "كان" هنا تامة بمعنى "حصل" أو "وُوندَ". 
التفضيل، فقد يعمل في ظرفي زمان وظرفي مكان وحالين لواحد من غير

عطف.

والظرفان يقدان ب"في"، وهما محل للفعل والفاعل والمفعول به إن كان لله،

والحال قيل: هي مفعول فيها، وقيل: لا تلحق بالمفعول (').

وأقوى تعدي الفعل إلى المصدر، ثم إلى المفعول به، خلافا للمبرد؛ إذ زعم العكس، ثم إلى ظرف الزمان، ثم إلى الحال، ثم إلى ظرف الم المكان آمان. ****** $*$ *

التمييز: اسم منتصب تفسيرا لمبهِ ذاتٍ، نكرةٌ، خلافا للكوفيين؛ إذ جوزوا أن يكون معرفة. ولا يفسر بمتوغل في البناء والإبهام، ولا بمختص بالنفي.

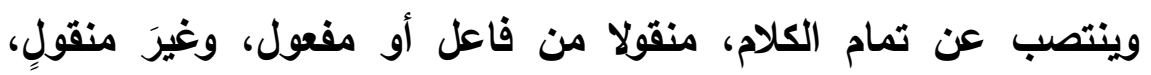

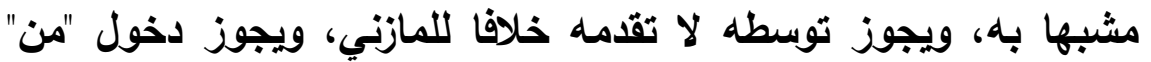
على غير المشبه بالمنقول، لا على المنقول، ولا على المشبه بهله به.

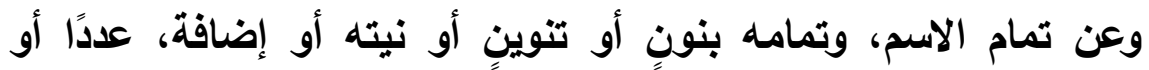

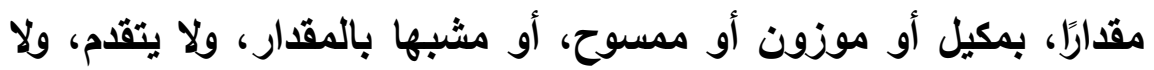
يتوسط. والصحيح أن الناصب للتمييز تمام الكلام، لا الفعل إن انتصب بعده، خلافا لزاعمه (r)

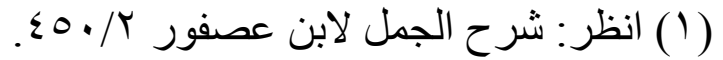

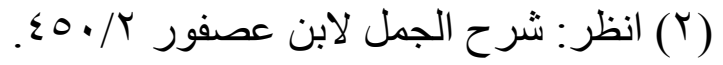

(r) الذي ذهب إلى أن التمييز منصوب بالفعل أو بالاسم الذي في معنى

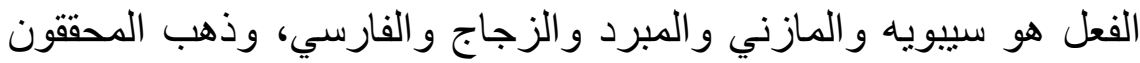

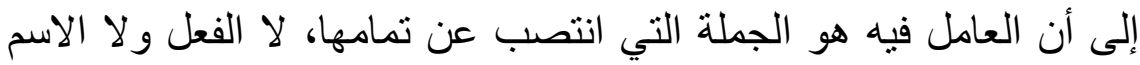

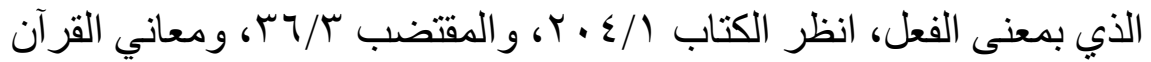


الاستثناء: إخراج الثاني مما دخل فيه الأول، بَ"إلا" و"غير" و"سِوَى" و"سُوَى" و"سواء" و"حاشا" و"خلا" و"عدا"، وقد يقرن بهما "ما"، و"ليس"

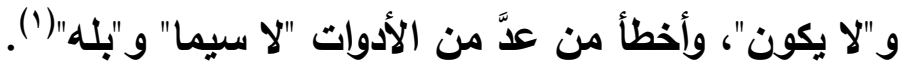

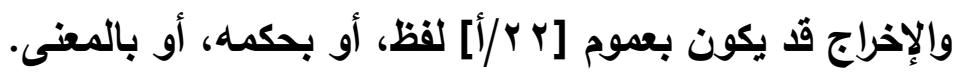

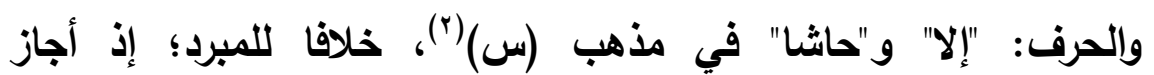

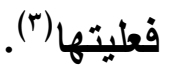

$$
\text { والاسم: "غير" و "سوى" و "سواء". }
$$
وإلفعل: "ليس" و"لا يكون" و"عدا"، وتقرن ب"ما"، و"ما خلا"، وحُكِيَ الجَرُ

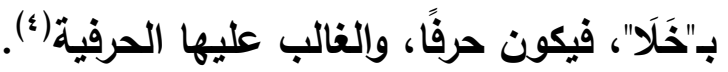

و إعرابه r/T

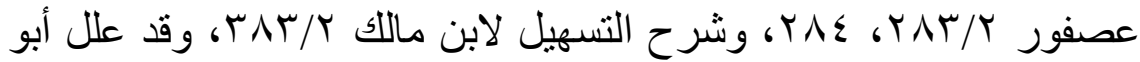
حيان لهذا الر أي الذي صححه بأن هذا النوع من التمييز شبيهُ بالتمبيز الذي وني

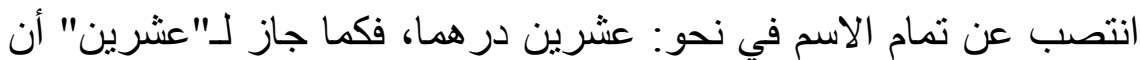

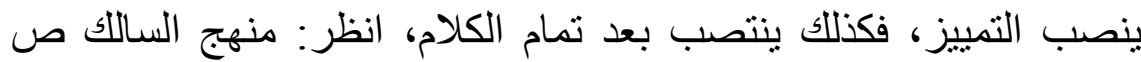

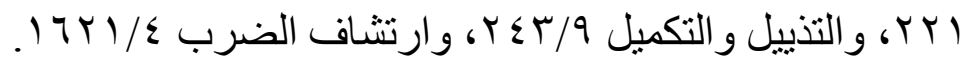

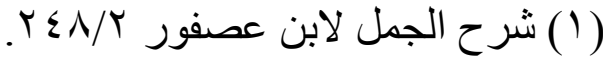

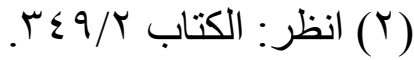

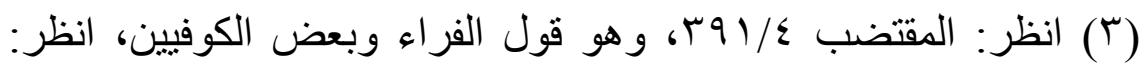

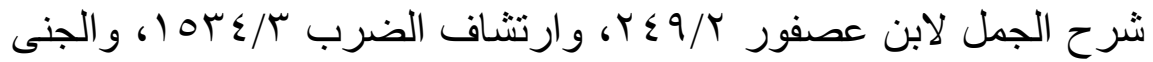

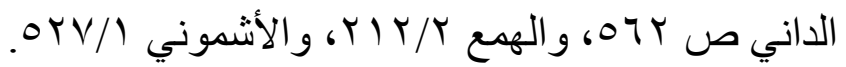

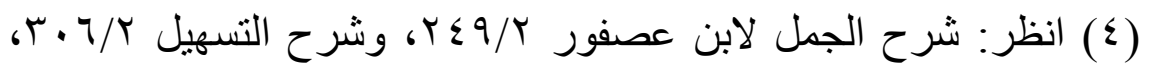

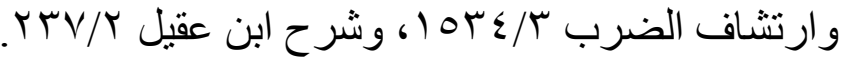


والصحيح أن المُخْرَجَ يكون أَقَلَّ من النصف (')، وما قَََّّ كان أحسن، ولا

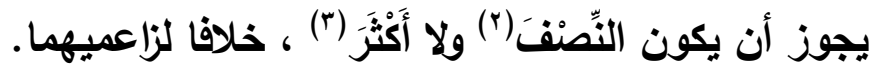
ولا يجوز الاسنتناء من العدد مطلقا(؛)، خلافا لمن أجاز مطلقا(ْ)، وخلافا لمن أجاز بشرط ألا يكون عقدا"جا".

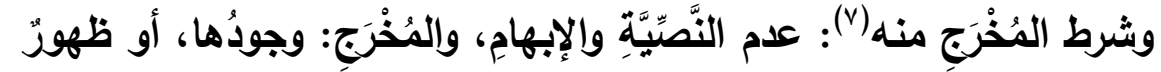

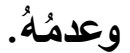
والناصب(^): المازني: ما في "إلا" من معنى الفعل.

(1) هذا قول جمهور البصريين، انظر: شرح الجمل r/r/ror، وشرح

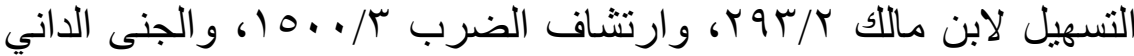

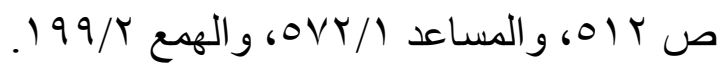

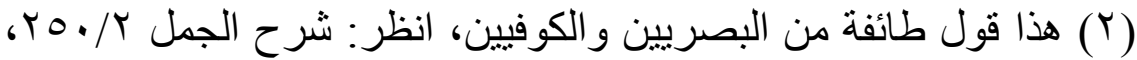

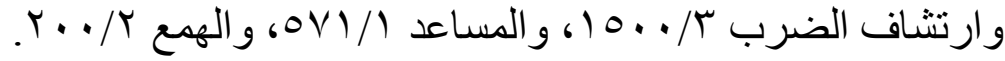

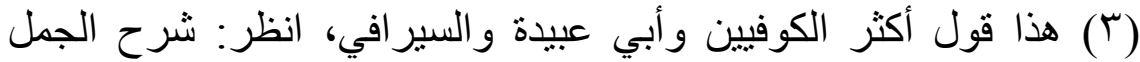

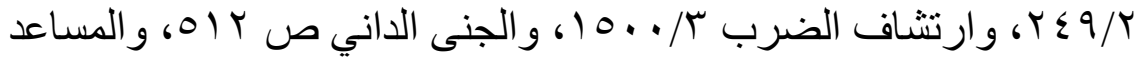

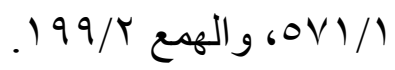

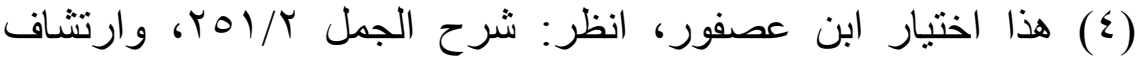

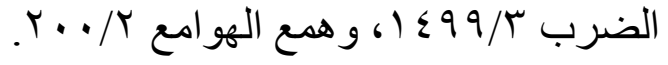

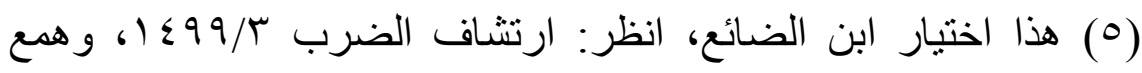

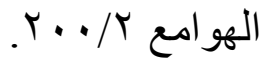

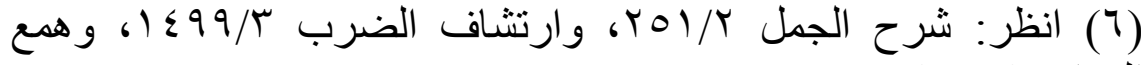

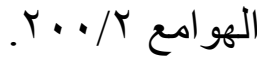
( انظر : شرح الجمل لابن عصفور / (V)

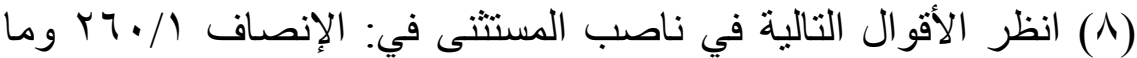

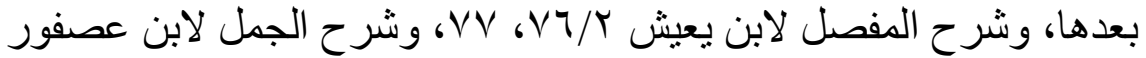


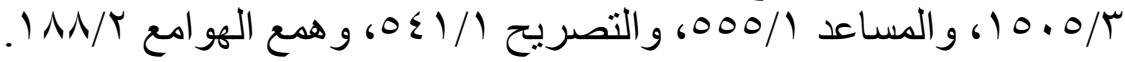




\section{الموفور من شرح ابن عصفور}

السيرافي وابن الباذش('): الفعل بوساطة "إلا" في نحو زيد، والفعل في

"غير" وما في معناه بلا واسطة.

$$
\text { الكسائي: الخلاف. }
$$

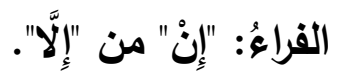

الصحيح: تمام الكلام.

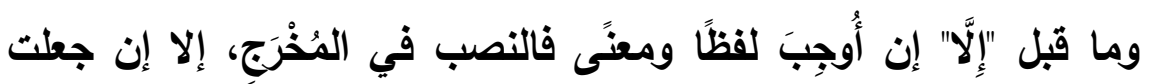

$$
\text { "إلا" وما بعدها صفةًَ، فالمطابقة في الإعراب. }
$$

ولا يوصف ب"إلا" إلا حيث يصلح الاستثناء بها، ويخالف الوَصنفَ بغير

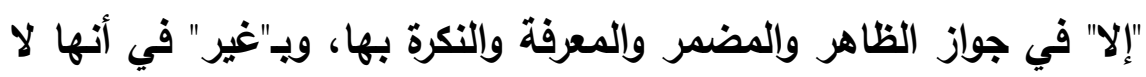

تقوم مقام الموصوف، وتقوم "غير"(؟).

وإن أدى التفريغ مع الإيجاب والاستثناء من محذوف لحذف عمدةٍ لا تُحْذَفْ لم يجزْ.

أو لفظا لا معنى جاز رَعْيُهُمَا، وذللك إذا كان الفعل خَبَرَ مبتدأ تَوَجَّهَ عليه

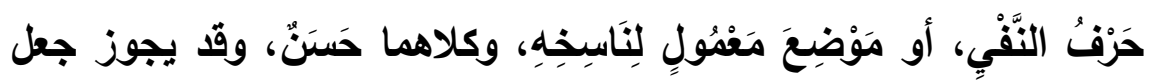
"إلا" صفةًً كما تقدم.

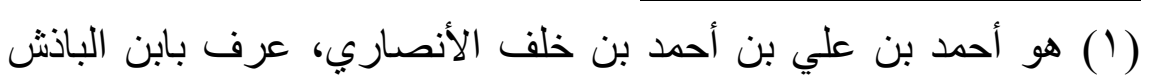

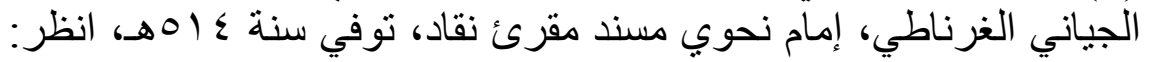

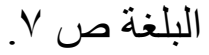

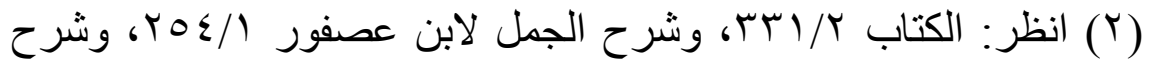

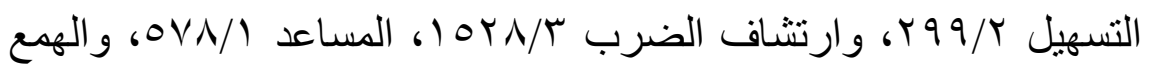
$r \cdot 1 / r$ 
أو نُفِيَ مُفَرَغًَا فعلى حسب العامل، أو غَيْرَ مُفَرَّغ فوجهان، الأحسن: البدل مطلقا، وقيل: بشرط ألا يستعمل المبدل منه إلا في النفي، والثاني: النصب

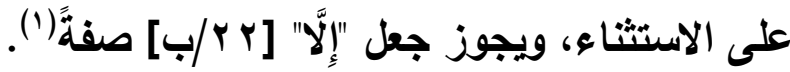

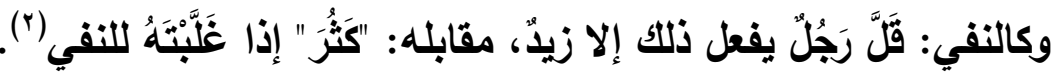
وإذا تكررت المستثنيات، والأَوَّلُ الثاني، فالثاني كالأول إعرابًا. أو غَيْرْهُ، ولا يمكن استثناؤه من الأول، فهو مسنثنى من الاسم الأي

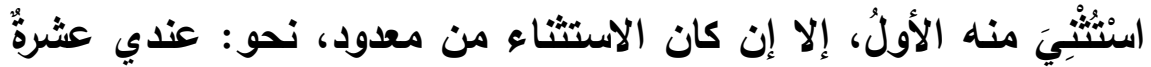

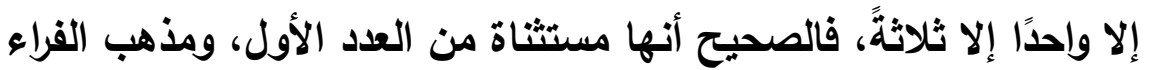
أن الأول مستثنى من العدد الأول، وليس الثاني كذلك(ّا"). أو ممكنا فذاهبٌ إلى أنها مستثيات من الأول، وذاهبٌ إلى أن بعضها مستثنى من بعض، ومجيزٌ الأمرين مع ظهورية الثاني، وهو الصحيح(؛). وإن تكررت في النفي، والفعل فارغ، رفعت أحد المستثيات، ونصبث الباقي

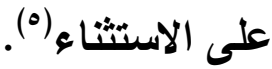

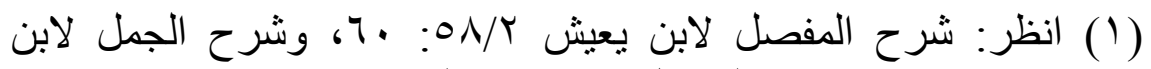

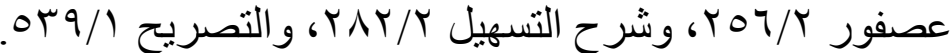

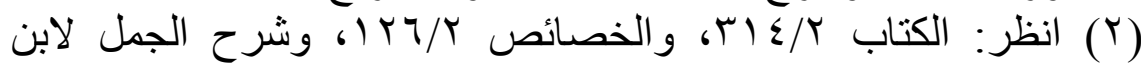

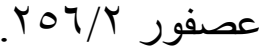

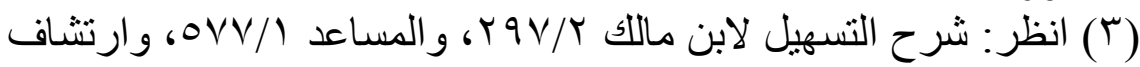

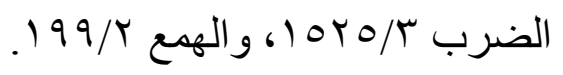

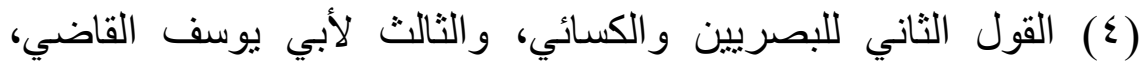

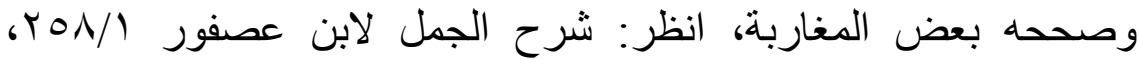
وارتشاف الضرب وه/ $.191 / \mathrm{r}$

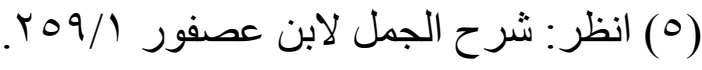


وإذا عطفتَ على مخفوضِ "غَيَرِ" جاز الحمل على اللفظ وعلى المعنى ('). و"سِوَى" و"سواء" بمعنى "غير"، إلا أنهما يلزمان الظرفية (؟).

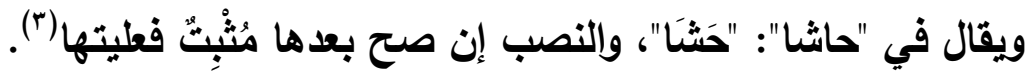

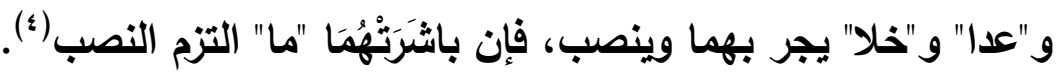
والنصب بعد الفعل على المفعولية، إلا بعد "ليس" و"لا يكون" فعلى الخبرية)(0).

واسمهما واجب الإضمار مذكر يراد به البعض، والجملة الفعلية حال، أو هي مستأنفة لا موضع لها، وما دخل عليه "ما" ففي موضع الحال قطعا (7) وإذا جعلت "ليس" و"لا يكون" صفتين فالضمير على حسب الأول(v). ( ) (1) (1) (انظر : السابق نفسه.

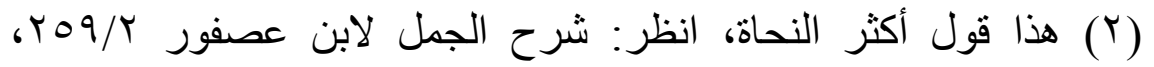

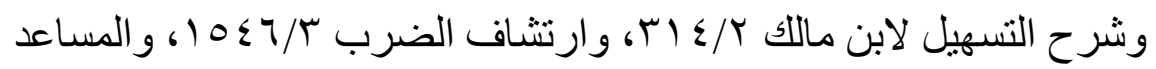

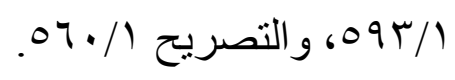

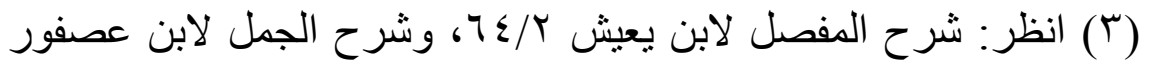

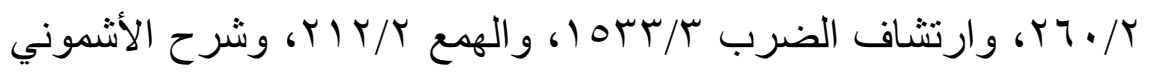
or $/ / 1$

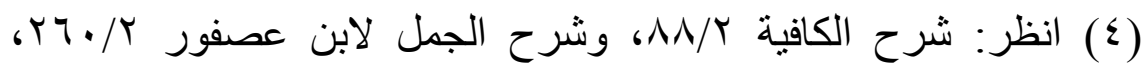

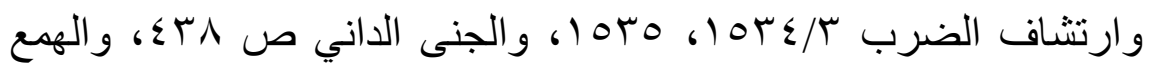
rI $r / r$

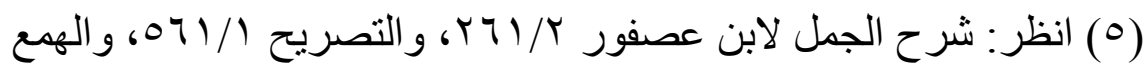
r) $10 / 4$

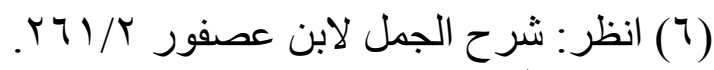

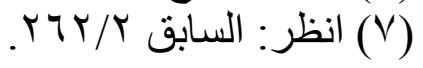


وانفردت "غير" و"إلا" بجواز حذف المستثى بعدهما في النفي، وغيرهما لا يأتي بعد عامل مفرغ.

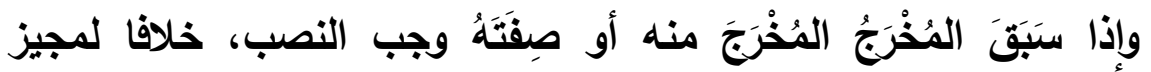
الوصف والبدل في الأولى، ومجيز البلال في الثانية('). والسابق والمتأخر يعطف على لفظهما، ويجوز -على ضعف-العطفُ على ولى معنى السابق (). والمنقطع يجب نصبه، فإن أمكن [r/Ylí] اتصاله مجازًا وَجَبَ عند

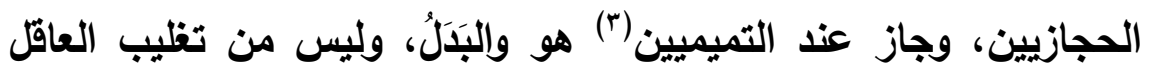
على غيره، خلافا للمازني (؛).

****** $* *$

المفعول معه: فضلة، انتصب بعد تمام الكلام، فُعِلَ الفعل معه، لا ينتصب

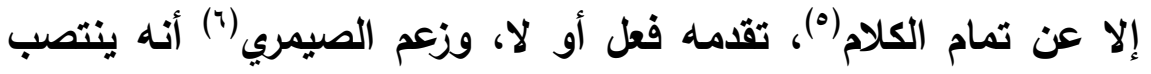
عن تمام الاسم، فُأجاز : ع إم

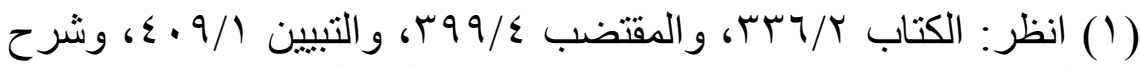

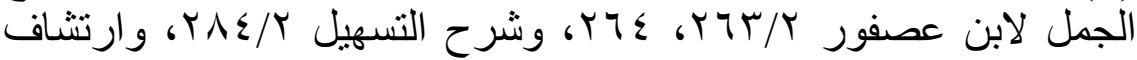

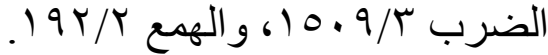

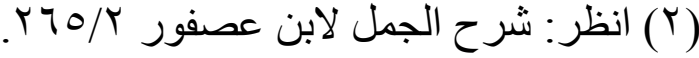

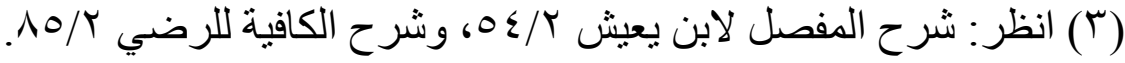

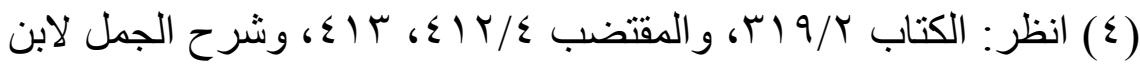
عصفور 1/

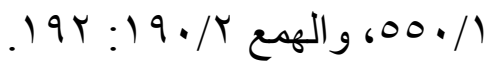

(0) في الأصل: "عن تمام الاسم"، وهو سهو، وانظر: شرح الجمل لابن عصفور

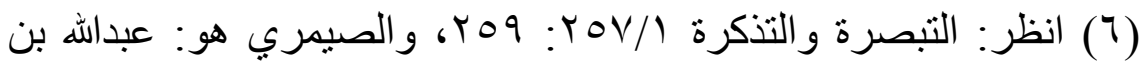
علي بن إسحاق الصيمري النحوي، لله كتاب التبصرة في النحو أحسنَ فيه 


\section{الموفور من شرح ابن عصفور}

دالحمد محسد الجندي

دا عبد الملك أحمد شتئيوي

كل رجل وضيعتَه (1).

والأصل: العطف، وعُلَّلَ إلى النصب لملاحظة المفعولية.

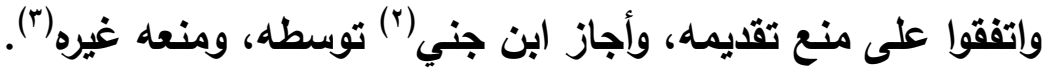
والمسائل: قسم يتساوى فيه أن يكون مفعولا معه ومعطوفا، وقسم يختار فيه أن يكون مفعولا معه، ويجوز فيه العطف، وقسم لا يجوز فيه إلا أن أن

يكون مفعولا معهة (4).

潘潘潘

المفعول من أجله: فضلة، انتصب بعد تمام الكلام على تقدير لام العلة(ه).

التعليل على قول البصريين، وكان أبو حيان ينكر وجود الصيمري، انظر:

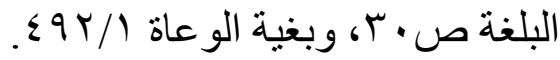

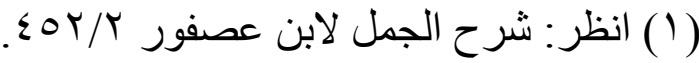

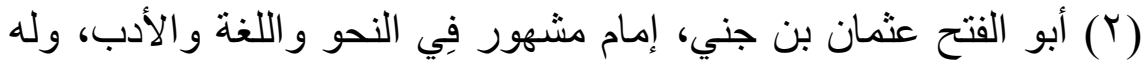

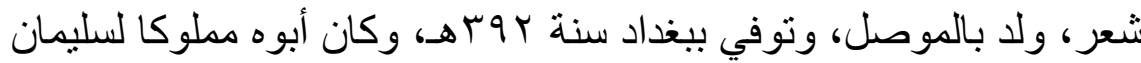

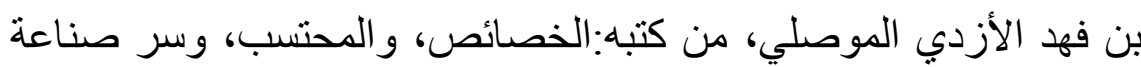

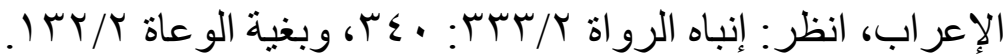

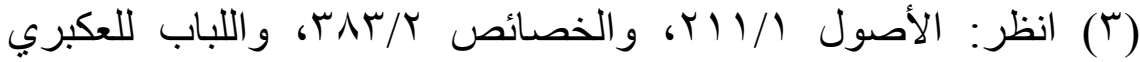

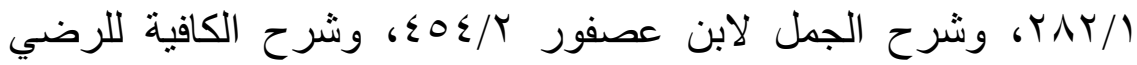

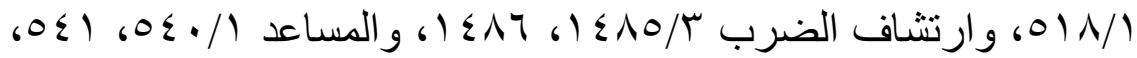

$$
\text { والهمع (s) }
$$

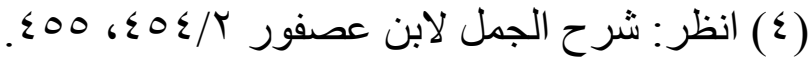

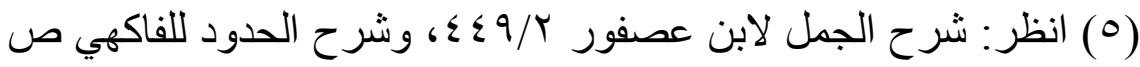


فإن كان المعلل به غير مصدر لم يصل الفعل إليه إلا باللام، أو مصدرا

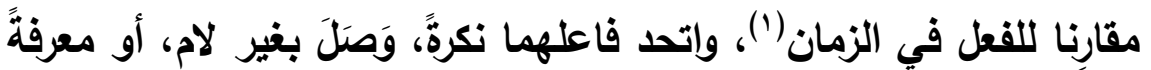
وصل باللام وينفسه، فإن لم يكن كذلك فلا بُدَّ من اللام (؟).

\section{أبواب النداء}

حروفه: "يا" و"أيا" و"هيا" و"أَيْ" وإلهمزة، وزاد الأخفش "آ"(").

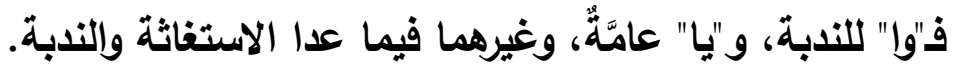

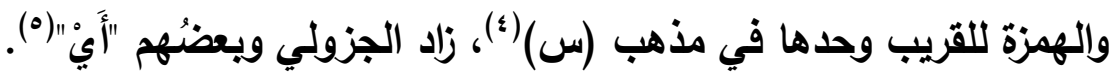

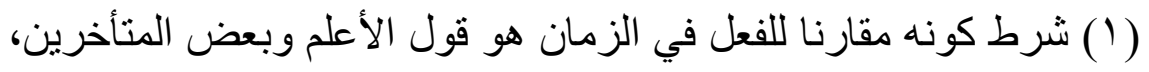

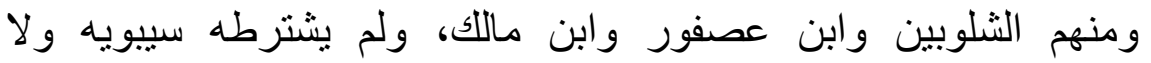

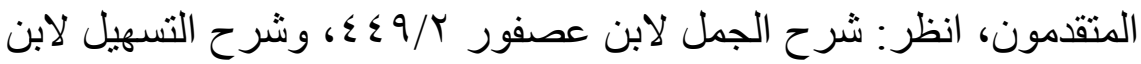

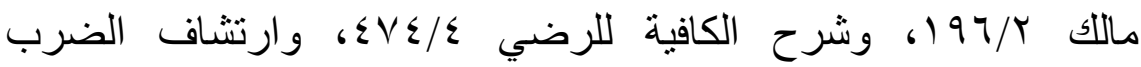

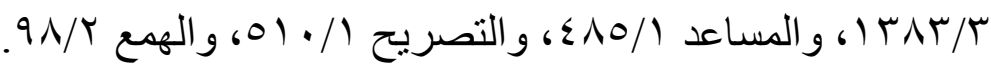

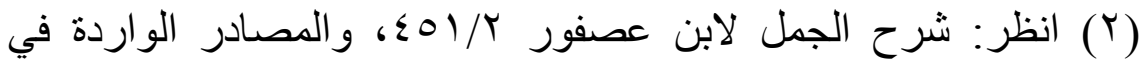
الحاثية السابقة.

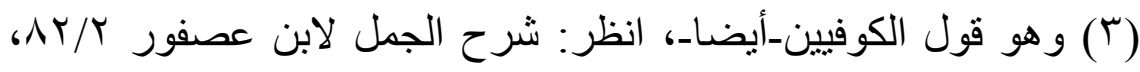

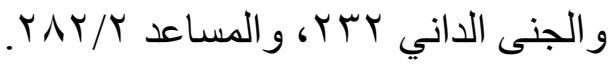

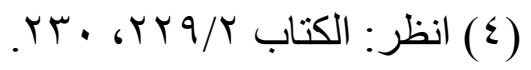

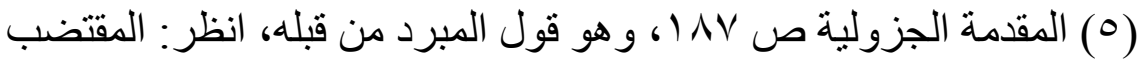

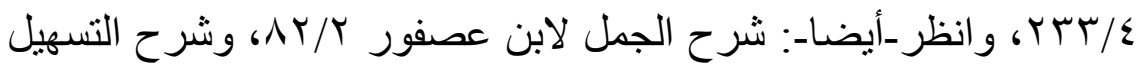

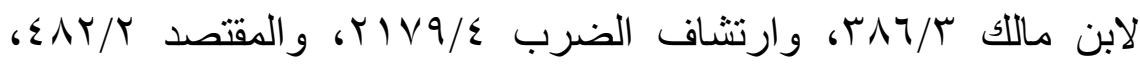

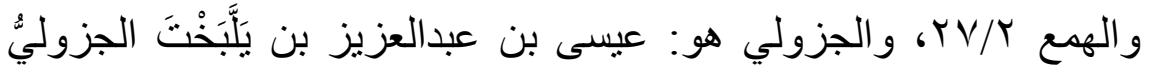

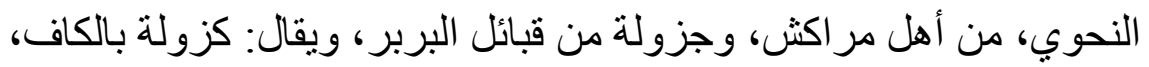

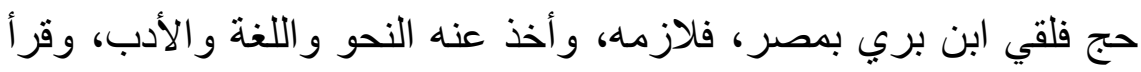

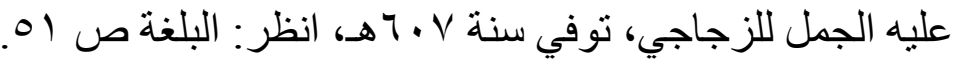




\section{الموفور من شرح ابن عصفور}

وغير الهمزة للبعيد وقد تستعمل للقريب على جهة التأكيد.

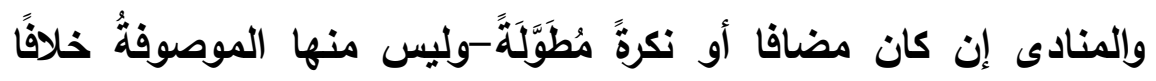
لبعضهم (1)، أو غَيْرَ مُقَتْلِ عليها عند الجمهور، خلافًا لمن نَفَى ذلك، وهو

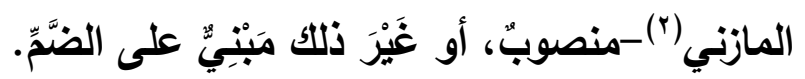

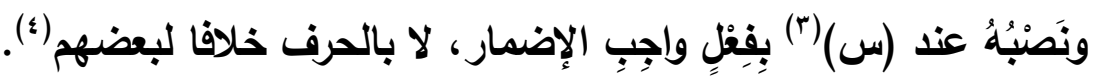
والأسماء كلها تنادى إلا المضمر. ويجوز حذف الحرف إلا من النكرة المقصودة وغير المقصودة والمشارِ، فلا يجوز إلا [بr/ب] ضرورةًَ، أو في قليلِ كَلَامِ. وتعريف المُقبَّلِ عليها قيل: بالخطاب، وقيل: بـ"أل" المحذوفةُ(ه)، وهو الصحيح.

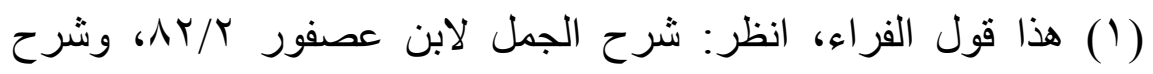

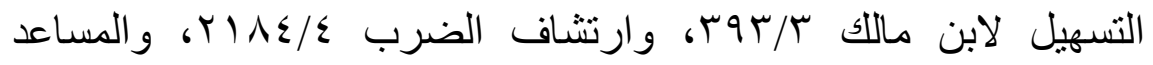

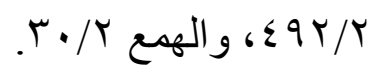

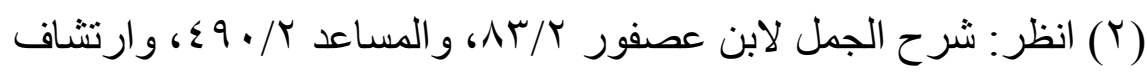

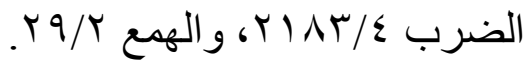

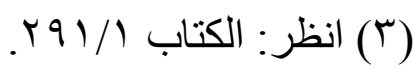

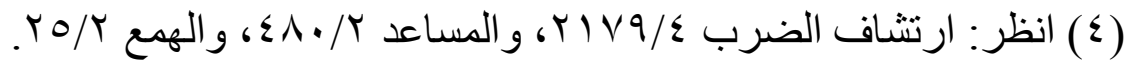

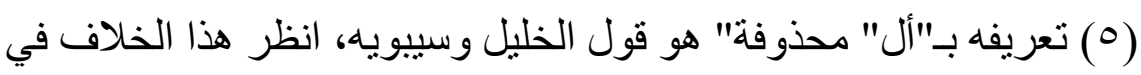

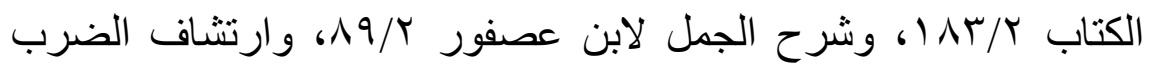

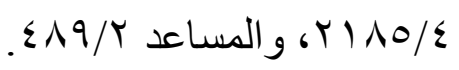


والعلم قيل: زال تعريفه، وتَعَرَّفَ بحرف النداع، وقيل: هو باقٍ على تعريفه(')، وهو الصحيح. ولا يُجْمَعُ بين "أل" والحرفِ إلا في "اللَّهَهِ، أو ضرورةً.

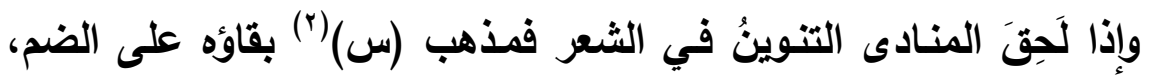
وأبو عمرو ينصبه(ז)، وليس في العربية موضع يتبع فيه المبني على لفظه إلا هذا الباب وياب "لا". وإِذا أَتَبْعَتَ المعرب فعلى اللفظ، أو المَبْنِيَّ معرفةً أو نكرةً مقصودةً بغير البلال وعطف النست، والتابع مضاف، فالنصب، كحاله لو وَلِّيَ الحَرْفَ، إلا

أن تكون الإضافة لفظيةً، فالرفع على اللفظ، والنصب على الموضع(؛). أو مفردٌ، فهذان الوجهان، والأحسن على اللفظ، إلا أن تلزم الصفة،

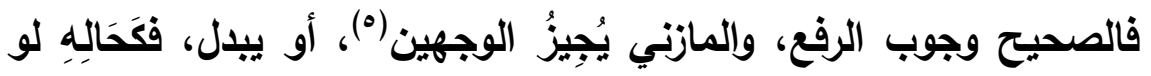

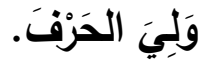

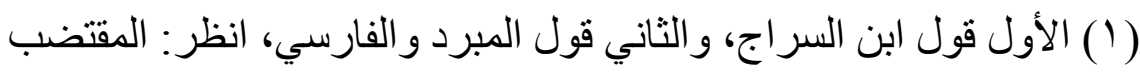

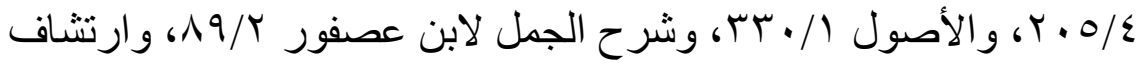

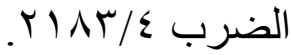

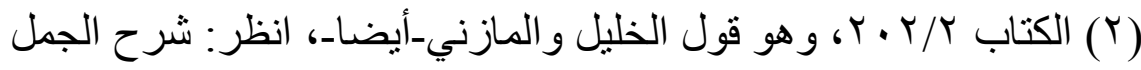

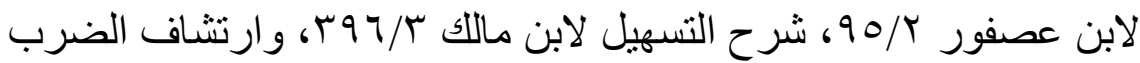

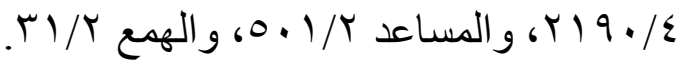

(r) وهو قول عيسي بن عمر ويونس والجرمي والمبرد_أيضا-، انظر:

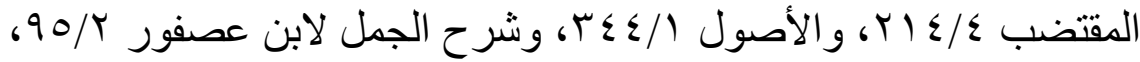

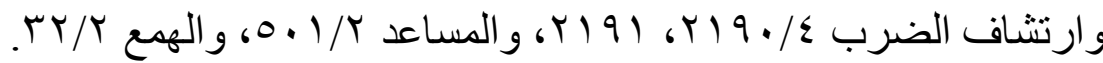

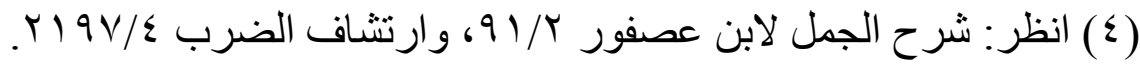

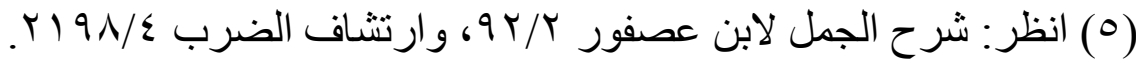


أو بعطف نسق، والتابع مضاف، فالنصب، أو مفردٌ دون "أل" فكحاله لو

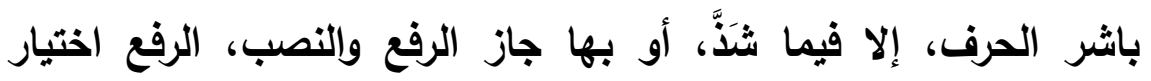

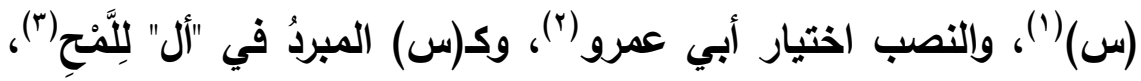

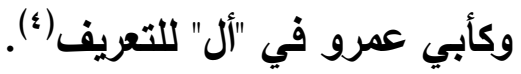
وقال الأخفش (ه): النكرة المقصودة معربة، فلا تتبع إلا على لفظها. وأن أتبعت التابع فعلى لفظه. ولا يعظف مقصود على مقصود، ولا على غيره، ولا عكسهما. *******

الندبة: نداء الميت، وهي من كلام النساء(؟). وحرفها: "يا" و"وا"، ولا يجوز حذفه.

(1) وهو اختيار الخليل والمازني-أيضا-، انظر: الكتاب /99/ 1، وشرح

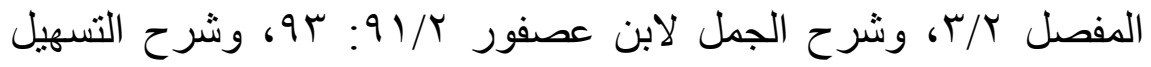

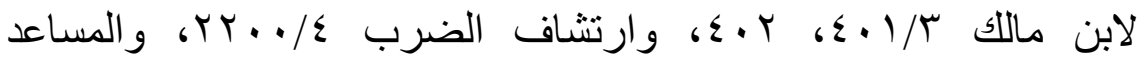
.01 $\varepsilon / T$

(Y) و هو اختيار يونس و عبسى بن عمر والجرمي-أيضًا-، انظر : الأصول ك rV/

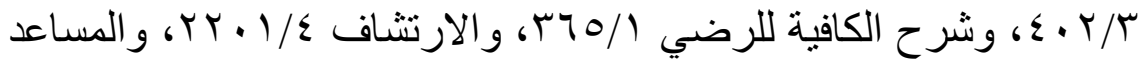
$.01 \varepsilon / T$

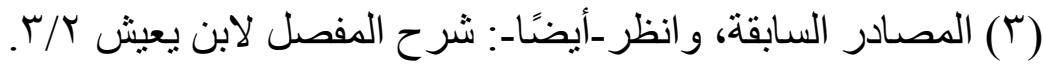

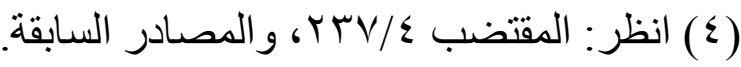

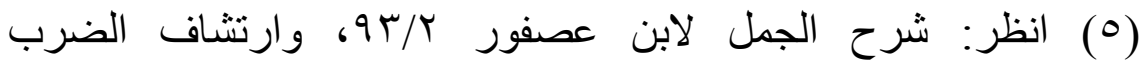

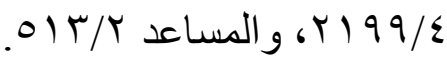

(T) انظر: شرح الجمل لابن عصفور 
ولا يُتْدَبُ إلا عَلَمُ، أو جارِ مَجْرَاهُ، لا مبهم، ولا ما عُرِّفَ بأداة مثُل "يا أيها

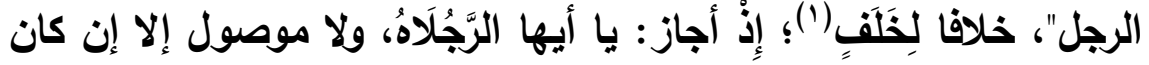

ولحاق علامتها جائز، وتثبت الهاء وقفًا لا وصلًا، وحُكِيَ ثبوتها وصلًا،

ولا يعوض منها تنوين وصلًا، خلافًا لبعض الكوفيين("). ولحاقها آخِرَ المندوب أو المضاف إليه هو [ع ب/أ] بواسطةٍ، أو مباشرة، ولا تلحق آخر النعت، خلافًا ليونس(ّ)، وتلحق الألفُ والهاءُ غيرَ المندوب قبلِاً.

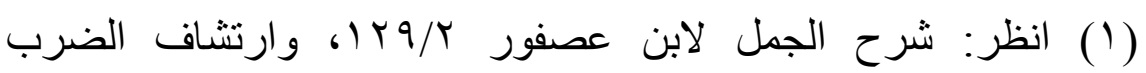

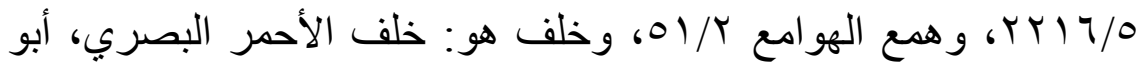
محرز بن حيان، مولى بلال بن أبي بردة، كان راوية ثقة، علامة، بسلك هو

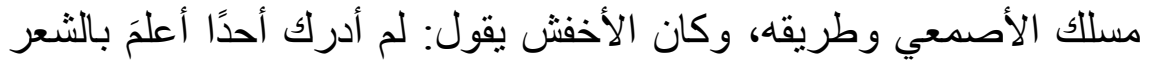

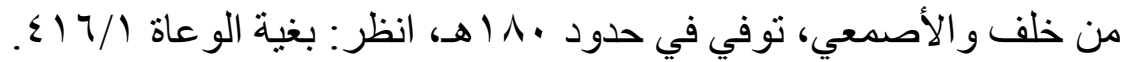

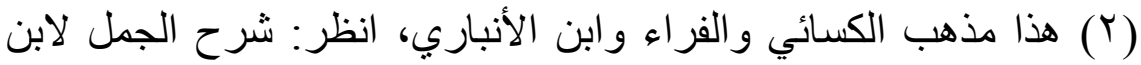

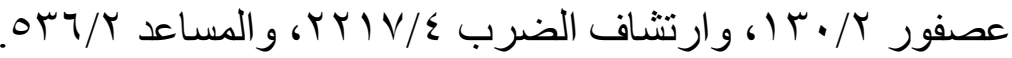

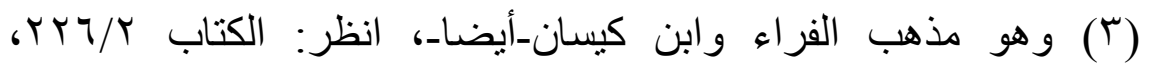

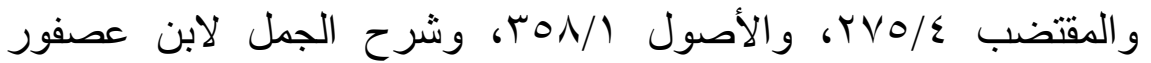

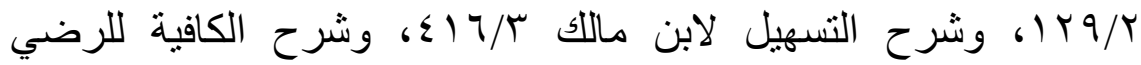

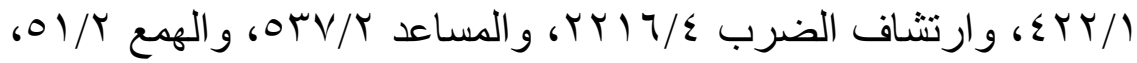
ويونس هو: يونس بن حبيب بن عبدالرحمن الضبي، مولاهم، أو مولى بني

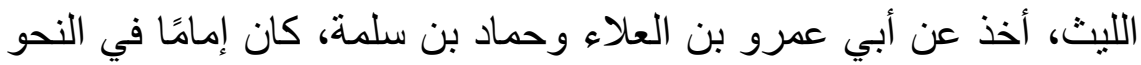

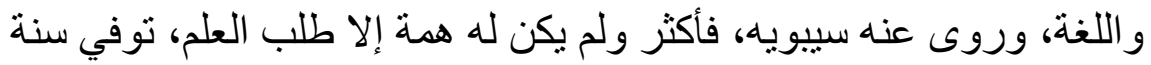

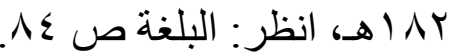


والأذي تلحقه العلامة إن تحرك آخرِرهُ غَيَرْ هَمْزَة بالفتح ألحقتها، أو بالضم أو بالكسر قلبت فتحة، وألحقتهما، هذا جائز باتفاق، ولا تقلب العلامة

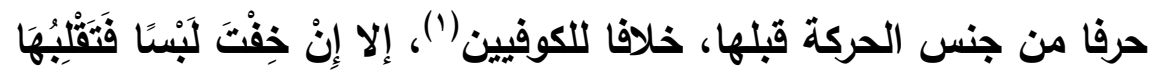
باتِقََّاق.

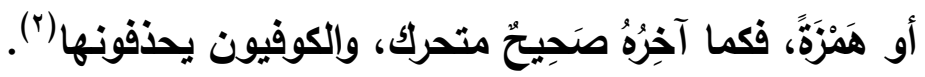
أو سكن تنوينًا فالبصريون يحذقونه، ويلحقون العلامة، والكوفيون يحركونه، وزعموا أنه مسموع(َ). أو حَرْفَ علة ألفًا، والاسم غير منون، فتحذف وتلحق، أو منونًا فتحذفها وتلحق، والكوفيون يحذفونها ويحركون التنوين(؛). أو واو أصلها الحركة فتقتحها وتلحق، أو ليست أصلَها فتحذفها.

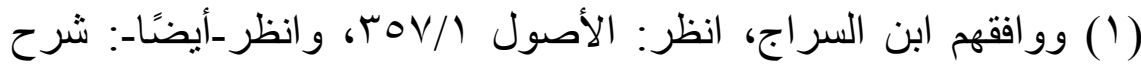

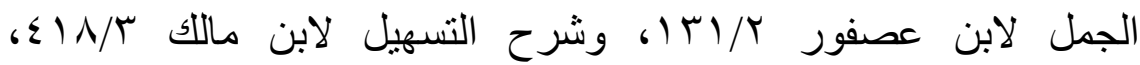

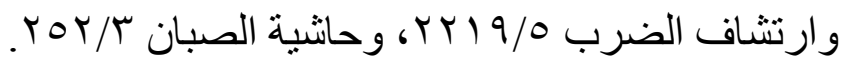

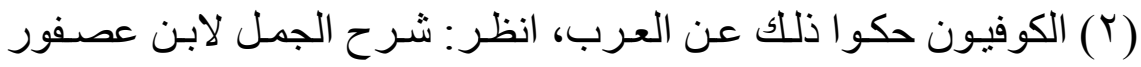

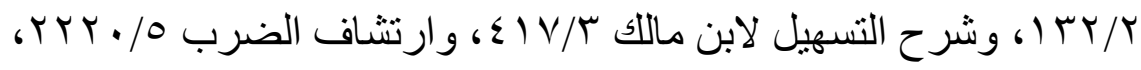

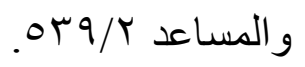

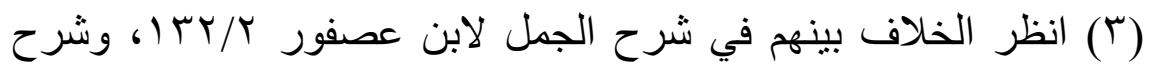

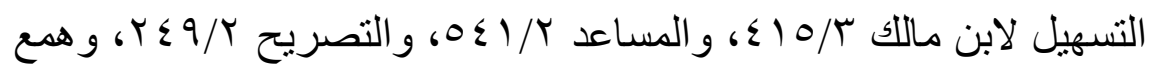

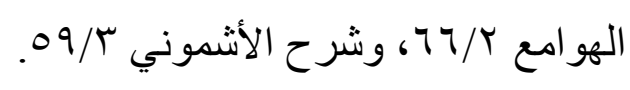

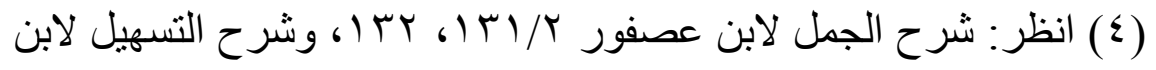

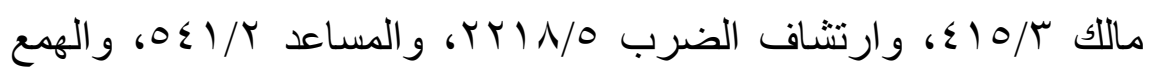


إصدار IV

حولية كلية اللغة العربية بالمنوفية العدد الثاني والثلاثون

أو ياء أصلها الحركة فتفتحها وتلحق، أو ليست أصلَها، وهي غير ضمير، فتحذفها وتقتح ما قبلها، أو ضميرٌ، فوجهان: حذفها وفتح ما قباهها، وإبقاؤها محركةً.

والكوفيون يحذفون إن كان آخرُهُ ياءًا أو واوًا، ويَرَدُوُنَ الحركةَ من جنس

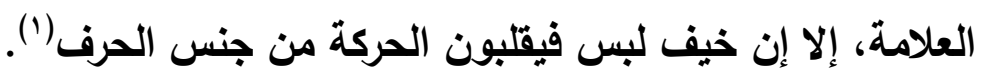
ولا يرخم مندوب.

******

المنادى المكرر: إن كان مضاقًا، واتحد لفظهما، ورفعت الأول، نصب الثاني بدلا أو منادى أو عطف بيان، أو نصبتَهُ فُ(س) يقول(؟): الأول مضاف للمجرور الثابت، والثاني حُذِفَ مضافه لالالة الأول، وأقحم بين المتضايفين، ولا يجوز الفصل بينهما إلا في هذا الباب، أو بالظرف والمجرور في ضرورة، ولا يجوز فيه إلا الإقحام، ويمتنع البدل والعطف. والمبرد يجعل الثاني مضافا للمجرور الثابت، وحذف من الأول، ويجيز فيه من الإعراب ما جاز مع رفع الأول(َّ).

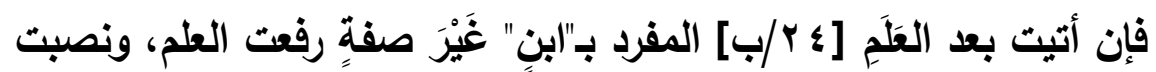

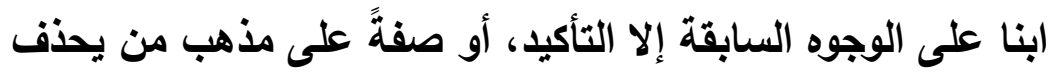

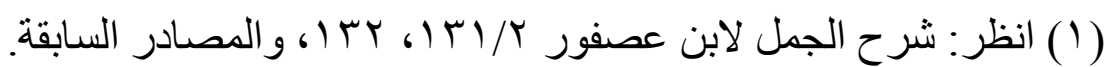

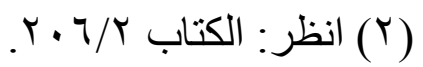

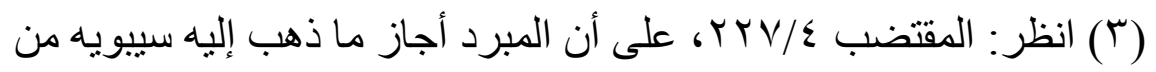
إقحام الثاني بين المتضايفين لتوكيد الأول. 
التنوين لالتقاء الساكنين، فترفع الأول، وتتصب ابنا ليس إلالا').

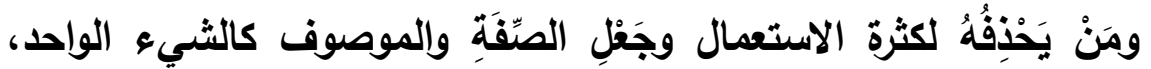

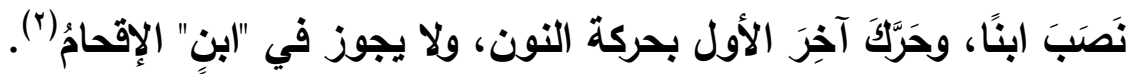

\section{****** $*$ *}

ياء المتكلم: تُحَرَّكُ أو تُُكََُّّ، وهما فصيحان، وتحذف، ويجعل ما بقي تاما، أو تقلب ألفا، ولا يجوزلن إلا في الشعر، وأما في التداء فيجوز

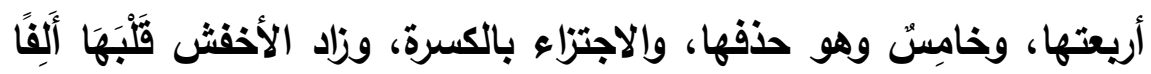

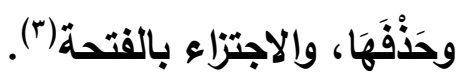
وأحسنها: يا غلام، ثم: يا غلامتا، ثم: با غلامِيَ، ثم: يا غلامِيْ، ثم: يا

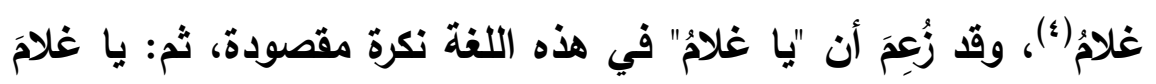

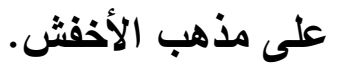

(1) انظر: شرح الجمل لابن عصفور 9V/Y، 919، وشرح التسهيل لابن

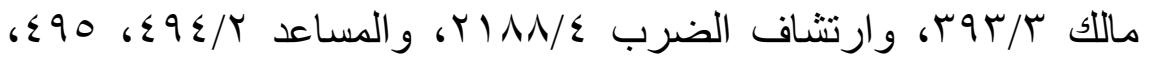

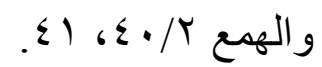

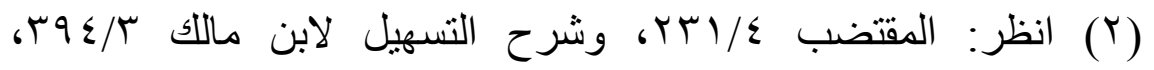
و المصادر السابقة.

(r) ووافقه الفارسي والمازني ومنعه الأكثرون، انظر في هذه اللغات:

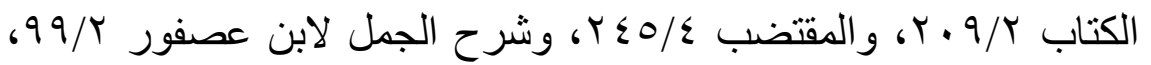

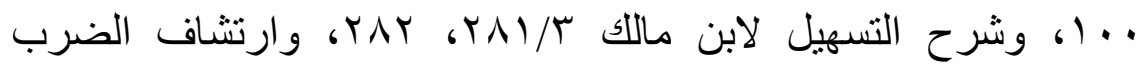

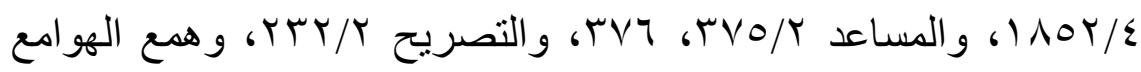
$\varepsilon \Gamma \wedge / r$

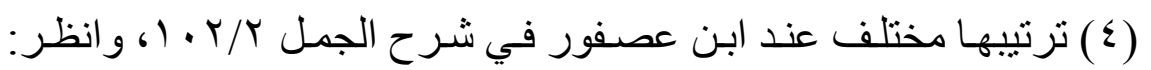

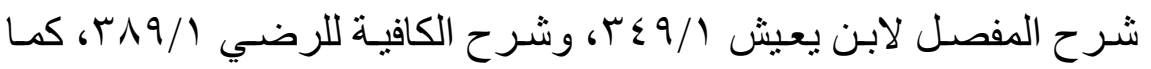

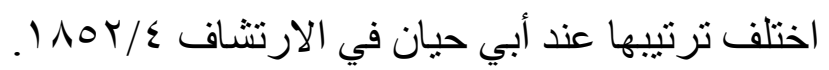


ولا تلحق تاء التأنيث في هذا الباب إلا الأب والأم، فيجوز: يا أبتِ ويا

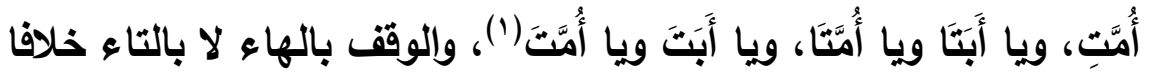
للفراء (r) والمضاف لمنادي إن كان "(بن أم" و"ابن عم" فالأجود: يا ابنَ أُمِّ ويا ابْنَ

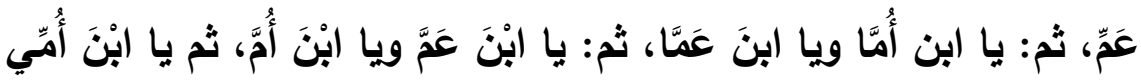

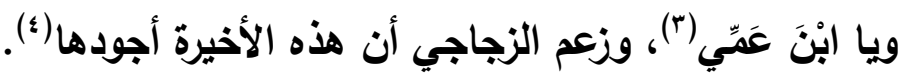
وهي في هذه الأحوال مركبة، خلافا لمن ادَّعَى البساطة، فلا يجوز عنده حذف الياء أصلا. وك"|بن" في ذلك: ابنة(•).

******

المختص باللداء: مسموعُهُ: يا أَبَتِ، ويا أُمَّتِ، واللَّهُهُه، وفُلُ كناية عن

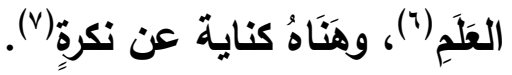

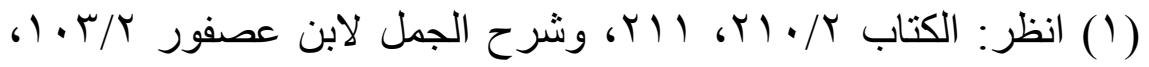

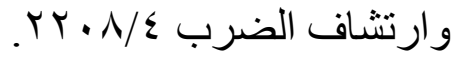

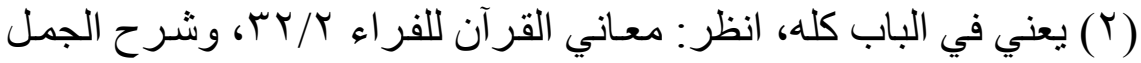

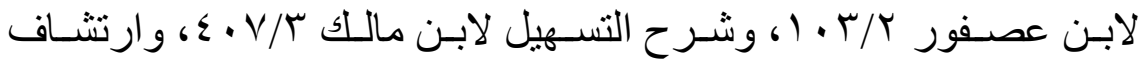

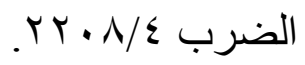

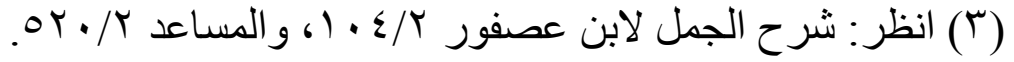

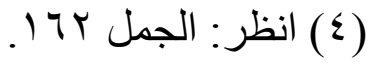

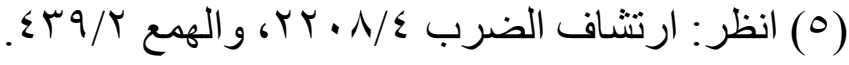

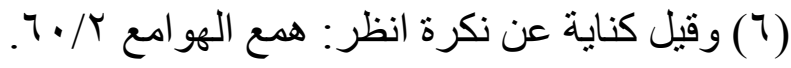

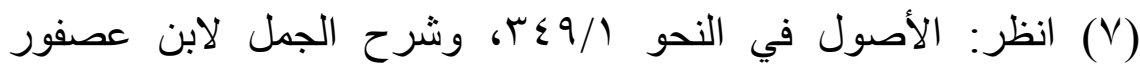

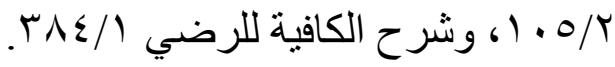


والميم في "اللهم" عوض من حرف النداء فلا يجتمعان، والكوفيون

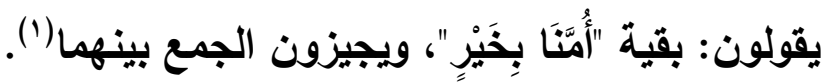
والألف واللهاء في "هَنَاهُ زائدتان كمَرْحَبَاهُ، وقيل: الهاء أصلية، والألف زائدة في نفس الكلمة، وقيل: مبلية من أصل، والألف [هب/أ] بدل من

و"فل" غير مرخم خلافا للكوفيين، ويستعمل في غير النداء ضرورة().

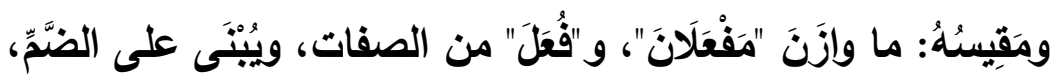

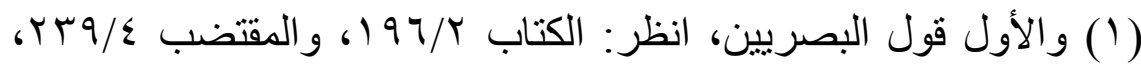

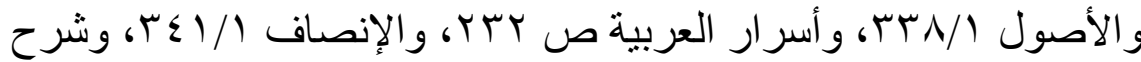

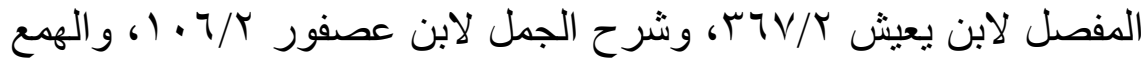
$\Sigma V / T$

(Y) القول الأول للكوفيين والأخفش وأبي زيد الأنصاري، والقول الثاني

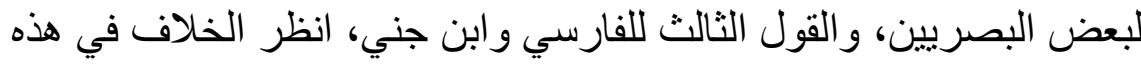

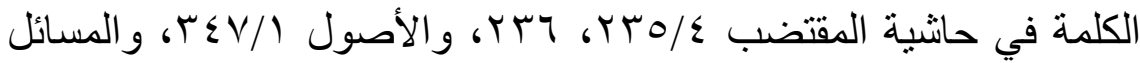

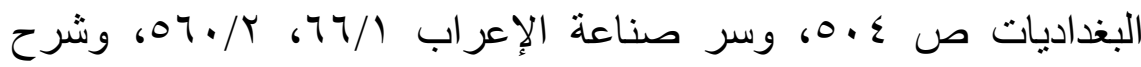

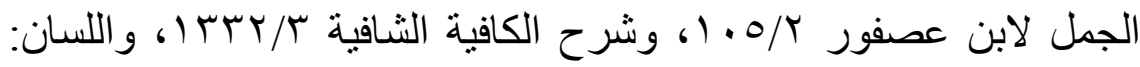

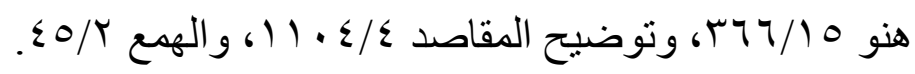

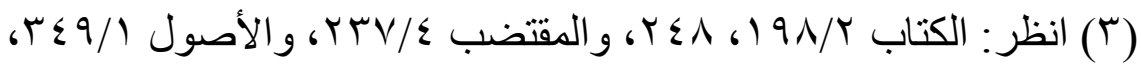

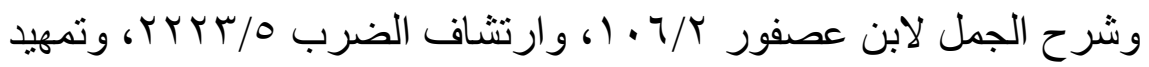

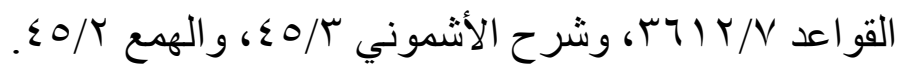




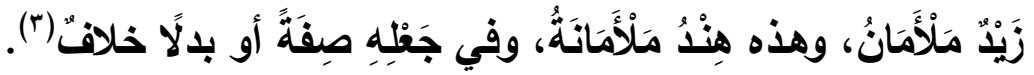

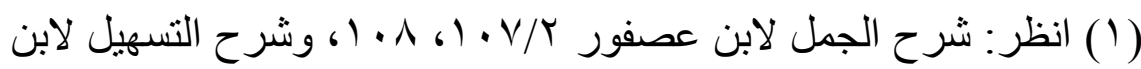

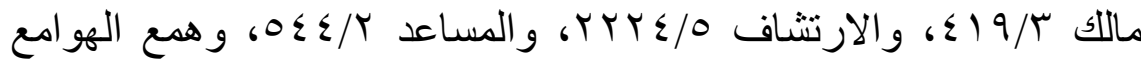

(Y) هو سهل بن محمد بن عثمان الجشمي أبو حاتم السجستاني نحوي لغوي

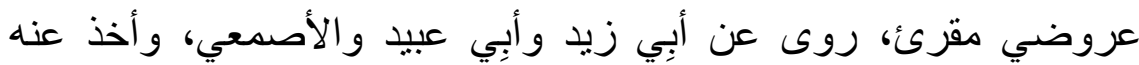

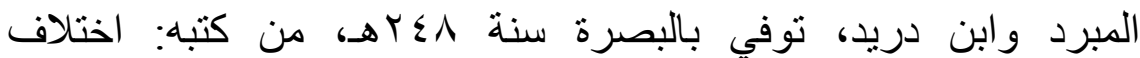

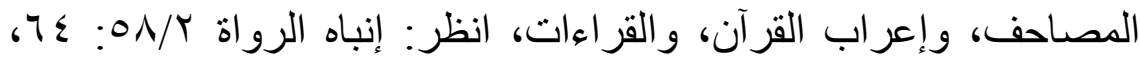
وبغية الوعاة //7 + 7.

(T) زعم أبو حاتم أن "ملأمان" و "ملأمانة" صفتان، وذكر ابن عصفور

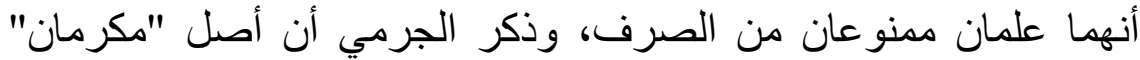

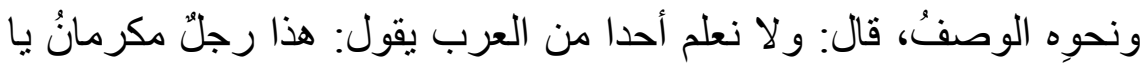

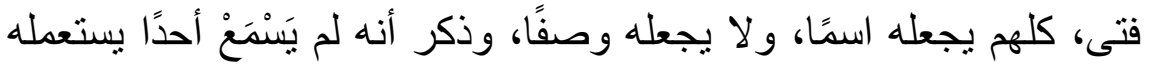

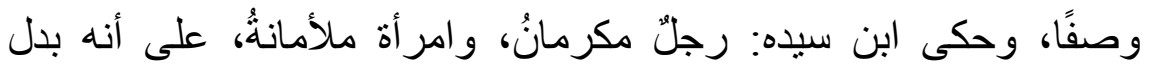

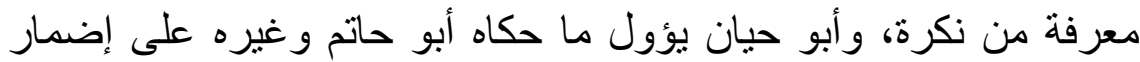

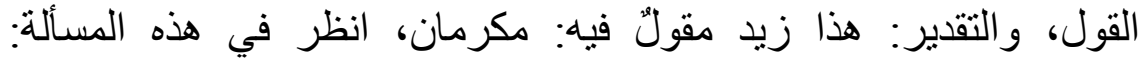

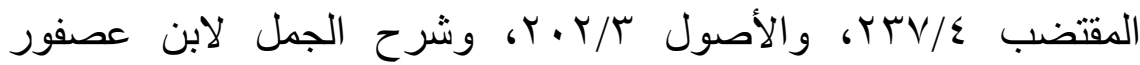

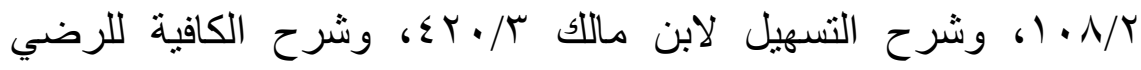

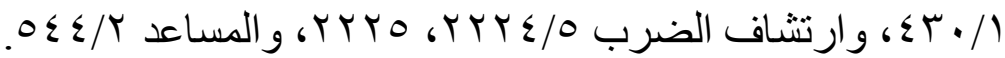




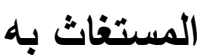

لامُهُ تتعلق بفعل النداء(')، لا بما في "يا" من معنى الفعل، خلافا لابن جني(ץ)، وليست بزائدة خلافا لبعضهم (ץ). ولا ينادى إلا ب"يا"، ولا يجوز حذقها ولا ترخيمه، وكالمستغاث به المُتَعَجَّبُ

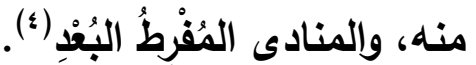

ويجوز حذف المستغاث به والمستغاث له، ولامه مفتوحة، ولام المعطوف على المستغاث به أوله مكسورة، ولا يجمع بين اللام والألف واللهاء. ******

الترخيم لغة: التسهيل، واصطلاحا(•): حذف آخر الاسم في النداء.

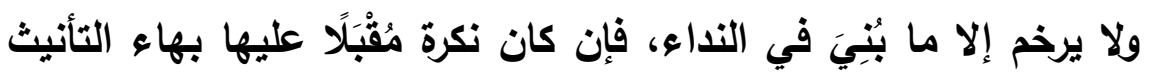
فتحذفها، أو دونها لم ترخم إلا صاحبا أو شاذا، ولا ينقاس، أو عَلَمَا

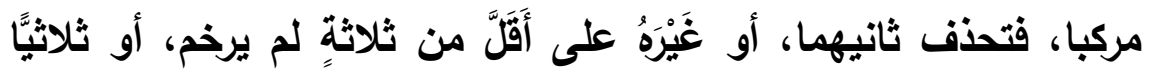

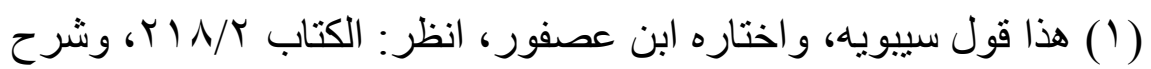

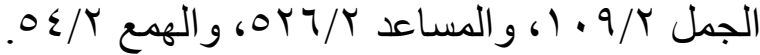

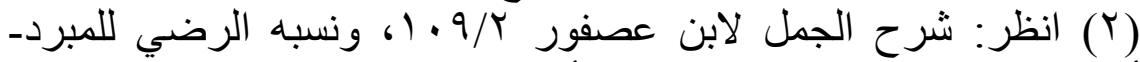

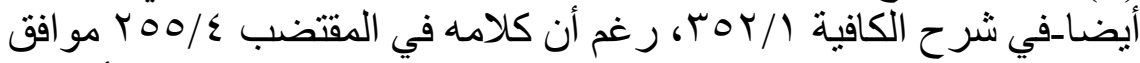

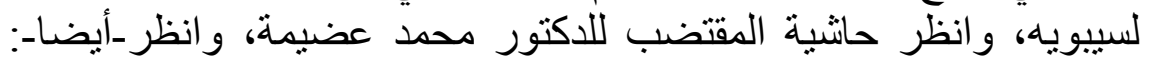

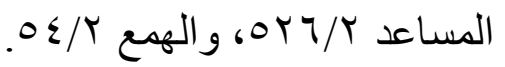

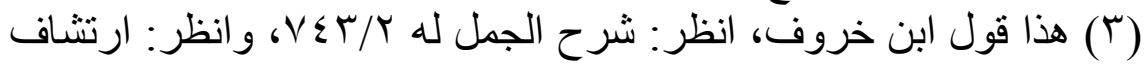

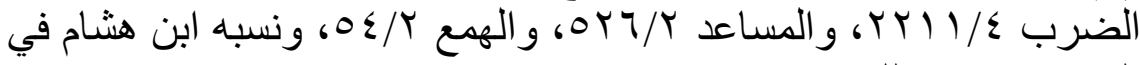

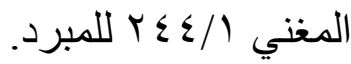

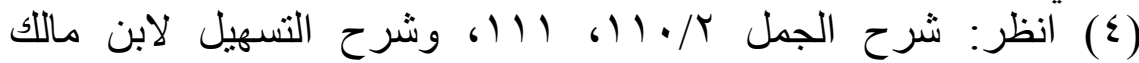

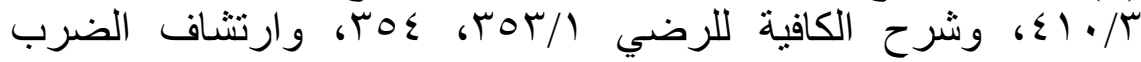

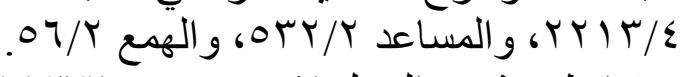

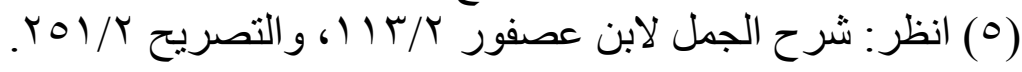




\section{r. IV إصدار}

حولية كلية اللغة العربية بالمنوفية العدد الثاني والثلاثون

بالهاء فتحذفها، أو عاريًا عنها ساكِنَ الوسط لم يرخم (')، أو مُتَحَرِكَهُ فكذلك خلافا للفراء فيه(').

أو رياعيًا جاز، فإن سكن ما قبل آخره فيحذف الآخر فقط خلافا للقراء؛ إذ

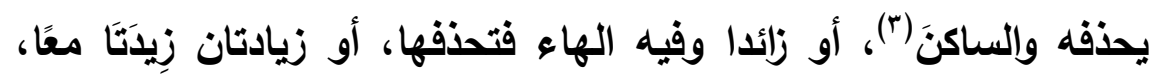
وهما ألفا التأنيث، والألف والنون، والواو واللنون، فتحذفهما، أو ليستا فيه، وقبل آخره حذف مد ولين فتحذفهما، أو ليس قبله فتحذف الآخِرَ (؛). والتترخيم على لغة مَنْ نَوَى فَيَبََى بَعْدُ على ما كان عليه من حركة أو سكون، وعلى لغة مَنْ لَمْ يَتْوِ فيجوز إلا في مثلْ قُائمة.

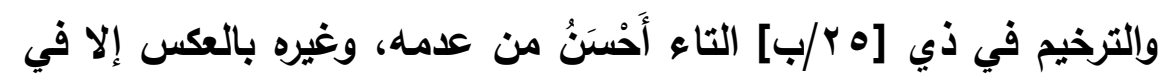
حارث وعائش ومالك، فالترخيم أحسن (ه).

(1) و أجاز الأخفش وبعض الكوفيين نرخيمه، انظر: شرح الكافية للرضي 190/1 Tr. $71 / 4$

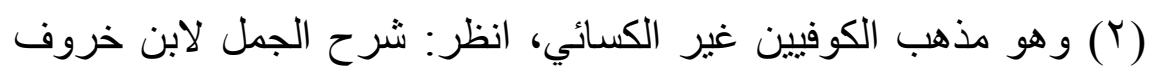

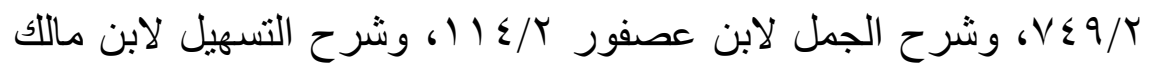
س/T

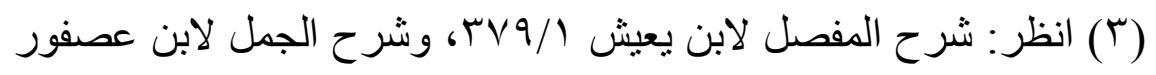

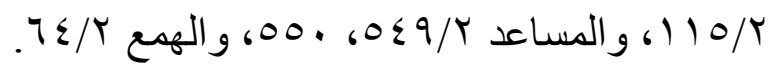

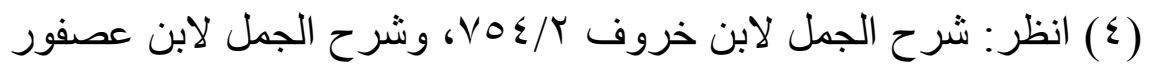

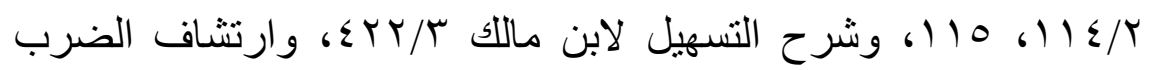

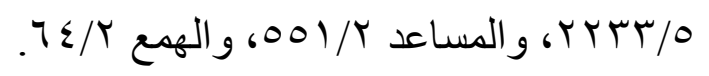

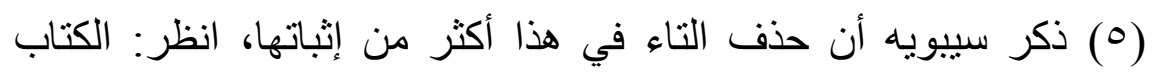
أل

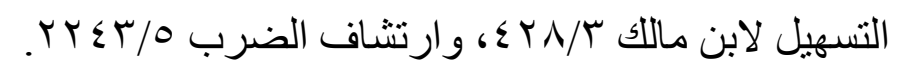




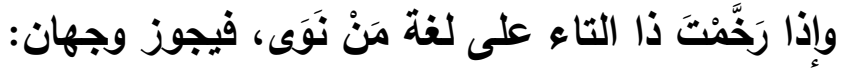
حذف التاء، وإبقاء الحرف بعدها على القتح كما كان. والثاني: أن تلحق التاء، وتحركها بالقتح، وهذه التاء قيل: زائدة في آخره، وقيل: مقحمة بين الحرف وحركته، وهو مذهب الفارسي (')، وهو الصحيح. وإذا وققت على المؤتث المرخم وققت عليه بالهاء إلا في ضرورة، فتعوض منها ألف الإطلاق (ז)، ولا يجوز أن يوقف بغير هاء إلا فيما سُمِعَ، حكى (س) عن العرب: يا حَرْمَلُُ (َ)، ولا يقاس عليه. والاسم إذا كان لله حكم قبل الترخيم، ثم زال بالترخيم سبب ذلك الحكم، زال الحكم بزوال سببه. والمرخم على لغة مَنْ لَمْ يَنْوِ حُكْمُهُ كحكمه لو لََمْ يكن مُرَخَّمًا: في بنائه على الضم، وإعلاله حيث يجب إعلاله. وعلى هذه اللغة إذا بَقِيَ بعد الترخيم على وَزْنِ غَيْرِ عَرَبٍِِ فمذهب الأخفش أنه لا يجوز (؛)، وغيره يجيزه(ه). ( ) و القول الأول للفارسي-أيضًا-، و القول الثاني ذكر ابن عقيل أن كلام

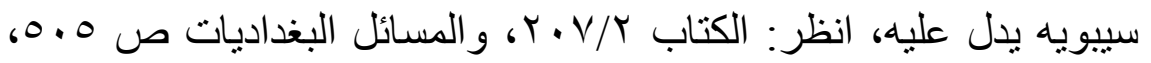

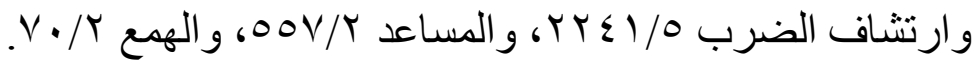

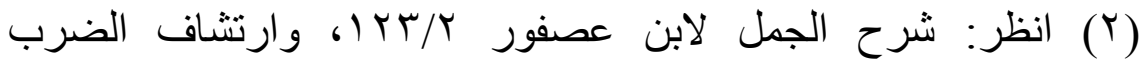

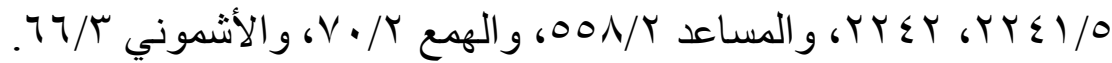

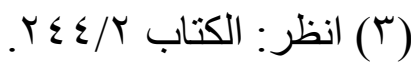

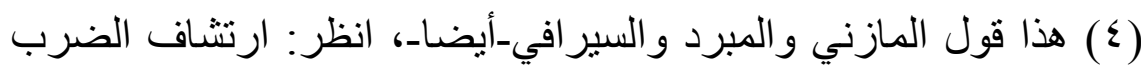


(0) هذا قول السيرافي، انظر: ارتثاف الضرب Y (1)

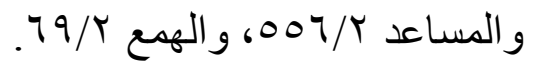


والترخيم في غير النداء ضرورة(')، فُ(س) يرخم على اللغتين (r)، والمبرد على لغة من لم يَنْوِ خاصةًَ("). ****** **

"لا" للتبرئة: إن دخلت على معرفة لزم تكرارها(؛) إلا ضرورةًّ()، ولم تعمل،

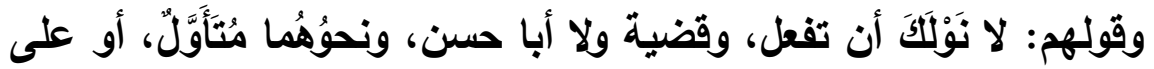
نكرة مضافة، أو مُطَوََلَّةِّ(؟). فتتعمل عمل "إنَّ"، وعمل "تَيَسنَ"، أو غيرِهما، مفردًا نُصِبَ بِلا تثوين،

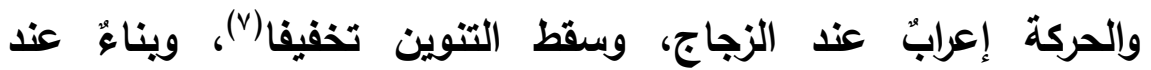

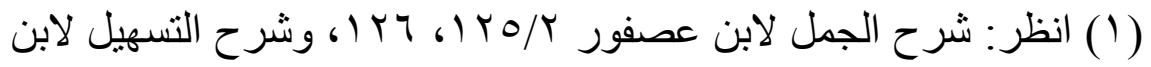

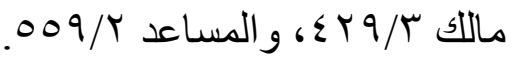
YV

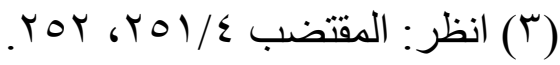

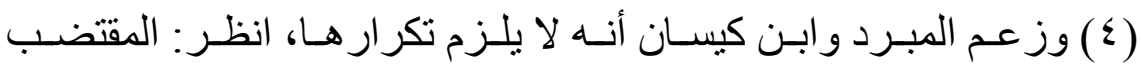

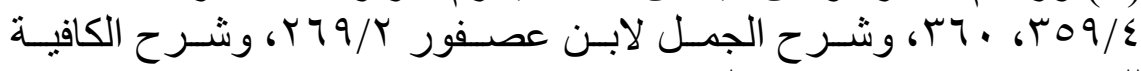

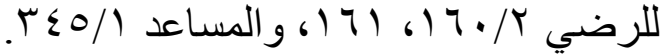

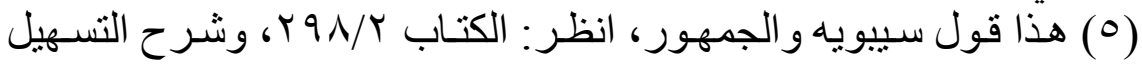

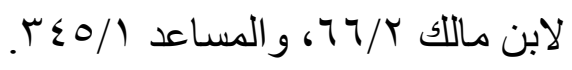

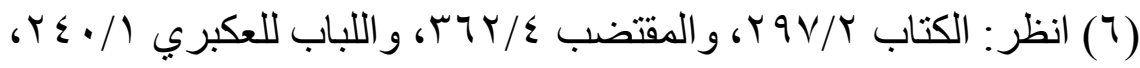

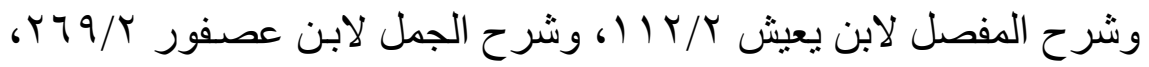

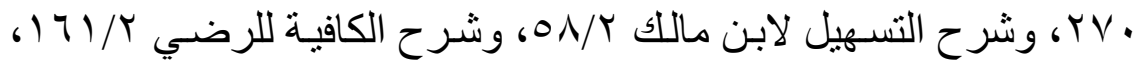

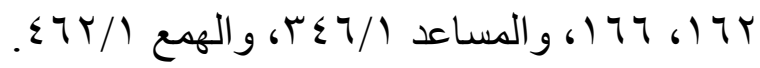

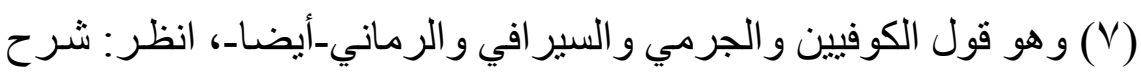

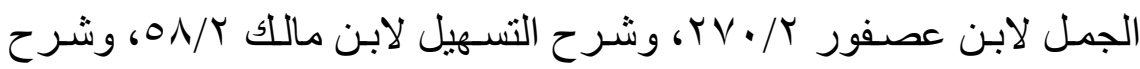

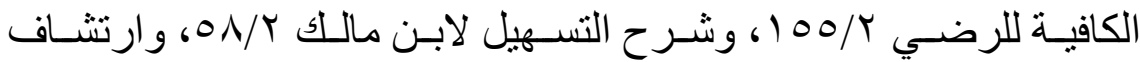




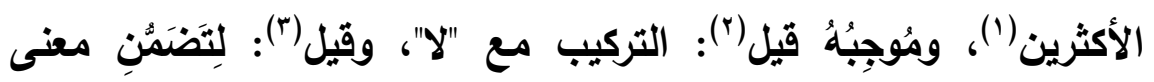
"مِنْ"، وهو الصحيح. أو مُستلًَّا بالألف والتاء، فالصحيح الكسر(؛)، وقيل(ْ): يجب الفتح، وهو خلافُ مَبْنِيٌ على الخلاف في حركة "لا رَجُلَ"، فمن قال: إعراب أو بناء

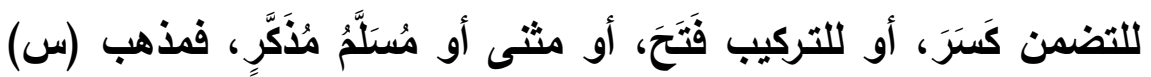

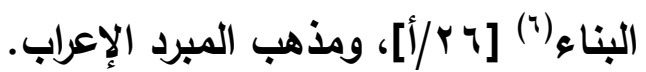

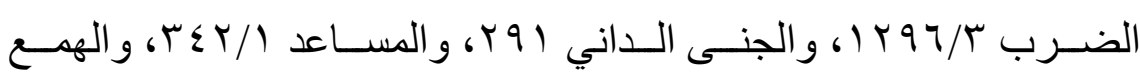
. $₹ 7 V / 1$

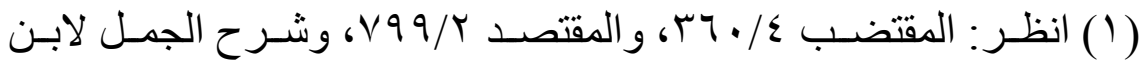

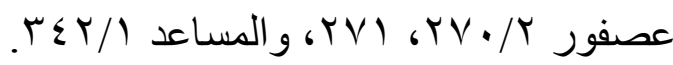

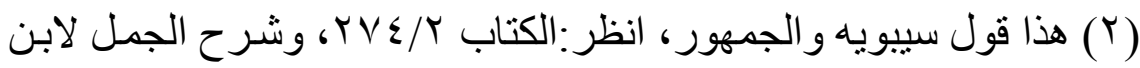

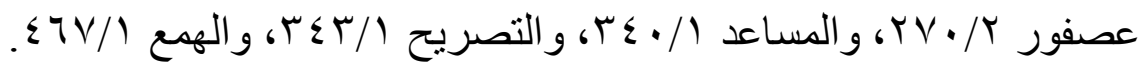

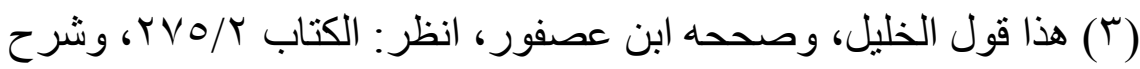

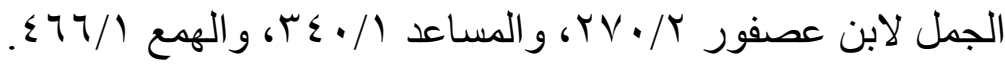

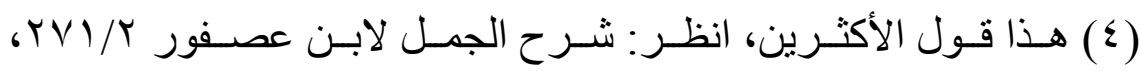

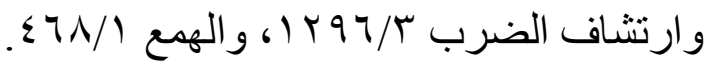

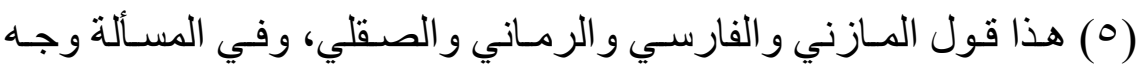

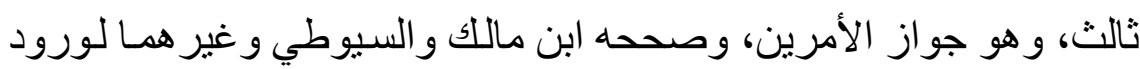

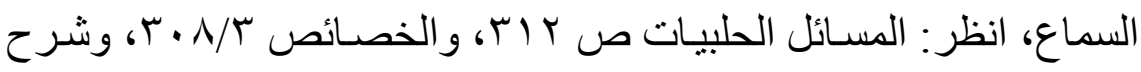

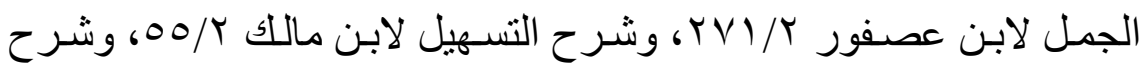

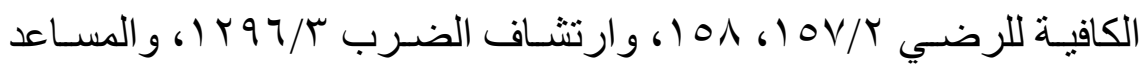

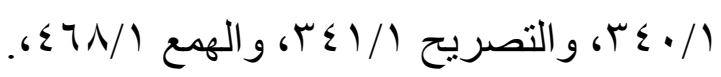

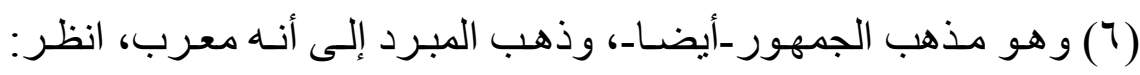

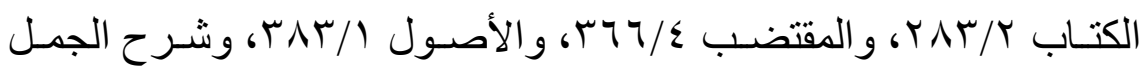

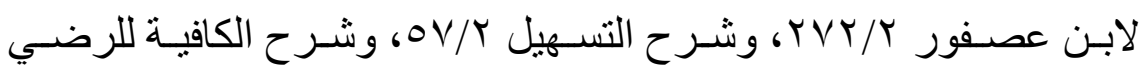


وإذا فصل بين "لا" ومعمولها على حاليها بطل عملها، ولزم التكرار، خلافا للمبرد؛ إذ قال: لا يلزم.

والخبر إن كان ظرفا أو مجرورا جاز حذفه، أو غيرَهما وجب عند تميم، وجاز عند الحجازيين.

والصحيح أن رفع الخبر على أنه خبر المبتدأ، لا على أنه خبر لد"لا"، خلافا لقوم.

والواقع بعد "لا" إن عمل فيه عامل ظاهر أو مضمر لم تؤيثر فيه "لا" (1. واسم "لا" المعرب يتبع على لفظه، والمبني إن أتبعته بنعت مضاف أو إن مطول فعلى اللفظ، أو غيرِهما فعلى اللفظ بتنوين وعدمه، وعلى الموضع. فإن كررت النعت فالنصب بالتنوين على اللفظ، والحمل على الموضع، أو بعطف ولم تكرر "لا" فَهُمَا، وحكى الأخفش: لا رجلَ في الدار وامرأةَّ، أو

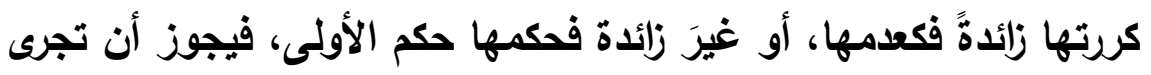
مجرى "إنَّ"، ومجرى "ليس". ويجوز إقحام اللام بين المضاف والمضاف إليه هنا، فتقول: لا أخا للك،

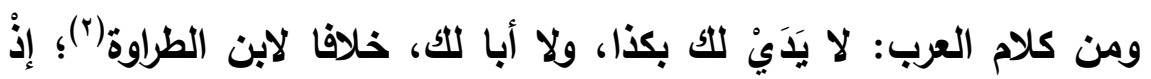
زعم أن اللام ليست مقحمة، بل ذلك على لغة من قال: أخانا بالألف في الأحوال الثثلاثة.

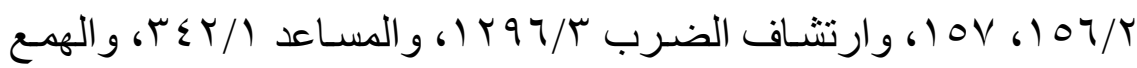
. $\leqslant 7 V / 1$ (1) نحو قو لهم: لا مرحبـا ولا أهلا، و لا مرحبّ، انظر: شـرح الجمل لابن عصفور rV (Y) انظر: شرح الجمل لابن عصفور rVT/T. 
وقد تزاد "لا" بين المتضايفين، ويين الجارِّ والمجرور، دالةً على معناها من النفي وغير ذلك. وإذا دخلت همزة الاستفهام على "لا"، ويقيت "لا" على معناها، فكحالها مجردةً عنها، وإن دخلها معنى التحضيض بطل عملها، أو التمني فكهي دونها عند (س)، إلا أنها لا خبر لها، ولا يُتبَعُ إلا على اللفظ، والمازني يزعم أن لها خبرا، ويجيز الحمل على الموضع.

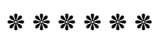

\section{حروف الجر (1) - (1)}

ما جاء منها على حرف: الباء، والكاف، والللام، والتواو، والتاء، والفاء، وهمزة الاستفهام، واللهزة المقطوعة من ألف الوصل، والميم مكسورةً ومضمومةًَ، على خلاف فيها. وعلى حرفين: "من"، و"عن"، و "في"، و"ها"للتنبيهه، و"مذ" و"مُنْ"، و"مَعْع"

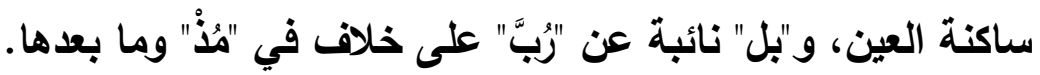

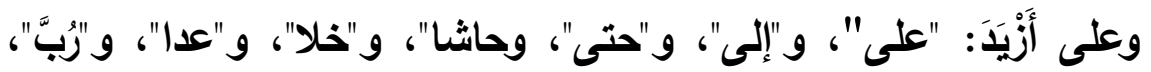

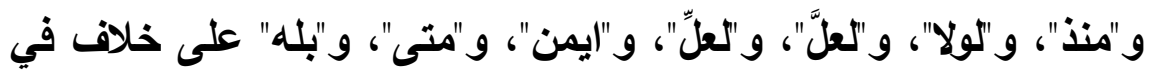

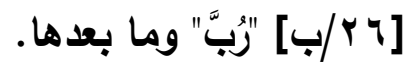
ف"لولا" تختص بالمضمرالمخفوض، خلافًا للمبرد ()؛ إذ زعم أن ذلك ليس

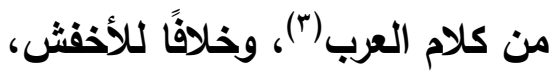

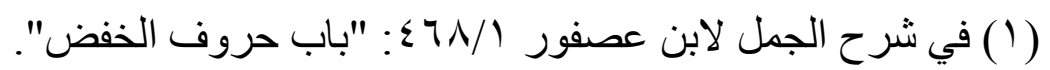

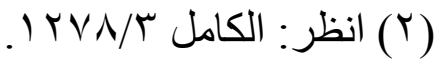

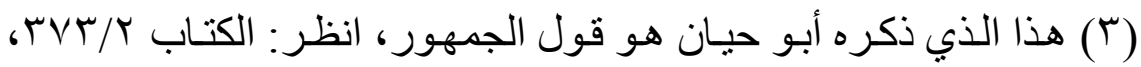

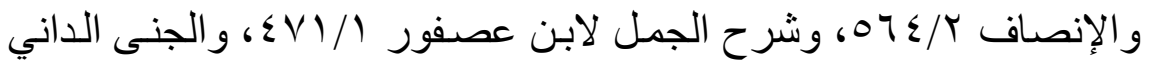

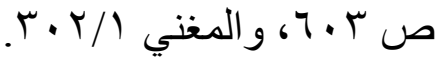




\section{إذ زعم أنه في موضع رفع (').}

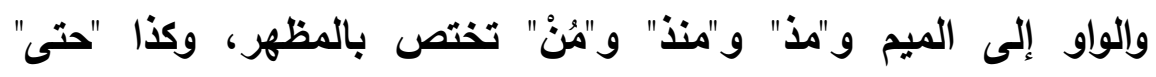
والكاف، إلا في الضرورة، فيجران المضمر، والباقي يجرهما.

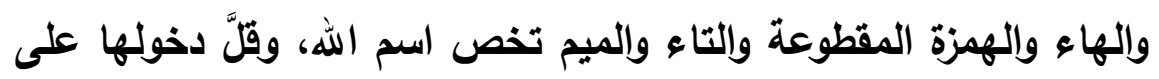

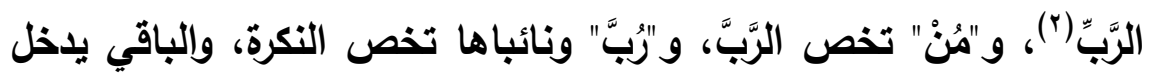
على كل ظاهر.

و"مذ" و"منذ" و"عن" حرف واسم، والكاف في الشعر اسم لا في الفصيح،

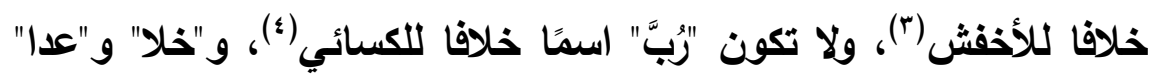
حرف وفعل، وكذا "حاشا" عند المبرد، و"على" اسم وفعل وحرف، خلافا لمن نفى حرفيتها(•)، والباقي لا يكون إلا حرفًا.

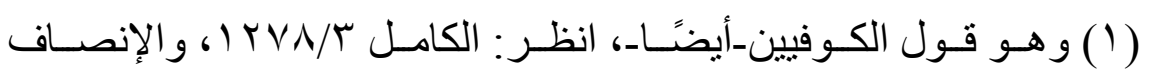

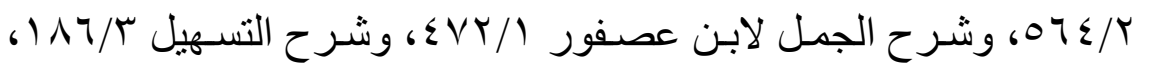

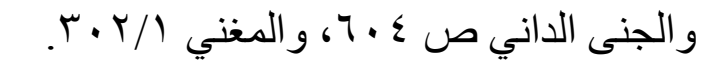

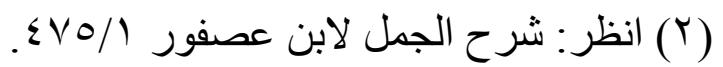

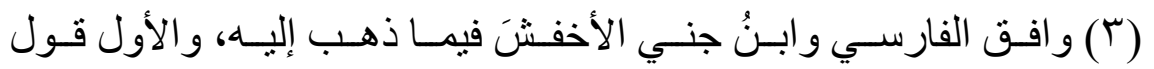

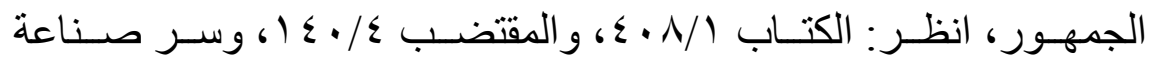

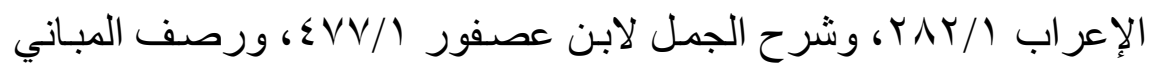

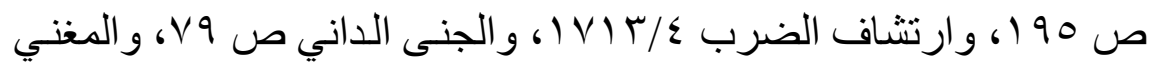

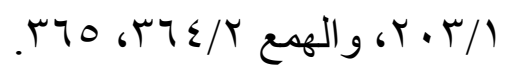

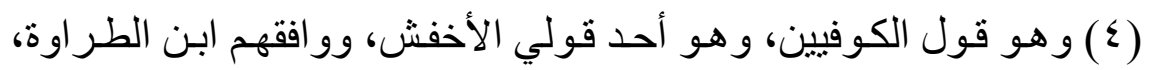

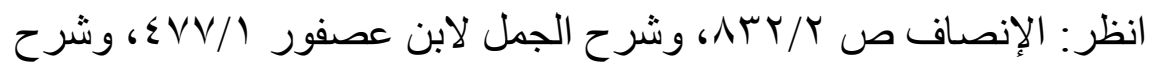

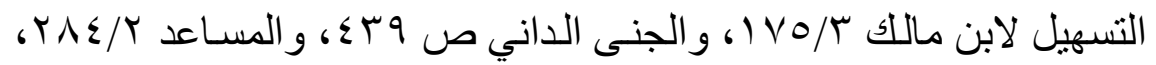

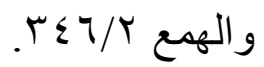
(0) انظر ما تقدم في باب الاستثناء. 
ولا بد لحرف الجر مما يتعلق به ظاهرًا أو مضمرًا، إلا "لولا" على مذهب

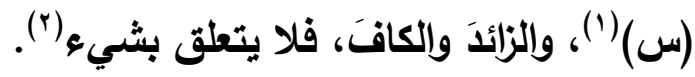
ولا يضمر الحرف ويبقى عمله إلا نادرًا أو ضرورةً. الباء زائدة بقياس في خبر "ليس" و"ما" و"حسبك" مبتدأ()، وفاعلِ "كفى" ومفعوله، ويغير قياس في فاعل "يأتي ونحوه، وأَحْنَنُهُ أن يَتَوَجَّهَ النفي عليه في المعنى (๕) وغير زائدة(ه) لمجرد الإلصاق حقيقةً أو مجازًا، وللاستعانة، وتدخل على الآلة التي توصل للفعل، وللسبب، وللقسم، وللحال، ويمعنى "في"،

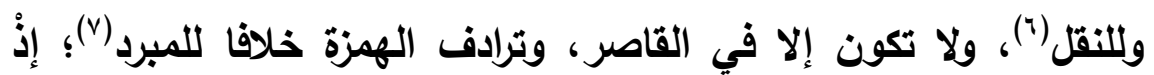

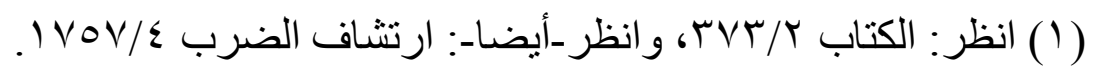

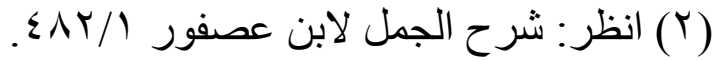

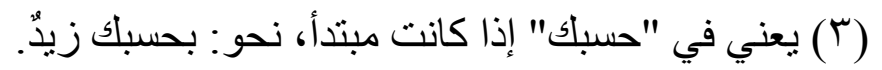

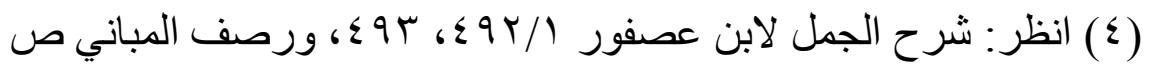

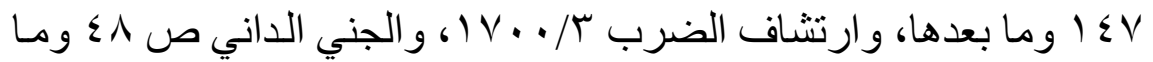

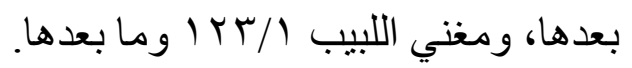

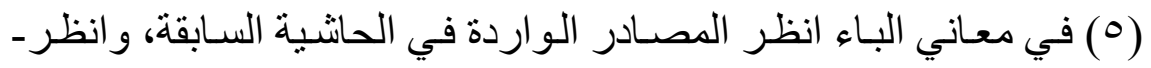

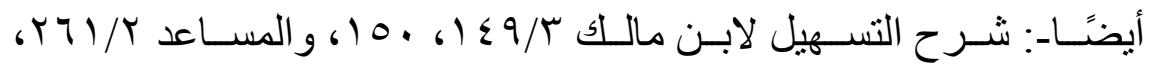

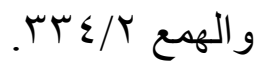

(ך) يعني تعديـة الفعل الـلازم إلى مفعول بنفسـه، انظر : شر ح الجمل لابن

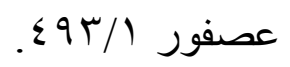

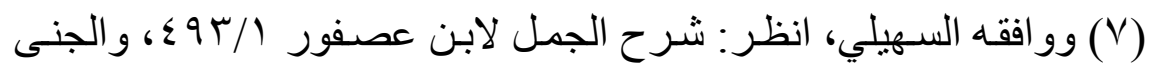

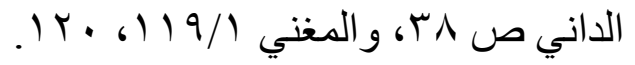


قال: ما بعد الباء يشرك الفاعل في الفعل، وما بعد الهمزة لا يشركه،

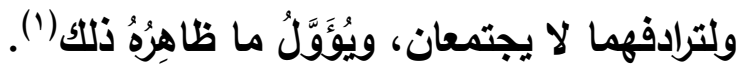

ولا يُبَمَّنُ بالباء، ولا تكون بمعنى "عن" خلافا لزاعميهما (؟).

الكاف: للتثبيه، وزائدة.

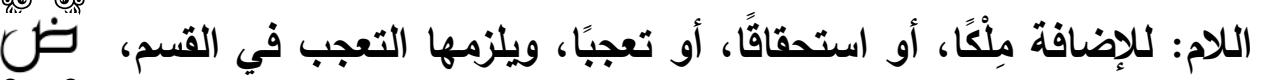
ومُفَقِيَةًة بشرط تقديم المفعول، إلا للضرورة أو ندورًا، فقد يتأخر، وزائدة في باب النداء، وياب "لا"()، ويمعنى [rv/أ] "كي"، وللجحد، وهي التي تقدمها حرف نفي و"كان"، أو ما تصرف منها، ولا تكون للمآل خلافا

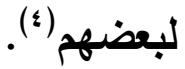

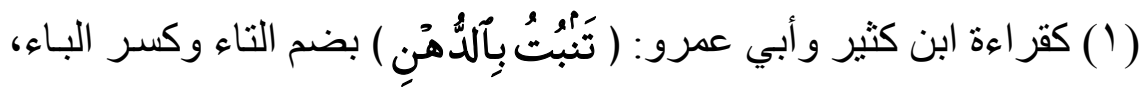

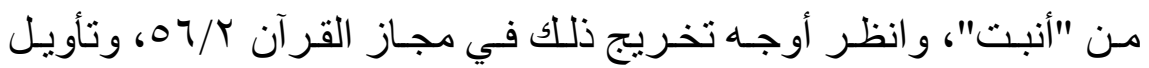

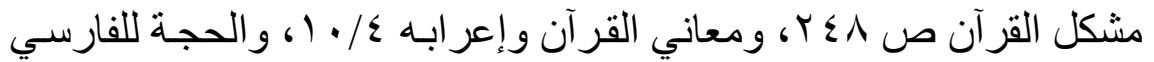

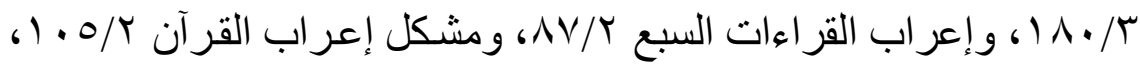

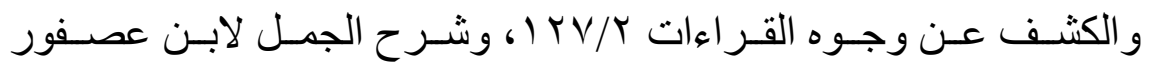

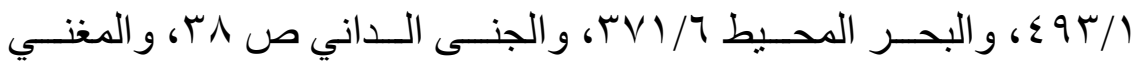
$.15 \cdot / 1$

(Y) هذا قول الأخفش و الكوفيين وابن مالك، انظر : معاني القرآن للأخفش

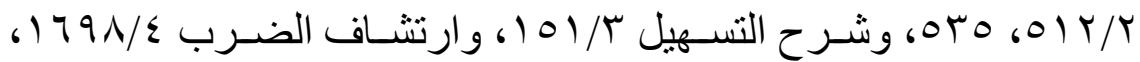

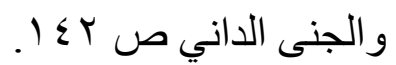

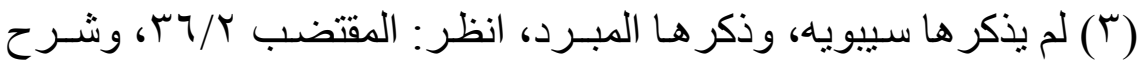

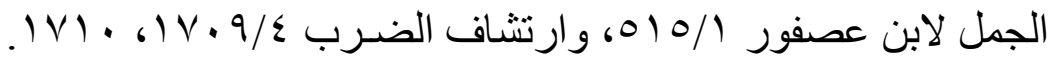

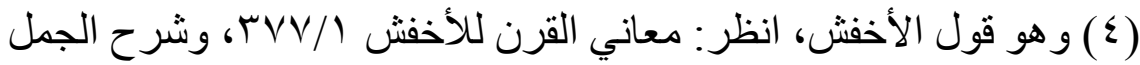

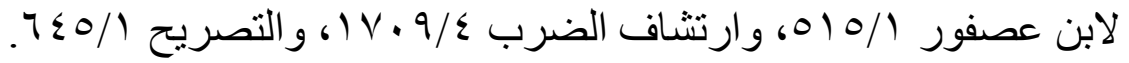


والواو إلى الميم و"مُنْ" والباء بمعنى تاء القسم، إلا أن التاء فيها

(التعجب(1) - (1) - (1)

"مِنْ" زائدة بشرطين: أحدهما: دخولها على نكرة، خلافا للأخفش؛ إذ أجاز

دخولها على معرفة (r).

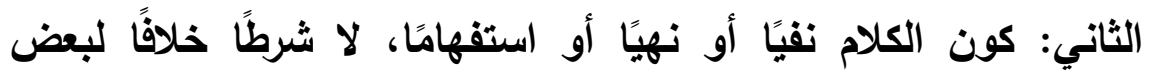
البصريين في الشرط(ّ)، ولا واجبًا خلافًا للكوفيين والأخفش فيه(ء). ومعناها استغرلقُ الجنس أو تأكيدُهُ(0).

والبصريون يجيزون في الضرورة دخولها في الواجب وعلى المعرفة(؟).

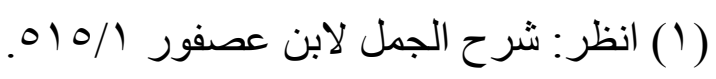

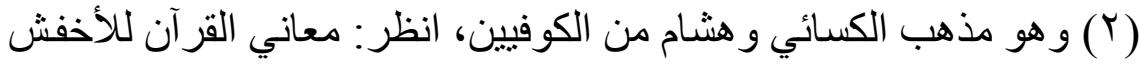

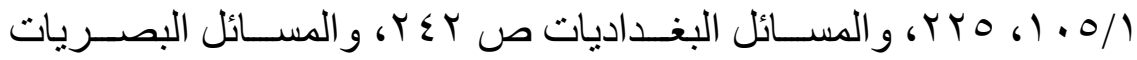

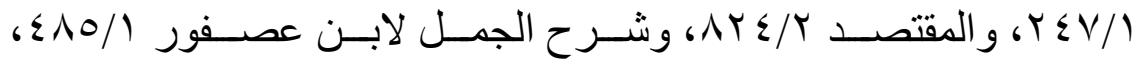

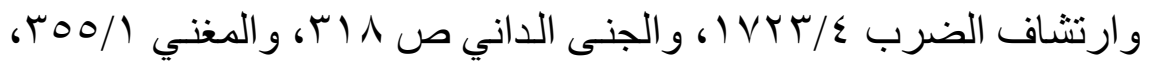

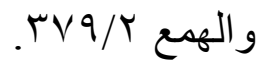

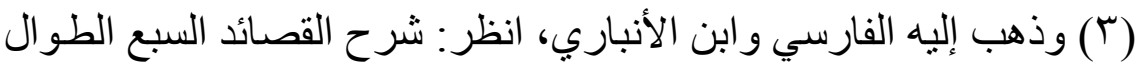


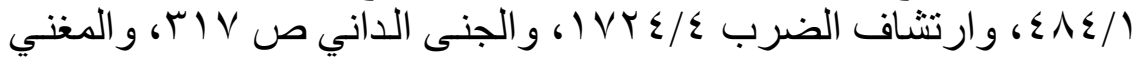
( )

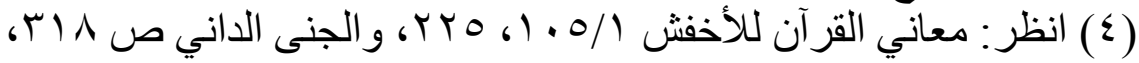

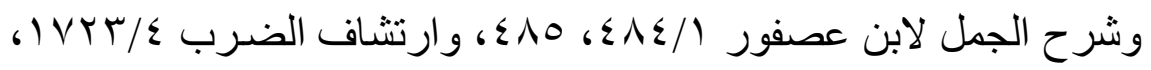

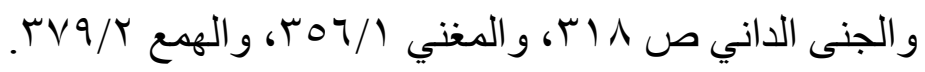

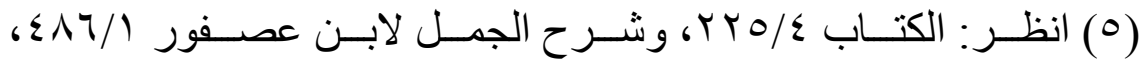

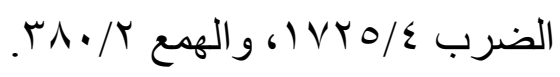

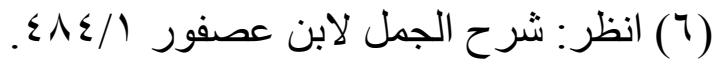




\section{r.IV إصدار}

حولية كلية اللغة العربية بالمنوفية العدد الثاني والثلاثون

فتزاد في المبتدأ وفي الفاعل وفي المفعول نائبًا أو غيرَه.

ولابتداء الغاية في غير الزمان مكانا أو غيره، لا فيه خلافا للكوفيين(')،

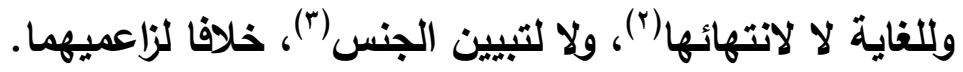

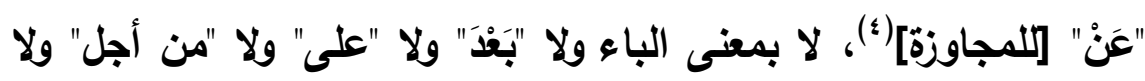

"أَنَّ"، خلافًا لزاعمي ذلك (ه).

(1) و وهو قول الأخفش و المبرد و الزجـاج و ابـن درسـتويه مـن البصـريين،

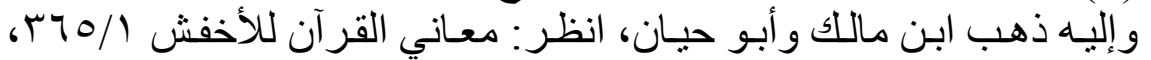

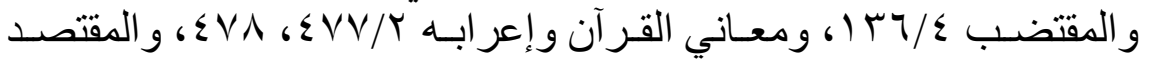

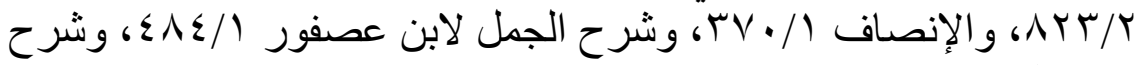

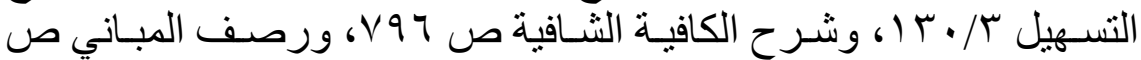

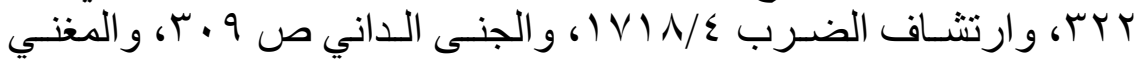
(

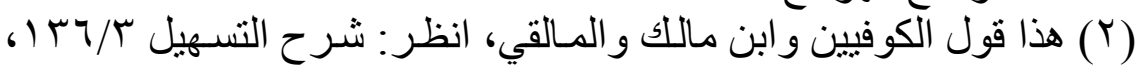

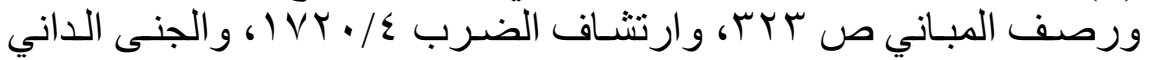
ص وردا"

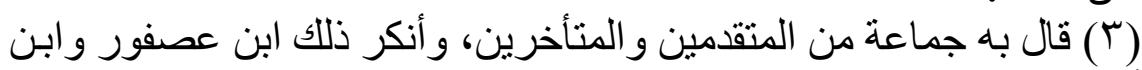

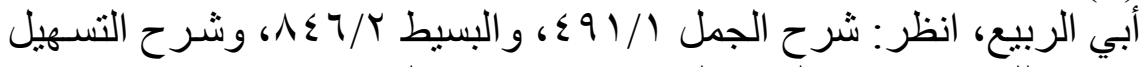

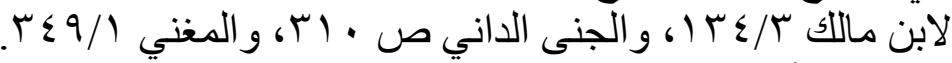

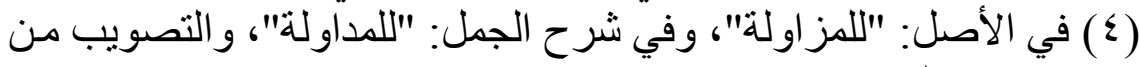
كتب حروف المعاني.

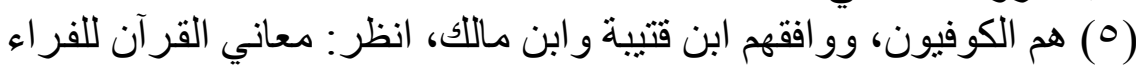

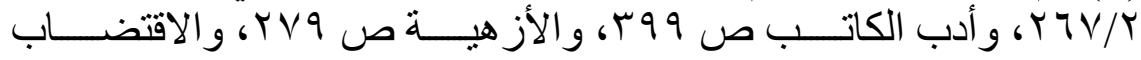

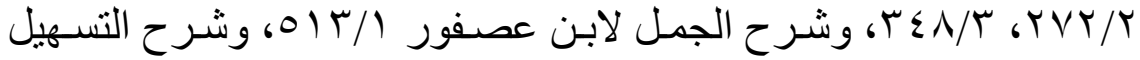

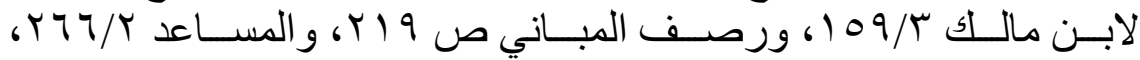

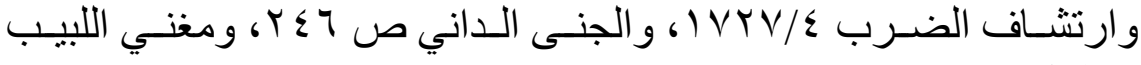
$.179 / 1$ 


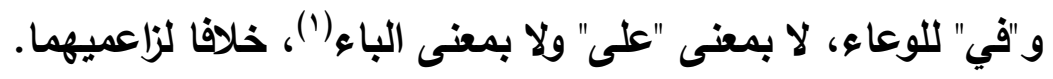

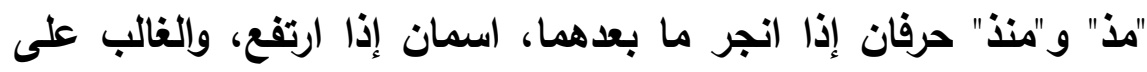

"مذ" الاسمية وعلى "منذ" الحرفية، خلافا لمن زعم لزوم اسميتهما (؟). وإذا دخلتا على الحال فلا يكون إلا مخفوضا، والحال هو اليوم والليلة والزمان وما أضفته إلى نفسك، أو ما أشرتَّ إليه، أو على الماضي والأخل "مُذْْ" ارتفع، وحُكِيَ الخفض قليلا، أو "منذ" فالعكس.

والاسم الواقع بعدهما إن كان مرفوعا معدودا فهما للغاية، أو غَيْرَ معدودٍ فهما لابتدائها، أو مخفوضا فكذلك، إلا أن يكون المخفوض حالًا، فما بعدهما غاية،، ومعناهما كمعنى "مِنْ". والرفع بعدهما قال الكسائي(َ)

(1) كلاهما قول الكوفيين وابن قتيبة، وو افقهم ابن مالك، انظر : أدب الكاتب

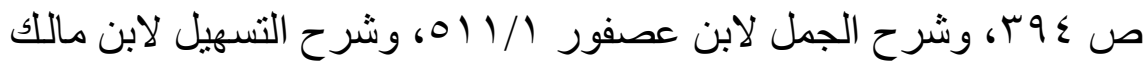

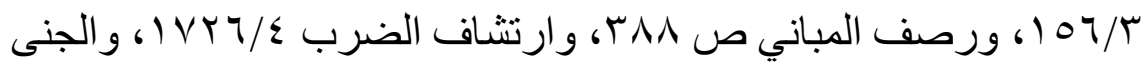

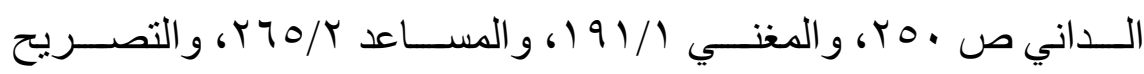
. $7 \leqslant 9 / 1$

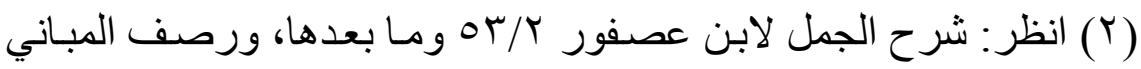

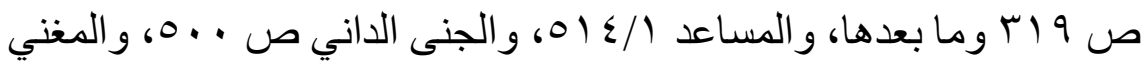
( اله

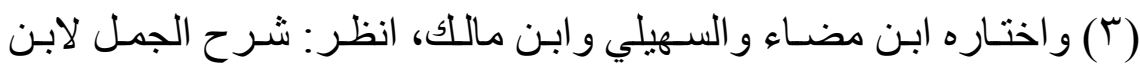

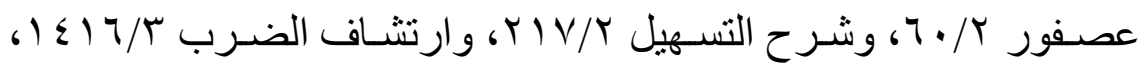

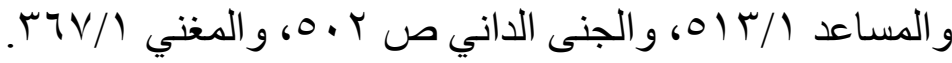




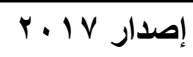

حولية كلية اللغة العربية بالمنوفية العدد الثاني والثُلاثون

$$
\text { على الفاعلية، وإلفارسي (1): على الخبرية، }
$$

و"مذ" و"منذ" مبتدآن، وهو الصحيح، وغيرهما(؟): على الابتداء، وهما

الخبر.

والتقدير على المذهب الصحيح في "ما رأيته منـذ يومـان": أَمَدُ انقطاع الروئية يومان، وفي "ما رأيته مذ يوم الجمعة": أول انقطاع [YV/ب] الروئية يوم الجمعة، ولا يجوز العطف على مجرورها، متقدمًا كان المعطوف على المعطوف عليه في الزمان أو متأخرًا، وإذا كان مرفوعا وهو لابتداعالغاية جاز عطف المتقدم والمتأخر من اسم الزمان، أو لانتهائها لم يجز عطف متقدم ولا متأخر، بل ينصب بإضمار فعل إن كان متقدما، وجاز ذلك في المنتهية، قيل: من غير شرط في المعطوف من تقدم أو

تأخر .

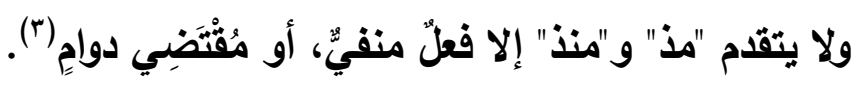

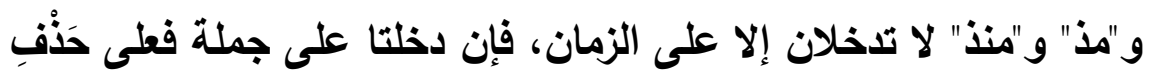

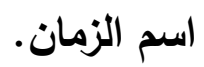

(1) انظر: الإيضـاح العضدي ص ^ • ب، وهو قول المبرد و ابن السـر اج-

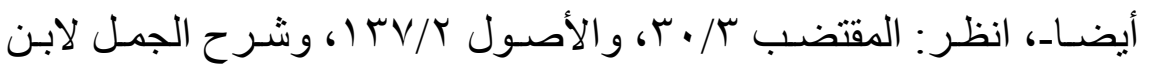

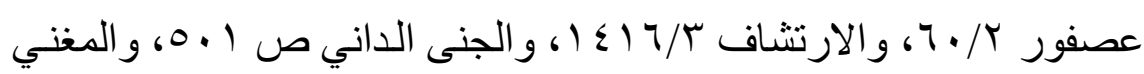


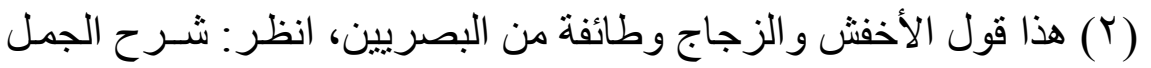

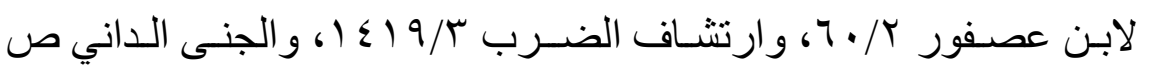

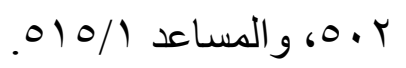

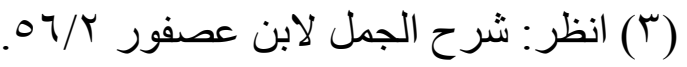


وإذا وقع بعدهما "أَََّ" فالعرب تكسر وتقتح، فإذا فتحت فقي ذلك وجهان، أحدهما: ان يكون على حذف اسم زمان مضاف، والآخر: أن تكون وما بعدها بتأويل المصدر الموضوع موضع الزمان، ويحكم على موضعه بالرفع والخفض (1). والزمان الواقع بعد "مذ" و"منذ" إذا كان معدودا فمن العرب من يعتدُ بالأول والآخر، [.......][^) إلى التجوز، وإن لم تكن الروئية في الجميع، ومنهم من لا يعتد بهما، ومنهم من يعتد بالأول، ولا يعتد بالآخر (ّ).

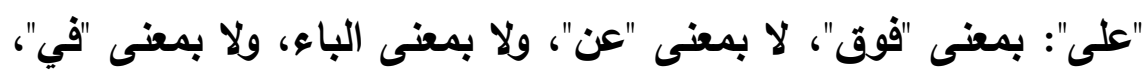
خلافا لزاعمي ذلك. "إلى": إن اقترن ما يبين المشاركة في الحكم أو الانفراد فعلى حسب ذلك، أو لم يقترن فالصحيح الأي عليه أكثر المحققين: أنه لا ياخل في حكم ما

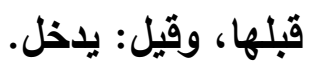
"حتى": حرف ابتداء، وعاطفة، وناصبة، وجارة. الجارة: إن وقع بعدها مفرد غير جزء مما قبلها، أو جزء لم يتوجه الحكم عليه، فالجر بمعنى "إلى"، أو توجه فالجر والعطف بمعنى الواو. وفي الحالين يشرَكُكُ المتقدمَ في الحكم، فإن جيء بعد الاسم بفعل يصلح للخبرية جاز الجر والعطف، والرفع على الابتاء،، والحمل على إضمار فعل، فيصير من باب الاشتغال، ومتى جررت أو عطقت فالجملة لا موضع

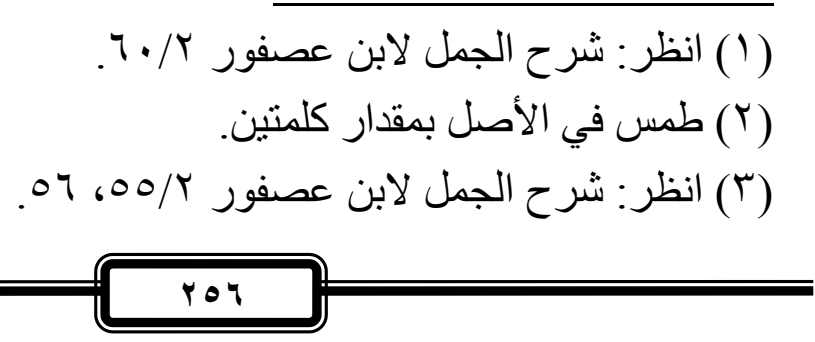


والأحسن الحمل على الاثتغال، ثم الرفع على الابتداء، ويضعف العطف

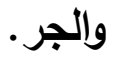

ولا يشترط في جواز الجر والعطف أن يعمل الفعل الأي بعد "حتى" في ضمير الاسم الأي قبلها، خلافا لبعض الأندلسيين. واو "رُبَّ" وفاؤها بمعنى "رُبَّ". "رُبَّب": معناها عند المحققين التقليل، وزعم بعضهم أنها للتكثير، وذلك في موضع المباهاة والافتخار، وهي جواب لسائلٍ، أو مُقَََّرٍ سؤالُْهُ. ويجب وصف مجرورها، ولا بذ لها من متعلَّي، ويجوز حذفه وحذف الوصف لاليل، وتخص النكرة، أو ضميرها مفردا مطلقا، وأجاز الكوفيون

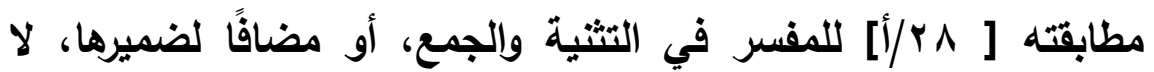

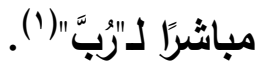

ولا ياخل على معرفة بـ"أل" خلافًا لبعضهم (º).

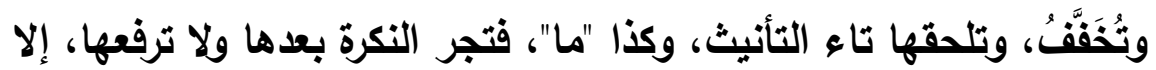
خَبَر مبتدأ مضمر، وتهيئها "ما" للاخول على الفعل، ويشترط مُضِيُّ

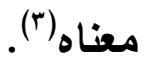

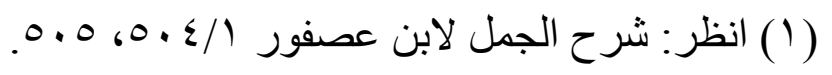

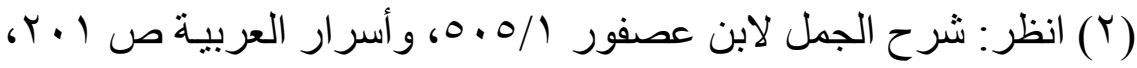

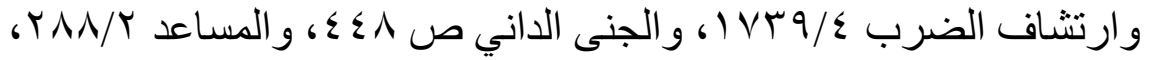

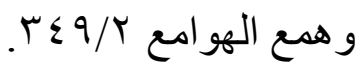

(r) هذا قول أكثر النحويين، ومنهم المبرد و الفارسي، واختاره ابن عصفور

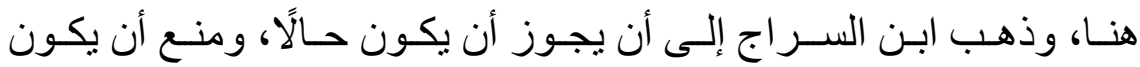

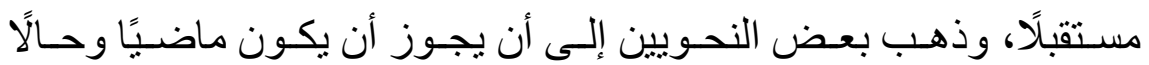

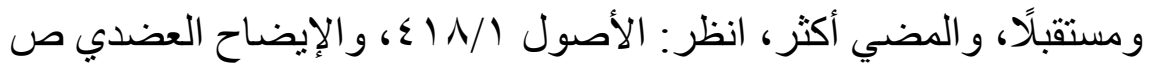


ولا يفصل بينها ويبين معمولها بشيء، ولا بالقسم، خلافا لِخَلَفٍ في

(القَسَمِ (1)

و"رُبَّ" لها صدر الكلام، وهي بمنزلة حرف زائد، فمجرورها يحكم على موضعه بالإعراب، ولذلك جاز فيه رَعْيُ الموضع إذا عطقت، فإن كان الفعل بعدها قاصرا فقي موضع رفع على الابتداء، أو متعديا رافعا ضَمِيرَ

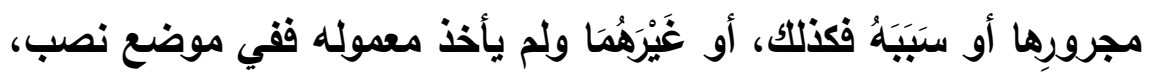

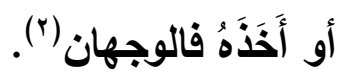
و"لعل" و"لولا" على معنييهما. ****** $* *$

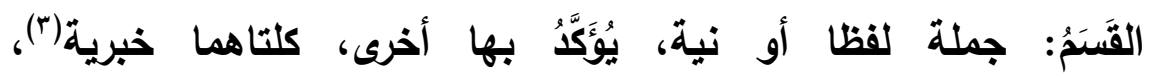

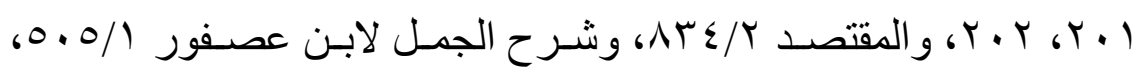

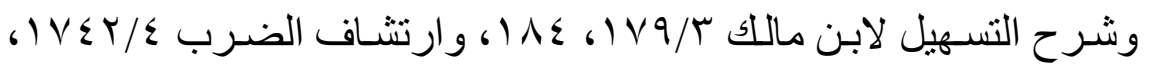

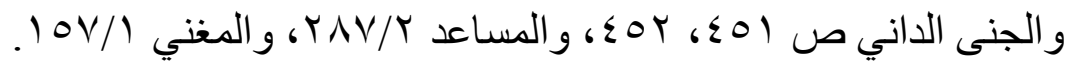

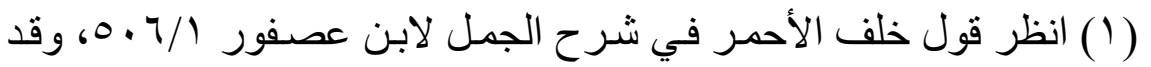

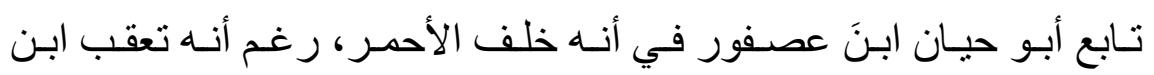

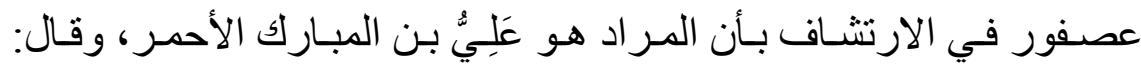

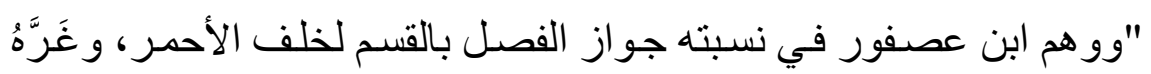

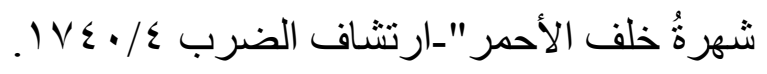

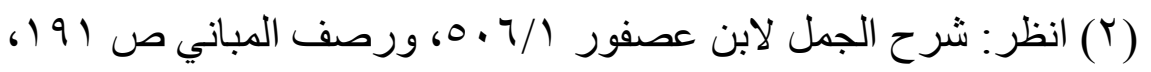

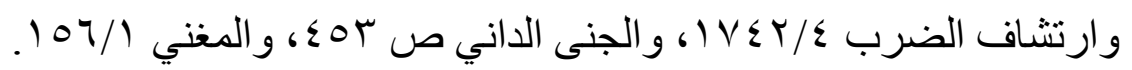

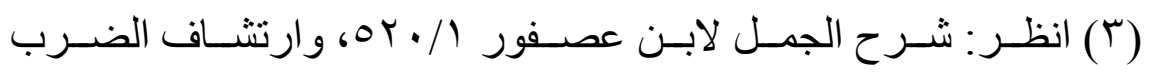




\section{حولية كلية اللغة العربية بالمنوفية العدد الثاني والثلاثون}

ولا يجاب بلام "كي" والفعل، فيكونَ المُقََْمَ عليه من قبيل المفرد، خلافًا

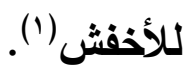

وما جاء كالقسم، وهو غير محتمل للصدق والكذب، حُمِلَ على أنه ليس

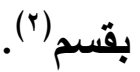

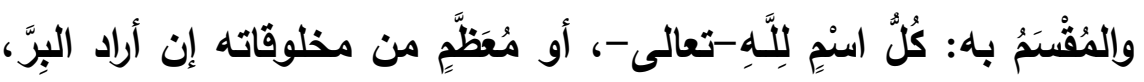

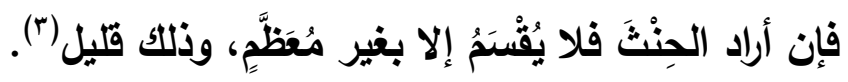

وحروف القسم تَقََََّتَّ، وأصلها: الباء، والواو بدل منها، والتّاء بدل من

الواو.

ويجوز إظهار الفعل مع الباء لا مع الواو، خلافا لابن كيسان في الواو(؛).

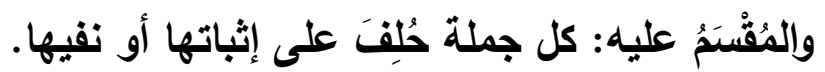

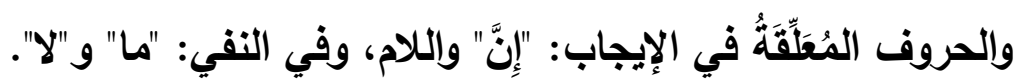

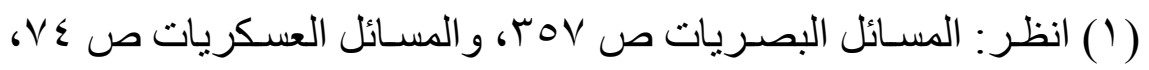

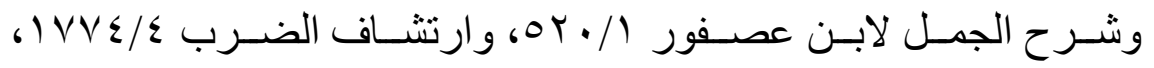

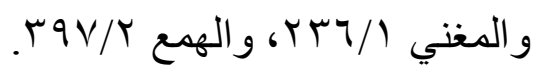

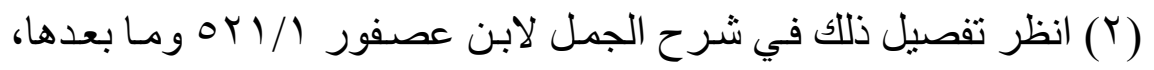

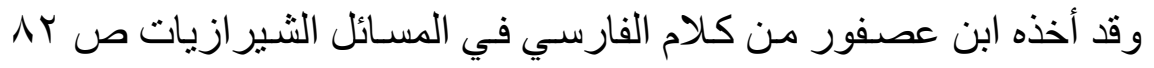

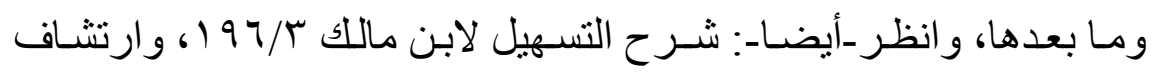

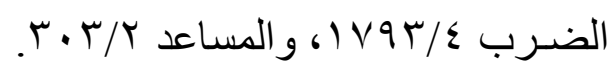

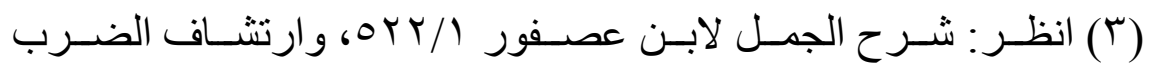

$$
\text { . } 1870 / \varepsilon
$$

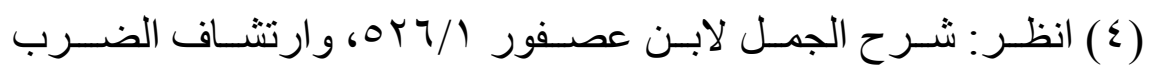

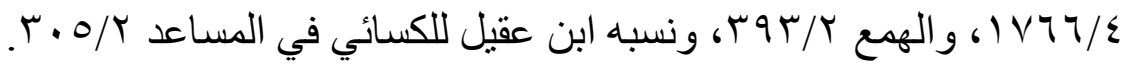




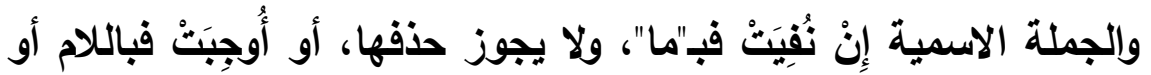

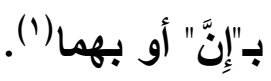

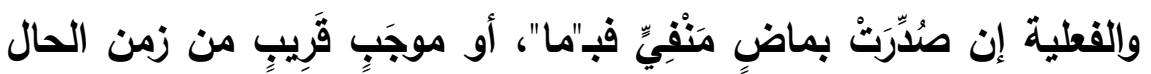

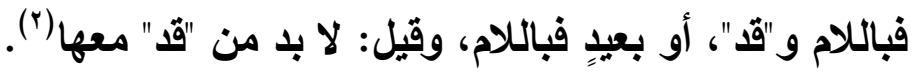
أو بمستقبٍِ مَنْفِيٍ [Y/ب/ب] فب"لا"، ويجوز حذفها، أو موجب فباللام والنون المؤكدة معها، ولا يجوز حذف أحدهما إلا ضرورة(").

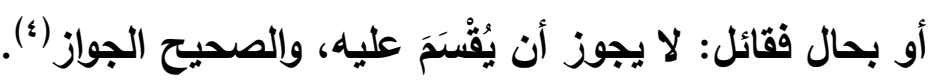
فَإن نُفِيَ فب"ما"، ولا يجوز حذفها، أو أُوجبَ فتبني منه اسم فاعل، وتُصَيِّرُهُ

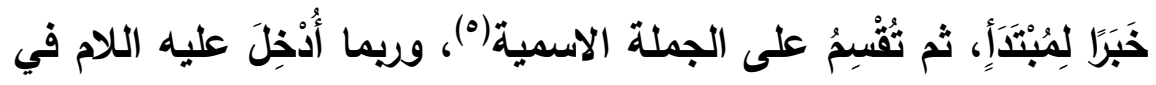

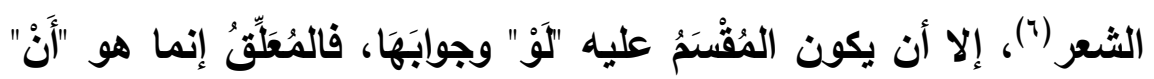

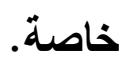

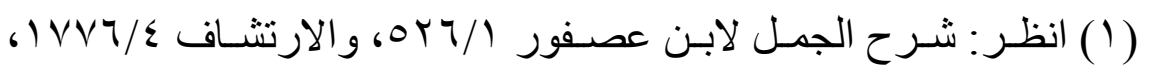

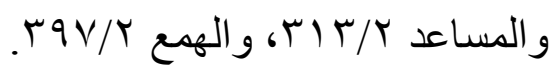

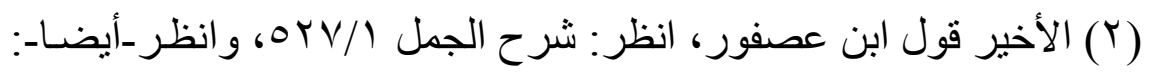

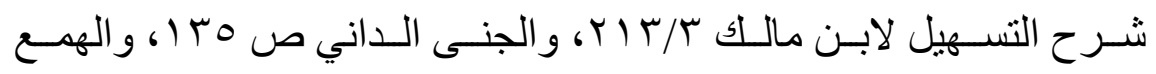
$\varepsilon \cdot / T$

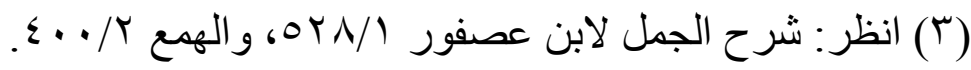

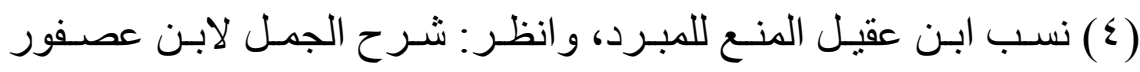
1

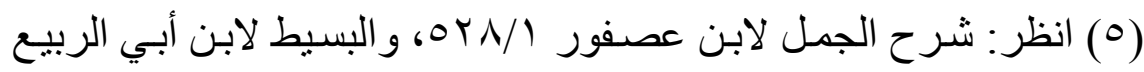

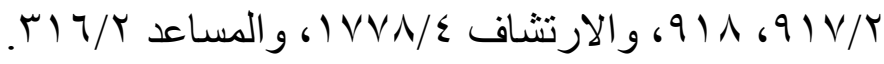

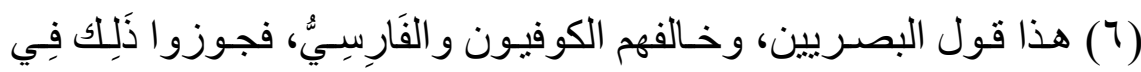

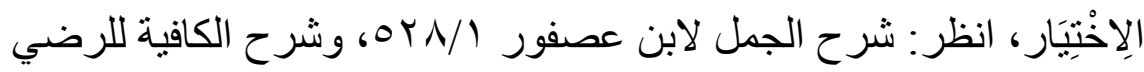

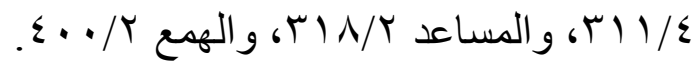




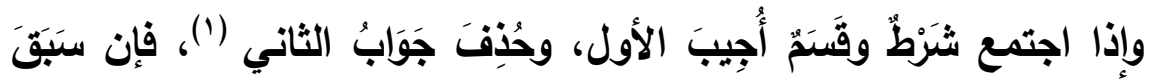

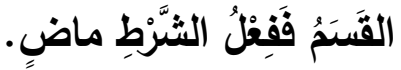

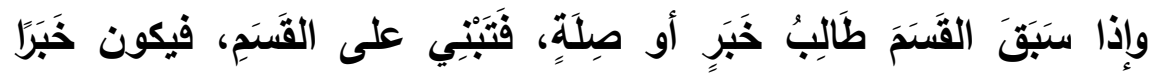

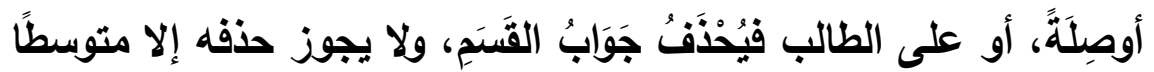

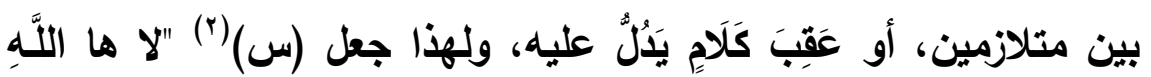

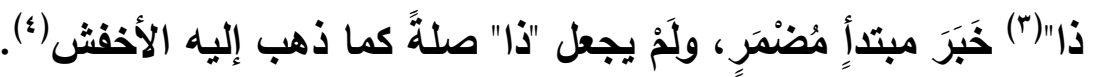
ولا يجوز حذف القسم إلا مع اللام أو "أَنَّ".

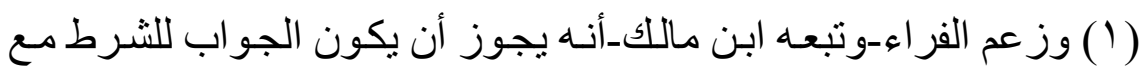

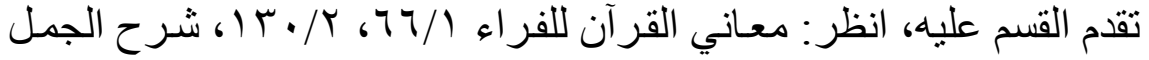

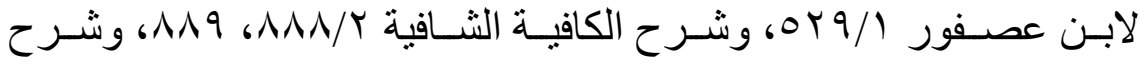

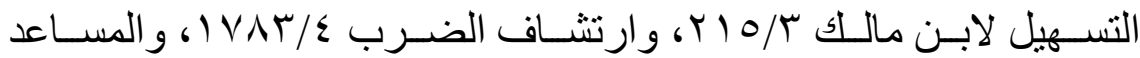

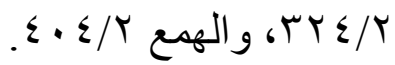

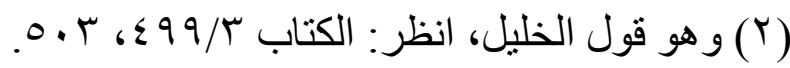

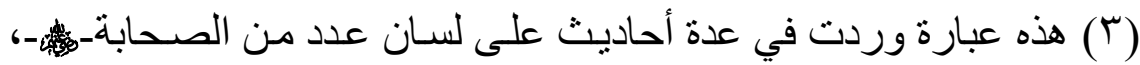

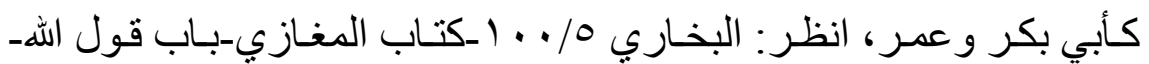
تعـالى :

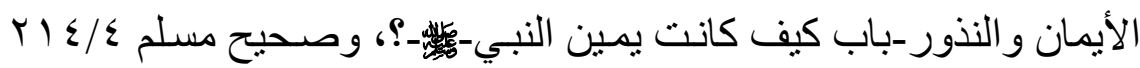
كتاب العتق-باب إنما الو لاء لمن أعتق.

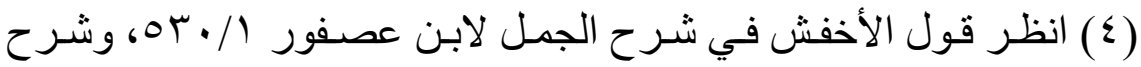

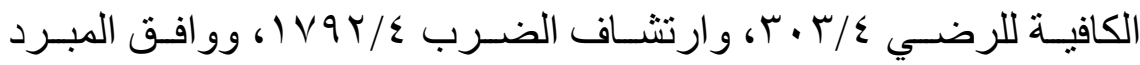

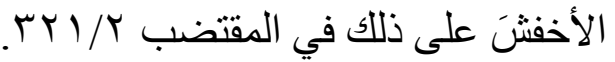


الموفور من شرح ابن عصفور

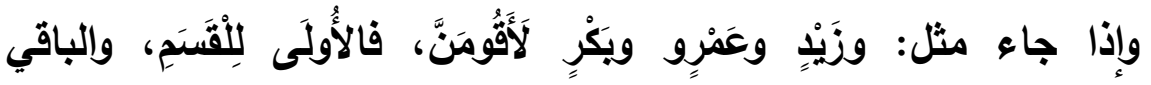

للعطف (').

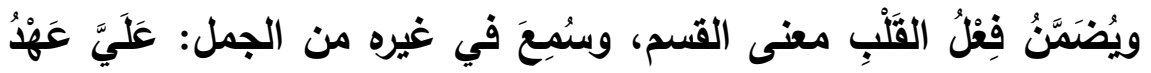

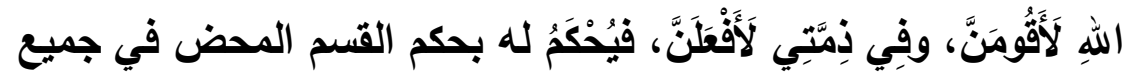

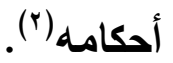

وإِذا عَوَّضْتَ من حرف القسم فالجَرُّ، والِعِوَضُ: "ها" التتبيهِ، وقَطْعُ أَلَفِ

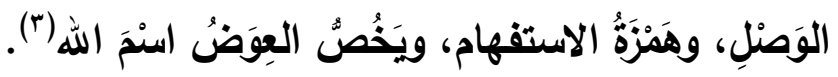
وإن لم تُعَّضض جاز الرفع على الابتداء، والنصب على إضمار فعل، وهو

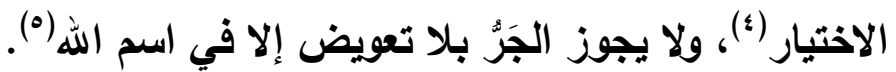

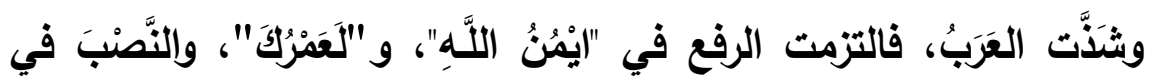

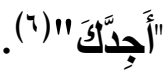

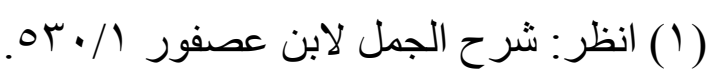

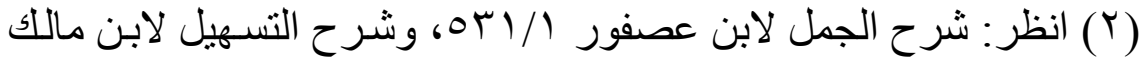

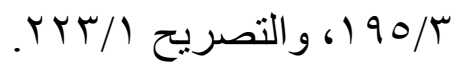

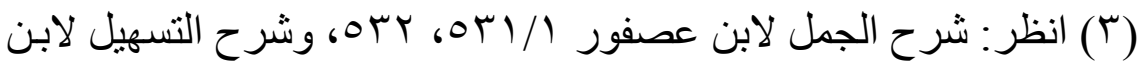
مالك س/199. 1.

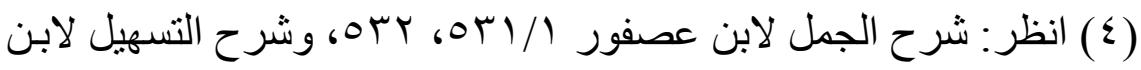

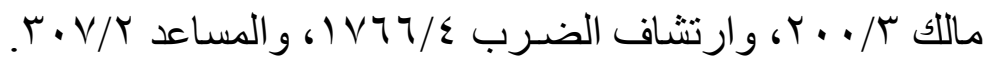

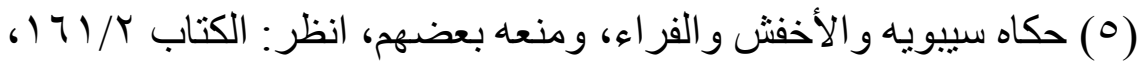

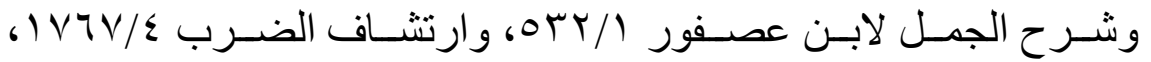

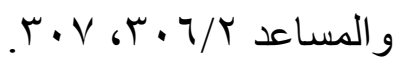

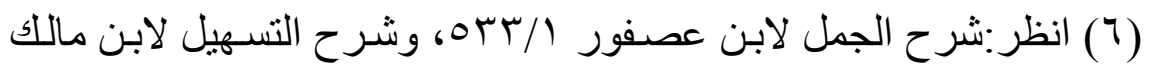

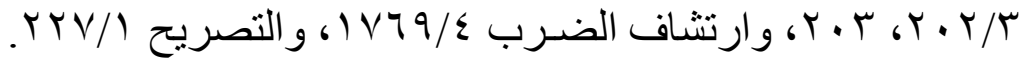


ومذهب (س) أن "ايمن" مفرد، همزته وصل، مشتق من اليُمْنِ (') ومذهب

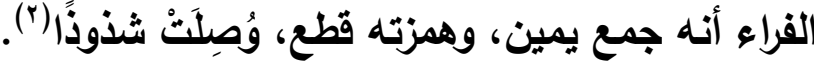

وأما "عَوْضُ" و"جَيْرِ" فمبنيان، يُحْكَمُ على موضعهما بالرفع والنصب(َ) $\cdot[1 / Y 9]$

******

الإضافة: محضة وغير محضة، فغير المحضة لا يكتسب المضاف من المضاف إليه تعريفًا إن أضيف إلى معرفة، ولا تخصيصا إن أضيف إلى نكرة (๕)

وتتحصر في اسم الفاعل، واسم المفعول، والأمثئة إذا أضفن بمعنى الحال والاستقبال، والصفةِ المشبهةِ، واسم الزمان المضاف إلى الجملة، والصفة

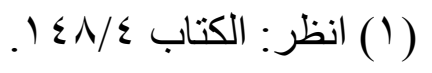

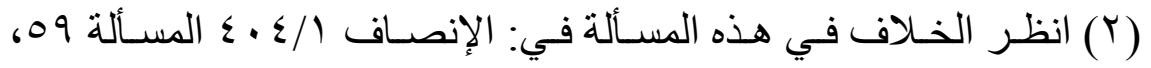

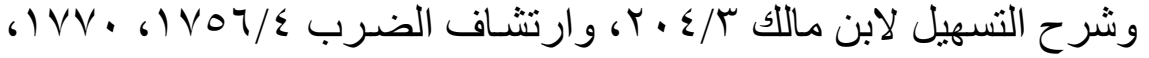

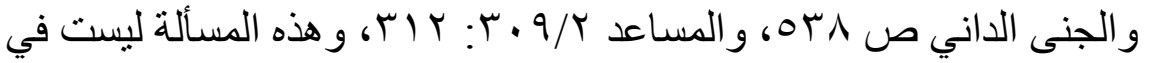
شرح الجمل لابن عصفور، بل هي مماز اده أبو حيان.

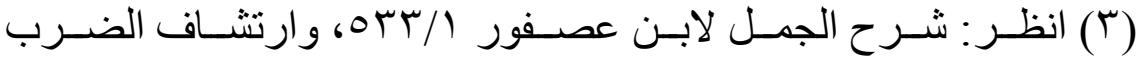

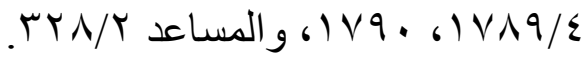
( ) انظر : شرح الجمل لابن عصفور r/ • V. 
المضافة للموصوف، والموصوف المضاف للصفة(')، و"أفعل" التفضيل(؟)، على خلاف في الثلاثة الأخيرة، والصحيح(") أن إضافة ذلك غير محضة.

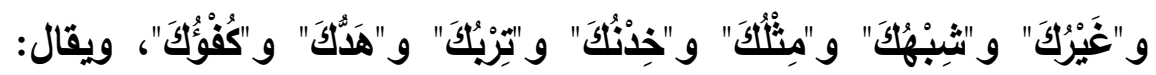

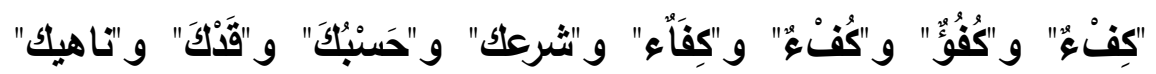

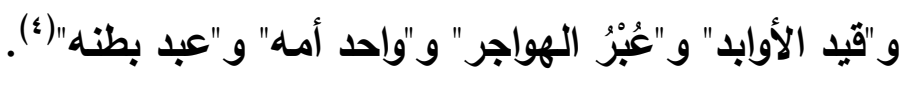
وذهب ابن السراج إلى أن غيرا ومثلا وأخواتهما إذا كان المغاير والمماثل

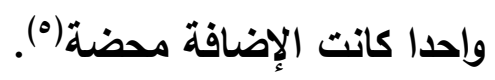
والمحضة: بمعنى "مِنْ"، وهي إضافة الجزء للكل، بشرط صدقه عليه، ويمعنى اللام (†).

(1) ذهب الكوفيون و الفارسـي وابن الدباس إلى أن إضـافة أفعل التفضبل

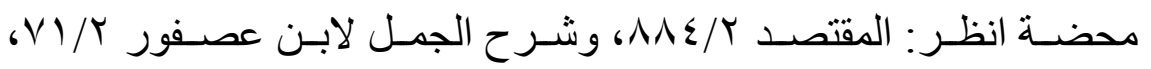

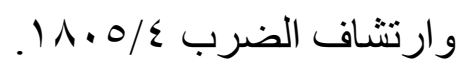

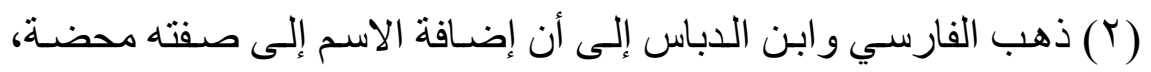

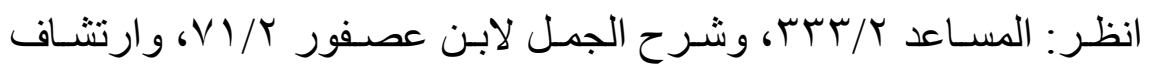

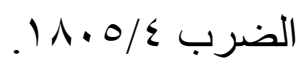

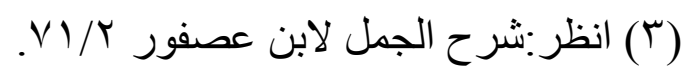

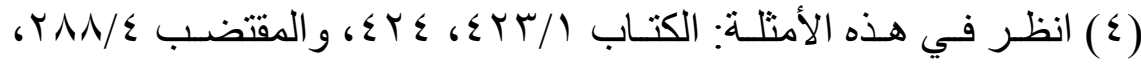

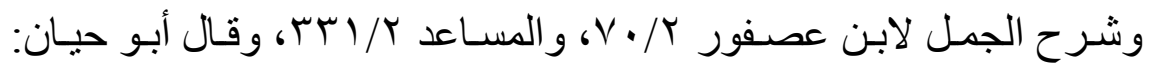

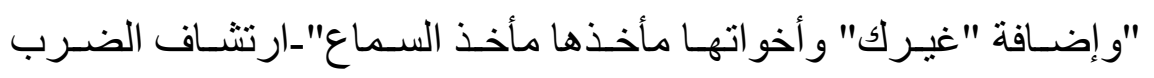

$$
.11 \cdot r / \varepsilon
$$

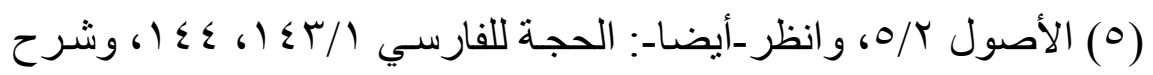

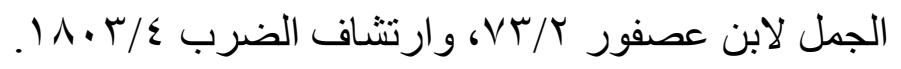

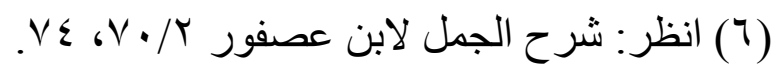


ويُحْذَفُ من المحضة التنوينُ من الاسم الأول، واللام أو "مِنْ" من الثانسي، ويجوز الانفصال في جميعها، إلا في "غيرك" وأخواتها، وما استثناه

الزجاجي في حروف الخفض('). ويجوز في التي بمعنى "مِنْ" الإضافةُ، والنصبُ تمييزًا أو حالاً، والإنْبَاعُ، وهو الأَقََلَ. ولا يُجْمَعُ بين "أل" والإضافِةِ، لا لمعرفة ولا لنكرة. ****** $* *$

\section{التّوابع}

النعت، والتأكيد، وعطف البيان وينفرد بها الاسم(؟)، وعطف النسث، والبدل

ويشترك فيهما الاسم، والفعل (ז).

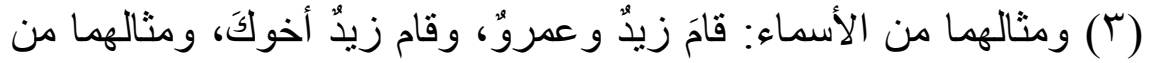

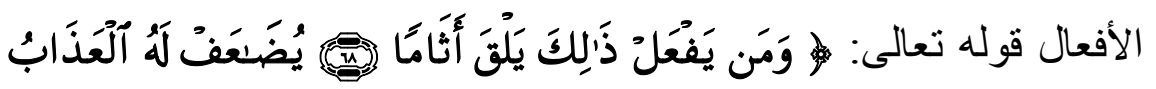

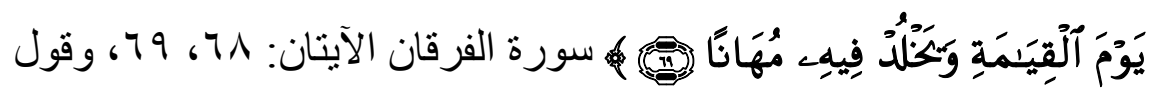

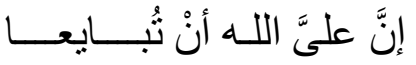
الر اجز :

$$
\text { راجع: شرح الجمل لابن عصفور / } 19 \text { اؤخذ كر أو تجيء طائعا }
$$




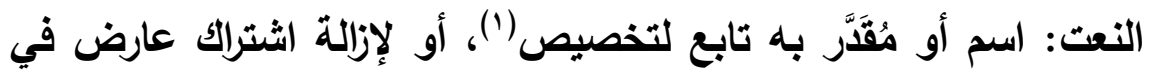
معرفة، أو مدح، أو ذم، أو ترحم، أو تأكيا بما يذل على حلية أو نسب أو لها لها

\section{فعل أو خاصة (؟).}

والمُقََّّر به الظرف، والمجرور التامان، والجملة الخبرية وفيها ضمير يعود على موصوف، وحكمه في الحذف [9 ب/ب] والإثبات حكم الضمير العائد على الموصول إلا أن يكون مرفوعاً، فإنه يجوز حذفه مبتـأ كان أو غيره، ولا يوصف بالمقر بالاسم إلا النكرة، فإن أردت أن تصف به المعابه المعرفة جعلته في صلة موصول. ولا يجوز أن يكون النعت للمدح، ولا للأم، ولا للترحم إلا إذا كان المنعوت مومول معلومًا أو منزلًا منزلته. والنعت إن رفع الضمير وكان مشنقًا جاريًا (ّ) تبع في أربعة من عشرة: واحد من وجوه الإعراب، وواحد من التعريف والتنكير، وواحد من الإفراد والتثية والجمع، أو غير جار تبع في ثلاثة من ثمانية(؛)، ويسقط التذكير

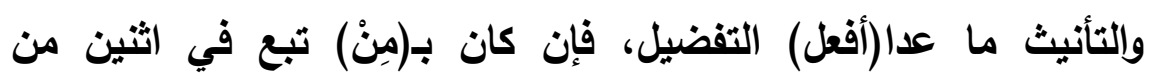
خمسة، واحد من وجوه الإعراب، وواحد من التعريف وإلتنكير.

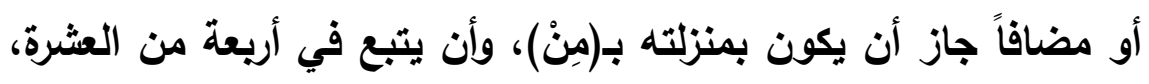

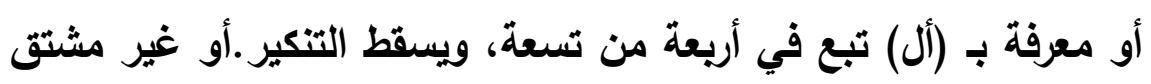
منسوب جرى مجرى المشتق الجاري فيتبع في أربعة من عثرة، أو غير

$$
\text { ( ) ( ) أي لتخصيص نكرة. }
$$

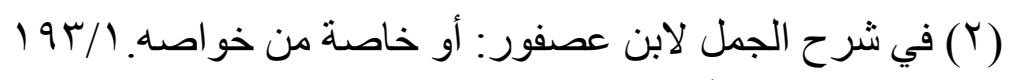

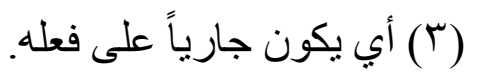

( ( ) وهي: الرفع و النصب و الخفض، والتعريف و التتكير، و الإفر اد و التنثية

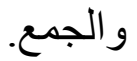


منسوب فلا يتبع إلا في أربعة من ثمانية ما عدا ( أيَّا ) ، فإنها تفرد وتذكر على كل حال، ولا تثى ولا تجمع، ولا يلزم تأنيثها فيتبع في اثنين من خمسة واحد من وجوه الإعراب والتتكير وما عدا مِثْلا، وتذَّكر وتفرد على كل حال. وقد يجوز جمعها وتثنيتها، وأما إذا كاتت غير مضافة،

فليزم تثنيتها وجمعها (1).

والوصف بالمصدر من قبيل ما هو في حكم المشتق والوصف به طريقان أحدهما: المبالغة على جعل الموصوف هو المصدر مجازاً لكثرة وقوعه منه.وزعم الكوفيون أن المصدر وقع موقع الصفة(ז)، ولا يثى ولا يجمع ولا يؤنث إذا وصف به وتأنيثه شاذ، وتأنيثه وجمعه موقوف على السماع.

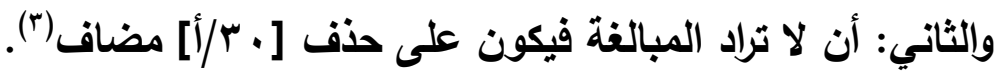
وإن رفع النعت ظاهرًا من سبب المنعوت(أ) تبع في اثثين من خمسة، وهي: وجوه الإعراب، والتعريف والتتكير.وأما الخمسة الباقية فيتبع فيها السبب على لغة أكلوني البراغيث، وأما في اللغة الفصيحة فيكون مفرداً على كل حال، ويتبع في التذكير والتأنيث خاصة للسببي. والنعت مطابق للمنعوت في الإعراب لفظاً إلا فيما له لفظ وموضع، فيجوز أن يتبع على لفظه وعلى موضعه وسيأتي بيانه في باب العطف. والنعت مساوٍ للمنعوت في التعريف أو أقل منه تعريفًا، ونذكر النكرة وإلمعرفة ومراتبها في باب المعرفة والنكرة.

( ( ) تقول:( مررتُ برجُلين مِثَلَيْنِ، وبرجالٍ أمثنال ).

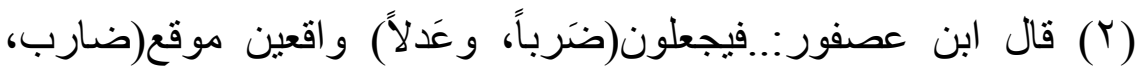

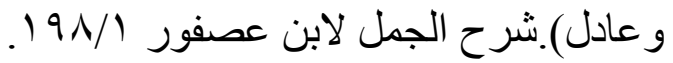

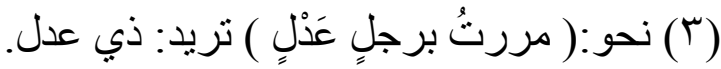
( ) نحو:( مررتُّ برجلٍ قائم أبوه ). 
والأسماء قسم لا ينعت ولا ينعت به وهي: المضمرات، وأسماء الشرط، وأسماء الاستفهام، وكم الخبرية، وكل اسم متوغل في البناء.

وقسم ينعت ولا ينعت به وهو: العلم(1)، وقسم ينعت وينعت به وهو: المشار، والمشتق، وما في حكمه.

والنكرة لا تنعت إلا بالنكرة، والعلم، والمضاف ومل إلى الضمير ينعت بالمشار ويالمضاف لمعرفة، والمشار بذي أل(؟)، والمضاف إليه(؟) بمثنه(؛)، ويذي أل ويالمضاف إليهما.(0) وذو أل، والمضاف إليه بمثثهما(؟). والنعت إن تكرر أو لـ يتكرر، والمنعوت مجهول، فالإتباع إلا إن جعله

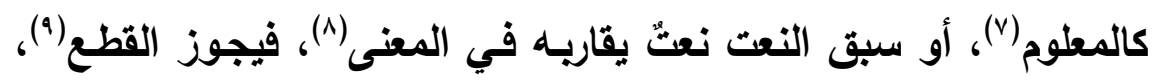

$$
\begin{aligned}
& \text { (1) نحو:( زيد، و عمرو، ومكة ). }
\end{aligned}
$$

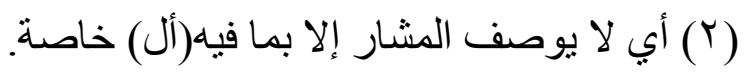

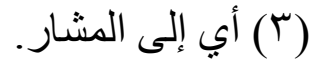

$$
\begin{aligned}
& \text { ( ) ( ) أي بالمشار. }
\end{aligned}
$$

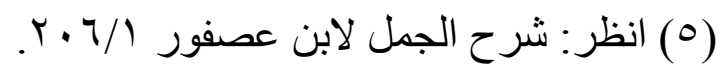

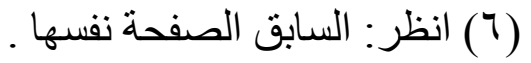

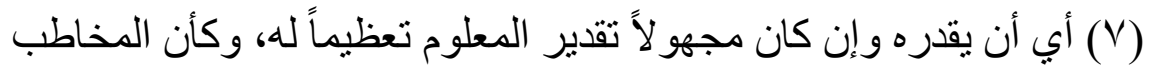

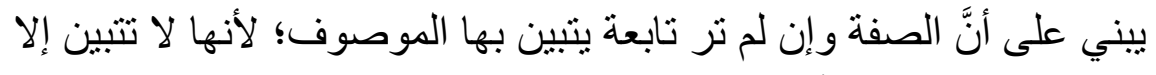

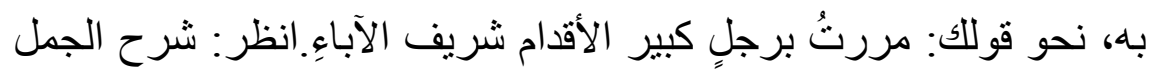

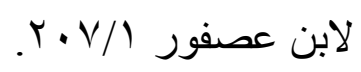

(^) أب أن تكون الصفة المقطو عة قد تقدمها صفة متبعة تقاربها في المعنى، وذلك نحو قولك: ( مررت برجلٍ شجاعٍ فارسٌ )؛ لأن الثجاعة تفهم منها

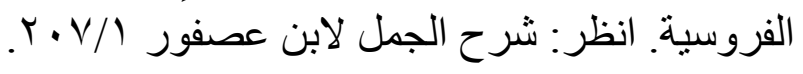

$$
\begin{aligned}
& \text { (9) أي مع الإتباع. }
\end{aligned}
$$


أو معلوم وهو لغير مدح أو ذم أو ترحم فالإتباع، أو لا يكون فالإتباع(')،

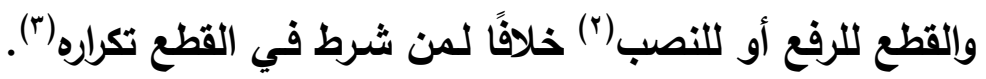
وفي المتكرر يجوز قطع بعض، وإتباع بعض، ويبدأ بالإتباع قبل القطع والعكس ممنوع(؛)، ويجوز العطف إن اختلفت النعوت أتبعته أو قطعته (ه). وإذا اجتمع نعوت ومناعيت أو [·r/ب] فرقا أو جمعت نعوت وفرق مناعيت، فكل منعوت منها يعرب بالإتباع والقطع في أماكنه. أو فرق نعوت وجعمت مناعيت فيجوز في جميع الأسماء إلا في اسم الإشارة، فلا يجوز تفريق النعوت وجمع المناعيت(؟).

$$
\text { (1) نحو:( مررت بزيدٍ الطويلِ وبزيدٍ الأزرقِ ). }
$$

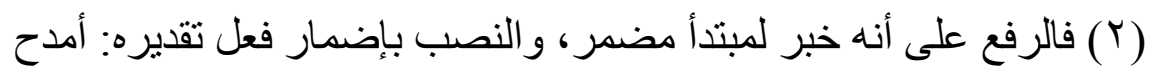

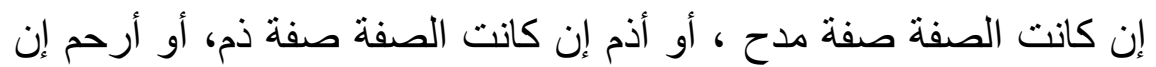
كانت الصفة صفة ترحم.

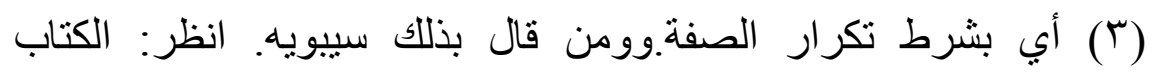

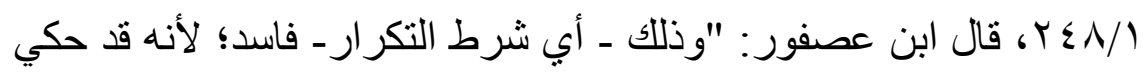

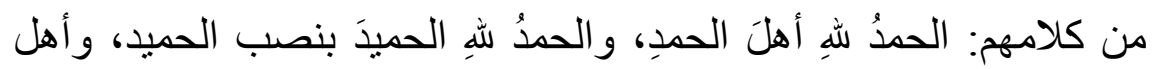

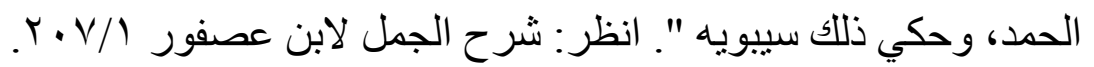

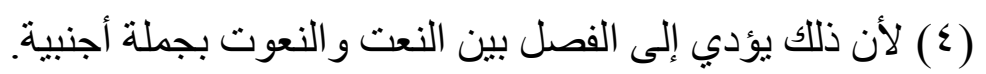

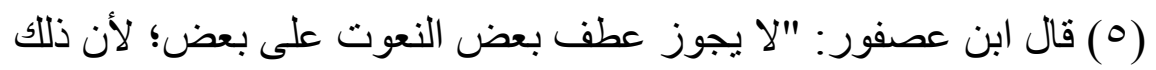

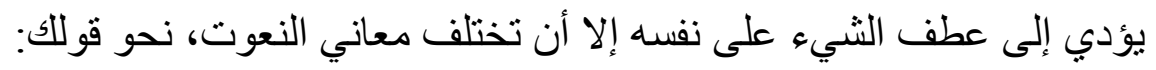

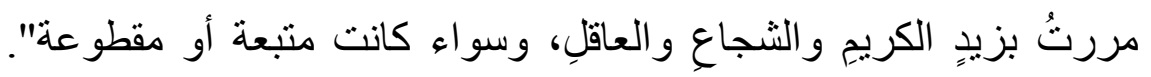

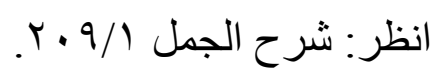

(ד) أي لا يجوز أن تقول: مررت بهذين الطويلِِ و القصيرِ. 
ومتى فرق نعوته وجمع مناعيث واختلف الإعراب، فالقطع خلافا للفراء ، إذ يجيز(') الإتباع في المتفق المعنى، فيوجب تغليب المرفوع، ولابن سعدان (ץ) ) ، إذ يجيزه. أو اتفق واختلفت عرفا ونكرا واتفقت فيهما وأحدهما مستفهم عنه والآخر ليس كذلك فالقطع أو كلاهما مستفهم عنه، أو لم يكونا كذلك واتحد العامل جاز أو لم يتحد، واختلف جنسه فالقطع خلافاً للجرمي(ّ) في جواز الإتباع.

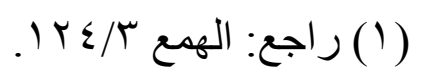

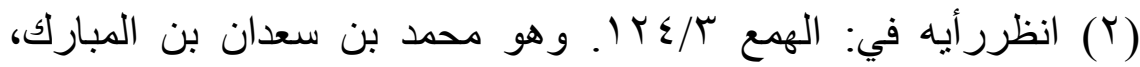

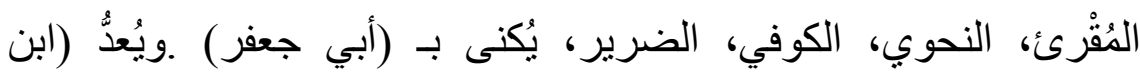

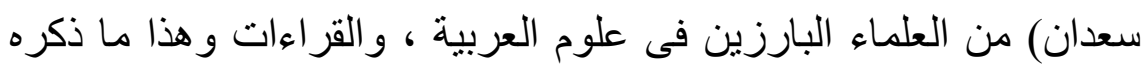

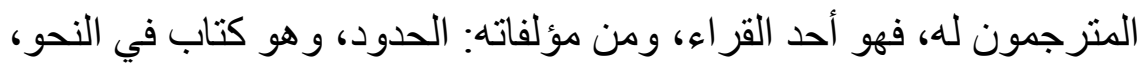
ومختصر النحو وغير ذلك. توفي يوم عرفه سنة إحدى وثناثثن ومائتين.

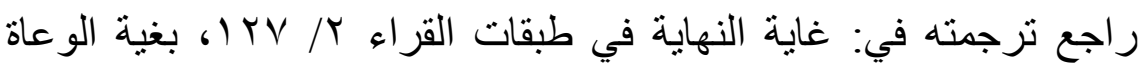

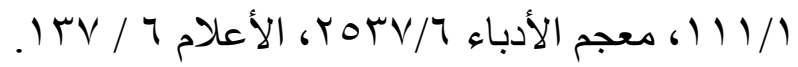

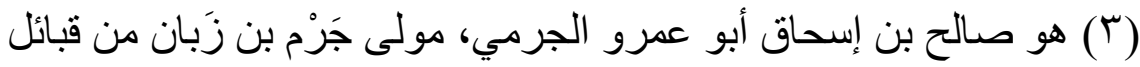

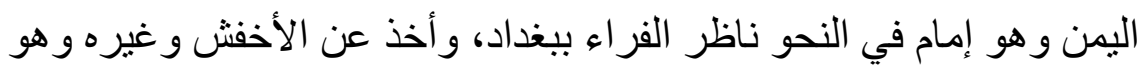

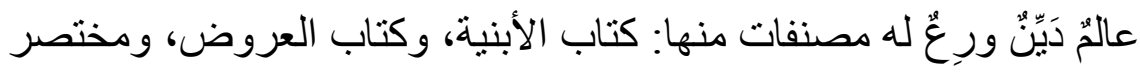

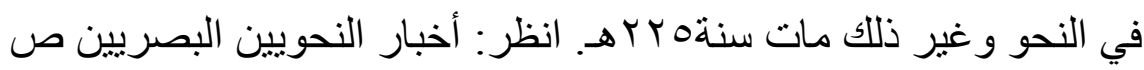

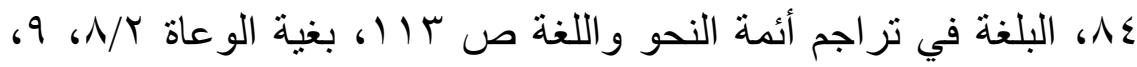
نشأة النحو ص البعه صي لرحاج 77. 
أو اتفق واختلف لفظاً ومعنيً أو معنيً لا لفظاً جازا خلافا للمبرد(')، وابن السراج(r) في منع الإتباع. أو اتفق في مقابليهما جازا خلافا لابن السراج في الإتباع إلا أن تقدر العامل الثاني في مقابل الأول توكيداً، فيجيزه فيها.

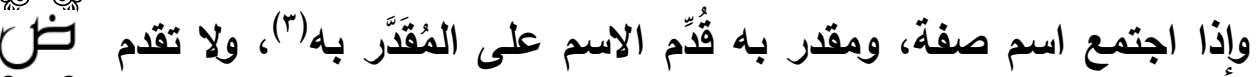
صفة على موصوف إلا حيث سمع وذلك قليل، وللاعرب فيما وجد من ذلك وجهان: أحدهما: أن تُقدّم الصفة وتبقيها على ما كانت عليه(؛)، وفي إعراب مثل هذا وجهان: إعرابه نعتاً مقدماً، والثاني: أن تجعل ما بعد الصفة بلاًا منها. واللوجه الثاني: أن تضيف الصفة إلى الموصوف إذا قدمتها(•).

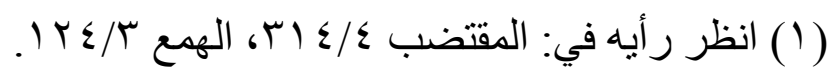

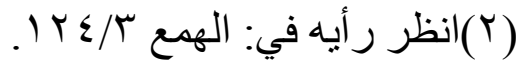

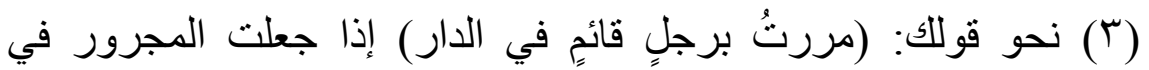
موضع الصفة لرجل، ولا يجوز أن تقول : ( مررتُ برجلٍ في الدار قائحٍ) إلا في ضرورة شعر أو في نادر كلام.انظر: شرح الجمل لابن عصفور r)

(ع) كقول النابغة الذبياني: و المؤمنِ العائذاتِ الطيرُ تمسحها ركبان مكة بين الغيل و السند

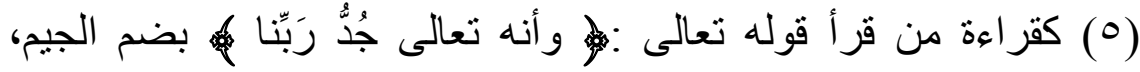
و أصله:( ربُّنا الجدُّ )، أي العظيم، فقدِّت الصفة وحذفت منها الألف و اللام

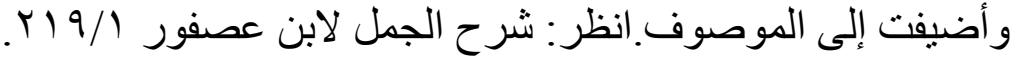


والصفة المقدرة بالاسم لا يجوز حذف موصوفها وإقامتها مقامه إلا مـع (مِنْ) أو يكون صفة لتمييز (تِعْمَ )(')، وما عدا ذلك ضرورة.

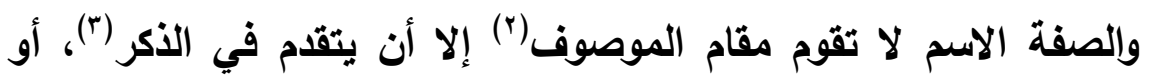

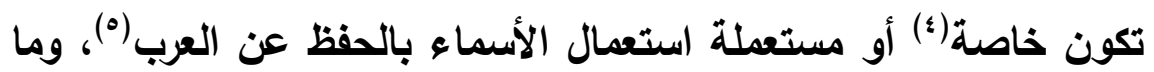
عدا ذلك ضرورة.

ولا يجوز الفصل بين الصفة والموصوف بأجنبي إلا إن كان جملة اعتراض (`)، ولا يفصل بغير ذلك إلا ضرورة. وقد يضاف [ آ/أ] الموصوف إلى صفته، ولا ينقاس. ****** $* *$

$$
\begin{aligned}
& \text { ( (1) نحو قولهم:( نعَمَ الرجلُ يقومُ ) نريد: نِنْمَ الرجلُ رجلاً يقومُ. }
\end{aligned}
$$

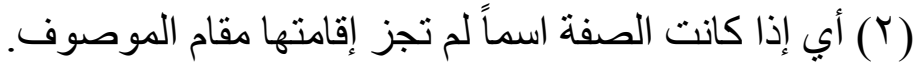

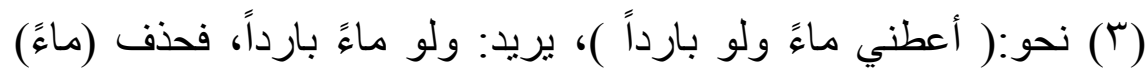
لالالة المقدَّم عليه. ( ) نحو:( مررتُ بكاتبٍ )، يريد:( برجل كاتبٍ )؛ لأن الكتب خاص بجنس العقلاء. (0) نحو:( الأبطح، و الأبْرَقِ ) في صفة المكان. (ך) فال ابن عصفور في شرحه للجمل: " وجملة الاعتر اض هي التي يكون

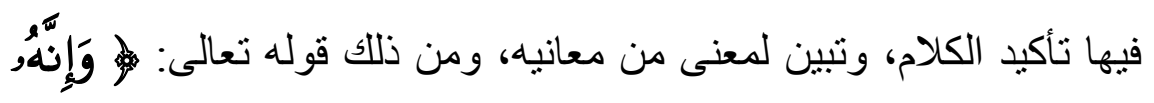

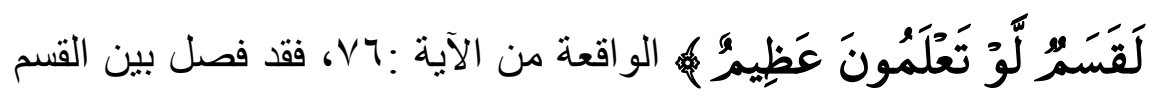
وصفته و هو(عظيم ) بقوله:( لو تعلمون)؛ لأن تقدير الكلام: لو تعلمون ذلك

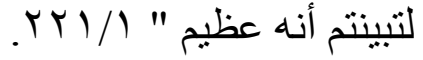


عطف النسق : حمل اسم أو فعل أو جملة على نظيره بشرط توسط حرف من الحروف(1): الواو، والفاء، وثث، وحتى ، وأو ، وأم ، ويل ، ولا بل ، ولكن خلافاً ليونس في (لكن) (؟). وليس لا بعطف بها خلافاً للبغداديين(ّ)، ولا بـ (كيف ، وأين ، وهلا ) خلافاً للكوفيين (؛).

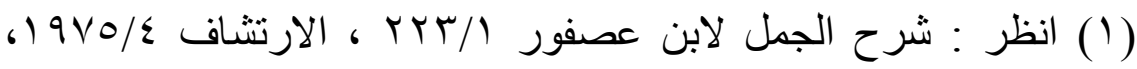

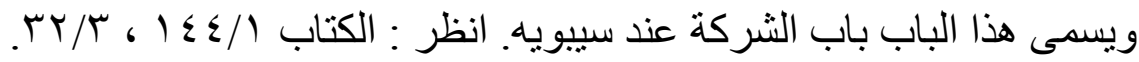

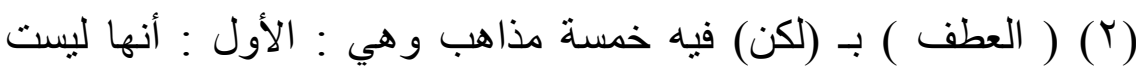
بحرف عطف ، بل هي حرف استدرالك ، والعطف بالواو ـ وهو مذهب الب

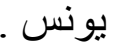

الثاني : أنها حرف عطف ، وهو مذهب أكثر النحويين . الثالث : أنها عاطفة بنفسها ، و لا بد في العطف بها من الواو قبلها ، و الواو زائدة قبلها إذا مها

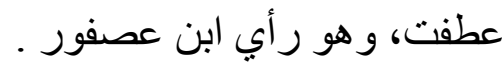
الر ابع : أن العطف بها وأنت مخير بين أن تأتي بالو او ، أو لا تأتي بها وهو

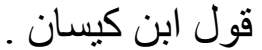
الخامس : أن العطف بها هو من عطف الجمل لا من عطف المفردات ، والواو هي العاطفة .

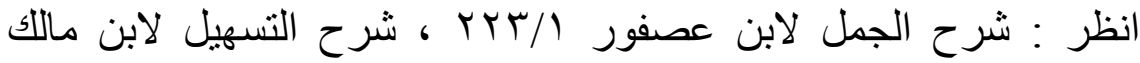

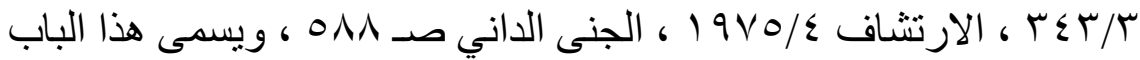

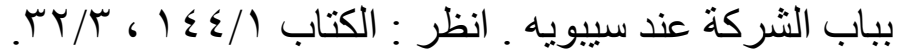

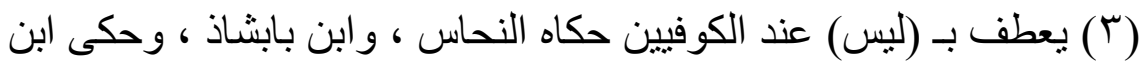

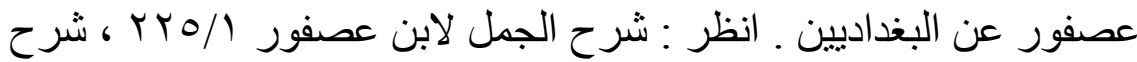

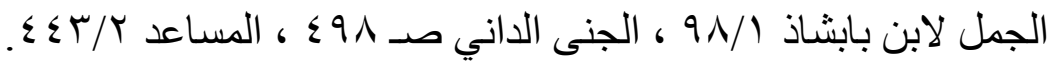

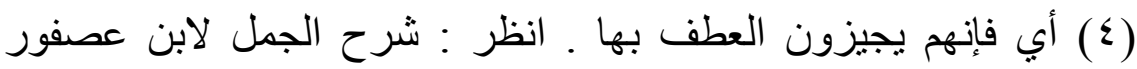
THT ، rTO/1 
والأريعة الأقرب تثرك في اللفظ والمعنى ، وياقيها في اللفظ خاصة.

الواو : لمطلق الجمع لا للترتيب خلافاً لبعض الكوفيين(').

الفاء : للترتيب مطلقًا(؟)، ولا تلل عليه أن تسبب أحد الفعلين عن الآخر عند الفراء(ז)، ولا في الأماكن والمطر عند الجرمي(؛) ، وهي كالواو في أنها لا ترتب عند طائفة من الكوفيين (०). ثم : للترتيب والمهلة لا كالواو خلافاً لبعضهم (؟).

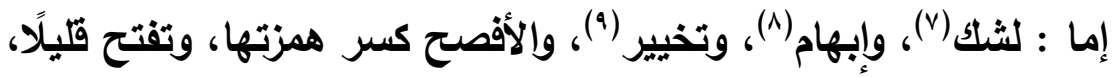

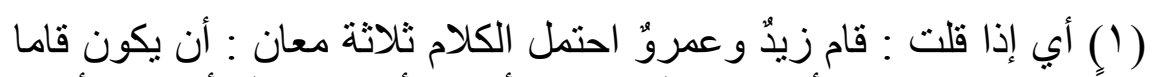

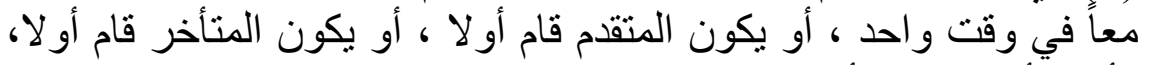

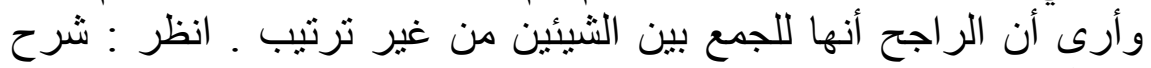

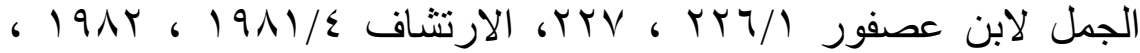

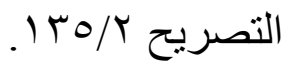
(Y) و هو مذهب جمهور البصرين (ب) في كل موضع .

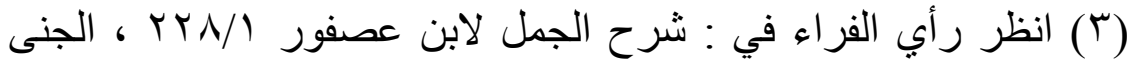

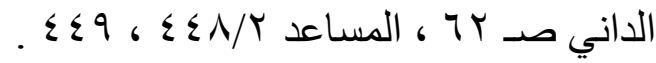

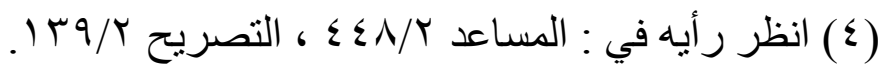

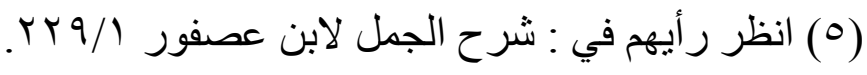

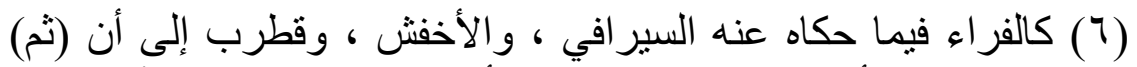

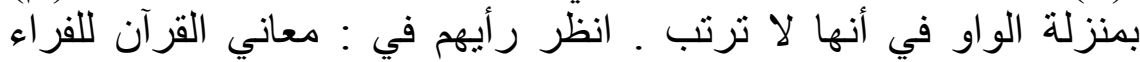

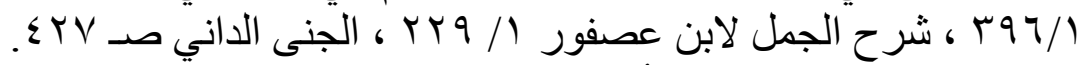

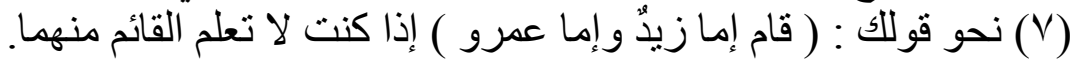

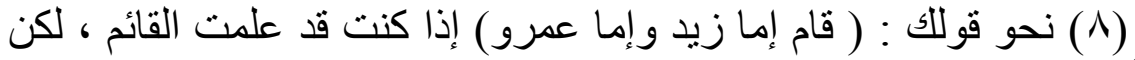
أردت الإبهام على المخاطب.

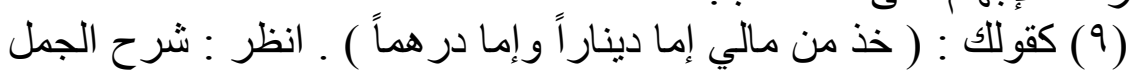

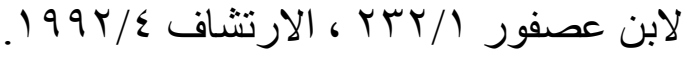


والمستعمل تكرارها، وقد لا تكرر إن أغنى عن التكرار "أو" و"إلا"، وقل أن لا تكرر بغير مغنٍ، وهي مركبة من ( إن ، وما)(' (1)

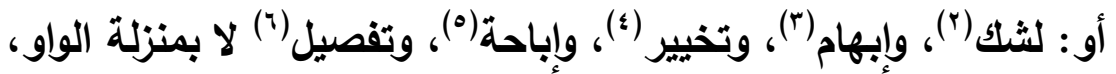

ولا بمعنى (بل) خلافاً للكوفيين (v).

أم: المنفصلة يتقدمها الاستفهام والخبر، ولا يليها إلا الجملة، وتتقدر بـ لضّل

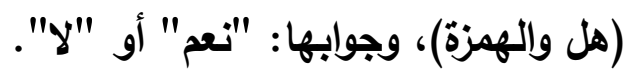

والمتصلة لا يتقدمها إلا الهمزة ، ولا يليها إلا مفردا ومقدر به ، وجوابها: أحد الثيئين أو الأشياء، والأحسن توسبط ما لا يسأل عنه بين المسئولين عنهما، ويجوز تقديمه وتأخيره.

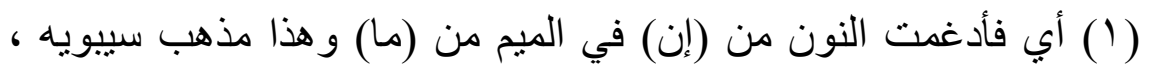
وذهب غيره إلى أنها بسيطة غير مركبة وهو الأولى ؛ لأن الأصل في من وني

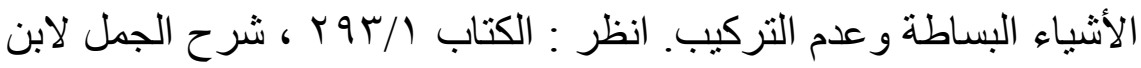

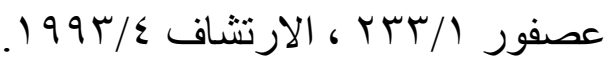

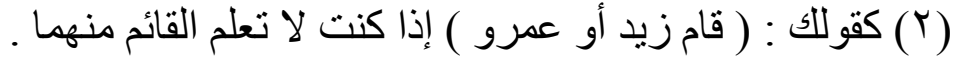
(Y) كقوللك : ( قام زيدٌ أو عمرو ) وأنت تعلم القائم منهما إلا أنك أبهمت على المخاطب .

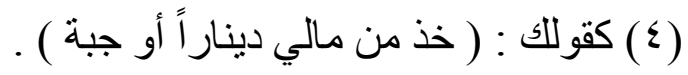

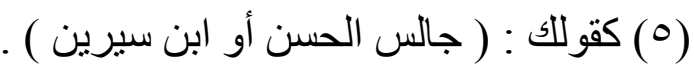

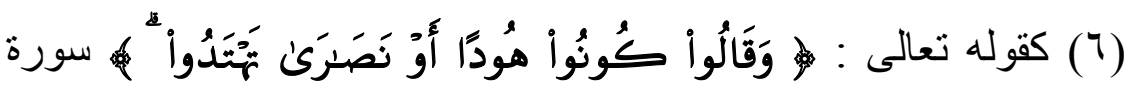

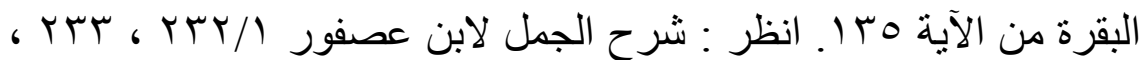

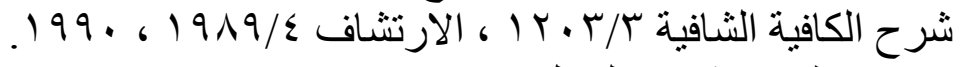

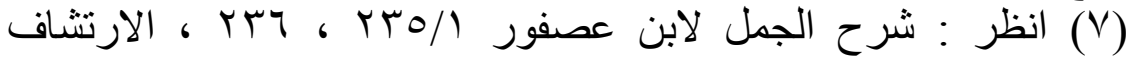
.1991 ، 199./5 
بل ولا بل: حرفا ابتداء إن وليهما جملة، ومعناهما: إضراب عن الأول، وإثبات القصة بعدهما، وللعطف إن وليهما مفرد، فإن وقعا بعد إيجاب فلإضراب في حق الأول وإثباته في حق الآخر أو بعد نفي فكذلك في مذهب سييويه (1)، ويجوز أن يتقدم بعدهما أداة التعريف في مذهب المبرد (r) مد (ب) لا : لا يعطف بها إلا بعد [آ/ب] إيجاب وهي لإخراج الثاني مما دخل فيه الأول، ويجوز أن يعطف بها الماضي خلافًا للزجاجي (ّ).

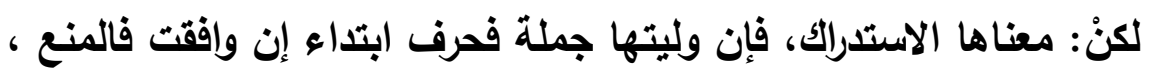
أو ضادت فالجواز، أو خالفت فخلاف والصحيح المنع(ء). أو مفرد فيعف بها بشرط النفي، ويجوز تشريك الاسمين إلا ضمير الرفع فشرطه الفصل أو التأكيا بمثله منفصلً، أو الخفض وإعادة الخافض إل وعروها عن الشروط ضرورة لا خلافا للكوفيين(•). ولا يجوز أن يتقدم معطوف على معطوف عليه إلا في الثعر ، وذلك بشرط أن يكون الحرف الواو، وأن لا يتصدر الحرف ، وأن يكون العامل

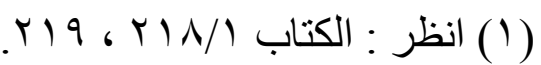

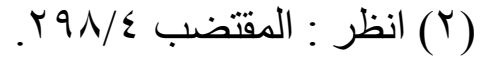

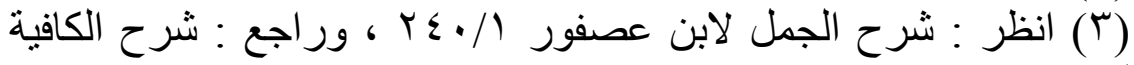

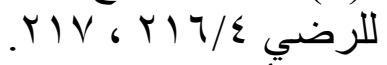

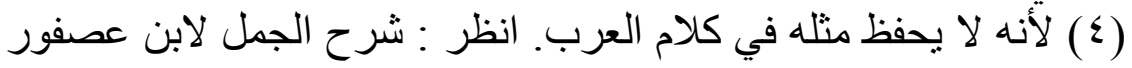

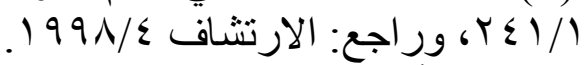

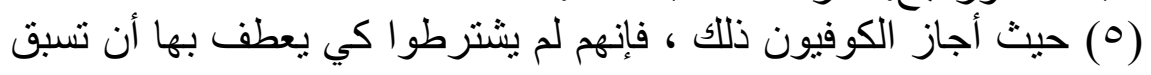

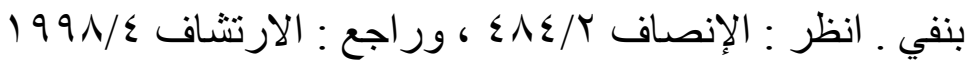




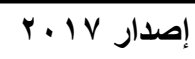

حولية كلية اللغة العربية بالمنوفية العدد الثاني والثُلاثون

متصرفاً غير خافض (') ولا الفصل بين الحرف وتاليه إلا بقسم أو ظرف أو مجرور بشرط أن يكون الحرف على أزيل من حرف(؟).

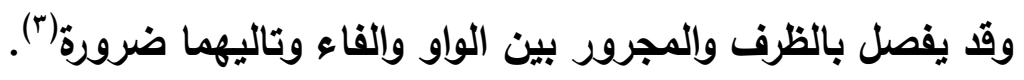
والمشتركان إن تأخر عنهما ضمير والحرف الواو أو حتى لزمت المطابقة إلا حيث سمع الإفراد أو الفاء أو ثم فكلاهما ، والإفراد في (ثم) أحسن أو غير ذلك فيراعى المعطوف عليه ، وشذ مراعاتهما في (أو). وإذا عطف فعل على فعل فيشترط اتفاق الزمان، والأحسن اتفاق الصيغتين مضيًّا أو غيره.

ولا يُشرك الاسم والفعل إلا إن حسن الاسم في موضع الفعل بكونه صلة لـ (أل) في اسم الفاعل ، واسم المفعول، أو كون الفعل في موضع الاسم يكون خبراً أو حالاً أو وصفًا. ****** $* *$

(1) انظر : شرح الجمل لابن عصفور (1) $r \cdot 19$ ، r. 11/

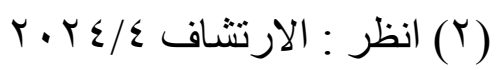

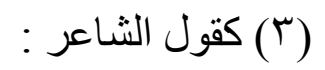

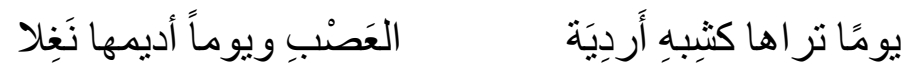

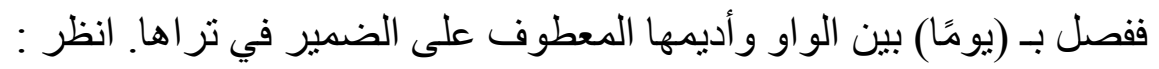

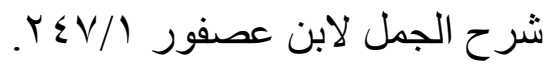


التوكيل(1): لفظي في الكلمة إلا الحرف فباعادة مباشرة، أو ضمير إلا في الضرورة. ومعنوي وهو قسمان(ז): مزيل شك عن حديث حقيقة أو ترشيح مجاز وهو التأكيا بمصدر أو عن مُحَََّث عنه وذلك بلفظ محصور وهو: (نفس، وعين) موحدان مضافان لضمير الواحد والواحدة أو يعامل

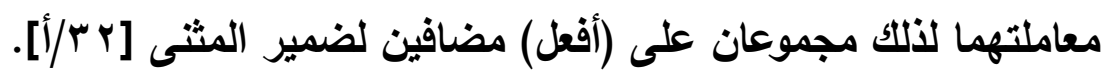

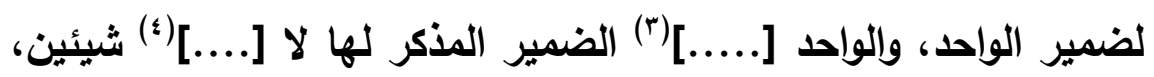
وكان مضافًا لضمير [.....]"(ه) لهما مفردان لفظا مثثيان معنى(؟) خلافاً للكوفيين في الدعاء تثنيتهما لفظا ومعنى(v)، وسبق إعراب كلا

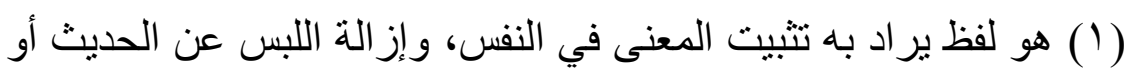

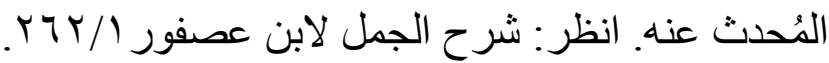

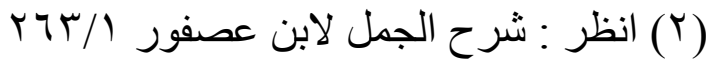

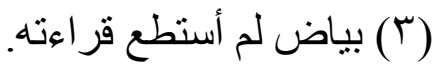

$$
\begin{aligned}
& \text { ( ) ( ) بياض لم أستطع قر اءته. }
\end{aligned}
$$

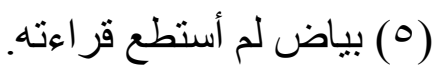

$$
\begin{aligned}
& \text { (T) هذا قول البصريين. }
\end{aligned}
$$

واستدلوا على ذللك باستعمال العرب لهما في حال إضافتهما إلى (V) المضمر بالألف في الرفع وبالياء في النصب و الخفض، فتقول: (جاءني

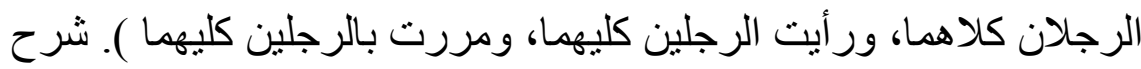

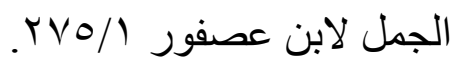




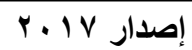

حولية كلية اللغة العربية بالمنوفية العدد الثاني والثُلاثون

وكلتا (')، وليس واحدة كِتِا كِلتَ خلافاً للبغدادينين(؟). و(أجمعُ، وأكتع)، وزاد() الكوفيون (أبصع)، والبغداديون (أبتع) على وزن (أَفََْل) للمذكر الواحد غير منصرف لوزن الفعل والتعريف، قيل: تعريف العلمية(؛)، وقيل: بنية الإضافة(ه). ولجمع سلامته لجمعه على وزن (فعلاء) للمؤنث غير منصرف للتأنيث

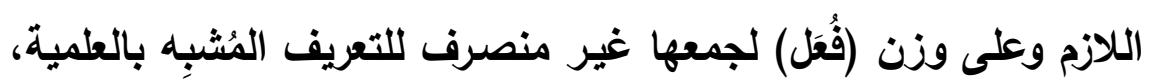
وللاعدل قيل: عن (فَقَالَى)، وقيل : عن (فُعْلَ).

وأريعتهن لا تثى لا لمذكر ولا لمؤنث خلافاً للكوفيين والبذداديين (ج). و( النفس، والعين ) لغير إحاطة، ويؤكد بهما المتجزئ وغيره(V) وغيرهما للإحاطة ويخص المتجزئ ذاتا أو بحسب العامل وفائدته رفع احتمال (1) أي يرفعان بالألف، وينصبان ويجران بالياء في حالة إضافتهما إلى

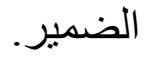
(Y) وقد استدلو ا على ذلك بقول الر اجز

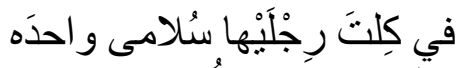

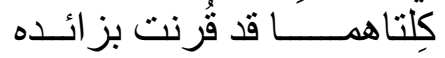

و هو مردود؛ لأن (كلِتَ) في البيت محذوفة من(كلتا) وليست بمفرد لهما.

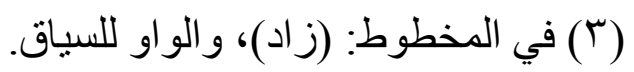

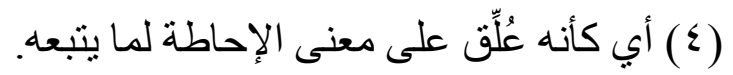

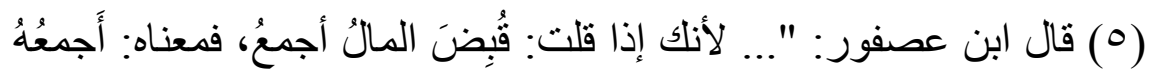

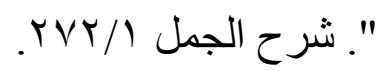
(7) انظر : شرح الجمل لابن عصفور 10/1 70، وما ذهب إلبه أبو حيان هو

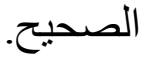
وراجع: شرح الجمل لابن خروف /وسب، المنهاج في شرح الجمل $r \leq \wedge / 1$ انظر : شرح الجمل لابن خروف (V) 


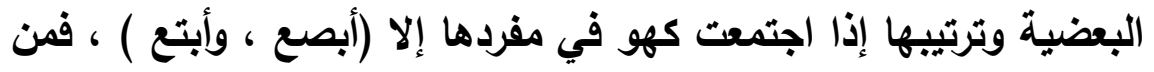

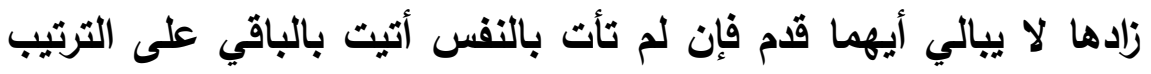

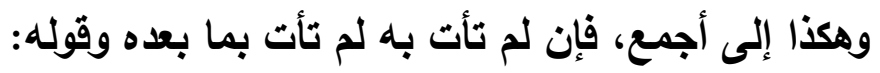

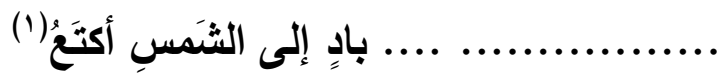

مؤول.

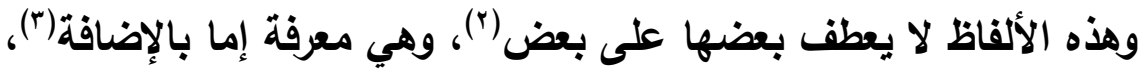

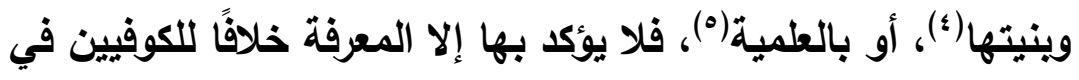

(1 (1) هذا جز ء من بيت من الطويل مجهول القائل، و هو بتمامه:

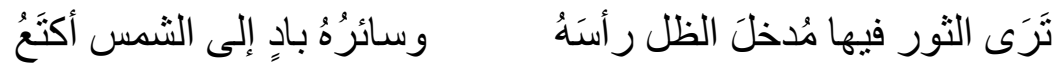

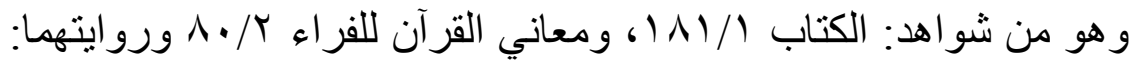

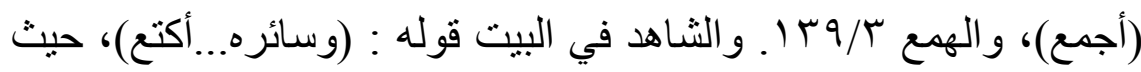

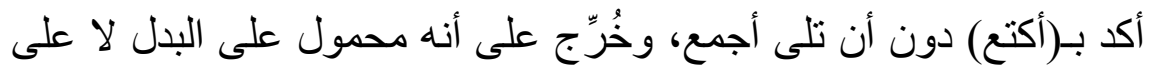

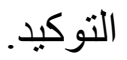

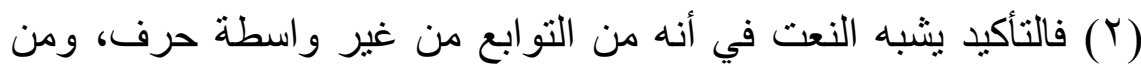

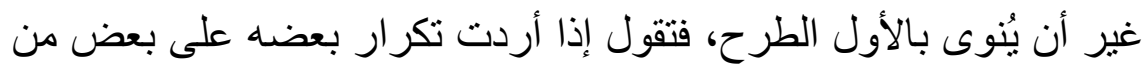

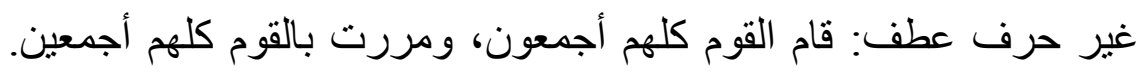

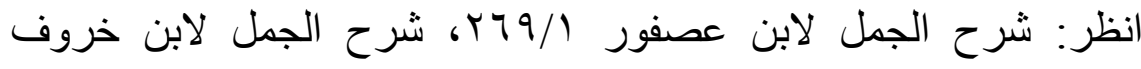

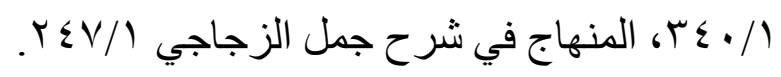

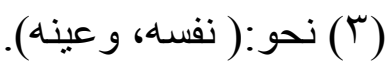

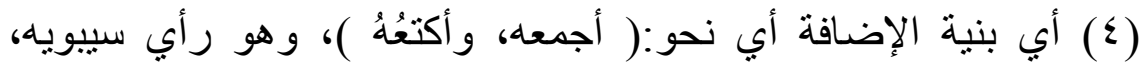

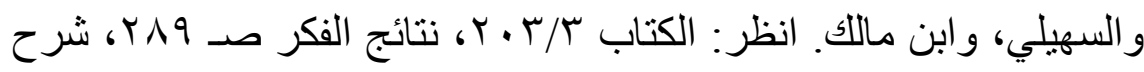

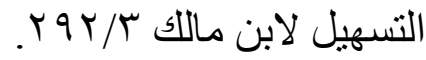
(0) ( نحو: ( أجمع ) ، و( أكتع ). 


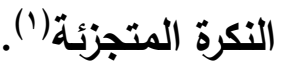

( (1) اتتلف النحويون فى توكيد النكرة توكيداً معنوياً على ثلاثة أقوال بيانها

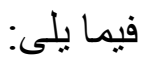

- ذهب سييويه، وجمهور البصريين عدا الأخفش إلى منع توكيد النكرة

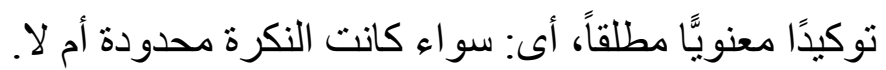
وقد علل البصريون لمذهبهم بأمور منها:

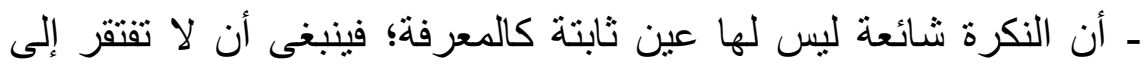
تأكيد؛ لأن تأكيد ما لا يعرف لان لا فائدة فيه.

ـ أن النكرة لا تثبت لها في النفس عين تحتمل الحقيقة والدجاز ، فيفرق بينهما

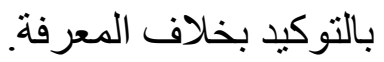
ـ أن التوكيد المعنوى إنما هو لتمكين معنى الاسم وتقرير حقيقتها، و النكرة لم يثبت لها حقيقة، وتمكين ما لم يثبت في النفس محال.

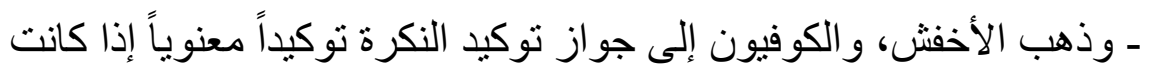

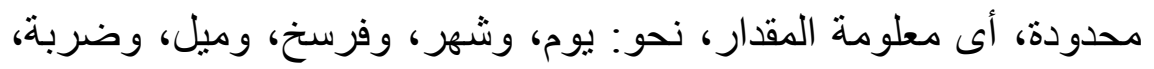
و أكلة ونحو ذلك.

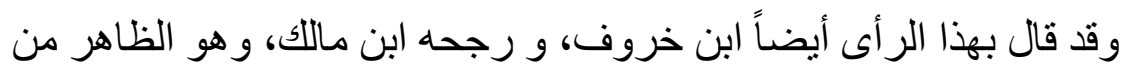

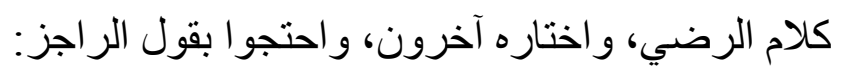

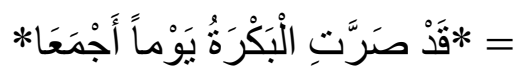

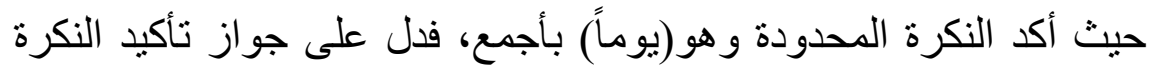

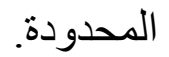

- وذهب بعض النحاة إلى جواز توكيد النكرة مطلقاً، أى: سواء كانت

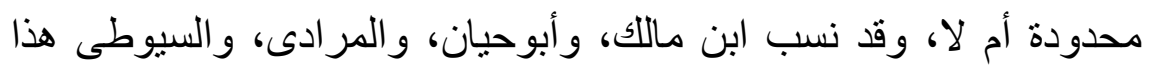

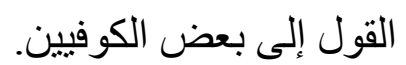

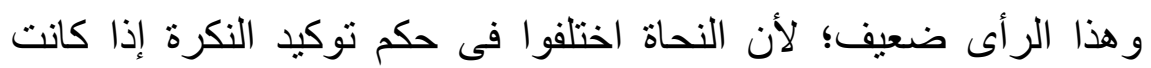

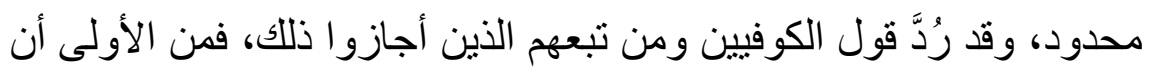
يندفع هذا القول الذى أجاز توكيد النكرة إذا كانت غير لكن محدودة. 
وضمير الرفع المتصل لا يؤكد بالنفس والعين إلا مفصولاً بمثله

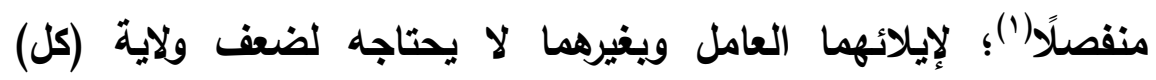
للعامل (ץ) والمتبوع ذلك في الباقي. وإذا أغنى [ץץ/ب] المعنى عن التأكيد()، أو كان الاسم غير مقصود

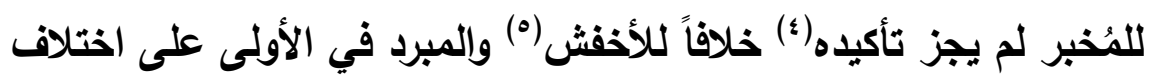

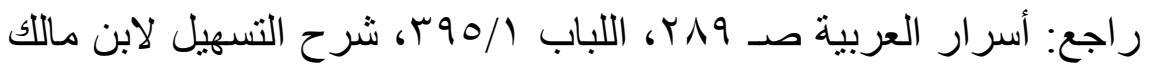

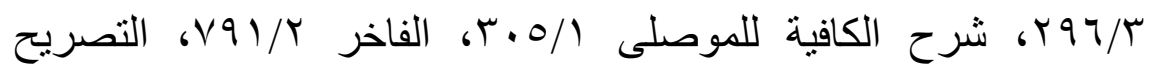

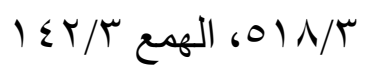
(1) تقول: قمتَ أنتَ نفسُلكَ، وقمتم أنتم أنفسُكم، وزيدُ قامَ هو نفسُه، ورلا

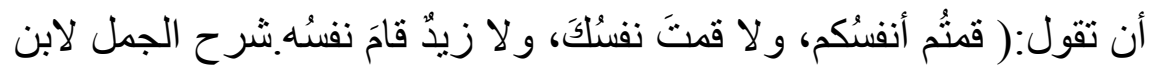

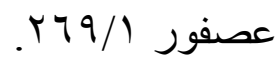
(Y) قال ابن عصفور: "...و أما (كل) فلم تحتج معها إلى أن تؤكد بالضمير المنفصل؛ لأن و لايتها للعامل ضعيفة، ولأنها بمنزلة أجمع في العموم، فلما

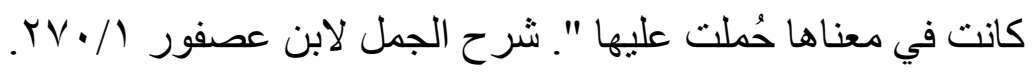

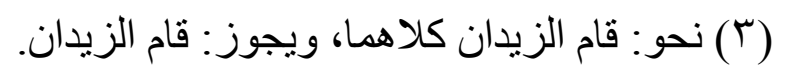

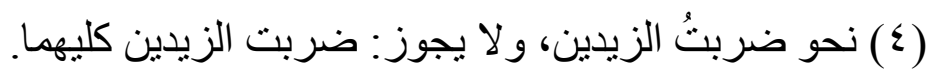
قال ابن عصفور: "لأنك لـم تقصد الإخبار عن الزيدين، فلو أكدتهما لكنت

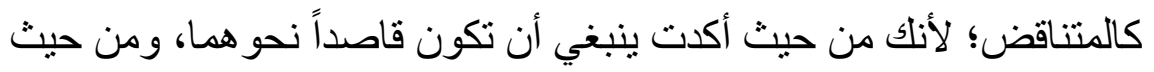
لـم تنو الإخبار عنهما لـم يكونا مقصودين، فلذلك لـم يجز تأكيده. انظر:

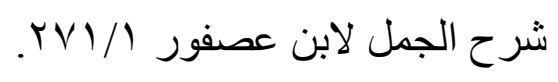
(0) يجعل الأخفش ذلك من باب التأكيد بعد التأكيد.وقد رَدَّ ابن عصفور

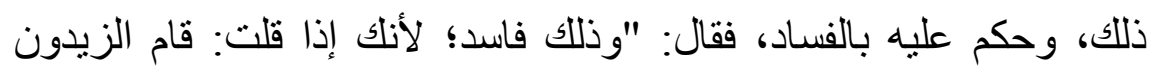


والتأكيا بـ ( كل، وأجمع ) سواء، ولا يفيد (أجمع ) الاجتماع وقت الإسناد للمؤكد خلافًا للفراء(')، وليبدأ بالنعت ثم بالتأكيد ثم بالبذل ثم العطف إذا إذا

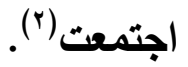

ويجري مجرى (كُلّ) في التأكيد اليد، والأارع، والظهر، والستَّهُل، والصغير، والقوي مع مقابلاتها(ّ)، وأسماء العدد من ثثلاثة إلى عشرة وفي مجاوزها خلاف، والصحيح الجواز وفاقًا للأخفش. وفي المفسر بواحد منصوب ثثلاثة أوجه: إضافة العدد لضمير المؤكد وهو الأضعف، وإبقاء التمييز ظاهراً، وحذفه لقهم المعنى. البدل: إعلام بمجموعي اسمين (؛) أو فعلين(•) للبيان(") منوياً بأولهما

كلُّهم جاز أن تغني بذلك البعض، وأكدت بكل مبالغة، فإذا قلت: أجمعون

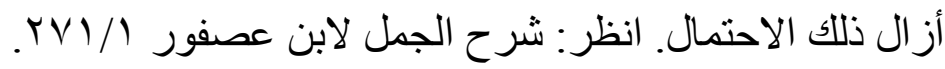

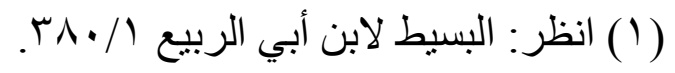

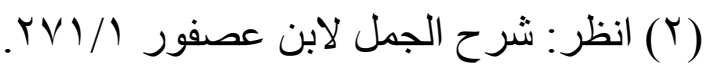

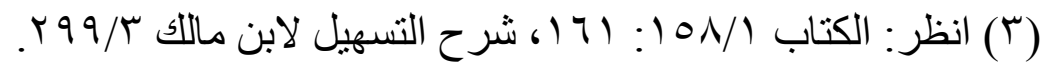
(ع) قال ابن عصفور: "فقولنا: إعلام السامع بمجموع الاسمين مثال ذللك :

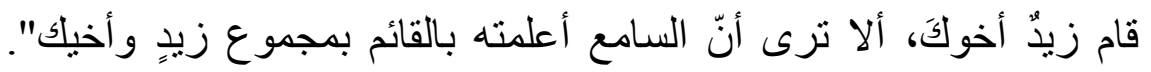

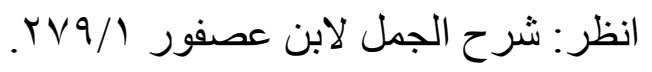

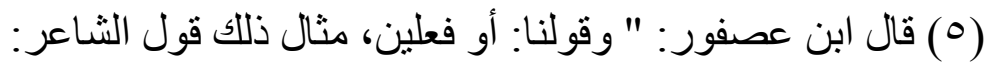
متى تأتنا تُلمِمْ بنا في ديارِنا

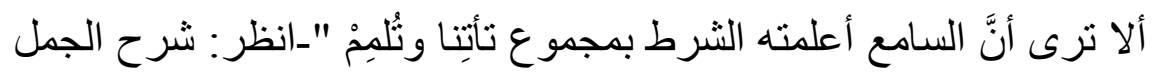

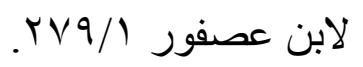

(T) قال ابن عصفور: " وقولنا: على جهة البيان: تحرز من العطف، ألا ترى أنك إذا قلت: قام زيدٌ و عمروٌ أعلمته بالقيام بمجموع زيد و عمرو إلا أن 
وأنواعه ستة: بلال شيء من شيع، وهو: أن يتحد اللفظان مُسمى.(؟) ويدل بعض من كل وهو: أن يكون الثاني بعض الأول. ويلال اشتمال وهو: أن يكون الثاني صفة للأول على مذهب الزجاج(َ)، أو يلون

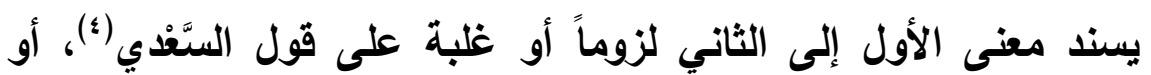
يكون الأول يكتفي بأكره عن الثاني، وتصح نسبة العامل إليه.

الثاني وهو عمرو ليس فيه بيان لزيد كما في قوللك: قامَ زيدٌ أخوكَ بيان لـ

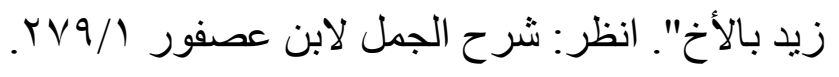

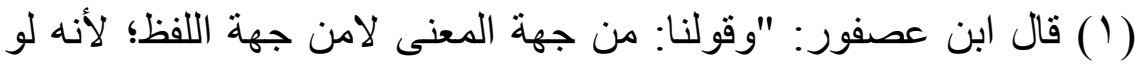

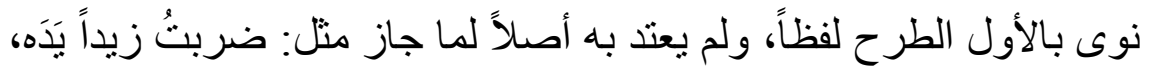

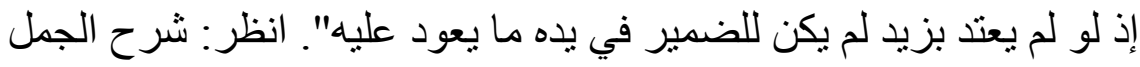

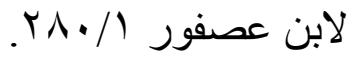

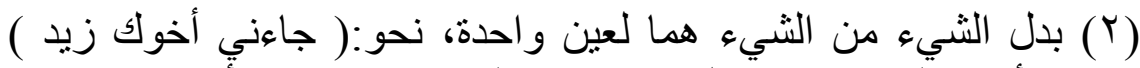

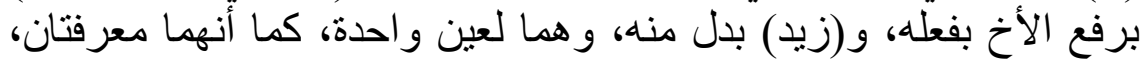

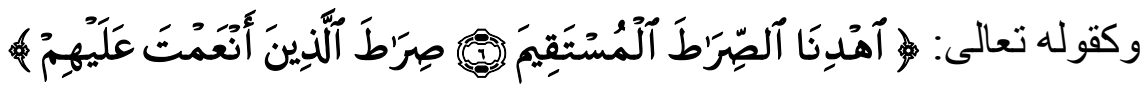
سورة الفاتحة الآيتان : جا، V، والصراط الثاني بدل من الأول، وهما

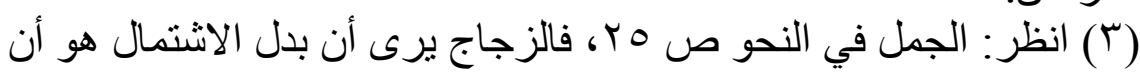
تبدل اسماً من اسم بشرط أن يكون الثاني صفة من صفات صنات الأول،

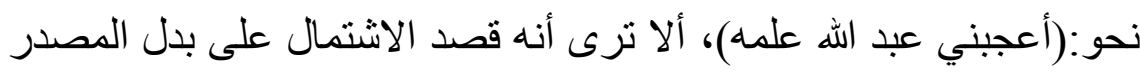

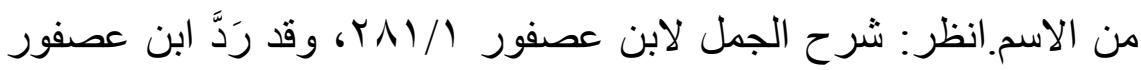
هذا القول فقال بعد أن ذكره: "وذللك فاسد؛ لأنهم يقولون: سُرِقِ عبدُ اللهِ

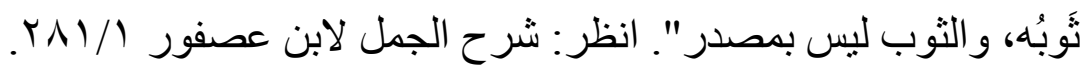

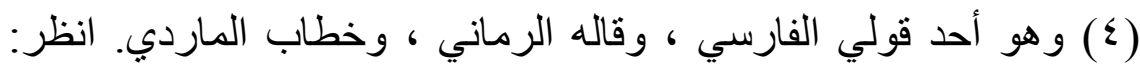

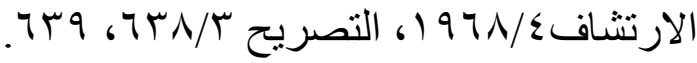




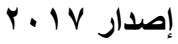

حولية كلية اللغة العربية بالمنوفية العدد الثاني والثُلاثون

وشرطهما: ضمير يعود على المبدل منه، وقل ورودهما عرياً عنه(').

هذه الثلاثة ورد بها السماع واتفق عليها(؟).

ويدل نسيان وهو: أن تنسى إرادة الأول ثم تأتي بالمراد ثانيًا("). ويدل الغلط وهو: أن يسبق لساتك إلى الأول ولا تريده ثم تأتي بالمراد ثانيًا (ई) وهذان اتفق على جوازهما قياساً(॰)، واختلف في وروده سماعاً(؟) فمثبت وناف(V)، وهو بلد البداع(^) وفي

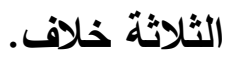

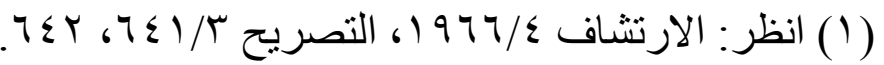
(T) انظر : التصريح

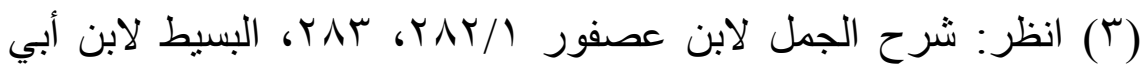

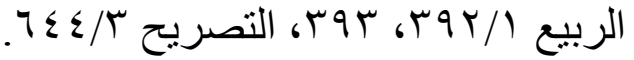

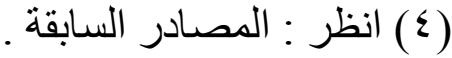

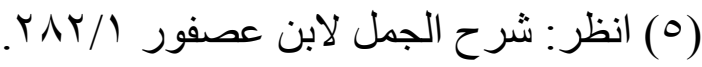

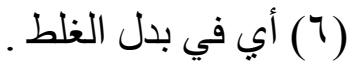

(V) ذهب المبرد، وخطاب الماردي إلى أن بدل الغلط لا يوجد في كلام

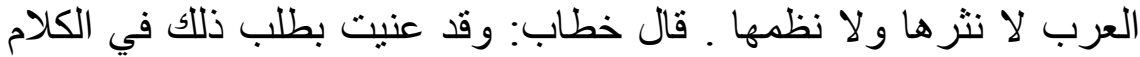

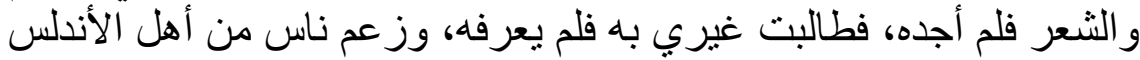

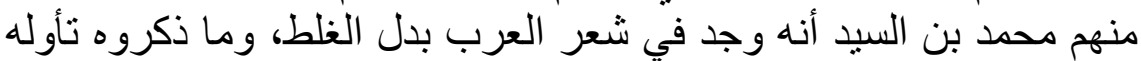

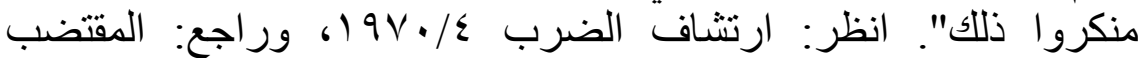
(

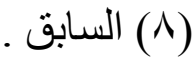



يجوز الحمل عليه إلا فيما يلي "إلا" مبدلا من [ب/r/أ] المخفوض أو من

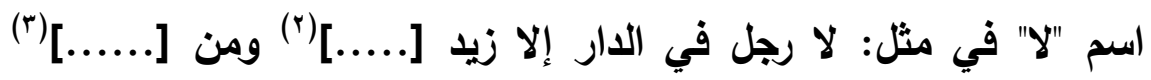
شرط ويشرط الوصفية على مذهب الكوفيين (؛).

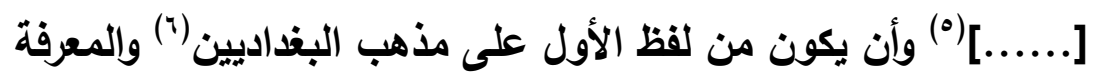

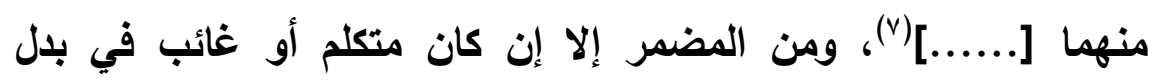
الشيء من الثيء، فالأخفش مجيز (^) وغيره مانع والمضمر منهما إلا في بلال البعض والاشتمال فمجيز ومانع والصحيح المنع.

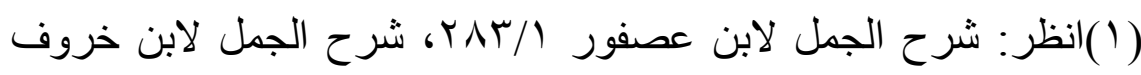
$r \varepsilon \varepsilon / 1$

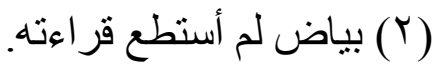

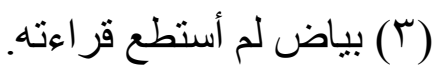
( () و استدلو ا على ذللك بأن النكرة لا تفيد في البدل إلا أن تكون موصوفة.

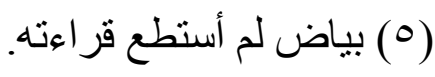

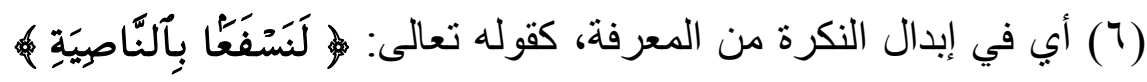

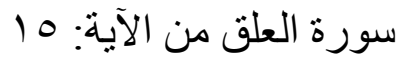

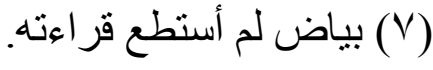

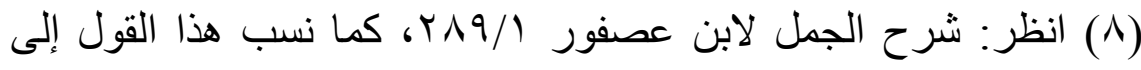
الكو فيين. انظر: الهمع / 101/ 
وتجيء أداة الاستفهام في البدل من اسمه(1)، وإذا كان الأول عدداً أو جمعاً يصدق عليه لفظهما فالإبدال والرفع على القطع(؟) أو لا يصدق الاول فالقطع () إلا إن سمع الإبدال فيخص بمورده. ويشترط في بدل الفعل منه توافقهما معنى، والبدل ليس معمولاً للأول ، بل بل على نية تكراره.

\section{****** $* *$}

عطف البيان: جريان اسم جامد على اسم دونه في الشهرة يبينه كما يبين

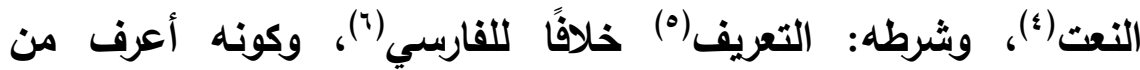
المعطوف عليه.

(1) قال ابن عصفور : " و إذا أبدلت من اسم استفهام لم يكن بدٌّ من ذكر أداة الاستفهام معه حتى يوافق البدل المبدل منه في المعنى، كقوللك: كم ماللكَ

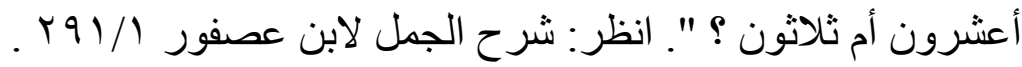

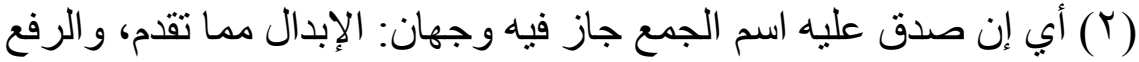

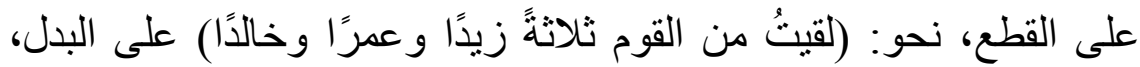

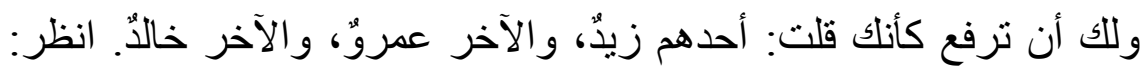

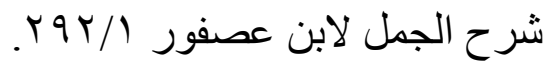
(ب) أب إن لم يصدق عليه العدد فالقطع ليس إلا تقول:( لقيتُ من القوم ثلاثنةً: زيدٌ وعروٌ )، و لا يجوز الإبدال؛ لأن (زيدًا و عمرًا) لا تقع عليهما ثثلاثة.

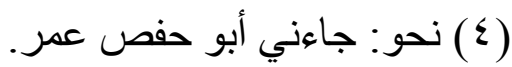
(0) هذا مذهب البصريين أنه لا يكون إلا معرفة تابعاً لمعرفة، وخصه

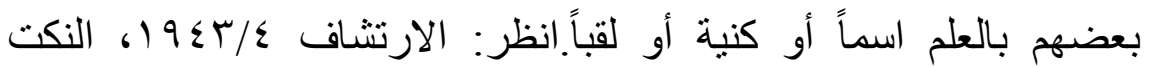
الحسان صـ 7 Y .

(T) ذهب الكوفيون، وتبعهم الفارسي، وابن جني و غير هم إلى أنه يكون في

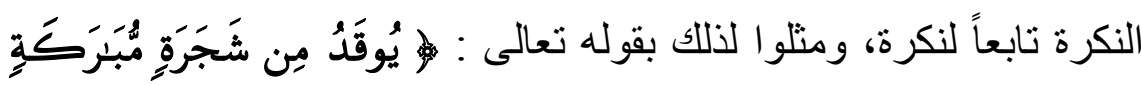


والفرق بينه ويين الببل: أن البدل تنوي فيه بالأول الطرح، ويكون بالمعرفة والنكرة والعطف ليس كذللك، ويفرق بيذهما أيضًا في باب اسم

الفاعل، والنداء إذا قلت: هذا الضاربُ الرجلِ زيدٍٍ(')، ويا عبدَ الله زيدًا (؟). والفرق بينه ويين التأكيا بَيِّنُ ويينه، ويين النعت جموده واشثتقاق النعت، ويشتركان في إزالة اشتراك عرض للمعرفة، لكن الوصف معهود منك ومن المخاطب والعطف أشهر من الأول من غير عهر وأكثر منه العطف في

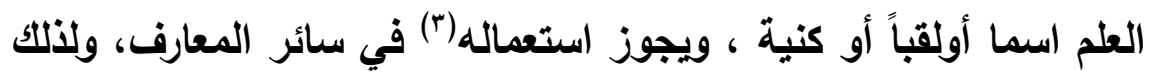
أجازوا في: ( مررت بهذا الرجل) الوصف والبيان. ويقدم الاسم مضافا للََّبِ إن اجتمعا مفردين، ولا يتبع [بّ/ب]. ****** $* *$

زَيْتُونَةِ هِه النور هب على أن (زيتونة) عطف بيان من (الثجرة). انظر:

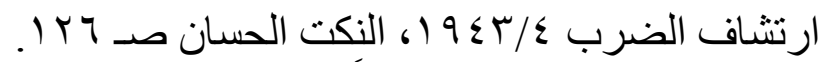

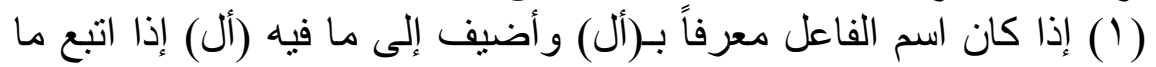
أضيف إليه اسما ليس فيه (أل) كالمثال المذكور، فإنه يجوز فيه فيه أن يكون عطف بيان لا بدل، وذللك لأن البدل في نية أن بياشر العامل، فلو جعلته بدلاً

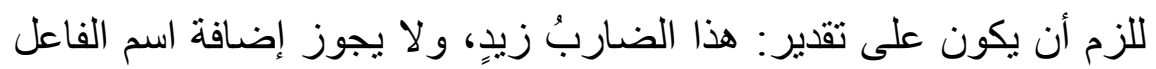
إلى ماليس فيه الألف واللام، و لا يؤدى إلى ذللك في عطف اللى البيان.انظر:

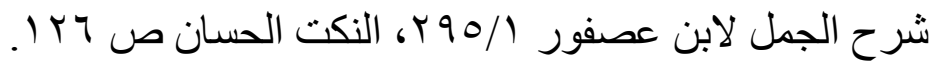

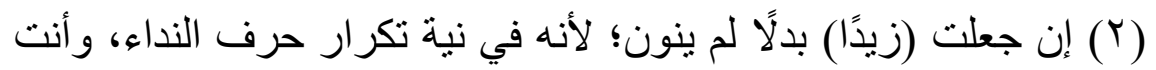

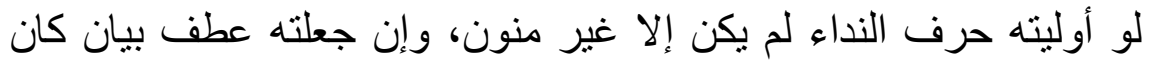
منونًا؛ لأنه ليس في نية تكرار الحرف معه فيلزم منه حذف التنوين. انظر :

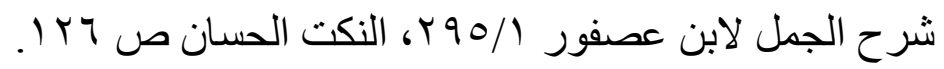

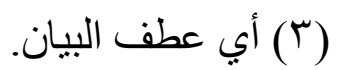


الإعمال: اقتضاء عاملين أو أكثر معمولا فأكثر من جهة المعنى(')

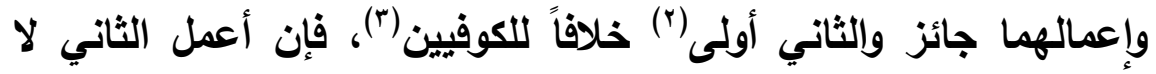

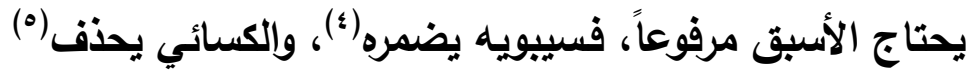

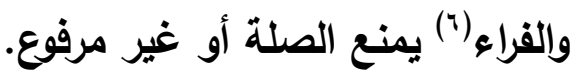
ويجوز حذفه اقتصاراً ، ولا يضمر إلا ضرورة أو لا يجوز فيحذف على لضن

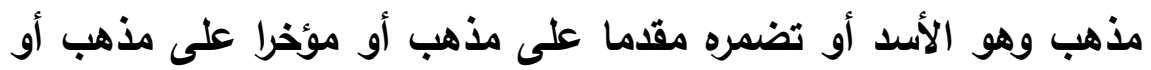
الأسبق أضمر في الثاني المرفوع وجويا وغيره جوازا أو إضماره أحسن من من موني حذقه.

$$
\text { (1) نحو قولك: ضربني وضربت زيدًا. }
$$
(Y) هذا رأي البصريين و علتهم في ذلك مجاورته، ولأنه يؤدي إلى عدم الفصل بين العامل و المعمول.

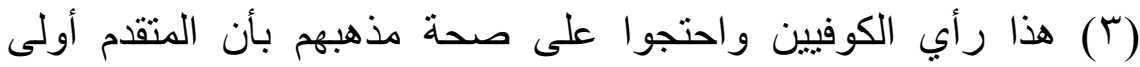

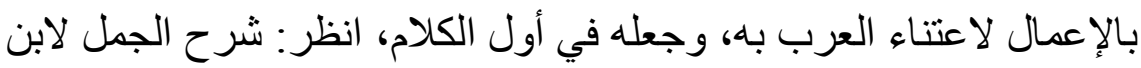

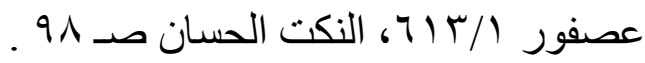

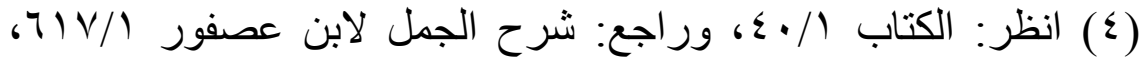
النكت الحسان صـ 91. (0) أي: فاعلً كان أو مشبهًا بالفاعل. انظر: شرح المفصل لابن يعيش

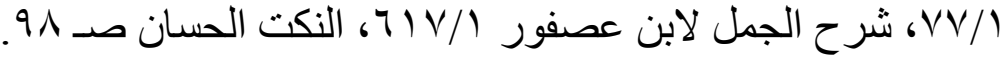

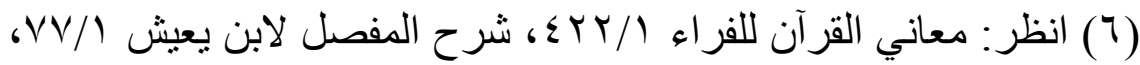

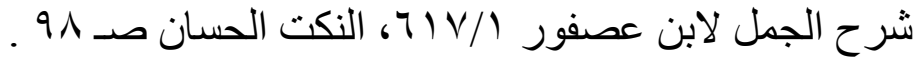


ويتصور في بعض المسائل عود الضمير على غير من هو لله في المعنى(') خلافًا لابن الطراوة في منعه ما أدى إلى ذلك، وقول امرئ

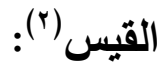

كفاني ولم أطلب قليل من المال(r).

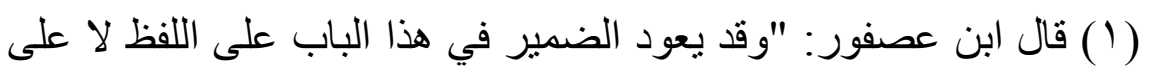

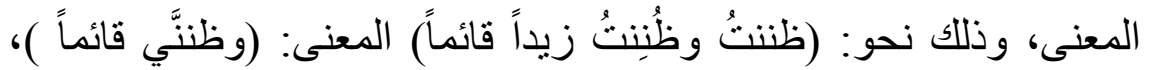
فعاد الضمير على(قائم) الأول لفظاً لا معنى، ألا ترى أنه لا يريد: وظنيّي

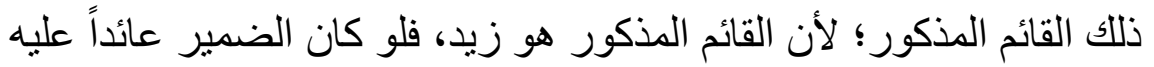

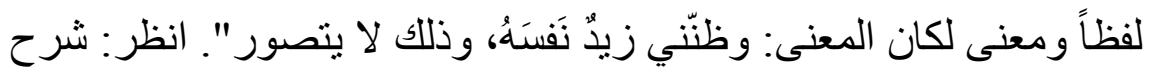

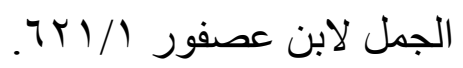

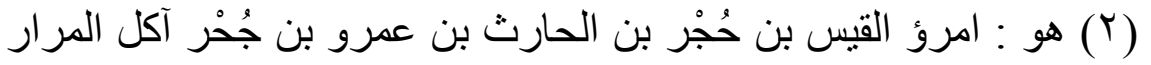

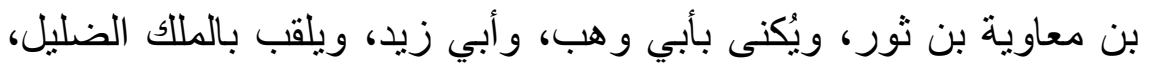

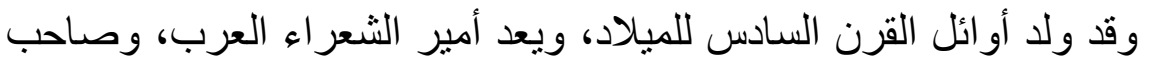

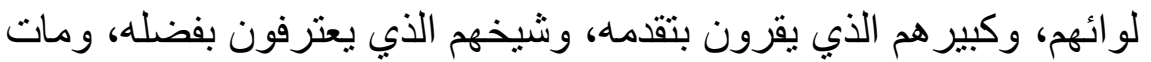

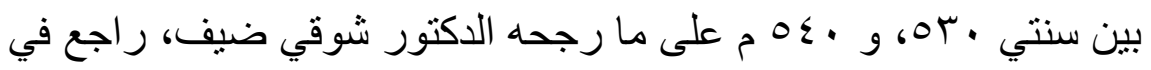

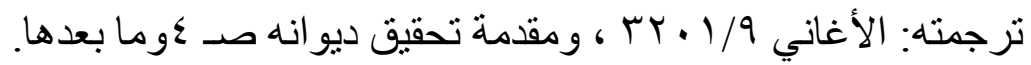
(T) هذا عجز بيت من الطويل وصدره: الأبي فلو أنّ ما أسعى لأدنى معيشة

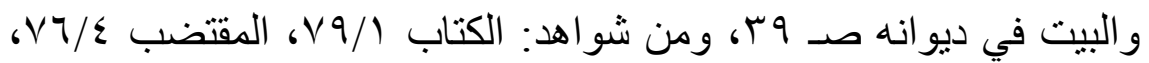

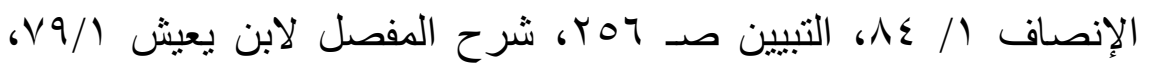

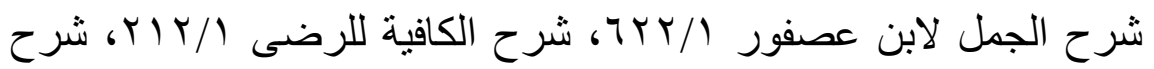

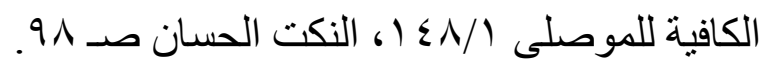


ليس من الإعمال ('خلافاً لأبي إسحاق بن ملكون (؟). *******

\section{المعمول لفعل يجب إضماره(r)}

المنصويات ثلاثة أقسام:

قسم ينتصب بفعل واجب الإضمار، وذلك كل فعل إذا أضمرته لم يكن على لُّل إضماره دليل من لفظ متقدم، ولا بساط حال. وقسم جائزة: وهو ما على إضماره دليل. وقسم بواجبة: وذلك يحفظ ولا ينقاس، فمنه المنـادى ينتصب بإضمار

(1) ذهب الكوفيون، وجمهور البصريين إلى أنه ليس من الإعمال لاختلاف

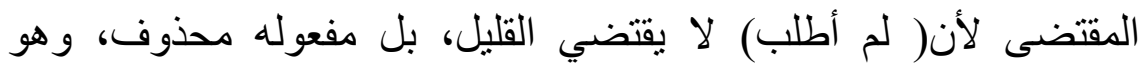

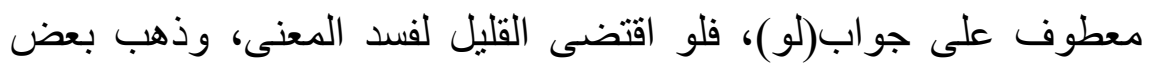
البصريين إلى أنه من باب الإعمال، وأنه معطوف على لولى جواب(لو)،

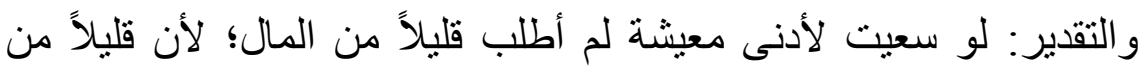

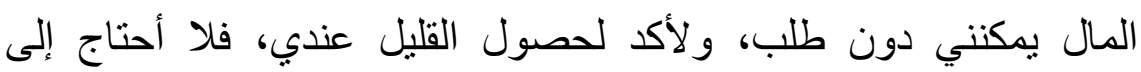

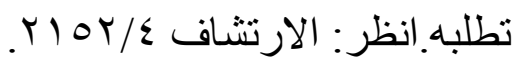

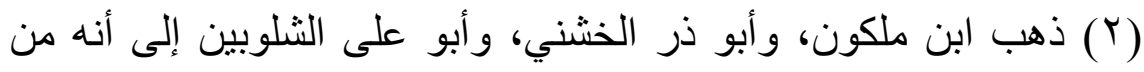

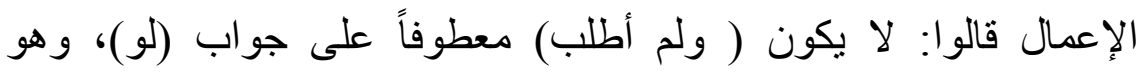

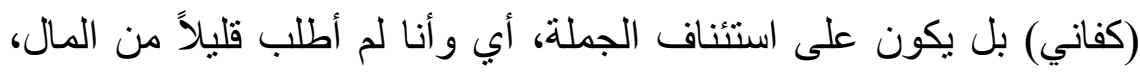

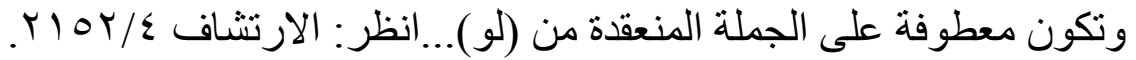

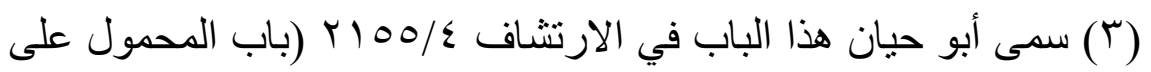
فعل واجب الإضمار)، وسماه ابن عصفور ( باب ما ينصب على الضى إضمار

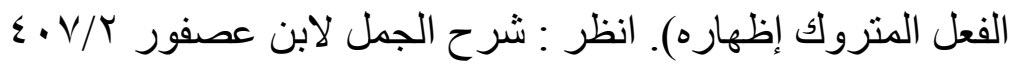


(أنادي)، ونابت (يا) منابه(')، ولذلك لا يجمع بينهما لا بما في (يا) من

معنى الفعل، ولا بنفس (يا) خلافًا لزاعميهما و(؟).

والمنصوب على الاثتغال لا بالفعل الأي بعد الاسم خلافًا للقراء. و(إياك) لا يستعمل إلا بمعنى الأمر، والتقدير: (إياك باعد)، ولا يقدر قبل (إياك)، ويتحمل إياك الضمير، ويؤكد، ويعطف عليه رفعًا. والاسم بعد الواو في: (إياك والأسد) وأمثاله تقديره: (إياك باعد واحذر الأسد)، فإن حذفت الواو فإن الفعل يجوز إظهاره وإضماره.

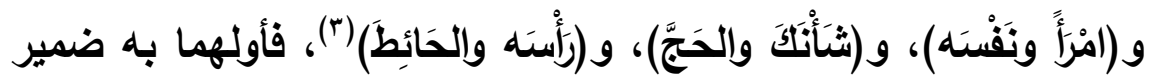

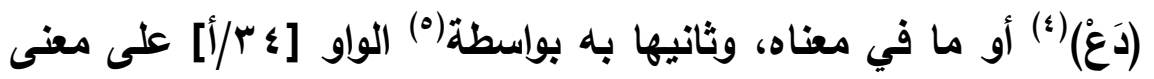
(مع)، و( أهْلَكَ وإلليلَ)(َ) تقديره: (بادر أهلك واللليل)، أي: ويادر الليل، أي: بادر أهلك قبل الليل، و(وَيْحَه وأَخَاه) ينتصب (وأخاه) على الفعل الأي ينتصب عليه (ويحه) وسيأتي، و(شَأَتْكَ وزَيْدًا، ومَا أَنْتَ وزَيْدًا)،

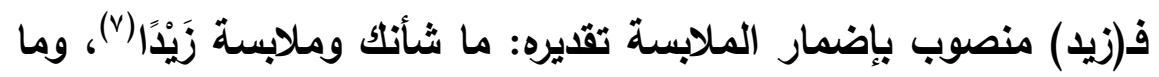

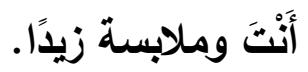

(1) انظر مذاهب النحاة في هذه المسألة في : شرح المفصل لابن يعيش

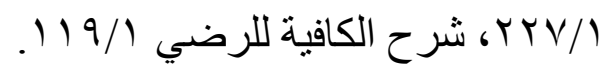

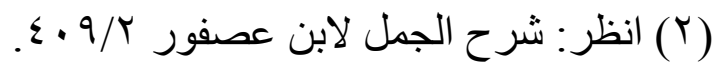

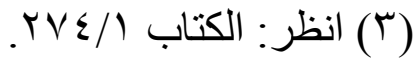

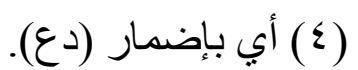

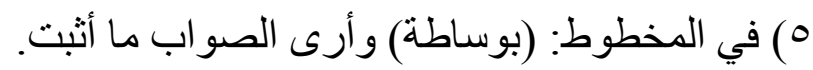

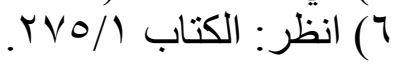

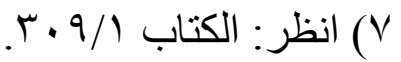


والمصادر الموضوعة موضع فعل الأمر فبفعل(') من لفظه، وما وُضِعَ

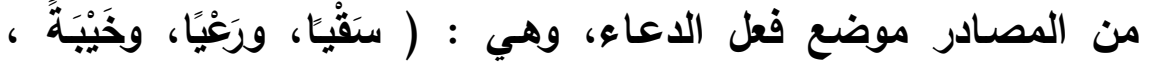

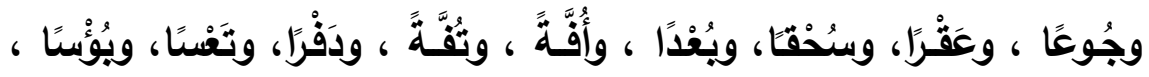

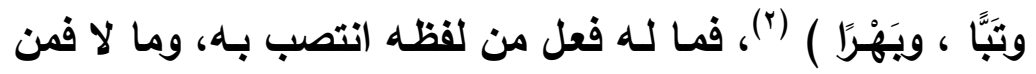
معناه(")

( ) أي تتصب بفعل من لفظها.

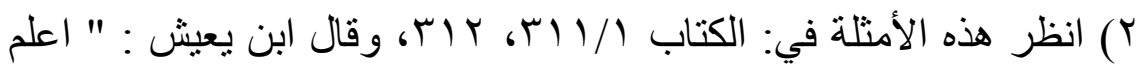
أن هذه المصادر قد وردت منصوبة بإضمار فعل، وذللك الفعل لم يظهر مع الته هذه المصادر، وذللك قوللك في الدعاء للإنسان: "سقيا ورعيا"، والمراد: سقالك الله سقيا ورعالك الله رعيا، فانتصبا بالفعل المضمر، وجعلوا المصدر بدلا من اللفظ بذلك الفعل. وذللك أنهم قد استغنوا بذكر المصدر عن ذكر بلاعر الفعل، كما قالو ا: "الحذر"، و المعنى احذر الحذر، ولم يذكروا "احذر"، فلما استغنوا بذكر هذه المصادر عن ذكر الفعل صار قوللك: "سقيا ورعيا" كقوللك "سقاك الله، ورعالك الله"، فلو أظهرت الفعل صـار كتكرار الفعل، ومن ذللك قوللك للمدعو عليه: "خيبة، وجدعا، وعقرا، وبؤسا، وبعدا،

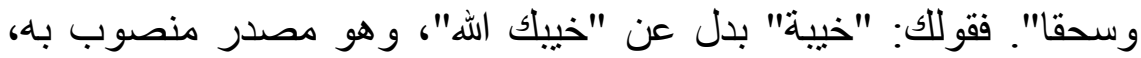

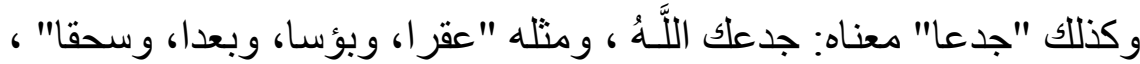

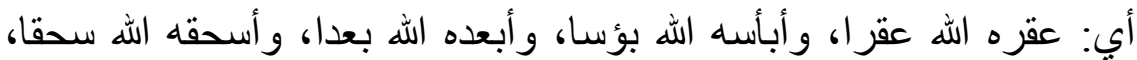
على حذف الزوائد ـ وكل هذه المصادر دعاء عليه أو له، وهي منصوبة

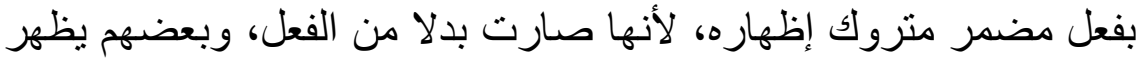
الفعل تأكيدا، فيقول "سقاك الله سقيا، ور عالك الله رعيا" وليس بالكثثير، ومنهر من يرفع فيقول: "سقى للك، ورعي"، والمعنى مفهوم كما يقال: "سلام

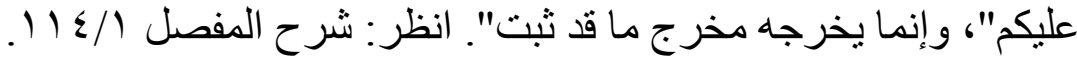

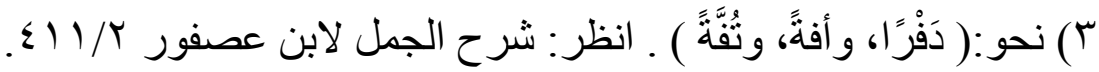




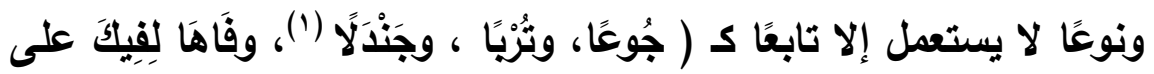
معنى الدعاء ) ، تقديره: جعل الله في فيه تُرْبًا، ووضع الله في فيه جَنْدَلَا، أي أماته الله، وجعل الله فم الاداهية لفيه.

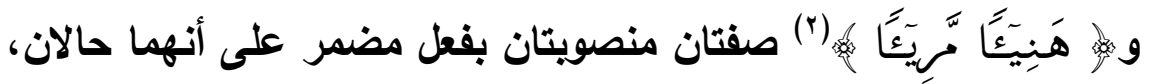
فإذا قلت لمن هو في حال التتعم: هنيئاً لك، فكأنك قلت: أدام الله لك من النعيم ما أنت فيه هنينًا، وكذلك(مريئًا) إلا أنه لا يستعمل إلا بعد ( هنيئًا)، وقيل: يستعمل وحده ولا يحفظ ذلك. و( سُبْحَانَ الله، ورَبْحَانَه)(َ) بفعل من معناهما، ولا يستعمل فعل مِنْ لفظهما، ومعنى (سبحان الله): تنزيهًا، و(ريحانًا) : استرزاقًا، و( مَعَاذَ اللَّهِه) بفعل من لفظه تقديره: أعوذُ بالله معاذَاً، و(عَمْرَكَ الله ) معناه: أسألك ببقاء اللَّهِ، وعَمْرُ مصدر من عَمَّرَ على حذف الزيادة، بمعنى: تعمير ، أي عمر من الله عمرتك به تعميرًا، أي: سألته بِعَمْر اللهِ أي بيقائه.

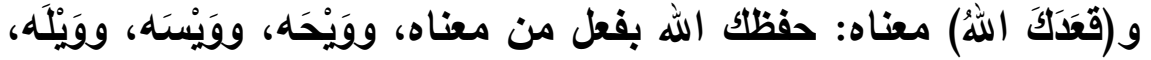

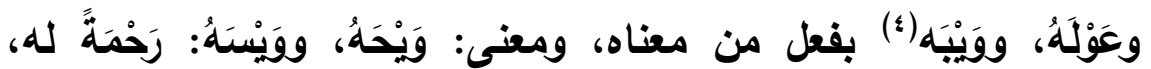

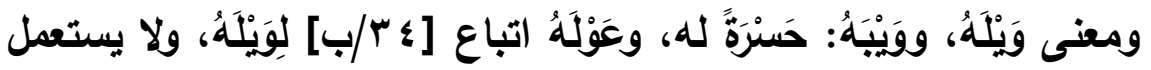
بغير (وَيْلَهُ)، ومنهم من ذهب إلى أنه قد استعمل من وَيْلَ، ووَيْحَ أفعال،

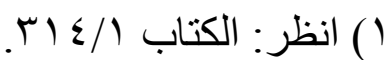

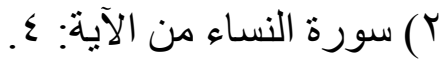

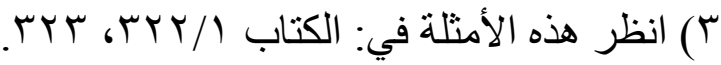

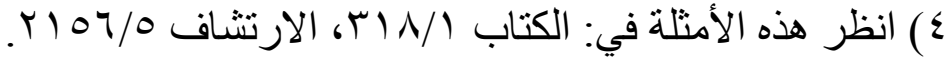


فهي عنده منصوية بأفعال من لفظها، أي وَاَح وَيْحَه، ووَاسَ وَيْسَه، وما استثل به مصنوع فيما زعموا، ولا يعلم له قائل.

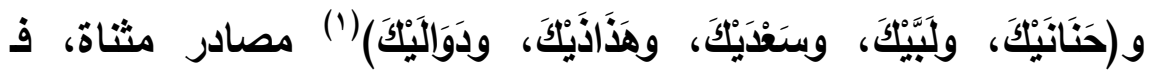
حنانيك، وهذاذيك بفعل من لفظهما، أي أحن حنانيك، وتهذ هذاذيك، وتداولنا دواليك، ومعنى سعديك: إجابة بعد إجابة كأنه قال إسعادا لأمرك

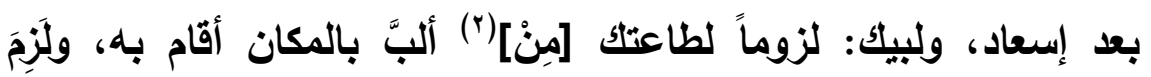
تنصب بأفعال من معناها.

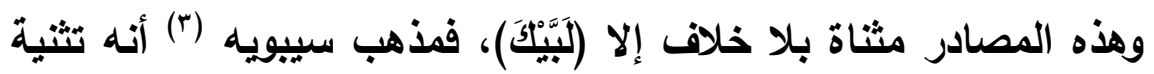
(لَبَّ)، ومذهب يونس(؛) أنه مفرد، ويفسد بثبوت الياء في إضافته إلى لـ إلى المظهر ، ويسماع (لب) في المفرد.

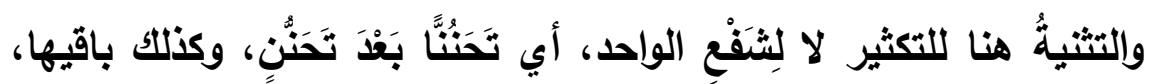
وليست الكاف حرف خطاب، فتحذف النون لشبه الإضافة خلافًا للأعلم (ه).

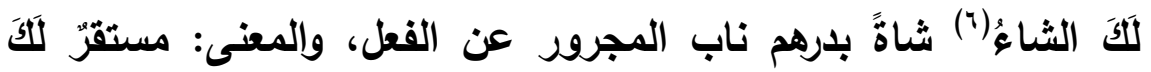
الثاء أخذته بدرهم(v) فزائداً أو بلرهم فصاعداً، أي فزاد الثمن صاعدًا، فهو

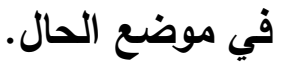

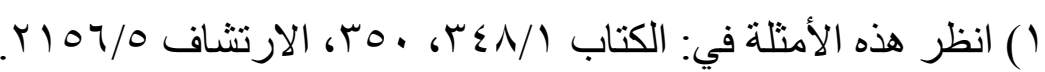

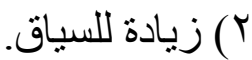

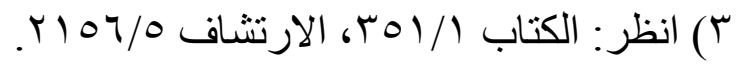

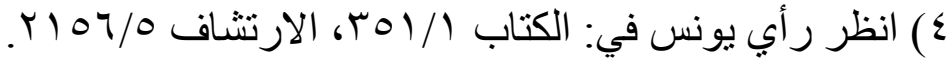

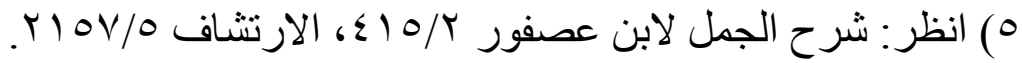

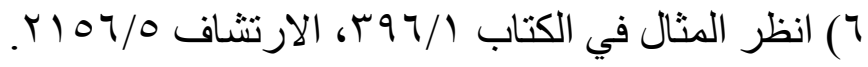

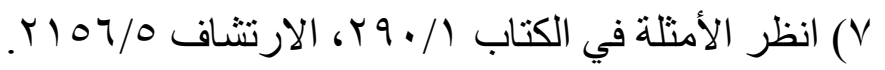


فأما سمينًا فسمينٌ، فبفعل مضمر، وهو ما في (أمَّا) من معنى الفعل، وانتصاب ذللك على المصدر في موضع الحال في لغة أهل الحجاز، ولذلك إذا دخلت عليه (أل) رفعوه، وفي لغة تميم مفعولًا من أجله، ولذلك إذا

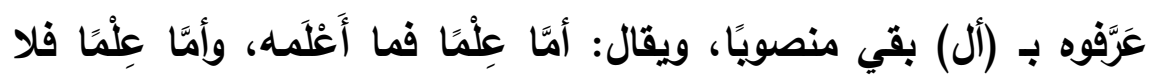

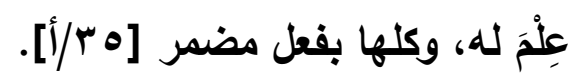
المصادر التشبيهيات: إن أريد بالأول الفعل الأي هو علاج لا إخراج الصوت انتصب ما بعده به، وليس من هذا الباب، وإن أريد به الصفة، فإن أردت بالثاني الفعل انتصب بفعل من لفظه، أي يُصَوِّتُ صوتَّ حمارٍ، وإن أريد به الصفة لا المصدر، فبإضمار فعل من غير لفظه، أي يخرجه صوتَّ حمار .

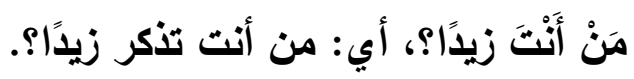
كليهما وتمرًا (َ) يستعمل لمن خُيرّز بين شيئين فطلبهما جميعًا، أي: أعطني كليهما، وزدني تمرًا.

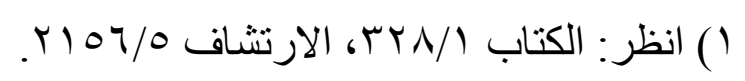
Y) ورد هذا المثل عندما قال ذلك رجل مر بإنسان وبين يديه زُبذّ وسنام

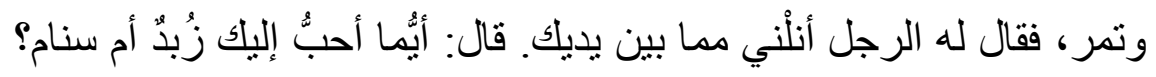

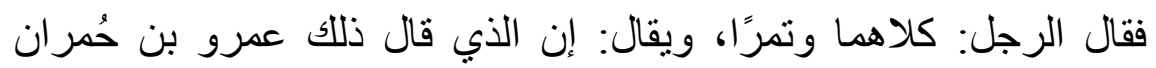

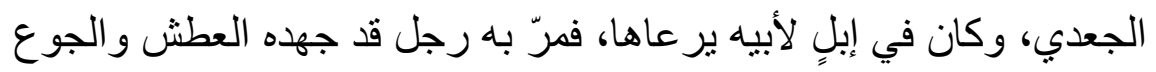

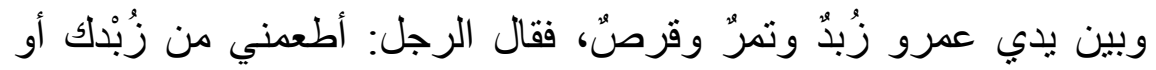

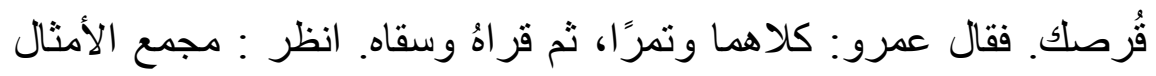
$.10 \mathrm{r}$. $101 / \mathrm{T}$ 


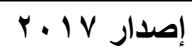

حولية كلية اللغة العربية بالمنوفية العدد الثاني والثلاثون

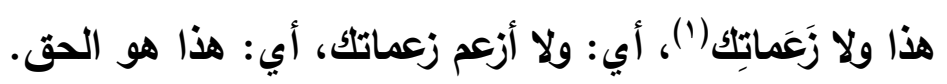

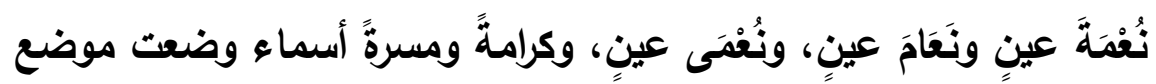

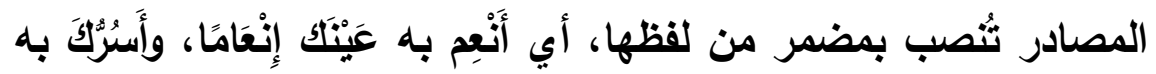

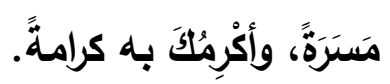
ولا كيدًا ولا همَّا ولا غمَّا ولا رغمَّاَ(؟)، أي: لا أفعل كيدًا، ولا أكيده كيدًا، أي

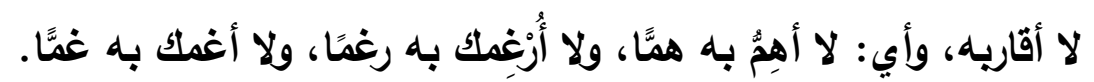

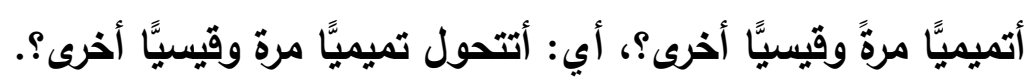
أعورَ وذا نابٍ؟، أي: أتستقبلون أعورَ وذا ناب(ّ)، يقال لإنكار الجمع بين قبيحين. كلٌ اسم ينتصب بمضمر على معنى الأمر قـ تقدم النهي عن ضده، وهي:

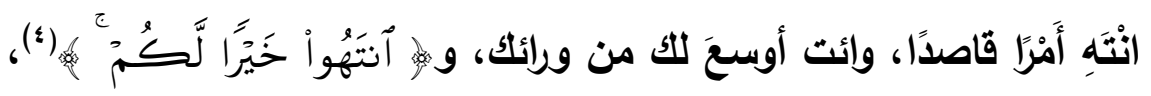
وأجاز القراء(ه) أن يكون (خيرًا) صفة مصدر محذوف، أي انتهاءً خيرًا المصادر الموضوعة موضع الخبر في المبالغة نحو: (ما أنتَ إلاسيرًا)(")،

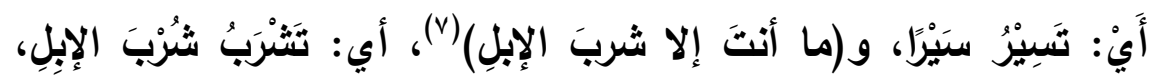

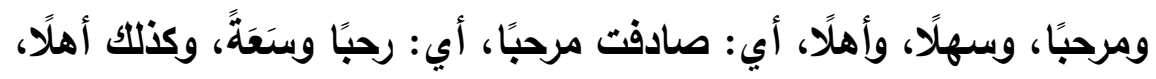

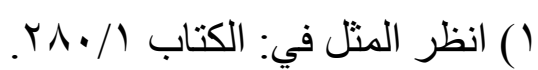

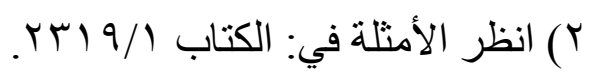

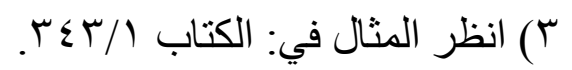

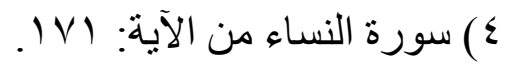

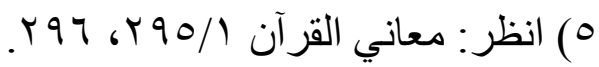

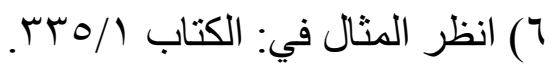

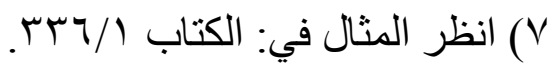


أي: صادفت من يقوم للك مقام الأهل، وسهلَا، أي: صادفت لينًا وخفضًا لا لإِال خوفًا [هر [ب/ب].

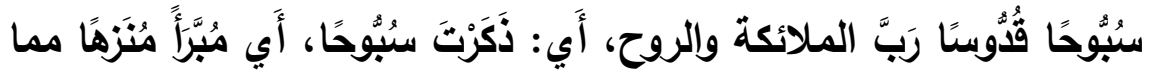

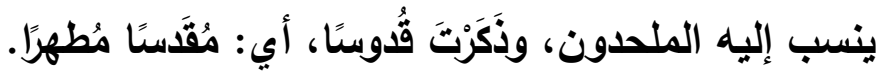
وإنْ تأتِ فأهلَ النهارِ واللايلِ، أَيْ تَجْدُ من يقوم للك مقامَ أهلك في الليل

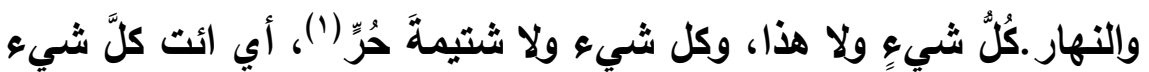

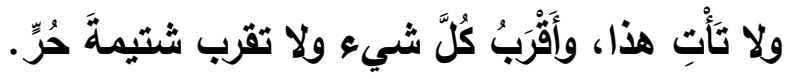

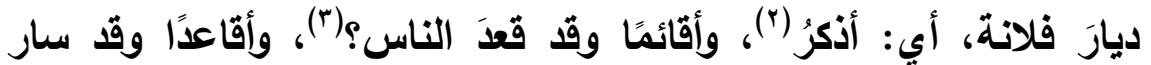

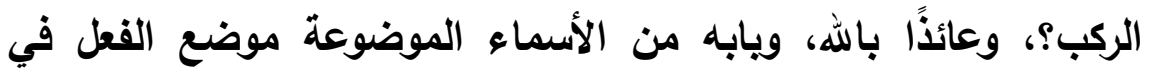
الخبر، وذلك موقوفت على السماع وفيه وجهان:

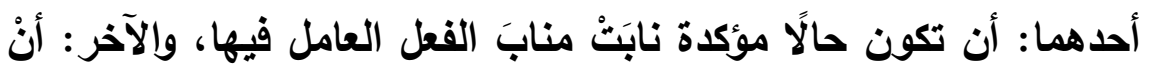

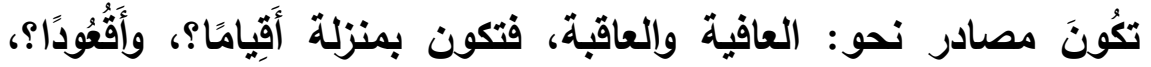
وعياذًا.

وأدخل أبو القاسم(؛) في هذا الباب ما ليس منهه، فمن ذلك: حَمْدًا، وشُكُكًْا،

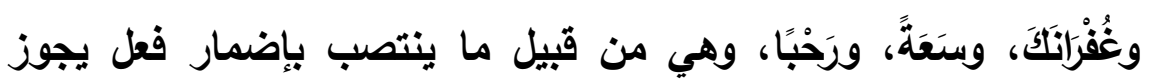
إظهاره.

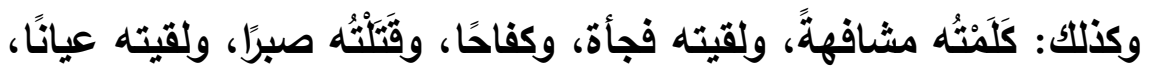

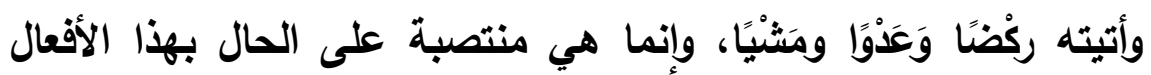
الظاهرة، وذلك على حذف الفعل، وإقامة المصدر مقامه فصار منتصبًا

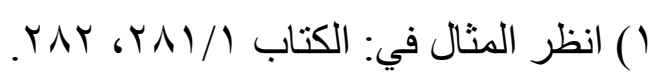
Y ( أي منصوب على إضمار فحل تقديره: ( أذكرُ ديارَ فلانةٍة).

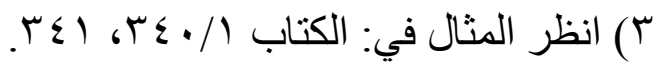

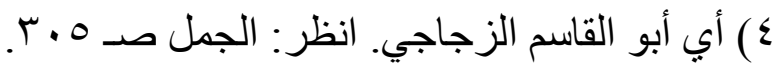


بالفعل على أنه حال، فمن راعى أنَّ هذه المصادر منتصبة بأفعال مضمرة جعلها من هذا الباب، ومن راعى أنَّ العامل في اللفظ إنما هو الفعل الظاهر لقيامه مقام الحال لم يجعله من هذا الباب.

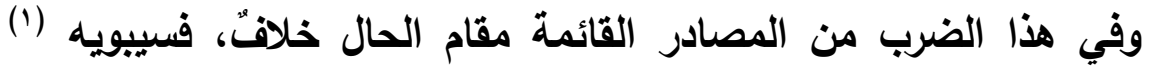

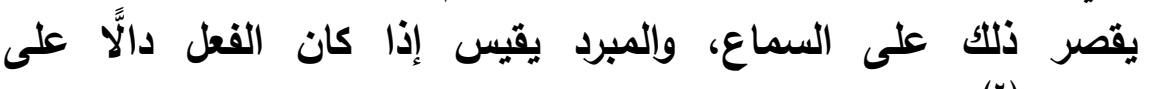
المصدر (r). (المصر

$$
\text { إعراب المضارع }
$$

الأفعال: ماض، ومستقبل [ף [ب/أ] وحال، وارتفع المضارع لوقوعه موقع

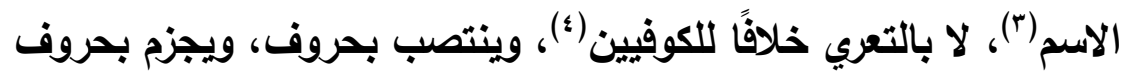

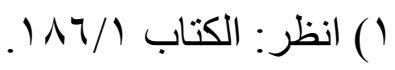

(Y) انظر: المقتضب /

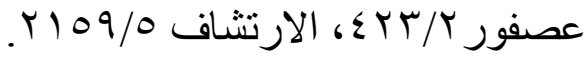

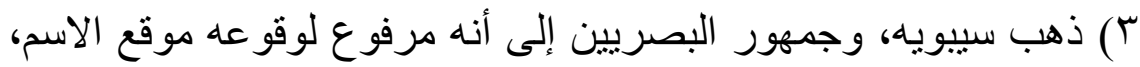
وقد احتجو الكلامهم بأمرين: 1 - أن قيامه مقام الاسم عامل معنوى فأثبه الابتداء، و الابتداء يوجب

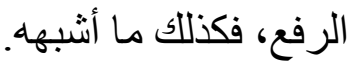
r - - أنه بقيامه مقام الاسم قد وقع فى أقوى أحو اله ، فلما وقع فى أقوى

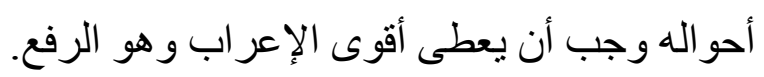

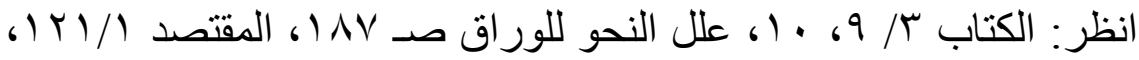

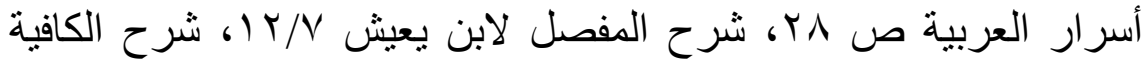

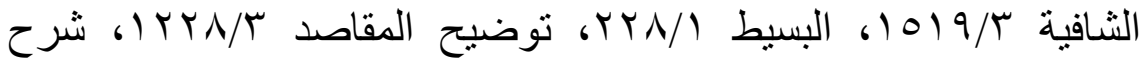

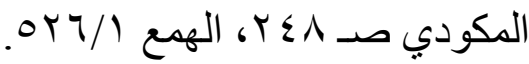
ع) ذهب الفراء و غيره من الكوفيين ، و الأخفش، وتبعهم ابن ماللك إلى أنه

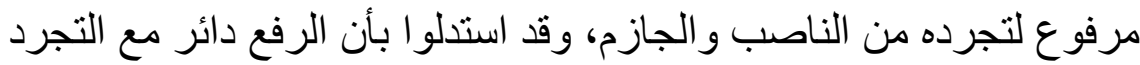

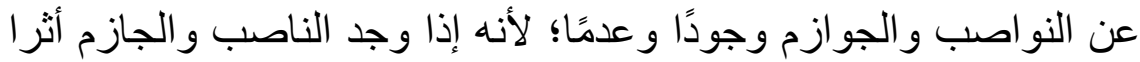




\section{الموفور من شرح ابن عصفور}

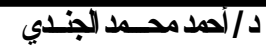

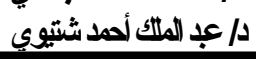

(') $[\ldots . . . .$.

النواصب: عند البصريين: أَنْ، ولَنْ، وإذَذنْ، ولكي، وكي في أحد

قسميها (ז).

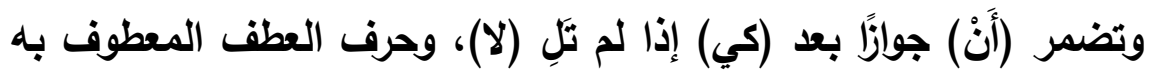

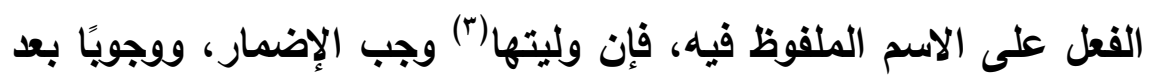

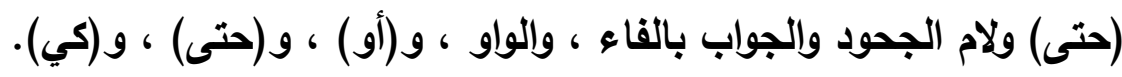

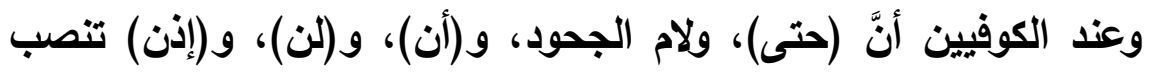
بنفسها(؛)، وأنَّ (كي) وحرف العطف المذكور تضمر (أن) بعدها جوازًًا،

فيه، و إذا لم يوجدا كان مرفوعًا، فدل على أن الرفع من مقتضيات التجرد،

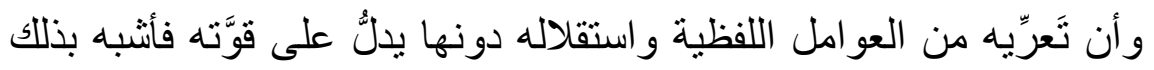

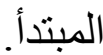

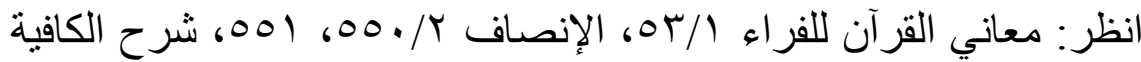

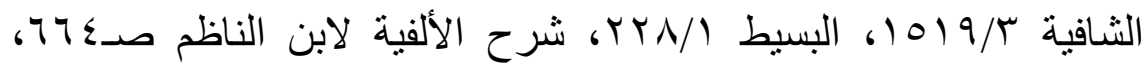

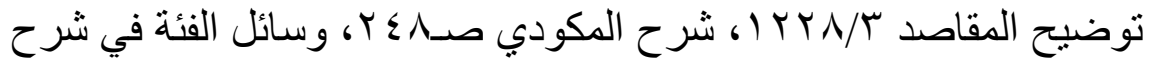

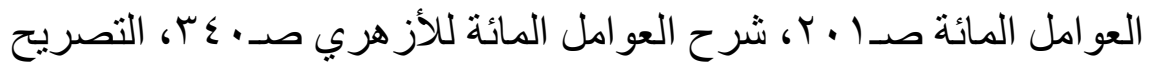

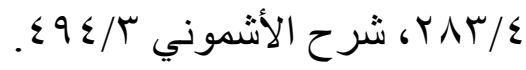
( ) (بلمنان لم أستطع قر اءاتهما.

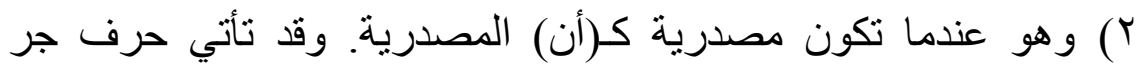

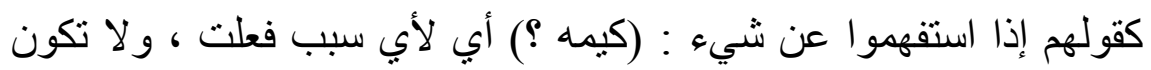

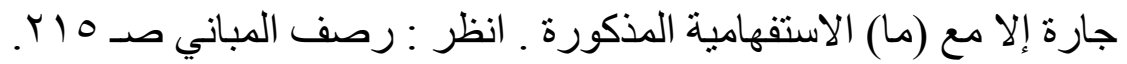

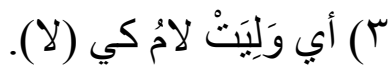

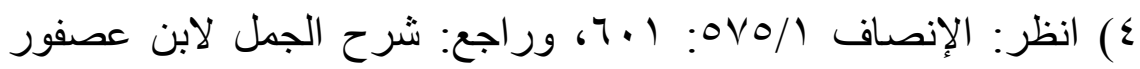
每 
وما بقي ينصب بالمخالفة(')، وزعموا أنّ (أنْ) تضمر بعد حروف الجر، ولا يقاس على ذللك عند البصريين(").

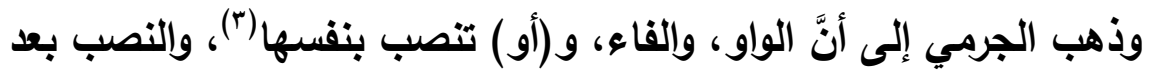
الفاء إذا كان ما قبلها أمرًا أو نهيًا، أو استفهامًا، أو تمنيًا، أو تحضيضًا، أو عرضًا، أو دعاءً، أو نفيًا (؛)، فإن كان ما قبلها خبرًا لم يجز النصب إلا ألا ضرورةً(م)، وزعم بعضهم أنه يجوز النصب بعد أفعال الثك("). و(أن) زائدة، وتفسيرية ، ومخفقة من الثقيلة، وناصبة للمضارع.

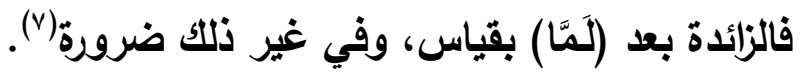

$$
\text { ( ) المر اجع المر المع السابقة. }
$$

ץ) وقد استدل على ذللك بأنها خرجت عن باب العطف، كما أنه وجد الفعل بعدها منصوباً، ولم يقم دليل على أن النصب بإضمار (أن)، فجعل النصب بها، وذهب البصريون إلى أن الفعل بعدها منصوب بتقدير (أنْ)، كما ذهب ونب الكوفيون إلى أن الفعل بعدها منصوب لمخالفة الثاني الأول. انظر : إصلاح الخلل صـ

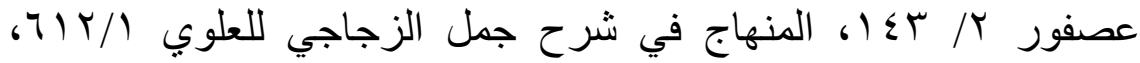

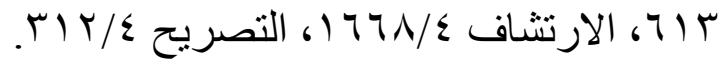
ع) وذللك بشرط أن تكون مسبوقة بنفي أو طلب محضين.

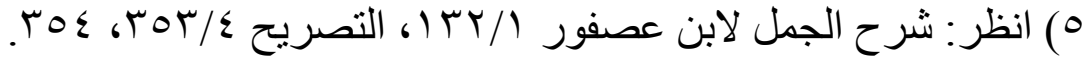

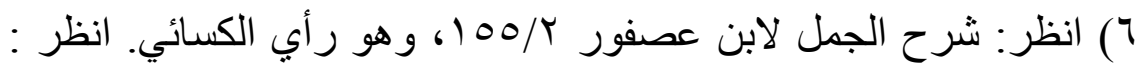

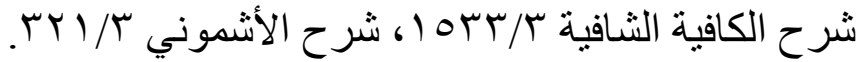

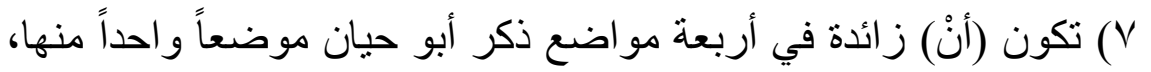

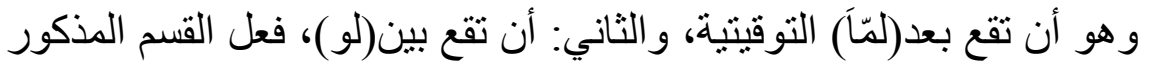

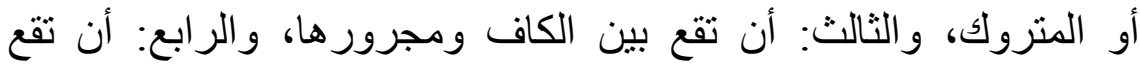


والمفسرة بعد القول أو ما يرجع معناه إلى معنى القول ، وما بعدها تفسير لما قبلها ، ولا موضع لها من الإعراب(').

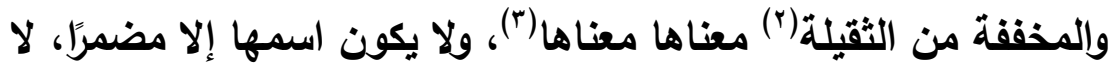

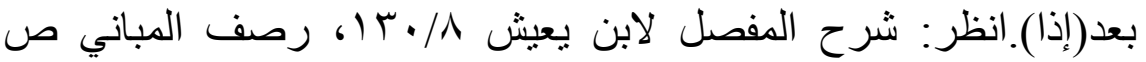

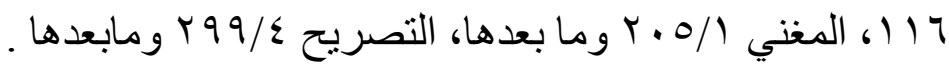

( ) تكون (أنْ) مُفَسِرَةُ إذا سبقت بجملة فيها معنى القول دون حروفه المتأخر

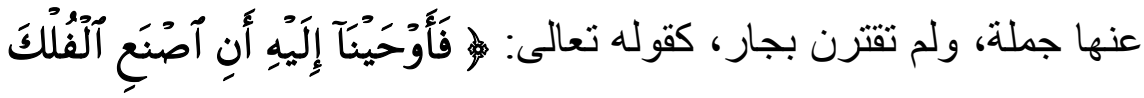

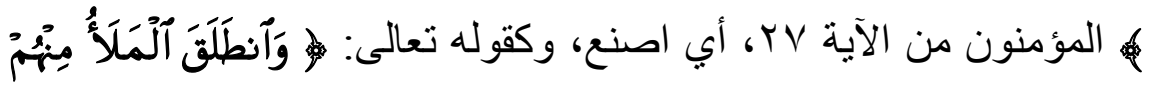
أَنِ آمُشُوأ هورة سورة ص الآية: ج، أي امشوا، وليس المراد بالانطلاق هنا المشي، بل انطلاق ألسنتهم بهذا الكلام. انظر: التصريح ع ؟ Y ومابعدها،

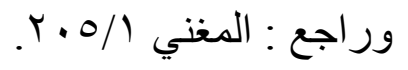

Y) وهي الو اقعة بعد علم خالص سواء دلَّ عليه بمادة( علم) أم لا، فالأول

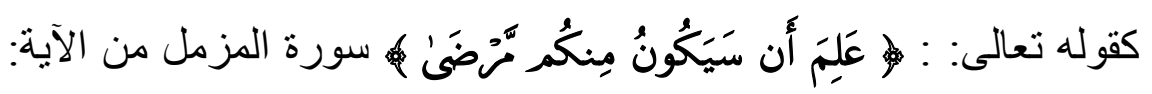

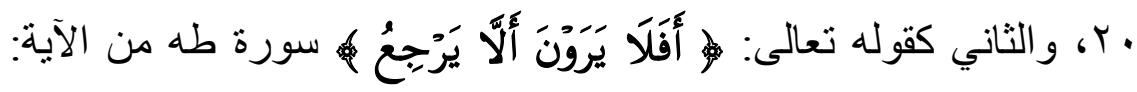

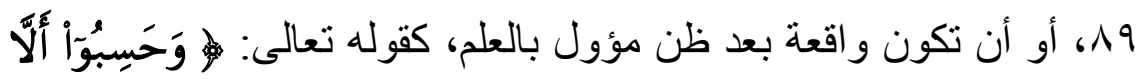
تَكُوبَ به سورة المائدة من الآية: اV في قر اعة الرفع. انظر: التصريح

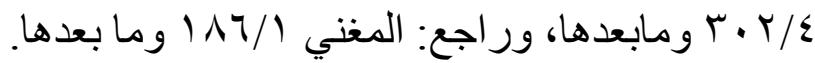

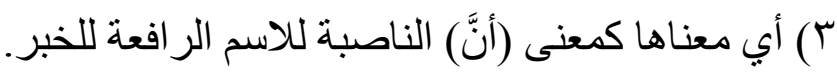


ظاهرًا إلا ضرورة(')، وإن كان خبرها فعلاً) (r)، فيشترط فيها الفصل بينها

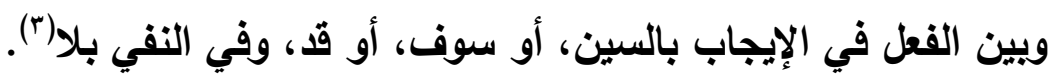

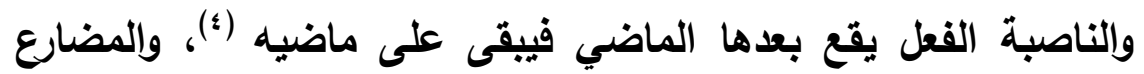
فيتخلص للاستقبال وتنصبه(•)، ويتقدمها من الأفعال ما لا يعطى التحقيق،

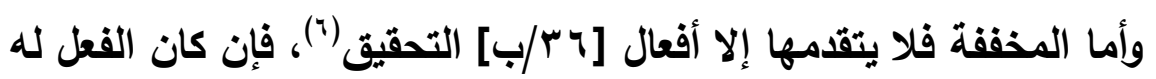

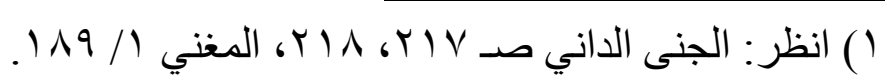

r) ويكون جملة اسمية كانت أو فعلية، فالاسمية كقوله تعالى : وَوَّاخِرُ

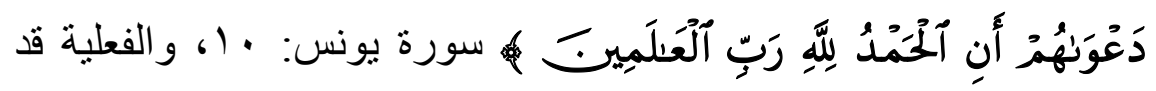
يكون فعلها جامداً أو دعاء فلا يحتاج إلى اقتر ان شيء، وإن كان متصرفًا

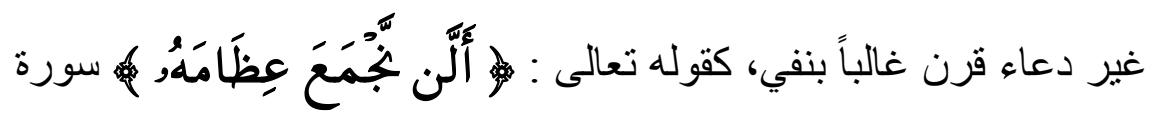
القيامة : ب، وقد يقرن بـ(لو) أو (قد) أو بحرف تنفيس، ولا يجوز أن تخلو

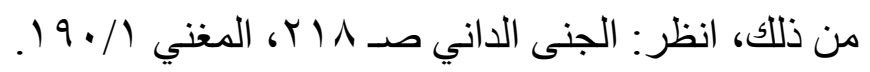

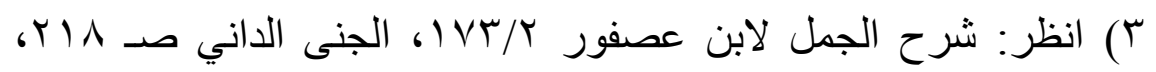
TAT/r ع) أي و لا تعمل فيه شيئا لأنه مبني.

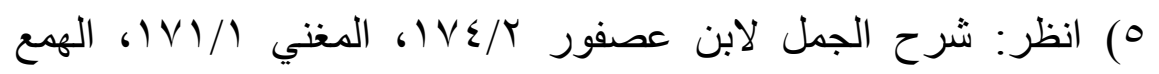
rAT/r T) كـ(علمت، ورأيت ، وما بمعناها ).انظر: شرح الجمل لابن عصفور . IV $\varepsilon / Y$ 
معنيان: التحقيق وغيره جاز أن تثقدم الناصبة للمضارع، والمخفقة من

الثقيلة (1)

(إذن) تكتب بالألف عند المازني(ץ)، ويالنون عند الأكثرين(ז)، ويالألف إن ألغيت ويالنون إن أعملت عند الفراء(؛)، فإن وقع بعدها الحال ألغيت(ه) أو

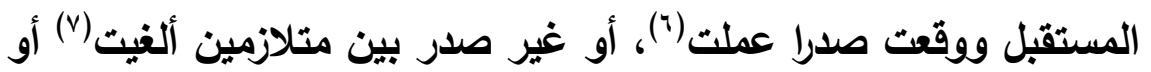
تقدمها حرف عطف فالإلغاء والإعمال(^).

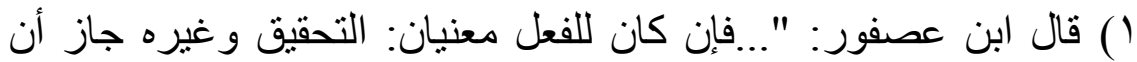

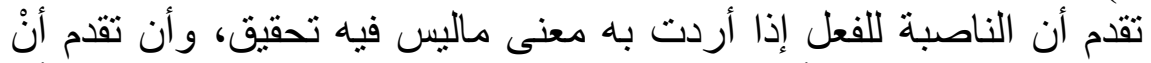

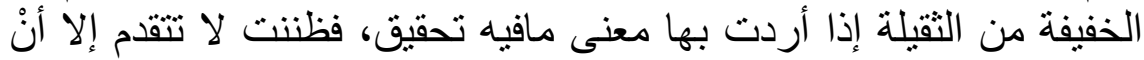

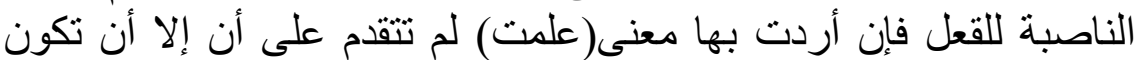

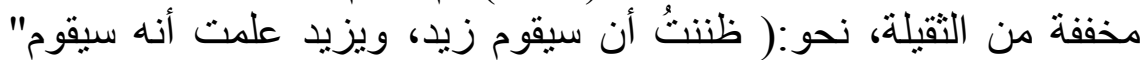

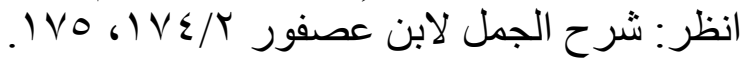

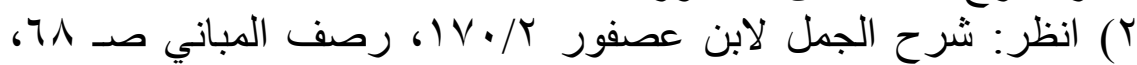
الجنى الداني صـ r) انظر: الّابق. نقل ذلك عن المازني ، و المبرد ؛ لأنها بمنزلة (أن)، و (لن)

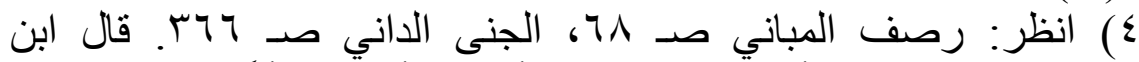

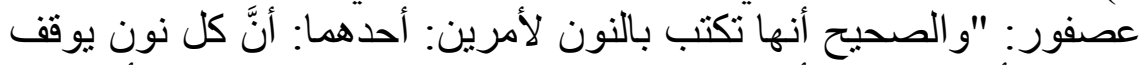

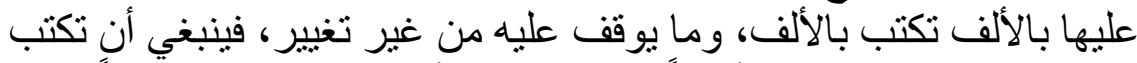

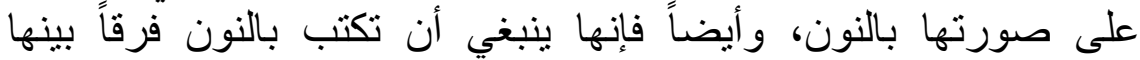

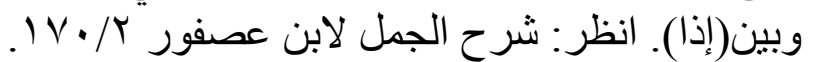

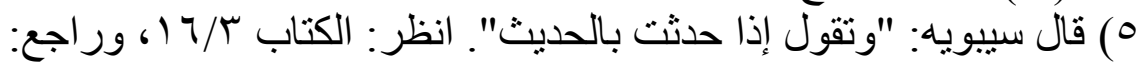

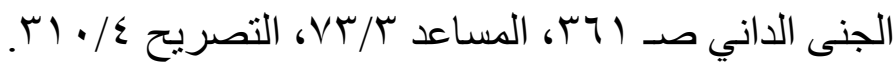

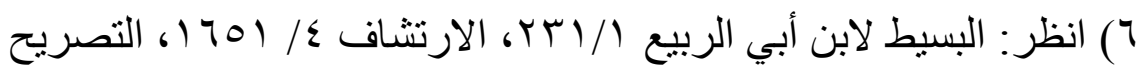
(1)

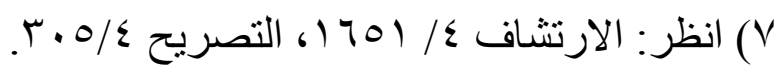

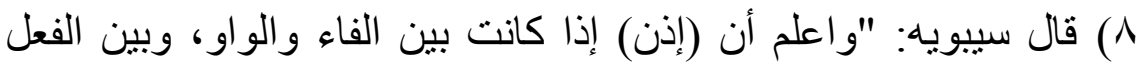

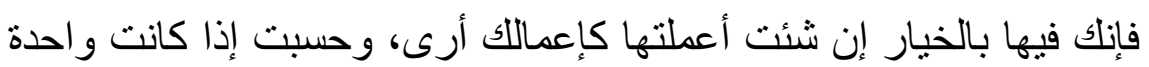


وحكى عيسى بن عمر (') إلغاءَها على كل حال()، وحكى الفراء(") إعمالها

متوسطة.

(حتى) إذا ارتفع المضارع بعدها فمن وجهين: إما أن تريد به الماضي، فتكون (حتى) عاطفة، وإما أن تريد الحال، فتكون حرف ابتداع(ء). وإذا انتصب فمن وجهين: على معنى )كي( أو )إلى أن ) في أنه إذا كان ما قبلها سبباً فالنصب على المعنيين معاً أو غير سبب لما بعدها لم يجز

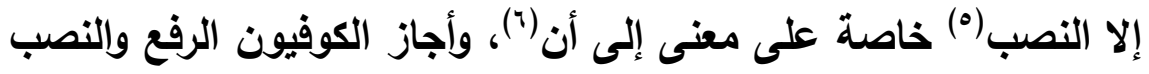

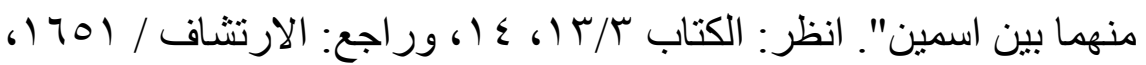

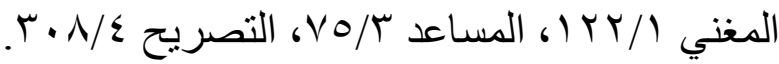

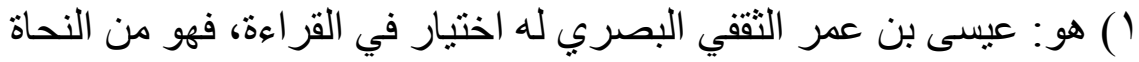

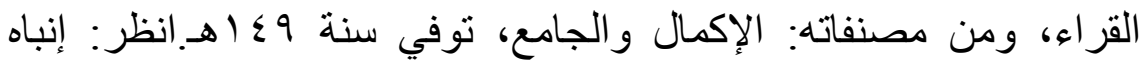

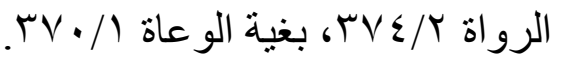

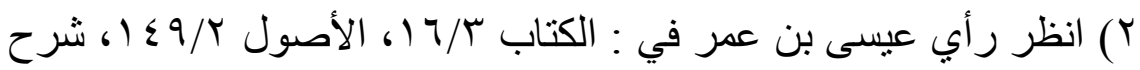

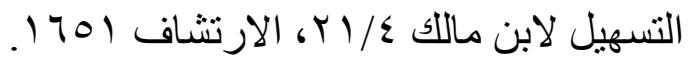

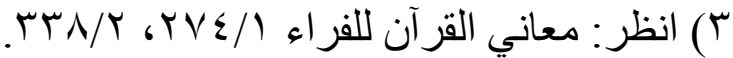

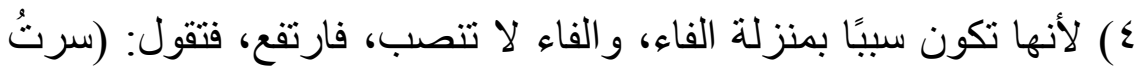

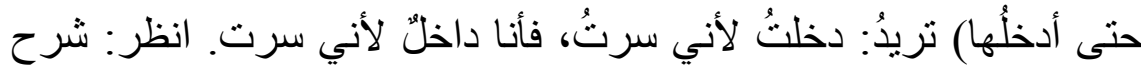

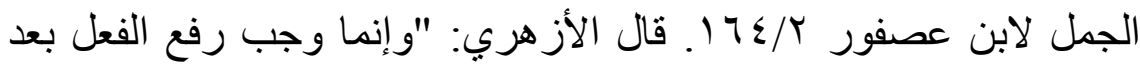
(حتى) عند إرادة الحال حقيقة أو مجازًا؛ لأن نصبه يؤدي إلى تلقدير (أنْ)

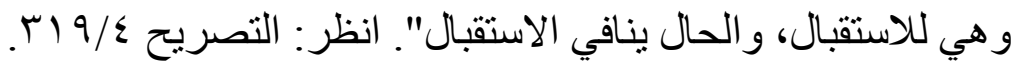
0) نحو: (سرتُ حتى تطلعَ الثمسنُ).

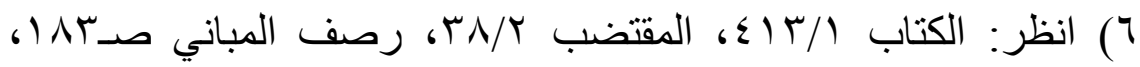

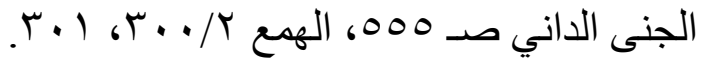


بعد ( حتى ) إذا كان ما قبلها سبيًا أو لا، وحكوا من كلام العرب: (سرتُ لمعن

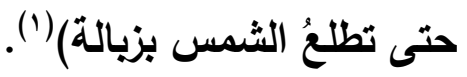

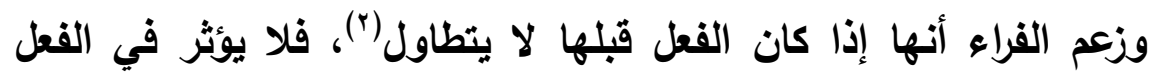

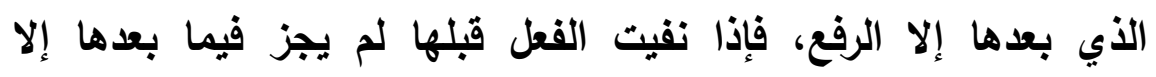

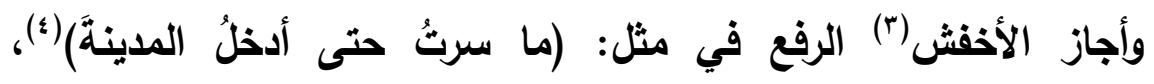

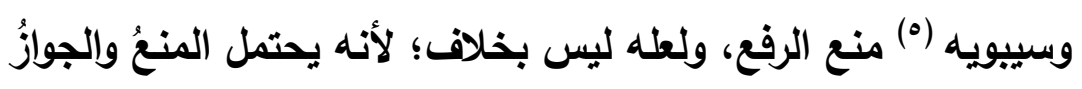

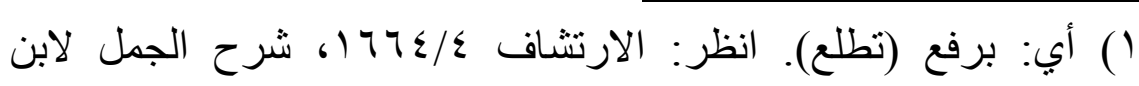

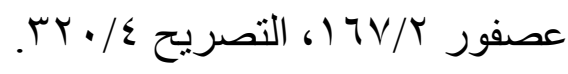
r) في الأصل: "إذا كان الفعل قبلها بعدها لا لا يتطاول"و أرى الصواب ما

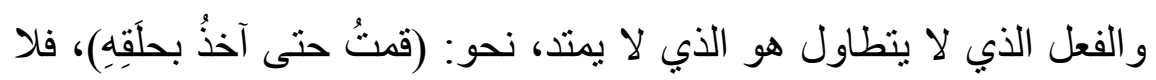

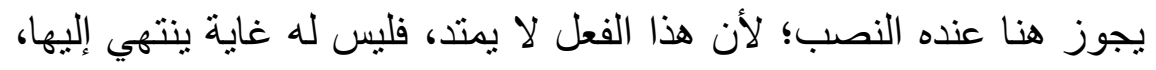

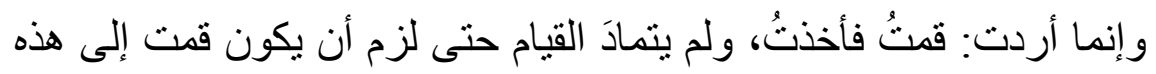

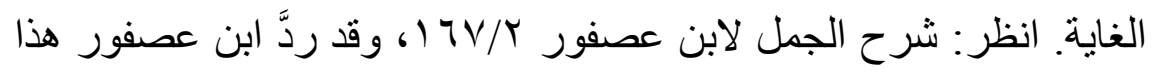

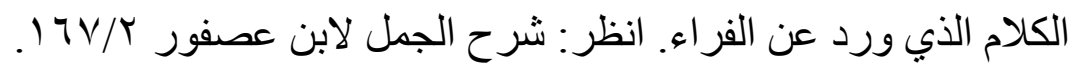

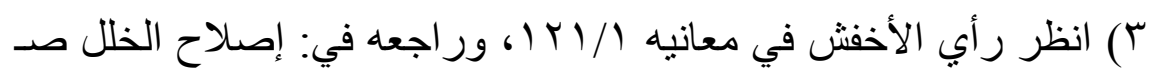

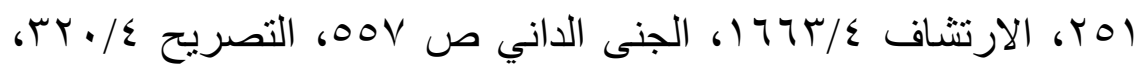
.rT

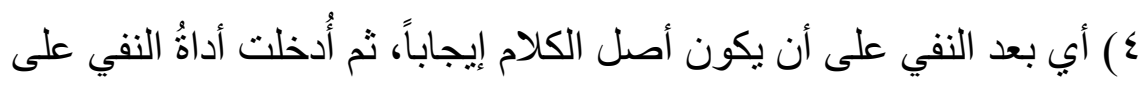

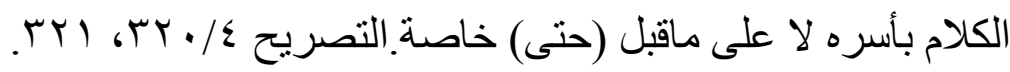

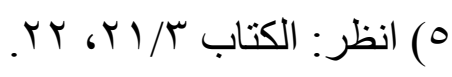


معنيين مختلفين (1).

(الفاء) إن تقدمها كلام غير تام لم يجز فيما بعدها النصب(r) خلافًا لبعض الكوفيين، فإنهم يجيزون النصب على التقديم والتأخير(")، أو تام وتأخر للفعل المعطوف بها معمول، فلا يجوز عند أكثر النحويين النصب(؛)، وزعم الكوفيون أنه يجوز النصب(•).

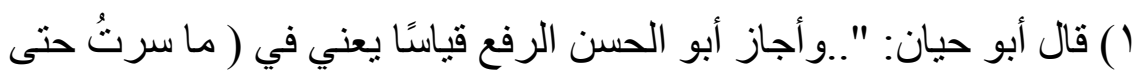

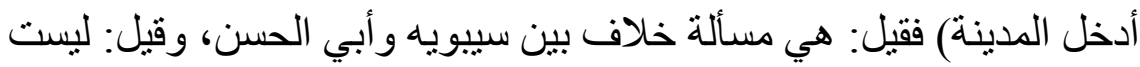
مسألة خلاف؛ لأن الوجه الذي منع سيبويه الرفع فيه غيرٌ الوجه الذي جوز

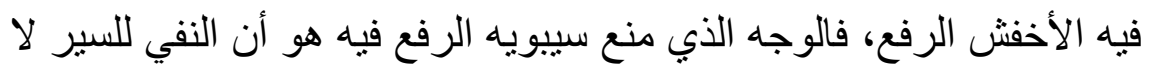

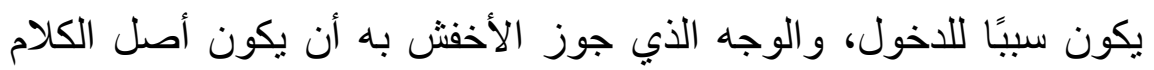
و اجبًا، وهو: سرتُ حتى أدخل المدينة ثم دخلت أداة النفي على الكى الكلام بأسره، فينتفي أن يكون عنك سير كان عنه دخول، فكأنك قلت: ما وقع السير

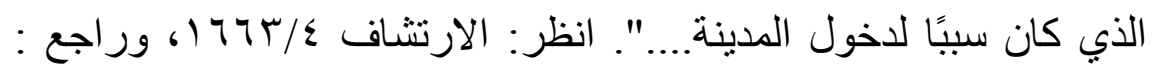

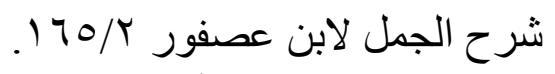

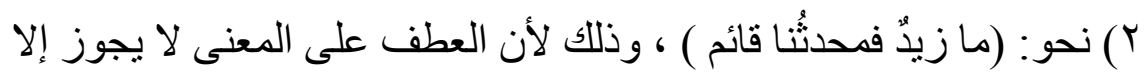

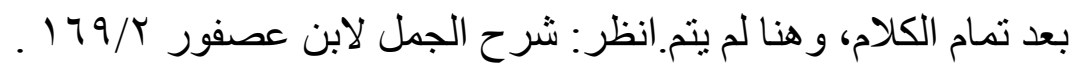

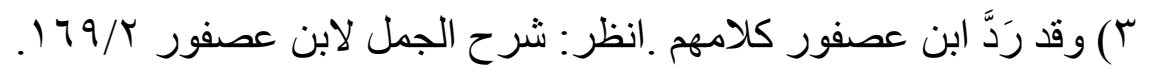

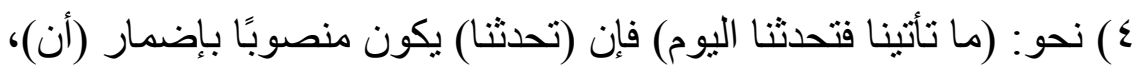

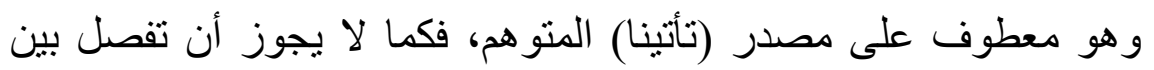

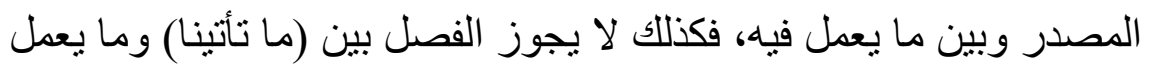

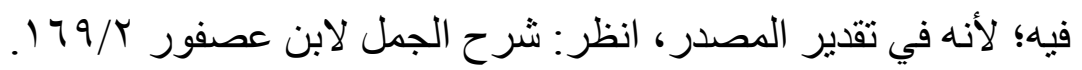

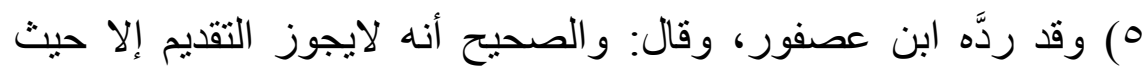

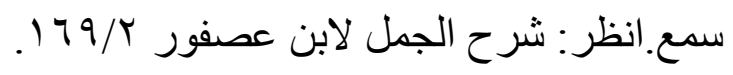


وإن لم يتأخر والجملة اسمية(')، فزعم ابن السراج(؟) وأكثر النحويين أنه لا

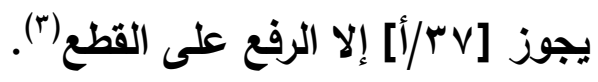

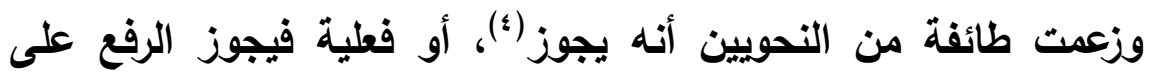

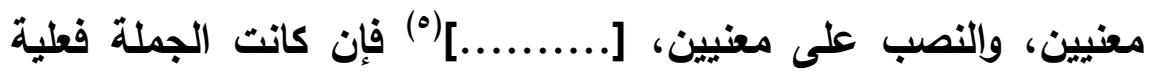
جاز في الفعل بعد الفاء الرفع على معنيين: التشريك في النفي، والقطع، أي: فأنت الآن تحدثنا، والنصب على معنيين: نفيهما على أن الثاني U๋ متسبب عن الأول، وإيجاب الأول ونفي الثاني، أو اسميةً فهما، فالرفع على معنى وإحد، وهو القطع (־)، والنصب على معنيي النصب في الفعلية. وإن تقدم القاء استفهام والجملة فعلية فالرفع عطفًا أو استئنافًا، والنصب فئي على ما ثبت، وتقدير الأول سببًا للثاني(v)، أو اسمية فهما الرفع على

$$
\text { ( ) ) نحو:( مازيدٌ قائمُ فيحدثنا ). }
$$

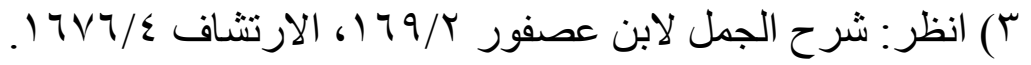
ع) انظر: السابق.

0) قال ابن عصفور: "وإذا نصبت أيضاً كان له معنيان: أحدهما أن يكون

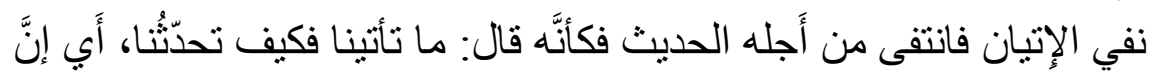

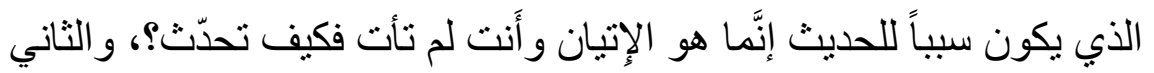

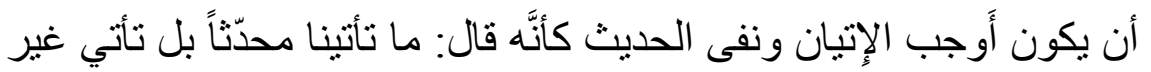

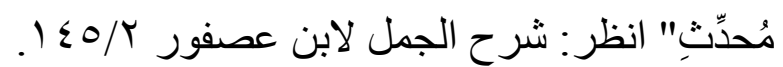
7) أي: ولا يجوز العطف لأنه لم يتقدم فعل فتعطف عليه. انظر: شرح

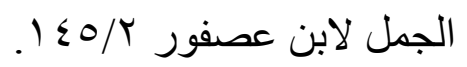

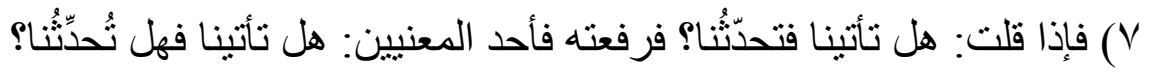

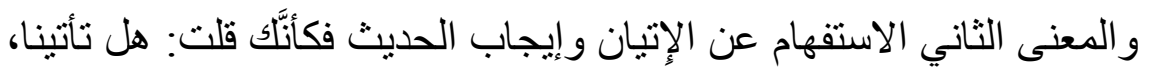
ثم قلت: فأنت الآن تحدّثنا، فإذا قلت: فتحدّثنا، بالنصب فكأنَّنَّ قلت: هل يكون 


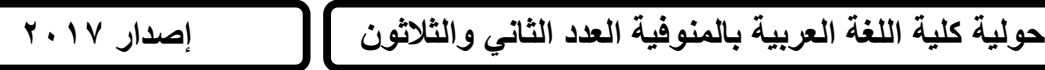

القطع خاصة(')، والنصب على أن الأول سبب للثاني ().

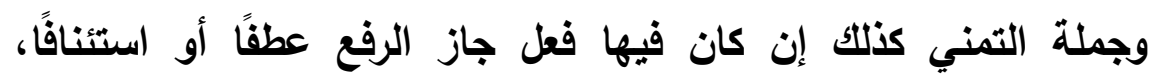

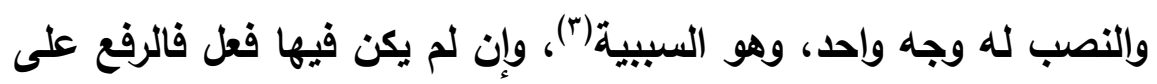
القطع لا العطف.

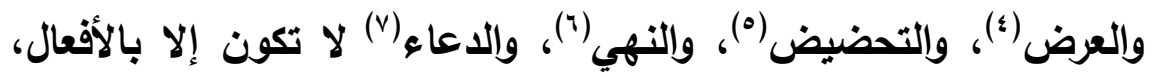

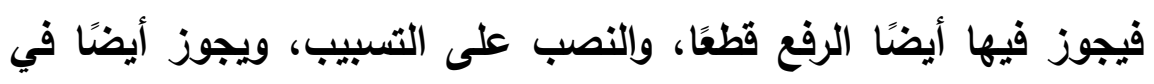
النهي الجزم على العطف.

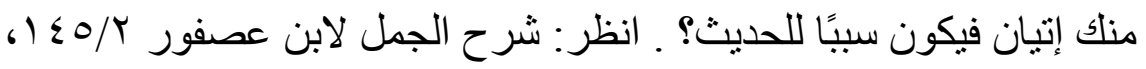
$1 \leq 7$

(Y) لأنه لم يتقام فعل فتعطف عليه.

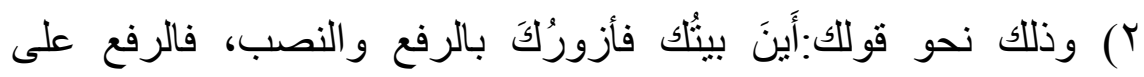

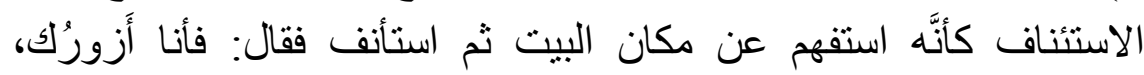

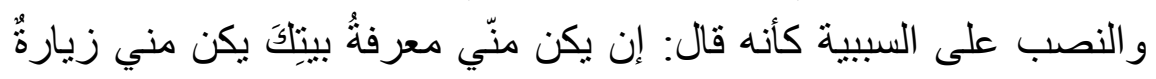

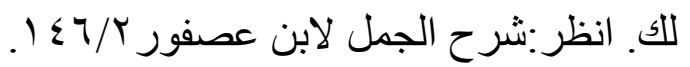

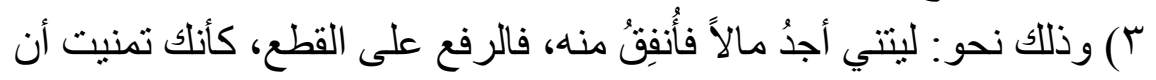

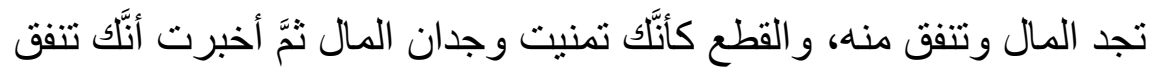

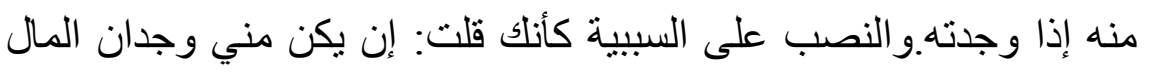

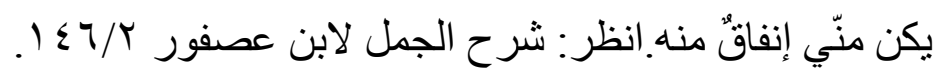

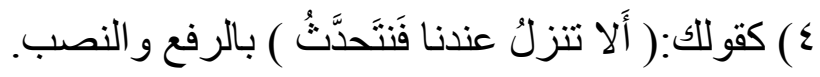

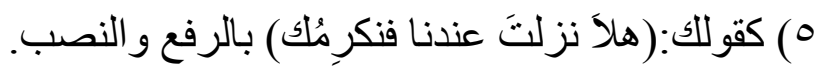

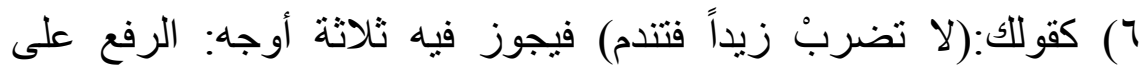

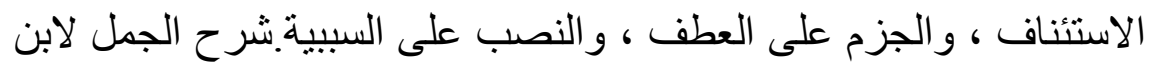

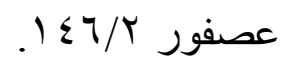

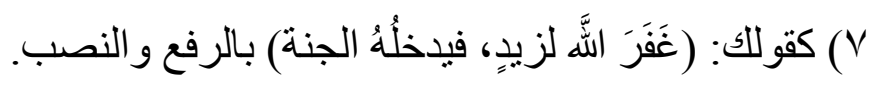
r.q 
والأمر باللام (') كالنهي، ودونها فالرفع على القطع، والنصب على السببية، ولا يجوز الجزم على العطف إلا ضرورة.

(الواو) ينتصب المضارع بعدها إذا عطفت فعلًا على اسم ملقوظ به(r)، أو تعذر العطف بها لمخالفة الفعل بعدها للفعل قبلها()، وذلك لا يكون إلا في موضع الفاء ومسائلها على نحو مسائلها(؛) أو لا ينتصب بعدها إلا إن كان قبلها اسم ملقوظ به، وما بعدها في تقدير اسم، أو يكون معناها

$$
\text { معنى (كي) أو( إلى أن) }
$$

( ) أي إن كان باللام جاز فيه ثلاثة أوجه: الرفع على الاستئناف، والجزم

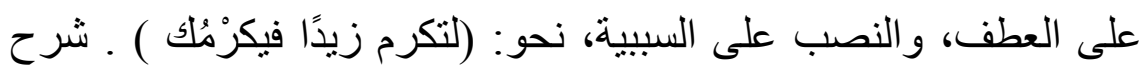

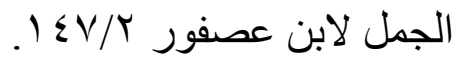

r) وحينئ لايمكن إلا نصب الفعل بعدها بإضمار (أن) على رأي

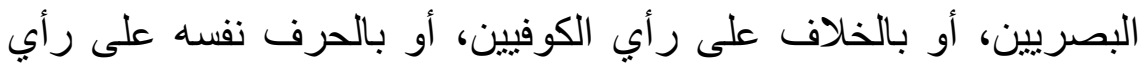

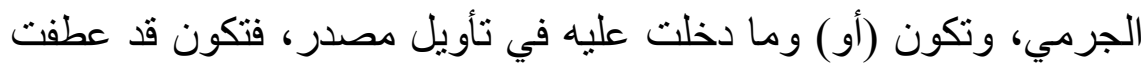

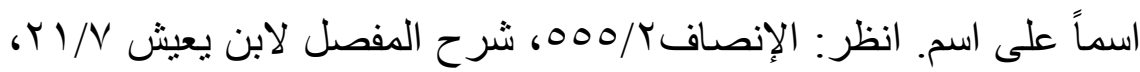

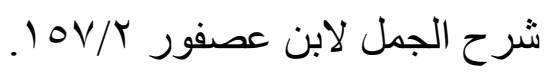

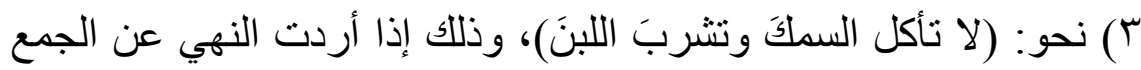
بينهما، ولم ترد النهي عنهما على كل حال، فلما خالف مابعدها ما قبلها

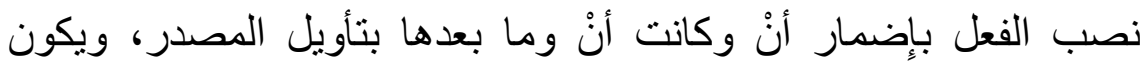

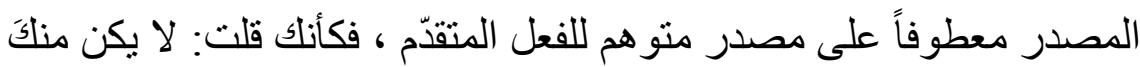

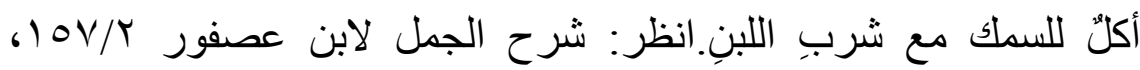

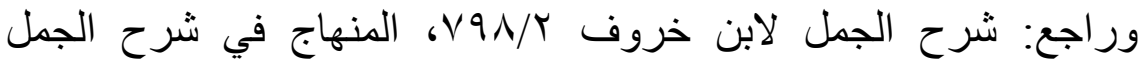
. T/ $\mathrm{V} / \mathrm{T}$

§) أي لا يكون إلاّ بعد أمر أو نهي أو استفهام أو عرض أو تحضيض أو

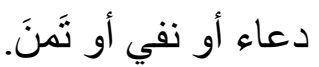


الجوازم لفعل واحد: (لَمْ)، و(لَمَّا)، ولام الأمر، و(لا) في النهي.

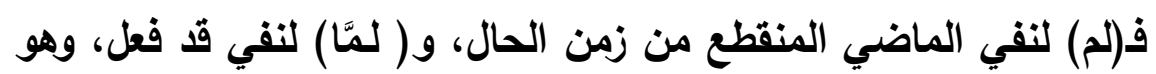
الماضي المنقطع من زمن الحال(')، وقيل: هي داخلة على المستقبل فتقلب معناه إلى المضي (r) [rV/ب]، وقيل: دخلتا على الماضي وصرفتا صيغته إلى صيغة المستقبل، وهو الصحيح) (").

والواقع بعد هذه الحروف إن كان معرياً بحرف فجزمه بحذف ذلك الحرف(؛) أو بالحركة صحيح الآخر فجزمه بسكونه(0) أو معتله بالياء أو بالواو أو بوه بالألف فالجزم بحذفها(`)، وقد يجزم بسكون آخره وذلك قليل

() انظر: شرح الجمل لابن خروف 100/Y، المنهاج في شرح الجمل $.709 / 1$

Y) وهو قول المبرد، وقوله: "وقيل: هي داخلة على المستقبل فتقلب معناه

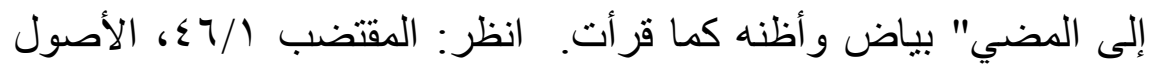

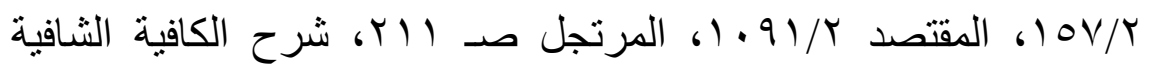
إ

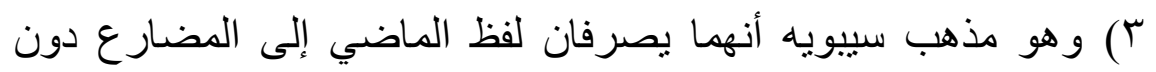

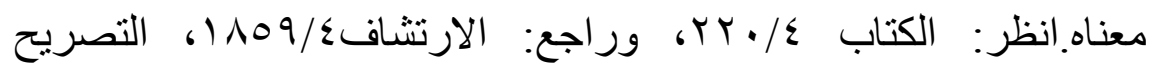
rur/s

ع) نحو: (لم يفعلا، ولم يفعلوا، ولم تفعلي ).انظر: شرح الجمل لابن

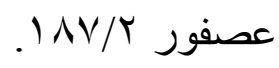
0) نحو: ( لم يضربْ، ولم يخرجْ ).انظر: شرح الجمل لابن عصفور $.1 \wedge \mathrm{V} / \mathrm{r}$ T) فيقال: ( لم يقضِ، ولم يغزُ، ولم يخشَ ). 
وقيل: يجوز إلا في الياء والواو، وقيل: يجوز فيهما، وفي الألف(؟).

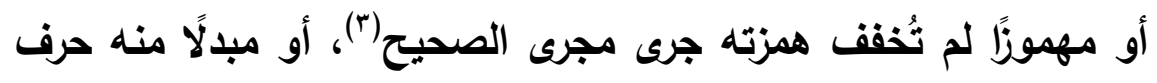

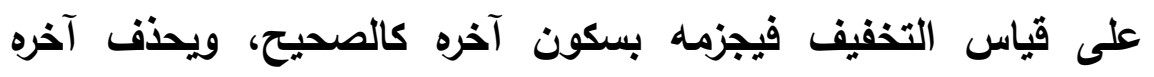

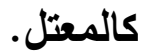
ولا يجوز حذف الجازم ويقاء عمله إلا في لام الأمر في الضرورة(؛)، ولا

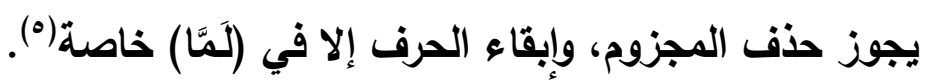
والأمر لمتكلم باللام، ولمخاطب مبني للمفعول باللام أو للفاعل بالتلام

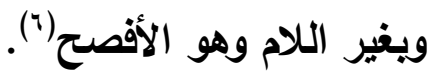

() ذكر الفراء أن بعض العرب لايحذفون فيقولون:( لم يقضي، ولم يغزو،

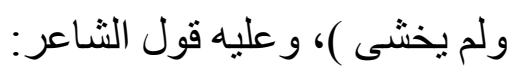

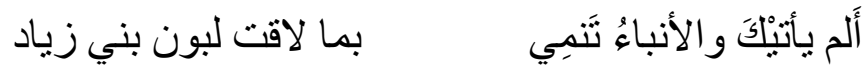

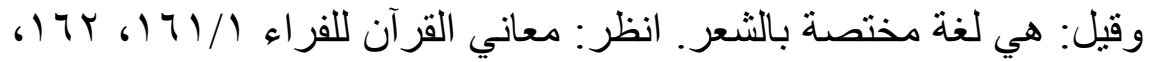

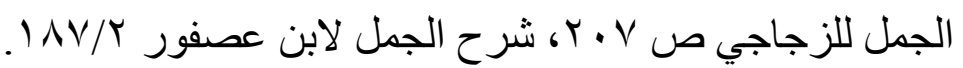

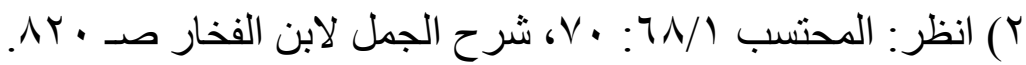

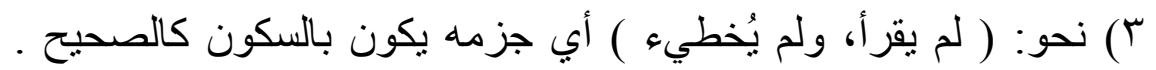

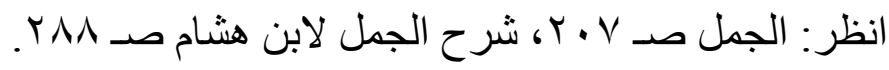

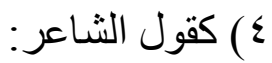

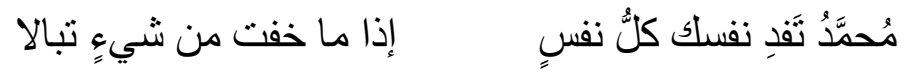
يريد: لتففي. ه) نحو: (سرتُ المدينة ولمَّا )، أب: ولمَّا أدخلها، لكن حذفت لفهم المعنى. 1) تقول: (لِنَضْرِبْ، واضربْ). 
وكيفية بنائه: أنه إن كان ما بعد حرف المضارعة متحركًا في اللفظ حذف حرف المضارعة، وسكنت آخره(')، أو في التقدير حذف الحرف، ورد المحذوف، وسكن آخره(ץ)، أو ساكنًا(ّ) حذف الحرف، وسئكّن آخره،

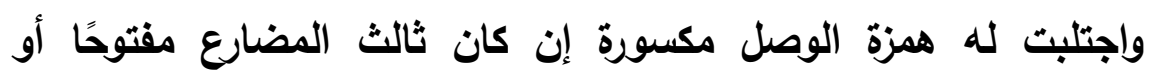

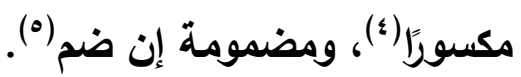

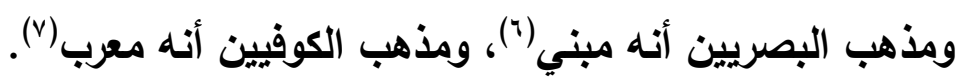

( ) تقول في: (يقوم) (قُمْْ).

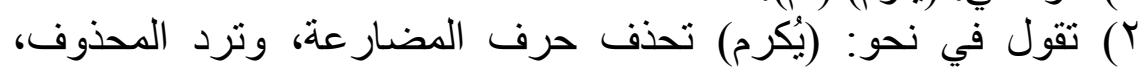
وتسكن الآخر ، فتقول: (أَكرْمْ).

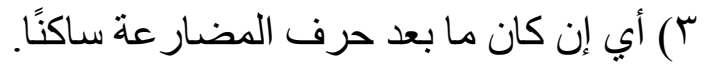
ع) نحو: (إذهَبْ، و اضرِبْن). (1) نحو: (أُقْنُل).

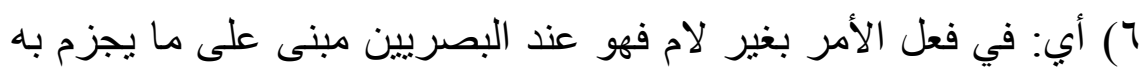

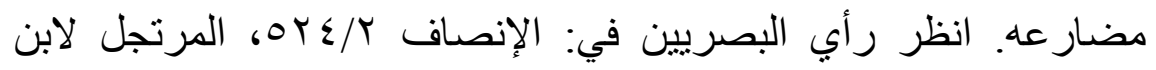

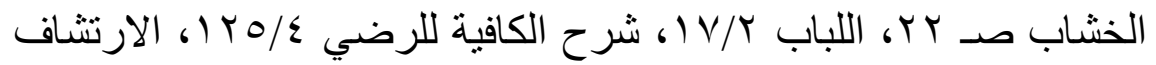

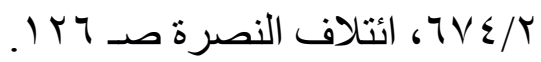

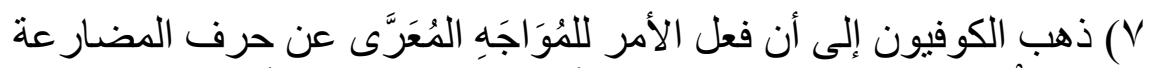

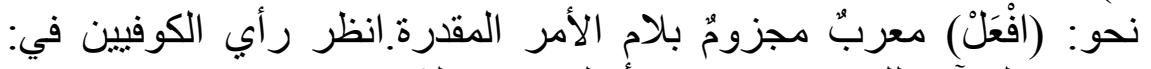

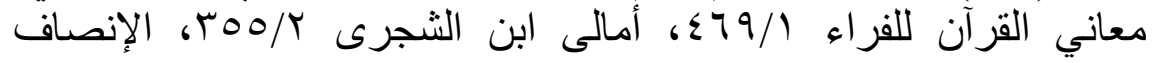


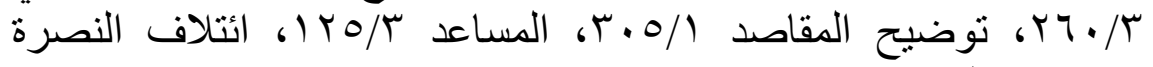

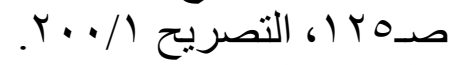
و المذهب الصحيح هو ما ذهب إليه إنه البصريون، وذللك لمايلي:

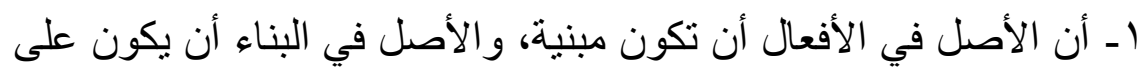

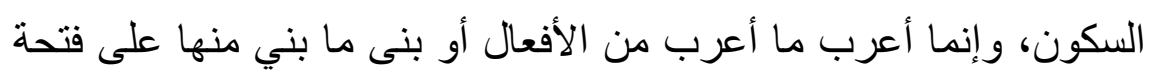


ويجزم ما كان جوابًا لأمر، واسم فعله، ونهي، وعرض، وتمن، واستفهام

غير تقرير، وتحضيض (1)

وقيل(؟): جزمت لتضمنها معنى الشرط(ّ)، وقيل: لنيابتها مناب الشرط

وفعله (๕)، وهو الصحيح. جرهن

لمشابهة ما بالأسماء، و لا مشابهة بوجه ما بين فعل الأمر والأسماء، فكان باقياً على أصله في البناء.

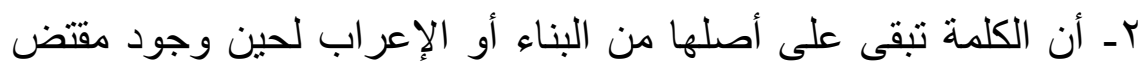

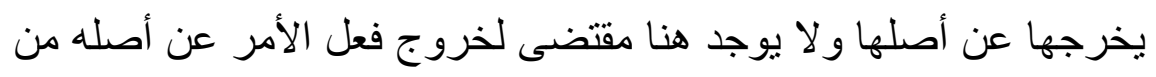
البناء.

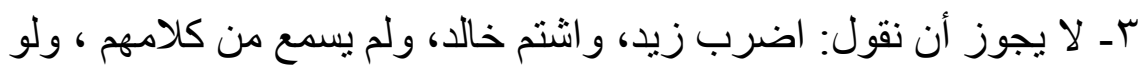

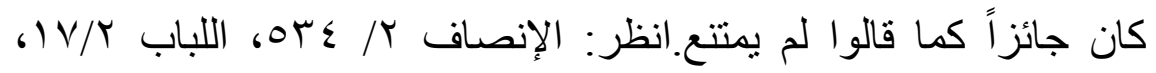

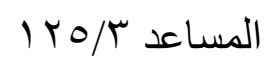

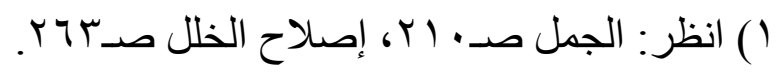

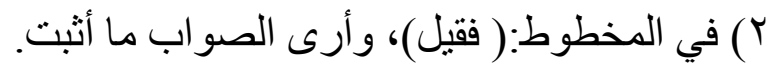
ب) قال ابن عصفور: "..لأنك إذا قلت:( أطع الله يغفر للك )، فإنما جزم جو اب أطع اله لأنه ضُمِّنَ معنى إن تطع." انظر : شرح الجمل لابن إن عصفور $.19 T / K$

ع) قال ابن عصفور: " لأن الأصل عندهم في:( أطع اللهَ يغفر للك )( إن تطع

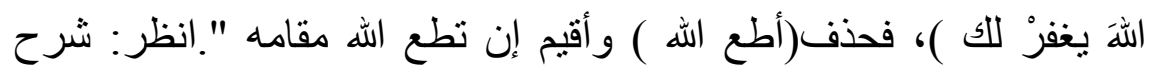

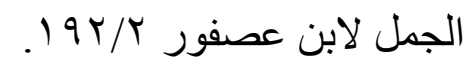


ومذهب البصريين: أنه لا يجزم جواب النهي حتى يسوغ فيه دخول حرف الشرط عليه مع أداة النفي(')، ومذهب الكوفيين أنه يجوز ذلك مع أداة النفي وغيرها()، فإذا لم تضمن الجملة معنى حرف الثرط ارتفع الفعل. ومما يجزم جوازاً إذا ضُمِّْنَ معنى الثرط:

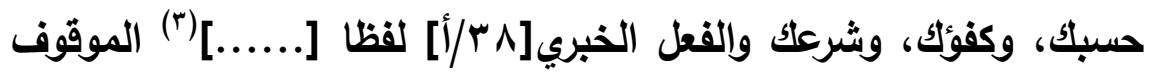
على السماع، والمسموع: اتقى اللهَ امروٌٌ فعل خيرا يثب عليه، ويجوز أن يضمن [....]") وأجاز الكوفيون جزم الفعل جواباً للفعل الواجب إن كان سبيًا للمجزوم، ولا يجزم هذا عندنا إلا ضرورة.

كلم الجزاء: (إنْ) وإ(ذُما)، وهما حرفان (•) خلافًا للمبرد (־) في (إذْ ما)،

() نحو:(( لا تعصِ الله يخفرْ للك )؛ لأنه يسوغ أن تقول:( إن لا تعص الله

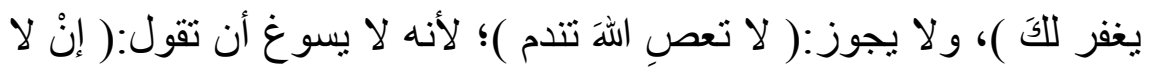

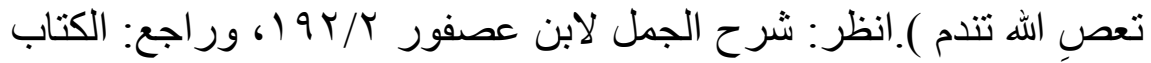

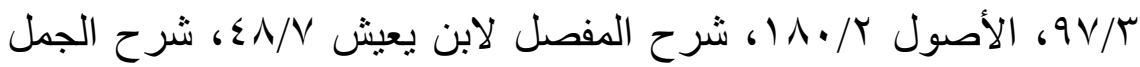

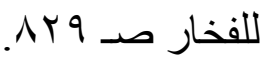

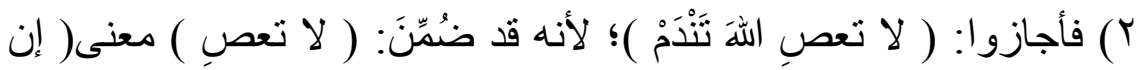

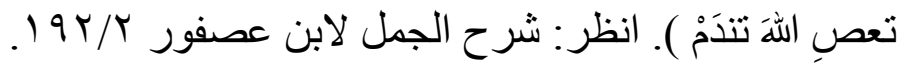

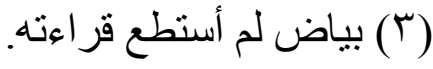

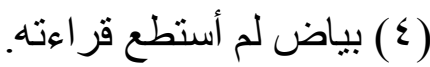

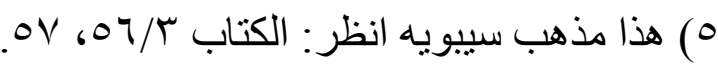

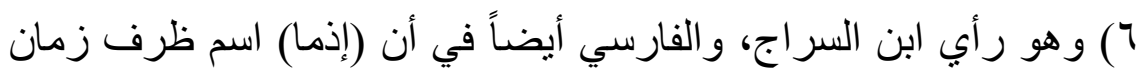

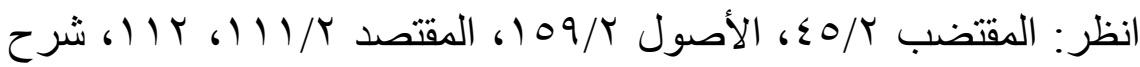

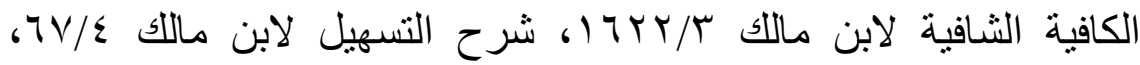

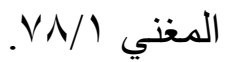




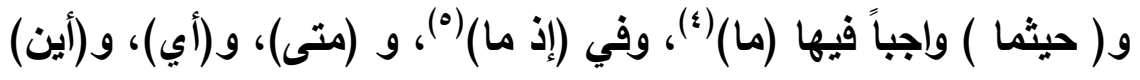

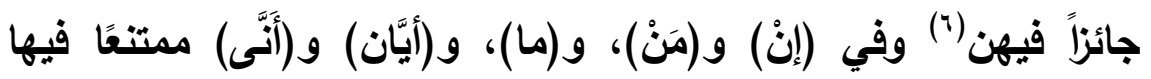

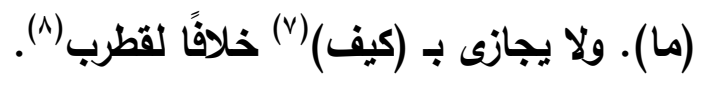

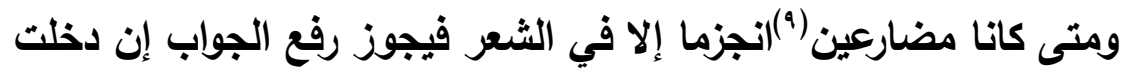

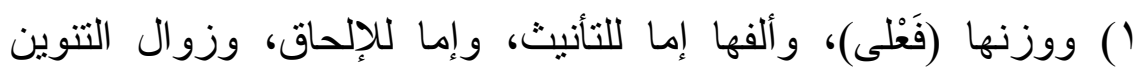

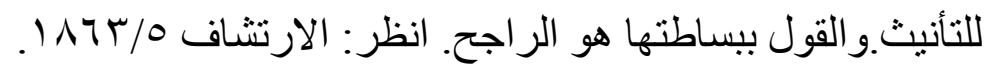

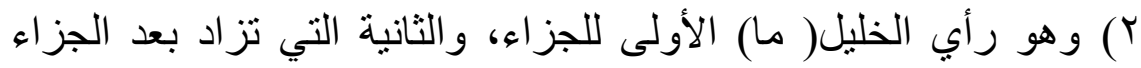

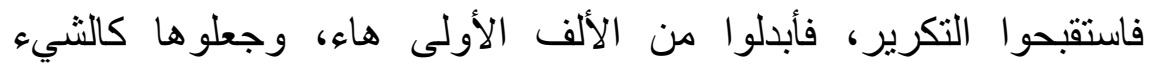

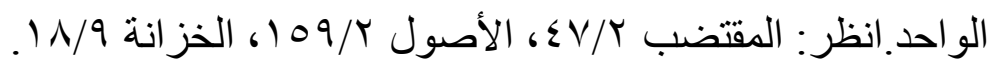

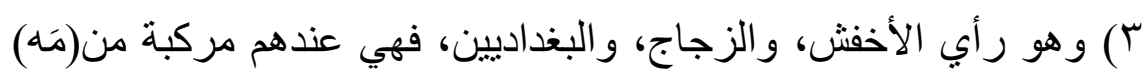

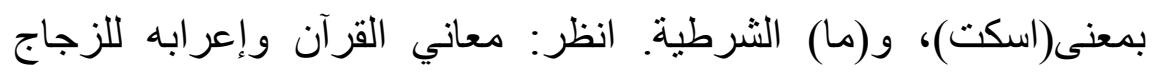

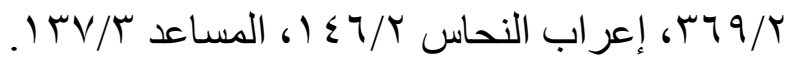

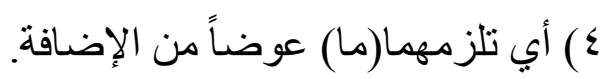
( ) الأنها ركبت معها. T) أي يجوز دخول(ما) عليها و عدمه فأنت بالخيار.

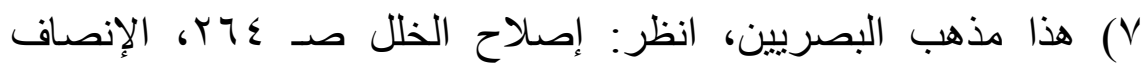

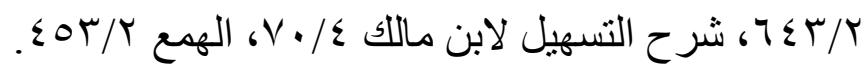

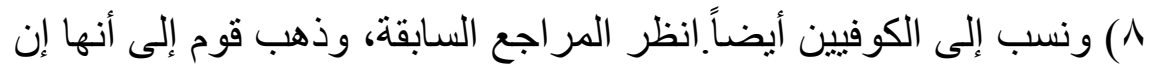

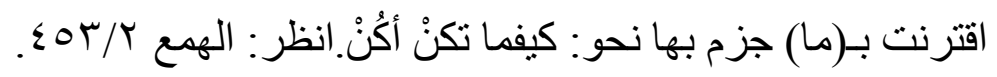

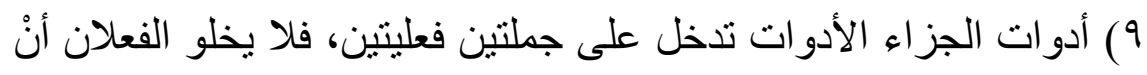
يكونا ماضيين أو مستقلين أو أحدهما ماضياً والآخر مستقبلاً. 


\section{عليه الفاء وكان في موضع جزم (1).}

أو ماضٍ ومضارع وتقدم الماضي(؟) جاز رفعه وجزمه أو المضارع فيجب جزمهه، ويختص هذا التركيب بالشعر(ّ)، فإن كان الجواب أمرًا أو نهيًا أو

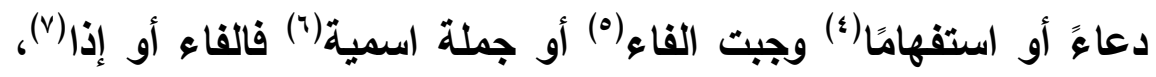
ولا تحذف الفاء إلا ضرورة أ(م).

( ) أي إن دخلت الفاء على الجواب فيرفع، و لايجوز الرفع إذا لم تدخل إلا ضرورة، كقول الشاعر:

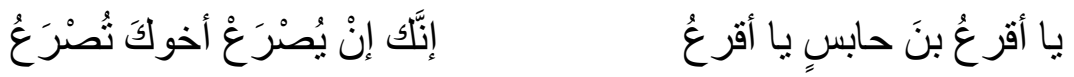
أراد: فتصرعُ وحذف الفاء ضرورة. انظر: شرح الجمل لاعب إعن عصفور $19 V / r$

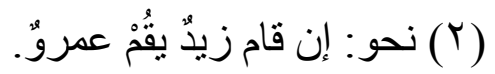

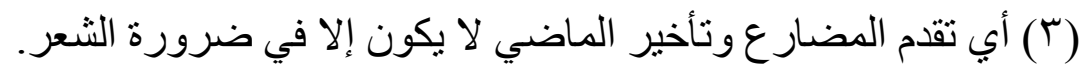
( ( ) أي وكان الفعل الأول ماضيًاً أو مستقبلاً.

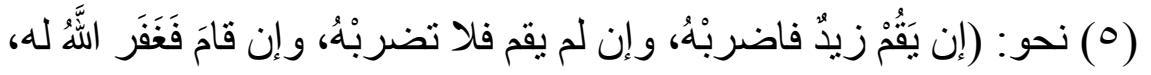

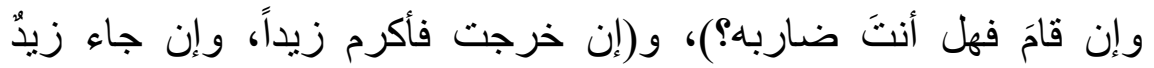

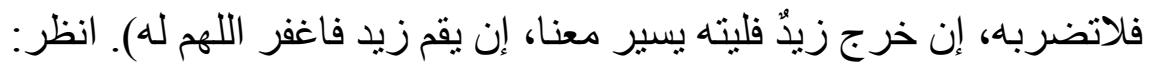

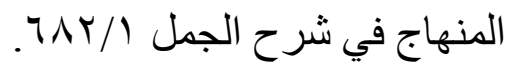
(7) أي و الجملة الأولى فعلية، و الجو اب جملة اسمية.

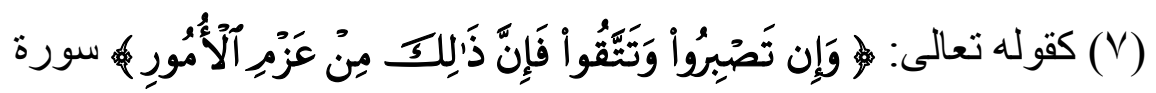

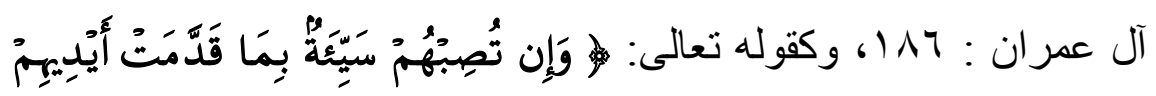

$$
\begin{aligned}
& \text { إِذَا هُمَ يَقْنَطُونَهَهَ سورة الروم: بَّ. }
\end{aligned}
$$

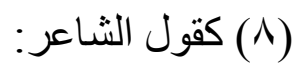

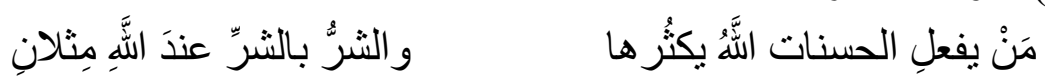


والاختيار أن يلي الفعل الأداة ولا يلي الاسم إلا ضرورة'(1) إلا في(إنْ )،

فيجوز إلا إن ظهر عليها فضرورة)(بان.

وإذا اجتمع الثرط والقسم يبنى الجواب على المتقدم منهما(ّ)، أو الثرط والاستفهام يبنى على الشرط، وياخل الاستفهام على الجملة من الشرط

والجزاء هذا مذهب سييويه (؛)، وأما يونس فيني على الاستفهام(•).

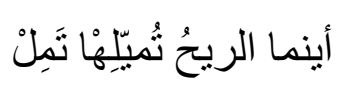

$$
\begin{aligned}
& \text { (1) كقول الثـاعر: } \\
& \text { صعدةٌ نابتهُة في حائرِ }
\end{aligned}
$$

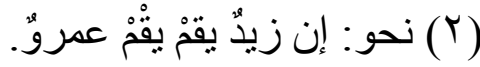

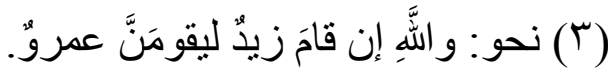

(§) أب أن سيبويه ييني الجواب على الثرط ويدخل الاستفهام على الجملة

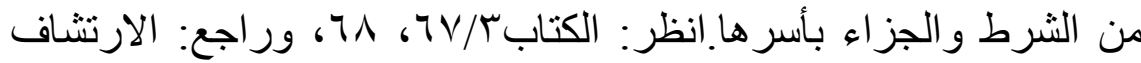

$$
\text { INVO/s }
$$

(0) أب أنَّ الفعل يينى على الاستفهام نحو: أَإن قامَ زيدُ يقمٌ عمروٌ، ويونس

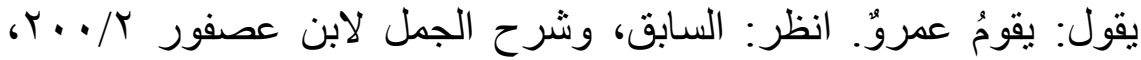

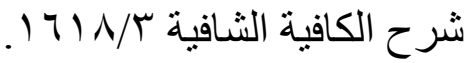
وقد رَجَّح ابن عصفور ما ذهب إلبه سيبويه فقال: " و الصحيح مذهب سيبويه

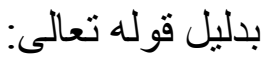

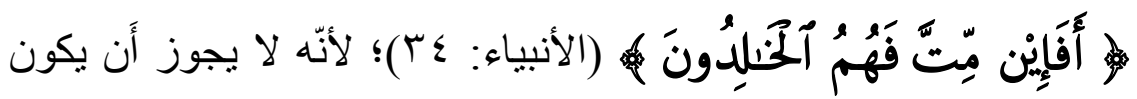

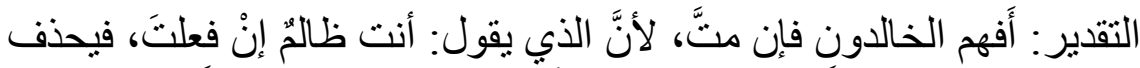

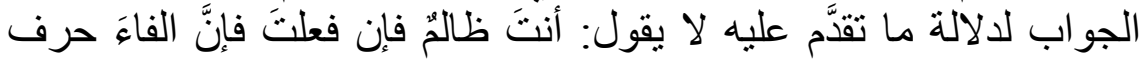

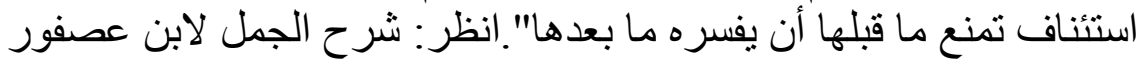




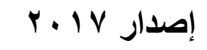

حولية كلية اللغة العربية بالمنوفية العدد الثاني والثلاثون

وإذا فُهم المعنى جاز أن يحذف الشرط(') أو الجواب(ץ) أو كلاهما(ّ). وإذا سبق اسمَ الشرط عاملٌ بطل عمله ما عدا حرف الجر(؛)، والاسم المضاف إليه(0) ويتعلق حرف الجر بما بعده.

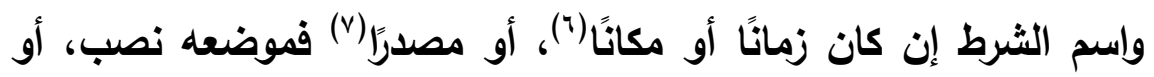
غير ذلك، وفاعل الفعل مضمر اسم الشرط فهو [^/ب/ب] مبتدأ، أو غيره

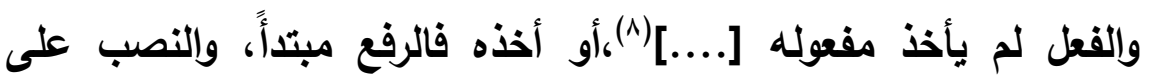

الاشتثال.

و إلاً بَعلُ مَفرِقَلَكَ الحُسَاُم

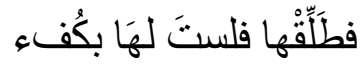

$$
\text { : (1) }
$$

أي: و إن لا تطلقها.

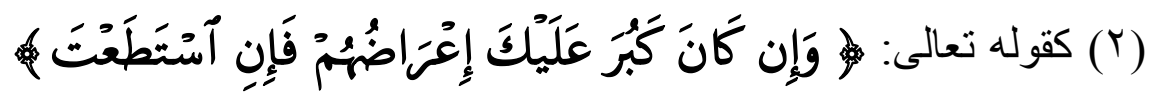
سورة الأنعام من الآية: هب أي فافعل.

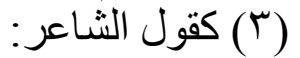

كانَ عَيِّاً مُعدَمَاً قالت و إنْْ

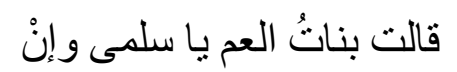

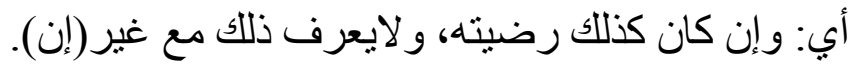

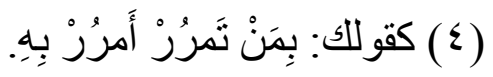

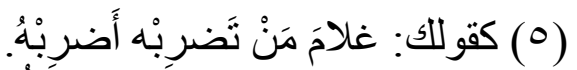

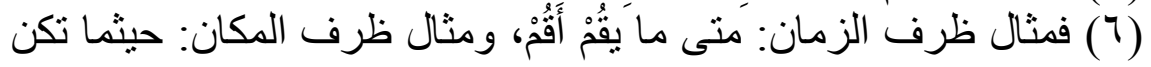

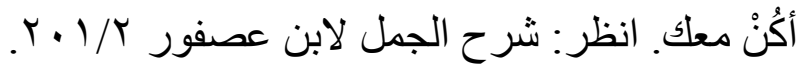

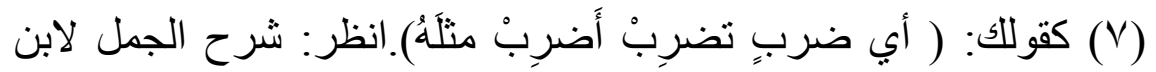

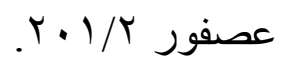

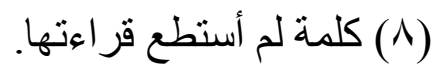


الموفور من شرح ابن عصفور

د/ لحمدمحسمد الجنــي

دا عبد الملك لمد شثيتيوي

ويبطل معنى الثرط إن تقدم عليه(')، وإضافة ظرف زمان إليه، ولا يجزم إلا ضرورة(ז)خلافًا لمجيزه في الكلام.

وإذا عطفت على فعل الشرط فالجزم() أو على فعل الجواب بالفاء فتلاثة

الأعاريب، والنصب أضعفها(؛)، أو بغير الفاء فالجزم(ه).

وإذا توبط بين الفعلين آخر في معنى الأول ارتفع حالًا، أو انجزم بدلًَا")،

أو ليس في معناه وجب رفعه حالًا(V)، وكذلك إن وقع بعد فعل الجزاء آخر.

و(إنْ) تأتي شرطية كما ذكرنا، ونافية للجملة الاسمية ولا تعمل فيها، وقد

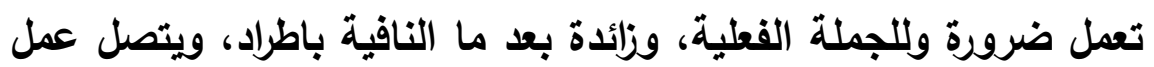
ما ويعد المصدرية قليلا، ولا تزاد في غير هذين و(لو) إن كانت شرطية

( (1) أي تقدم عليه أسماء الثرط، فيبطل معنى الثرط، ويرتفع الفعل.

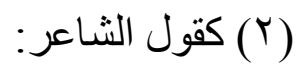

على حين مَنْ تَلَبَتُ عليهِ ذَنُوبُهُ

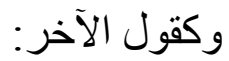

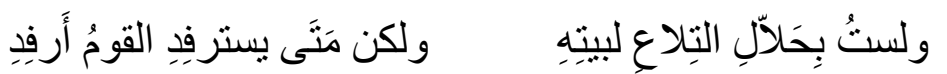

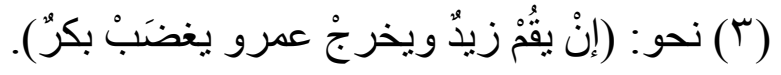

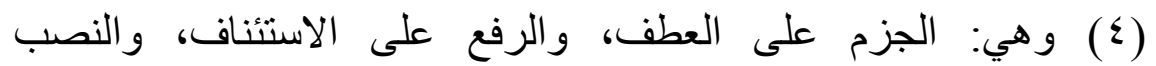
بإضمار (أنْ).

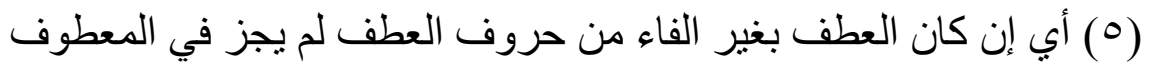

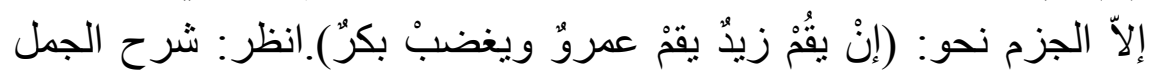

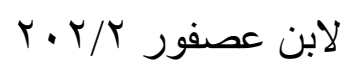

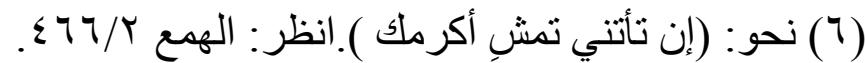

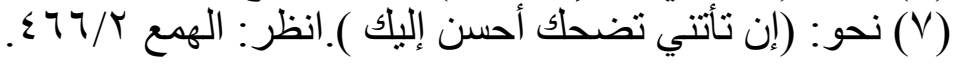


فالفعل بعدها مستقبل لفظا ومعنى أو معنى لا لفظا أو امتتاعية فهو

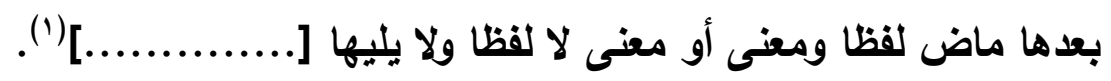
******

الاسم المنصرف ينون، ويخفض(ץ)، واشتق من الانصراف، وهو الرجوع(ז)، وقيل: من الصريف بمعنى الصوث(؛)، وقيل: من الصرف وهو (الخالص(•).

والتنوين يكون للتمكين، وهو تتوين الصرف(")، ويلحق ما عدم شبه الحرف، وشبه الفعل(v).

$$
\text { ( ( ) بياض لم أستطع قر اءته. }
$$

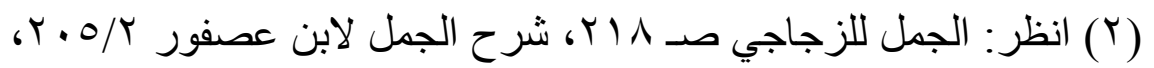

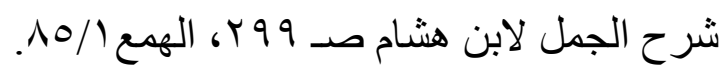

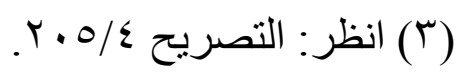

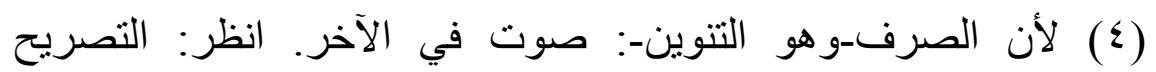

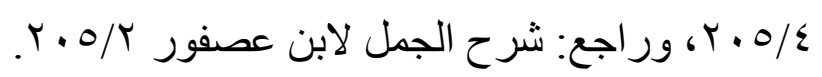

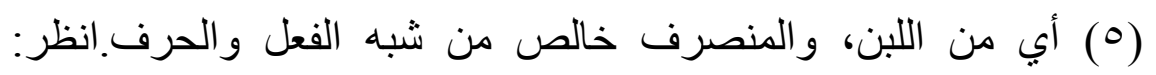

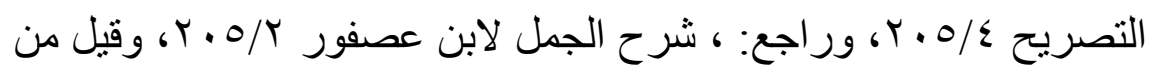

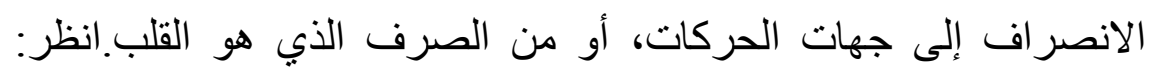

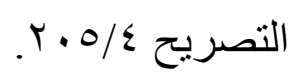

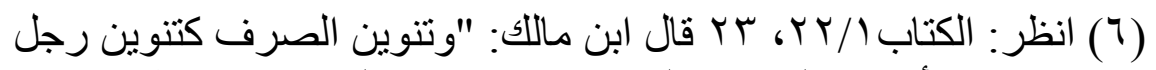

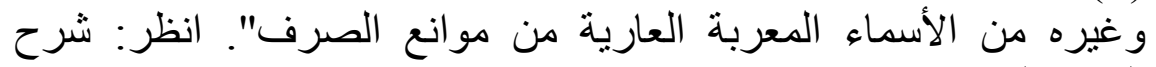

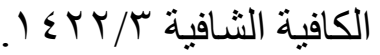
(V) أي هو اللاحق للأسماء المعربة المنصرفة؛ لأنها لم تشبه الحروف

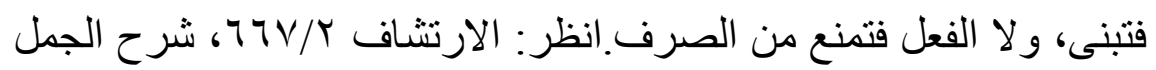

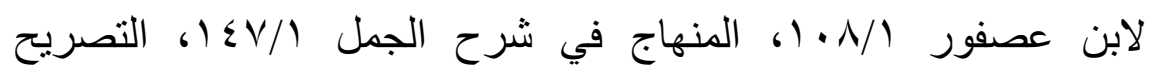




\section{الموفور من شرح ابن عصفور}

دالحمد محسمد لجندي

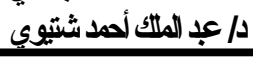

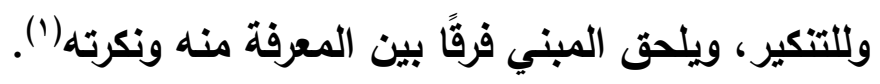

وللمقابلة، ويلحق جمع المؤنث السالم (ץ).

وللعوض، ويلحق (إذْ) عوضًا من الجملة المحذوفة (ب)، والجمع المعتل

اللام على صيغة (مفاعل) (؛).

(1) فهو يلحق قياساً العلم المختوم بـ(ويه)، وسماعًا في باب اسم الفعل

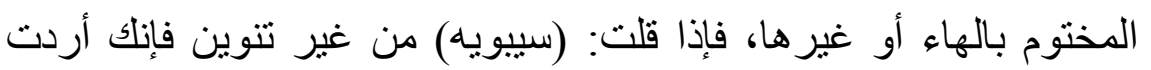

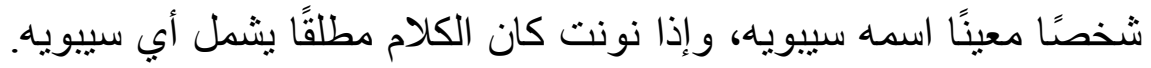

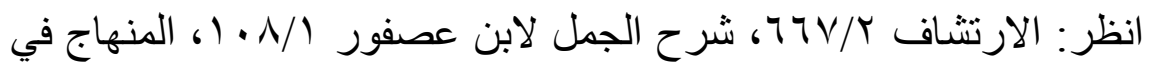

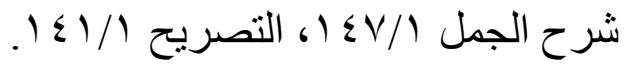

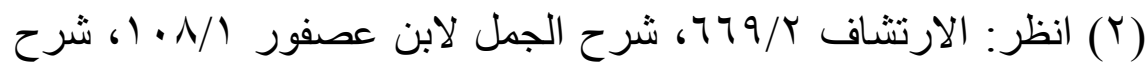

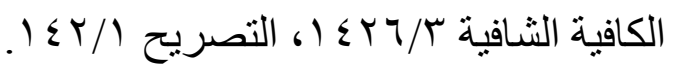
(r) قال ابن عصفور: " وهو الذي يلحق إذْ عوضاً من الجملة المحذوفة

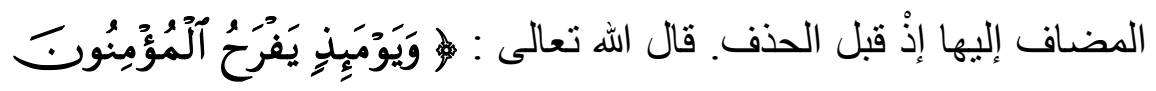
هورة سورة الروم من الآية : ؛، أي: ويوم إذ تغلب الرومُ فارسًا، وقال الله

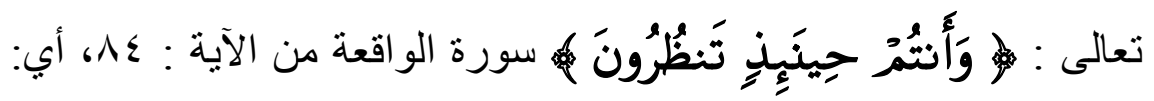

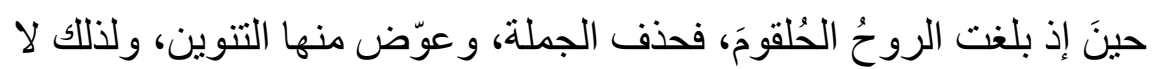

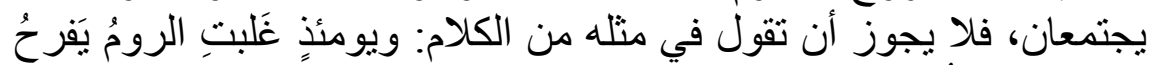

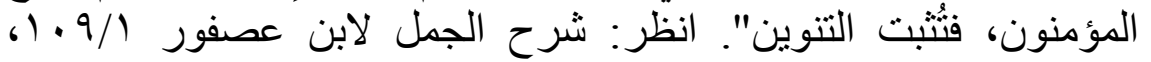

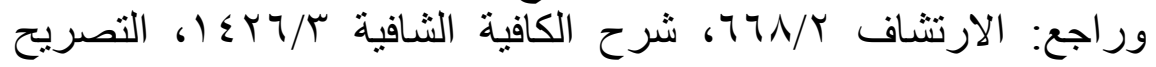
. $1 \leqslant \varepsilon / 1$

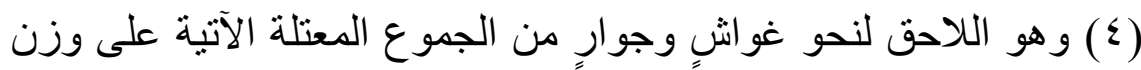
(فو اعل)، وهو عوض عن الياء المحذوفة في حالتي الرفع والجر، تقول:

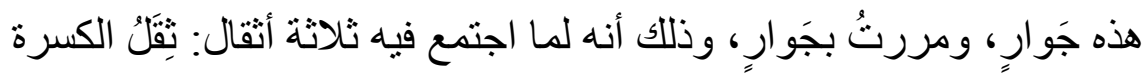

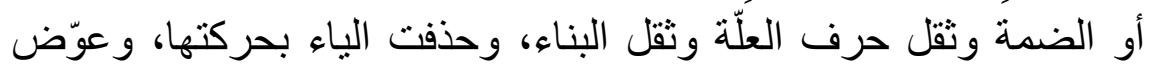




$$
\text { r. IV Rدار }
$$

حولية كلية اللغة العربية بالمنوفية العدد الثاني والثلاثون

وتختص أربعتها بالاسم (').

وللترنم، ويلحق القوافي المطلقة بحرف علة عوضًا من حرف الإطلاق،

ويوجد في الاسم ، والفعل ، والحرف(؟).

وإذا لقي التنوين ساكنًا فالأصل أن يكسر لالتقاء الساكنين، ولا يحذف الاست لألك إلا ضرورة، فإن كان الساكن باء ابن، أو المتحرك باء بنت فإنه يحذف التتوين، وذلك إذا وقع بين علمين أو ما يقاريهما، وهو الكنية واللقب والصفة الغالبة، وكان صفة غير مصغز ولا مثنى ولا مجموع، ولا يجوز إثباته إذ ذاك إلا ضرورة وحذف التنوين على لغتين إحداهما لكثرة الاستعمال، والأخرى لالتقاء الساكنين [9 ب/أل] ****** **

غير المنصرف لا ينون ولا يخفض، وهو ما اجتمعت فيه علتان فرعيتان من علل تسع على ما يذكر، وهي: العدل، والتعريف، والعجمة، والصفة،

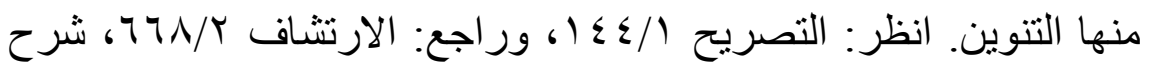

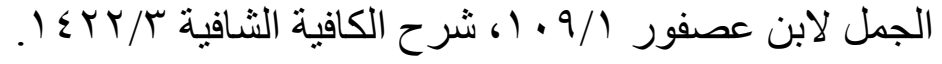
(1) قال الأزهري: "فلا تدخل على غيره؛ لدلتها على معانٍ لاتوجد في

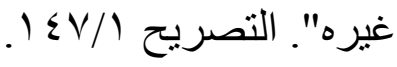

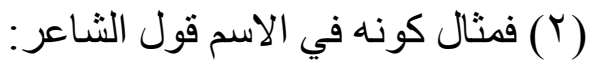

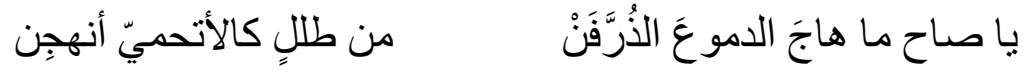
يريد: أنهج، أي خلق، ومثال كونه في الحرف قول لاف الثون الثاعر :

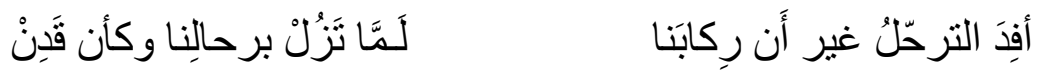
ولم يأت أبو حيان على تنوين آخر يلحق القوافي المقيدة، وهو المسمى لئى بالتنوين الغالي. 
والتركيب، وزيادة الألف والنون، ووزن الفعل، والجمع الذي لا نظير له في الآحاد، والتتأنيث(')، زاد الكوفيون لزوم "ابن".

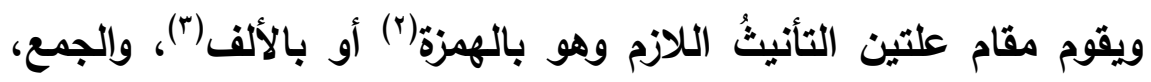
وهو موازن "مفاعل" أو "مفاعيل".

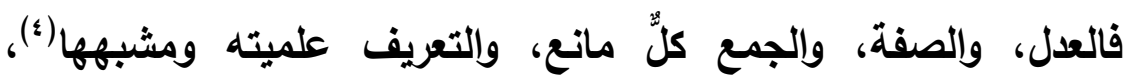
والوزن مختصه وغالبه(•) لا مشتركه المنقول من الفعل خلافًا لعيسى(").

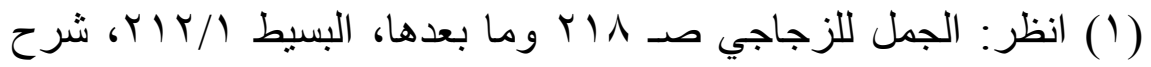

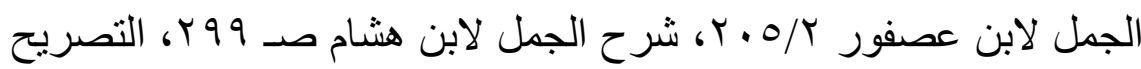

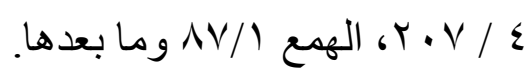

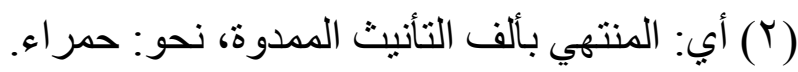

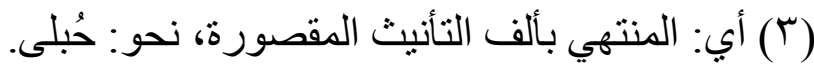

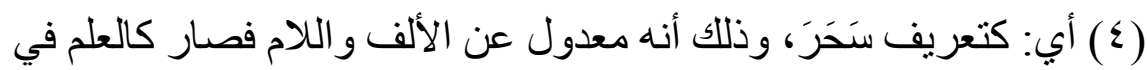

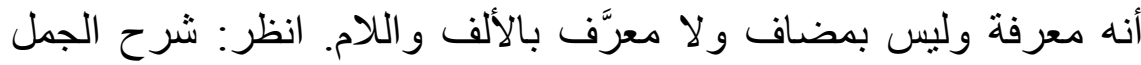

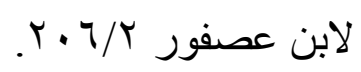

(0) وزن الفعل على ثلاثة أقسام: غالبُ، ومختص، ومشترك، فالغالب هو

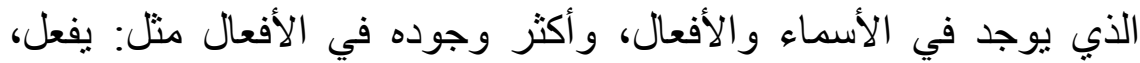

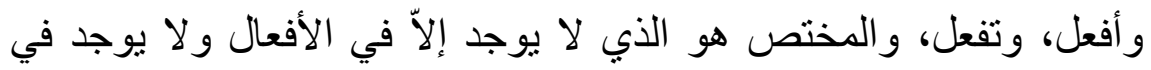

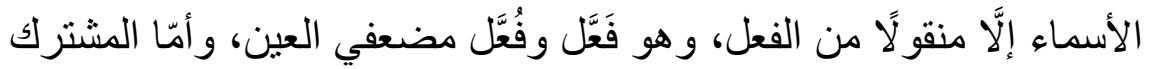

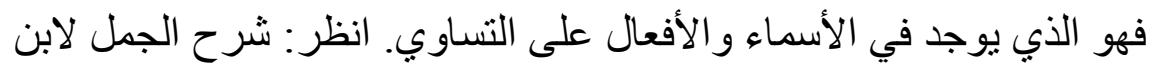

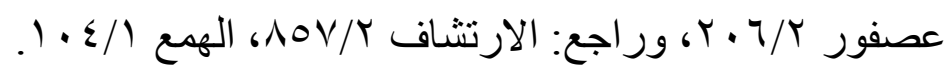

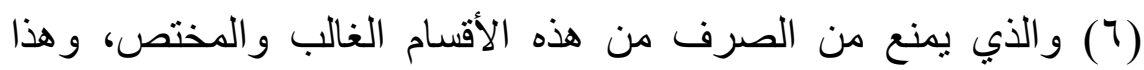

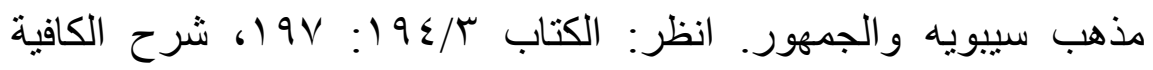

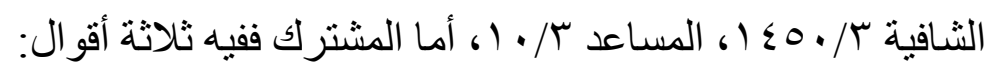

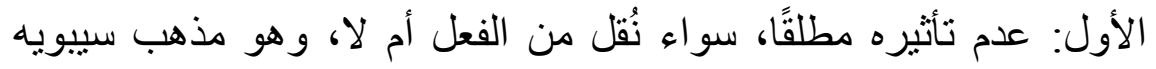
و الجمهور؛ لإجماع العرب على صرف كعسب اسم رجل، وهو منقول من 


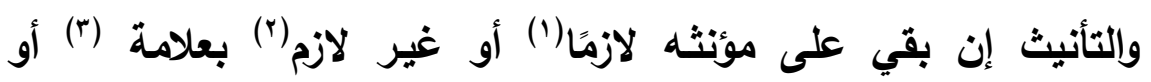

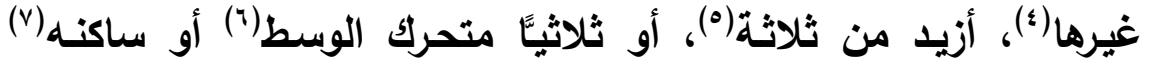
منقولًا من مذكر()، أو غير منقول، منضاف إليه أزيا من علة واحدة

كَعْسَبَ (فعلل)، و الثاني: تأثثيره مطلقا، و عليه يونس، و الثالث: يؤثر إن نقل

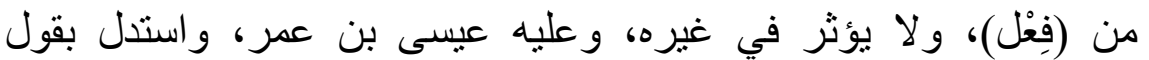
الثاعر: - الثن

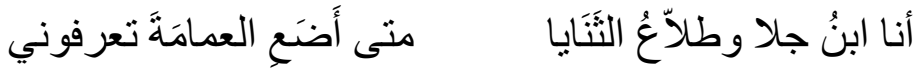

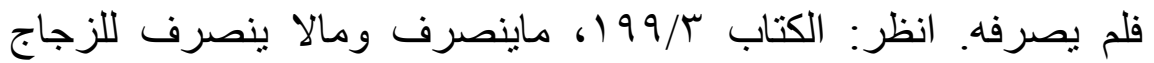

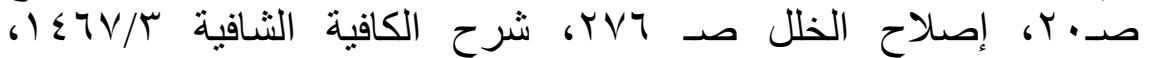

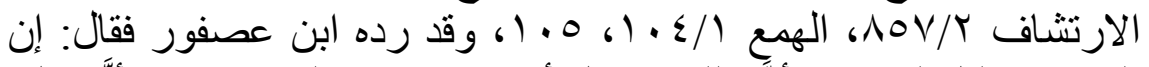

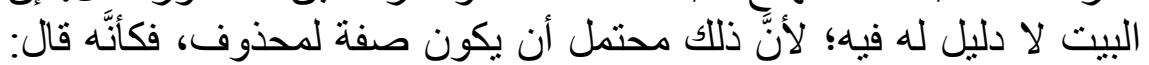

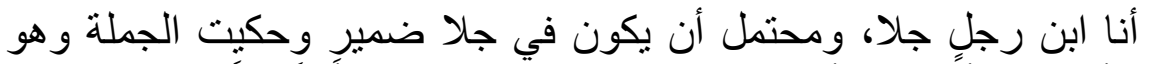

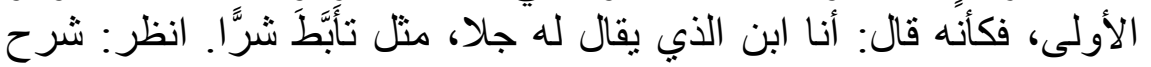

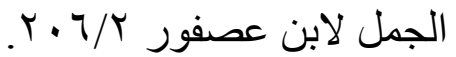

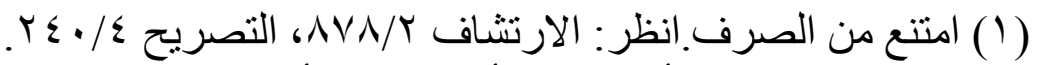

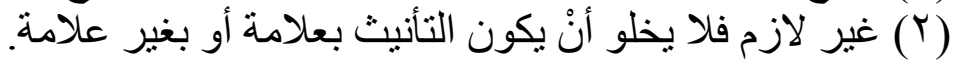

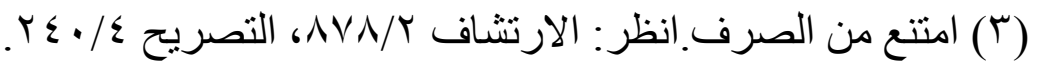

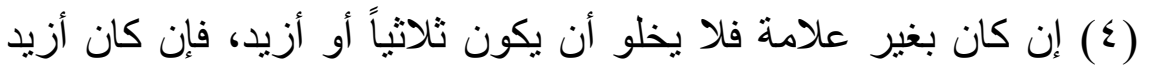
فيمنع الصرف.

(0) إن كان ثلاثياً فلا يخلو أن يكون متحرك الوسط أو ساكن الوسط.

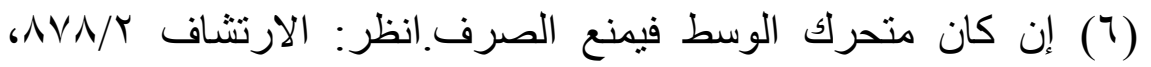

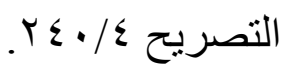

إن كان ساكن الوسط فلا يخلو أن يكون منقو لاً من مذكّر أو لا يكون. (Y)

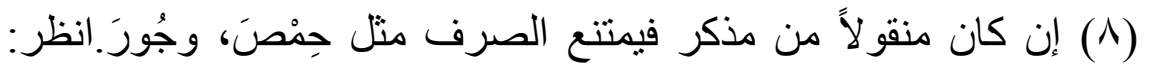

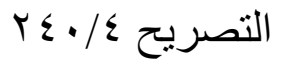


الموفور من شرح ابن عصفور

وجب المنع خلافًا لعيسى (') في مثل: (زيل) اسم امرأة فإنه عنده كهند(؟)،

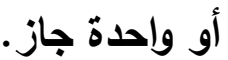

وإن لم يبق، وسمي به مذكر، وكان بعلامة أو بغيرها(ّ)، أزيد من ثلاثة

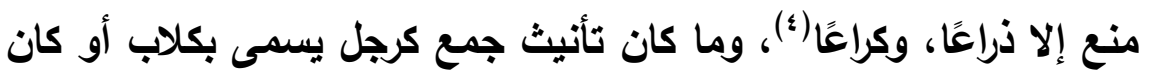
ثثلاثياً ، فالصرف كان متحرك الوسط أو ساكنه، ويعض العرب يمنع

كراعًا (0)

(1) إن انضافت إليه أزيد من علة واحدة فيجوز فيه وجهان: الصرف، ومنع الصرف.

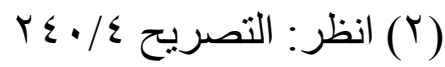

(T) فإن كان الاسم المؤنّث قد سمّي به مذكر فلا يخلو أن يكون مؤنثًا بعلامة

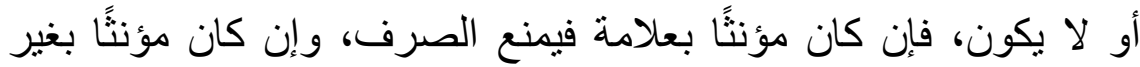

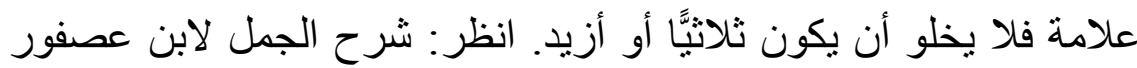

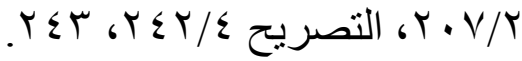

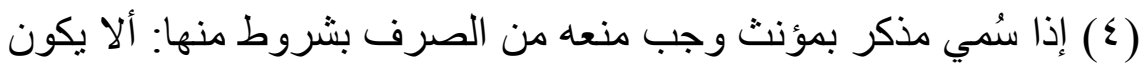

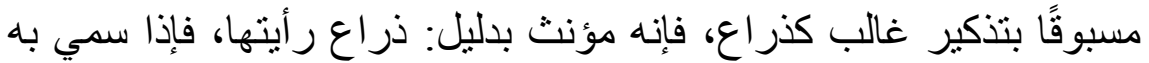

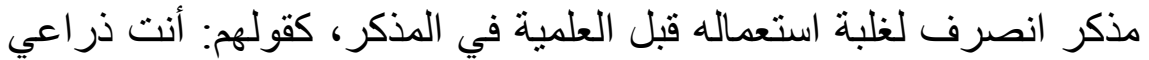

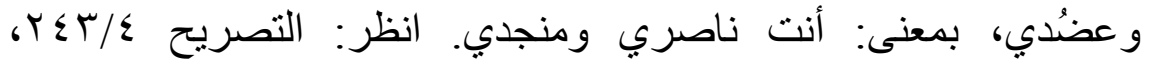

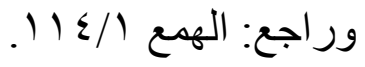
(0) قال ابن عصفور: "فإن كان أزيد فيمنع الصرف إلا أن يكون التأنيث

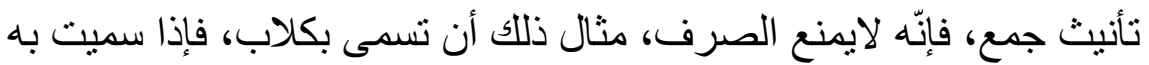

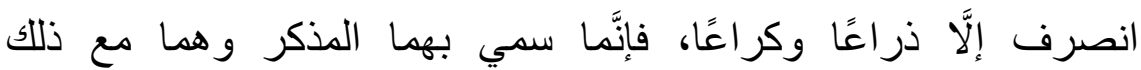

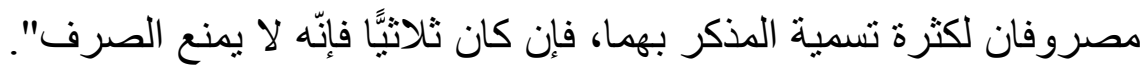

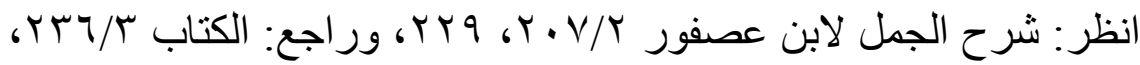
المساعد س/ Y T. 


\section{إصدار IV}

حولية كلية اللغة العربية بالمنوفية العدد الثاني والثُلاثون

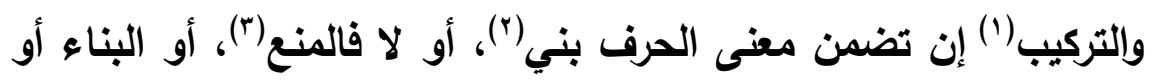

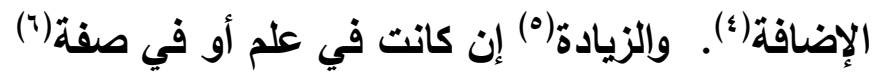

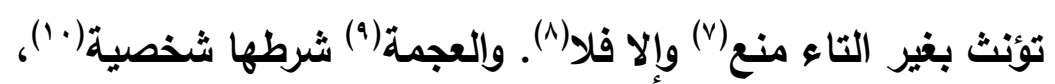

( ( ) التركيب وهو جعل الاسمين اسمًا واحدًا، وهو التركيب المزجي.

$$
\begin{aligned}
& \text { (Y) S ( خمسة عشر). }
\end{aligned}
$$

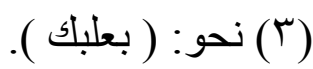

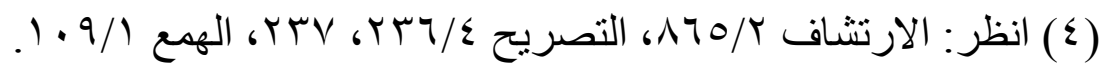

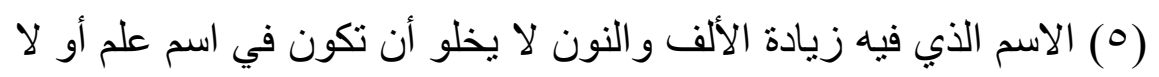

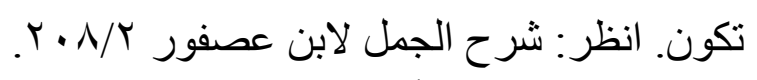

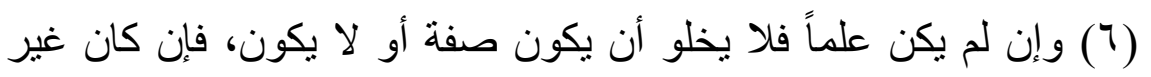

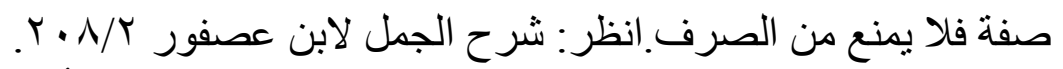

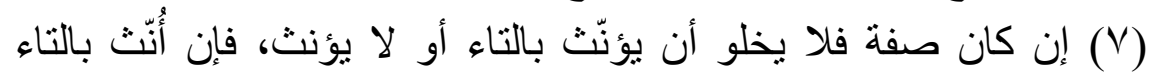

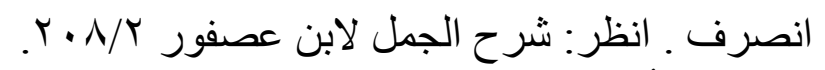

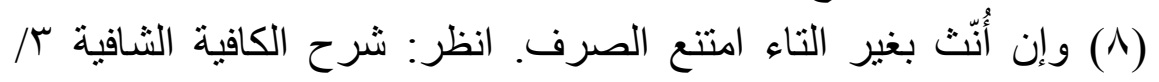

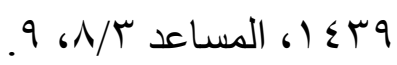

(9) قال سيبويه: "اعلم أنّ كل اسم أعجمي أُعرب واع وتمكن في الكلام فذخلته

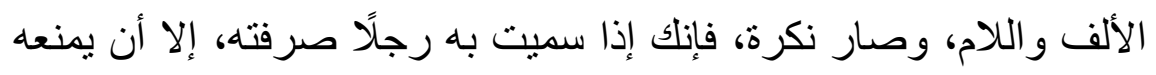

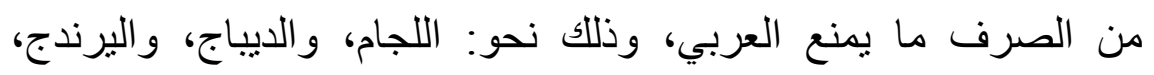

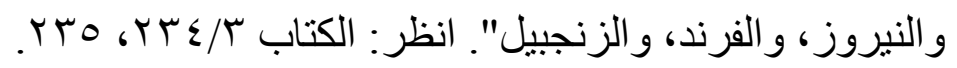

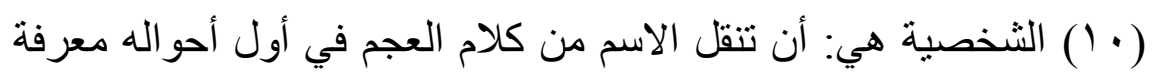

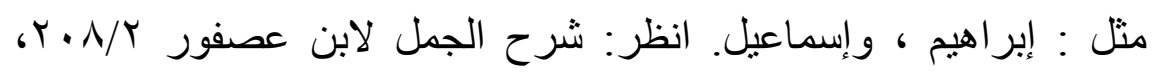

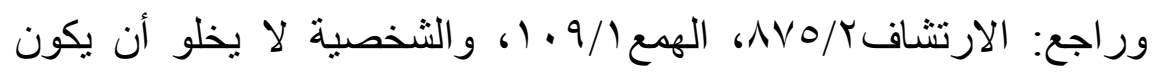

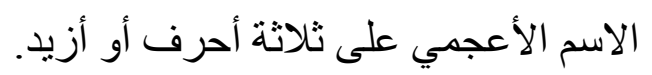




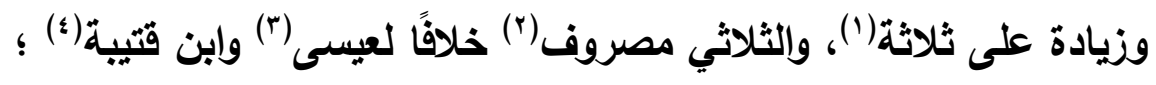

إذ جعلاه كالمؤنث الثثلاثي، والأفصح فيه عندهما الصرف(ه). التعريف مؤثز (־) مع الكل إلا مع الوصف أو المانع بمفرده العجمة،

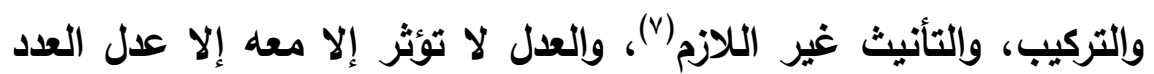
[9 [ب/ب] فخلاف سيأتي، والزيادة والوزن يؤثثران مع التعريف والوصف، والوصف معهما.

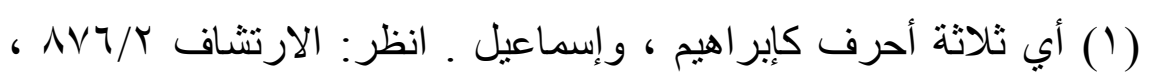

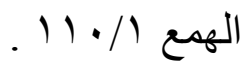
(Y) أي إذا كان ثلاثيَّا ساكن الوسط ، نحو: نوح ، ولوط ، أو كان متحركاً.

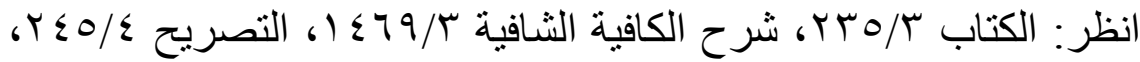

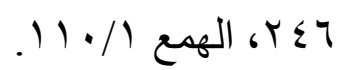

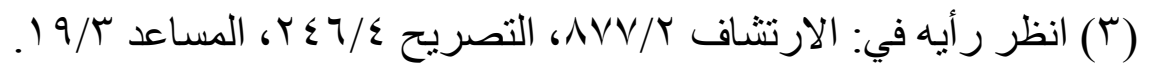
( ) هو عبد الله بن مسلم بن قتيبة الدينوري، عالم نحوي ولغوي، نشأ بليغداد

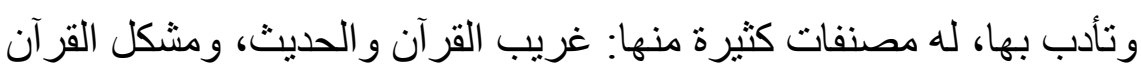
و الحديث وغير ذلك ، توفي سنة بVY Tهـ ـ راجع ترجمته في: إنباه الرواة

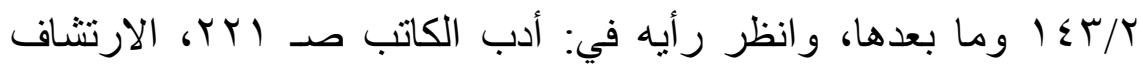
N NV/Y يجعلان حكمه حكم المؤنث الثلاثي، وهو رأي الجرجاني، و الزمخشري

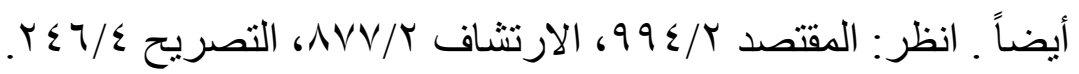
(0) وقد رد ابن عصفور قولهما، وحكم عليه بالفساد فقال: "وذللك فاسد لأنّه الته

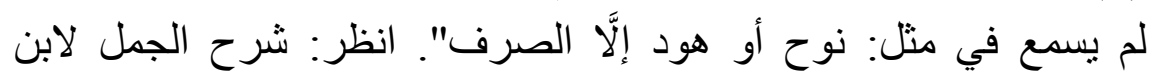

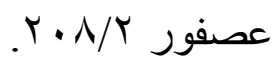

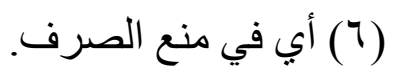

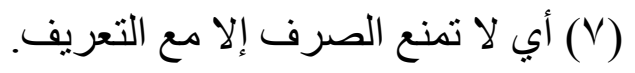


غير المنصرف منه: ما لا ينصرف معه (')، وينصرف نكرة مطلقًا، وهو ما ليس إحدى علتيه التعريف أو هي، فإذا سقطت خلقت أخرى، ومنه ما لا ينصرف معرفة، وينصرف نكرة، وهو ما التعريف إحدى علتيه ، فإذا سقط

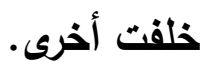

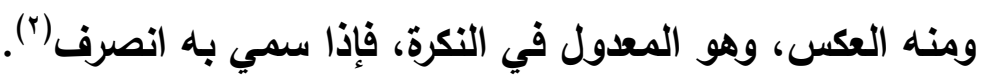

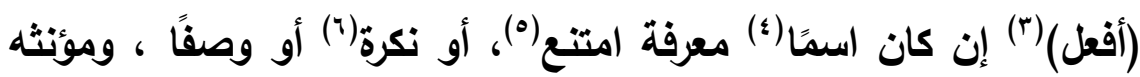

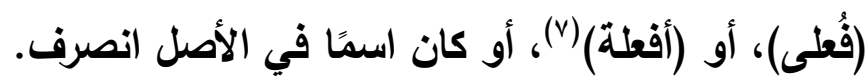

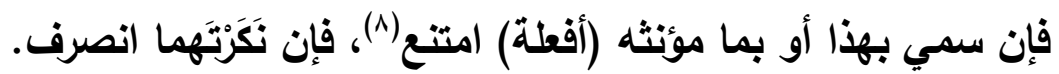

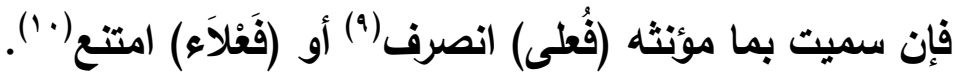

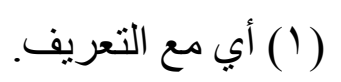

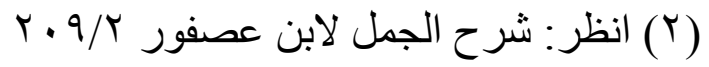

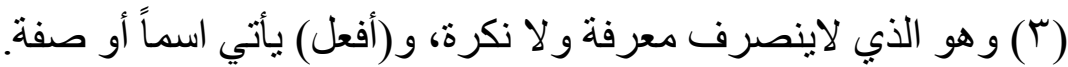

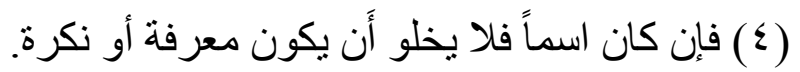

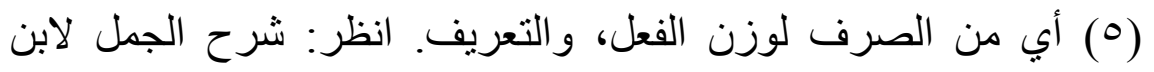

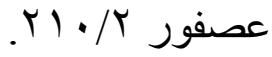

$$
\begin{aligned}
& \text { (7) انصرف. }
\end{aligned}
$$

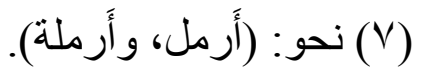

(^) امتنع من الصرف لوزن الفعل والتعريف. انظر: شرح الجمل لابن

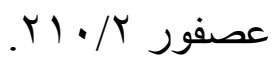

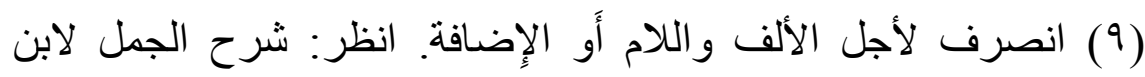

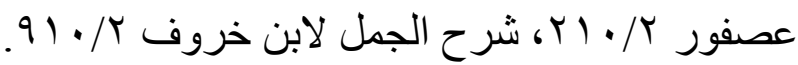

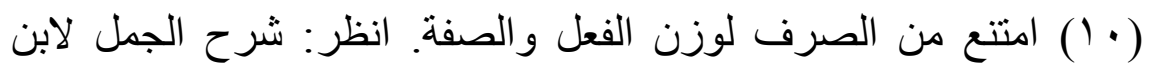

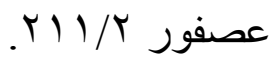




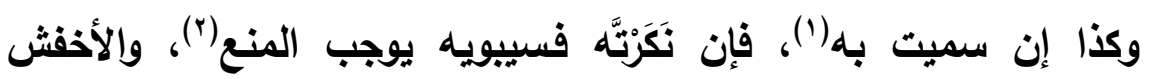

\author{
يصرف(ז)، وإلفارسي يجيز الوجهين (؛).
}

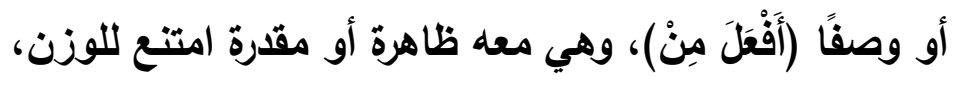

(1) امتنع من الصرف لوزن الفعل والتعريف.انظر: شرح الجمل لابن

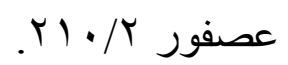

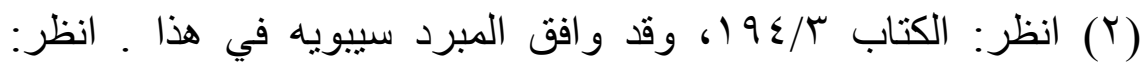

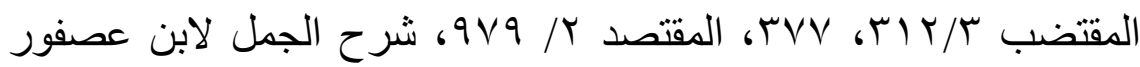
. $1 \cdot / r$

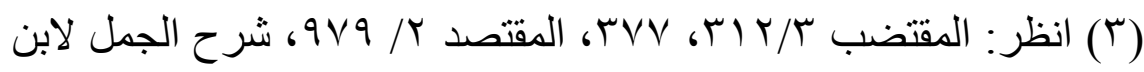

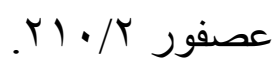

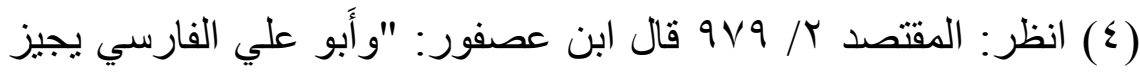

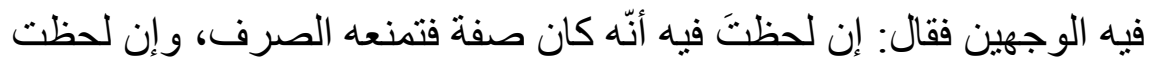
أنه انتقل عن الصفة إلى الاسمية فتصرفه، والدليل على صحة هذا أنَّ العرب إذا سمَّت بالصفة فتارة تحكم لها بحكم الصفة وتارة تحكم لها بحكم الأسماء، ألا ترى أنّها لما سمت بأحوص حكمت له بحكم الصفة، وتارة

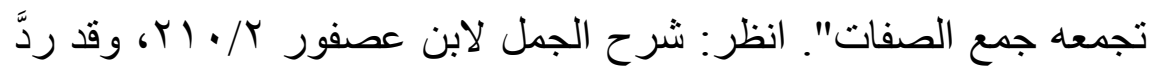
ابن عصفور ماذهب إليه الأخفش، و الفارسي مرجحًا قول سيبويه فقال:

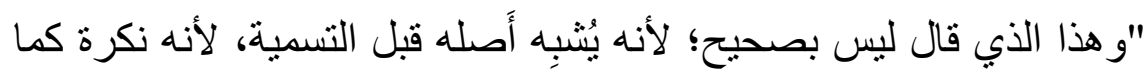

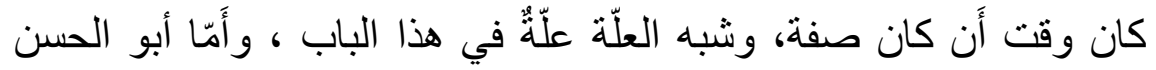

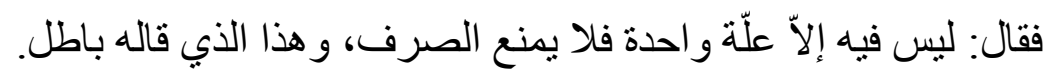

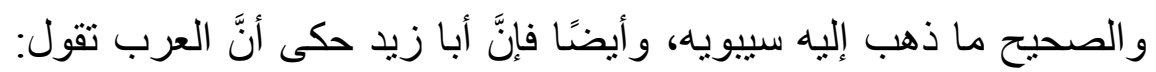
عندي عشرون أحمر في رجال اسم كل واحد منهم أَحمر". انظر: شرح

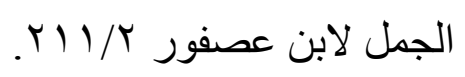


وللوصف عند البصريين (')، ولزوم (مِنْ) عند الكوفيين (Y)، فإن سميت به مع (مِنْ) امتتع (َّ)، أو دونها أو نكرته بعدُ معها امتتع ، أو دونها

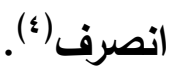

وإن تصدرث همزة ويعدها ثلاثة فهن أصول، وهي زائدة، إلا إن قام دليل على الأصالة)(ه).

(1) قال سيبويه: "هذا باب أفعل منك اعلم أنك إنما تركت صرف أفحل منك ونك

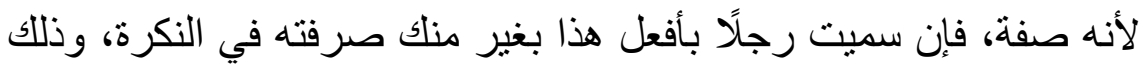

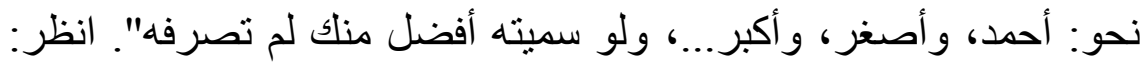

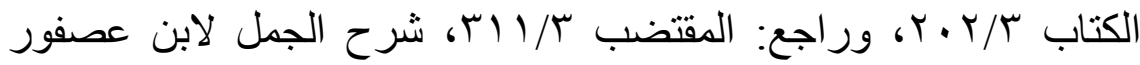

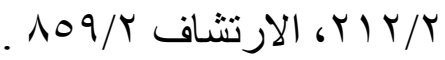

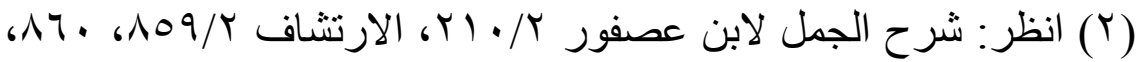

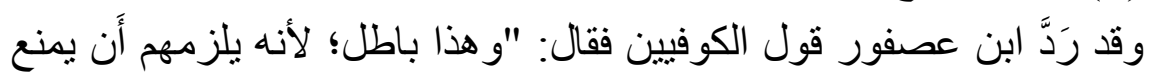

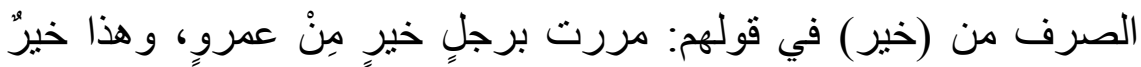

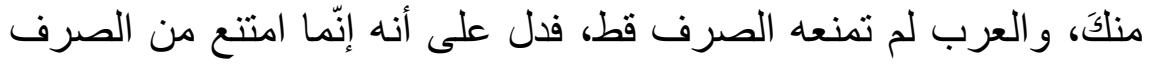

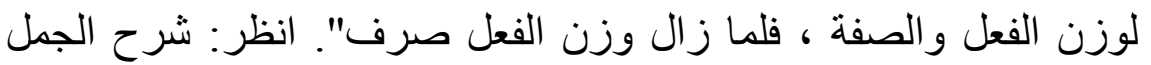

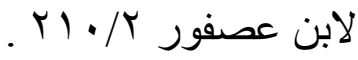

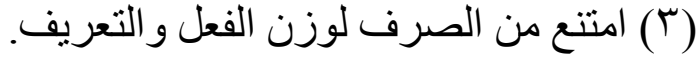

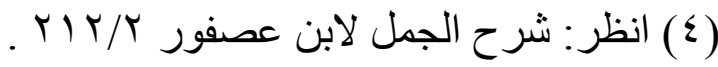
(0) أي من اشتقاق، أو تصريف، أو فلك مدغم، فمثال ما دلَّ الاشتقاق على لَّى

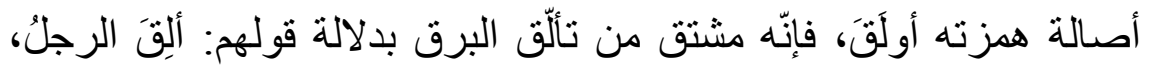

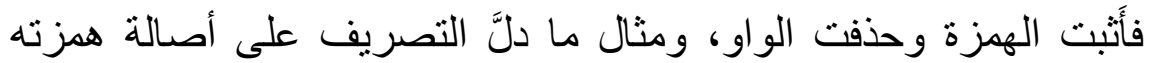

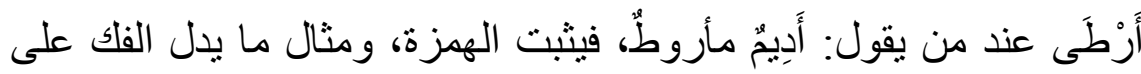

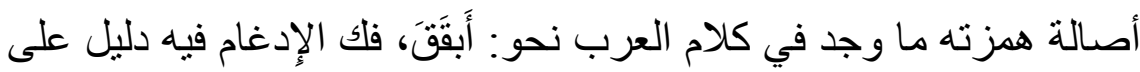

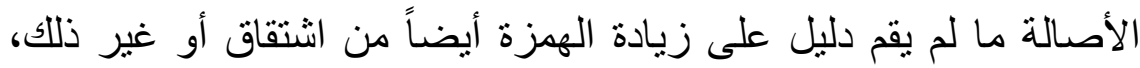

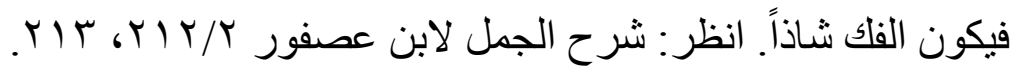


والتأنيث اللازم يمنع وحده مطلقاً (1)، وسمي لازمًا لأنا لو حذفنا العلامة لم تبق كلمة تامة، وقيل: لأنها بمنزلة حرف من نفس الكلمة وهو الصحيح(r). والجمع سمي جمعًا لا نظير لله في الآحاد لأنه ليس فيها ما يوافقه حركاتٍ وسكناتٍ وعددَ حروف()، وسراويل أعجمي، ويتقدير أنه عربي فجمع سروالتة، وقد نطق بها(؛)، وحضاجِر جمع، وتغاز: تفاعل، ويمان ألفه ويه

بدل (0)

وقيل: سمي بذلك لأن كل جمع يجمع، فيصير مفرداً بالنظر إلى الجمع الثاني، وهذا لا يجمع، ولهذا سمي المتناهي(")، وقيل: لعدم جمعيتِه

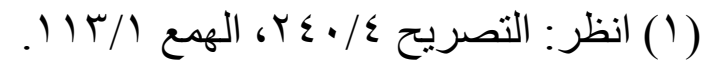

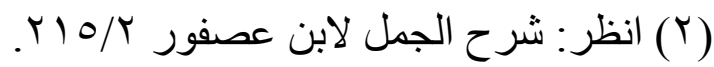

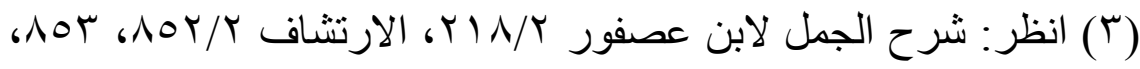

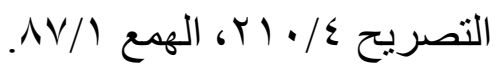

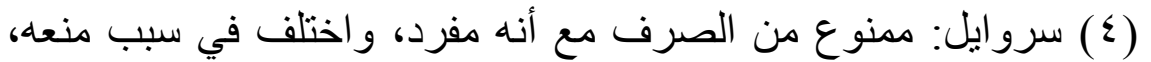

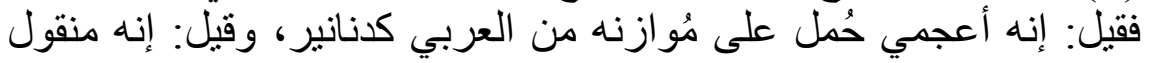

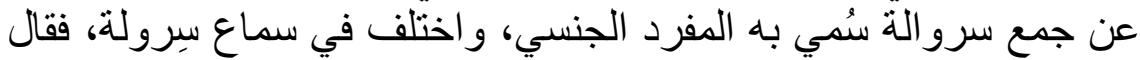

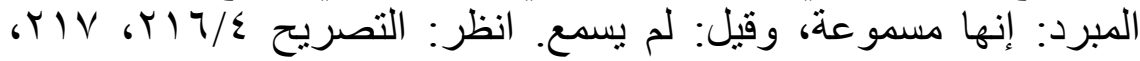

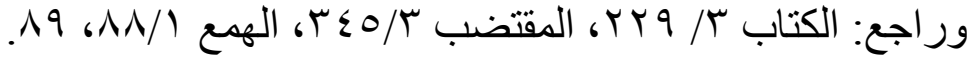

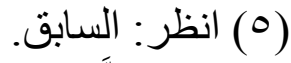
(7) وقد ردَّ ابن عصفور هذا التعليل، فقال: "وهذا ليس بصحيح؛ لأنه

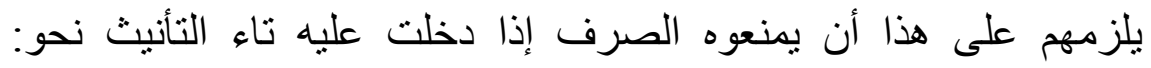

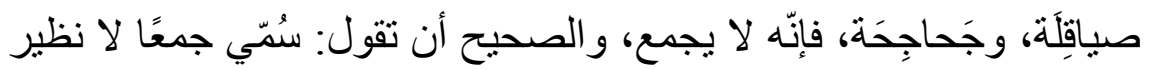
له في الآحاد ؛ لأنّه ليس في الآحاد على وزنه، ورلا يجمع". انظر : شرح

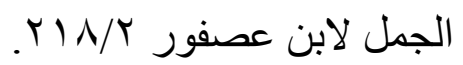




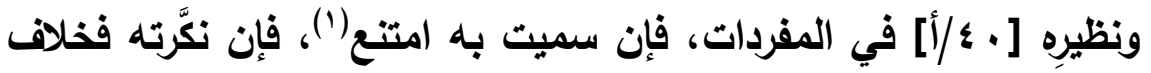
(أحمر)(؟)، هذا ما لم تعثل لامهه، فإن تعرَّف باللام أو بالإضافة انصرف

مطلقًا، فُإن كان نكرة امتتع نصبًا، واتصرف رفعًا وجرًا (ب). وتنوينه عند الزجاجي عوض من الحركة المحذوفة(؛)، وعند غيره من

( ) للتعريف وشبه العجمة، و أشبه العجمة لأنه دخل في الآحاد مثلما دخل

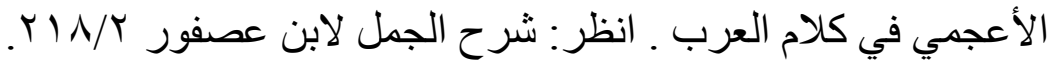
(r) أي: كالخلاف الذي تقدم في (أحمر).

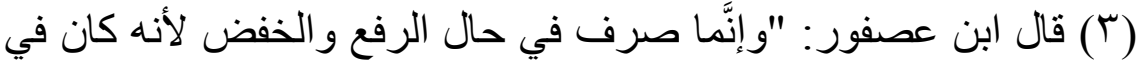
الأصل جواريُ، فاستثقلت الضمة في الياء مع ثقل البناء فحذفت الياء رأسًا

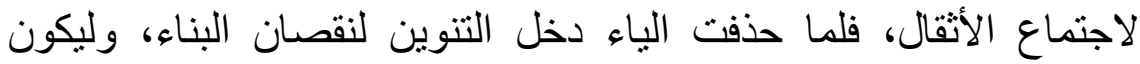
عوضًا من المحذوف، والدليل على أنه كالعوض ألنك لا تحذف هذه الئ الياء في

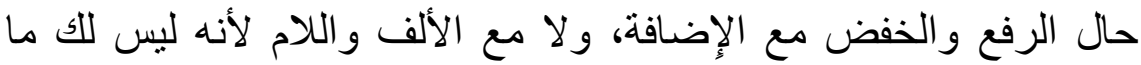

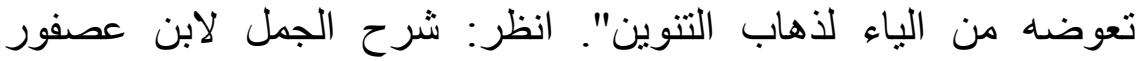

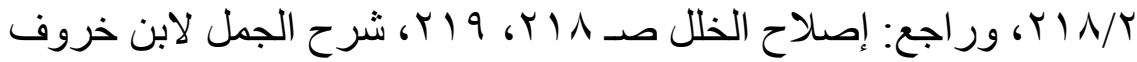
(

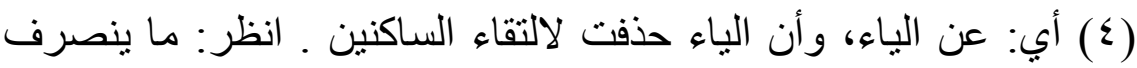

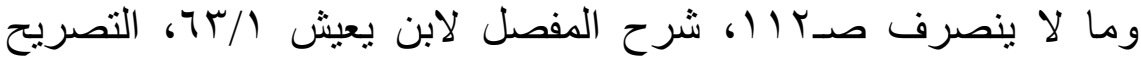

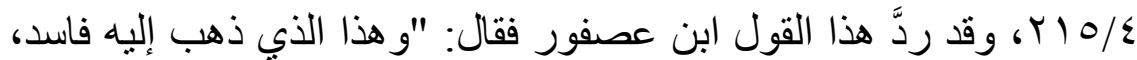
لأن التنوين حرف فينبغي أن يكون عوضا من حرف لأن عوضن الحف الحرف

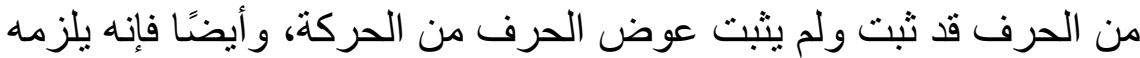
أن يعوض تنوينًا في يرمي بابه من الحركة المحذوفة، فإن قيل: الفحل لا لانيت

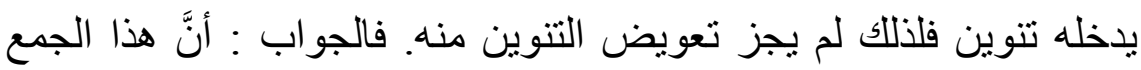

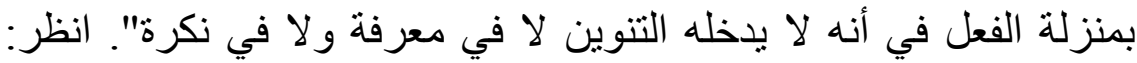

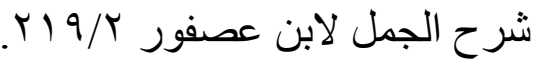


الحرف(')، ويعض العرب إذا حذف الياء صير الإعراب على ما قبلها().

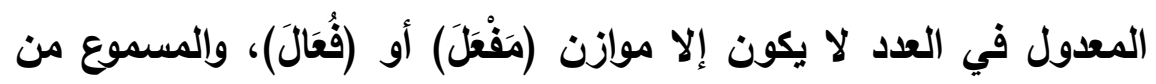

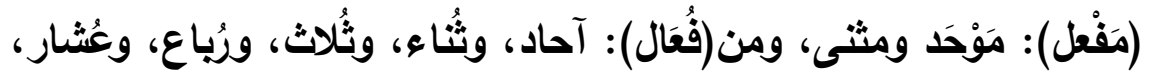

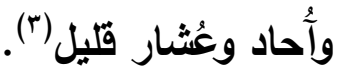

وقال الأزهري: "و هو ضعيف؛ لأنه لو صح التعويض عن حركة الياء لكان التعويض عن حركة الألف في نحو : موسى أولى؛ لأنها لا تظهر بح بحال

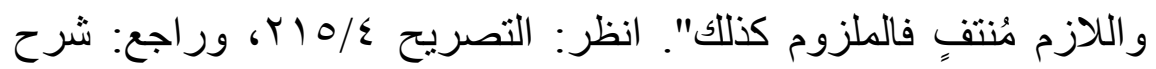

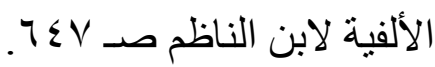
(1) هذا رأي سيبويه، أي: تنوين عوض من الياء المحذوفة لا تنوين

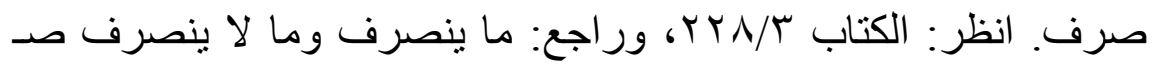

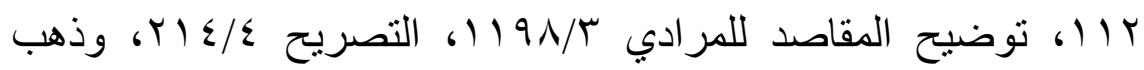
الأخفش إلى أنه تنوين صرف؛ لأن الياء لما حذفت تخفيفًا زالت صيغة (مفاعل)، وبقي اللفظ كجناح فانصرف ـانظر : توضيح المقاصد للمر ادي

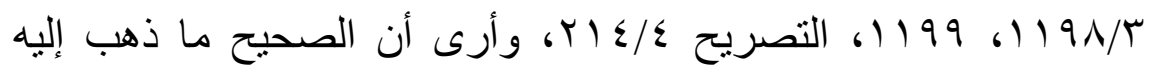

$$
\text { سيبويه. }
$$

لها ثنايا أربعُ حسانُ

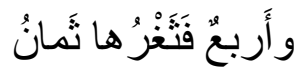

(T) انظر: الارتشاف / ( 
والصحيح الوقوف مع مورد السماع(')، وامتنع للعدل والوصف(؟)، وقيل: للعدل والتعريف(ז)، وقيل: للعدل خاصة، لكنه عدل في اللفظ وفي

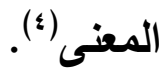

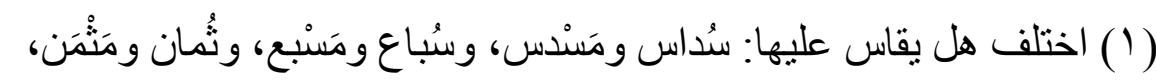

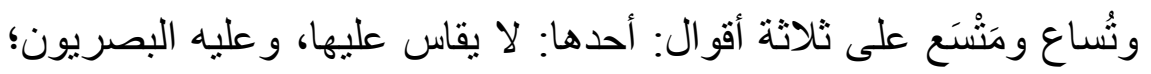
لأن فيه إحداث لفظ لم تتكلم به العرب، و الثاني: يمكن القياس علئ عليها، و وعليه

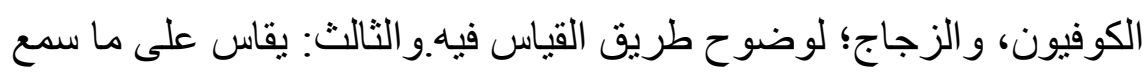

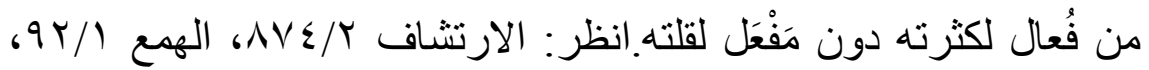

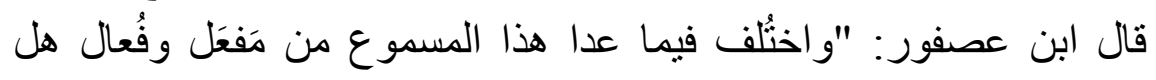
يقاس عليه أو لا، فمنهم من قاسه ومنه من لم يقسه، و هو الصحيح، لأنه لم

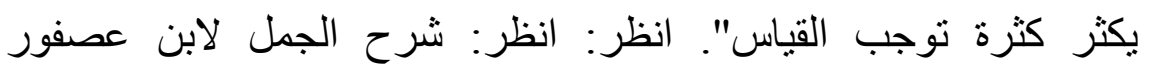
r $T / Y$

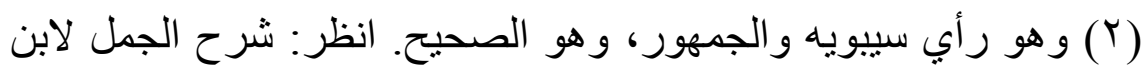

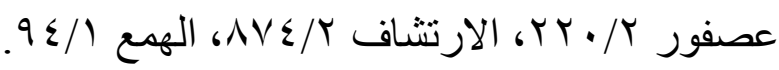

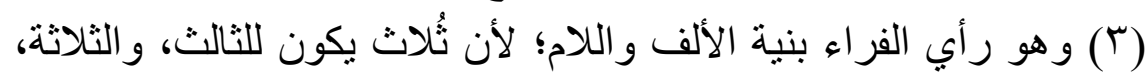

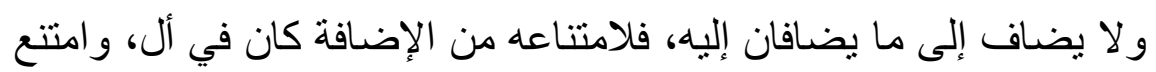

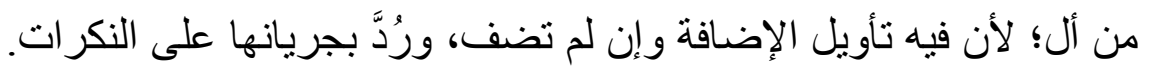

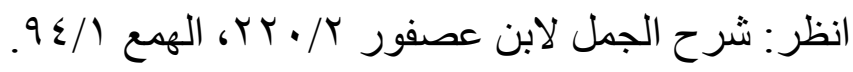

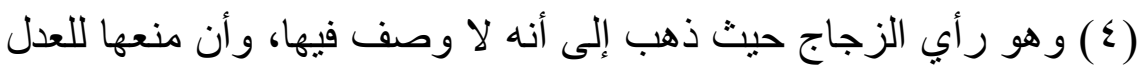

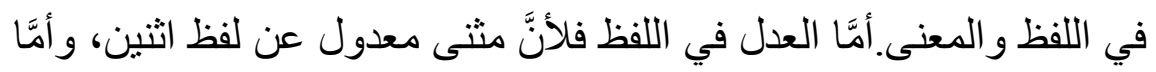

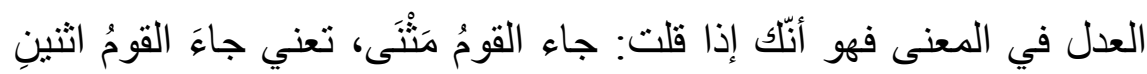

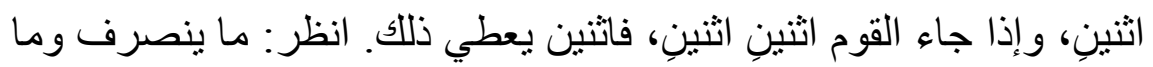

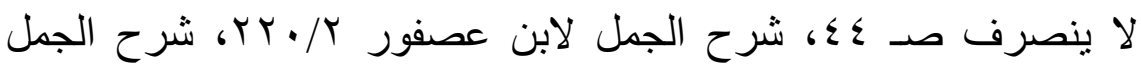

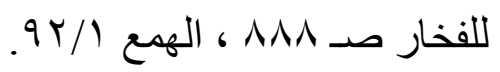


ما وزلن المضارع|'، وسُُمي به، ولم ينقل منه، أو نقل ولا ضمير فيه

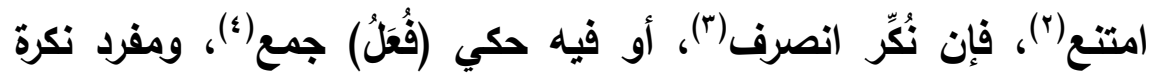

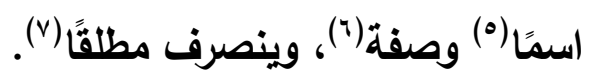

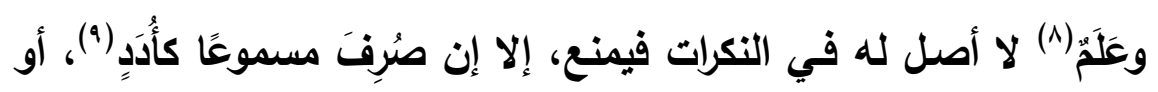

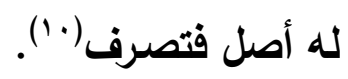

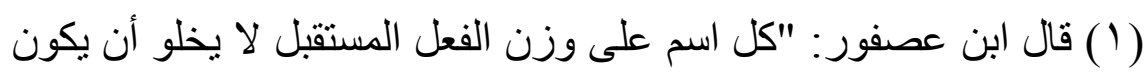

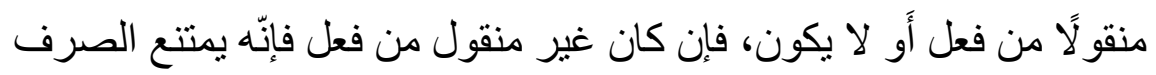

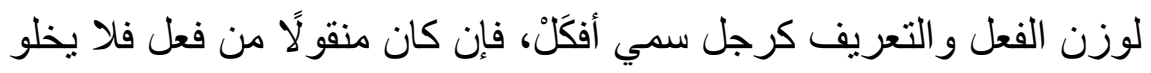

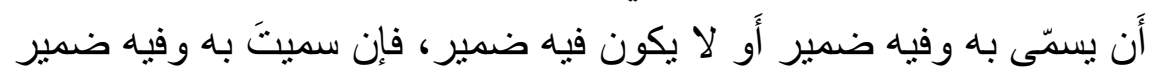

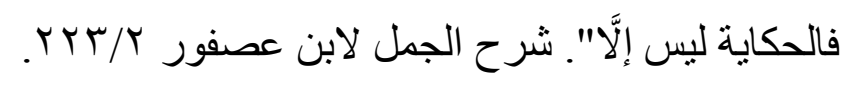

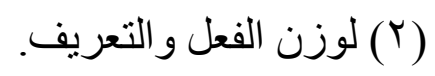
(Y) قال ابن عصفور: "فإن نكرّته بعد التسمية فإنّه ينصرف قولَا واحدًا

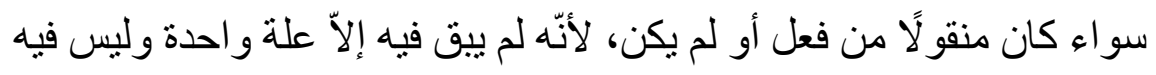
شبه أصيل، لأنه في الأصل فعل وهو الآن اسم". شرح الجمل لأن لابن لان عصفور

$$
\begin{aligned}
& \text { r } Y \leqslant / T \\
& \text { (ع) نحو: غُرَرَ، ودُرَرَ. }
\end{aligned}
$$

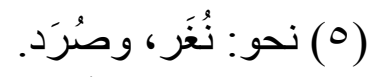

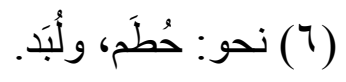

$$
\begin{aligned}
& \text { (V) }
\end{aligned}
$$

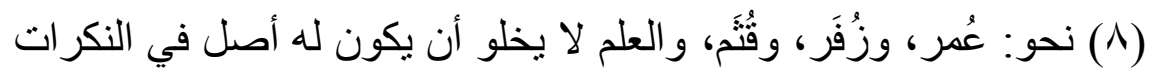
أو لا يكون.

(9) حكي عن العرب أنهم يقولون: فلان بن أُدرَ. انظر : شرح الجمل لابن

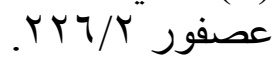

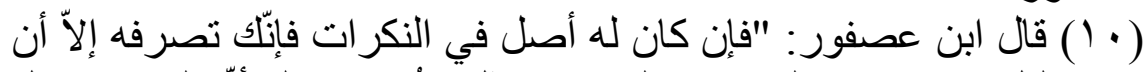

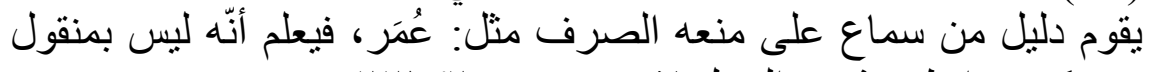

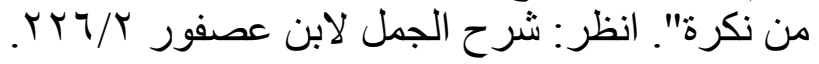


ما نقل من الماضي ولا نظير له في الأسماء(') إن كان فيه ضمير حي)، وإلا منع إلا إن أخرجه الإعلال إلى وزن الاسم، ولم ينطق له له بأصل، أو نطق واعثد بالعارض صرف، أو لم يعتد منع، وإن سُمي

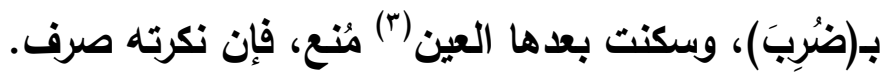

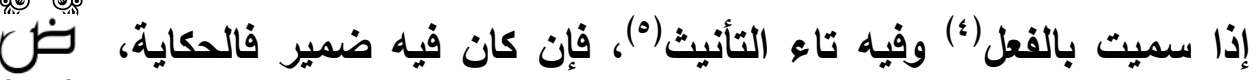

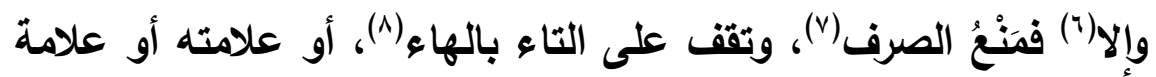
الجمع(9)، فلابُّ من النون، وحكمه إذ ذالك حكم التسمية بالتثنية

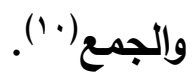

وإذا سمي بالمثنى(') فحكاية للتثنية(r')، أو جعل الإعراب في الآخر (rا')

$$
\begin{aligned}
& \text { (Y) لا يخلو أن تنقله وفيه ضمير أو خاليًا من الضمير. }
\end{aligned}
$$

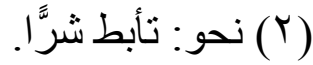

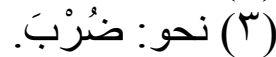

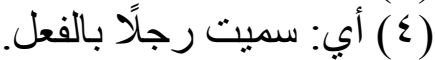

$$
\begin{aligned}
& \text { (0) نحو: ضربتَّت } \\
& \text { (7) أي: و إن لم يكن فيه ضيكير. } \\
& \text { (V) للتعريف و التأنيث. }
\end{aligned}
$$

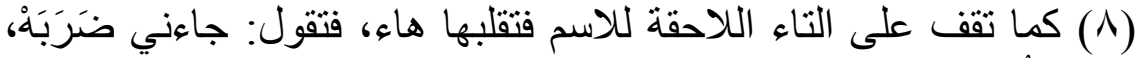

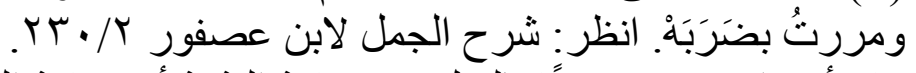

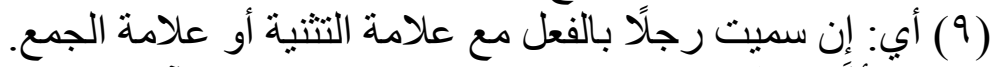

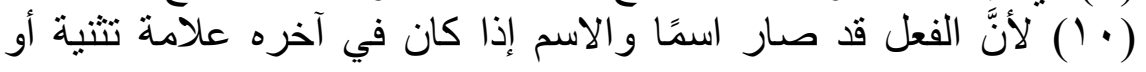
جمع، فلا بدَّ من النون بعدهما ويكون حكمها حكم التسمية بالتثنية و الجمع.

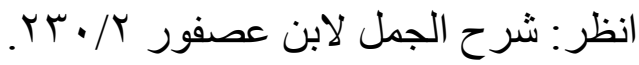

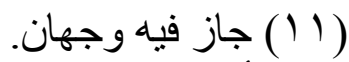

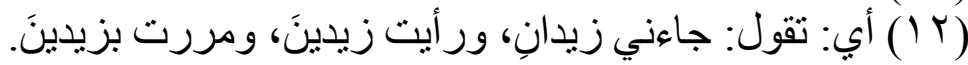

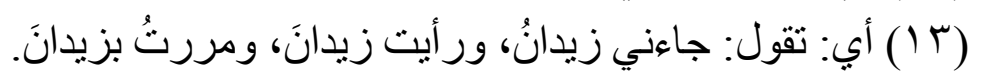


ومنع الصرف(')، والجمع كذلك(r) إلا أن في وجه الإعراب تقلب الواو ياء،

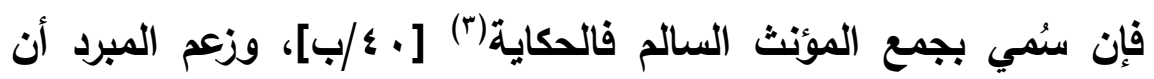

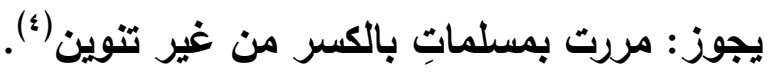

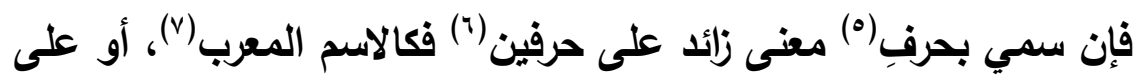
حرفين(^) والثاني صحيح فكالمنقوص(")، أو معتل فتزيد عليه آخر من

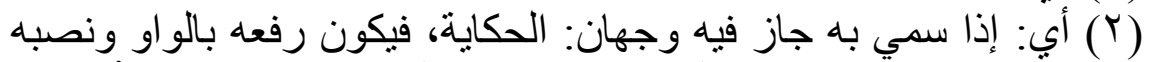

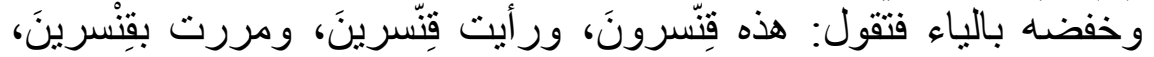

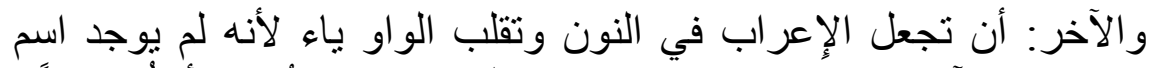

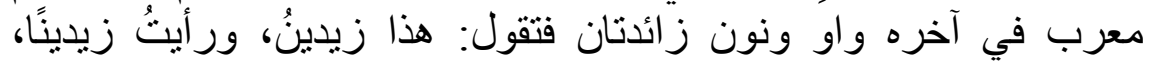

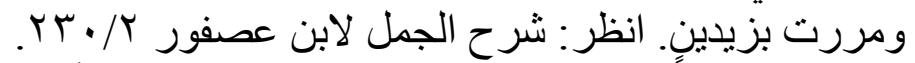

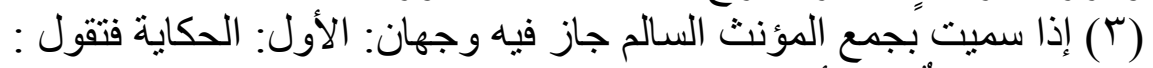

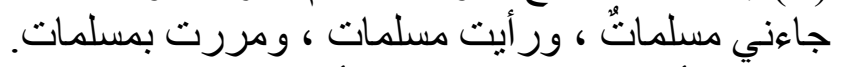

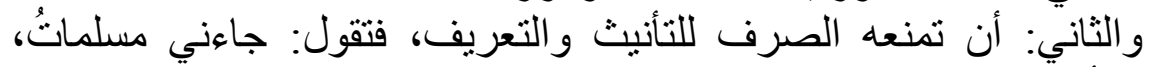
ورأيت مسلماتَ، ومررت بمسلماتَّ. انظر: شرح الجمل لابن عصفور

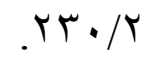

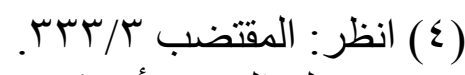

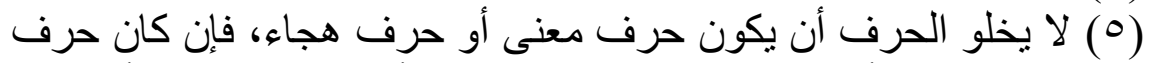

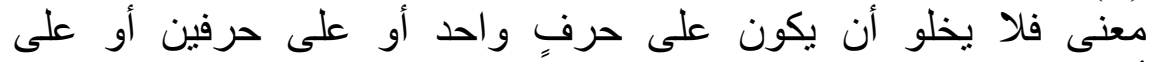

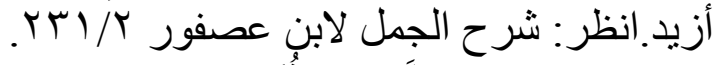

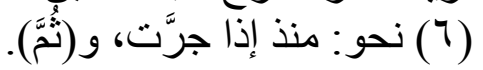

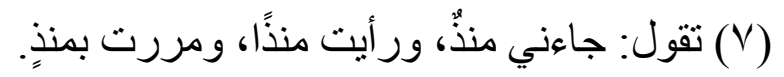
(^) لا يخلو أن يكون الثاني حرف علة أنة، أو حرفًا صحيحًا.

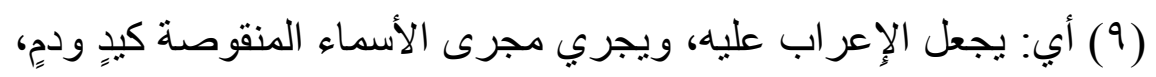

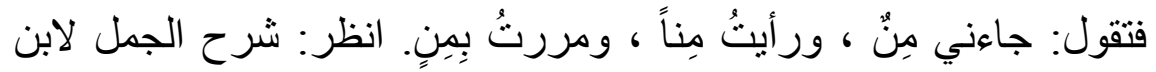

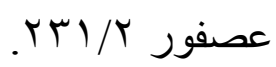


جنسه(') أو على واحد(r) وهو متحرك، فتشبع الحركة حرفًا من جنسها، ويصير كالثنائي المعتل(ّ)، أو ساكن فتحركه بالكسر، وتفعل ما تفعله بالحرف المكسور أو بحرف هجاء فكحرف المعنى. وزعم قوم أنك ترد حرفًا من أصول الكلمة، واختلف فقيل: الأقرب أبدًا،

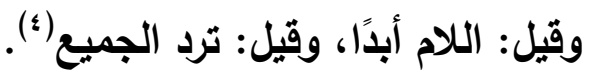
****** $* *$

واسم القبيلة: منقول من أب أو أم، وغير منقول. المنقول(0) مضاف إليه (بن وغير مضاف.

(1) أي: تزيد عليه حرف علة آخر من جنس حرف العلَّة، فإن كان ياءً زدتَ

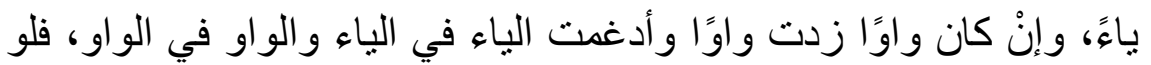

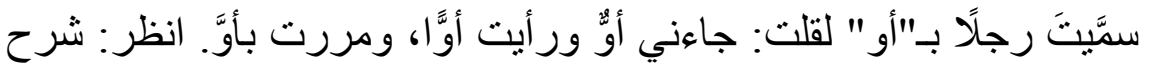

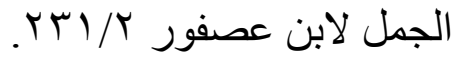
(Y) لا يخلو أن يكون ساكنًا أو متحركًا.

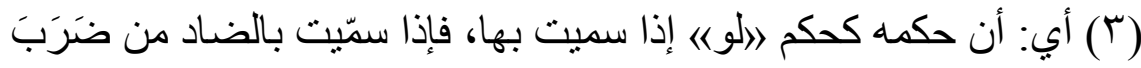

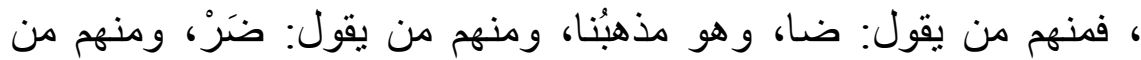

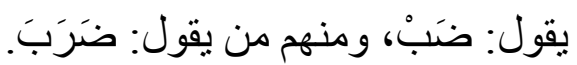

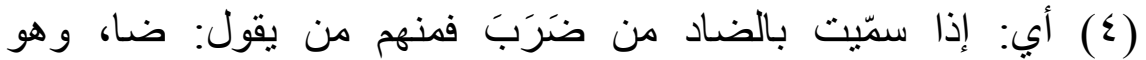
مذهبنْاومنهم من يقول: ضَرْ، ومنهم من يقول: ضَبْْ، ومنهم من يقول:

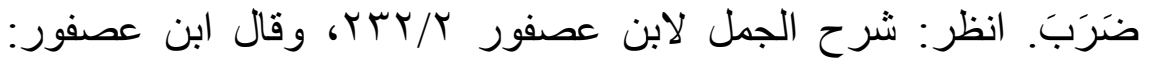

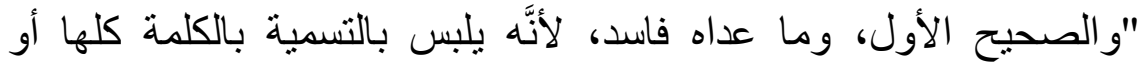
بالتسمية بأكثر من حرف واحد منها". انظر: شرح الجمل لابن عصفور ب (0) أب المنقول من اسم أب أو أمّ. 
المضاف لفظًا أو نية يبقى على ما كان عليه في الأصل إن كان مانع منع، وإلا فلا(')، وغير المضاف وغير المنقول إن قصد به الحي صرف، إنه إلا إن منع مانع، أو القبيلة منع(؟)، وكذا إن نقل من اسم أب ولم يستعمل بهل

على إضافة ابن أو ابنة إليه(").

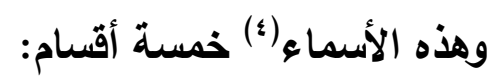

قسم يخص القبيلة، وذلك: مجوس، ويهود، وآدم (•).

(1) أي من الصرف، فنع الخفض و التنوين وإلا صُرَّف.انظر: إصلاح

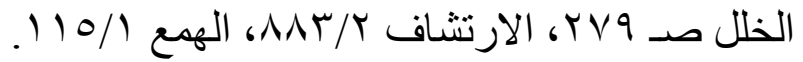

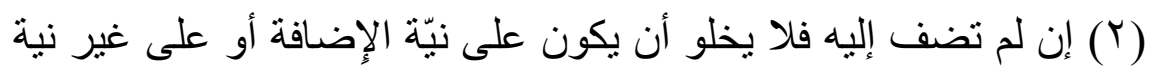

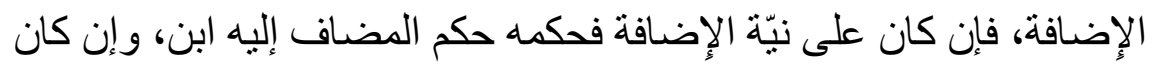
على غير نيّة الإضافة، فلا يخلو أن تقصد به قصد الحي أو قصد القبيلة، فإن إن إنهان

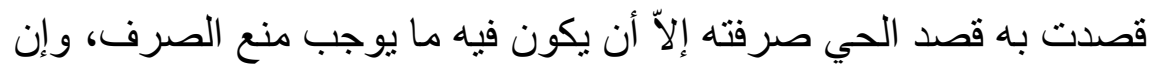

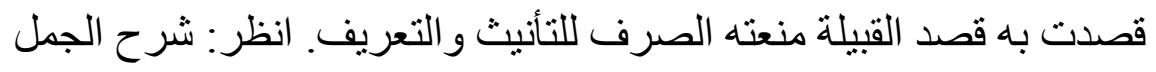

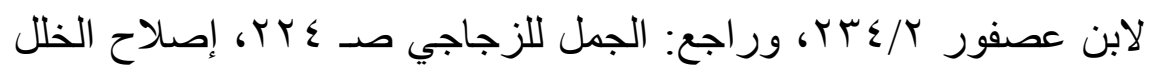

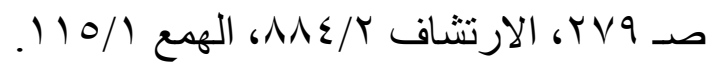

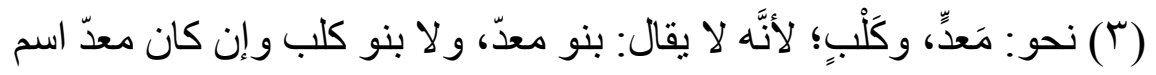

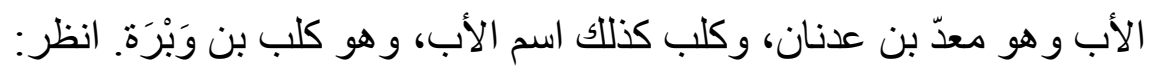

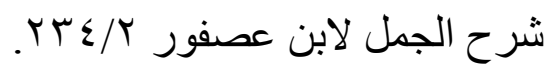
( ) أي: أسماء القبائل و الأحياء. (0) فهذه أعلام على قبائل، ويمنعان من الصرف، فإن جعلتهاء إنها جمع يهودي، ومجوسي، وآدمي كـ رومي وروم، فيجوز إذ ذالك دخول (أل) عليها.انظر :

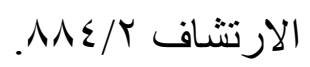




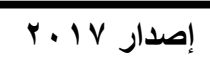

حولية كلية اللغة العربية بالمنوفية العدد الثاني والثلاثون

وقسم يغلب عليه الحي وهو قُريش، وتَقَيف، وكلب، ومَعَد، وعاد (').

وقسم يتساوى فيه الأمران، وهو ثمود، وسبأ(؟).

وقسم يغلب عليه الأب، وهو تميم. (ז)

وقسم يغلب عليه القبيلة، وهو ما بقي.

****** $* *$

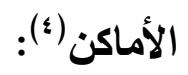

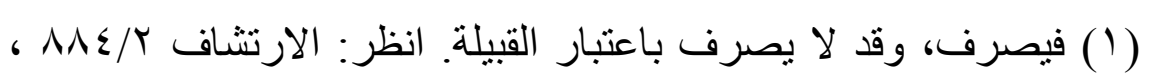

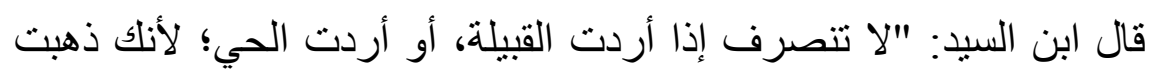

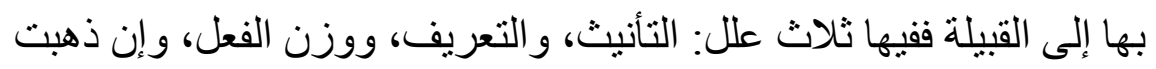

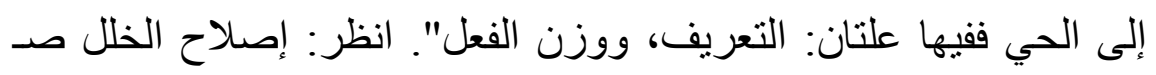
rVa

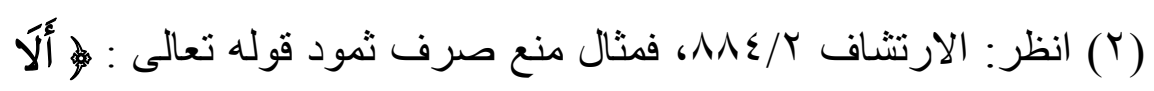
بُعْدًَا لِّمَدْيَنَ كَمَا بَعِدَتْ ثَمُودُ هُه سورة هود من الآية : 90، وقال تعالى :

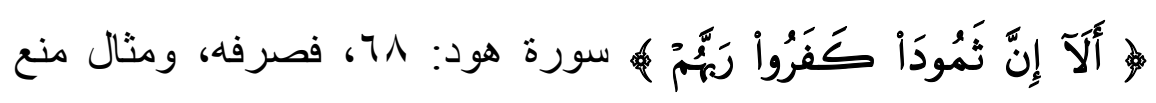

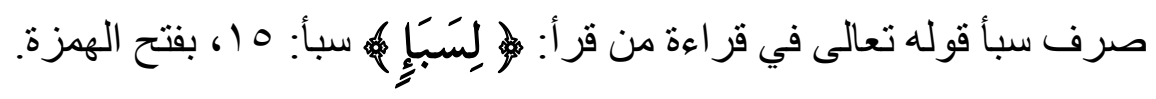

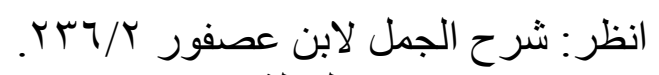

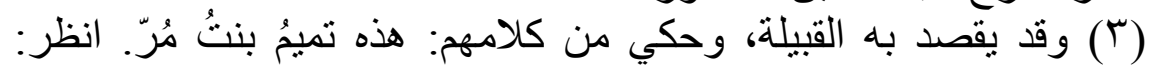

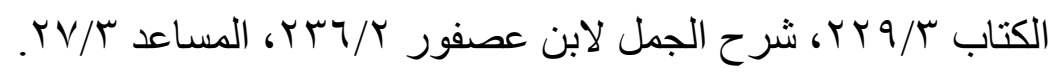
(ع) أسماء الأماكن على قسمين: قسم فيه علامة تأنيث، وقسم لا لا علامة تأنيث فيه. 
الموفور من شرح ابن عصفور

دالحمدمحسد الجندي

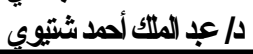

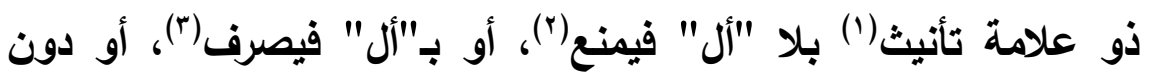
علامة فالغالب التأنيث، وقد يجوز أن يُنَكَّر مذهويًا به مذهب المكان، وهو

مع ذلك خمسة أقسام (๕):

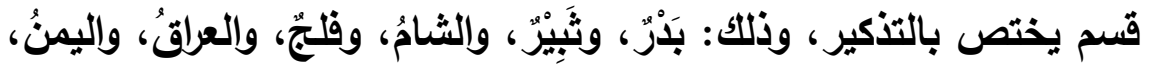
والحجازُ، ونجدُ.

وقسم يغلب عليه التأنيث، وذلك: فارس، وعُمان (•). وقسم يظلب عليه التذكير وهو: مِنَى، وهجر، ودابِق، وواسط، وحِجْر اليمامةة، وحُنَينَ (َ). وقسم يتساوى فيه [1 \&/أ] الأمران، وذلك: حِراء، وقُباء، ويغداذ. وقسم يخص المؤنث، وهو ما بقي.

( ) القسم الذي فيه علامة التأنيث على قسمين: قسم فيه ألف ولام، وقسم ليس فيه ألف و لام.

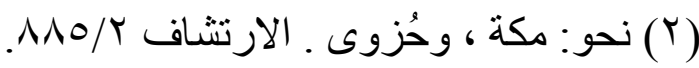

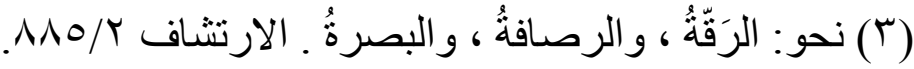

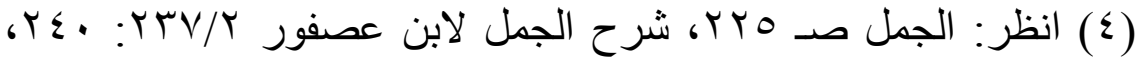

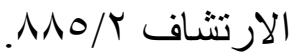

(0) قال سيبويه: "هذا باب أسماء الأرضين إذا كان اسم الأرض على ثلى ثلاثة

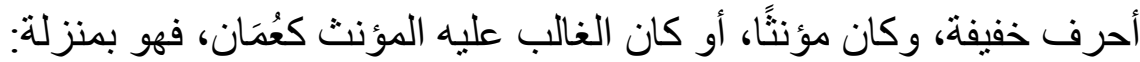

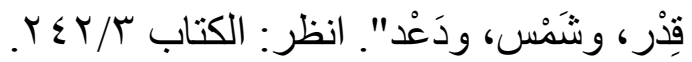

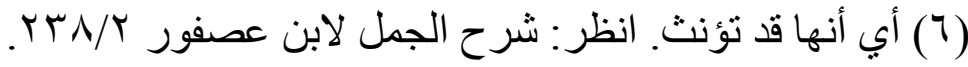


السور(') وما سمي بجملة محكي(r)، أو بفعل فكما تقدم، وتقطع ألف الوصل إن كانت فيه(ז)، أو باسم(؛) حرف هجاء(() على حرف مضاف إليه

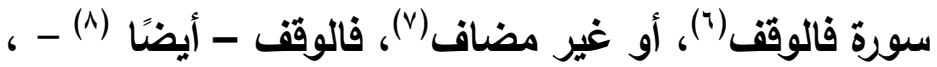

(1) (1) أسماء السور تنقسم ثلاثة أَقسام: قسم مسمى بجملة، وقسم مسمى بفعل، وقسم مسمى باسم.

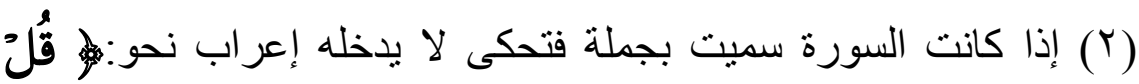

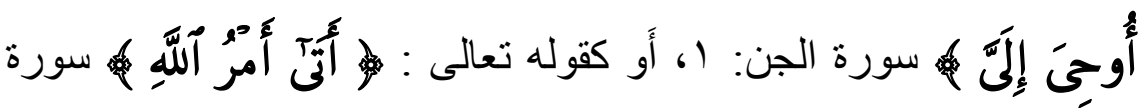

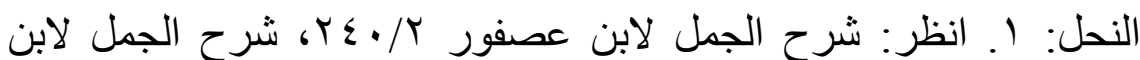

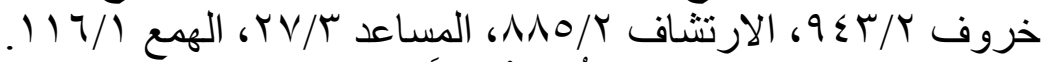

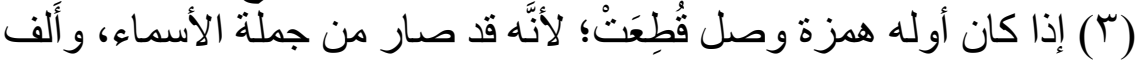

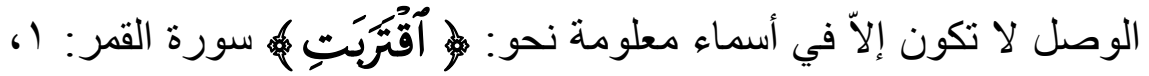

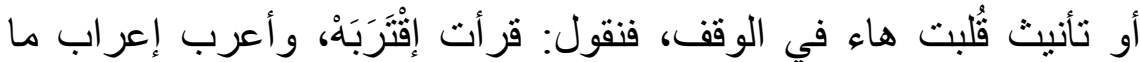

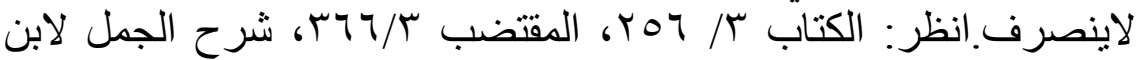

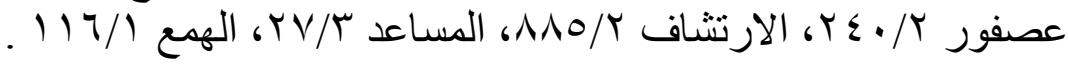

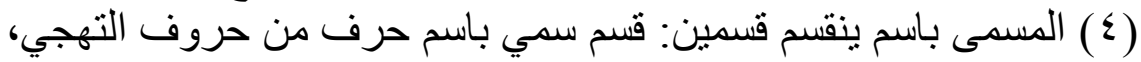
وقسم سمّي بغير ذلك من الأسماء. (0) المسمى باسم حرف من حروف التهجي لا يخلو أن يكون مسمى باسم و احد أَو بأكثر. (7) أي حكمه الوقف و لا إعراب فيه، فتقول: هذه سورةُ صـاد. و و إن لم تضف إليه سورة في اللفظ ولا في التقدير جاز فيه ثلاثة أَوجها. (Y) (^) ( أي الوقف على الحكاية. 
وعلى أكثر (ץ) موازنًا الأسماء الأعجمية(") مضافًا إليه سورة لفظًا أو نية

فالوقف، أو غير مضاف فالوقف، وكما لا ينصرف(4).

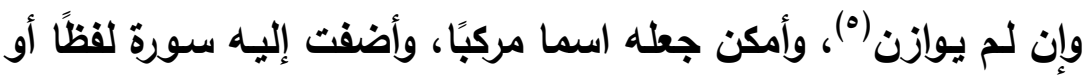

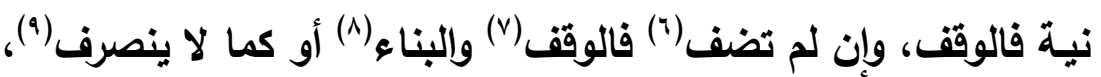

() أب أن تعربه إعر اب ما ينصرف إن قدرته منقو لَ من مذكَّر، و إعر اب ما

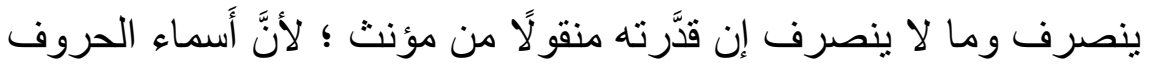

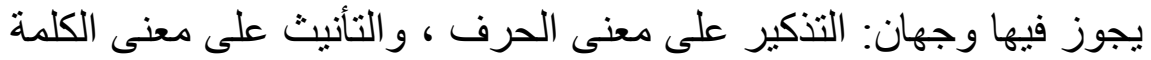

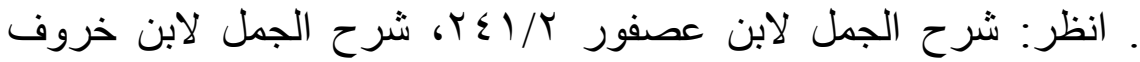

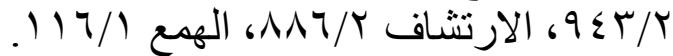

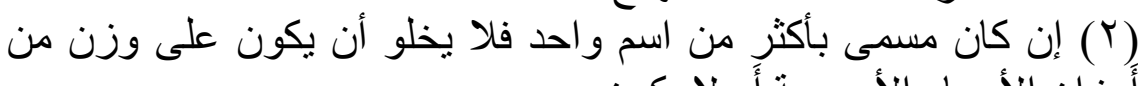
أوزان الأسماء الأعجمية أو لا لايكون. (T) فإن كان على وزن من أوزان الأعجمية فلا يخلو أَن تضيف إليه سورة

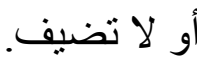
(乏) أي فيعرب إعراب ما لاينصرف، والوقف على الحكاية، وذللك

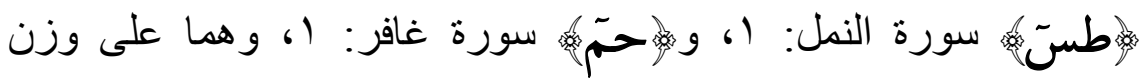

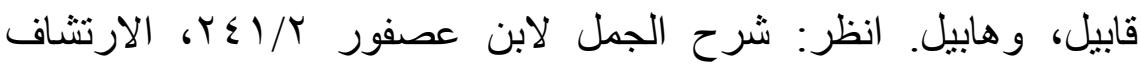

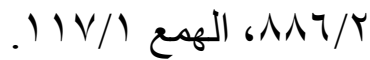

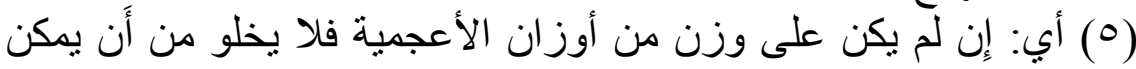

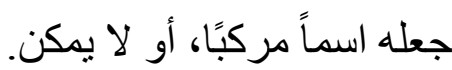
(7) أي إن لم تضفها إليه لا لفظًا و لا تقديرًا ففيها ثلاثة أوجها.

$$
\begin{aligned}
& \text { ( أي على الحكاية. } \\
& \text { (^) نحو: خمسة عشر. }
\end{aligned}
$$

(9) نحو: بعلبك، وكذللك (طسّم) سورة الثعر اء : (، وحاميم. 


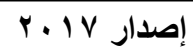

حولية كلية اللغة العربية بالمنوفية العدد الثثاني والثلاثون

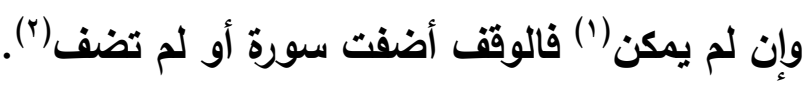

أو غير حرف هجاء(")، وفيه (أل) فينصرف(؛)، وإن لم يكونا فيه فيمنع(ه)،

وإن أضفت إليه سورة فكحكمه قبل الإضافة(؟).

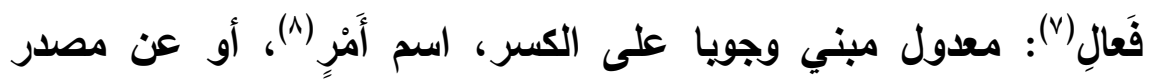

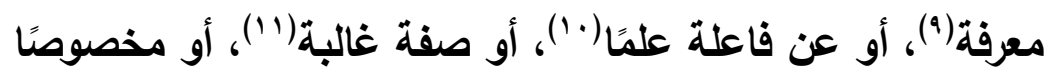

\section{(1) أب إن لم يمكن جعله اسماً و احداً.}

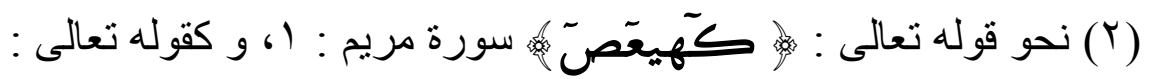

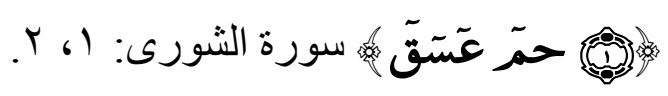

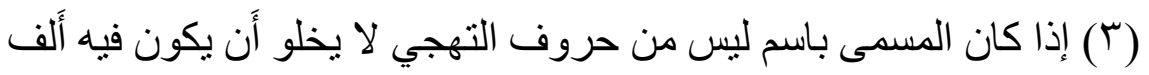

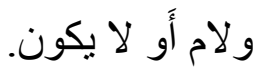

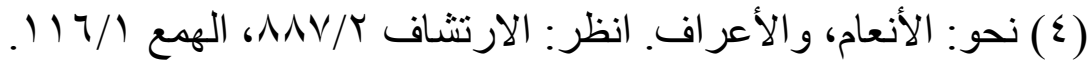

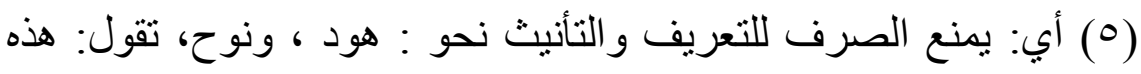

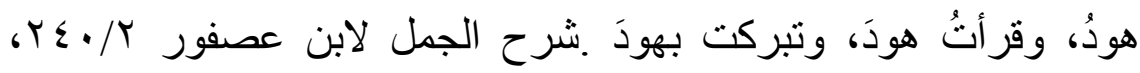

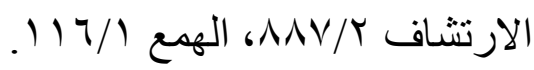

(7) أي: إِن كان فيه ما يوجب منع الصرف لم تصرفه و إلاّ صرفته، تقول: سورةُ يونس، فتمنع يونس الصرف للتعريف والعجمة، وتقول: هذه سورة

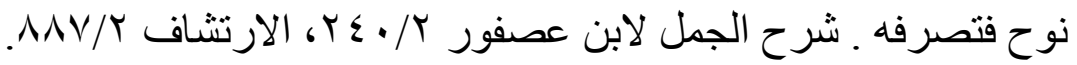

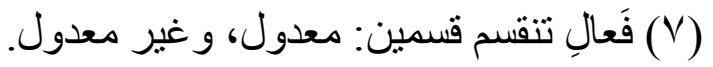
(^)

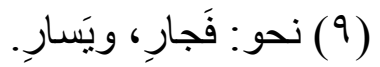

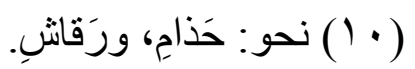
(1 (1) و هي على وزن فاعلة منل: حَلاقِ اسم للمنية، ووَقاع للكيَّة في الرأس. 
بالنداء(') إلا العلم المعدول عن فاعلة، فالحجازيون يبنون مطلقًا، وينوي تميم كما لا ينصرف إلا ما في آخره راء فيبنون (؟)، وقد لا يبنون.

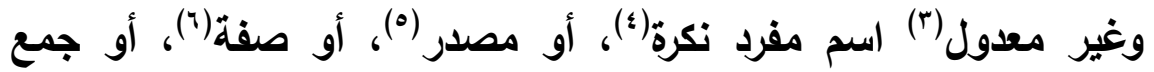

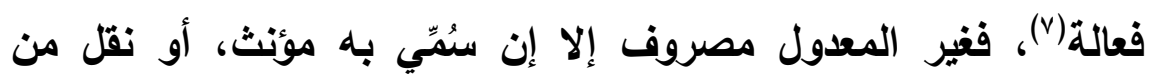

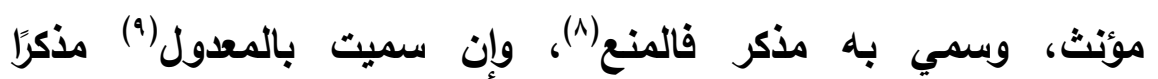

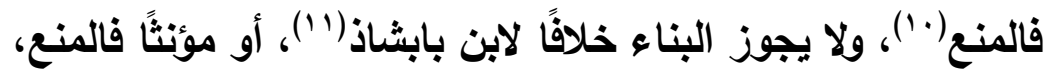

(1) أب: أَن يكون معدولاً في النداء نحو: فَساقِ، وخَباثِ.

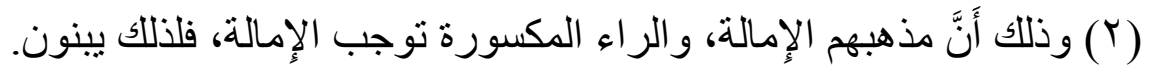

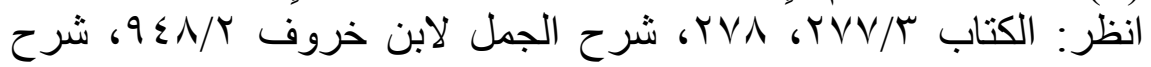
الجمل لابن عصفور النطاب/

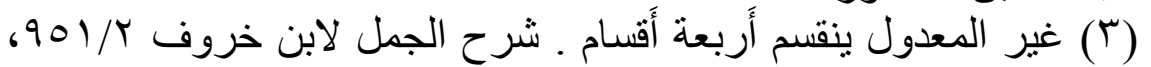

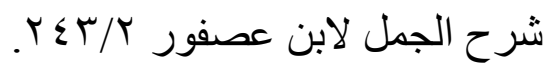

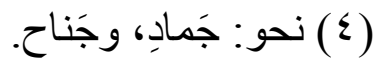

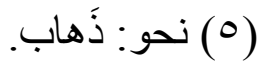

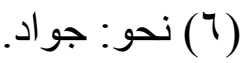

(V) أب: أن يكون جمعًا، وبينه وبين و احده حذف الهاء ، نحو: سَحاب.

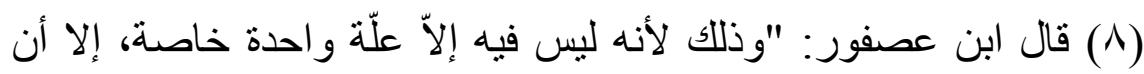
يكون منقولًا من مؤنث ، نحو : رجل سميته بعَناق". شرح الجمل لابن الانه عصفور r r (9) أي: لا يخلو أَن تسمي بها مذَّكرًا أَو مؤَّنثًا.

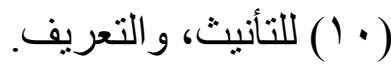
(1) هو طاهر بن أحمد بن بابشاذ، أبو الحسن النحوي المصري أحد أئمة

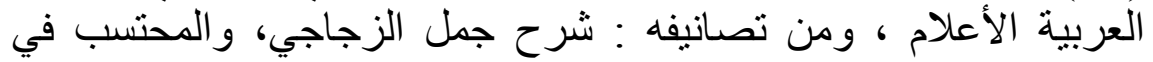

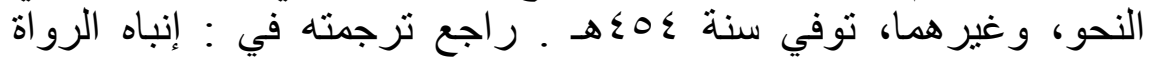

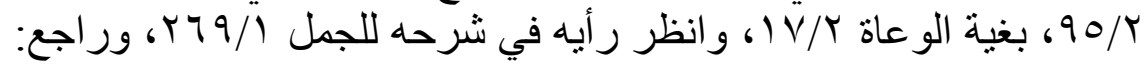


ويجوز البناء خلافًا للمبرد؛ إذ أوجبه (').

البناء: هو اللفظ الاي لزم آخره حالة واحدة(ץ). والكلام: اسم، وفعل، وحرف ـ الحرف مبني، والفعل ماضيه مبني على الفتح، ومضارعه معرب

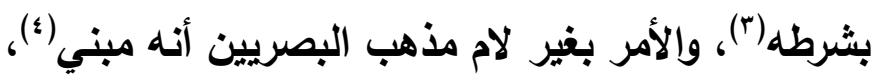

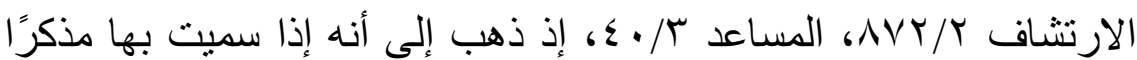

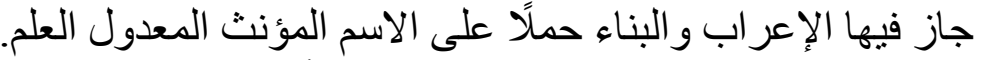

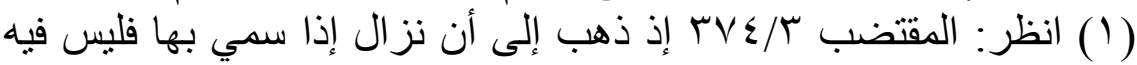

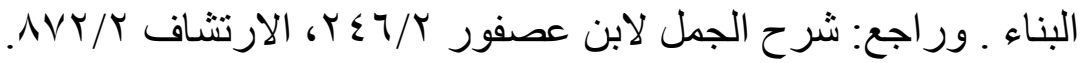

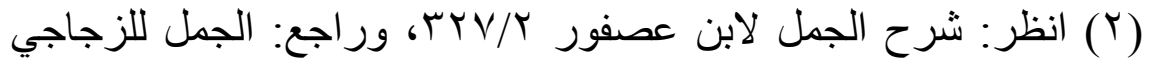

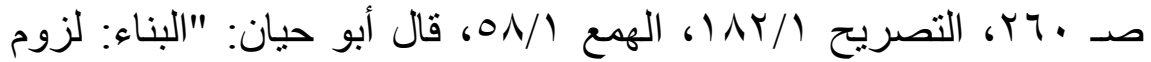

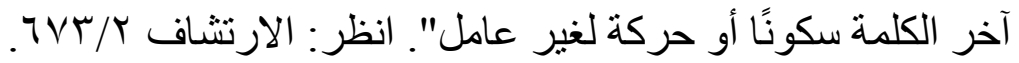

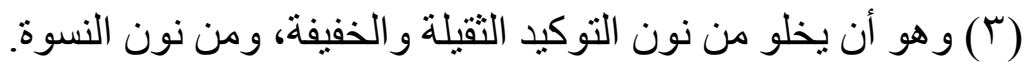
( ) فذهبو إلى أنه مبنى على السكون إذا كان صحيح الآخر كاضْرِبْ، و إذاذ

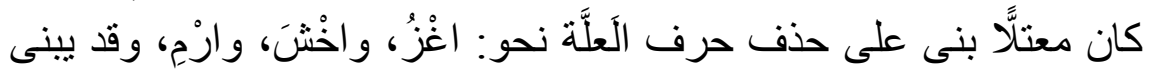

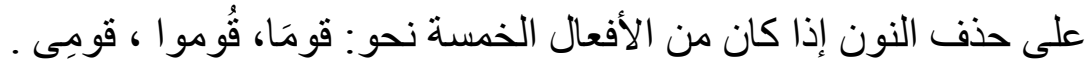

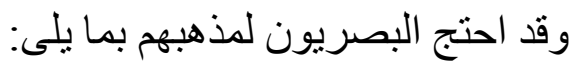

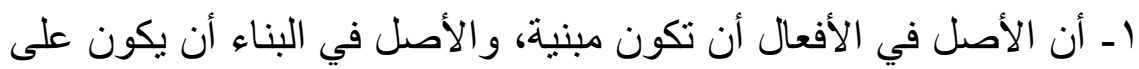

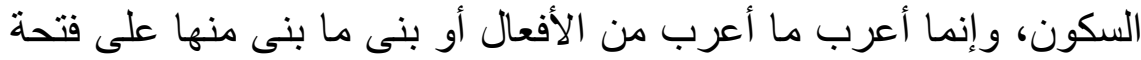

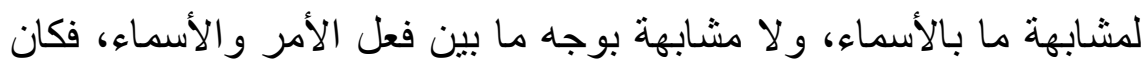
باقيًا على أصله في البناء.

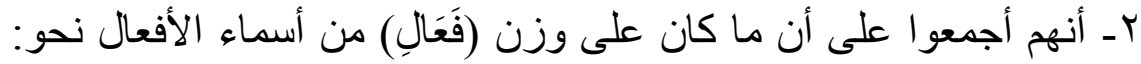

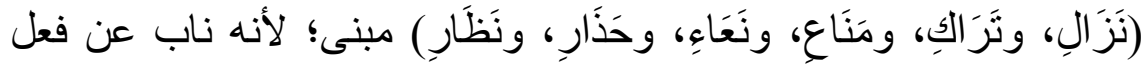

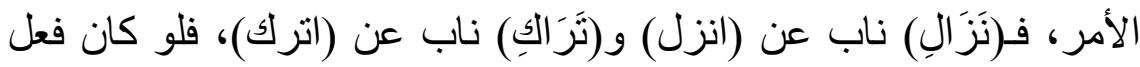

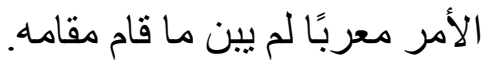




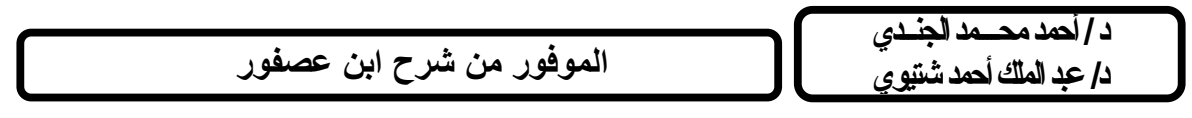

ومذهب الكوفيين [1 ع/ب] أنه معرب(').

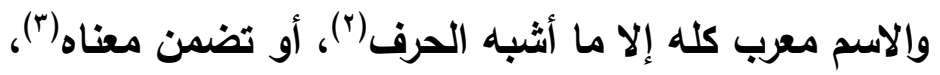

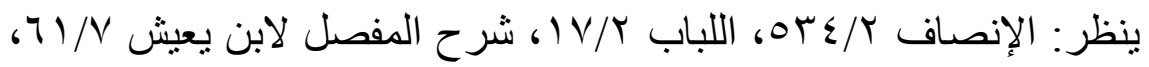

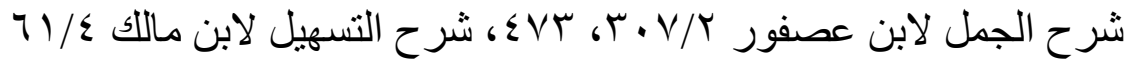

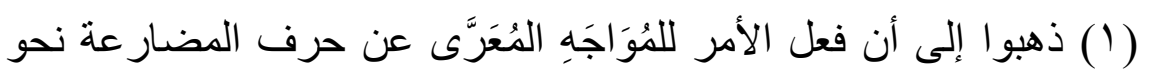

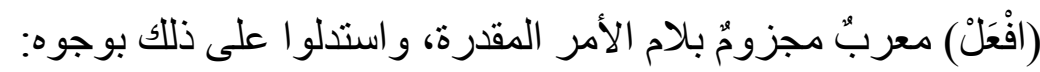

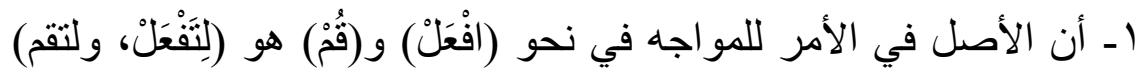

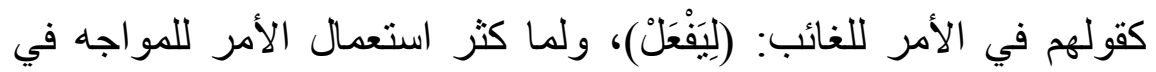

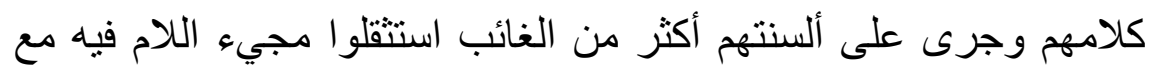
كثرة الاستعمال فحذفو ها مع حرف المضار عة طلبًا للتخفيف.

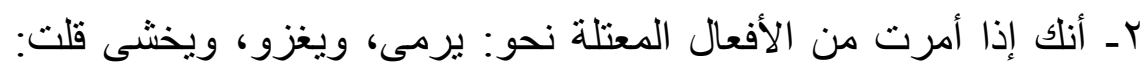

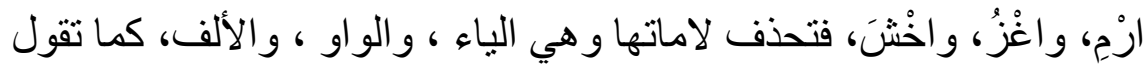

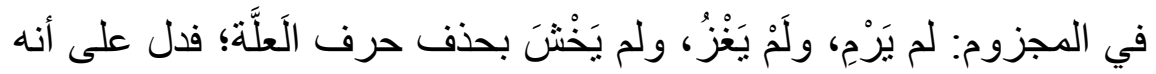

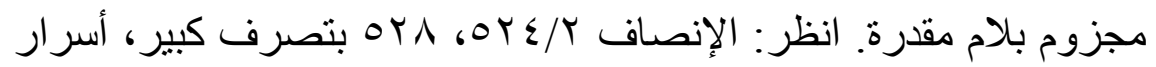

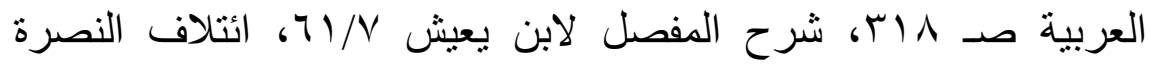

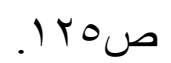

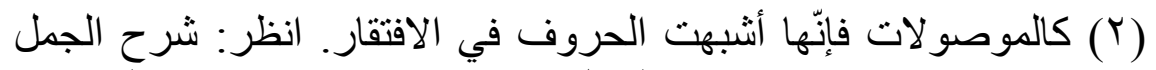

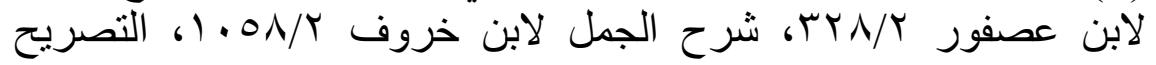
إلإن

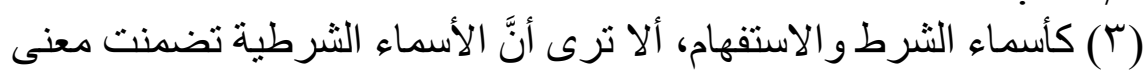

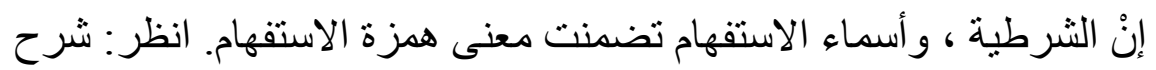

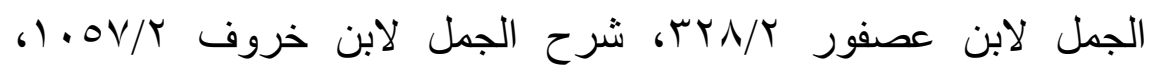

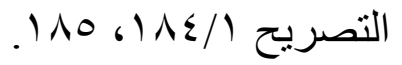


أو وقع موقع المبني(')، أو ضارع ذلك(r)، وهو كل معدول لمؤنث على (فَعالِ)، وتقدم في باب ما لا ينصرف، أو أضيف إلى مبني (ّ)، أو خرج عن نظائره، وهو (أيّ)(؛) في مذهب سيبويه (•)، فيجوز بناؤه، ومن المضاف إلى مبني: ما أضيف إلى جملة، فالكوفيون يبنون مطلثًا،

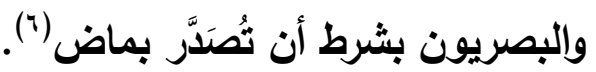

(1) كالمناديات وأسماء الأفعال، فالمناديات وقعت موقع ضمائر الخطاب وهي مبنية، وأسماء الأفعال وقعت موقع الفعل وهو مبني. انظر: شرح ح

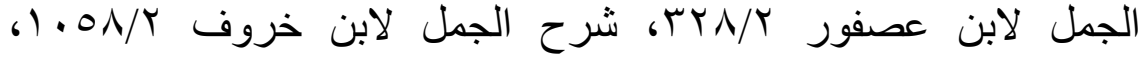

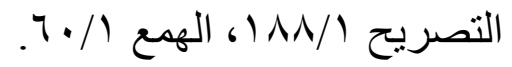

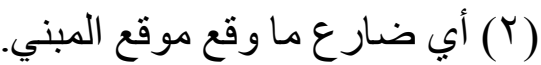

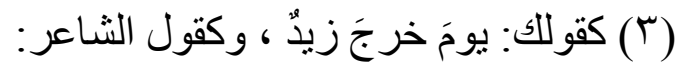

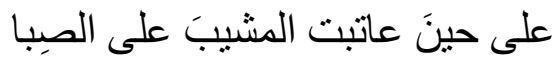

(§) قال ابن عصفور : "أي من الموصو لات فإنَّها فارقت سائر الموصولات لات

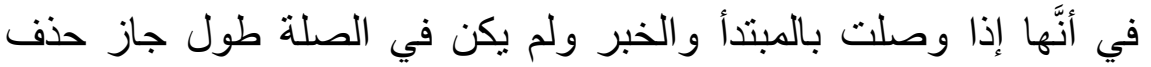

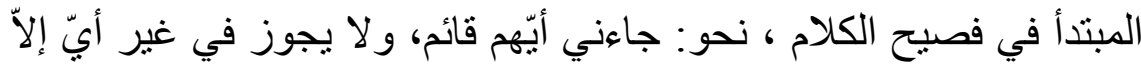

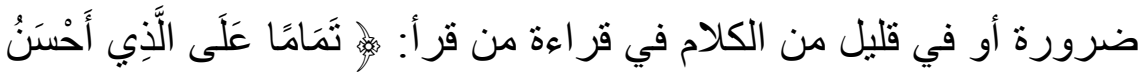

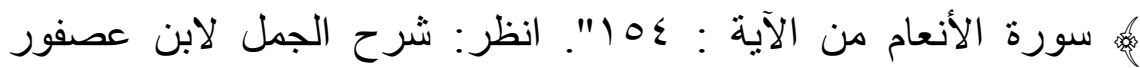

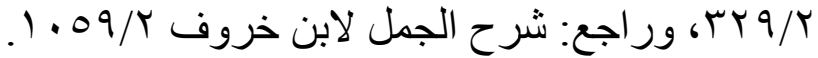

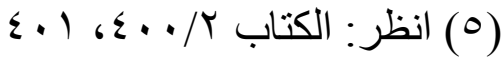

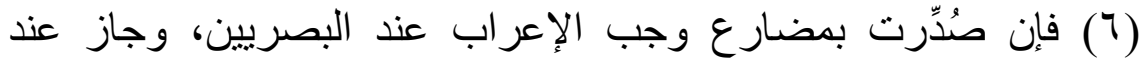

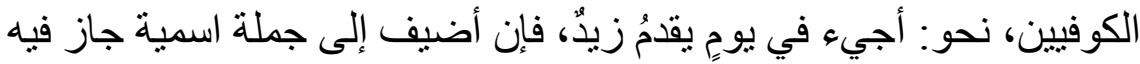

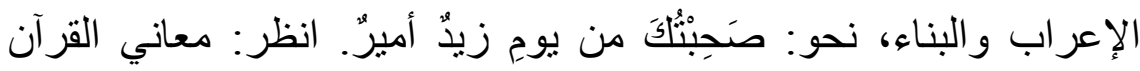

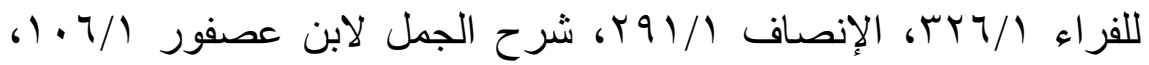

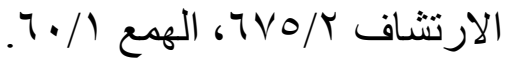


وزعم الفارسي أنه لا يجوز أن يبنى الاسم إلا لشبه بالحرفئول، أو تضمن

وأصل البناء السكون، والإعراب بابه أن يكون بالحركات، فما وجد من حرف أو فعل مبنيَّا على السكون فلا سؤال فيه(ّاّ). وما وجد منها مبنيَّا على حركة فيقال: لم بُني على حركة؟، ولم خُصَّ بتلك الحركة دون غيرها؟(؛)، وما بني من اسم على سكون فيقال: لـ بُنب؟؟، أو على حركة

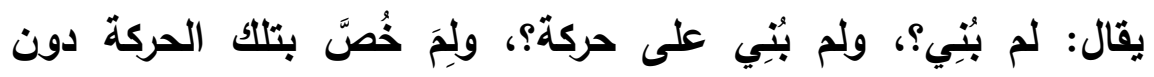
غيرها؟(0)

والذي بُني على حركة ما كان متمكنًا في موضع، ثم طرأ عليه البناء(")،

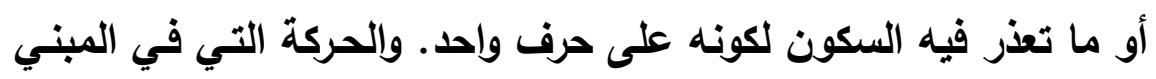

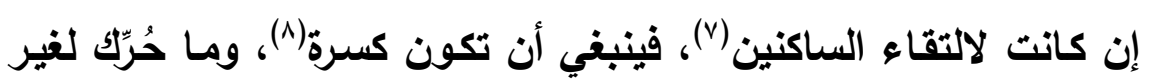

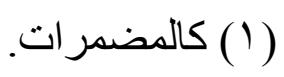

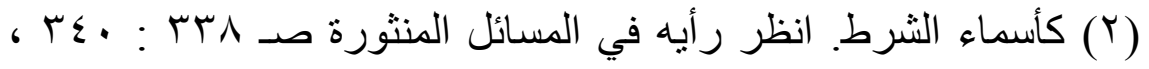

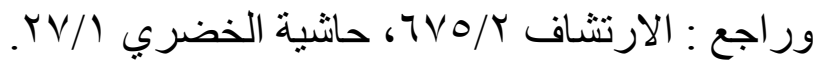

$$
\begin{aligned}
& \text { (r) وذللك لأنَّ أصلهما البناء، و أصل البناء السكون. }
\end{aligned}
$$

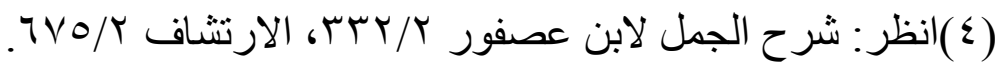

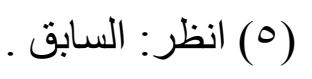

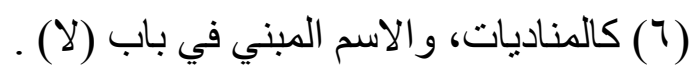

(V) وذللك لكونه على حرف و احد نحو: و او العطف وفائه، و لام الجر وكافه أو لالتقاء الساكنين نحو أمس، وما ودا عدا ذلك فمبني على السكون.انظر : شرح

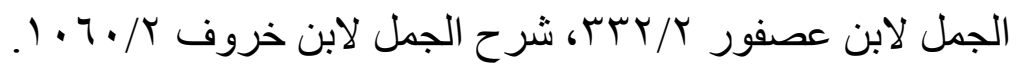

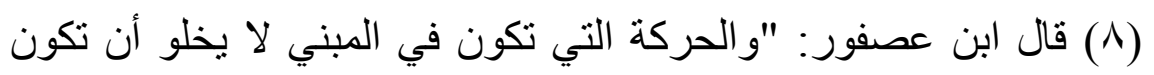

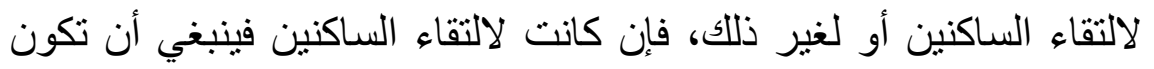

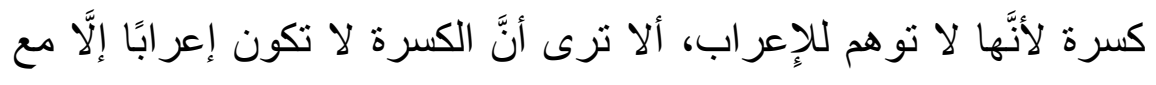


ذلك فينبغي أن تكون فتحة (1)، ولا يعدل عن الكسر فيما ذكر، ولا عن الفتح إلا لموجب، والموجب: الإتباع(ץ)، أو طلب التخفيف(؟) ، أو

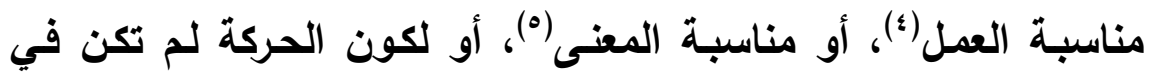

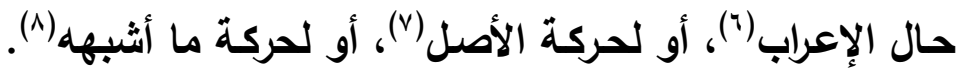

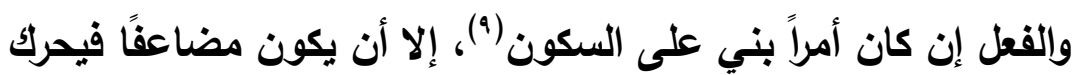

التنوين أو ما عاقَبَهُ من الإضافة و الألف واللام، و أيضًا فإنَّ الكسرة نظير السكون كما أنَّ الخفض نظير الجزم، فلما اضطررنا إلى الحركة حركناه بما

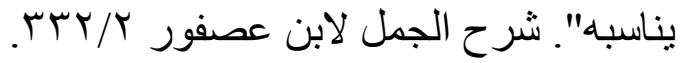

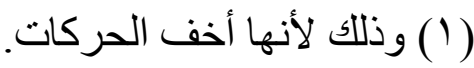

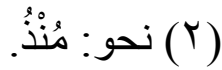

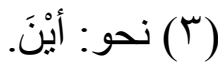
( ) نحو: لِزيدٍ ويزيدٍ.

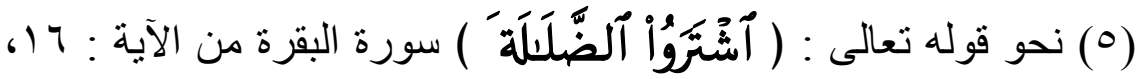
فإنَّ الضمة من الواو، و الواو من علامات الجمع ـ انظر : شرح الجمل لابن

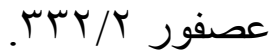

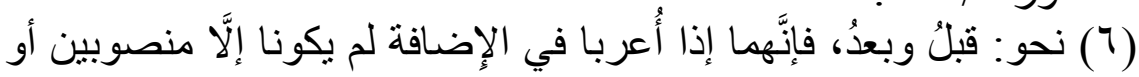

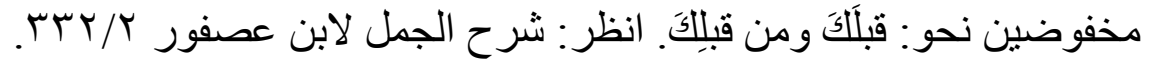

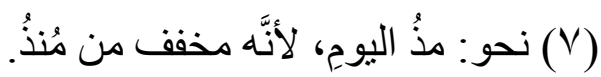

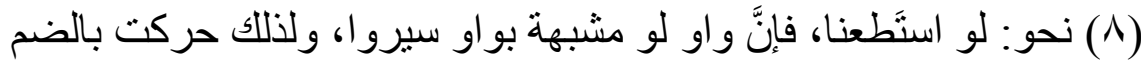

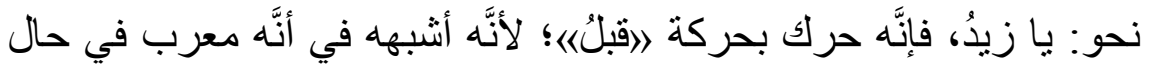

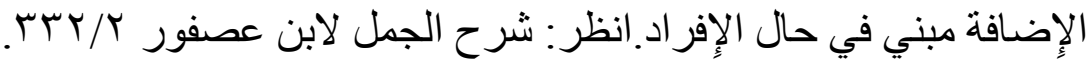

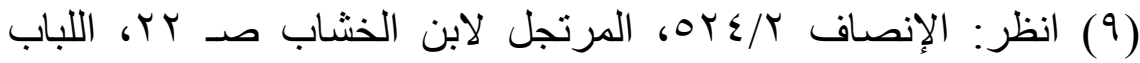

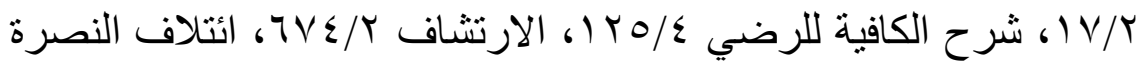




\section{الموفور من شرح ابن عصفور}

لالتقاء الساكنين بالفتح، والضم، والكسر (')، أو ماضيًا بني على حركة،

$$
\text { وهي فتحة (r). }
$$

\section{$* * * * * *$}

الحكاية: إيراد لفظ المتكلم على حسب ما أورده في كلامه(ّ). وحق العامل أن يؤثز فيما بعده إلا أن يمنع من ذلك بناء المعمول، أو

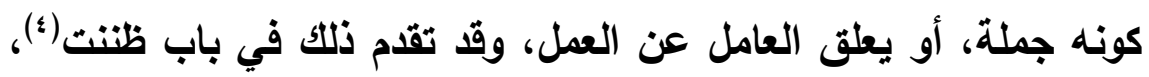

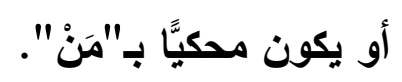
والمحكي إن كان مفردًا، فلا يكون إلا في الاستثبات بـ"مَنْ" عن الأعلام

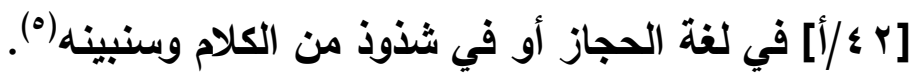

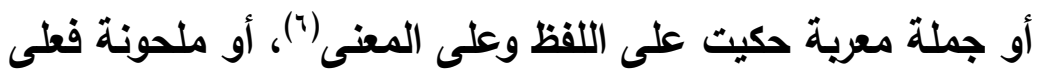

$$
\begin{aligned}
& \text { (1) انظر : شرح الجمل لابن عصفور r/r (Y إس. }
\end{aligned}
$$

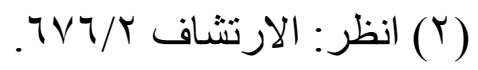

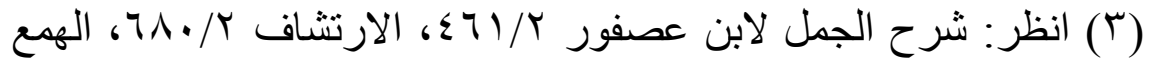

$$
\begin{aligned}
& \text { Y Y } / \text { / }
\end{aligned}
$$

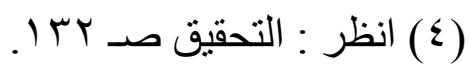

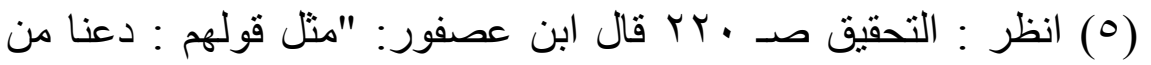

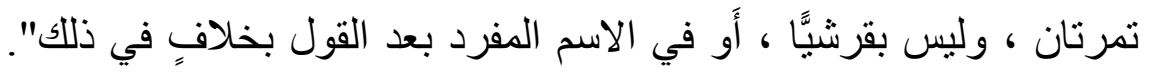

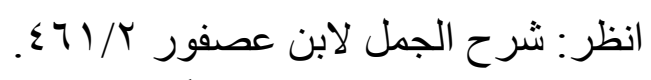

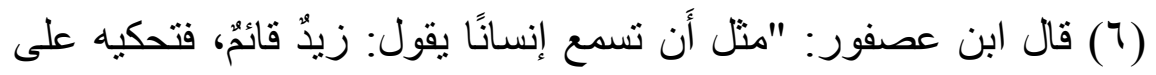

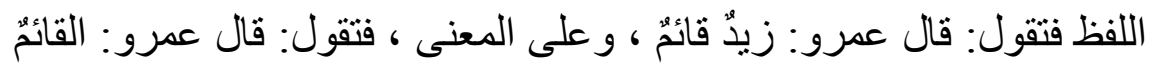

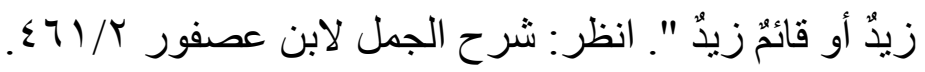


المعنى"(')، والصحيح أنها لا تجوز على اللفظ().

القول(ז): إن وقع بعده مفرد(؛) مصدر فـلا يحكى، بل ينصب بفعله(ه)، أو غير مصدر (؟) اسمًا لجملة فلا يحكى(v)، واختلف فيه فقيل : صفة لمصدر محذوف(^)، وقيل: مفعول به،، وهو الصحيح. أو غير اسم لجملة، فقيل: لا يحكى، والصحيح أنه يحكى، ولا يجوز فيه غير الحكايـة.

(1) قال ابن عصفور: "مثل أَن تحكي قول من قال: قامَ زيدٍ، بخفض زيد

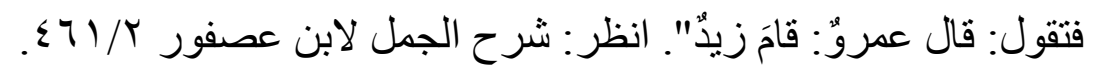

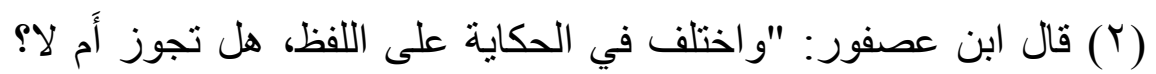

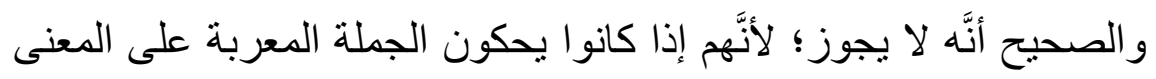

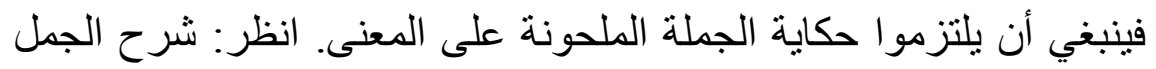

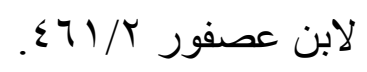
( (Y) لايخلو القول أن يقع بعده مفرد أو جملة.

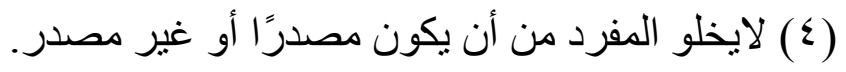
(1) نحو: قال زيدّ قولًا.

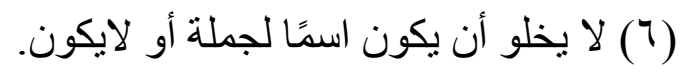

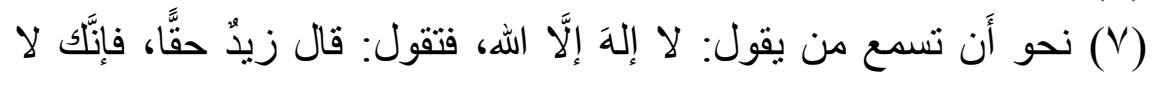

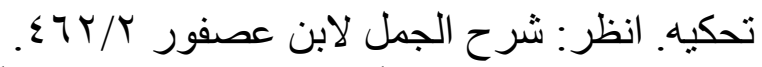

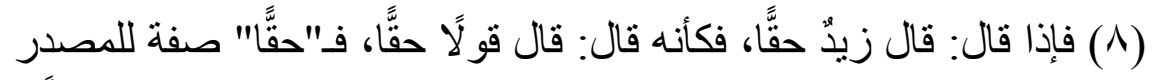

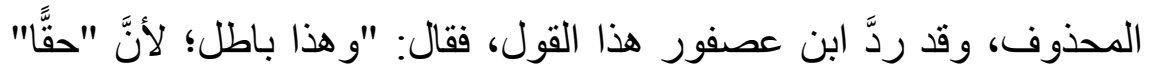
ليس من الأسماء الجارية، و الوصف ودَ بالأسماء غير الجارية ليس بقياس و إنّما يقال منه ما سمع مثل قولهم: مررتُ برجل حجَرِ الرأسِ". انظر : شرح

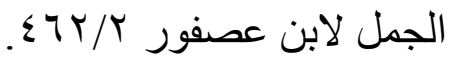


أو جملة اسمية(') جازت الحكاية ، وجاز أن يعامل القول معاملة الظن ،

فينصب به المبتدأ والخبر (ץ)، وقد تقدم ذلك في باب "ظَنَّ"(؟).

وقد يحكى بعد القول مضمرًا (؛)، ويجرى مجرى القول، فيحكى بعده الجمل:

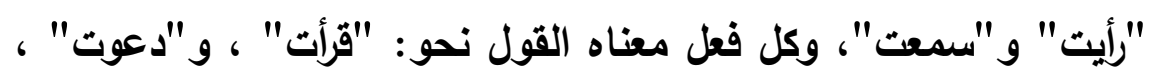
و "ناديت"

********

حكاية الاسم المفرد لا تكون إلا بـ"مَنْ"، بشرط أن يكون علمًا أو لقبًا أو كنيةً.

( ( ) أي: إن كانت الجملة الو اقعة بعد القول اسمية.

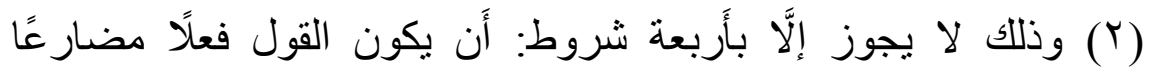
لمخاطب قد تقدمه أداة الاستفهام غير مفصول بينها وبينه إلَّا بظرف فئل أَ

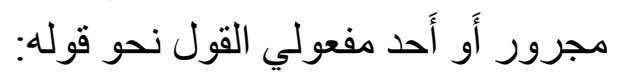

لعرُ أبيكَ أم متجاهلينا

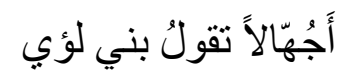

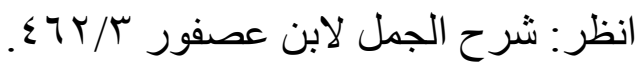

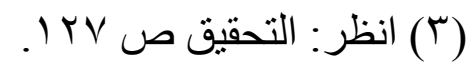

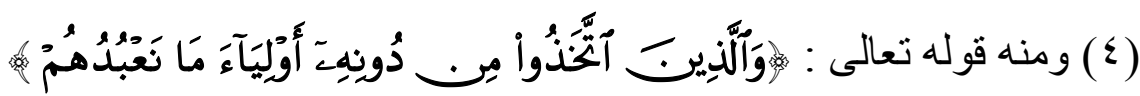
سورة الزمر من الآية : r، أي: يقولون: ما نعبدُهم، وكذللك قوله تعالى :

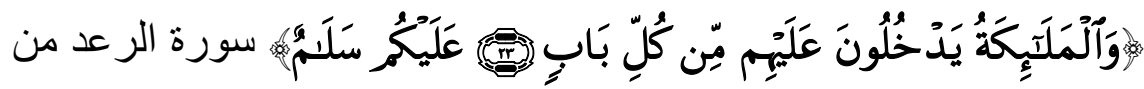

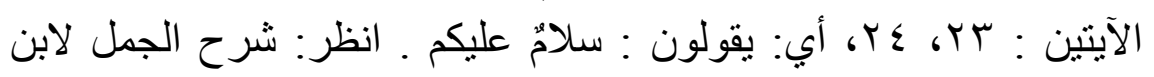

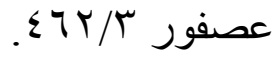


ولا بُدَّ من الحكاية عند أهل الحجاز (1) ، ولا يجوز بـ"من" إلا بشروط منها: ألا ياخل على "مَنْ" حرف عطف، وألا يكون الاسم المحكي متبوعًا

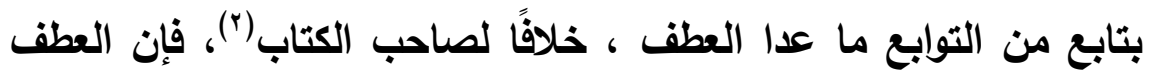
يمنع من الحكاية إلا أن يكون التابع مع المتبوع قـ جعلا كشيء واحد، فتجوز الحكاية.

فإن كان الاسم نكرة فسيأتي حكمه(") ، ويعض العرب(أ) يحكي سائر المعارف وإن لم تكن أعلامًا، وذلك قليل إلا أن يكون مضمرًا أو مُشَارًا، فلا تجوز حكايته. وحكي عن بعض العرب أنَّهم يحكون المعرفة غير العلم كالنكرات وستأتي (o) ، فإن اجتمع ما يحكى مع ما لا يحكى بنيت على المتقدم، فإن كان مما يحكى حُكي، وأتبع الثاني، وإن كان مما لا يحكى أعرب وأتبع الثاني. و"مَنْ" في هذا الباب خبر مقدم، والأسم العلم بعدها مبتدأ، وقد يجوز عكس ذللك.

****** $* *$

الاستفهام عن نكرة [Y \&/ب] بـ"مَنْ" لا يكون كالعَلَمِ، بل تحكيه على لغتين إحداهما: إلحاق علامة على الإعراب خاصة وهي : واو في الرفع،

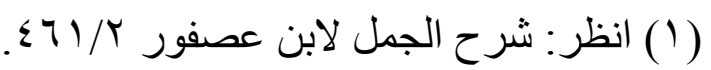

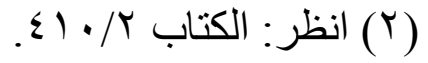

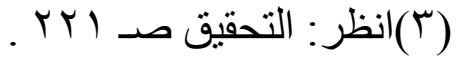

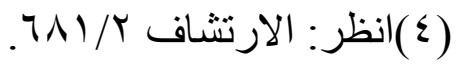

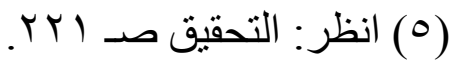


وألف في التصب، وياء في الجر، سواء كان مثنَّى أو مجموعًا أو مذكرًا أو

مؤنثًا (1)

الثانية: إلحاق هذه العلامة، ويلحق معها علامة التثية ، والجمع ،

والتأنيث(؟).

وهذه العلامة التي تلحق "مَنْ" تحذف في الوصل في كلتا اللغتين، وحكى يونس أن بعض العرب يعرب "مَنْ"، ويحكي بها النكراتِ كما يحكي

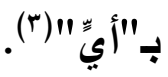

وإذا قلت : مَنَهْ؟ فتحت النون، وفي التثنية: منتان؟ تبقي النون على

سكونها.

و "مَنْ" لا يخلو أن يكون حكايةً لمجرور، فيعد العلامة، ولا بـ من دخول حرف الجر عليها، فتكون مجرورة به، والعامل مضمر تقديره بعده، أو

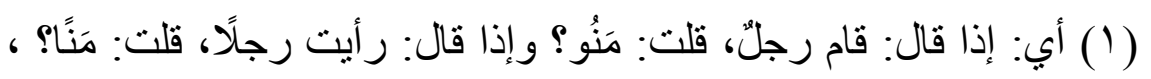

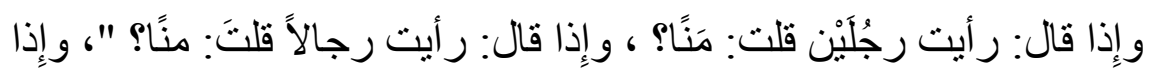

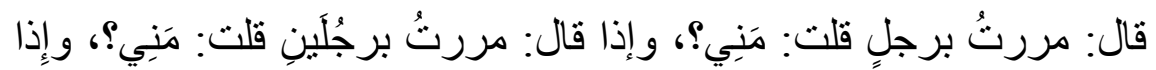

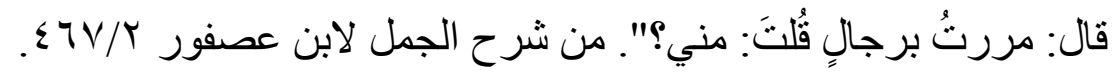

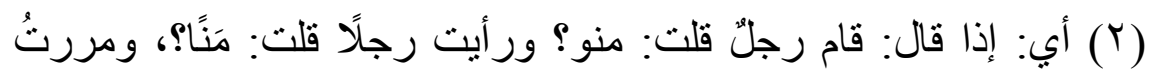

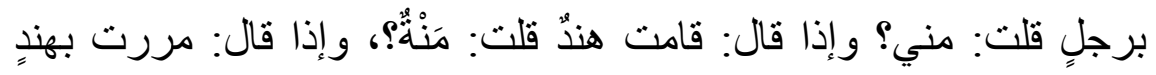

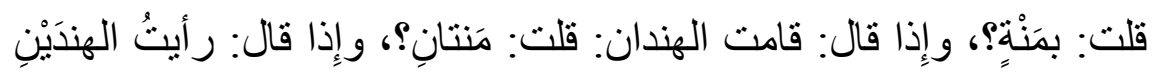

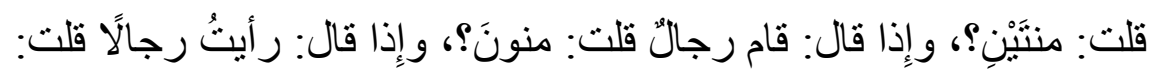

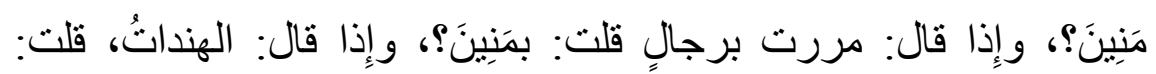

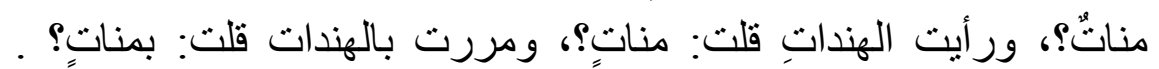

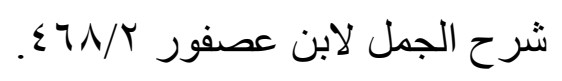

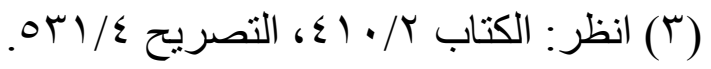




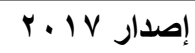

حولية كلية اللغة العربية بالمنوفية العدد الثاني والثلاثون

لمنصوب فمفعولة بفعل مضمر وتقديره بعدها، أو لمرفوع لحقته العلامة،

فمبتأ والخبر محذوف، ولا يجوز أن يكون فاعلا بفعل مضمر ('). ****** $* *$

الجملة وما هو في تقديرها وهو الفعل إذا كان فيه ضمير إذا سمي به فالحكاية ليس إلال(r).

والذي يشبه الجملةَ حرفُ العطف والمعطوف، ويحكى على حسب الموضع الأي نقلته منه()، والمعطوف عليه والمعطوف، والصفة والموصوف، والمضاف والمضاف إليه، والمطول، وهو كل اسم عمل بعضه في بعض يحكى فيها ما كان يجوز فيها في حال الإعراب قبل التسمية، وحرف الجر والمجرور إن كان حرف الجر على حرف واحد(؛)، أو على حرفين ثاتيهما

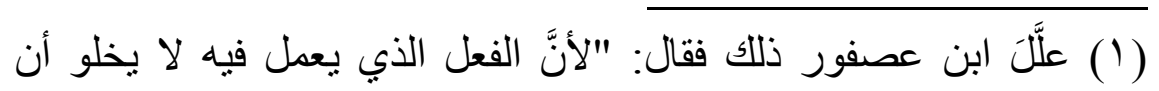

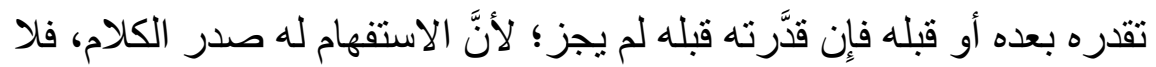

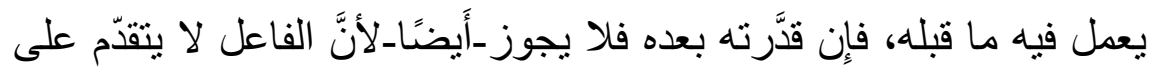

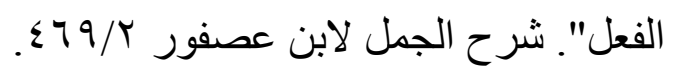

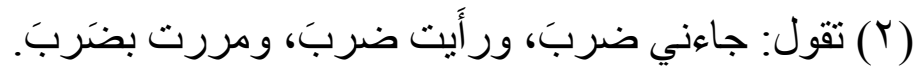

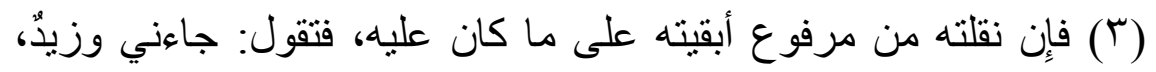

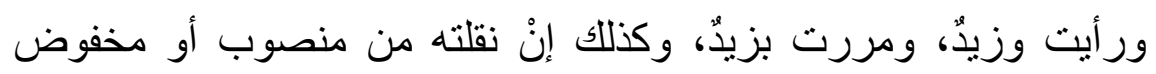

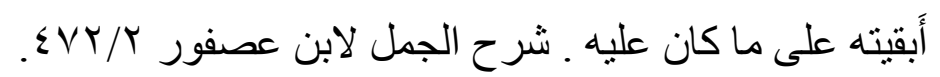

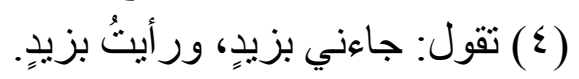


الموفور من شرح ابن عصفور

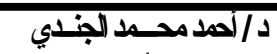

دا عبد الملك أحمد شنتيوي

عليل حكيث لفظه (')، أو صحيح (؟) ، أو على أَزْيََ من حرفين حكيته، ويجوز أن تعربه وتضيفه إلى الثاني (َّ).

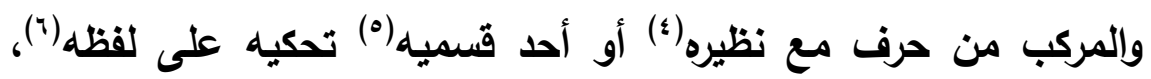

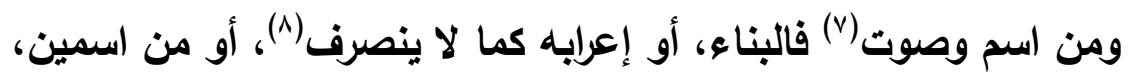

(1) تقول: جاءني في زيدٍ ، ورأيت في زيدٍ ، ومررت بفي زيدٍٍ.

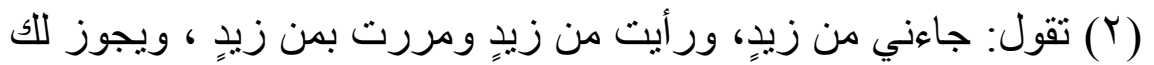

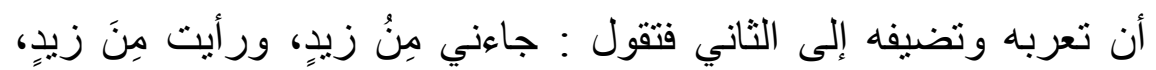

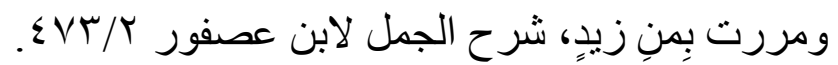

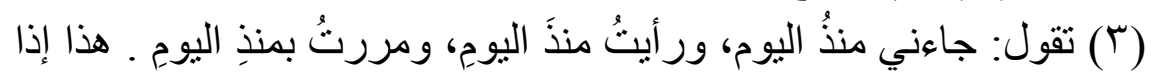

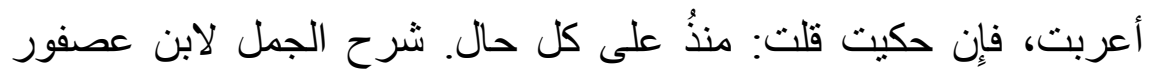
$\Sigma V T / Y$

( ) ( ) مثل: إِنَّما و أخو اتها.

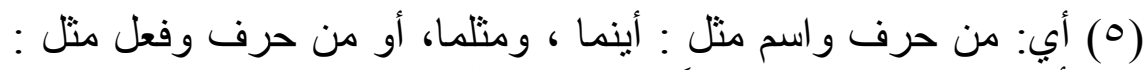

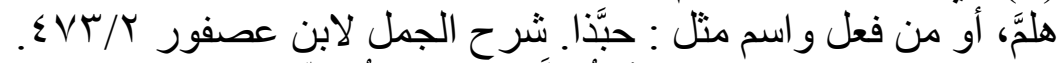

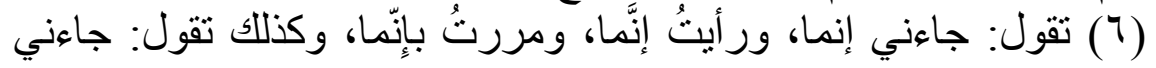

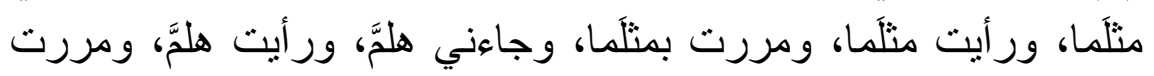

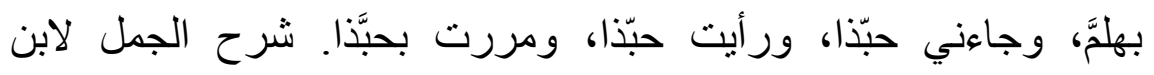
عصفور ( ) مثل: سيبويه، و عمرويه.

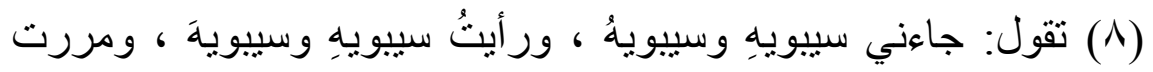
بسيبويهِ وسيبويَ. 


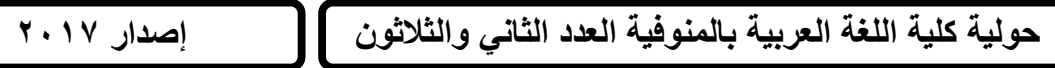

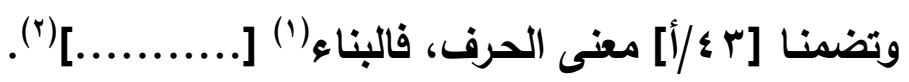

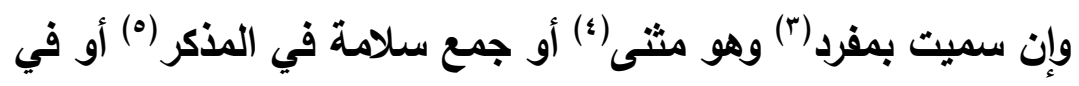

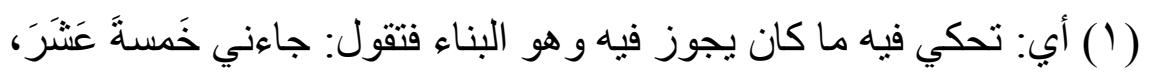

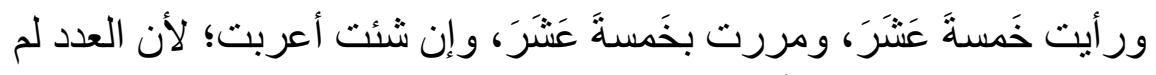

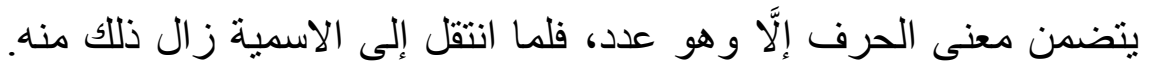

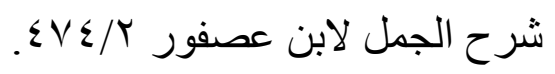

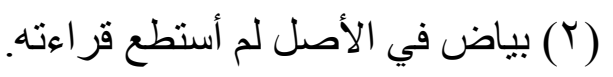

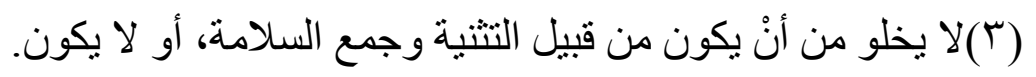

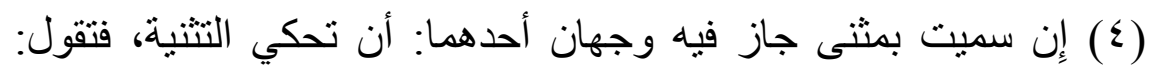

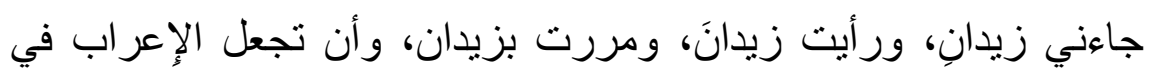

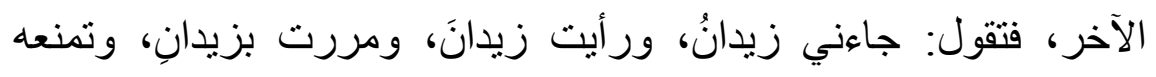

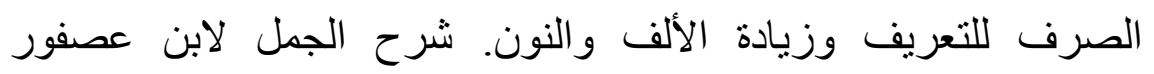
$\varepsilon \vee \varepsilon / Y$

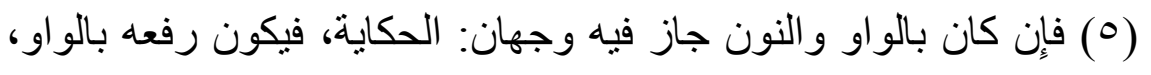

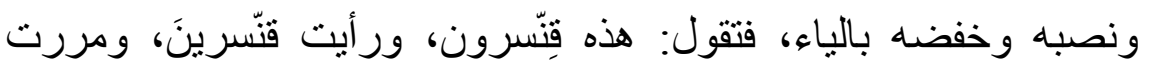

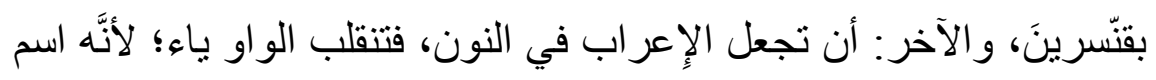

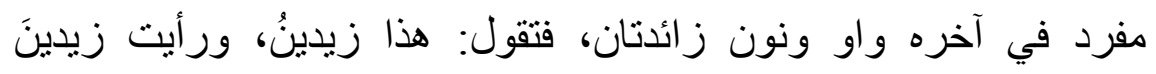

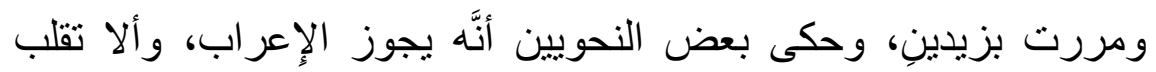

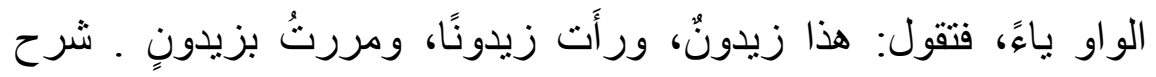

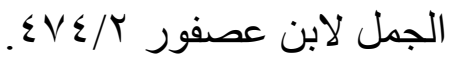


الموفور من شرح ابن عصفور

المؤنت (')، أو بحرف من حروف التهجي، فقد تقدم في ما لا ينصرف (r). *******

وإذا قلت: لأيت في خاتمه أسدًا(ّ)، فإن كان مصورًا فالإعراب(؛)، ولا يوصف إذ ذاك إلا بمصدر أو ما في معناه لا بصفة لا تدرك، ويطابق الموصوف في الإعراب، و "في فصه" متعلق بـ"رأيت" أو بمحذوف ، أي: كائنًا في فصه.

وإن كان مكتويًا حكيت وهو منصوب بفعل مضمر، التقدير: ائتوا أسدًا، أو اقصدوا، ولو رفعت لحكيت، وتقديره: أنا أسدُ، ولا تصف ذلك إلا بمكتوب أو مكتوية أو ما في معناهما. فإن أنثت ذهبت إلى الجملة، وإن ذكرت ذهبت إلى الكلام، وتكون الصفة التي هي مكتوب أو مكتوية منصويةً أبدًا على الحال، والجملة تصير

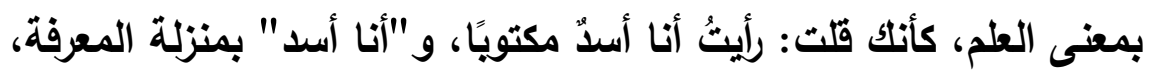
والمجرور الأي هو "في فصه" متعلقًا بـ"رأيت" لا بمحذوف.

التذكير والتأنيث: الأفعال مذكرة كلها، والحروف تذكر وتؤنث، والأسماء مذكر ومؤنت.

(1) أي: بالألف والتاء، فيجوز فيه وجهان: الحكاية، فتقول: جاءني

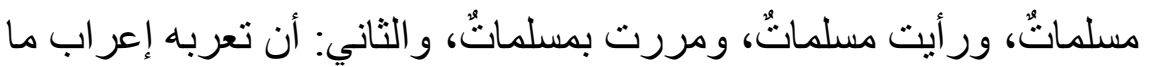

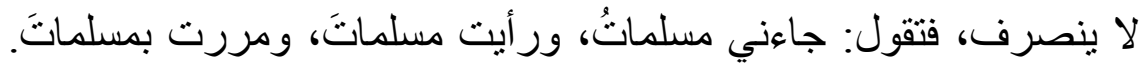

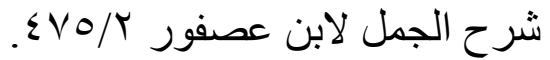

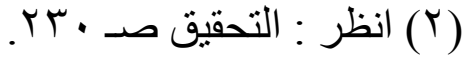

$$
\begin{aligned}
& \text { (ז) أي: ولا وجع للحكاية. }
\end{aligned}
$$

(乏) لا يخلو من أنْ يكون المرئي مكتوبًا، أو المسمى بهذا الاسم مصورًا. 
فالمؤتث ما فيه علامة وهي الألف والتاء، وأما الهمزة فمنقلبة عن الألف، والمؤنث بالتاء تكون فيه للفرق بين المذكر والمؤنث، وذلك في الصفة الجارية، ولمجرد التأنيث(1)، فيما له مذكر من غير لفظه، وفيما لا مذكر

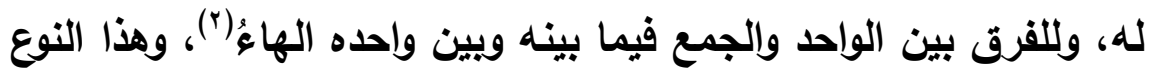
ليس لله واحد مذكر، وإنما المفرد المذكر مثل المفرد المؤنث.

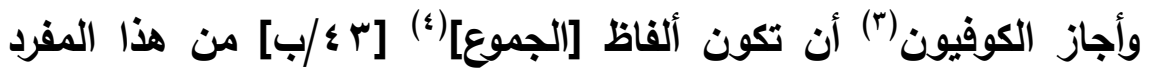
المذكر، فيقولون: بقر للواحد، وحكوا عن بعض العرب: رأيت حماما على حمامة، وأيت عقريًا على عقربة إلا في حية ، فإنهم يقولون: حية للمذكر والمؤنث، وهذا عندنا شذوذ. وللمبالغة: وتذخل في المذكر والمؤنث(*)، ولغير المبالغة(")، وتكون فيهما. وللعوض (v)"، وللالالة على العُجمة (^) أو على النسب(9)، وذلك في كل جمع على "مفاعل" أو "مفاعيل" ون

$$
\text { (1) (1) نحو: قائم ، وقائمة. }
$$

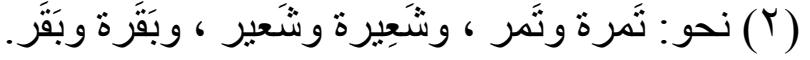

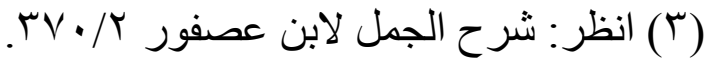
( ) زيادة للسياق.

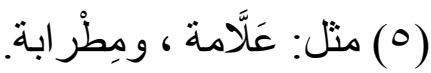

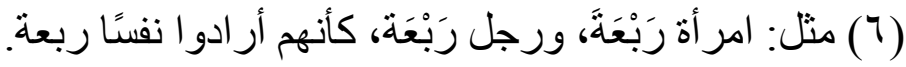

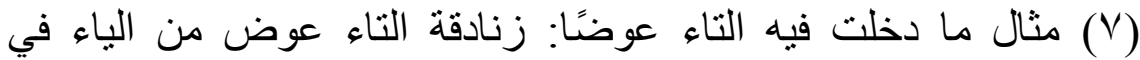
زناديق، فلم يجمع بينهما.

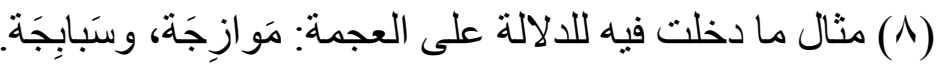
(9) مثال ما دخلت فيه عوضنًا من ياءي النسب: مهالبة، و أَثناعِنَة. 
وللنسب والعجمة [....]"(')، والمؤتث بالتاء يوضحها كون مـا تكون فيه

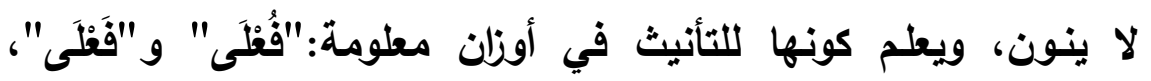

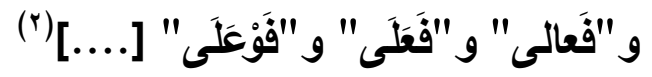

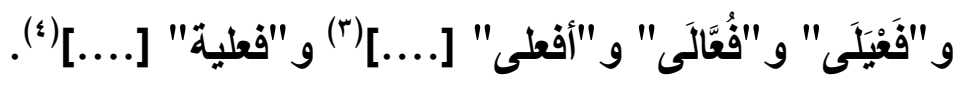

والهمزة يعلم أنها منقلبة عن ألف التأنيث بكون ما تكون فيه لا ينصرف.

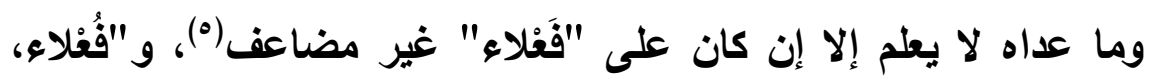

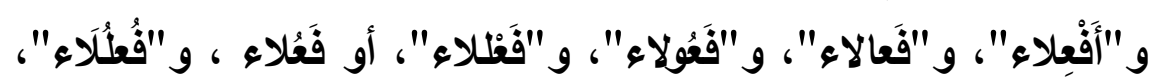

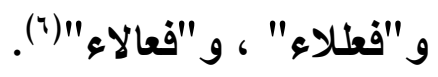

ويعلم تأنيث ما لا علامة فيه بالصفة، ويالإخبار، ويالإثارة، ويإضماره،

ويتصغيره، ويجمعه، ويعدده، ويكونه واققًا على مؤنت حقيقي.

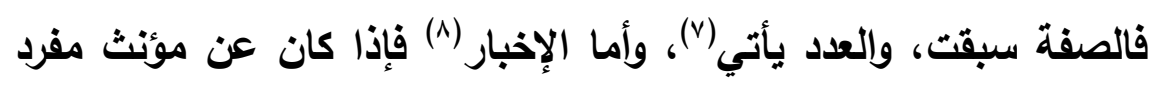

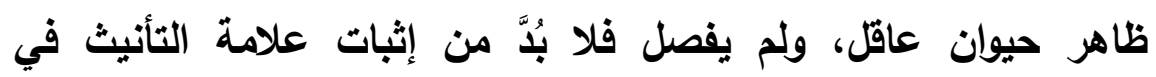

$$
\begin{aligned}
& \text { ( ( ) بياض بمقدار كلمة لم أستطع قر اءته. } \\
& \text { (Y) بياض بمقدار كلمة لم أستطع قر اءته. } \\
& \text { (Y) بياض بمقدار كلمة لم أسنطع قر اءته. } \\
& \text { ( ( ) بياض بمقدار كلمة لم أستطع قر اءته. } \\
& \text { (0) نحو: غَوْضناء. } \\
& \text { (T) نحو: قَرَتَنيساء. }
\end{aligned}
$$

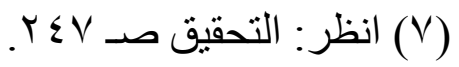

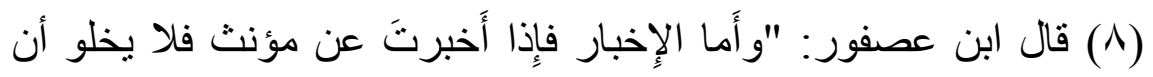

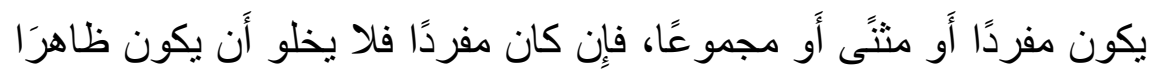

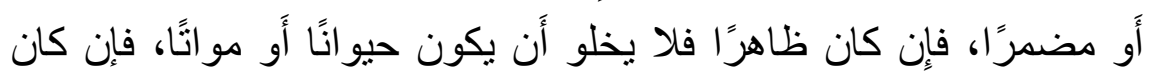

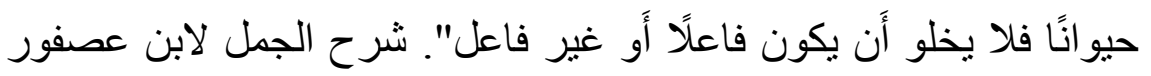




\section{إصدار P. P}

حولية كلية اللغة العربية بالمنوفية العدد الثاني والثلاثون

الفعل(')، ولا يحذف إلا حيث سمع نحو ما حكى سيبويه : قال فلانة، ولا

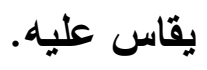

\section{أو فصلت جاز حذفها، والإثبات أحسن()، وكلما طال الفصل كان أجود(ّ)،}

والإثبات في كل هذا أجودُ، أو غير عاقلَ(؛)، ولم تفصل فَهُمَا، ويقبح الحذف، أو فصلت جازًا(•)، والإثبات أحسن، وكلما طال الفصل كان الحذف أجود، والإثبات في كل هذا أحسن.

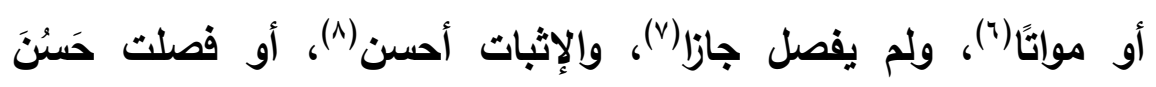
الحذفُ (9)، وكلما طال الفصل كان الحذف [ع \&/أ] أجود والإثبات في هذا

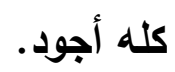

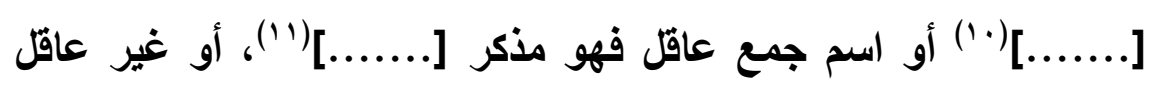
فالعرب تخبر عنه إخبار المؤنث(r')، أو جمع تكسير فالعرب تخبر عزير عنه

$\overline{~(1) ~ ن ح و: ~ ق ا م ت ~ ه ن د . ~}$

(Y) نحو: قام اليوم هندُ، ومن كلام العرب: حَضَرَ القاضِيَ اليومَ امر أَّ.

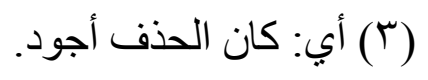

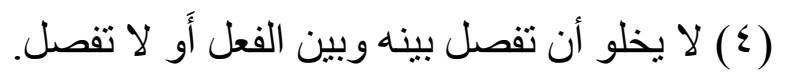

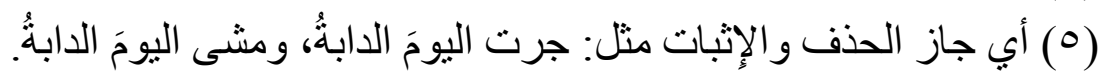

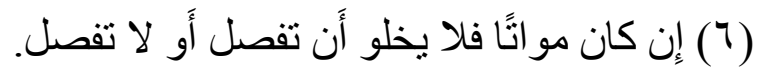

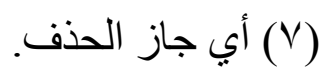
(A) تقول: انكسرت جو انكسرَ القِدرُ. (9) تقول: انكسرت اليومَ القِدرُ، و انكسرَ اليومَ القِدرُ. ( ) ( ) بياض لم أستطع قر اءته. (1 (1) (1) بياض لم أستطع قر اءته.

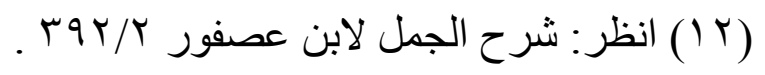




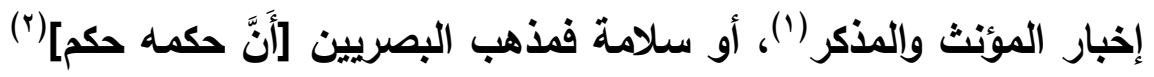
المفرد، ومذهب الكوفيين أَنَّ حكمه حكم التكسير، فيذكَّر ويؤنَّث، والفارسي إني يفصل، فيقول: إن كان لمذكر فيخبر عنه إخبار المذكر، وإن كان لمؤنث فإخبار المذكر والمؤنث (זّ). أو مضمر عائد على مفردٍ فلا بـ من العلامة، أو ضمير جمع فلا يحتاج إلى علامة، ثم الضمير إن عاد على مفرد أو مثنى طابق في إفراد وتثنية، أو على مجموع اسم جنس عاد الضمير مفردًا مؤنثًا. أو اسم جمع لمن يعقل فكما يعود على المذكر، أو لما لا يعقل فيعود الضمير عليه كما يعود على المؤنث المفرد. أو جمع تكسير() لمن يعقل (0) وهو مذكر، فيعود كما يعود على جماعة

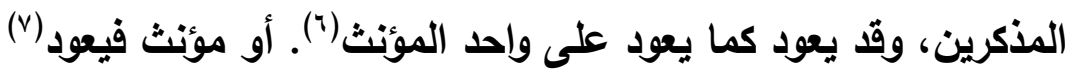

(1) فتقول: انكسرت الجذوع، و انكسر الجذوع، فتذكّر إن ذهبت به مذهب جمع، وتؤنّث إن ذهبت به مذهب جماعة . شرح الجمل لابن عصفور (

(r) بياض لم أستطع قراعته، والزيادة من شرح الجمل لابن عصفور .

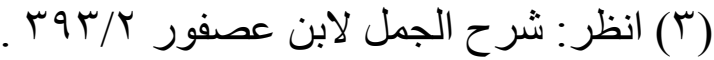

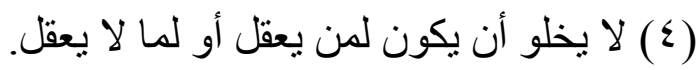

$$
\begin{aligned}
& \text { (0) لا يخلو أن يكون مذكرًا أو مؤنثًا. } \\
& \text { (7) نحو: الرجالُ و النساءُ و أعجاز ها. }
\end{aligned}
$$

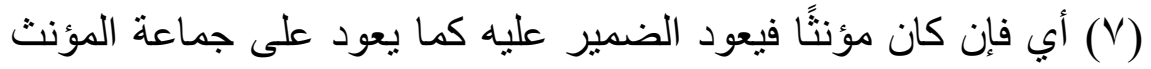
نحو قولك: النساءُ قُمنَ. 
كما يعود على جماعة المؤنث، وقا يعود كعودته على الواحدة المؤنثة: (1. أو لما لا يعقل عاد الضمير عليه مجموعًا، وقا يعود كعودته على الواحدة

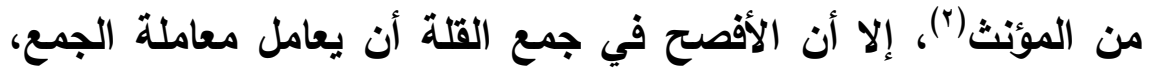
والأفصح في جمع الكثرة أن يعامل معاملة الواحدة من المؤنث، وقد يعود الضمير عليه كما يعود على الواحد المذكر (r). أو جمع سلامة(؛) لمذكر فيعود عليه ضمير جماعة المذكرين، أو لمؤنث فضمير جماعة المؤنثات. وأما الصفة(0) فإن عملت في ظاهر فكالفعل إذا [ع \&/ب] رفع الظاهر، أو في مضمر فكهو إذا رفع المضمر. وأما اسم الإثارة فكالمضمر يفرد في موضع يفرد فيه، ويثى حيث يثنى، ويجمع حيث يجمع. وأمَّا المذكَّر إذا أخبر عنه إخبار المؤنث الأي فيه علامة تأنيث، فإنها يخبر عنه كما يخبر عن المذكر، ولا يخبر عنه إخبار المؤنث إلا في قليلٍ

$$
\text { (1) - (1) كقول الثاعر: }
$$

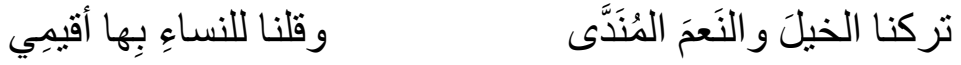

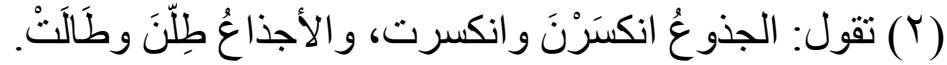

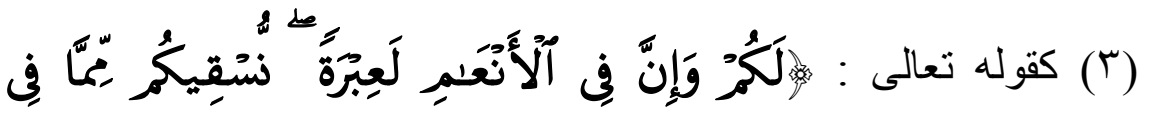

بُطُوِيِهِ سمورة النحل من الآية : 77.

( ) لا يخلو أن يكون مذكرًا أو مؤنثًا.

(0) لا يخلو أن تكون قد عملت في ظاهرٍ أو مضدر. 
حملا على المعنى، إلا أن يكون المذكر مضافًا إلى مؤنث هو منه المعنى،

$$
\text { ويجوز أن يلفظ بالثاني وأنت تريد الأول (1). }
$$

أو مضاف إلى مؤنث يجوز أن يلفظ بالثاني وأنت تريد الأول، أو يكون

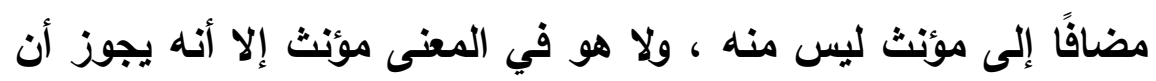

يلفظ بالثاني وأنت تريد الأول (ץ).

$$
\text { ******* }
$$

العدد: مفرد، ومضاف، ومركَّب، ومعطوف(ॅ).

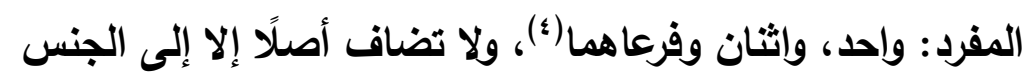

ضرورة(ه)، بل يعلم الجنس بقرينة حال أو بإشارة أو بتبيين بـ"مِنْ بعدها، أو بنصٍٍ عليه مفردًا أو مثنى، والعشرون وسائر العقود، ويُعْلَمُ هُن الجنس بقرينة أو بذكره منصويًا تمييزًا.

(1) نحو قولك: ذهبت بعضُ أصابعه و البعض مذكر وأخبر عنه إخبار

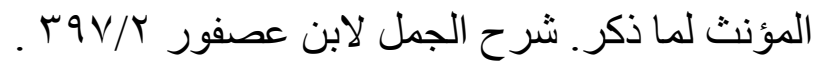

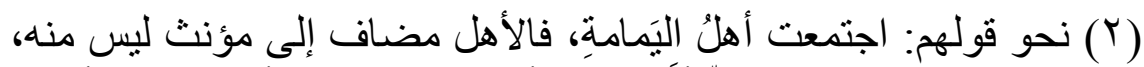

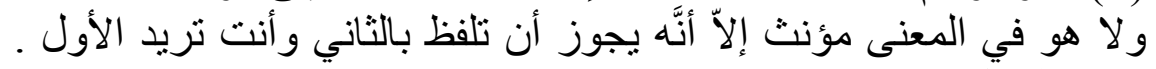

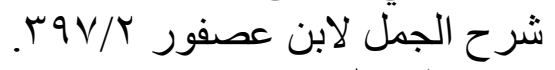

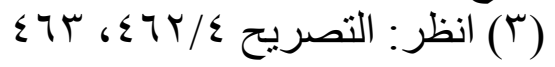
( ) ( ) أي الو احدة و الاثنتان.

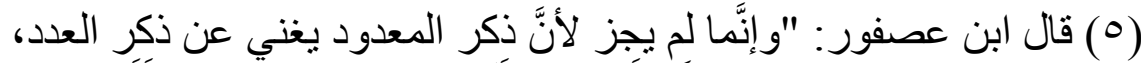

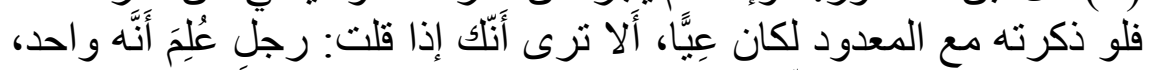

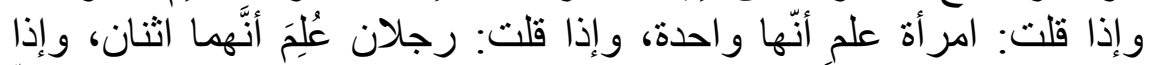

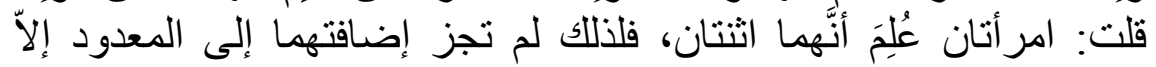

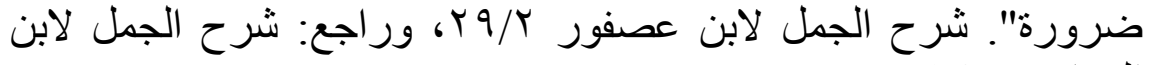

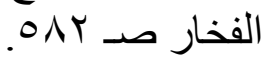


المضاف من ثثلاثة إلى عشرة(')، فإن أردت بالعدد مجرده (ץ) كان بالتاء كله ، وتمنعه الصرف، أو المعدود(َ) وذَكَرْتَه كان للمذكر بالتاء، وللمؤنتث بغيرها، أو لم تذكره فالفصيح كحاله مذكورًا، ويجوز حذفها منه كلّّه. والمعدود() إن اختص بجمع قلة أو كثرة أضفته إليه، أو كانا له فالأحسن

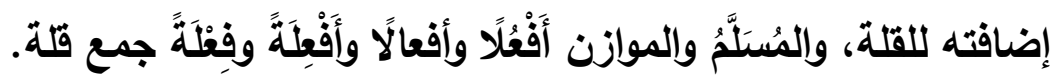
والمضاف إليه(ه) إن كان جمعًا اعتبرت مفرده، فإن كان مذكرًا ألحقتها(")، أو مؤنثًا فلا، والبغداذيون لا يعتبرون المفرد، بل لفظ المضاف [0 \&/أ] إليه(v)، أو اسمًا لعاقل فكالمذكر، أو غيره فكالمؤنث، أو اسم جنس جازا،

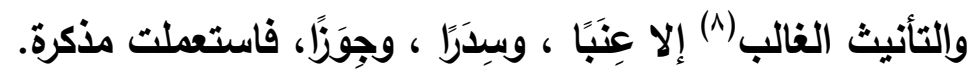

(1) (1) لا يخلو أَن ثريد بالعدد المعدود أَو العدد مجرداً من المعدود .

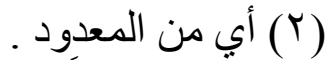

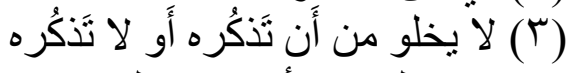

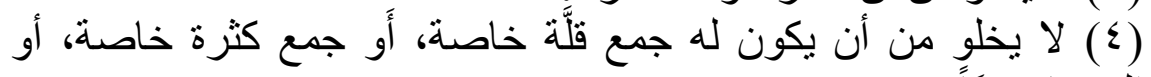

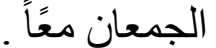
(0) المضاف إليه العدد لا يخلو من أَن يكون جمعًا أو اسم جمع أَو اسم جنس.

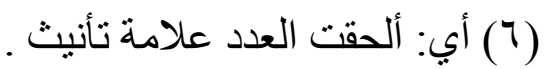

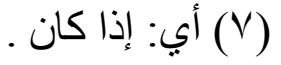

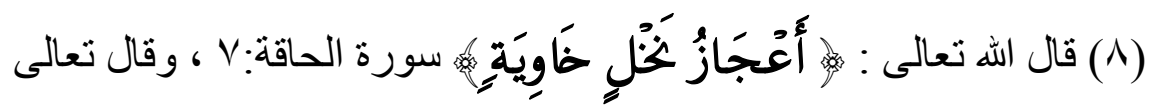

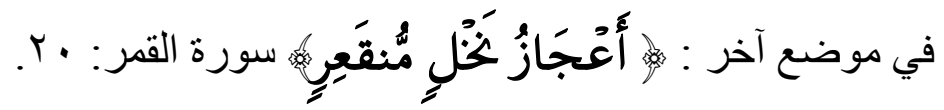




\section{الموفور من شرح ابن عصفور}

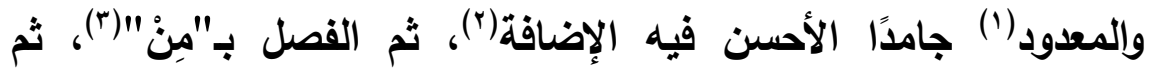

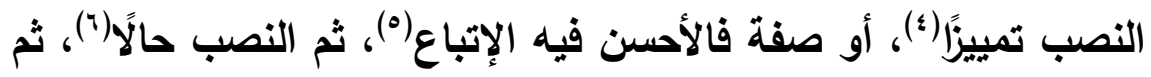

الإضافة) (v)

المركب من أحد عشر إلى تسعة عشر، وييقي الثَّيَُّْ (^) على أصله في

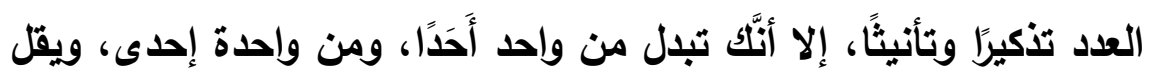

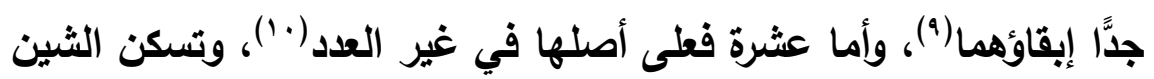

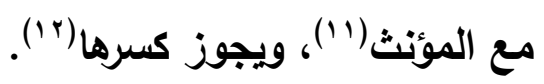

( ( ) لا يخلو أن يكون المعدود صفة أو جامدًا.

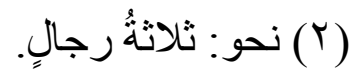

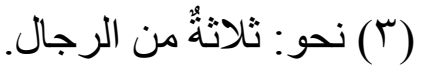

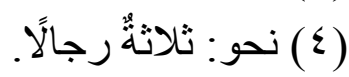

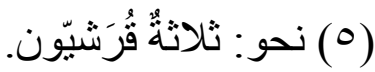

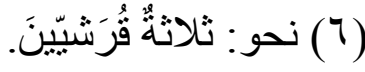

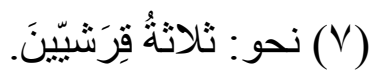

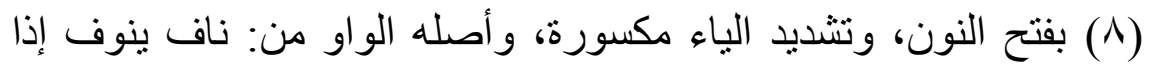

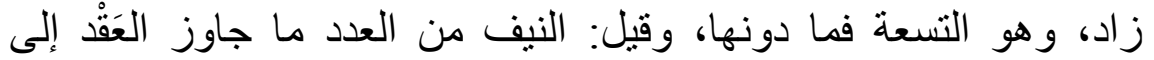

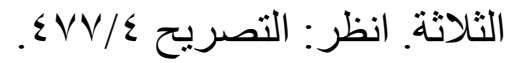

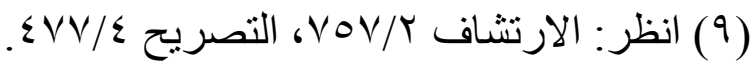
( • ( أي: تكون بتاء النأنيث مع المؤنث، وبحذفها مع المذكَّر.

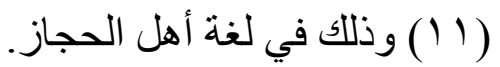

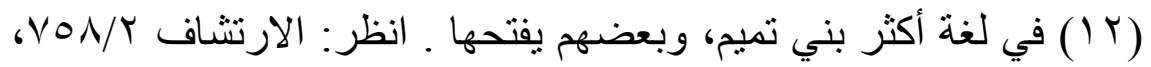

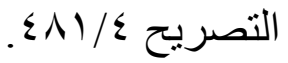


والنَّيَّْْ مبني مع العقد (') إلا "(ثنا عشر "(r)، فالنَّيّف معرب، والعقد مبني،

وأجاز الكوفيون إضافة النَّيّفِ إلى العقد، فتقول: هذا أحدُ عشر (َّ). ويجوز أن تضيف النيفَ والعقد إلى اسم، فيجوز وجهان: إبقاؤه على بنائه، والآخر: إعرابه، وجعله في آخر المركب(؛)، وأجاز الفراء أن تضيف النيفَ إلى العقدِ، والعقدَ إلى الاسم بشرط أن تكون العثرة مضافة إلى الاسم(*)، ولا يضاف اثنا عشر إلى الاسم(").

( ( ) وذلك لتضمّنه معنى الحرف. (Y) قال ابن عصفور : "فإن قيل: فلأي شيءٍ لم يُيْنَ؟ فالجواب: أنّه اسم مثنَّى

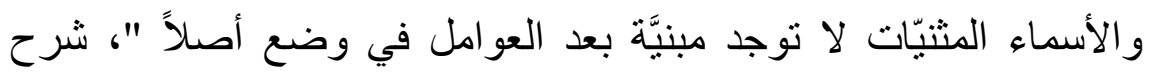

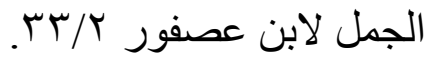

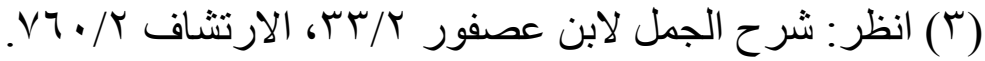

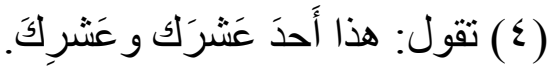

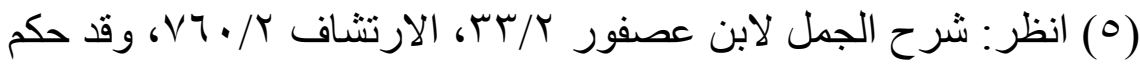

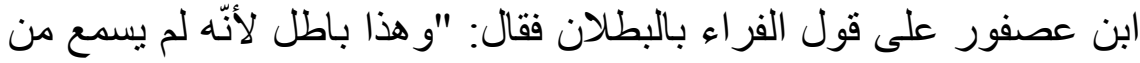

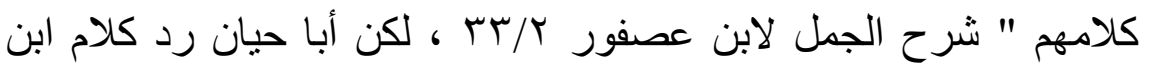

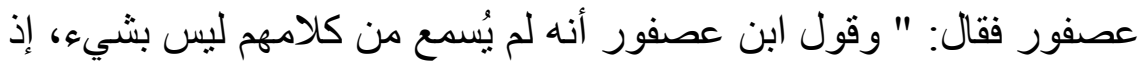
قد سمعه الفراء من ابن فقعس الأسدي، وأبي الهيثم العقيلي " انظر:

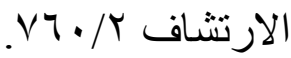

(T) قال ابن عصفور: " لأنّه لا يخلو أن تحذف عشراً أو تثبته، فإن أثنَّْه

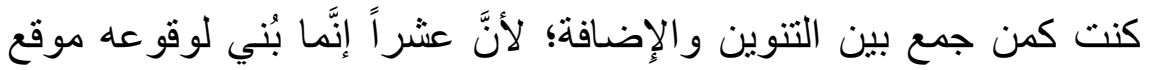
النون ، وإن حذفت التبس بإضافة اثنين فلذلك لا يجوز إضافته إلى الاسم

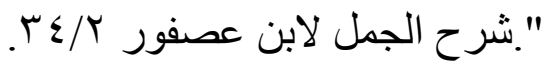




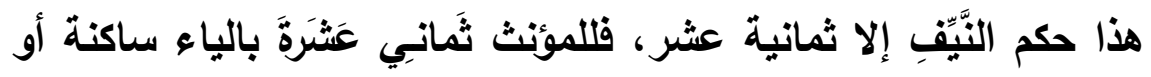
مفتوحة أو محذوفة، وتفتح النون(')، ويجوز تسكين العين في المركب

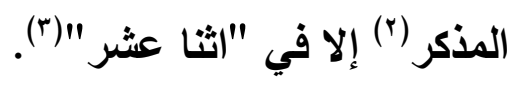

ويُمَيَّز المركب بمفرد منصوب(؛)، ولا يجوز أن يكون جمعًا. ولا يفصل بين التمييز والعدد إلا ضرورةً.

المعطوف: النَّيّف على العقود من واحد وعشرين إلى تسعة وتسعين، وحكمه كحال إفراده، ويستوي المذكر والمؤنث في لفظ عشرين والعقود بعدها، وتمييزها منصوب عطقت عليها النيف [0 \&/ب] أو لا، إلا في مائة

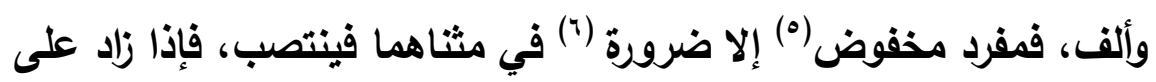

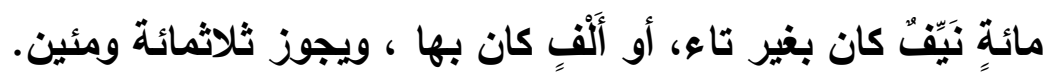
يُعرَّف المفرد والعقد بـ"أل"، والمركب بـ"أل" في ثانيه لا فيهما خلافًا للكوفيين، وعكسه ممنوع ، والمركب بها في أوله لا فيهما خلافًا

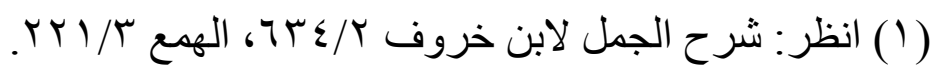

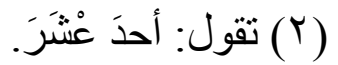

(r) فإنّه لا يجوز لألنّه يؤدي إلى الجمع بين ساكنين.شرح الجمل لابن

$$
\text { عصفور r/ }
$$

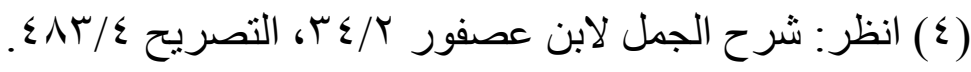

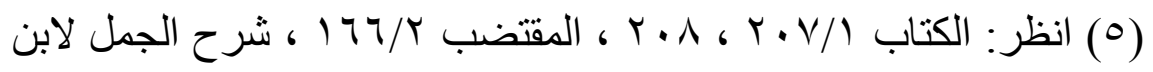

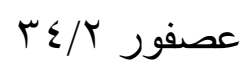

V 


$$
\text { r.IV إصدار }
$$

حولية كلية اللغة العربية بالمنوفية العدد الثاني والثلاثون

$$
\text { للكوفيين(') ، وحكى أبو زيد (ז): }
$$

الأحد عشر الدرهم، وهو شاذ ، وأجاز بعضهم إدخالها في النيِّفِ ، والعقد، والتمييز ، والمعطوف بها فيهما، وأجاز بعضهم إدخالها في المعطوف بهادي عليه لا في العقد.

\section{$* * * * * *$}

اسم الفاعل من العدد: سمع من ثاني اثثين إلى تاسع تسعة عشر، وقد حكي في عشرين، فمن واحد إلى عشرة لمؤنث بالتاء، ولمذكر بغير تاء.

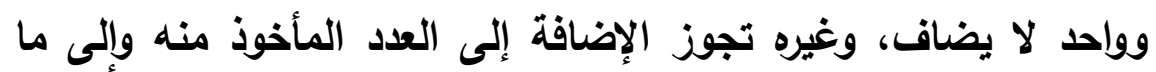

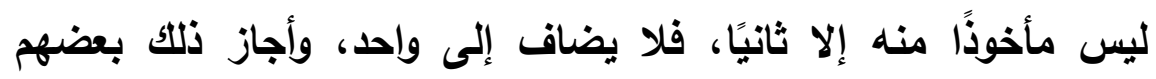
قياسًا، والصحيح الوقوف مع السماع(َّ).

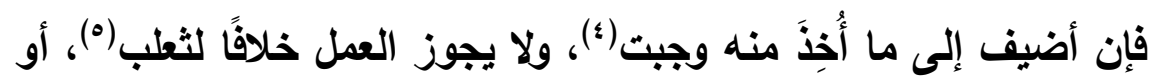

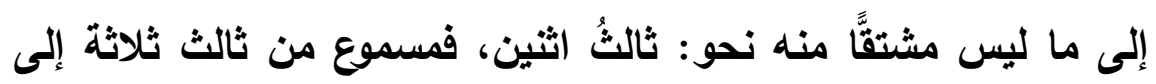

(1) أهل البصرة لا يجيزون دخول "أل" إلا على الأول، فيقولون : عندي

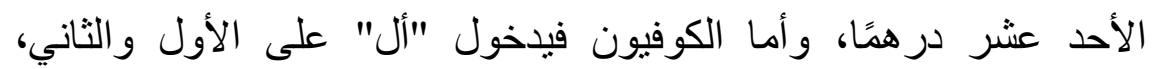

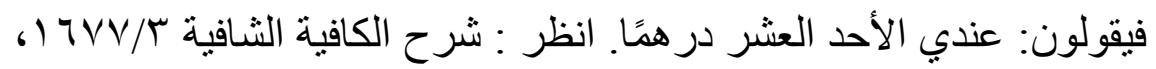

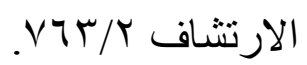

(r) انظر: شرح الجمل لابن عصفور r/r/r، شرح المفصل لابن يعيش

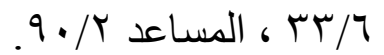

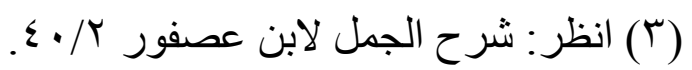
( ) ( ) أي: الإضافة.

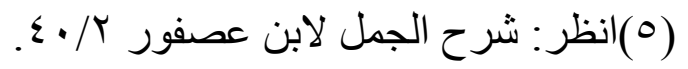


عاشر عشرة، فإن كان ماضيًا وجبت(')، أو حالًا أو مشتقًاً فالإضافة والعمل.

وإما من المركب، فإن كان اسم الفاعل مفردًا قلت: حادي عشر إلى تاسع عشر، أو مضافًا إلى ما اثتق منه فأوجه: حادي عشر أحد عثر مبنيين، ويجوز حذف "عشر" الأول، ف"حادي" معرب، ويجوز حذفه مع "أحد"، فتعربهما، وأجاز بعضهم البناء، أو إلى غير ما اشتث منه وجبت الإضافة فتقول: ثاني عشر أحد عشر. وأما ما بعد العشرين فعلى حكمه من وإحد إلى عشرة. وأما العقود من الثثلاثين وتمامُ العقود فمنهم من يقول: مُتَمَّم، أو مكمل عشرين، والصحيح كمال أو تمام العشرين [† ؛/أ]، أو تأتي بأسماء العقود، فتقول: العشرون، والثثلاثون إلى تمامها. ****** $* *$

العدد محمول على اللفظ، ويعنى به أنه إن أخبر عنه إخبار مؤنث فهو مؤنث، وإن وقع على مذكر ويالعكس، وشذوذًا في: دابة ونفس وعين بمعنى ربيئة، فحملوا على المعنى (ץ). والمعتبر من الجموع مفردها لا جمعها، فتقول: ثلاثة حمَّامات(ّ) خلاقًا

$$
\text { (Y) (1) (1) (1) (أي: الإضـافة. }
$$

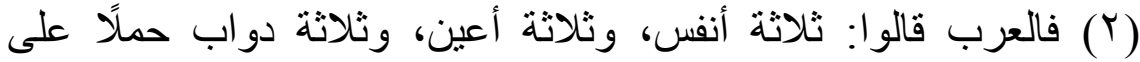

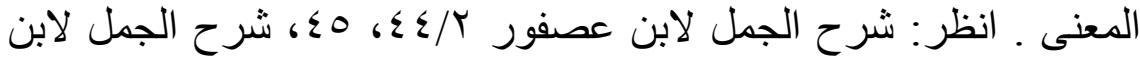

$$
\text { الفخار صـ V • 7، } 1 \text { • T. }
$$

(T) فمفردها حمَّامُ، و هو مذكر. 
للبغداديين، فإنهم يقولون: ثُلاث حمامات، فيعتبرون لفظ الجمع(')، ومن

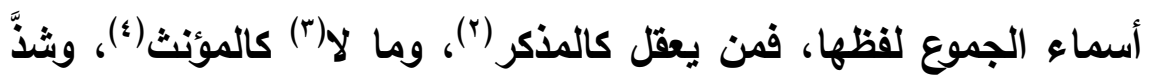
أشياء، فتقول: ثلاثة أشياء(•)، ومن اسم الجنس لفظها، وجاز فيها

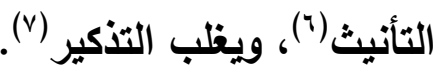

\section{****** $* *$}

التأريخ: عدد الليالي والأيام بالنسبة لما مضي من السنة والثهر، أو ما بقي(^)، فإن ذكرتهما بالنظر إلى شيء وجب ذكر التمييز، وجاز حذفه إن

(1) وذلك إذا كان لفظه مؤنظًا، قال ابن عصفور : "والصحيح أنه لا يعتبر إلا

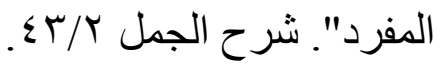
(Y) تقول: عندي تسعة من النفر، وحكي عن العرب أنهم قالوا: ثلاث بقرٍ

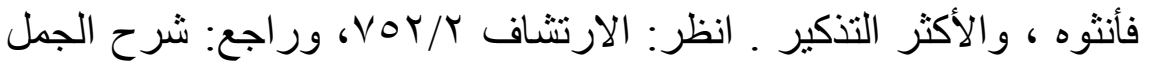

$$
\begin{aligned}
& \text { لابن عصفور /r/Tء. }
\end{aligned}
$$

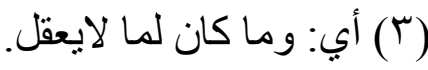

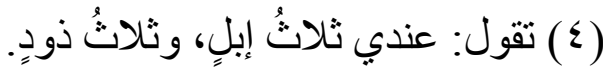

(0) فبنو ا العدد على مفرد، وهو شيء، وكان تلان القياس أَن يبنى العدد عليه؛

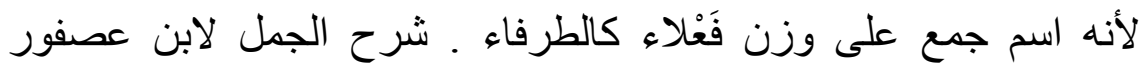

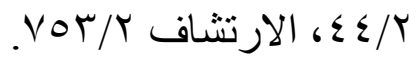

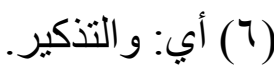

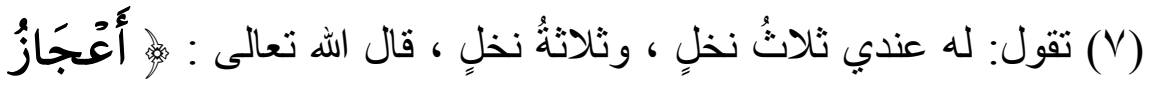

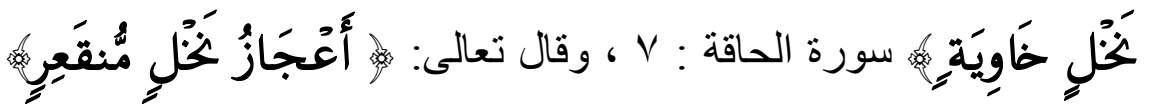

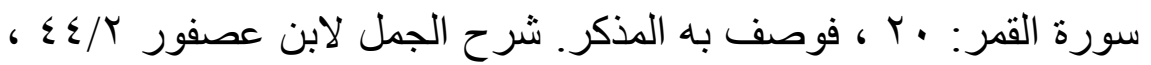
الارتشاف VOr/r

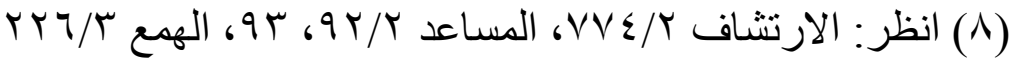


فهم المعنى، نحو: صمنا خمسًا، وإذا ذَكَرْتَهُ، ووقع بعده مذَكر حملت العدد

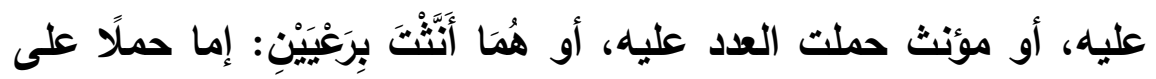
المُدَدِد، أو حملًا على الليالي والأيام. أو بالنظر إلى السنة والشهر، وذكرث المعدود، فعلى حسبه من تذكير أو تأنيث، أو لم تذكره، فيستغنى بالليالي عن الأيام.

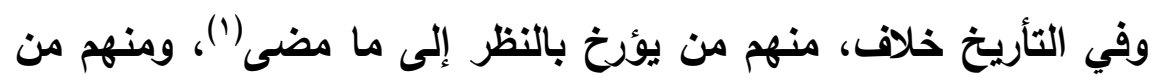

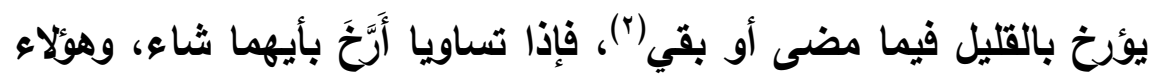

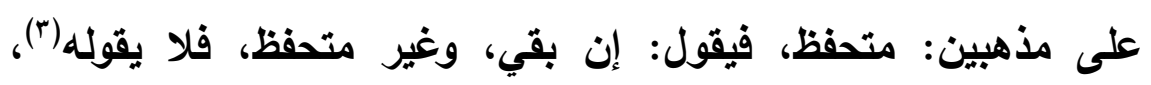
ويجوز أن يخبر عنه إخبار جمع المؤنث أو المؤنثة من ثثلاثة إلى عشرة، والأحسن كجمعهما من ثلاثة إلى عشرة، وكالمؤنتة في المجاوز.

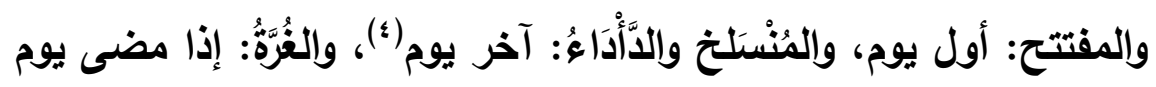

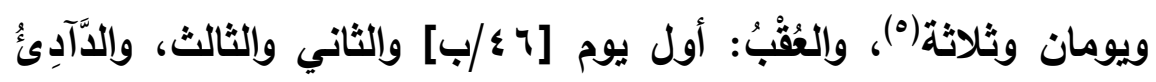
والعقب: الثلاثة الأخيرة، وهلالٌ قيل: كالغرة، وقيل كمفتتح، فإن خفي ففي الثاني.

(1) تقول: كتبتُ لعشرينَ ليلةً خَلَتْْ من شهر كذا، ولثمانٍ و عشرين ليلةً خلت من كذا.

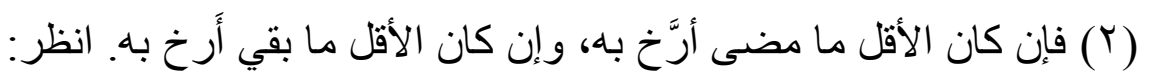

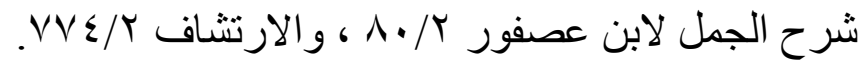

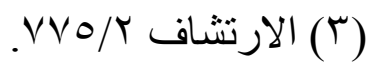

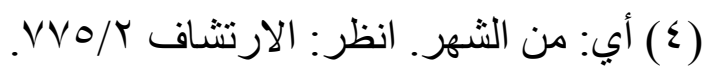

(0) أي: من الشهر، فتقول: كتبثُ في غُرة شهر كذا، تريد: في الثناث 
كَمْ: كناية عن عدد، وهي مبهم، وتجيء استفهاميةً، وتستدعي جوابًا، وتمييزها منصوب مفرد(')، وخبريةً، ولا تستدعيه، وتمييزها مجرورٌ جمع

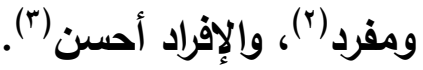

وينيت لتضمن الحرف في الاستفهام، وتثثبُهًُا بـ"ريََّّ" في الخبر (؛).

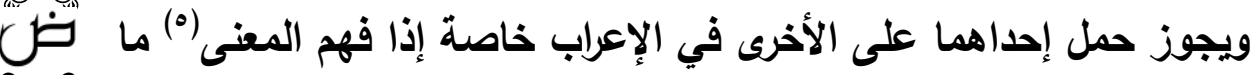

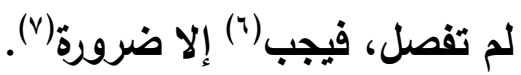

(1) نحو: كم شخصًا سما؟، وأجاز الكوفيون كونه جمعًا مطلقًا، كما يجوز ذللك في "كم" الخبرية، نحو: كم غلمانًا للك؟، وأجازه الأخفش إذا أردت

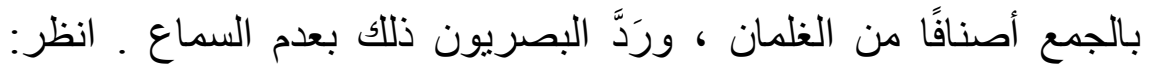

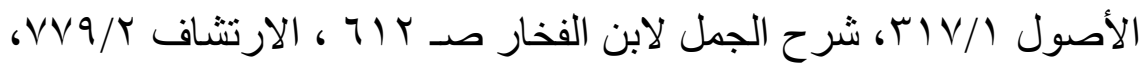

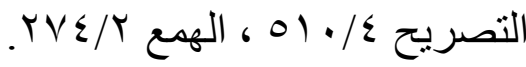
(Y) نحو: كم كتابٍ عندي!، وكم كتبٍٍ عندي!، فمن أفرد المفسِّر جعلها بمنزلة مائة و ألف، ومن جمعه جعلها بمنزلة ثنالثة إلى عشرة.

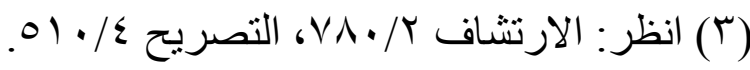

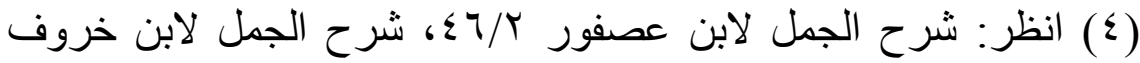

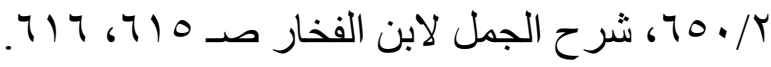
(0) فمثال حمل الخبرية على الاستفهامية: كم غلامًا ملكتَ، ومثنال حمل

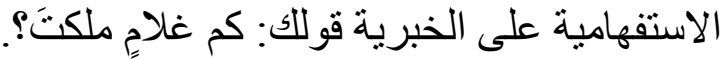
(T) أب: يجب الحمل على الاستفهامية. (V) أي: لا يجوز خفض تمييز الاستفهامية إلَّا في ضرورة شعر أَو نادر

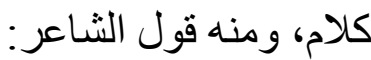

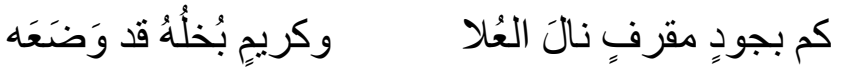

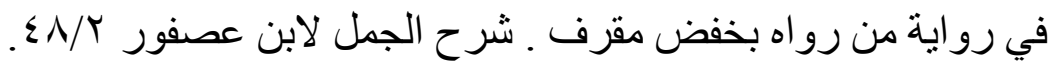




$$
\text { الموفور من شرح ابن عصفور }
$$

وزعم الزجاجي أنْ لا حَمْلَ، وأجاز الخفض في تمييز الاستفهامية على

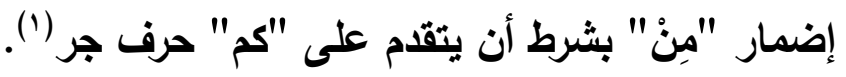

وقوله في الاستفهامية صحيح، وأما في الخبرية فحكي سيبويه نصب

تمييزها من غير فصل حملًا على الاستفهامية(؟).

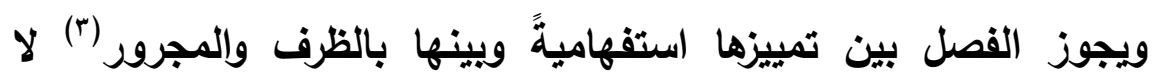

خبرية إلا ضرورة(؛)، وزعم يونس أنه لا يفصل في الثعر إلا بشرط أن

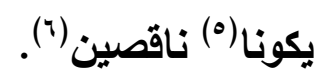

(1) الجمل صـ هب ا، فأجاز: بكم درهمًا اشتريت ثوبك؟، وبكم درهمٍ

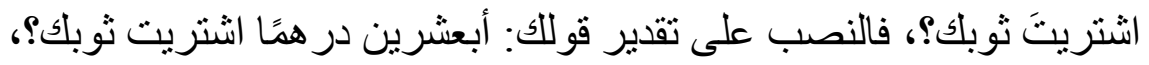

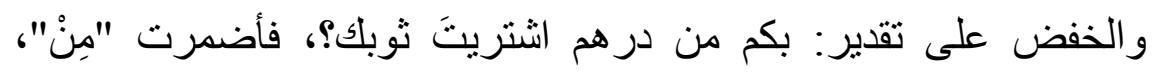
وخفض بها.

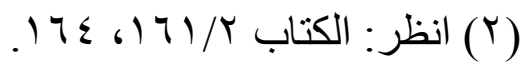

$$
\begin{aligned}
& \text { (ז) نحو قوللك: كم في الدارِ رجلًا } \\
& \text { ( ) كقول الثـاعر : } \\
& \text { كم دونَ سلمى فلواتٍ بيدِ }
\end{aligned}
$$

$$
\text { (0) أي الظرف و المجرور. }
$$

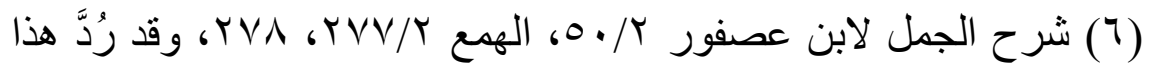

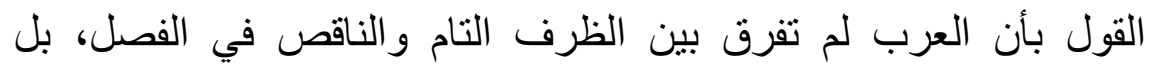

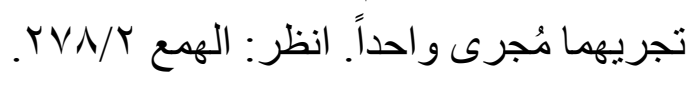


ولا تميز بمعرفة، ولا متوغلٍ (')، ولا مختصِّ بالنفي (r)، ولا مقرونٍ بـ"لا".

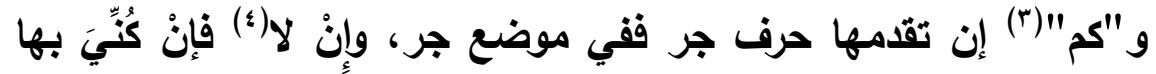
عن مصدر أو مفعول فيه، ففي موضع نصب، وإلا(ه) فإن لم يقع بعدها

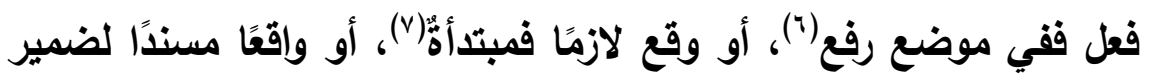
"كم" فمبتذأ(^)، أو لغيره(9) والفعل لم يأخذ معموله، فهي هو، أو أو أخذه فالابتداء والنصب على الاثتنغال. والجواب مطابق لإعراب "كم"، ويجوز رفعه كانت هي في موضع رفع أو

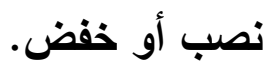

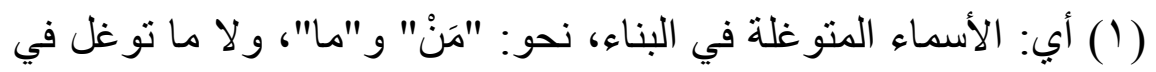

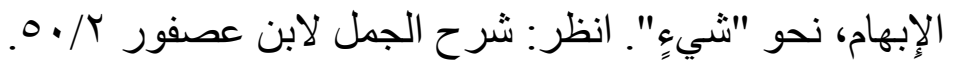

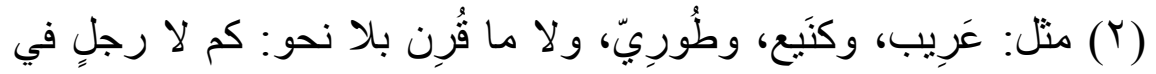

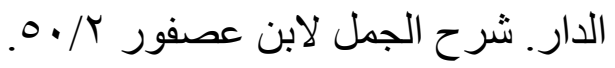

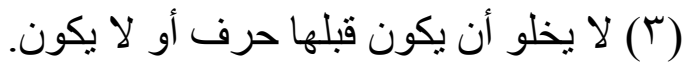

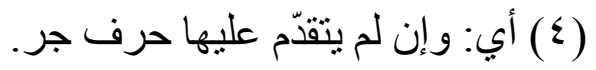
(0) أي: إن لم تكن كناية عن شيءٍ من ذللك فلا يخلو أن يكون بعدها فعل أَو لا بكون.

$$
\text { (T) نحو: كم رجلٍ في الدارِ. }
$$

( أب: إن كان بعدها فعل غير متعدَ. (V)

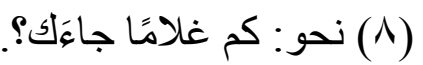
(9) وإن لم يكن فلا يخلو أَن يكون الفعل قد أَخذ معدولَه، أَّ لا يكون قد أَخذه. 


\section{الموفور من شرح ابن عصفور}

ويجوز حذف تمييز "كم" للاليل(')، ويحسن إن كان ظرفًا (†).

كأيَّن: مثل "كَمْ" في الخبر، ويلزم تمييزها "مِنْ"(())، ويفصل بينها وبينه

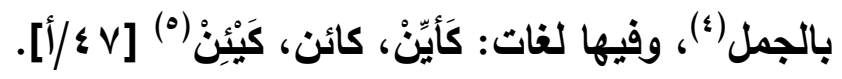

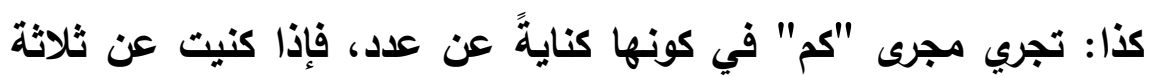
إلى عشرة قلت: له كذا من الدراهم، وقال الكوفيون: له كذا دراهم.

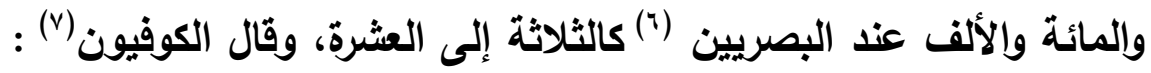
لـ أله كذا درهمٍ. وعن أحد عثر إلى تسعة عشر: له كذا كذا درهمًا، وعن عشرين إلى إلى

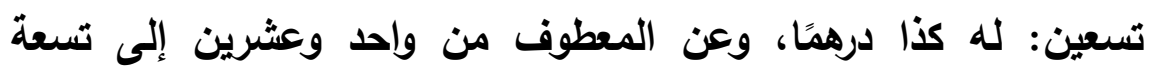
وتسعين: له كذا وكذا درهمًا.

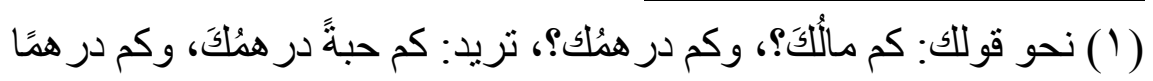

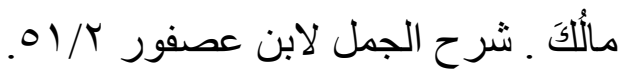

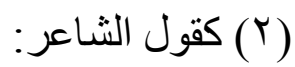

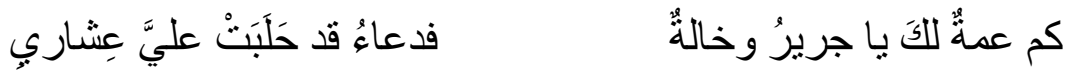

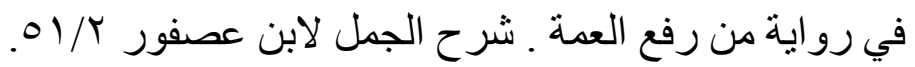

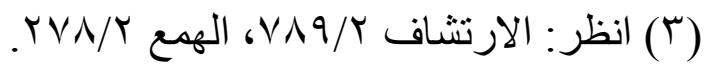

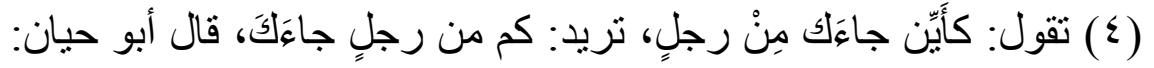

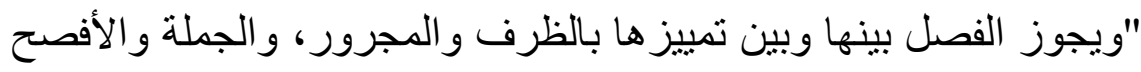

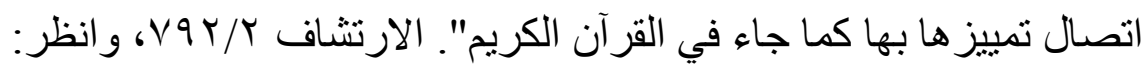

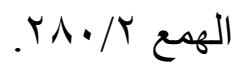

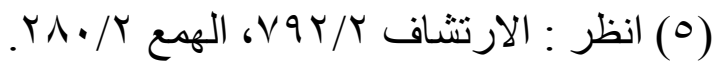

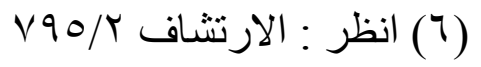

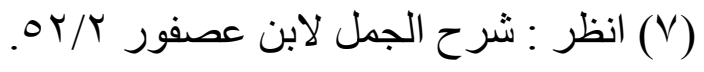


الههزة إن كاتت أوَّلَا فلا تُسَهِّل، وتكون صورتها ألفًا، أو كاتت حشوًا (') ساكنةً متحركًا ما قبلها بالضم أو بالقتح أو بالكسر فتدبر بحركة ما قبلها،

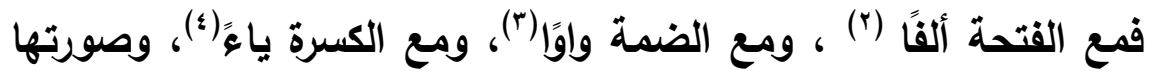
في الخط على قياس تسهيلها.

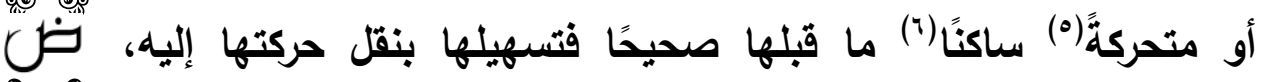
وتحذفها(V)، ولا صورة لها في الخط.

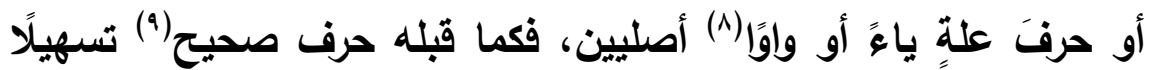
وخطاً، أو زائدين فتقلب الهمزة مع الياء ياءً، ومع الواو واوًا، وتدغم(·')، ولا تثبت لها صورة.

(1) (1) لا يخلو أن تكون ساكنة أو متحركة.

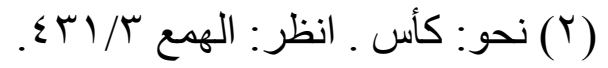

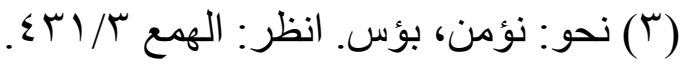

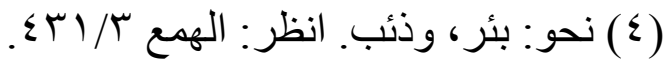

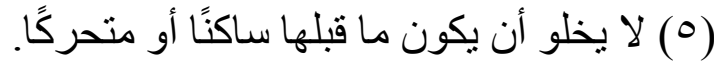
(T) لا يخلو أن يكون الساكن حرف علة أنة أو حرفًا صحيحًا.

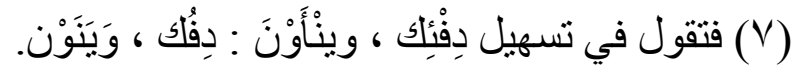
(^) لا يخلو أن يكوناز ائدين أَو أَصليين. (9) نحو: شيئك، وضوؤك.

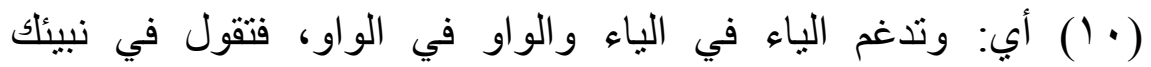

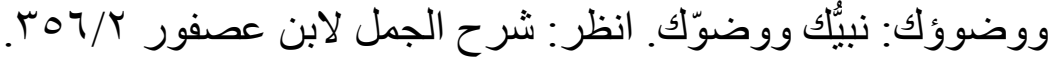


ومع الكسرة ثتبت في التسهيل، ولا في الخط، أو ألفًا فبينها ويين الحرف الأي منه حركتُها، فمع القتحة لا تثبت لها صورة، ومع الكسرة تثبت

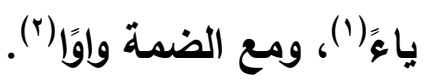

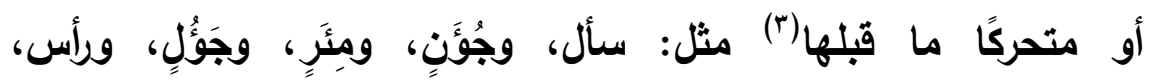
ويستهزئون، وسئم، ودُئيلِ، ومئينِِ، فتسهل بينها ويبن الحرف الأي منه

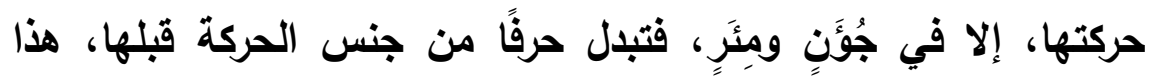
مذهب سييويه (؛)، وزاد الأخفش والكوفيون إبدال مثل: يستهزئون ياءً

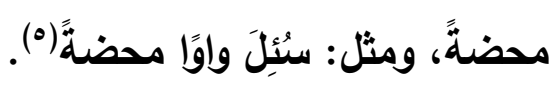

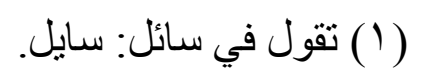
(Y) (Y) تقول: طاؤس.

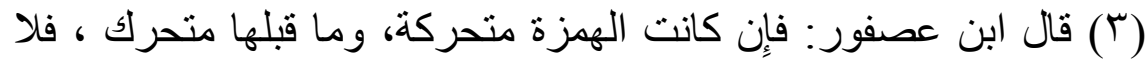

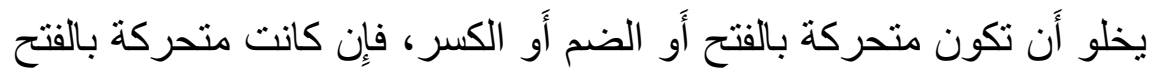

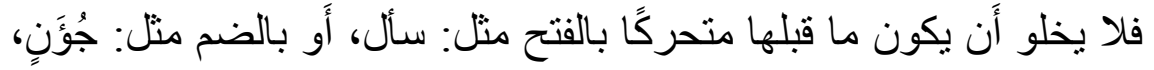

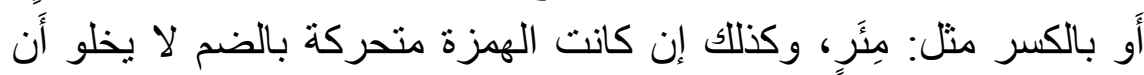

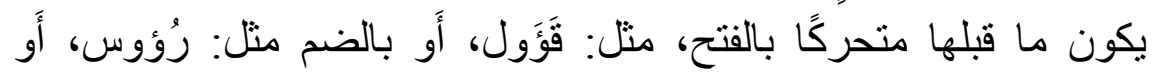

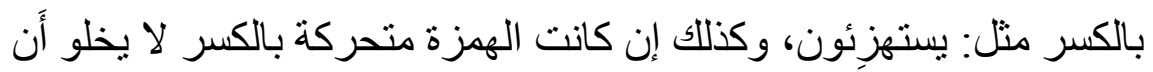

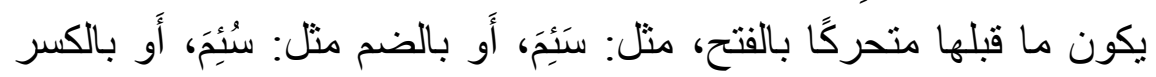

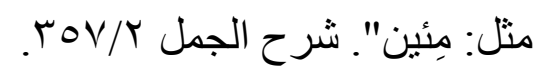

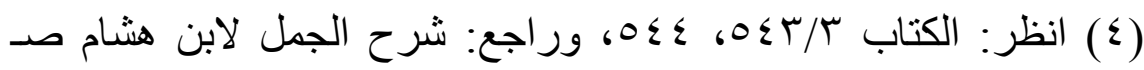

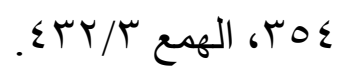

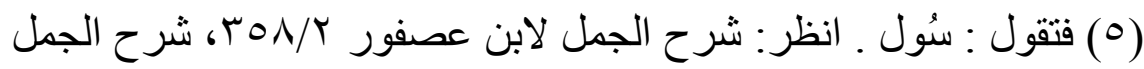

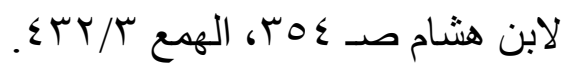


أو طرفًا(1) ساكنة دبرت بحركة ما قبلها، فقي الكسرة [V\&_ب] تبدل ياء، وفي الضمة واوًاً، وفي الفتحة ألفًا، والخط على ذلك، أو متحركة(؟) ساكنًا ما قبلها(") صحيحًا فقياس تسهيلها بحذفها وإلقاء حركتها عليه، ولا صورة لها في الخط. أو حرف علة ياءً أو واوًا أو غيرَ زائدين، فكما ذكر في الحشو، وكذلك

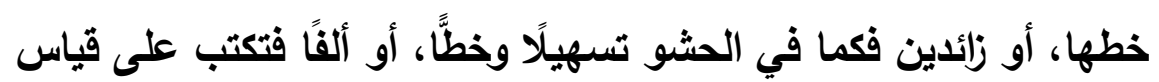
الوقف.

\section{******}

الأفعال المهموزة: لا تضبط بقياس، قيل: يجوز أن تبدل الهمزة ياءً في كل موضع، وقيل: يقصر ذلك على السماع، والصحيح التفصيل، فنقول: الهمزة من الفعل(؛) إن وقعت لامًا فالأجود إثباتها، ولغة للعرب ضعيفة إبدالها ياءً)(0) حكى ذلك الأخفش (؟).

(1) (1) أي: إن كانت الهمزة طرفًا، فلا يخلو أن تكون ساكنة أو متحركة.

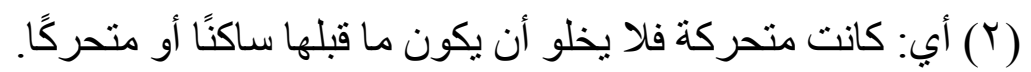

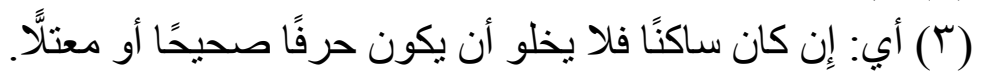
( ( ) الهمزة من الفعل لا يخلو أن تقع فاء أو عينًا أو لاهًَا.

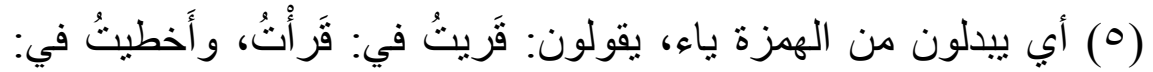
أَخطأتُ.

(T) انظر : المحتسب IV/ 
أو فاعً فلا تبدل إلا فيما سمع، وهو : واتَّيَتُ، ووامَزْتُ، وواخَيْتُ، وهو من:

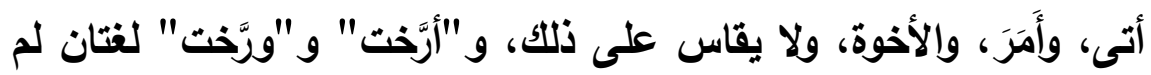

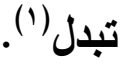

أو عينًا لم تبدل ألفًا إلا فيما جاء، وهو سال في سأل(؟)، فمنهم من يبدل

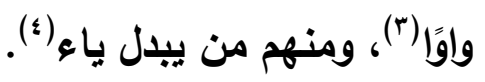

*******

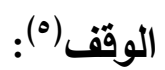

إن كان على مثنى أو مجموع فكالوقف على المبني وسيأتي ، وغيرهما(؟)

(1) أي يبدل الهمزة واواً، فيقول: سِلثُ أسأل، كما يقال: خِفَُُ أَخاف،

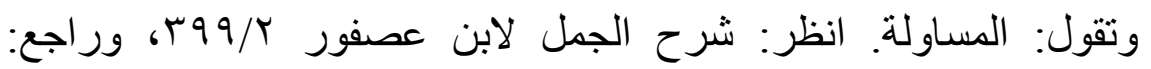

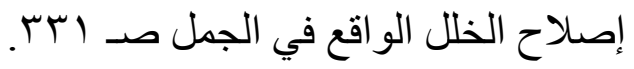

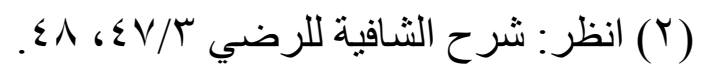

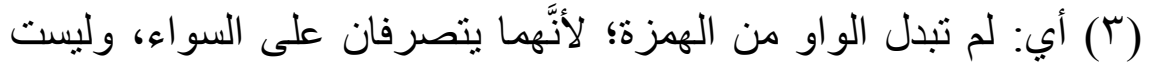

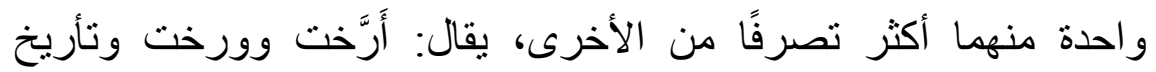

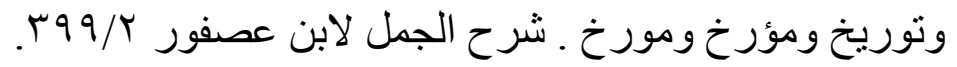

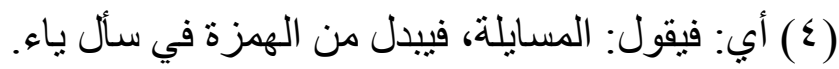

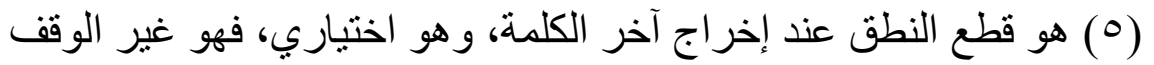

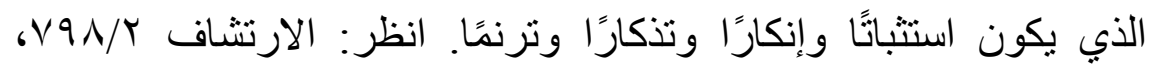

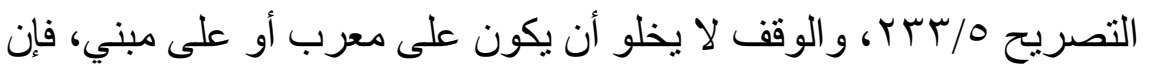

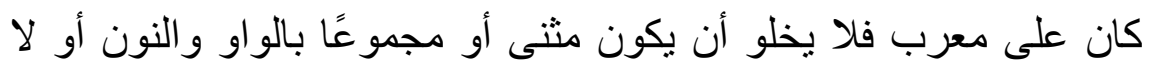

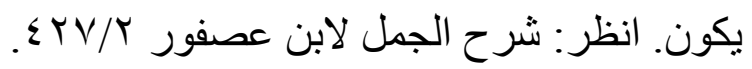

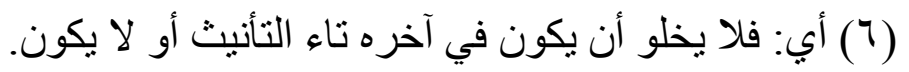




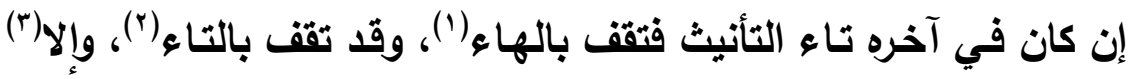
فإن كان غير مهموز(๕) منونتا منصويًا(ه) متحركًا ما قبل آخره(") فالإبدال ألفًا، ثم السكون، ثم بالهمزة، ثم التثديد في الضرورة فقط(v)، أو ساكنًا

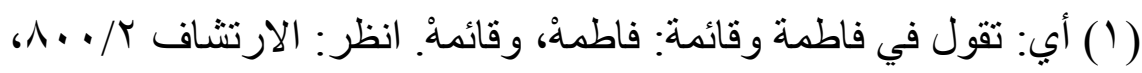

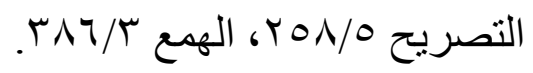
(Y) هذا عند بعض العرب، و عليه قول الر اجز

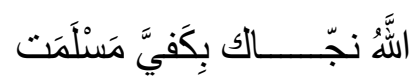

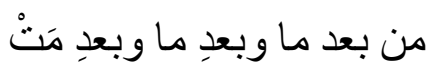

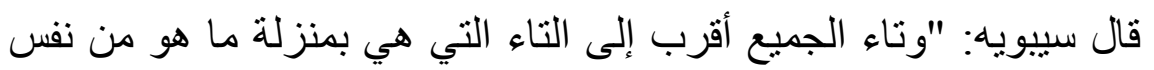

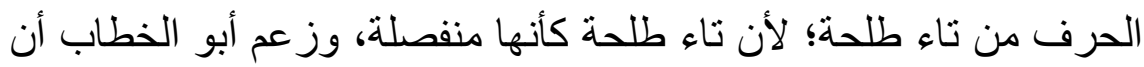

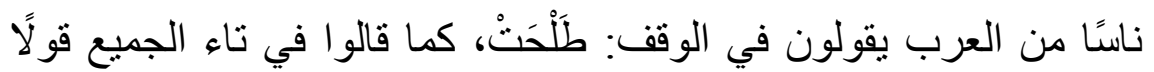

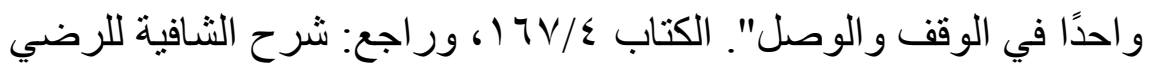

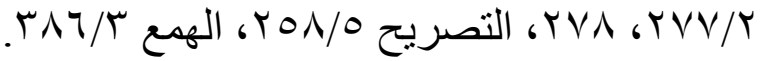

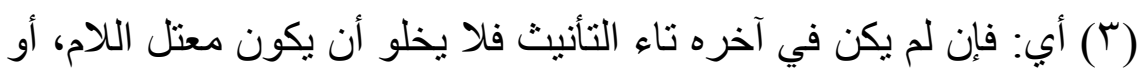

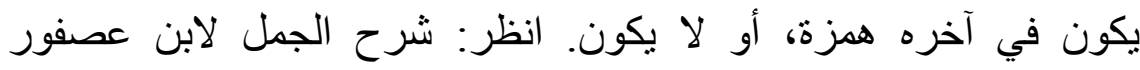
E $Y V / T$ (ع) أي: فإن لم يكن في آخره همزة، ولا يكون معثلَّ الآخر فلا يخلو أن يكون منوّنَا أو غيرَ منون. (0) أي فإن كان منصوبًا فلا يخلو أن يكون ما قبل آخره ساكنًا أو متحركًا.

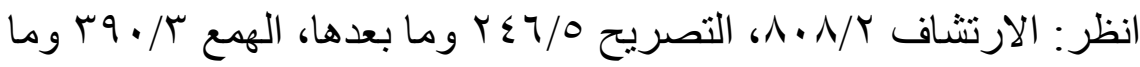

$$
\begin{aligned}
& \text { بعدها. } \\
& \text { (7) أي: جاز فيه أربعة أوجه. } \\
& \text { (V) كقول الشاعر: جارئ }
\end{aligned}
$$

لقد خَثَبِيتُ أن أُرَى جَدَبَّا 
فهي(') إلا التشديد() أو مرفوعًا أو مخفوضًا (َ) متحرئَ ما قبل الآخر ففي

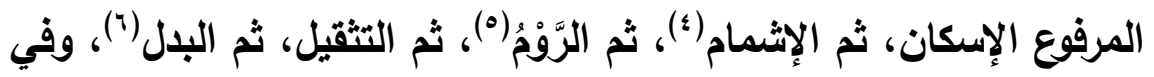
المخفوض تلك إلا الإثمام (v).

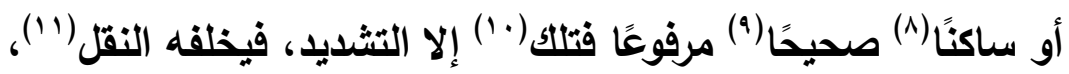

( (1) أي: فإنه يوقف عليه بالإبدال ألفاً ثم السكون ثم بالهمزة .

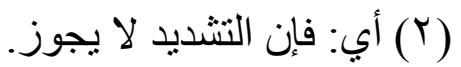

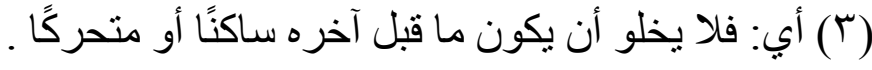

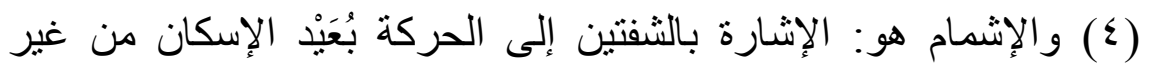

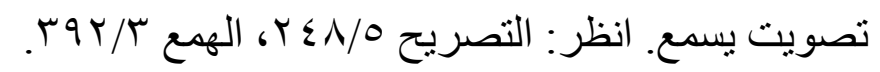
(0) و الروم هو: إخفاء الصوت بالحركة، فلا تميلها ، بل تختلسها اختلاسًا

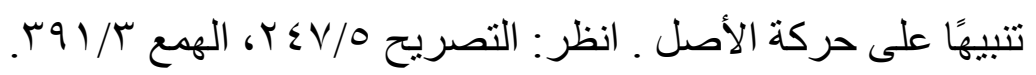

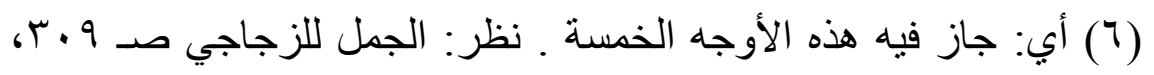

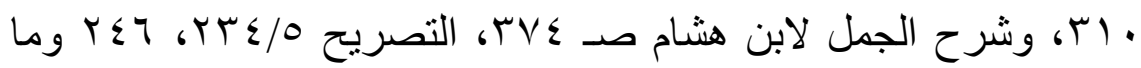

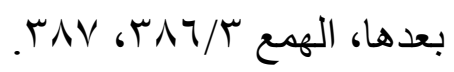

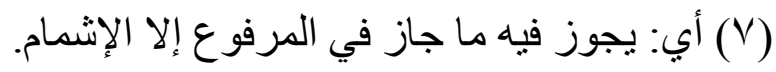

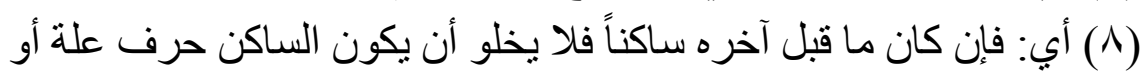
حرفًا صحيحًا. (9) أي: فإن كان الساكن حرفًا صحيحًا فلا يخلو أن يكون الآخر مرفوعًا أو مخفوضًا.

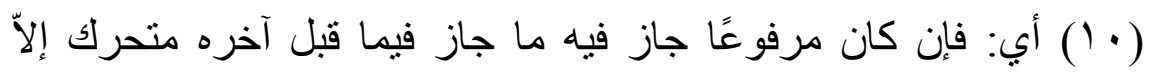

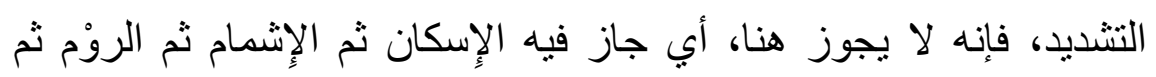

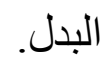
(1) أي: أن تنقل حركة الإعراب إلى الساكن قبله. انظر: الارتشاف

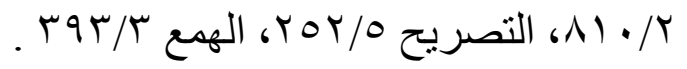




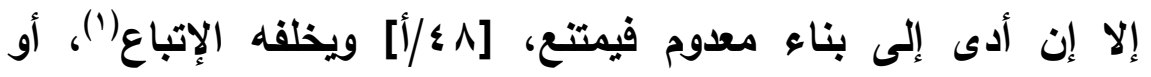
مخفوضًا فكالمرفوع إلا الإثمام، أو عليلًا مرفوعًا فكالمرفوع الساكن الصحيح إلا النقل، أو مخفوضًا فكالمرفوع الذي قبل آخره ساكن عليل إلا الإثشمام .

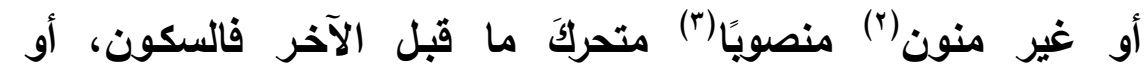

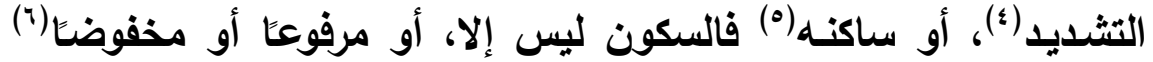
فكالوقف على ما قبل آخره متحرلك من المنون إلا البدل، فإن تحرك ما قبل آخره(v) وهو صحيح(^) مرفوع فالسكون والروم والإثمام والنقل إلا أن يؤدي إلى بناء معدوم، أو مخفوض فالروم والإثمام والنقل إلا أن يؤدي أيضًا -إلى بناء معدوم، فيعقبه الإتباع.

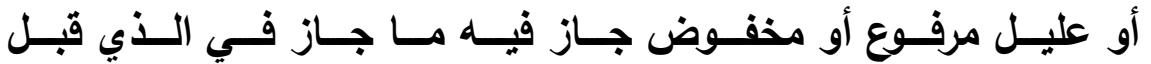

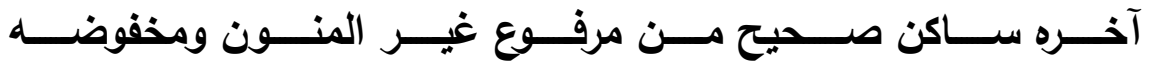

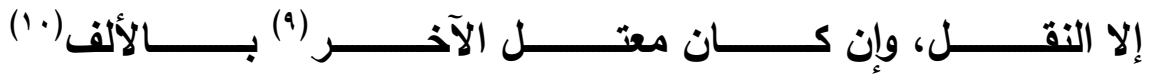
(1 (1) أي: يُحَرِّك الساكن بحركة منل حركة ما قبله.

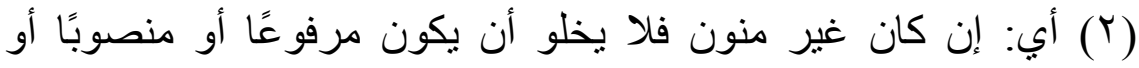
مخفوضًا. (ז) أي: فإنَّ كان منصوبًا فلا يخلو أن يكون ما قبل آخره ساكنًا أو متحركًا. ( ) أي: جاز فيه هذان الوجهان. (0) أي: إن كان ما قبل آخره ساكنًا. (7) أي: فلا يخلو أن يكون ما قبل آخره ساكنًا أو متحركًا.

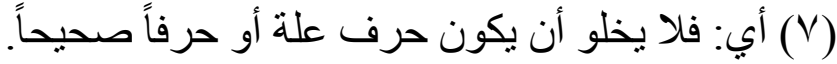
(^) أي: فلا يخلو أن يكون مرفو عًا أو مخفوضيًا.

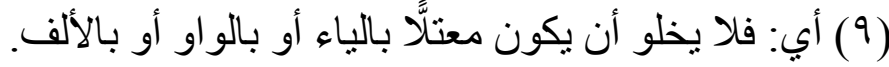

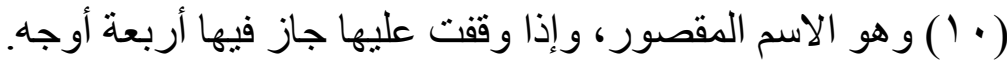




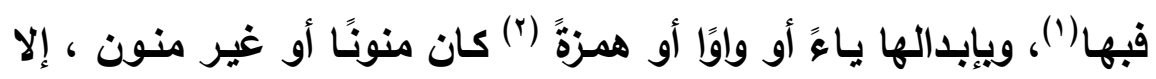
أنك إذا وققت على الألف المنون ، فقيه خلاف قيل : الألف عوض من

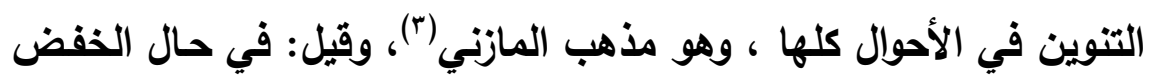

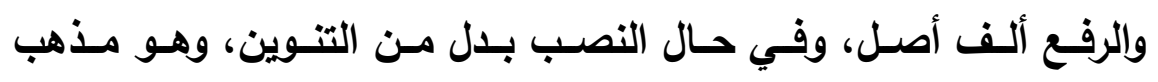
سييوية(؛) ، وقيل: الألف ألف أصل مطلثًا، وهو مذهب الكسائي (॰).

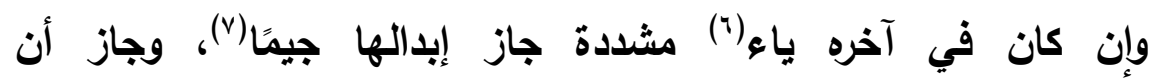

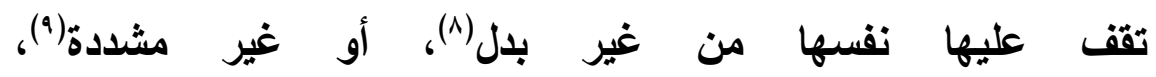

(1) (1) إي: إبقاء الألف كما هي من غير تغيير.

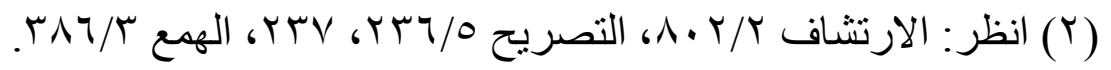

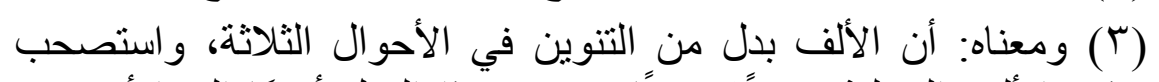

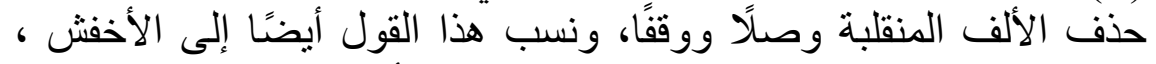

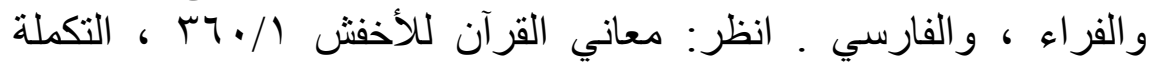

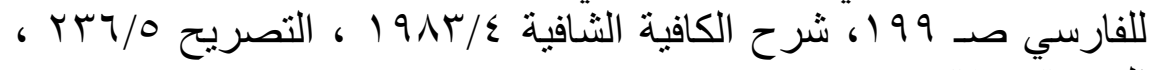

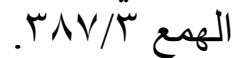

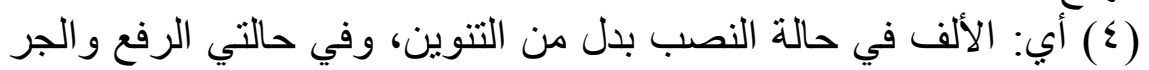

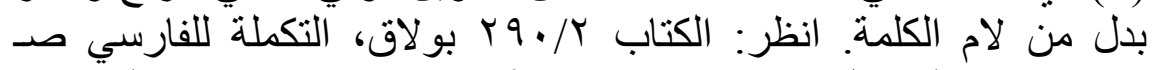

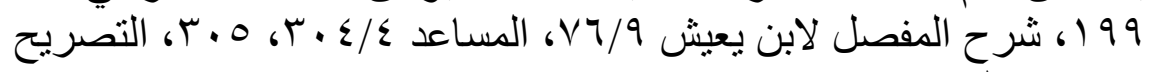

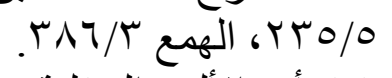

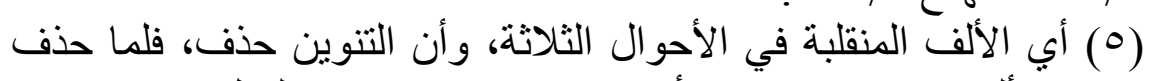

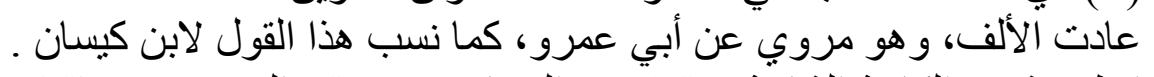

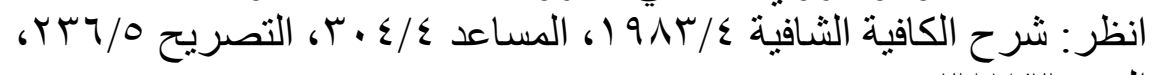

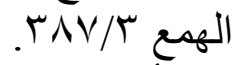
(T) أب فلا يخلو أن تكون مشددة أو غير مشددة.

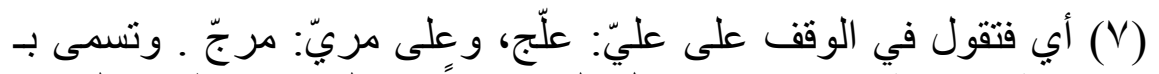

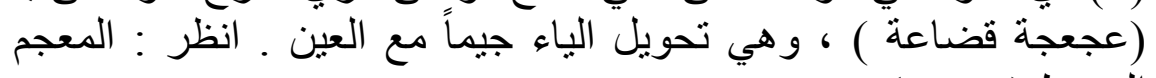

$$
\begin{aligned}
& \text { الوسيط ( عجعج) . } \\
& \text { (^) أي تقول: علي، ومري. }
\end{aligned}
$$

(9) أي فلا يخلو أن يكون ما قبلها متحركاً أو ساكناً. 
وما قبلها متحرك(')، والاسم منون(؟) غير منصوب فالأفصح حذف الياء(זّ)، والآخر: إثباتها(؛) إلا أن يؤدي ذلتك إلى توالي الحذف على الاسم، فلا يجوز إلا إثبات الياء(•)، أو منصوب فإبدال التنوين ألفًا فقط(ج). أو غيرُ منون(V) معرب(^) اسمًا، فالأفصع في الرفع والجر إثبات الياء(")، وفي النصب لا يجوز إلا إثبات الياء(·)، أو فعلًا فلا يجوز إلا إثبات

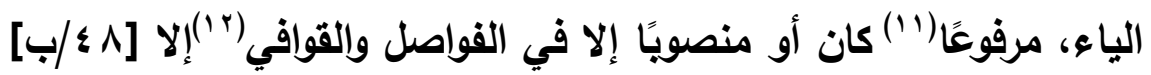

( (1) أي إن كان متحركاً فلا يخلو أن يكون الاسم منوناً أو غير منون.

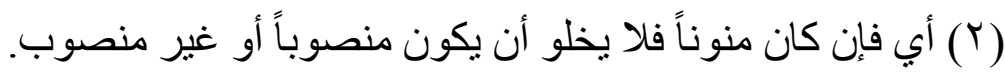

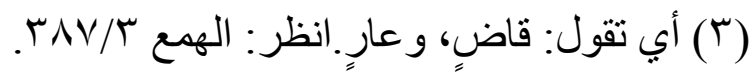
(ع) أي تقول: قاضي، و عاري..

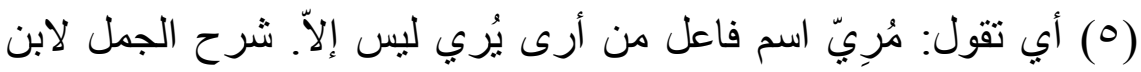

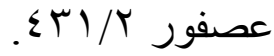

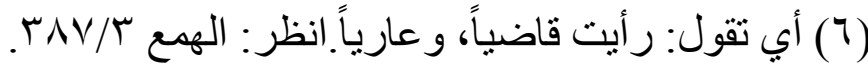
(V) أي فلا يخلو أن يكون معرباً أو شبه معرب واب وهو المبني في باب النداء نحو: يا قاضي. (^) أبي فإن كان معرباً فلا يخلو أن يكون اسماً أو فعلاً. (9) أي أفصحهما إثبات الياء ، فتقول: القاضي ، و والآخر : حذفها فتقول:

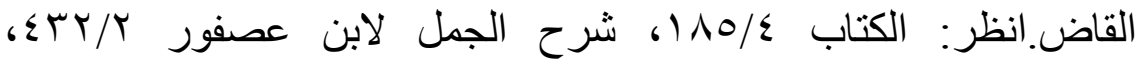

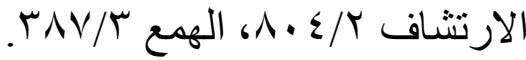

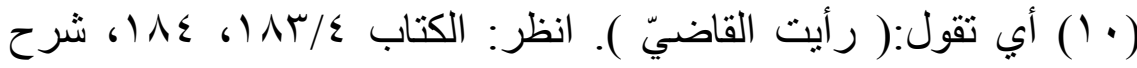

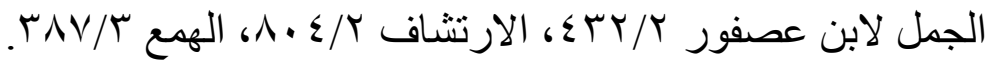

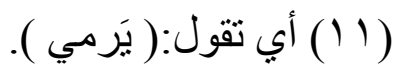

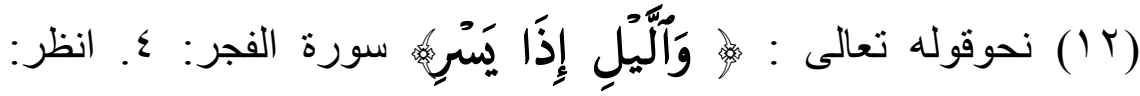

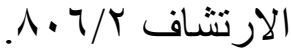


"لا أدري" و"ما أدري"، فإنَّ العرب حذفت منهما الياء في الوقف في غير

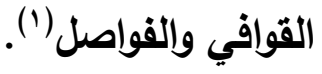

أو شبهُ معرب، وهو المبني في باب النداء(ז)، فإثبات الياء، وهو اختيار

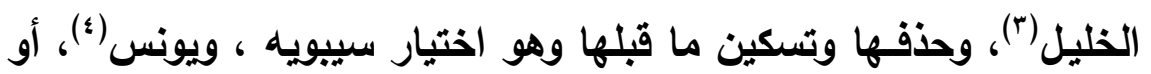

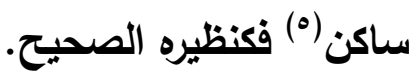
وإن كان في آخره واو(؟) ساكن ما قبلها فالوقف عليه كنظيره من الصحيح(V) أو متحرك ، فلا تكون الحركة إلا ضمة، ولا يوجد إلا في الفعل (^)، ولا يجوز الوقف عليه إلا بالسكون . أو مهموز الآخر فالوقف عليه كالوقف على الصحيح إلا أنه يخالفه في أن النقل يجوز هنا، وإن أدَّى إلى بناء معدوم، وفي أن الإتباع يجوز هنا حيث لا يؤدي النقل إلى بناء غير موجود (9).

$$
\begin{aligned}
& \text { (1) أي فيقول: لا أَدْرْ، وما أَدْرْ. } \\
& \text { (Y) نحو: با قاضي. (Y) }
\end{aligned}
$$

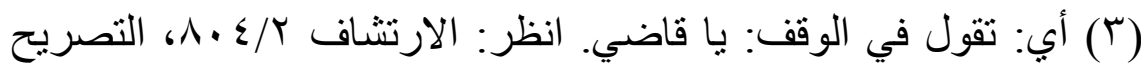

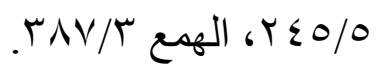

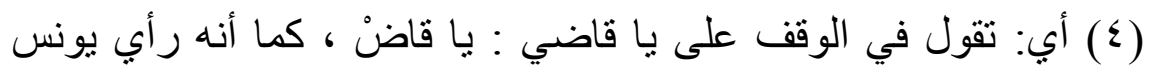

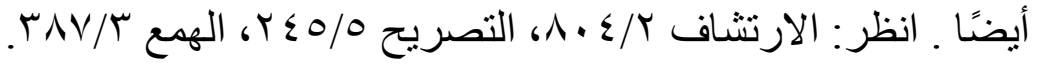

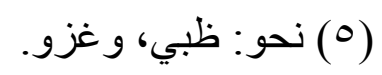

(7) أي: فلا يخلو أن يكون ما قبلها ساكنًا أو متحركًا.

$$
\begin{aligned}
& \text { (V) نحو: يغزو. (V) }
\end{aligned}
$$

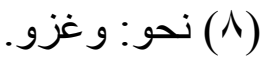

(9) أي: تقول: البُطِيء في الخفض، و الرُّدُء في الرفع، ولا يجوز ذلك في 
ويجوز في الهمز وإن لم يؤد التقل إلى ذلك(')، ويخالفه - أيضًا - في أنه يجوز أن تبدل من الهمزة حرفًا من جنس حركتها(؟)، وفي أنه لا يجوز التضعيف هذا في لغة المحققين، فأما المُسَهِّلون فينقلون الحركة إلى ما قبلُ في مثل "الوَثَئ، فيكون الوقف عليه كالوقف على ما آخره صحيح، ويُسَهِّلون الهمزة في مثل الكلا بينها وبين الحرف الذي منه حركتها، فيكون الوقف عليه كالوقف على ما في آخره حرف علة. وإن كان مبنيًّ أو مشبهًا بمبني ، وهو ما في آخره حرف ليس فيه علامة

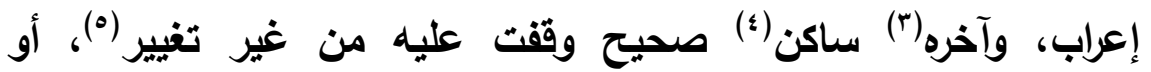

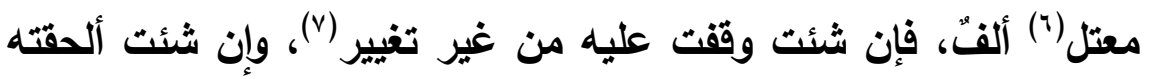

(1) أي: يجوز أن تقول: رأيت البُطؤُ فتتبع، ولو نقلت فقلت: البُطَأ، لكان له

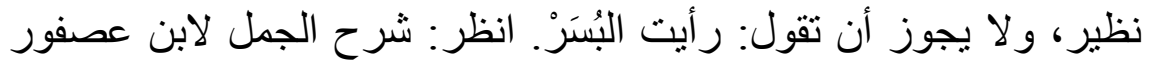

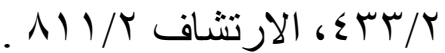

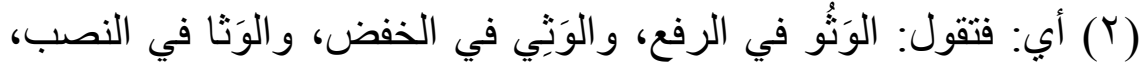

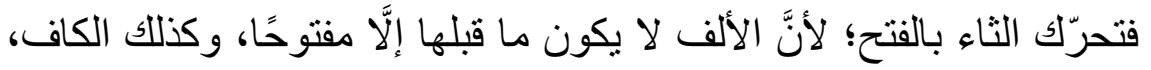

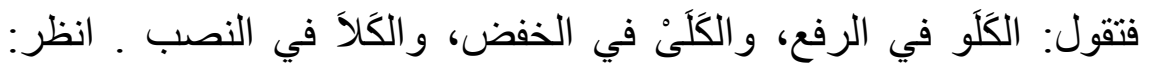

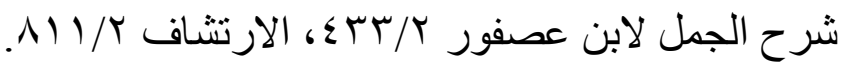

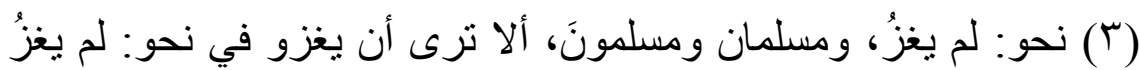

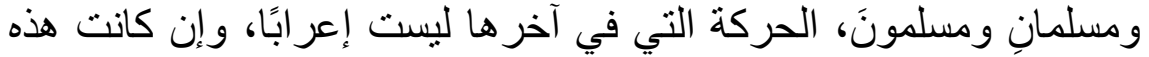

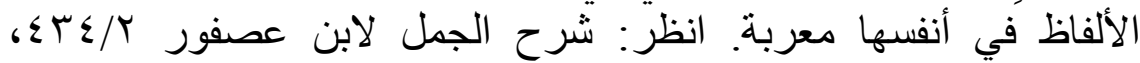

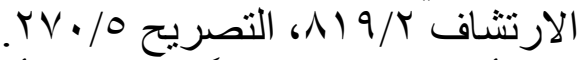
(ع) أي: فإن كان ساكنًا فلا يخلو أن يكون الساكن حرف علة أو حرفًا

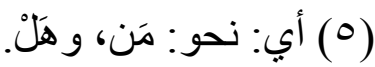
(7) أي: فإن كان حرف علة فلا يخلو أن يكون ألفًا أو غير ألف. (V) 
الهاء إلا أن تكون للندبة فتلزمه الهاء(')، أو ياء أو واو(؟) صلتان للمضمر لم يجز فيهما إلا الحذف(ّ)، أو ليسا بصلتين لزمت الهاء(؛). وإن لم يكونا في آخره وققت عليهما من غير تغيير ولا زيادة(ه) إلا ما شذ فئ من إبدالهم الهاء من الياء في الوقف على: هذا لي، فتقول: هذا لِّلْ.

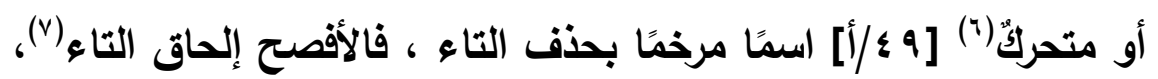
وقد يستغنى عن الهاء في الثعر بألف الإطلاق (^).

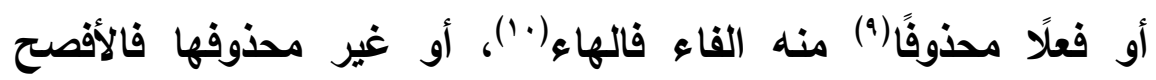
إلحاقها، ويجوز في المضموم الكسر أو [.....]"') محذوف الآخر قـ

(1) فتقول: يا غُلاماه، و لا يجوز في الوقف: يا غُلاما.

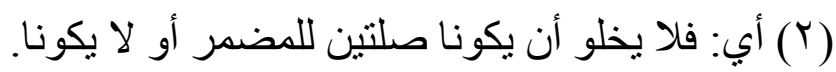

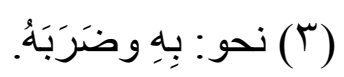

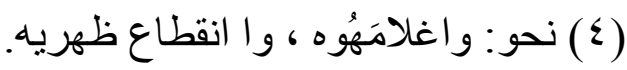

$$
\text { (1) نحو: لو، ولي. }
$$

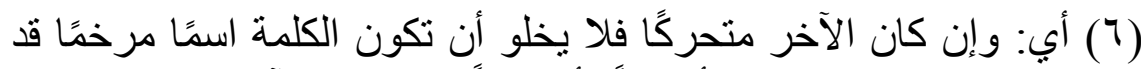

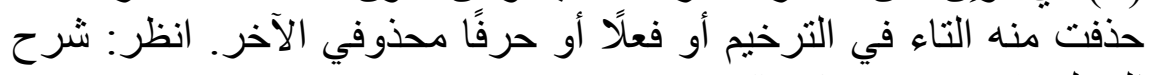

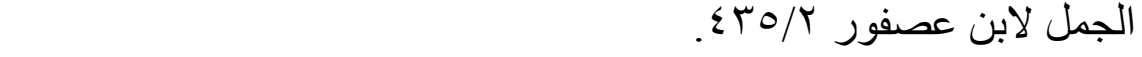
(V)

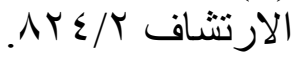

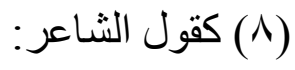

عوجي علينا واربَعِي يا فاطِما

(9) أي: لا يخلو أن يكون قد حذفت منه الفاء أو لم تحذف وائ.

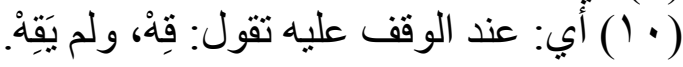
(1) (1) بياض في الأصل بمقدار كلمة. 
جرت باسم فالهاء، أو بحرف(1) فالأفصح إلحاقها(ץ)، وندر بغير هاء فيما

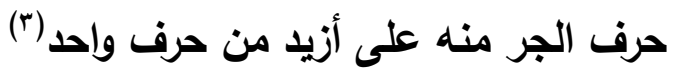

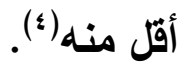

وإن كان متحركَ الآخر، ولم يحذف منه شيء(ْ)، وهو بهاء ضمير فالأفصح الإسكان(")، ويجوز نقل الحركة من الضمير إلى الساكن(v)، ويجوز كسر الساكن الأول(^)، أو غير ذلك فالإسكان، وإلحاق هـاء

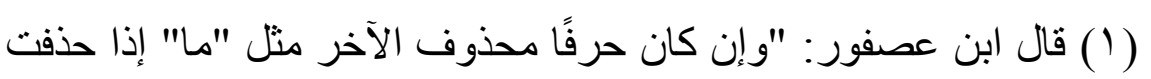
ألفها في الاستفهام إذا اتصلت بخافض فلا يخلو أن يكون الخافض الذبي دخل

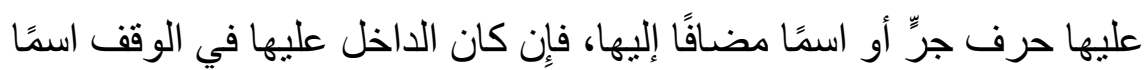

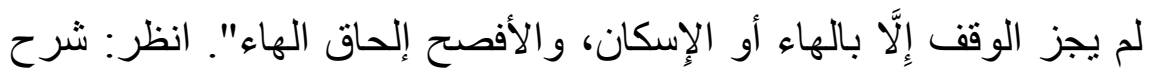

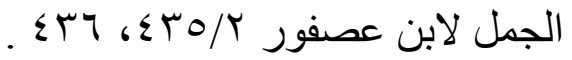

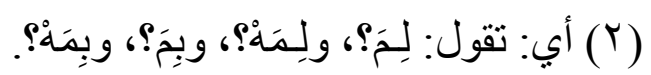

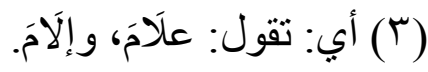

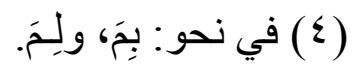
(0) أي: وإن كان المبني الموقوف عليه متحرك الآخر، ولم يحذف منه شيء فلا يخلو أن يكون بها ضمير قبله ساكن أو غير ذلك. (T) أي: تقول: اضرِبُهُ، وضربنُّهُ (N) (^) 
الموفور من شرح ابن عصفور

دإكمدمحسمد لجنداي

دا عب الملك أحمد شثتيوي

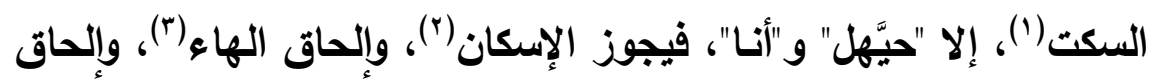

الألف (๕).

\section{*******}

همزة الوصل: لا توجد إلا ويعدها ساكن لفظًا أو نية(ه)، وتكون في الكلم، ففي الحرف مع أداة التعريف خاصة"(")، وفي الماضي موازن "(نفَلَّل،

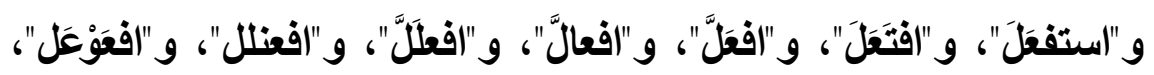

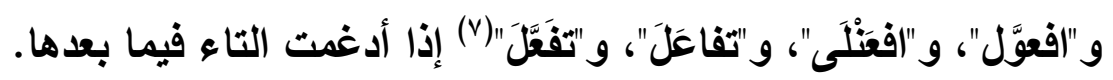
وفي الأمر بغير لام بشرط أن يكون من الثثلاثي، أو من مثال ما تقدم.

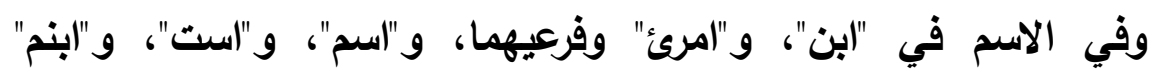

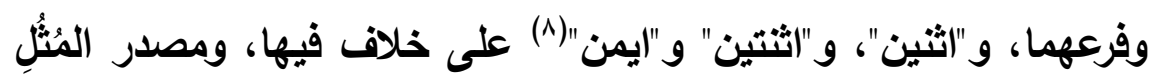
المتقدمة.

(1) نحو: 》أَناه، يجوز في الوقف عليها: أَنْ وأَنَه، وقد يجوز في الوقف هو هُ عليها: هو و هوه.

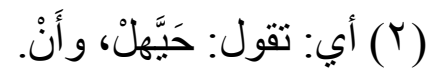

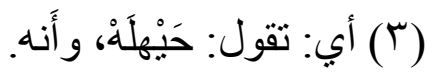

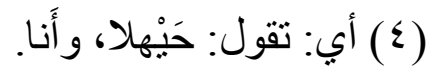

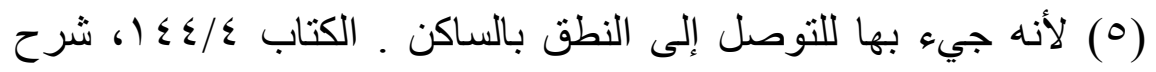

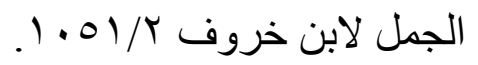
(7) نحو: الرجل، و المعلم. انظر : الجمل صـ YOV، شرح الجمل الجمل لابن هشام صـ סדז.

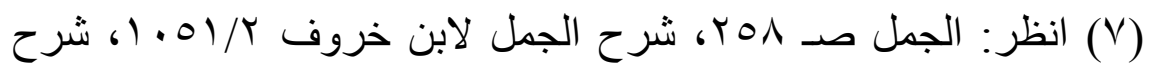

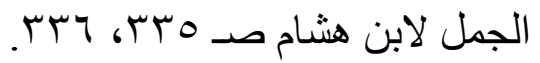

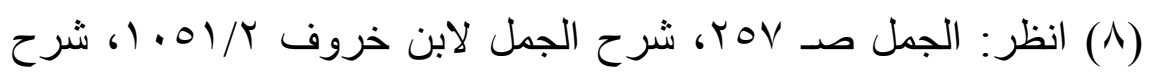

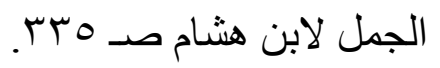




\section{إصدار IV}

حولية كلية اللغة العربية بالمنوفية العدد الثاني والثلاثون

ومذهب الخليل أن الههزة الداخلة على الأداة همزة قطع، ومذهب غيره

همزة وصل (') - (1)

وأصل الهمزة الكسر (r)، إلا إن عدل إلى الفتح أو الضم لموجب، فتقتح فيه مع لام التعريف، وفي "ايمن "(r)، وتضم في كل فعل ثالثيه مضموم لزومًا

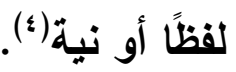

\section{$* * * * * *$}

التثية: ضم شيع إلى مثله بشرط اتفاق اللفظين [9 \& /ب] والمعنيين، أو المعنى الموجب للتسمبة(•). والاسمان إن اختلفا لفظًا فالعطف إلا ما سمع من قولِهم: العُمَرَانِ،

(1) انظر: سر صناعة الإعراب // إ(، وراجع: شرح الجمل لابن

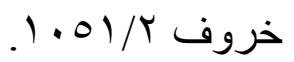
(Y) اختلف في أصل همزة الوصل: هل هو السكون أو الحركة؟ فالأول مذهب الفارسي، و الثاني مذهب سيبويه، وهو الظاهر . قال ابن جني: "واعلم أنَّ هذه الهمزة أبدًا في الأسماء والأفعال مكسورة". انظر : سر

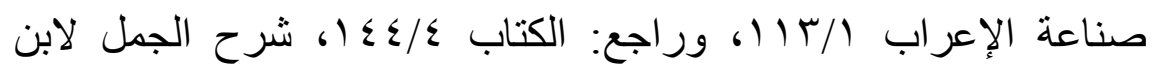

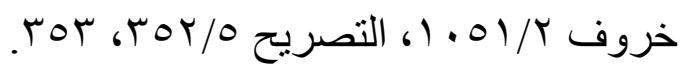
(r) و علة فتحها مع الأول: دخولها على ما ليس من جنسها أن تدخل عليه، فخولف بحركتها، و "أيمن" اسم غير متصرف، لا يكون إلا في القسم، فثبه بالحرف في عدم التصرف، فقتحت هزته . شرح الجمل لابن خروف $.1 .01 / 4$

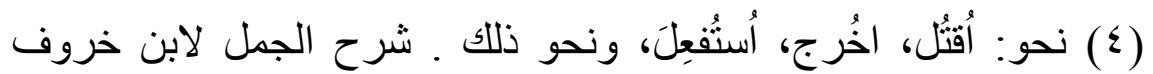
$.1 .01 / \mathrm{r}$ (0) أي و المعنى الموجب للتسمية فيهما واحد. 
والقمران، والعجاجان (')، أو اتفقا واختّفا معنى فالعطف(ז)، أو اتفقا في موجب التسمية فالعطف إلا فيما سمع، نحو: الأحمرين(")، والأصفرين(؛)؛ والأبيضين(॰)، وإن اتفقا فيهما، وكانا علمين فالعطف(†)، أو لم يكوناهما فالتثية، ويختص العطف بالضرورة(v). والتثنية تثنيةٌ لفظًا ومعنَّى (^)، أو لفظًا أو معنًى (9)، وجميع الأسماء تثلى

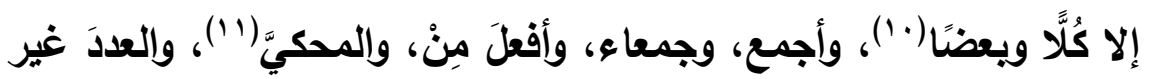

(1) أب: فيما غلب أحدهما على الأخر، فالأول لأبي بكر و عمر، والثاني

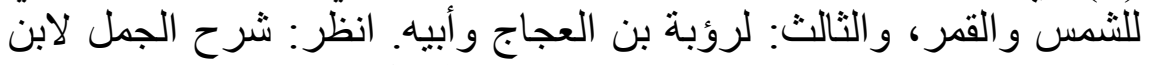

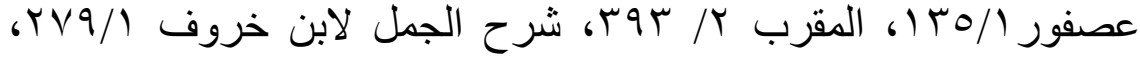

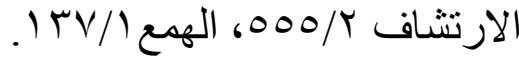

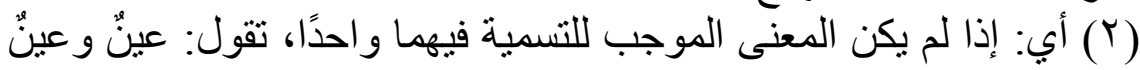

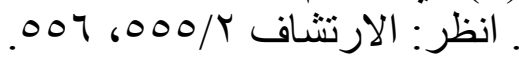

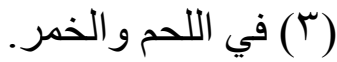

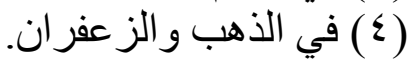
(0) في الثحم و الثباب. (7) أي: و لا تجوز التنثية؛ لأنَّ الاسم لا يثنى إلا بعد تنكيره ـ انظر: شرح

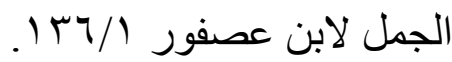

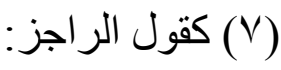

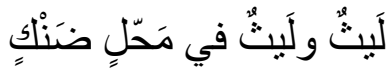

(^) نحو: الزيدين، و العَدرين.

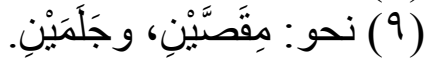

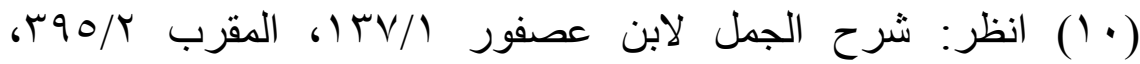

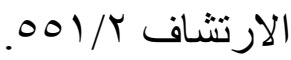

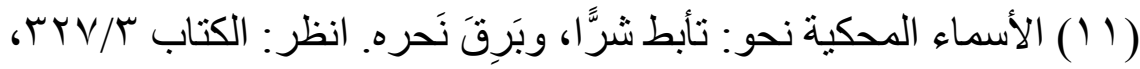

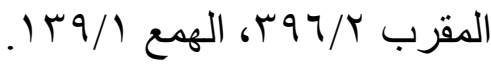


مائة وألف(')، وإلمتوغلَ في البناء(؟)، والمختصنَ بالنفي(")، والمثنى، والمجموع جمع السلامة في المذكر، واسمَ الجنس(؛)، واسمَ الجمع(•)، والمكسَّر، ووردا مثنيين في الضرورة.

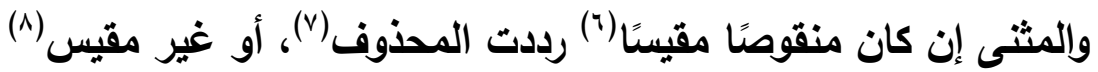

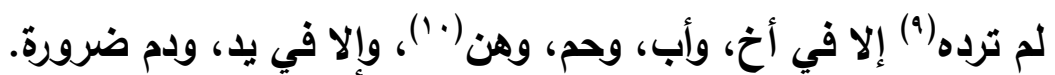
وغير المنقوص("') إن كان صحيحًا ألحقت العلامتين من غير تغيير،

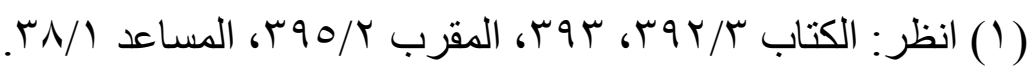
(Y) و هي التي لم تكن معربة قطّ ، نحو : مَنْ وكَّ.

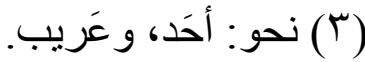

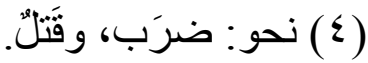

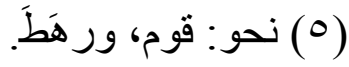

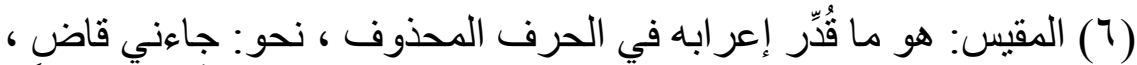

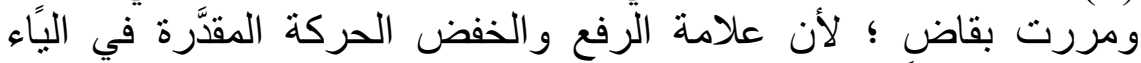

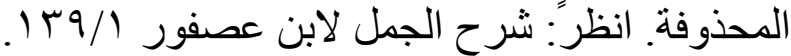

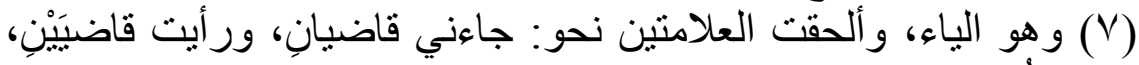
ومررت بقاضيين.

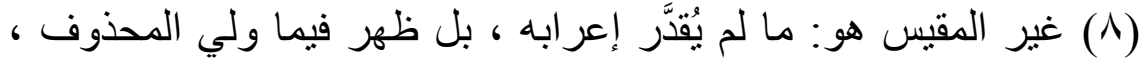

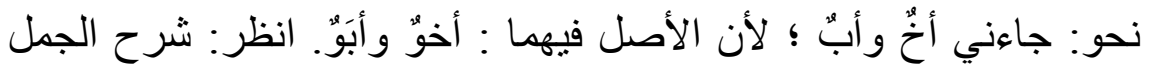

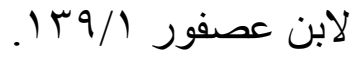

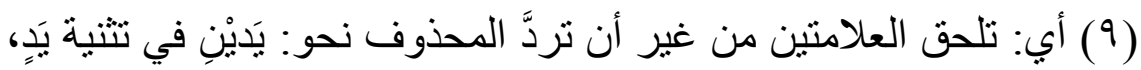

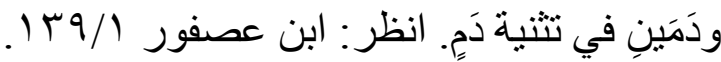

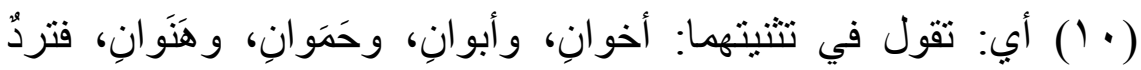

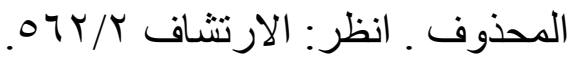

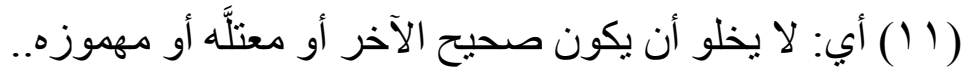




\section{إلا ما شذ من قولهم: أليان، وخُصيان (').}

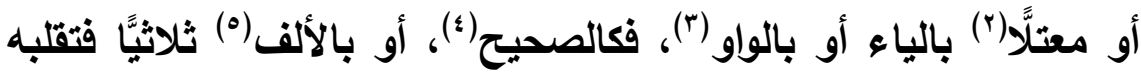

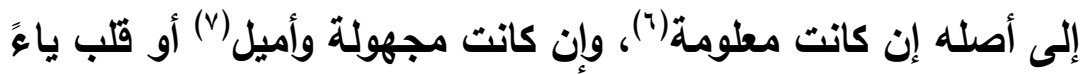

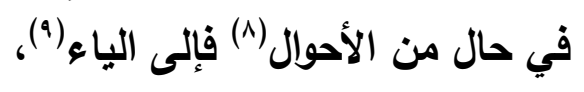

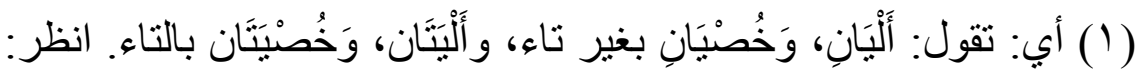

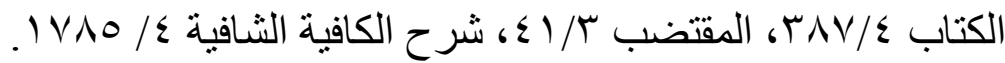

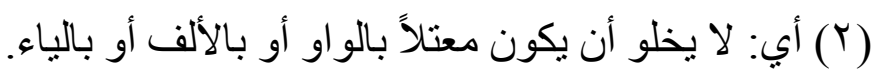

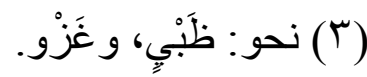

(§) أب: تلحق به العلامتين من غير تغيير، فتقول: ظَبَيْانِ، وغَزْوانِ في

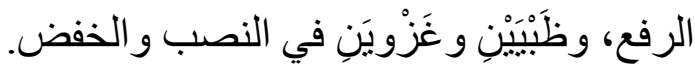

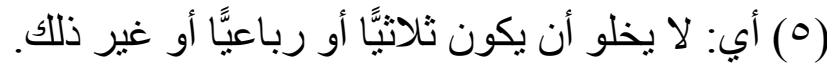

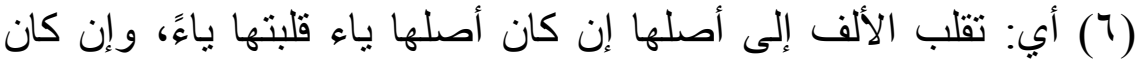

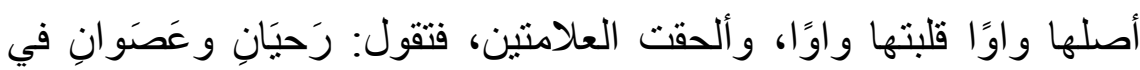

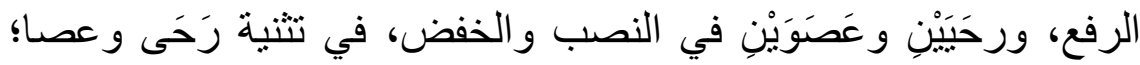

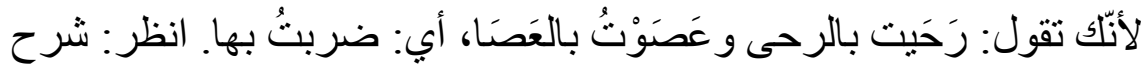

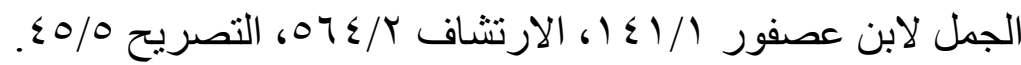

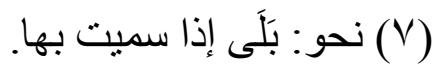

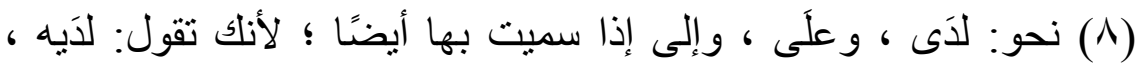
و علَيه ، و إليهـ.

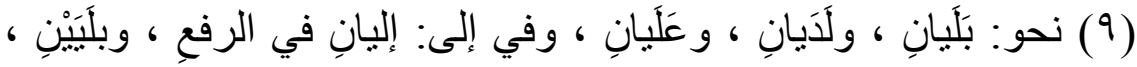

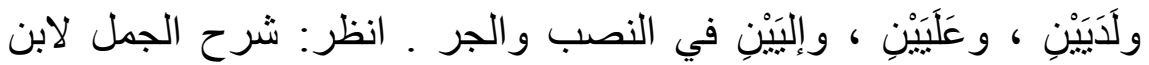

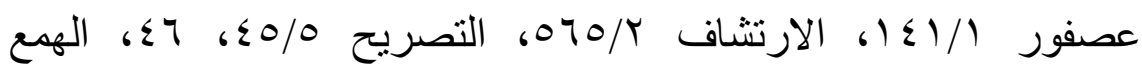




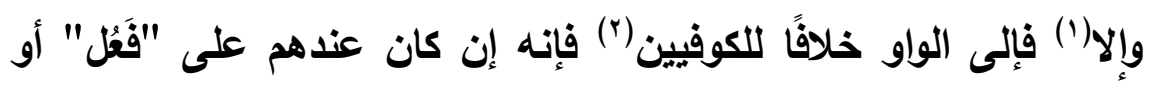

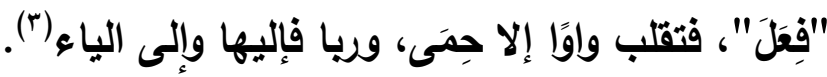
أو أزيد فإلى الياء مطلقًا(؛) خلافًا للكوفيين فيما زاد على الرياعي؛ إذهاء

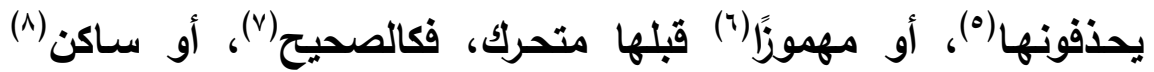
صحيح، فكالصحيج، ويجوز النقل(9).

(1) أي: وإن كانت لم نُمَل ولم تقلَب ياء في حال نحو: إلى إذا سميّتَ بها

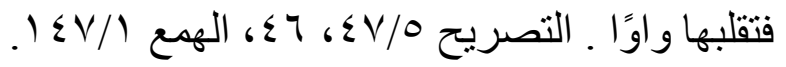

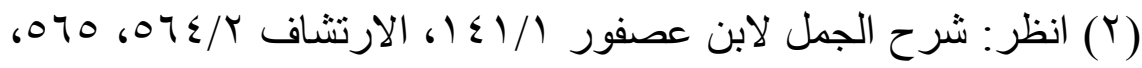

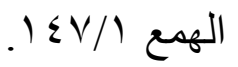
(ז) فقالو ا: حميَانِ وحَمِو انِ، وربَو انِ ورَبيانِ.

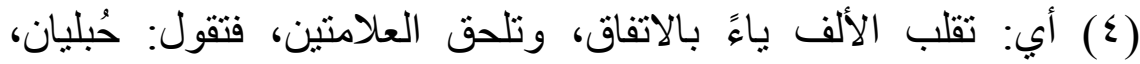
و ملهيان في حُبلى، وملهى. (0) رأيُ البصريين قلبُ الألف ياء كالرباعي، و عند الكوفيين تحذف، فتقول

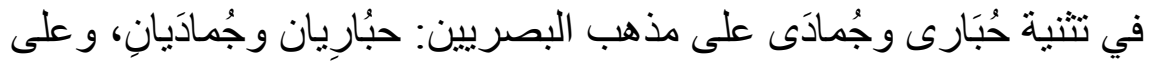

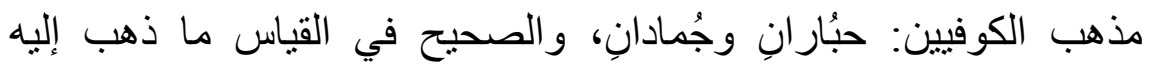

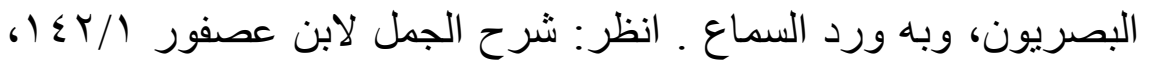

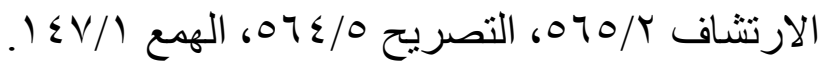
(ج) لا يخلو ما قبل الهمزة أن يكون ساكنًا أو متحركًا. (V)

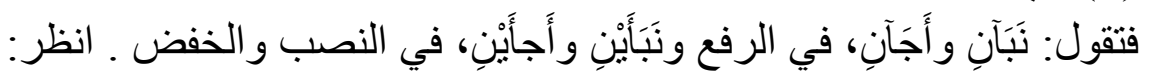

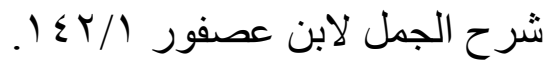

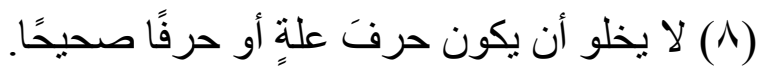

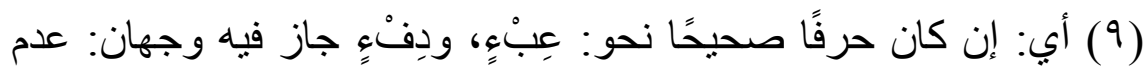

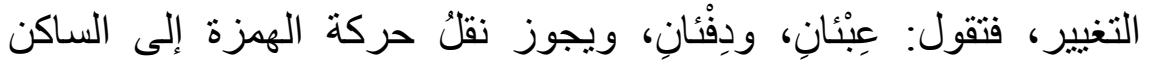

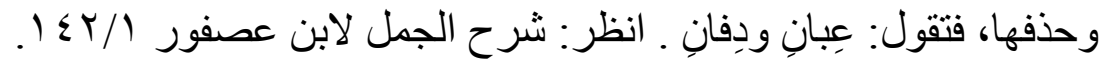


أو معتّل بالياء أو بالواو (') مزيدين فكالصحيح، ويجوز الإدغام(؟)، أو غير

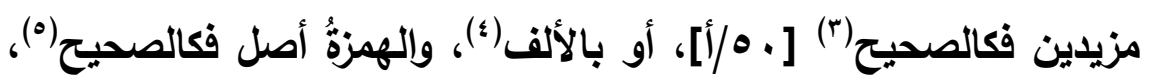
ويقل قلبها واوًا (`)، أو منقلبة عنه(V)، أو زائدة للإلحاق فكالصحيح،

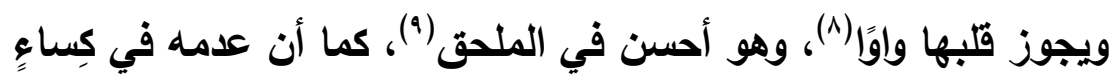

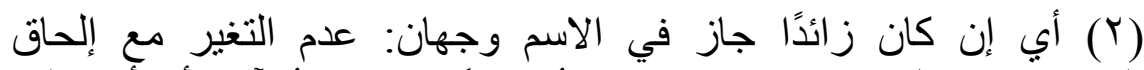

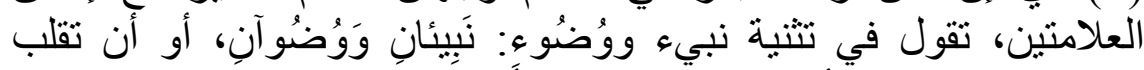

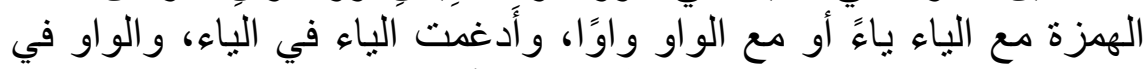

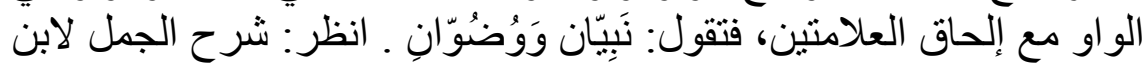

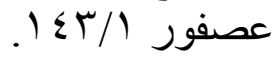

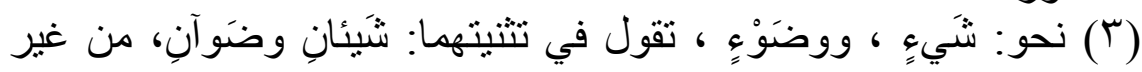
تغيير إلا بإلحاق العلامتين. (ع) لا تخلو الهمزة أن تكون أصلًا أو منقلبةً عن أصل أو زائدة إمّا للإِلحاق ، و إمّا للتأنيث.

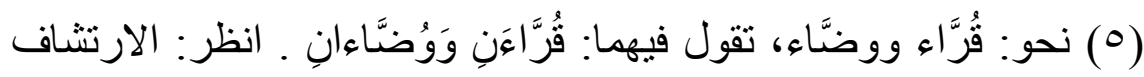
$.009 / 4$

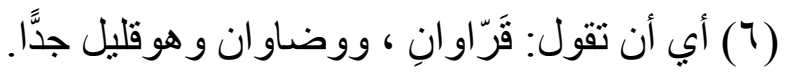

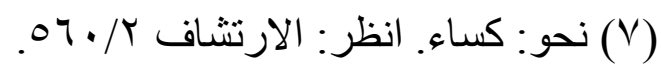

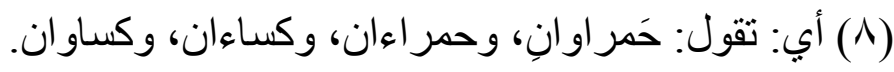

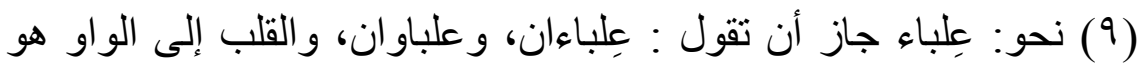
الأحسن . انظر: التصريح 10 •. 


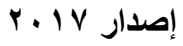

حولية كلية اللغة العربية بالمنوفية العدد الثاني والثُلاثون

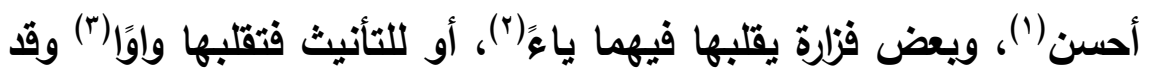

تبقى شاذَّاً (؛).

والمذكر والمؤنت إن اختلفا لفظًا فالعطف، إلا فيما شذ نحو قولهم: أبوان في "أب" و"أم"، أو اتفقا غَلَّبت المذكرَ(ه) إلا في ضَبُع وضِبْعانٍ (")، فنقول: ضَبَعَانِ (v)، ومن العرب من يقول: ضبعانان، فيُعَلِّب المذكرَ. ****** $* *$

الجمع: ضم اسم إلى أكثر منه بشرط اتفاق الألفاظ والمعاني، أو المعاني الموجبة للتسمية(^). والأسماء(9) إن اختلفت لفظًا فالعطف، إلا فيما سمع نحو: المهالبة،

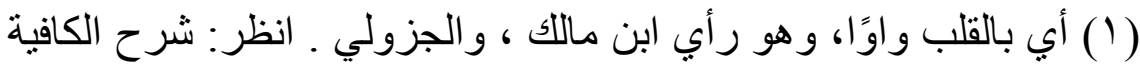

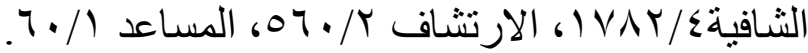

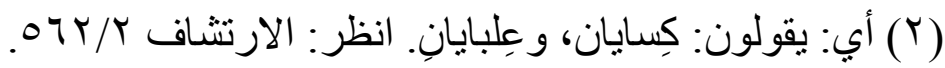

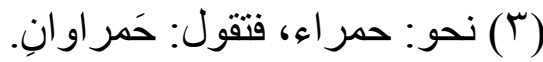
(ع) أي: تقول: حمر اءان، وحمر اعَينِ.

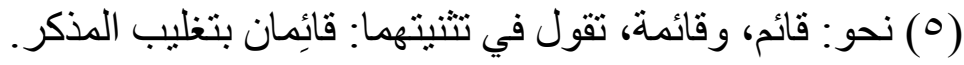
(7) فالأول للمؤنث، و الثاني للمذكر.

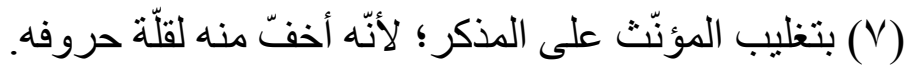
( ) أي: كون المعاني الموجبة للتسمية فيهما واحدًا. (9) لا تخلو الأسماء أن تتفق في اللفظ أو تختلف. 
والحُوص(')، أو اتفقت(ץ) واختلفت المعاني فالعطف، إلا فيما سمع نحو: الأحامرة(ז)، أو اتفقت(؛) وكانت أعلامًا فالعطف وإلا فالجمع، ولا يجوز العطف إلا ضرورة.

والجمع: مسلَّمُ، ومكسر، واسم جمع، واسم جنس. والأول هو المتكلم فيه، وهو بالواو والنون، وشرطه إن كان صفة: الأكورية، والعقل، وخلوه من تاء التأنيث، وأن يجمع مؤنثله بالألف والتاءع).

أو غير صفة فكذلك إلا الثرط الأخير، ويزاد العلمية، وعدم التركيب(")،

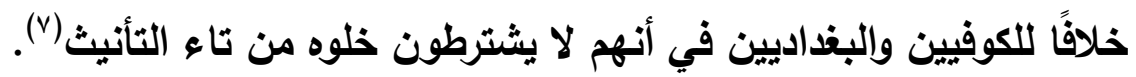

(1) أي: جمعت، لكنه موقوف على السماع، فالمهالبة في المُهَّبَّبِ وبنيه، و الحُوص في الأحوص و إخوته. (r) أي: و إن اتفقت في اللفظ ، فلا تخلو المعاني أن نَتَفق أو تختلف.

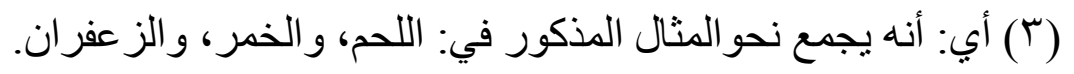
(ع) أي: الألفاظ والمعاني فلا تخلو الأسماء أن تكون أعلامًا باقية على ولى النى علميتها أو لا تكون.

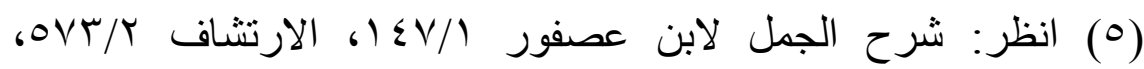

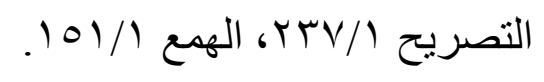

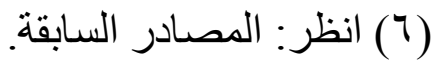

(V) وبالياء و النون في النصب و الخفض، فيقولون: طلحون وحمزون، وذللك لا

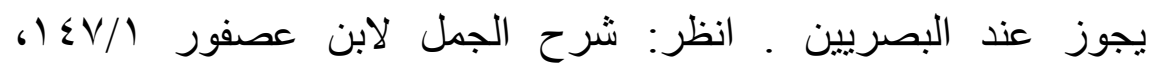

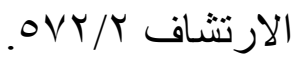


أو بالألف والتاء: وهو علم لمؤتث(')، أو فيه تاء التأنيث لمذكر أو

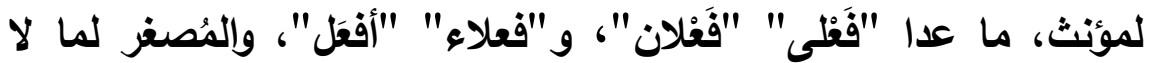
يعقل (ץ)، وما عدا ذللك لا يجمع بهما إلا حيث سمع، نحو: حمامات ، وسجلات ، وسُرادقات ، واصنطبلَات ، ولُحِّنَ المتنبي في جمع [••/ب] بوق على بوقات(־). وحكم المجموع بالواو والنون حكم المثنى إلا المنقوص، فلا ترد المحذوفَ(؛)، وإلا المعتل بالألف، فتحذفها ويكون ما قبلها مفتوحًا(•) خلافًا

للكوفيين ، إذ أجازوا ضمه(؟). ونون الاثنين مكسورة أبدًا، وحكي فتحها مع الياء(V)، وأجازه بعضهم مع

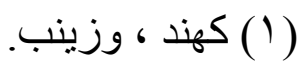

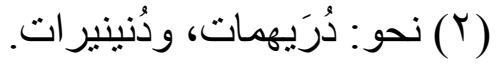

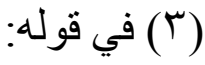

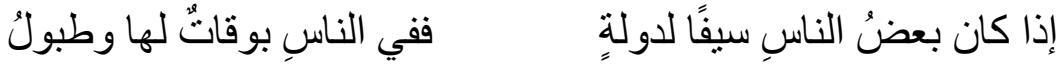

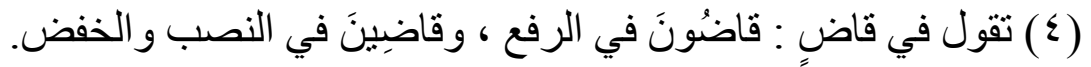

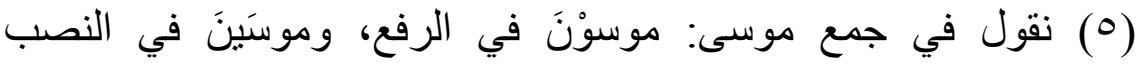

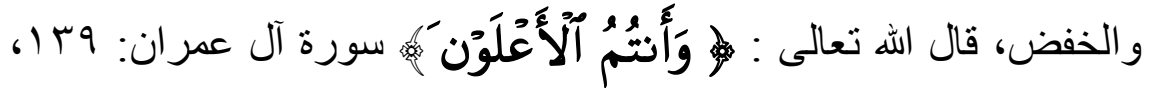

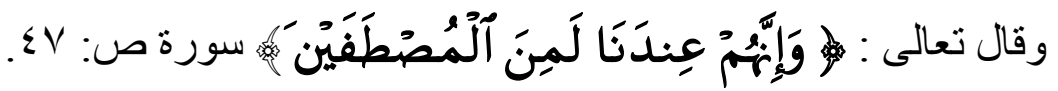
(ך) فيقولون: موسُونَ في الرفع، وموسَنَنَ في النصب والخفض. انظر:

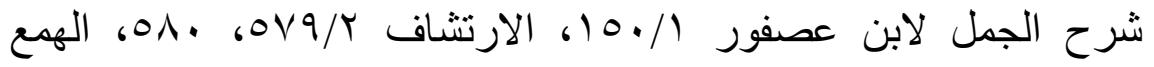
.10\%/ (Y) وهي لغة بني أسد. انظر: التصريح / (Y)

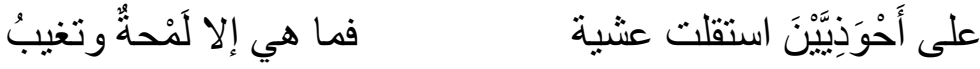

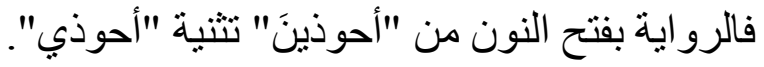


الألف(1)، ولغة خثعم استعمال المثنى بالألف على كل حال(؟)، ونون الجميع مفتوحة(؟)، والعقود (๕) من قبيل أسماء الجموع. وحكم المجموع بالألف والتاء حكمه في التثنية ما لم تكن فيه تاء التأنيث،

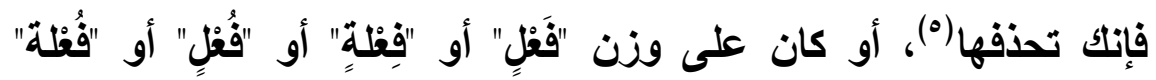

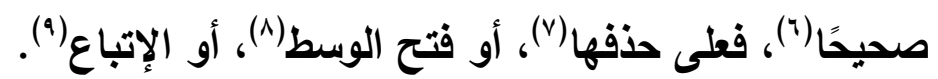

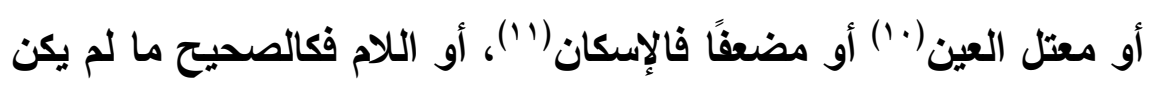

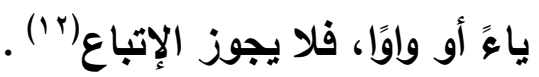

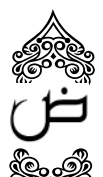

$$
\text { ياء أو واو، فلا يجوز الإباع (1). }
$$

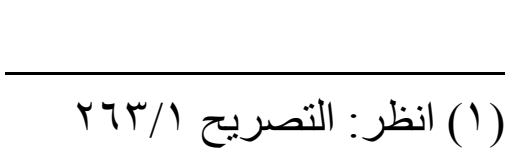

$$
\begin{aligned}
& \text { (Y) وختعم: فَخذ من طيىء، قال الثـاعر : (Y) }
\end{aligned}
$$

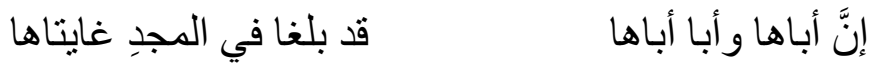

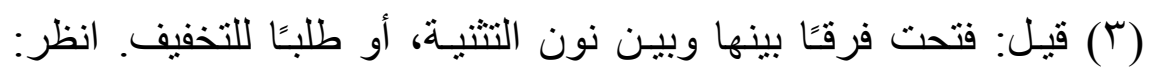

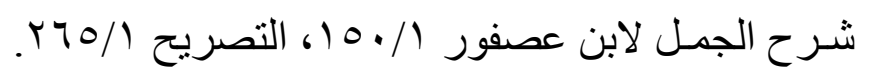

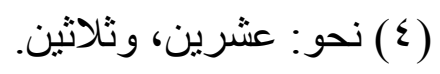

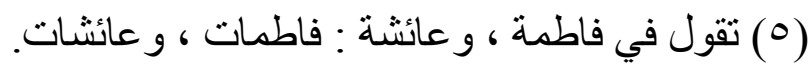

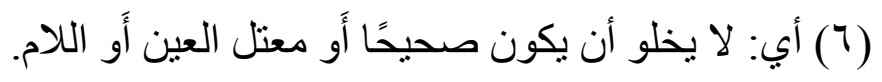

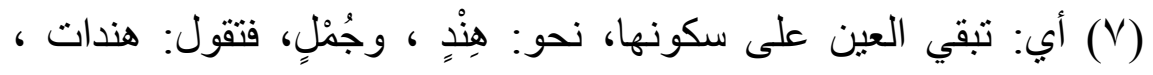
وجُمْلات.

(^) أي: تفتحها طلبًا للتخفيف، فتقول: هِنَدات ، وجُمَلات.

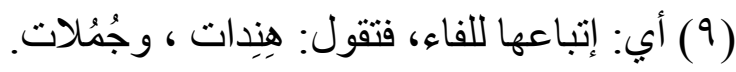

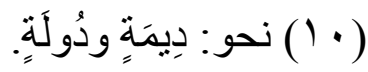

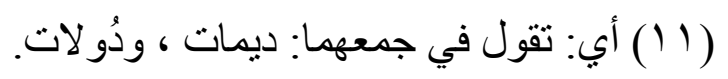

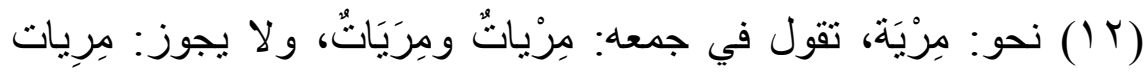

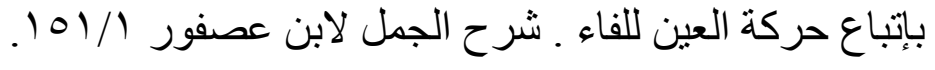




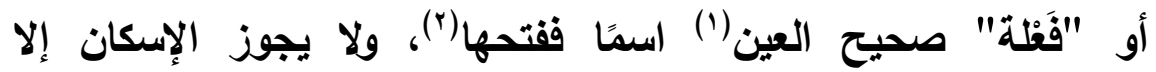

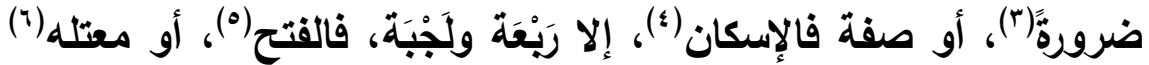
فالإسكان (v) إلا بني هذيل، فكصحيحه يفتحونه(^). والنون زيات ليظهر فيها حكم الحركة في المفرد وتتوينه، لا عوضًا من

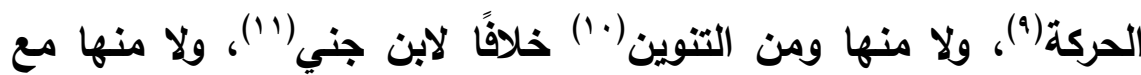

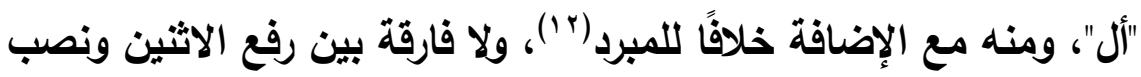

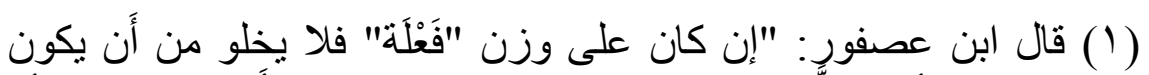

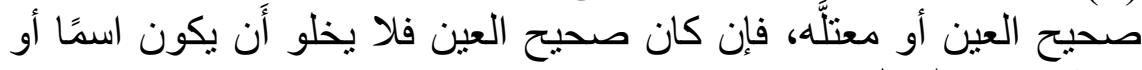

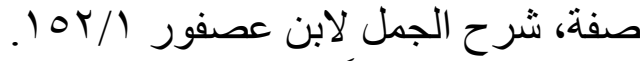

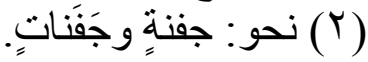

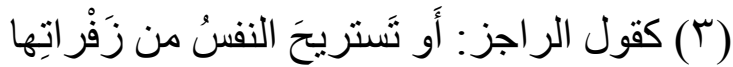

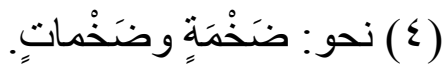

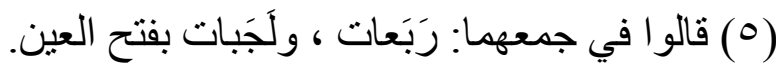

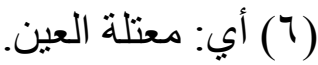

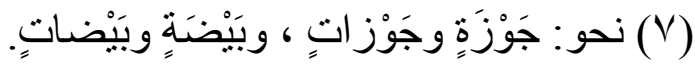
(^) أي: يجرونه مجرى صحيح العين في الفتح فيقولون: جَوزَّات وَبَيَضِات.

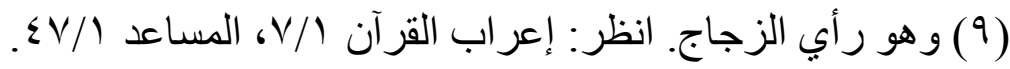

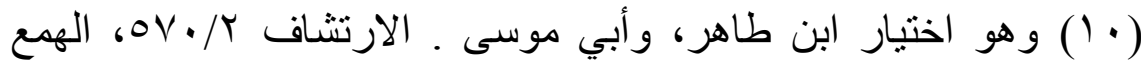
$.109 / 1$

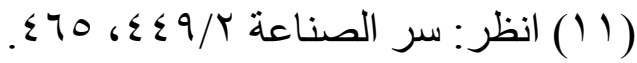

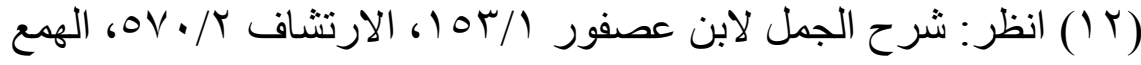
$.109 / 1$ 


$$
\text { الموفور من شرح ابن عصفور }
$$

الواحد في حال الوقف خلافًا للفراء(')، ولا من تنوينين في التثية ومن

تنوينات في الجمع خلافًا لثُعب( (ץ).

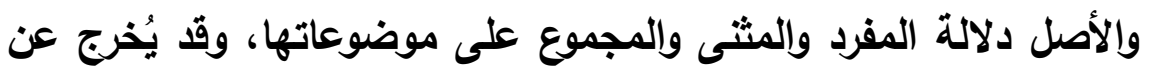

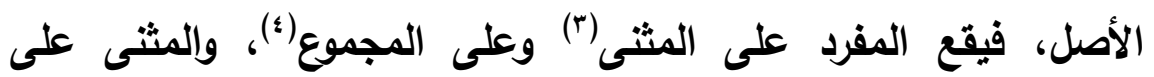

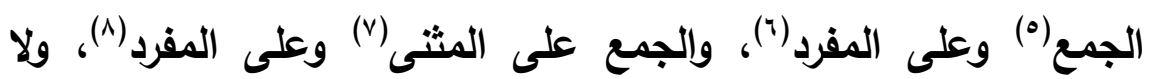
ينقاس شيء من ذلك إلا الجمع للمثى في كل شيئين من شيئين (9).

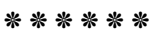

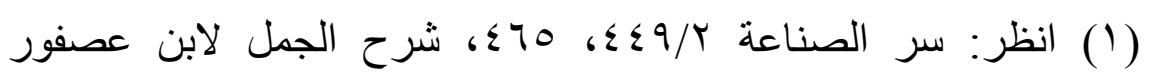

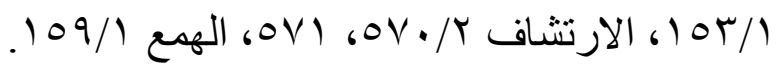

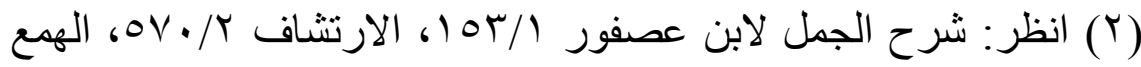
$.109 / 1$

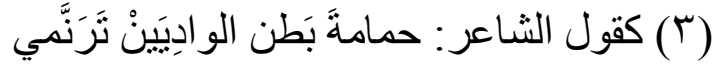
يريد: بطني الو اديين. - (باعل

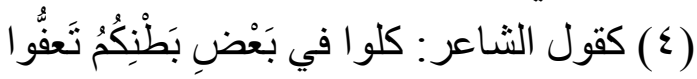
أبي: في بِطُوِْكُم.

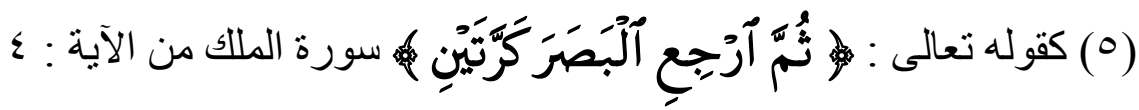

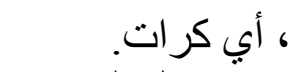

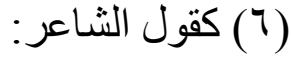

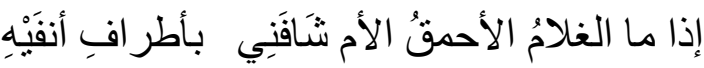

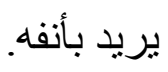

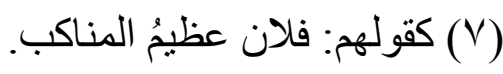

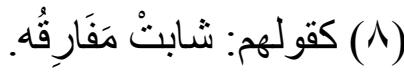

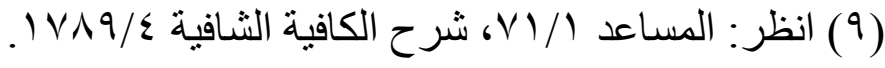


النسب: هو الإضافة(')، ويكون للأب، والأم، والحي ، والقبيلة ، والمكان،

والمذهب ، والصنعة، ولما يُكَلََمُ، أو يُمْلَك، وللصفة وهو قليل (). وق تلحق الياءان لفظًا، ولا يكون منسويًا(ّ)، كما أنه يجيء النسب بغيرها، فيجيء على "قاعل" فيما يُملك، وعلى "فَََّال" في الصنعة(؛)، وعلى "فَعِل" في الملازم، وعلى "مِفعال" و "مِفعيل"(ه) و "مِفعَل"(")، وكله

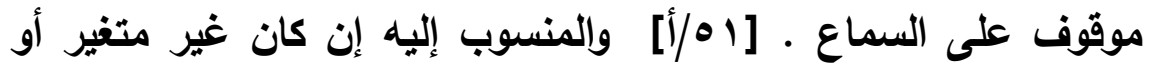

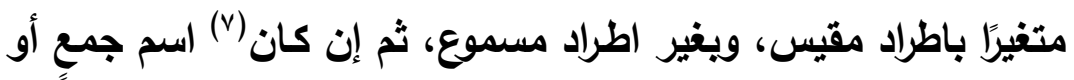

(1) النسب و الإضافة بمعنى واحد، ولذلك قال سيبويه: "باب الإضافة، وهو باب النسبة. انظر: الكتاب س/ه وسب.

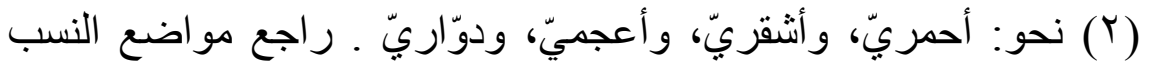

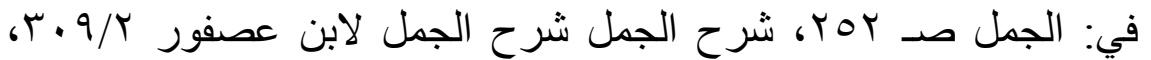

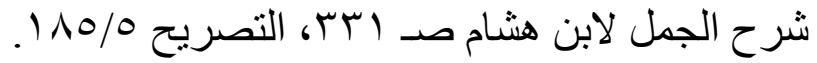
(؟) أي في المعنى ، نحو : كُرسيّ، ويُحتيّ.

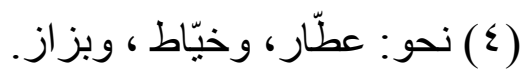
(1) نحو: ناقة مِخطير.

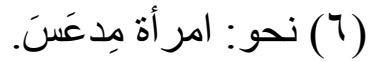

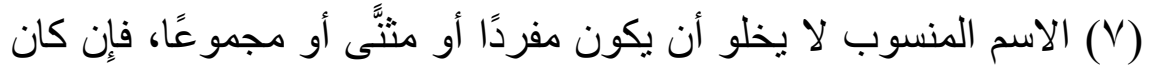

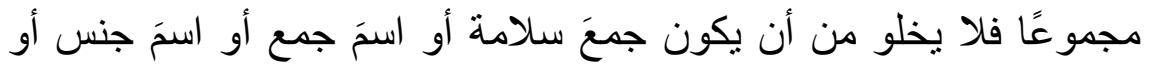

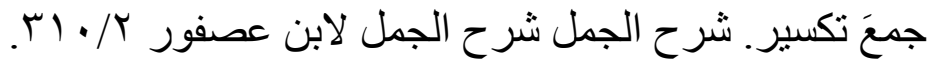




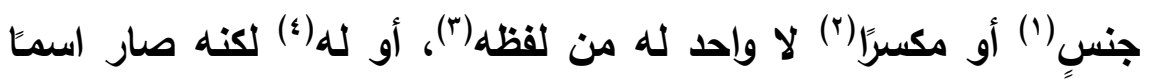

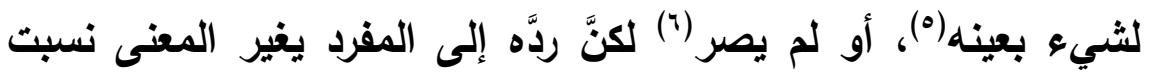
على لفظه (v).

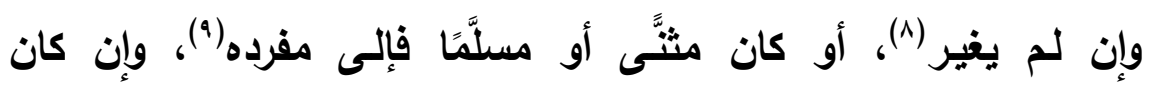

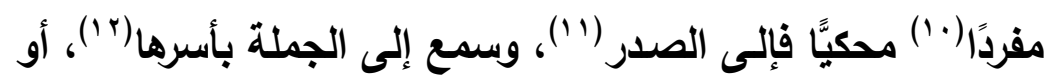

(1) فتقول في النسب إلى قوم: قومِيُّ، و إلى رهط: رَهطَيّ، و إلى شجر : شَجَرِيّ ، و وإلى تمر : تَمَرِيّ. (Y) إن كان جمع تكسير فلا يخلو من أن يكون له واحد من لفظه أو لا له يكون.

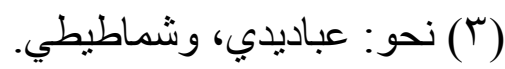
( ) أي: إن كان لله واحد من لفظه فلا يخلو من أن يكون قد بقي على

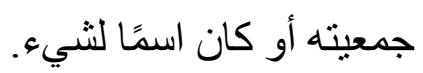
(0) نحو: أنمار و أنصار ، نقول: أنماريّ و وأنصاريّ.

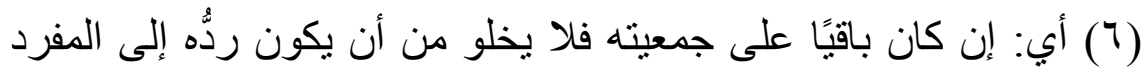
يغيّر المعنى أو لا يكون، نحو : أعراب وأب أعرابيٌ. كالأمثلة السابقة. (N) نحو قولهم في النسب إلىى الفرائض: فَرَضِيٌّ، و إلىى القبائل: قَبَليُّ، و إلىى أبناء فارس: بَتَويٌّ.

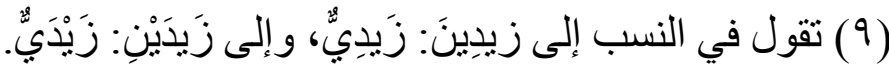

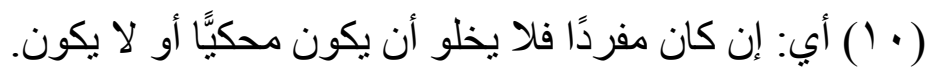
(1 (1) فتقول في النسب إلى تأبط شرَّا: تأبطي.

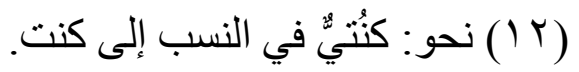


مضافًا(') لم يصيرا بمنزلة اسم واحد نسبت إلى أيهما شئت(؟)، أو صارا

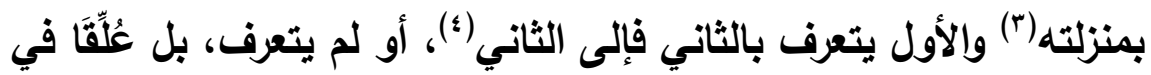
أول حال فإلى الأول إلا إن خِفْتَ لبسًا فإلى الثاني (•)، أو مركبًا فالفصيح

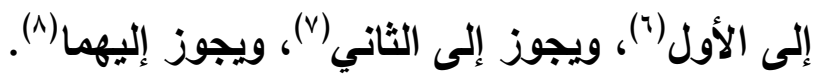

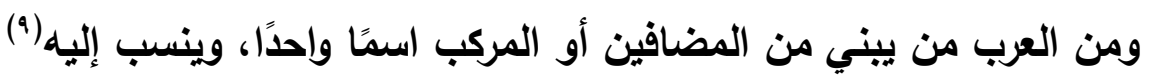
وهو موقوف على السماع.

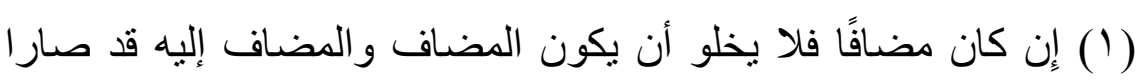
بمنزلة اسم و احد لثيءٍ أو لا يكونا. (r) نحو: غلام زيد إن أردت النسبة إلى زيد نسبت، أو إلى الغلام نسبت.

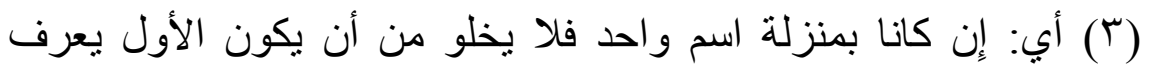

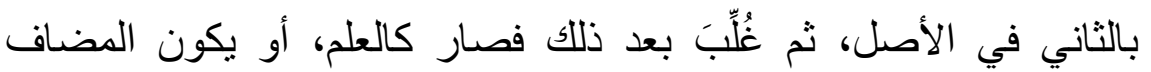
و المضاف إليه عُلِّقَ في أول أحو اله علمًا على مسماه ـ شرح ح الجمل شرح

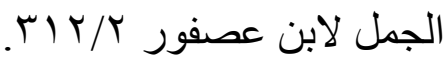

(§) نحو: ابن كراع، وابن دألان، وابن عمر، أَلا نرى أن جميع ذللك أضيف

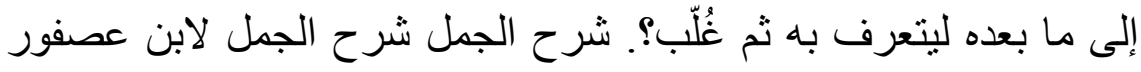
إلى

(0) تقول في النسب إلى امرىء القيس: امرئي؛ لأنك لم تَخَفْ في الأول

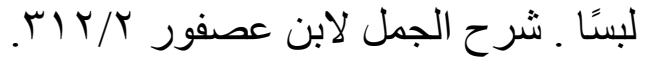
(T) تقول: بعليٌّ في النسب إلى بعلبك.

$$
\text { (^) }
$$

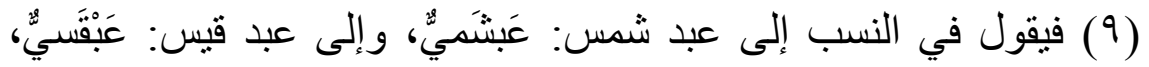

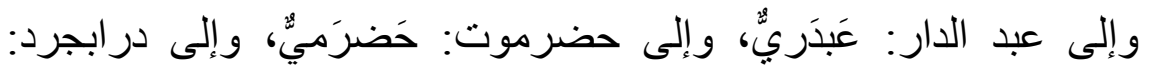

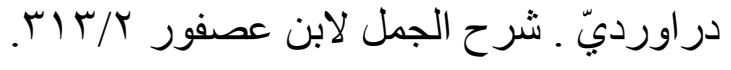




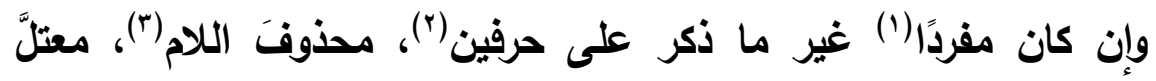

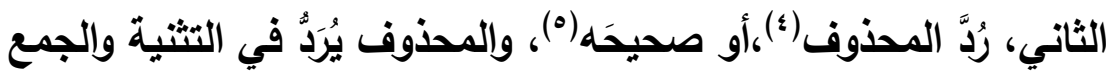

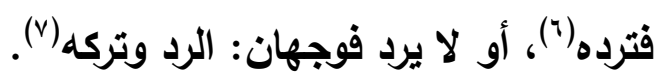

وإذا رددت فمذهب سييويه أن العين على حالها من الحركة(^)، ومذهب الأخفش ردها إلى أصلها من السكون(9) ما لم يكن المحذوفُ اللام فيه

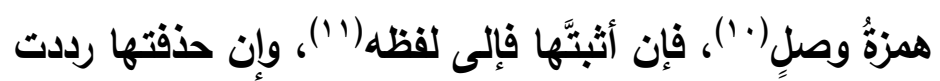

( ( ) أي: لا يخلو أن يكون على حرفين أو على أزيد. (Y) فإنْ كان على حرفين فلا يخلو أن يكون محذوف اللام أو أو الفاء أو العين.

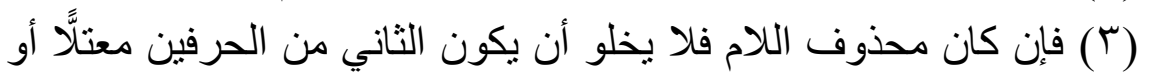
صحيحًا.

( ) فتقول في النسب إلى قوللك: ذو مال، ذَوَويّ. (0) لا يخلو أَن يكون المحذوف قد رُدّ إليه في التثنية و الجمع بالألف و التاء

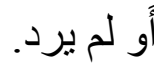

(T) أبي ترده في النسب، فتقود في النسب إلى أَخِ: أَخَوِيّ، و إلَى أَبِ: أَبَوِيّ.

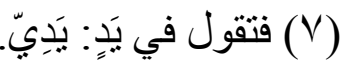

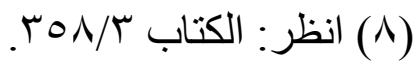

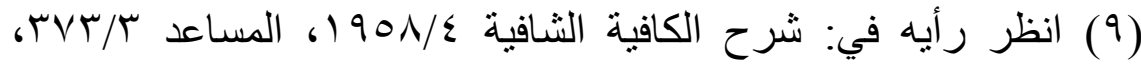

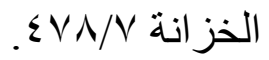

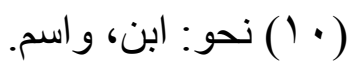
(11) فتقول في ابن: ابني وفي اسم اسمي. 


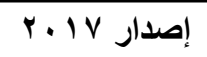

حولية كلية اللغة العربية بالمنوفية العدد الثاني والثلاثون

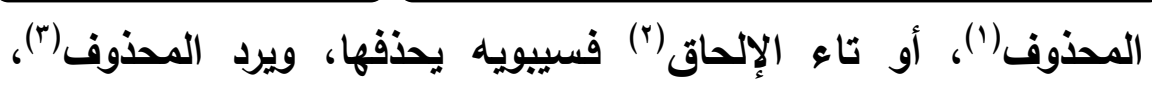

ويونس لا يحذقها(؛)،

والأخفش يحذفها، ويبقي ما قبل التاء على حركته (ه).

أو محذوف العين فلا ترد(ّ)، أو محذوف الفاء(v) صحيح الثاني فلا ترد(^)

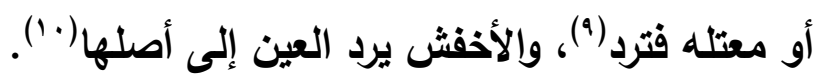

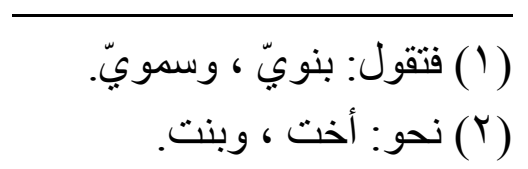

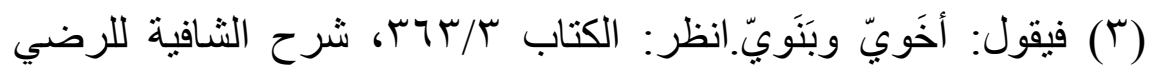

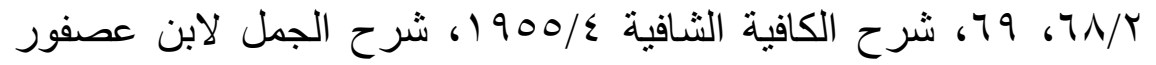
10/r

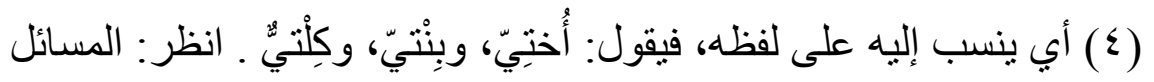

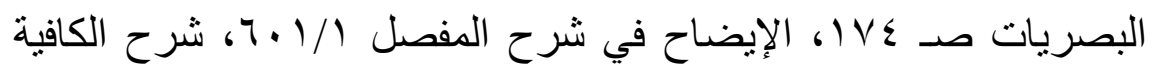

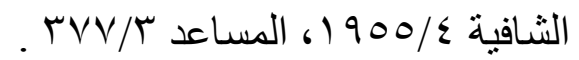

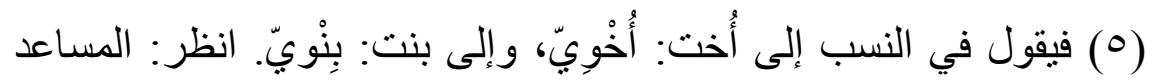

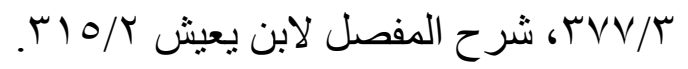

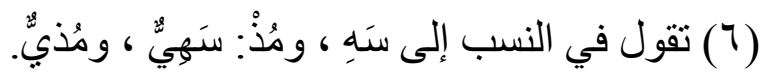

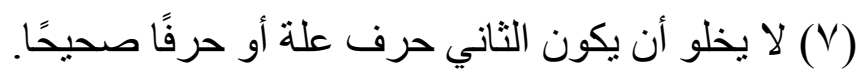

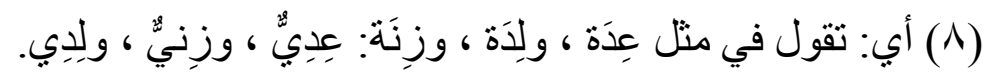
(9) أي: تنسب إليه كما تنسب إلى فِعَل، فتقول: وشَبِيّ. ( • (1) أي: من السكون، فيقول: وِثْيَيّ. 
الموفور من شرح ابن عصفور

د/ لحمدمحسمد الجنــي

دا عبد الملك أحمد شثيوي لئي

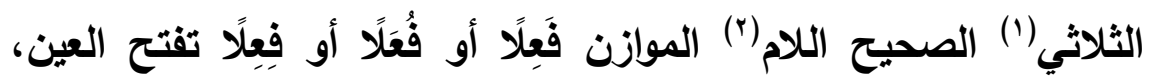
وتبقي الفاء على حركتها(ّ) إلا إن كاتت كسرة الفاء إتباعًا(؛) فيجوز

فتحها (0).

أو غيرها من الأوزان فإلى لفظه، والمعتلة بالألف [1ه/ب ] تقلب واوا

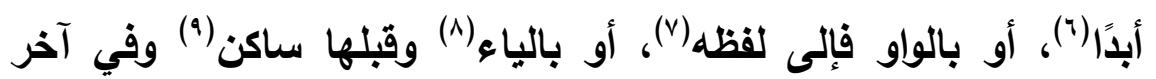

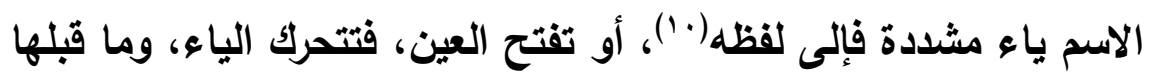
مفتوح، فتنقلب ألفًا، فيصير من باب رَحى، أو مخففة(')، وعري عن تاء التأنيث فإلى لفظه(r')، أو كاتت فيه حذفت، فسيبويه ينسب على لفئ لفظه،

$$
\text { (1) أي: فلا يخلو أنْ يكون معنل اللام أو صحيحًا. }
$$

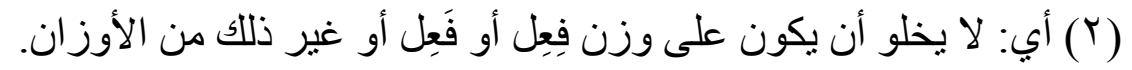

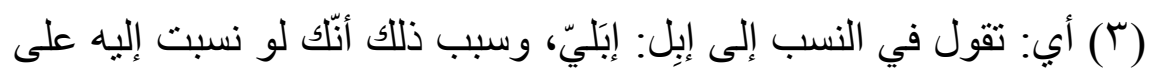
لفظه لاجتمع ثلاث كسرات مع ياءي النسب، فيتو الى التقل، شرح الجمل الجمل

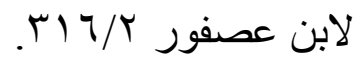

( ) أي: لكسرة العين نحو: صِعِق، فإنّه في الأصل صَعِق فأتبعت حركة الفاء.

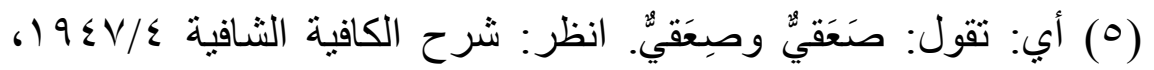

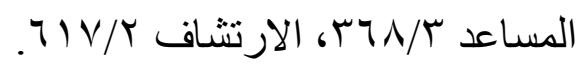

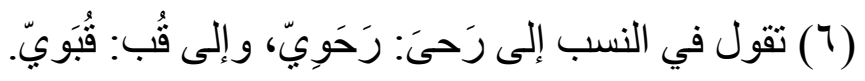

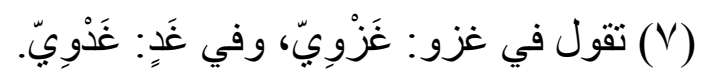

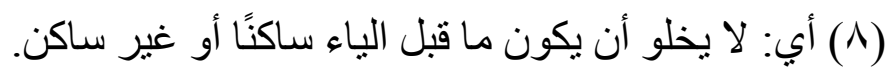

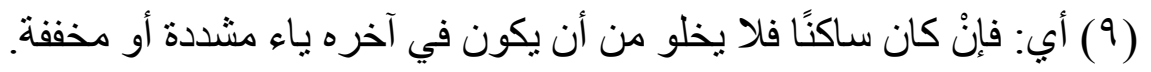

$$
\text { ( • ( ) أي: تقول في النسب إلى حَيّ: حَيِّيّ. }
$$

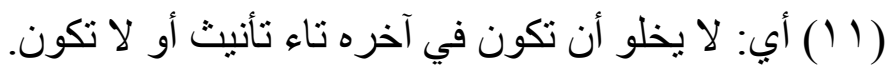

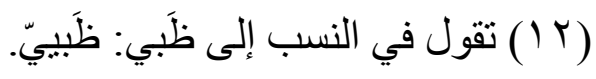




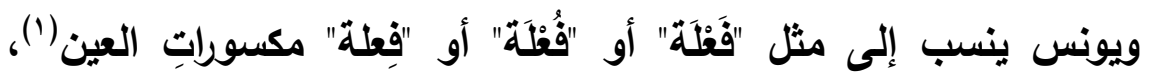

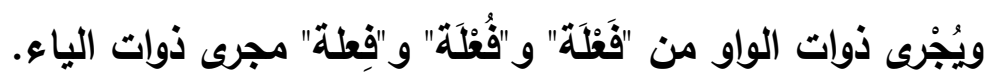

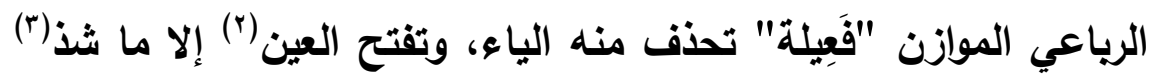

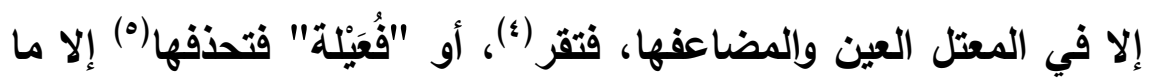

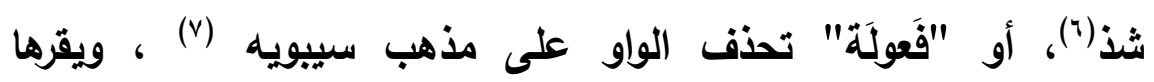

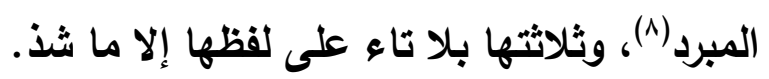

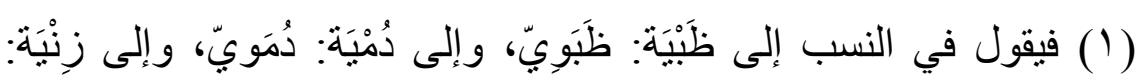

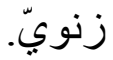

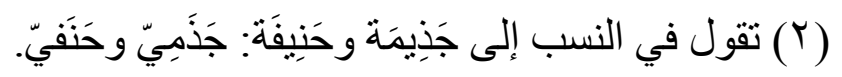

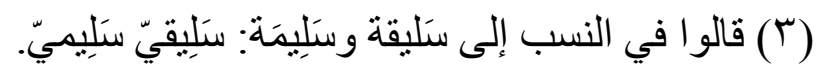

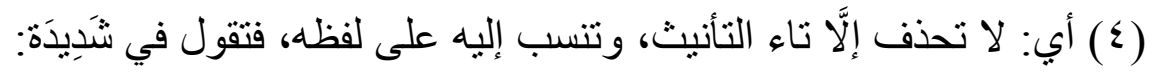

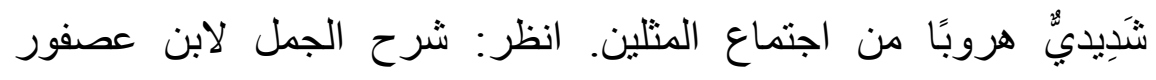

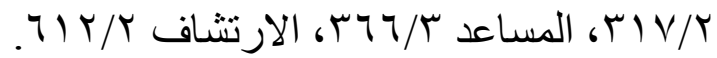

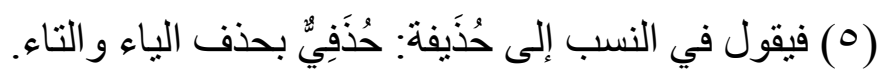

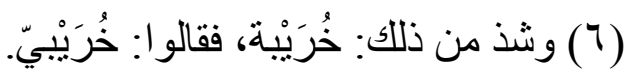

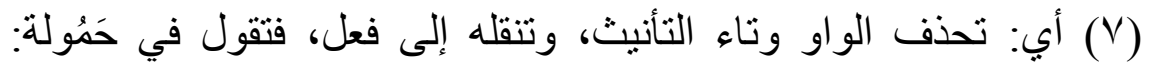

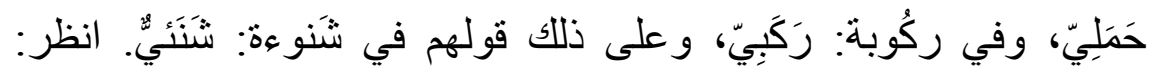

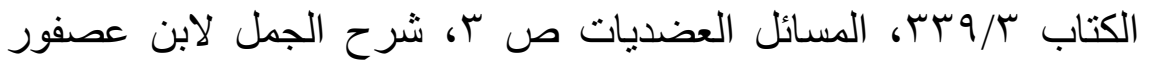
r)

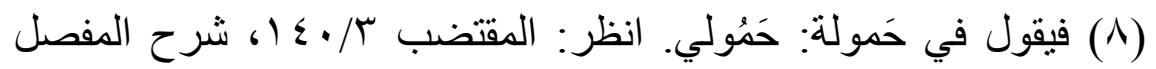

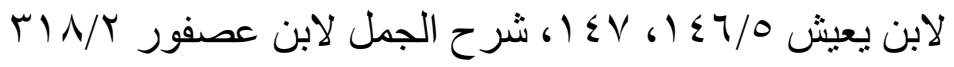




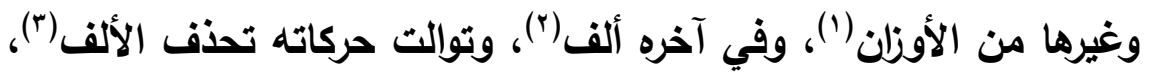

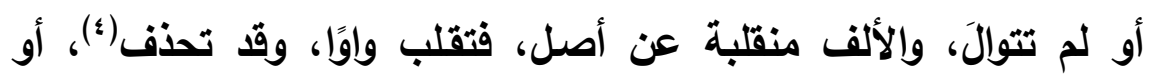
للإلحاق فتحذف، وق تقلبها(ه)، أو للتأنيث فتحذف فصيحًا، وقد تقلبها،

وتجوز زيادة ألف قبل الواو (־). أو ليست في آخره ألف(v)، بل همزة(^) أصل فالإثبات(ه)، أو بلادل من أصل فهما(·) أو في آخره واو فتبقى، أو ياء فيجوز قلبها همزة، وإذا قلبت فإن شئت أبقيتها، وإن شئت قلبتهما واوًا(')"، وإن عري عن ذاءو ذلك، وقبل

$$
\begin{aligned}
& \text { (1) (1) لا يخلو أن يكون في آخره ألف أَو لا يكون. }
\end{aligned}
$$

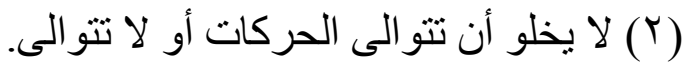

$$
\begin{aligned}
& \text { (ب) ثقول في جمزى: جَمزيّ. }
\end{aligned}
$$

(ع) فتقول في النسب: مَلهَوِيّ، وقد يجوز حذف حَف الألف، وذللك قليل، فتقول:

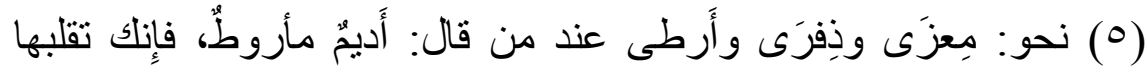

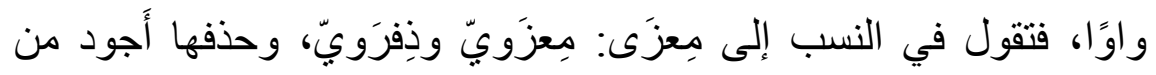

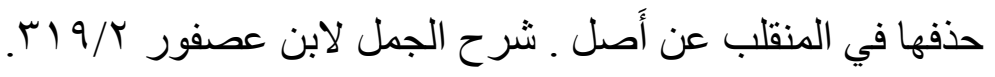

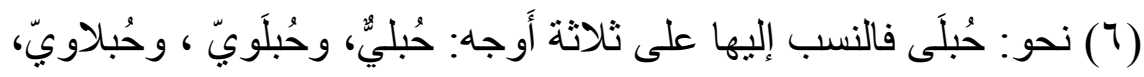
و الأفصح حذفها.

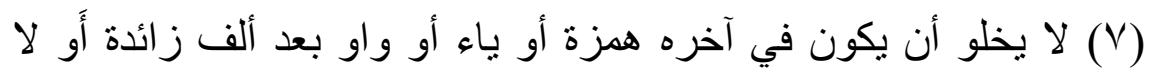
يكون.

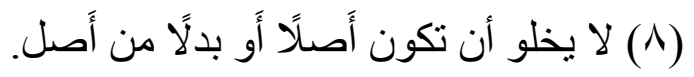
(9) نحو: حِربائي ، وقُبائي. ( · (1) نحو: كسائي ، وردائي. (11) نحو: سقائي في سِقاية. 
آخره كسرة، فعلى لفظه، ويجوز قلبها فتحةً (1)، أو بعدها ياء، فإن لم تقلب

الكسرة حذفت الياء، وإن قلبتها قلبت الياء ألفا، وقلبتها واوًا(؟). الخماسي(") الأي في آخره ألف، أو ياء قبلها كسرة تحذف()؛، أو همزة بعد ألف(ه) زائدة للتأنيث فلا يجوز إلا قلبها واوًا (־)، أو أصلاً فثبت، ويجوز القلب، أو بدلا منه أو ملحقة فالإثبات، والقلب والإثبات في البدل أحسن

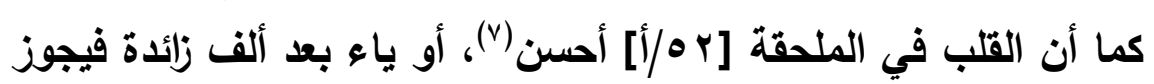
قلبها همزة وواوا (^). أو قبل الآخر ياء مشددة فتحذف المتحركة منهما (9) إلا إن كان بعد الياعين حرف مد ولين فلا تحذف(·)، وما بقي من الخماسي والرياعي

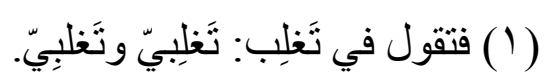

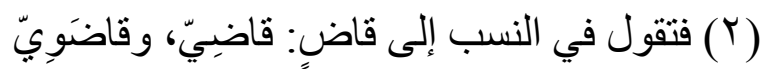

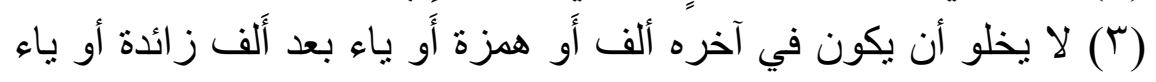

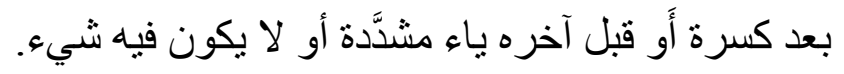

$$
\text { ( ) ) تقول في النسب إلى مُر امَى: مُر امِيّ. }
$$

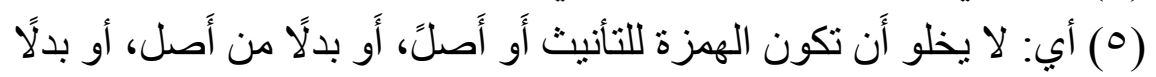

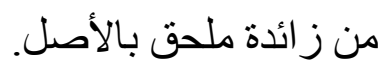

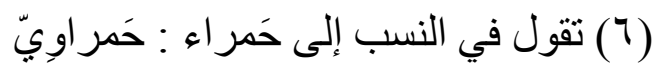

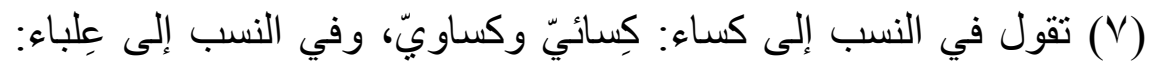
عِلبائيّ و عِلباويّ، و الإثبات في كساء أحسن، و القلب في عِلباويّ وبابه أَحسن

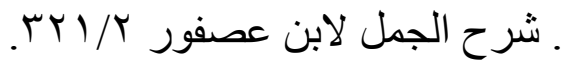

$$
\begin{aligned}
& \text { (^) تقول في النسب إلى دِرحايَة: دِرحائي، ودِرحاويّ. }
\end{aligned}
$$

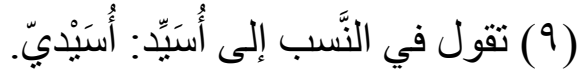

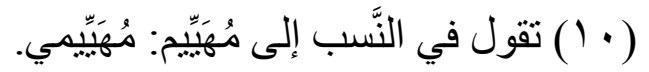




\section{الموفور من شرح ابن عصفور}

د/ لحمدمحسمد الجنـدي

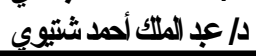

ينسب إليه على لفظه إلا ما شذأئه (1).

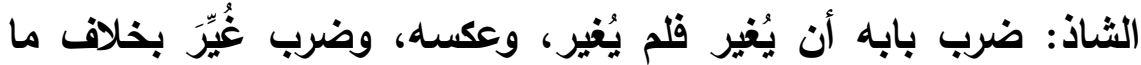

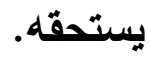

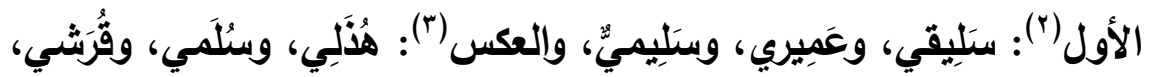

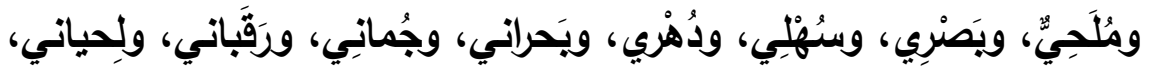

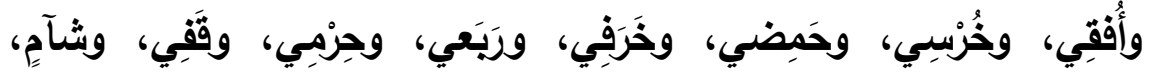

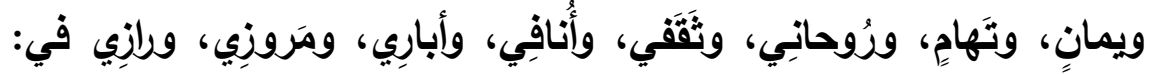

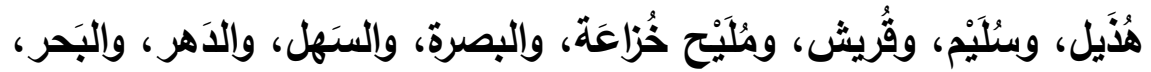

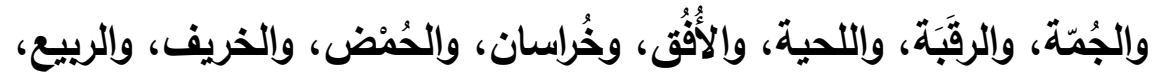

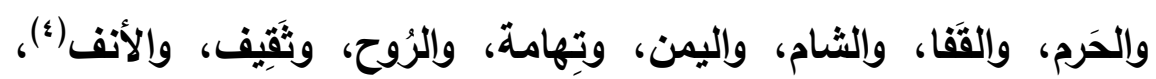

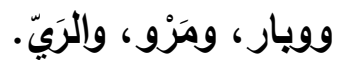

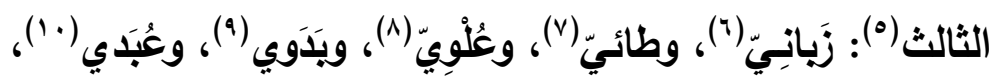

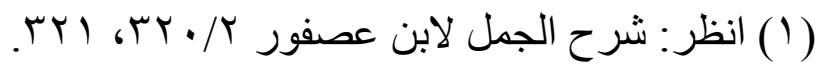

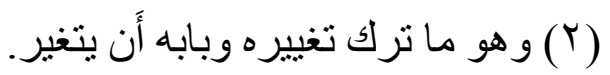

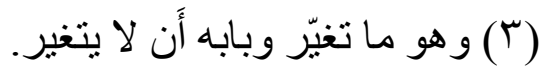
( ) ( ) أي: الرجل العظيم الأنف.

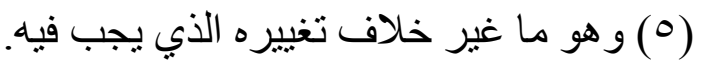
(7) و وبابه: زَبَنَيّ. (V) و وبابه: طَيَيْيّ.

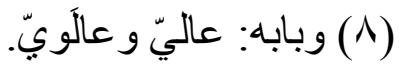

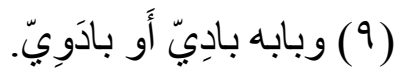

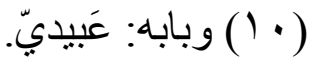




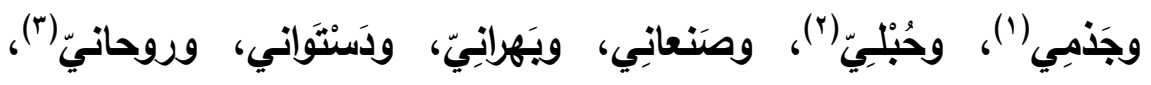

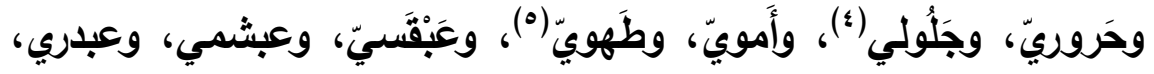

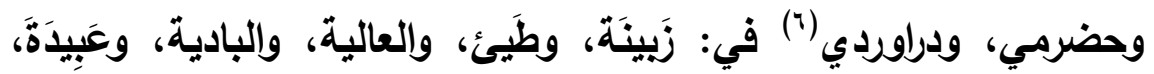

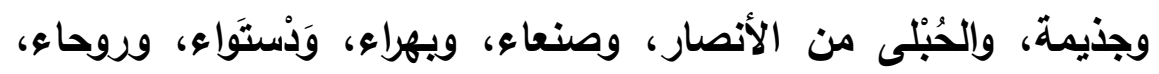

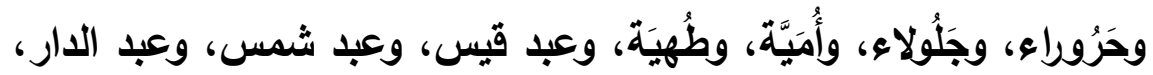
وحضر موث، وداربجرد.

نون التوكيد: لا تدخل إلا على الأمر(V)، والتهي(^)، والدعاء،

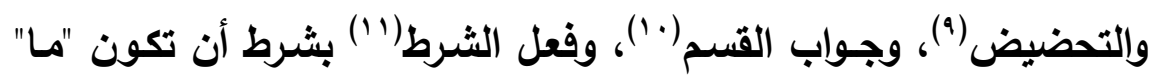

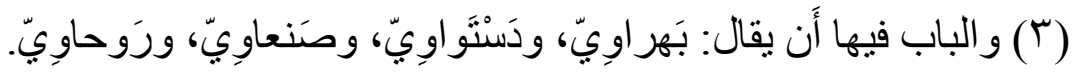

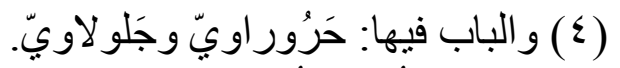

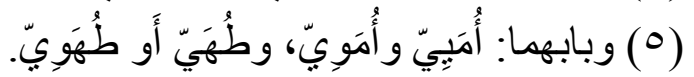

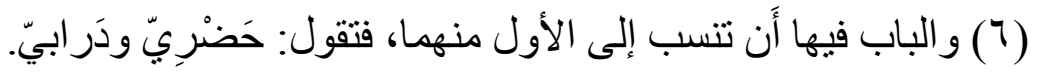

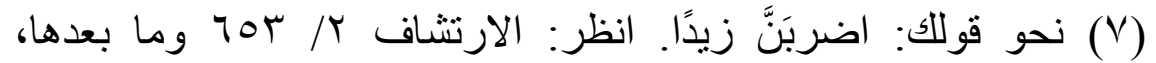

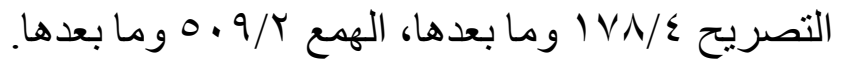
( ) نحو قوللك: لا تضرِبَنَّ خالدًا. (9) كقول الثاعر : (9)

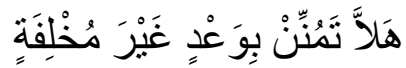

$$
\text { ( • (1) نحو قولك: و الله ليقومنَّ زيدُ. }
$$

(1) نحو قولك: إنْ تضربنَّ زيدًا يُسِيْْ إليك. 
قد زيلدت بعد الأداة(1) [ץ ه/ب]، فإن لم تكن زيدت فلا تدخل إلا ضرورة

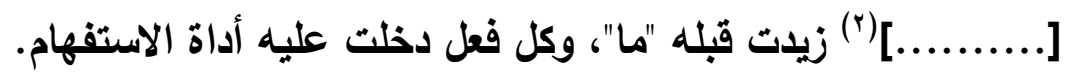
والأفعال التي ياخل فيها النونان إن كانت صحيحة غير مضعفة، ولم يتصل بها ضمير أدخلت النونين، وفتحت آخر الفعل() بناء، وقيل: لالتقاء الساكنين، أو اتصل مذكرًا ضمير تثنية ألحقت الثديدة لا الخفيفة. والساكنان إذا التقيا في كلمة، وإحداهما الألف، ويعده غير مشدد لم يجز الجمع بينهما عندنا(؛)، وذلك مقيس عند الكوفيين(॰)، ولا ينقاس عندنا، أو الياء والواو، ويعدهما غير مشدد لـ يجز الجمع بينهما، أو مشدد لا أصل له في الحركة لم يجز الجمع بينهما، أو له أصل في الحركات جاز، لهول

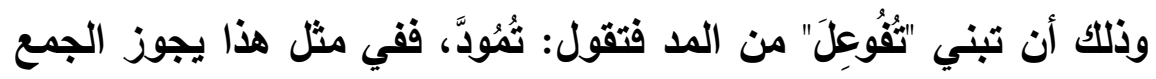

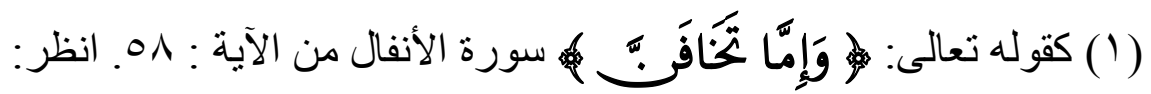

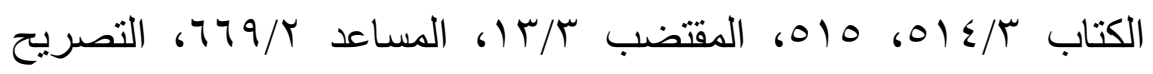
$.1 \wedge r / s$ (Y) (Y) طمس بمقدار أربع كلمات.

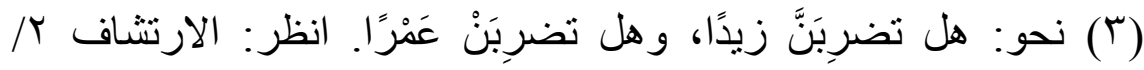

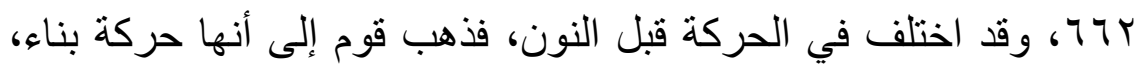
وآخرون إلى أنها حركة عارضة لالتقاء الساكنين، وهو قول سيبويه. انظر :

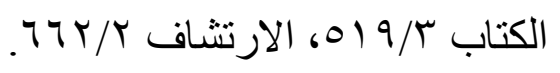
(ع) نحو قوللك: هل تضربانِّ تحذف النون ؛ لأنّها علامة إعراب و ألحقت النون الثديدة خاصة، و لا سبيل إلى إلحاق النون الخفيفة لئلا يجتمع ساكنان.

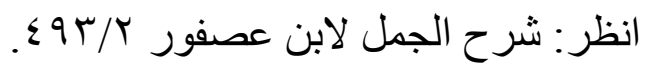
(0) أجاز يونس و الكوفيون وقوع الخفيفة بعدهما، فتقول: اضربانْ زيدًا،

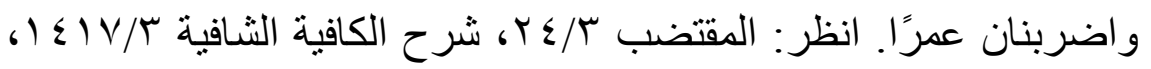

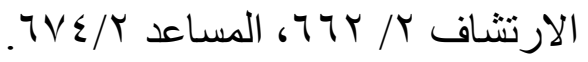


بينهما، أو ضمير الجمع فالثديدة والخفيفة، وتحذف علامة الرفع، فتلتقي

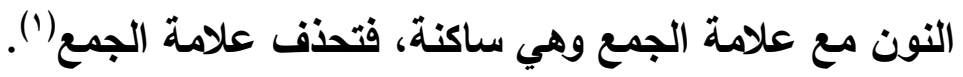
أو مؤنثًا لم يتصل به ضمير فالثديدة والخفيفة أيضاً ، ويفتح آخر الفعل، أو اتصل ضمير مفرد، فالثديدة لا الخفيفة أيضًاً ، وتفصل بين أجزاء الفعل والنون الشديدة بالألف. أو مضعقًا(ץ) فحممه حكم غير المضعف(ז) غير أن الأكثر ممن كان يقول: اردد يرجع إلى لغة من كان يقول: رُدَّ. وإن كان مهموزًا فحكمه حكم غير المهموز. وإن كان معتلًّا(؛) بالياء والواو، ولم يتصل به ضمير، فإن كان لمذكر قلت: هل ترميَنَّْ؛، وادعونَّ، وترد المحذوف، أو اتصل به ضمير تثنية فالثديدة، أو ضمير جمع فالثديدة والخفيفة، وإن كان لمؤنث اتصل به ضمير مفرد

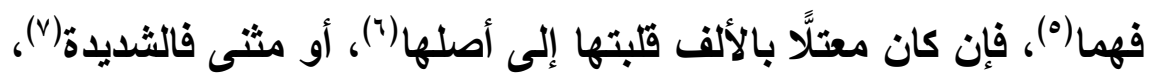

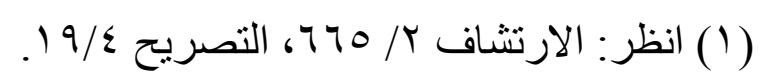
(Y)

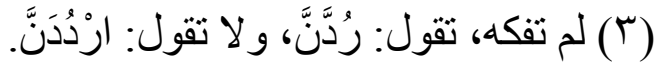

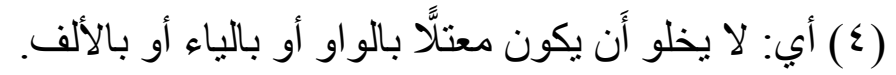

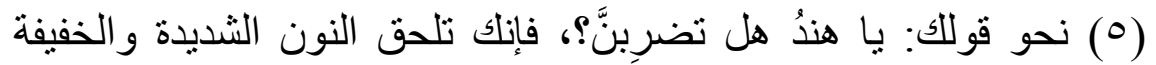
فيلتقي ساكنان فتحذف الياء لالتقاء الساكنين ويبقى ما قبل الياء على حركته

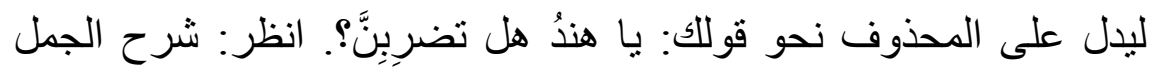

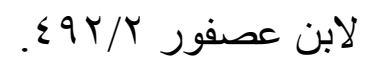

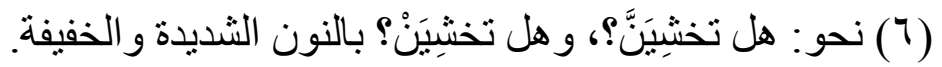

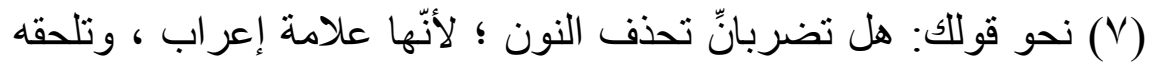
النون الثديدة فقط. 


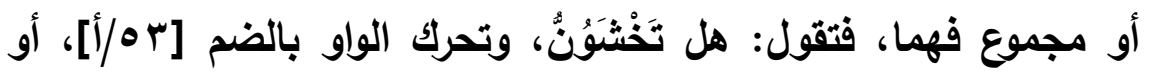

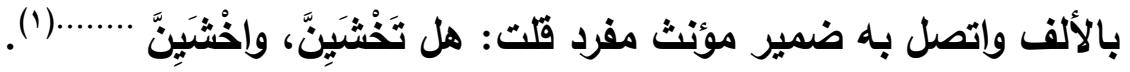
أو [....][(ץ) فالثديدة، أو جمع قلت : هل تخشينان، والوقف على الشديدة

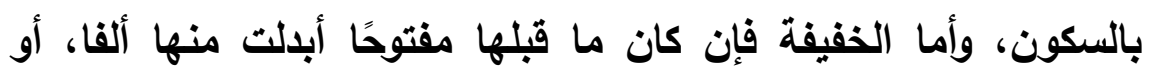
مضمومة أو مكسورة فتحذفها، وذهب يونس إلى إبدالها حرفا من جنس الحركة التي قبلها(ّ)، والنون الثديدة إذا وصلتها بساكن بعدها لم تغيرها

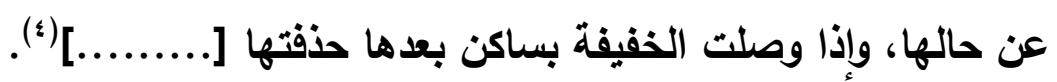

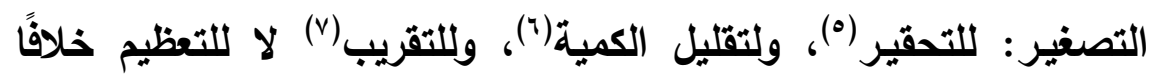
للكوفيين في ذلك(^).

$$
\begin{aligned}
& \text { ( ( ) بياض لم أستطع قر اءته. } \\
& \text { (Y) بياض لم أستطع قر اءته. }
\end{aligned}
$$

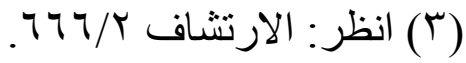

$$
\begin{aligned}
& \text { ( ) ) بياض لم أستطع قر اءته. } \\
& \text { (1) نحو: زيَيَدْ، ورُجَيْلِ }
\end{aligned}
$$

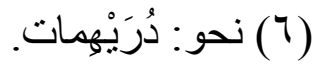

من أب: تقريب الثيء، نحو: أُخَيِّ وصُديقِّي، والمراد تقريب منزلة الأخ

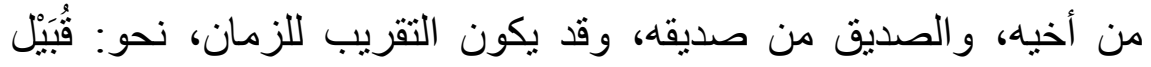

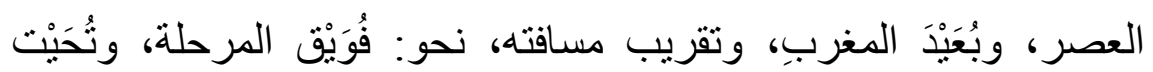

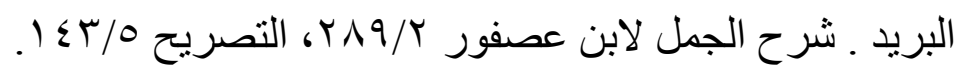

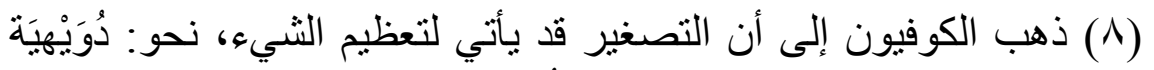

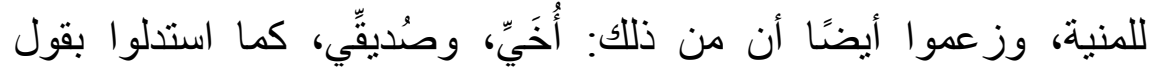

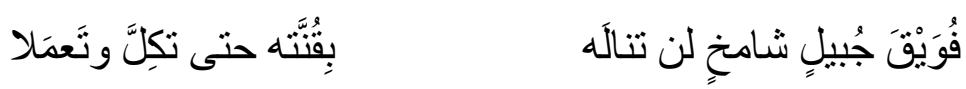


ولا يُصَغّر متوغلٌ في البناء(') إلا اسم الإشارة(؟)، و "الذي"، و و"التي"، ولا اسم استفهام أو شرط وإن أعرب، ولا مختص بالنفي (ّ)، ولا أسماء الأيام،

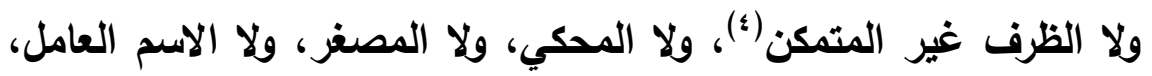
ولا جمع كثرة.

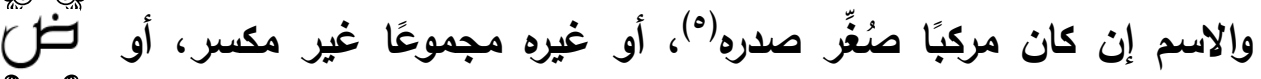

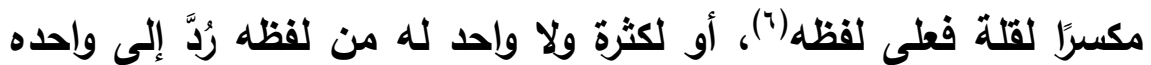
على القياس، وصُفِّر، أو له(V) واحد، ولهه جمع قلة، فيردُّ إليه، ويُصَفَّر (^)،

قالو ا: فقوله:(حتى تكلَّ وتعملا) دليل على عظمته ، وقد رُدَّ قولهم بما يتو افق

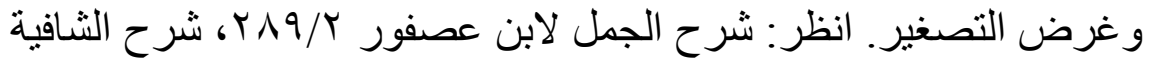

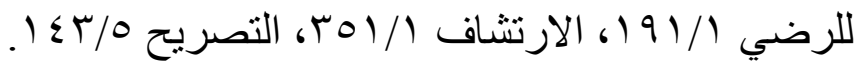

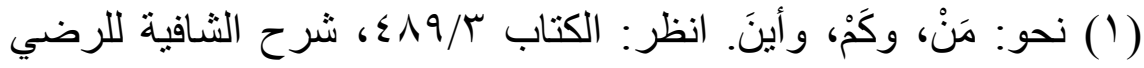

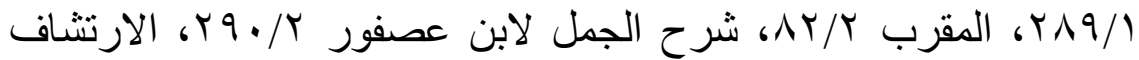

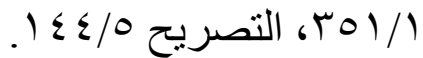

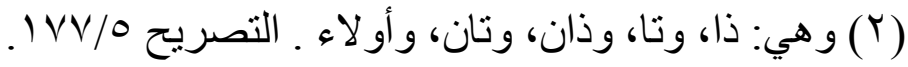

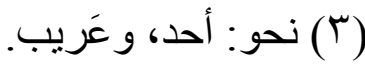

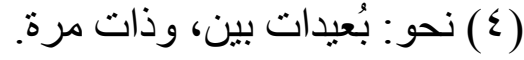

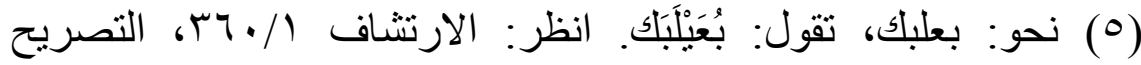

$$
.11 \mathrm{V0} 0
$$

(7) نحو: أفلُس، فإنكأك تقول: أُفَيْلسِ.

نحو: عباديد، وشماطيط، فإنك ترُدُّ إلى واحده على إنى القياس، فتقول: (V)

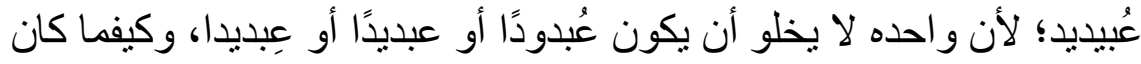

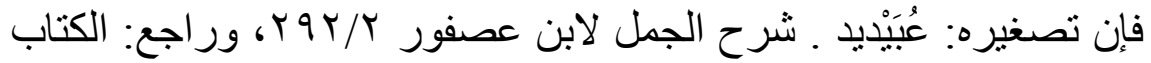

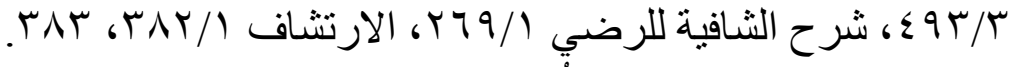
(^) نحو: فلوس، فإنك تقول: أُقليس. 
أو ليس له رُدَّ إلى واحده، وصُفِرَّ، وجمع بالواو واللنون للعاقل، ويالألف

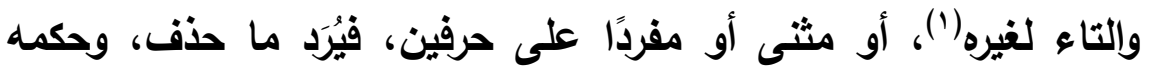
كالثلاثي (Y)، أو على أزيد ثلاثيَّا مذكرًا ضممت أوله، ويجوز كسره إن كان ثانيه ياءً، وفتحت ثانيه، وألحقت ياء التصغير ثالثة، وجرى الحرف الذي بعدها بالإعراب، أو مؤنثًا فكذلك إلا أنك تلحق علامة التأنيث إلا في حَرب، وقوس، وناب للمسن من الإبل، وعُرْسئ، فلا تلحق، أو رباعيَّا مذكرًا، فيضم أوله، ويفتح ثانيه، وتلحق الياء ثالثثة، ويكسر ما بعدها، إلا إن كان الرابع تاءَ تأتيث أو ألفَه، فتبقيه على حركته، أو مؤنثًا فكالمذكر، ولا تلحق التاء إلا أن تحذف [سه/ب] في التصغير حتى يصير ثلاثيًّا، أو يكون ظرفًا غير متمكن، أو أزيد من أربعة دون تاء التأنيث، أو ألفه الممدودة، أو الألف والنون المشبهتين لها، فإنك لا تحذفه حتى ترده إلى إلى أريعة أحرف إن لم يمكن رَدُّهُ إلى خمسة رابعها حرف علة، فإنك إن رددته إلى أربعة فقد تقدم حكمه.

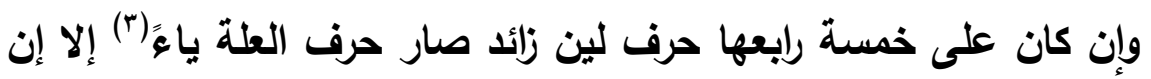

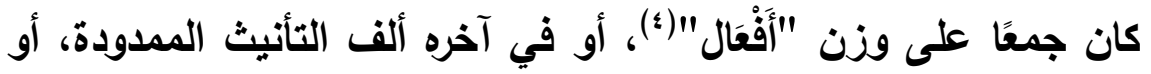
الألف والنون المشبهتان لها، وذلك كل اسم هما فيه، ولم يكسر على "فعالين"، فتبقي على حركته، فعلى هذا إذا صغرت الخماسي، فإن كانت

(1) نحو: در اهم، و عمُور، فإنلك تقول: دُرَيْهمات، و عُمَيَرون.

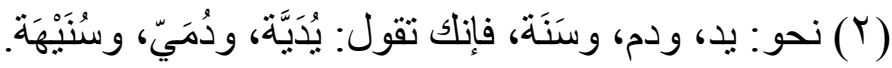

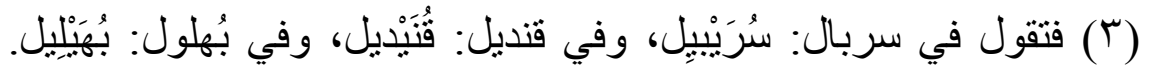

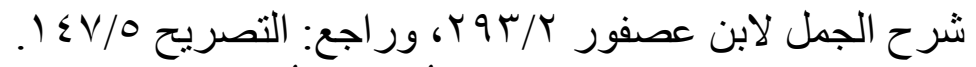

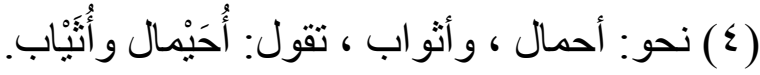




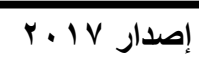

حولية كلية اللغة العربية بالمنوفية العدد الثاني والثلاثون

حروفه أصولًا حذفت الخامس(')، أو الرابع إن أشبه الزائد(؟)، وعوضت إن

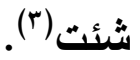

أو واحد منها فلا حذف أينما كان، أو اثنين للإلحاق حذفت أيها شئت، أو لغيره حذفت الأخير، إلا إن فضل الواحد بالتقايم، والآخر بالحركة فالخيار(؛)، أو أحدها له تركته وحذفت الآخر، والتعويض جائز في كليهما.

وإن كان أحدهما(ْ) لمعنى، والآخر لا لمعنى، ولم يَفْضُلْ أحدُهما الآخرَ، فبعض النحويين لا يحذف إلا ما ليس له معنى، وهو القياس، وتحذف واله أيهما شئت في مذهب سييويه (")، نحو: حُبَارى، تقول: حُبَيِّ، وأبو عمرو

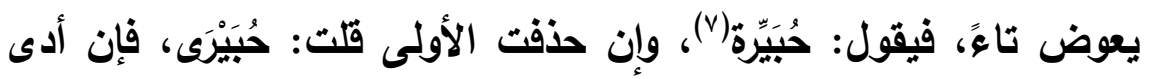

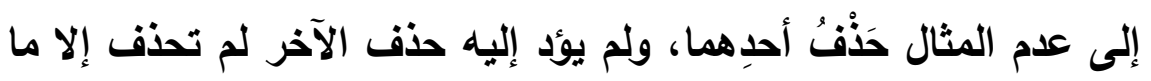
لا يؤدي(^)، فإن كان رابع الخماسي حرف مد ولين لم تحذف منه شيئًا،

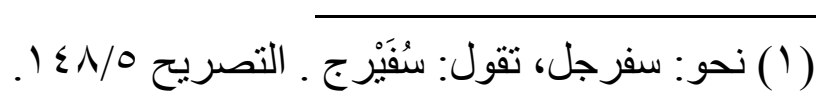

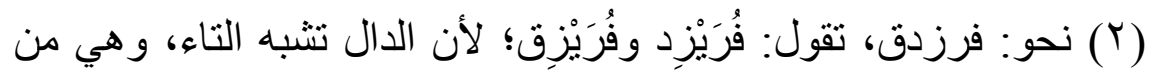

$$
\text { حروف الزيادة. }
$$

(Y) أي: عن المحذوف، فنقول: سُفَيْريج وفُرَيزيد.

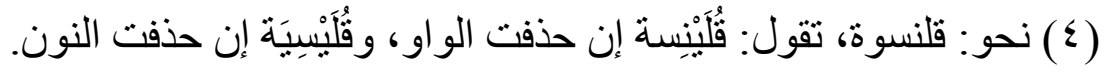

$$
\begin{aligned}
& \text { (0) أي: أحد الزيادنين. }
\end{aligned}
$$

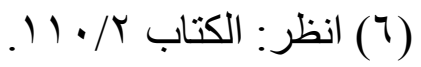

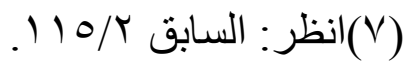

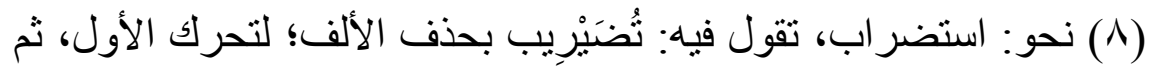
تحتاج بعد ذللك إلى حذف حرف و احد، فتحذف السين، فيبقى : تِضْر اب مثل : سربال، و لا يبقى السين؛ لأنه يبقى سِضر اب، وليس في كلامهم سِفْعال .

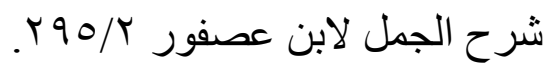


الموفور من شرح ابن عصفور

فلو صغرت (انطلاقًا) قلت: نُطَيْلِقُ، والمازني لا يجيز إلا طُليَِّّ، ويحذف

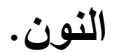

والزائد على الخماسي جارٍ على هذا القياس، والكوفيون يجيزون في الخماسي فما زاد ألا يحذف منه، فيقولون: سُفَيْرِجل بكسر ما قبل الآخر (')، وقُبَيََْثرى (r)، ومنهم من لا يجيز ذلك في الخماسي إلا بشرط أن يسكن ما قبل الآخر، فيقول:(سُفَيْرِجْل) [ـ هـ/أ].

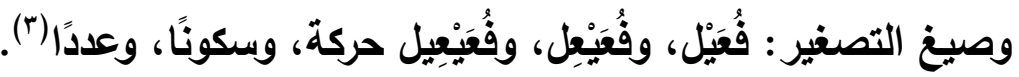
وهذا تقسيم جارٍ في التصغير، فنقول: الثلاثي المذكر الصحيح والمعتل الفاء أو العين بالواو والياء يضم أوله، ويفتح ثاتيه، وتلحق الياء ثالثة(؛)؛ وتجري ما بعدها بالإعراب إلا في مثل: وُجَيْه ونُيَيْب، فيجوز قلب الواو همزة، وكسر النون، أو بالألف فترد إلى الواو فيما هي أصله أو مجهولة، وإلى الياء فيما هي أصله، أو يائيَّا، فيبقى على حاله، أو بالألف أو بالواو، فإلى الياء.

والمؤنث كالمذكر، إلا أنتك تلحق تاء التأنيث(•)، ويفتح ما قبلها إلا ما شذ

$$
\begin{aligned}
& \text { (1) أي في سَفَرْجَل. } \\
& \text { (r) أبي في قَبَعثَرى ل) }
\end{aligned}
$$

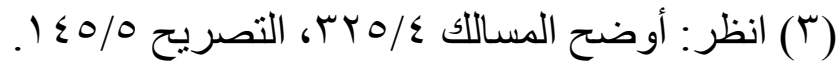

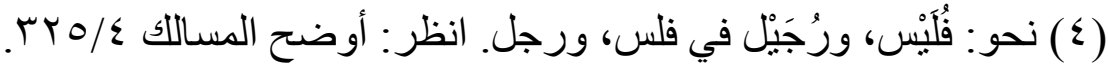

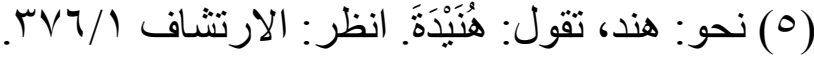




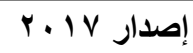

حولية كلية اللغة العربية بالمنوفية العدد الثاني والثلاثون

من ناب ، وحَرْبٍ ، وعُرْسِ ، وقَوس، فلا تلحق (')، والمحذوف كغيره(؟)،

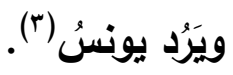

الرياعي الصحيح كالثلاثي إلا أنك تكسر ما بعد الياء إلا المؤتث بالتاء

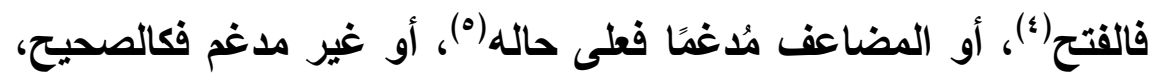

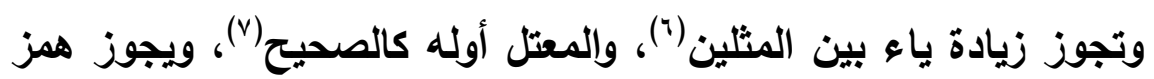

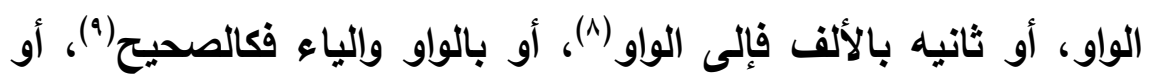

(1) لأنها مؤنثة، ولا تلحقها تاء التأنيث. انظر: شرح الثافية للرضي

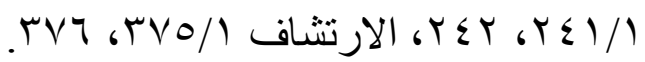

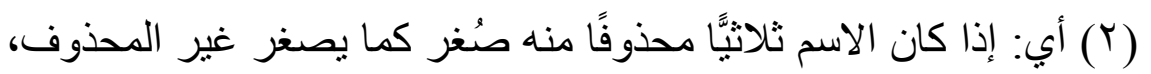

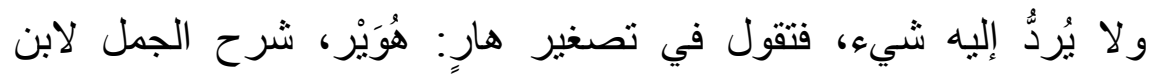
عصفور (r) أي: أن يونس يرد المحذوف، فيقول: هُوَيْيُر؛ لأن أصله هائر، وهو

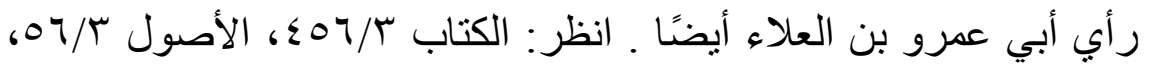

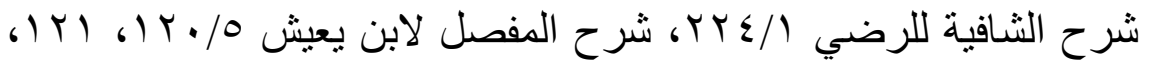

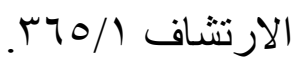

(ع) نحو :(طلحة) نقول:( طُلَيْحة).

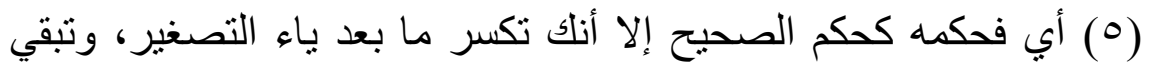

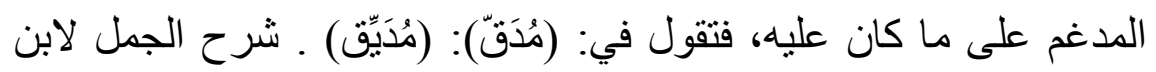
عصفور

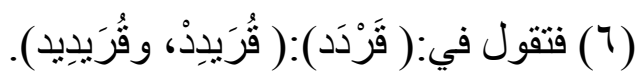
(V)

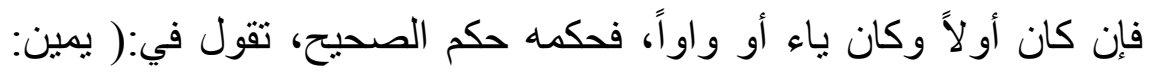

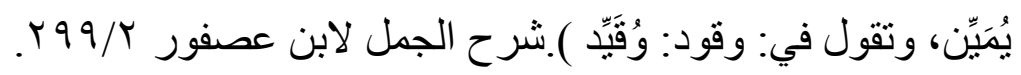

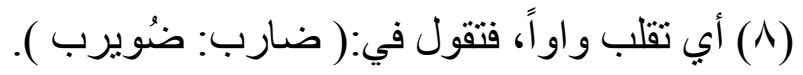

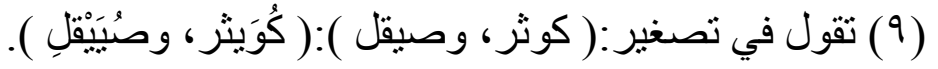




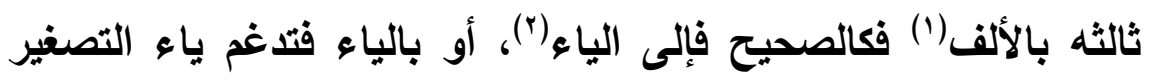

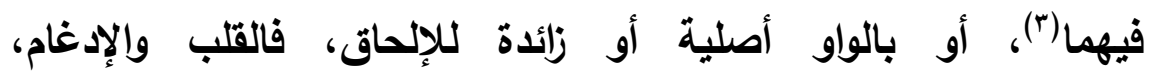
وكالصحيح(؛) أو لغيره(0) فالقلب والإدغام(") أو رابعة بالياء فكالصحيح(v)، ويالألف للتأنيث

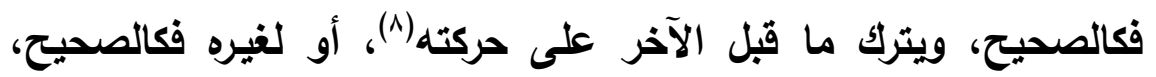
وتقلبها باء (9).

$$
\text { ( (1) بعدها في المخطوط( فكالصحيح ) و أرى أنها زائدة. }
$$

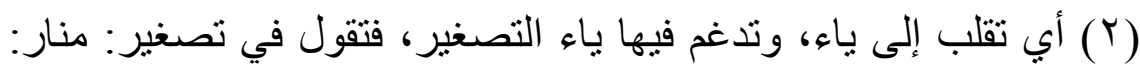
هُنَيِّرِ

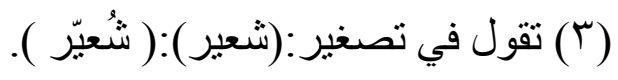

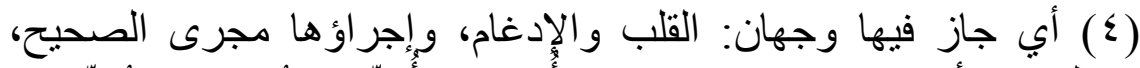

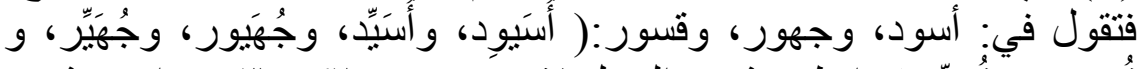

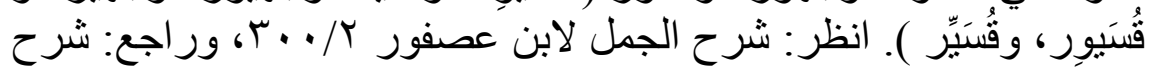

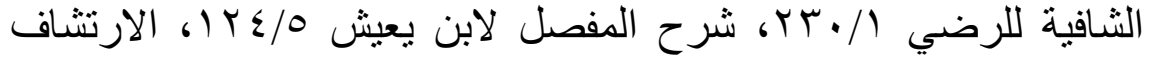
r.00/1

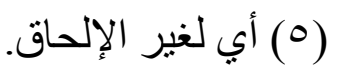

(T) أب قلبت ياء، وأدغمت في ياء التصغير ، تقول في: عجوز : عُجِيِّ.

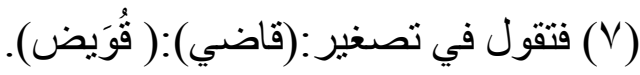
(^) نحو:( حُبْلى) تقول في تصغير ها:( حُبَيْلَى ). (9) نحو :( ملهى) تقول في تصغير ها:( مُلَيَة ). 
وإن كان في المصغر مبدل حرف علة أو همزة طرف رُدّ إلى أصله(') إن زال بالتصغير موجب البدل، أو غير طرف أو صحيح لم يرد(؟)، والمقلوب

والرباعي إن أدي به التصغير لحذف حرف منه ردت تاء التأنيث(؛)، وإن

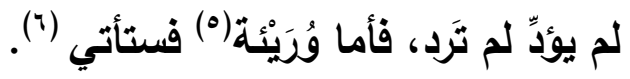
الخماسي المجرد تَحْذفف آخرَه وجويًا (v) إلا إن كان ما قبل آخره من حروف

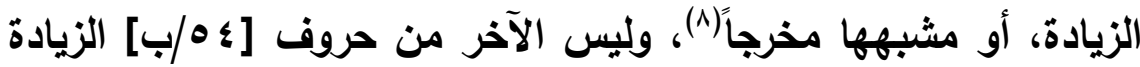
فجوازًا، ويجوز أن تحذف ما قبله، والتعويض في الكل جائز.

(1) أب: إن كان حرف علة، فتقول في موقن: مُيَيِِْن برد الواو إلى الياء؛

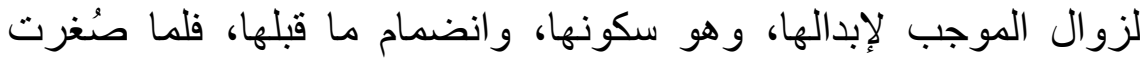

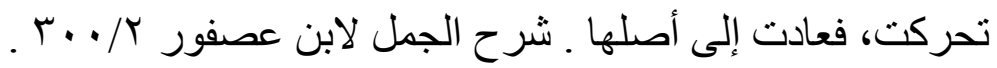
(Y)

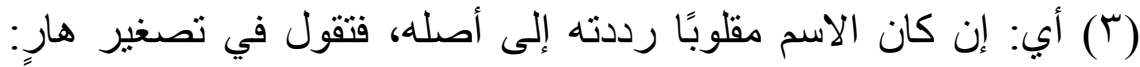

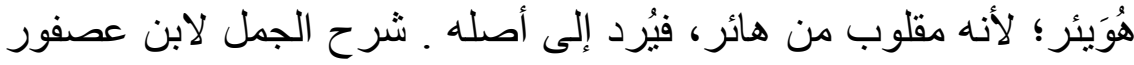
$\Gamma \cdot 1 / r$

ع) نحو: سماء، تقول في تصغير ها: سُمَيَّة.

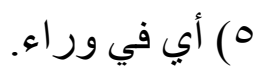

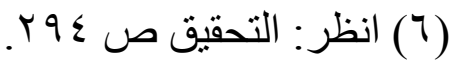

V فتقول في سَفَرجَل: سُفَفَرِِج، ويجوز أن تعوض، فتقول: سُفَرِيِج. انظر :

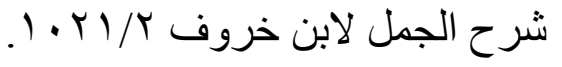

(^) نحو: خَدَرْنَق، وفَرَزَدَق، فالنون من حروف الزيادة، والدال تشبه التاء،

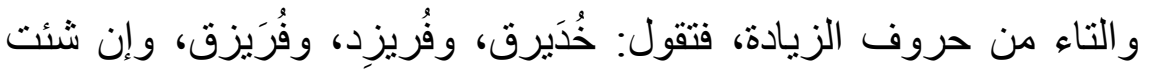


والمزيل فيه حرف تحذفه منه إلا إن كان حرف علة قبل الآخر فلا، بل

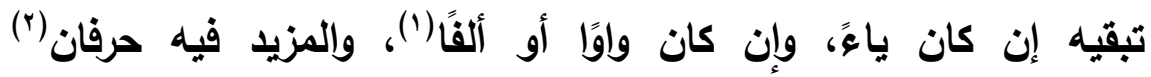
للإحاق(ז) تحذف أيهما شئت إن كانا من غير لفظ الأصل، فإن كان

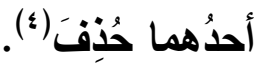
وإن كان أحدهما ملحقًا، والآخر غيرَه، حذفت غير الملحق(ه) إلا إن كان زائدًا مع الملحق دفعة واحدة، فحممه حكمه(")، وإن كانا لغير الإلحاق

عوضت باء قبل الآخر، فتقول: خُدَيْرِق، وخُدَرْيق، وفُريزيد، وفُرَيزيق،

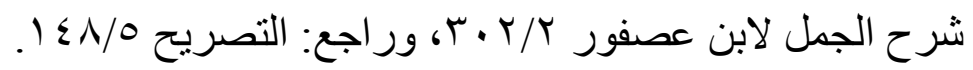

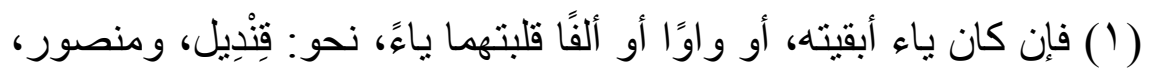

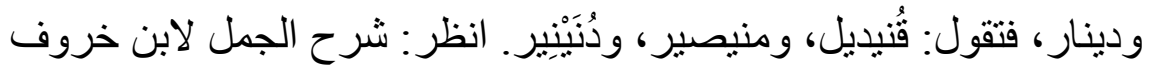
. I. TI/T

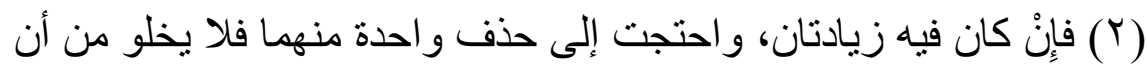
تكون للإِلحاق أو لغيره، أو إحداهما للإِلحاق، والأخرى لغير الإِلحاق. انظر

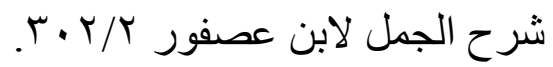

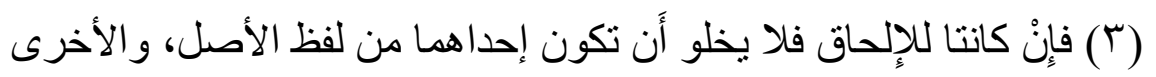

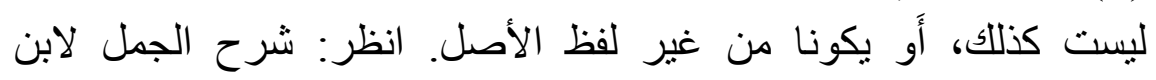

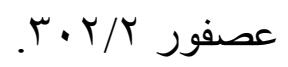

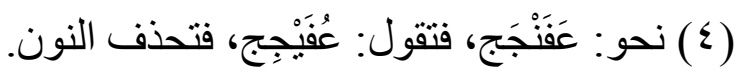

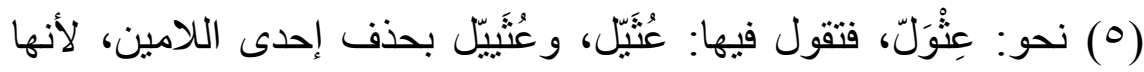
زائدة لغير الإِلحاق، وتترك الواو. انظر: شرح فئول الجمل لابن عصفور

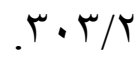
(T) نحو: مُقعَنسِس، تَقول: مُقَيَعِس. 
حذفت المفضول(')، والتقاضل بالتقدم، والتحرك، ووجود المثال(r)، فإن تفاضلا حذفت أيهما شئت("). والخماسي موازن "أفعال"، وفي آخره ألف التأنيث ممدودة أو مقصورة،

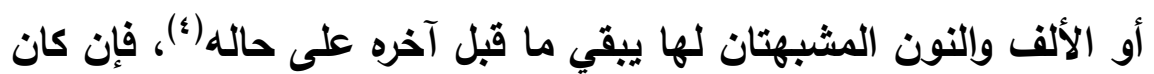
أزيد من خمسة حذف حتى يرجع إلى أربعة إن لم يمكن رده لخمسة رابعها حرف مد ولين. وحكم الحروف في الحذف حكمها في الخماسي، ولا يعتد بتاء التأنيث، ولا بألَفَيَهْه، ولا بمشبهُها، بل بما عدا ذلك. ****** $*$ *

متصرف الظروف تصغيره كغيره من الأسماء، وغير متصرفها(ه) أصلًا لا

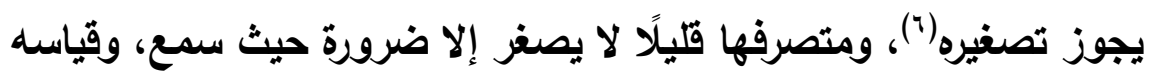
كقياس غيره، إلا أنك تلحق المؤنث منه تاء التأنيث وإن زاد على الثلاثة. ****** $* *$

$$
\text { ( ) ( ) أي: وتركت الفاضلة. }
$$

(r) نحو: منطلق، تقول في تصغيره: مُطَيِْقِق بحذف النون؛ لأنَّ الميم

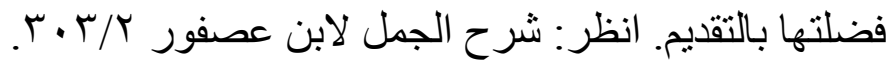

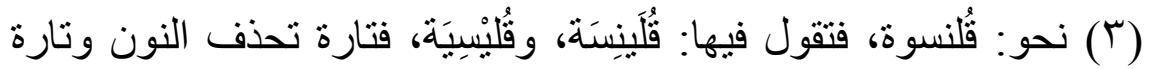

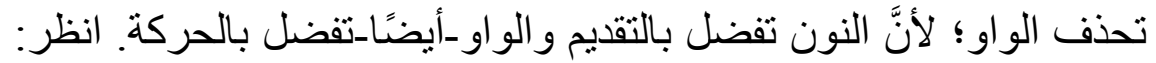

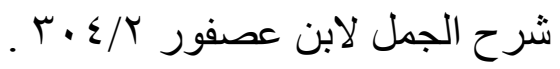

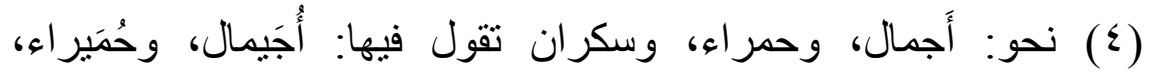
وسُكير ان. (0) غير المتصرف ينقسم قسمين: قسم لم يتصرف في موضع أصلًا، وقسم يتصرف قليلًا. (T) نحو: بُعيداتِ بَيْنِ، وذاتَ مرَةِّ، وسبحانَ الله. 
المتوغل في البناء لا يصغز إلا اسم الإشارة، و"الذي" و"التي" و"اللاني"

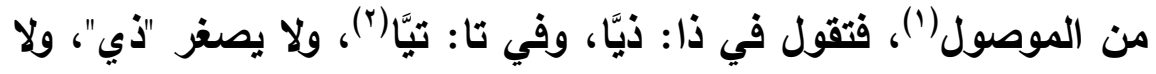

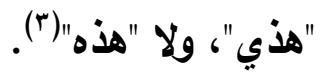

وفي "أولى" المقصورة: أُلَّْا، والممدودة: أُوليَّاءء، والحال في التثنية ولحاق الهاء والنلام والكاف كالحال في المكبر. وفي تصغير الذي: اللَّنَّاَ، و"التي": اللَّتََّّا بقتح اللام أو بضمها، وفي

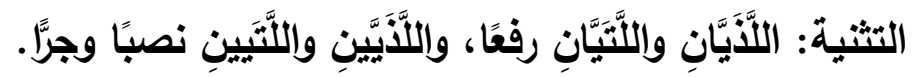

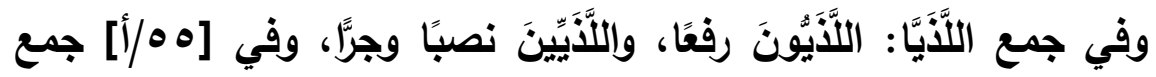

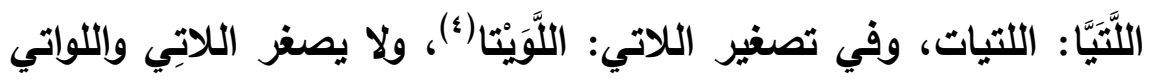
والثلَّئي (•)

وقد تحذف العرب زوائد الاسم ويسمى تصغير الترخيم(؟).

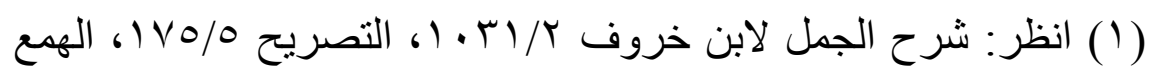
rOT/T

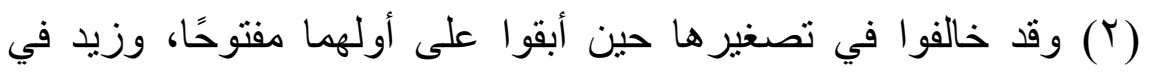

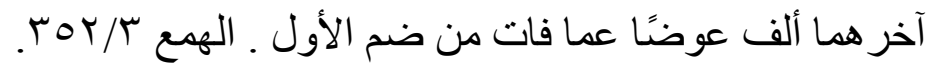

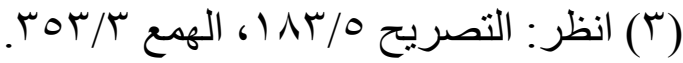

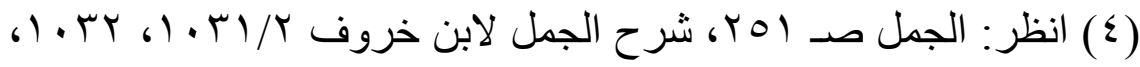

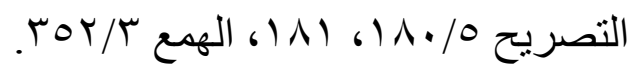

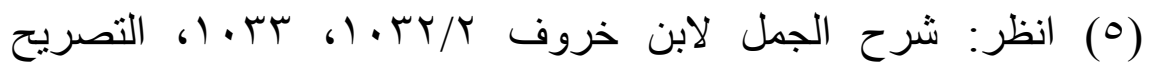

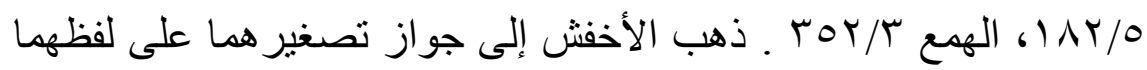

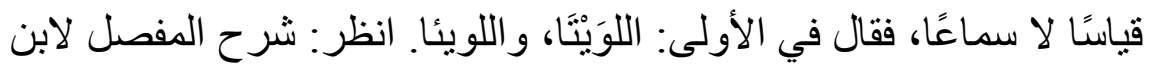

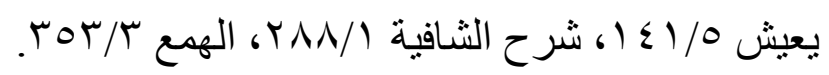
(T) نحو: اثهيباب، تقول في تصغيره: شُهيّب. انظر: التصريح

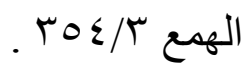




\section{التكسير}

سبق أن الجموع جمع سلامة وسبق حكمه(')، واسم جمع، ولا يارك بالقياس إنما هو محفوظ، وجمع تكسير، واسم جنس، وهما اللأن يذكران

هنا.

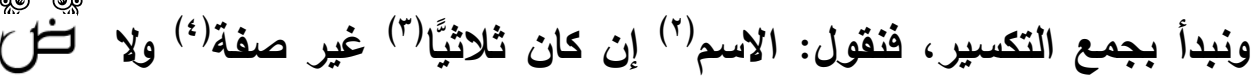

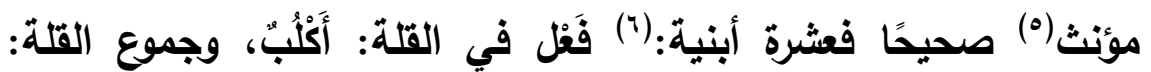

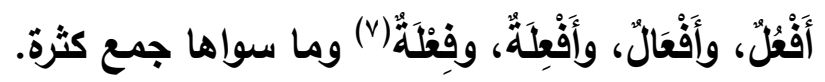

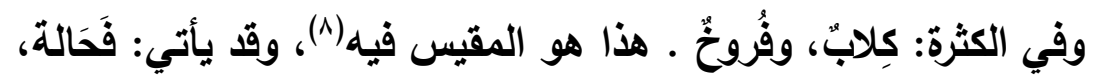

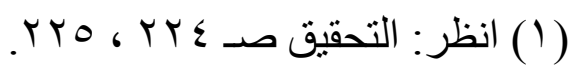
(Y) الاسم الذي ير اد جمعه جمع تكسير لا يخلو أن يكون ثلاثيَّا أو رباعيَّا أو (Y) زائدًا على ذلك.

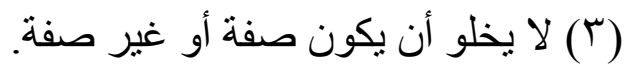

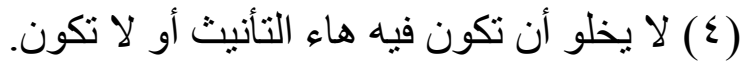

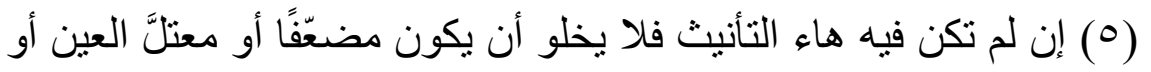
اللام أو صحيحًا.

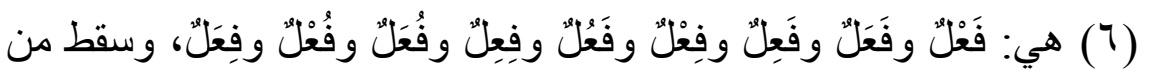

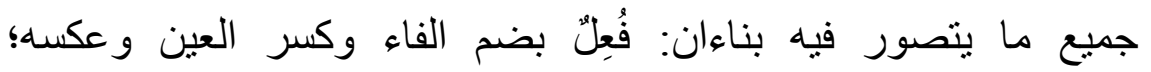

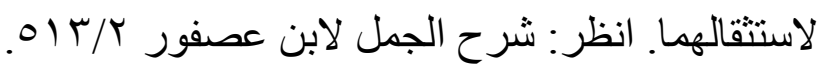

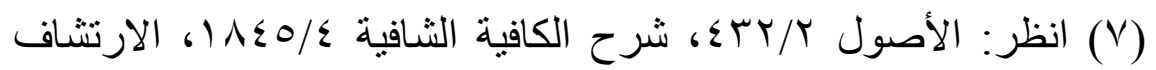

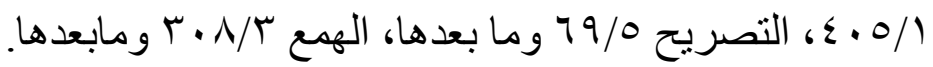
(^) ( أي: على فُعول وفِعال. 


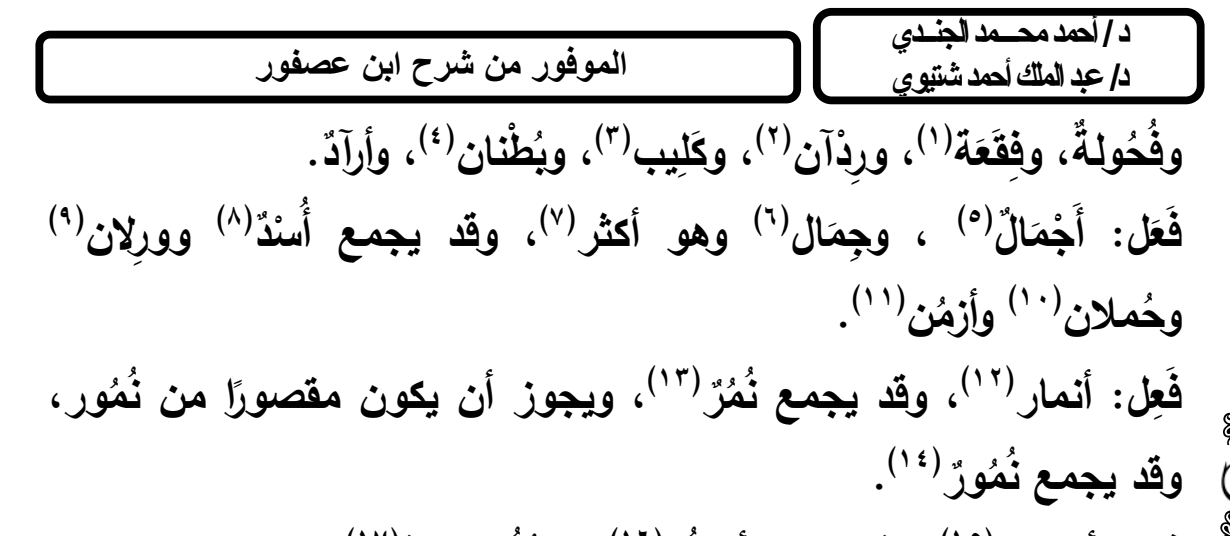

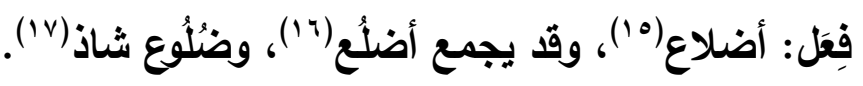

(1) أي: يجمع في الكثير على فِعَلَة.

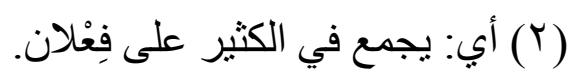

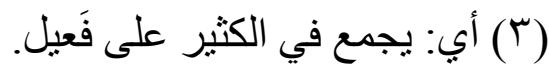

( ) أب: يجمع في الكثير على فُعلان.

(0) أي: يجمع في القليل على أفعال.

(7) أي: يجمع في الكثير على فِعِال.

(V) لأنه يجمع في الكثير أيضاً على فُعُول، وفِعال أكثر منها.

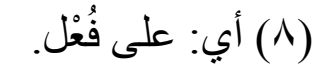

(9) (9) أب: على فِعْلان.

(1) (1) (1) أي: على فُعُعلان.

(1) (1) أي: يجمع في القليل على أفعُل.

(T) (T) أي: يجمع في الكثير و القليل على أفعال.

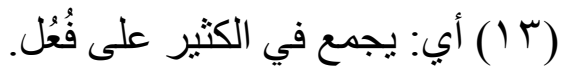

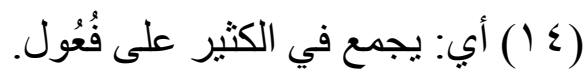

(10) أب: يجمع في الكثير و القليل على أفعال.

(17 (1) أي: يجمع في القليل على أفعُل.

( ) ( IV) 


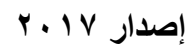

حولية كلية اللغة العربية بالمنوفية العدد الثاني والثلاثون

فُعُل: أعناق (')، ولا يتجاوزه.

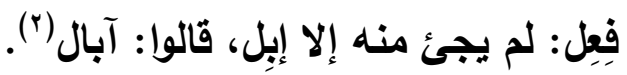

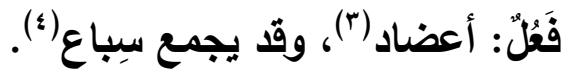

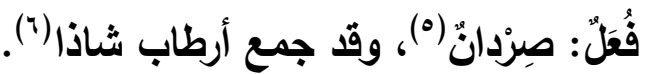

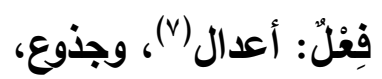

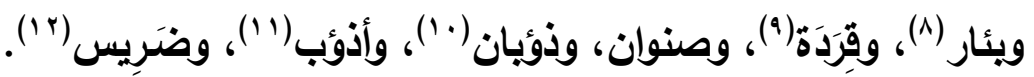

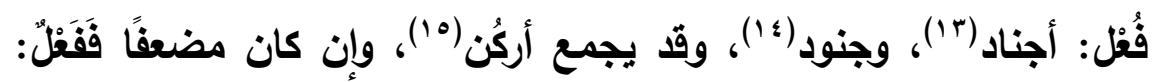

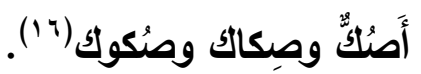

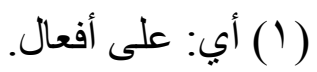

$$
\begin{aligned}
& \text { (Y) أي: في الجمع. (Y) }
\end{aligned}
$$

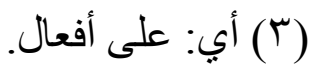

$$
\begin{aligned}
& \text { ( () أي: يجمع في الكثير على فِعال. } \\
& \text { (1) أي: على فِعْلان. }
\end{aligned}
$$

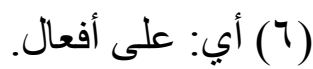

$$
\begin{aligned}
& \text { ( أي: على أفعال. (V) }
\end{aligned}
$$

(N) أي: ويجمع في الكثير على فُعول وفِعال، لكن فعول أكثر. (Y)

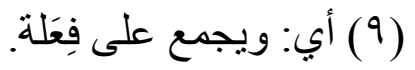

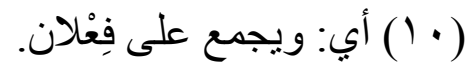

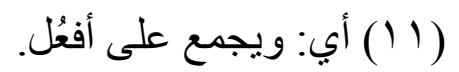

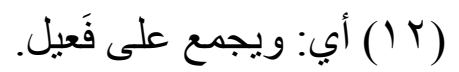

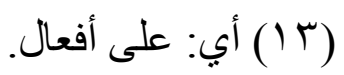

( ع ( ) أي: في الكثير على فُعول، وفِعال، أي: جنود، وجنِاد. (0) (10) أي: على أفعُل، وذللك في القليل. (7 1 أي: يجمع في القليل على (أفُعل)، وفي الكثير على (فِعال، وفُعول). 


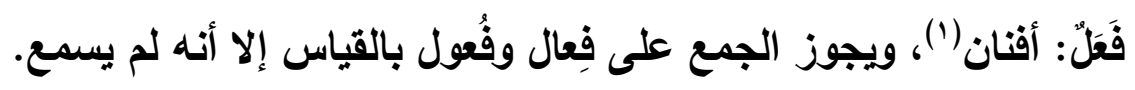

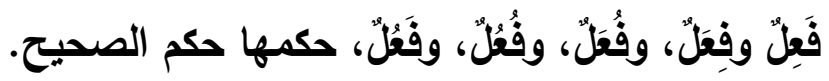

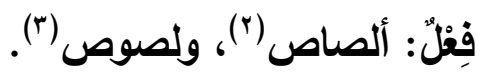

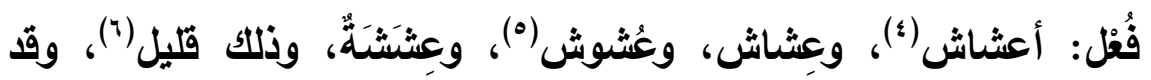

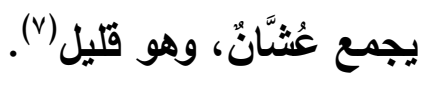

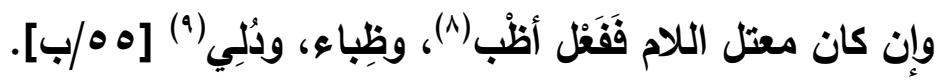

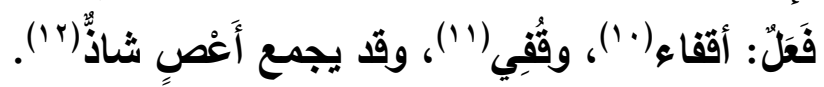

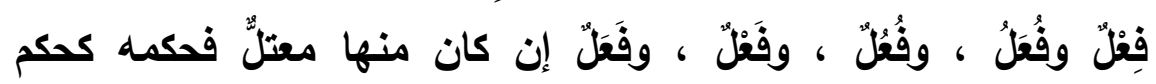
الصحيح.

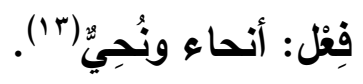

( ( ) أي: فإنه يجمع في القليل و الكثير على (أفعال).

$$
\begin{aligned}
& \text { (Y) أي: على (أفعال). }
\end{aligned}
$$

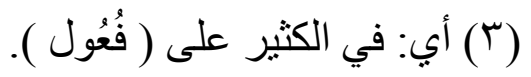

$$
\begin{aligned}
& \text { ( ( ) أي: على (أفعال). } \\
& \text { (0) أي: في الكثير على ( فُعُول، وفِعال). }
\end{aligned}
$$

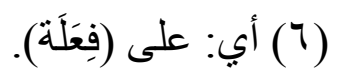

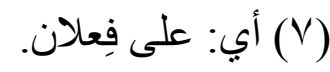

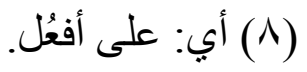

$$
\begin{aligned}
& \text { (9) أي: في الكثير على ( فِعال)، و(فُعول ) . }
\end{aligned}
$$

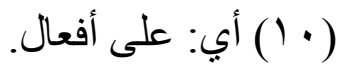

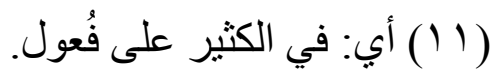

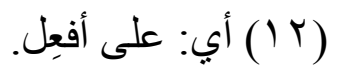

(T ( ) أي: يجمع في القليل على أفعال، وفي الكثير على فُعُول. 


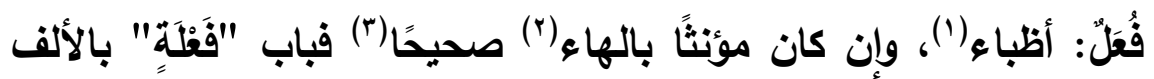

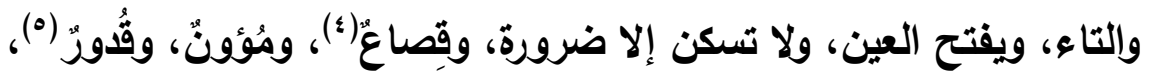
وهِضَب(")، وقد يجمع في الكثير بالألف والتاءع(v).

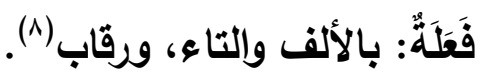

فُعْلَة: بالألف والتاء، ويجوز (9) (الفتح والإتباع والسكون، ورُكَبُ ، وبِرام (·).

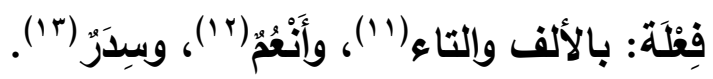

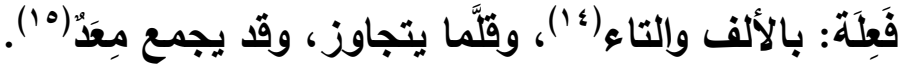
(1 ) (1) أي: على أفعال. (Y) فلا يخلو أن يكون صحيحاً أو مضعَفاً أو معتل اللام.

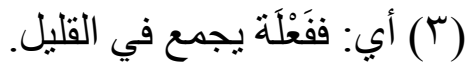
( () أي: ويجمع في الكثير على (فِعال). (1) أي: وقد يجمع على (فُعُول). (†) أي: وقد يجمع على ( فِعَل).

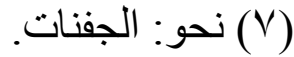
(^) أي: ويجمع في الكثير على (فِعال). (9) أي: ويجوز في عينها. ( • (1) أي: وفي الكثير على (فُعَل) و(فِعال).

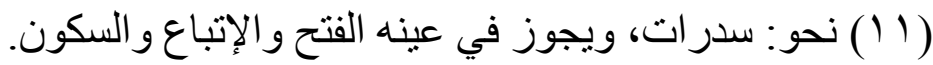
(T) ( ) أي: وقد يجمع على (أفعُل).

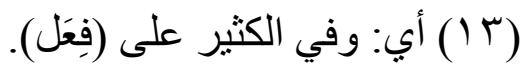

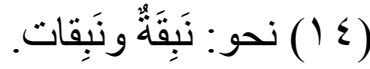
(10) أي: يجمع في الكثير على ( فِعَل). 
فُعْلَةُ: بالألف والتتاء(')، وما عدا ذلك لا يتجاوز فيه الجمع بالألف والتاء

$$
\text { في القليل، ويحذفها في الكثير. }
$$

هذا ما لم يكن مخلوقًا، فإن كان مخلوقًا، وتوجه الخلق عليه جملة واحدة جمع في القليل بهما(؟)، وفي الكثير بحذف التاء. وقا يجمع جمع المصنوع، وأكثر ما يكون ذلك فيما كثر استعماله، أو لم يتوجه دفعة واحدة، فصخار إن كان صحيحًا، وإن كان مُضعَّفًا فَفَلَةة:

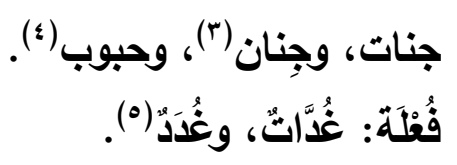

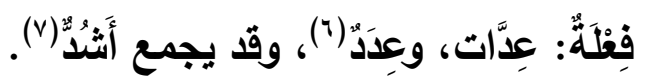

وما بقي من الأمثلة إن وجد فجمعه جمع صحيحه، وإن كان معتلّ اللام

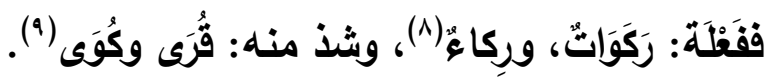

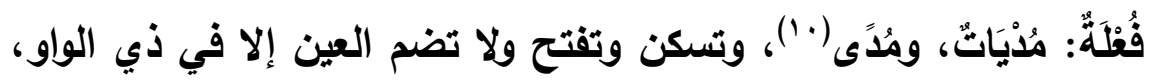

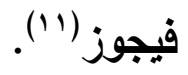

$$
\begin{aligned}
& \text { (1) (1) نحو: تُخْمَة وتُخْمَات. } \\
& \text { (Y) أي: بالألف و التاء. }
\end{aligned}
$$

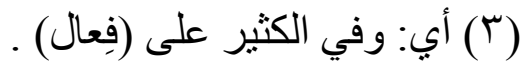

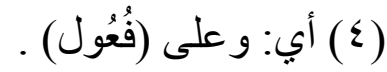

$$
\begin{aligned}
& \text { (0) أي: و على (فُعَل) في الكثير. } \\
& \text { (T) أي: و على (فِعَل) في الكثير. } \\
& \text { ( أي: وقد يجمع في القليل على ( أفعُل). } \\
& \text { (^) أب: و ولى (فِعال) في الكثير. }
\end{aligned}
$$

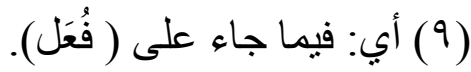

$$
\begin{aligned}
& \text { ( • (1) أي: و على (فُعَل) في الكثير. }
\end{aligned}
$$

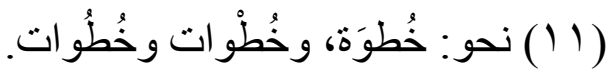


وما بقي إن جاء فجمعه كجمع صحيحه، وما كان منه مخلوقًا فبالألف والتاء(ץ)، ويحذف التاء(") إلا ما جرى مجرى المصنوع، فجمعه كجمعه.

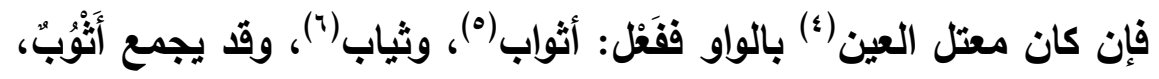

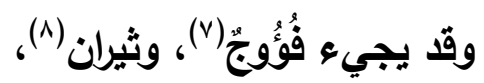

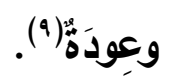

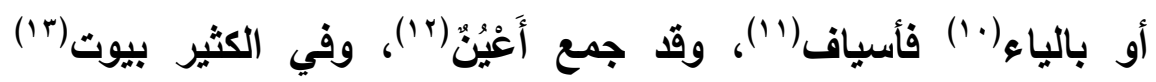

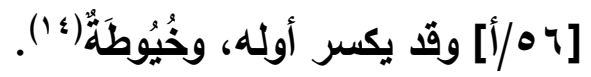

( ( ) أي: تُجمع في القليل بالألف و التاء.

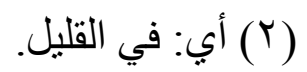
(צ) أي: في الكثير.

(ع) فلا يخلو أن يكون بالياء أو بالواو. (0) أي: يجمع في القليل على (أفعال). (†) أبي: يجمع في الكثير على (فِعال). (V) أي: قد يأتي في الكثير على (فُعول). (^) أي: وقد يجيء على (فِعلان). (9) أي: وقد يجيء على (فِعَلة). (1 (1) (1) أي: فإن كان معتل العين بالياء. (1) (1) أي: يجمع في القليل على (1) (أفعال).

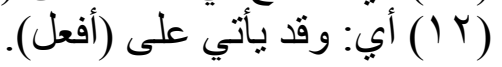

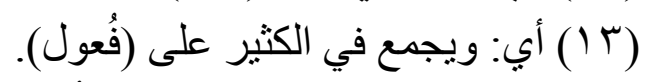

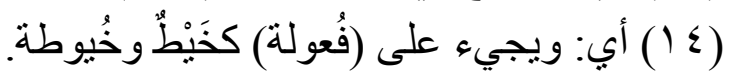




\section{الموفور من شرح ابن عصفور}

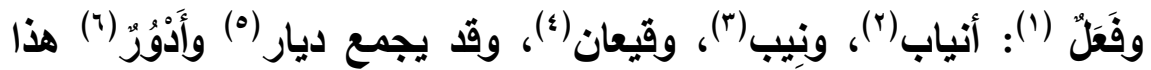
مذهب سيبويه (V) ، وزعم يونس أنه إن كان مذكرًا فأفعال ، أو مؤنثًا

فأفْعُل (^).

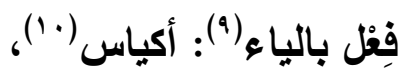

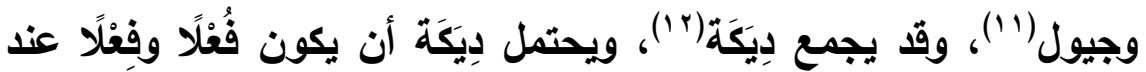

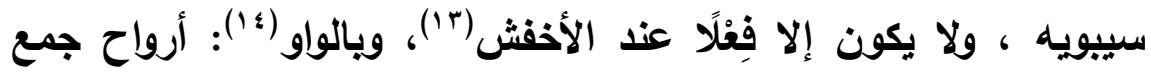

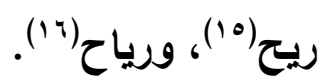

(1) (أي: إذا كان المعتل العين على (فَعْل). (Y) أي: يجمع في القليل على (أفعال).

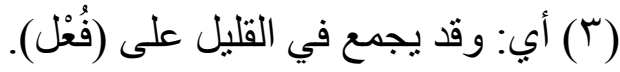
( ) ( ) ويجمع في الكثير على (فْعْلان). (0) وقد يجمع في الكثير على (فِعال). (T) (T) وقد يجمع في القليل على (أفعُل).

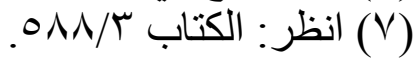

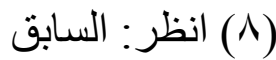

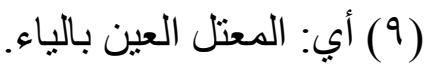
( • (1) أب: يجمع في القليل على (أفعال).

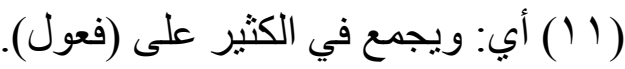

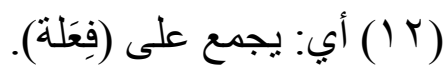

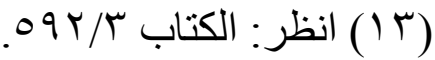

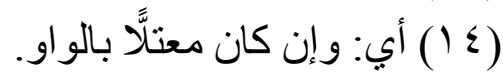
(10 (1) أي: يجمع في القليل على (أفعال). ( 7 (1) أب: يجمع في القليل على (فِعال). 


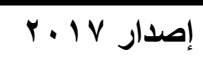

حولية كلية اللغة العربية بالمنوفية العدد الثاني والثلاثون

فُعْل بالواو: أحُوات(')، ونينان(؟)، وما عدا ذلك إن جاء فحكمه حكم

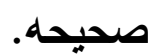

وإن كان هذا المعتل العين بالهاء ففَعْلَةُّ(َ) من ذوات الواو: روضات(؛)،

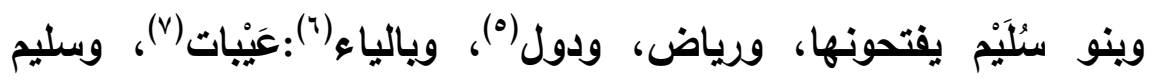

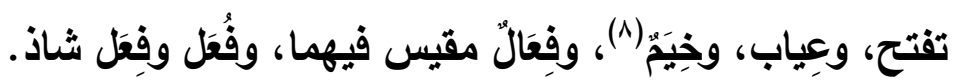

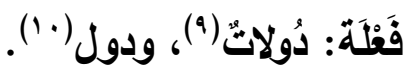

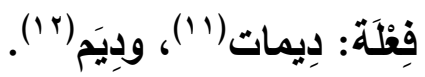

( ( ) أي: يجمع في القليل على (أفعال).

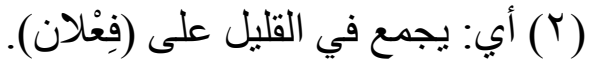

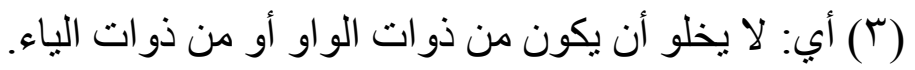

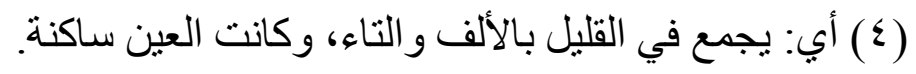

$$
\text { (0) أي: يجمع في الكثبر على (فِعال) ووفُعَل ). }
$$

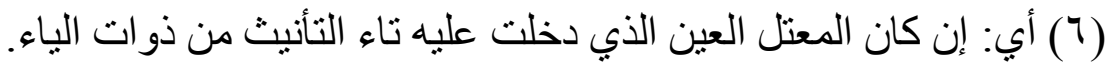

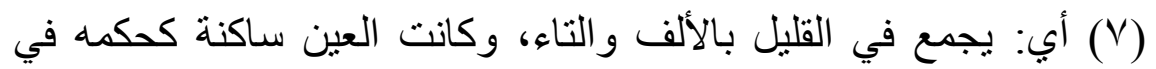

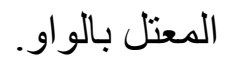

( ) أي: يجمع في الكثير على (فِعال) و (فِعَل).

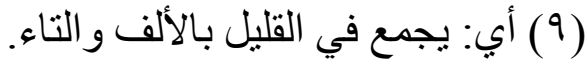
( • (1) أي يجمع في الكثير على (فُعَل).

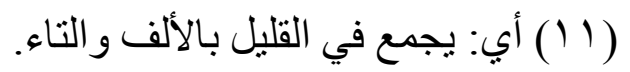
( ا ( ) أي: يجمع في الكثير على (فِعَل). 


\section{الموفور من شرح ابن عصفور}

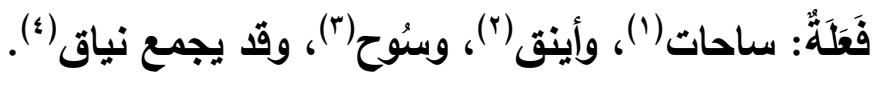
هذا كله إن كان ذو التاء واقعًا على مصنوع، فإن كان مخلوقًا فجَوْزات

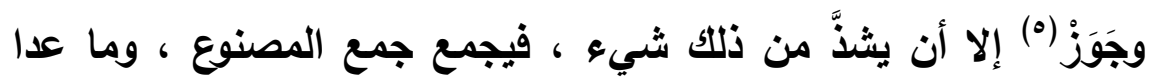
ذلك إن وجد فقياسه كالصحيح.

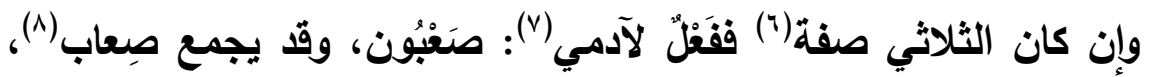

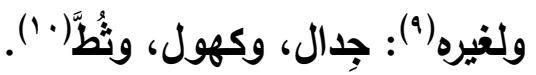

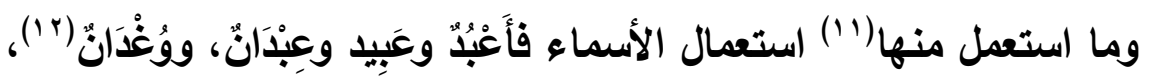

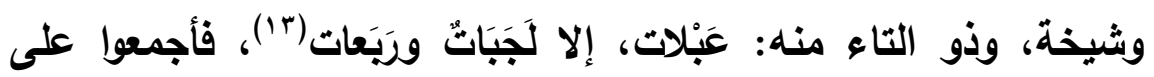

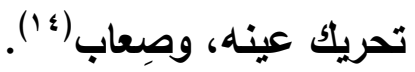

( ( ) أي: يجمع في القليل بالألف و التاء. (Y) أي: قد يجمع على (أَفعُل).

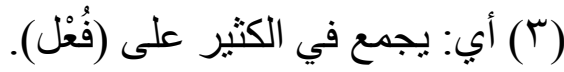
( ( ) أي: قد يجمع على (فِعال). (0) أي: جمع بالألف والتاء في القليل، وبحذفها في الكثير. (7) أي: لا يخلو أن يكون على (فَعْل) أو غير ذللك من الأوزان. ( أي: جمع بالواو و النون في القليل من الآدمبين. (A) أي: يجمع في الكثير على (فِقعال).

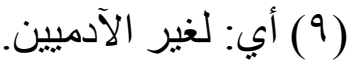
( • (1) أي: يُكسَّر قي القليل و الكثير على فِعال، أو فُعول، أو فُعْل.

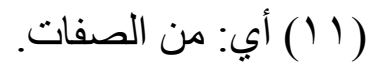

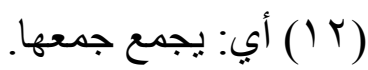
(T ( ) أي: ما كان فيه تاء التأنيث يجمع بالألف و التاء في القليل. ( ع ( ) أي: يجمع في الكثير على (فِعال). 


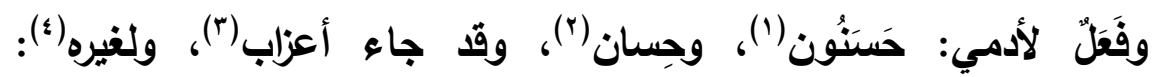

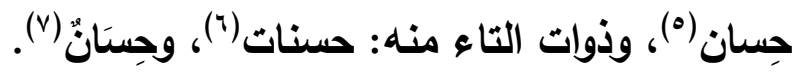

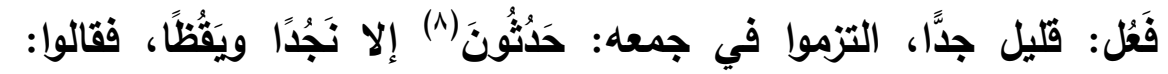
أنجاد، وأيقاظ، وحكى الثيباني(9): يَقَّاظ، ولم يجئ منه في المؤنتث شيء.

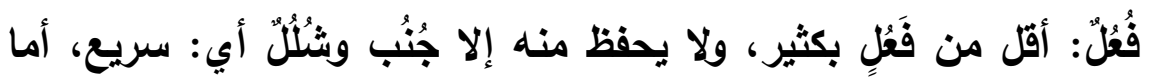
جُنُب فالأفصح إفراده، ويجوز [آه/ب] جُنبُون، وقالوا: أجناب.

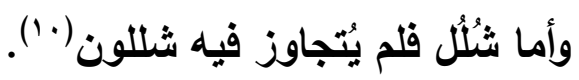

(1) (1) أي: يجمع في القليل بالواو والنون. (Y) أي: ويجمع في الكثير على (فِعال). ( (T) أي: جاء على (أفعال) قليلًا. ( ) أي: فإن كان لغير الآدميين. (0) أي: يجمع في القليل و الكثير على (فِعال). (T) أي: يجمع في القليل بالألف و التاء.

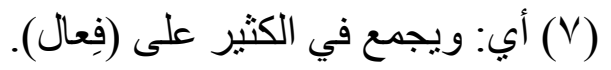

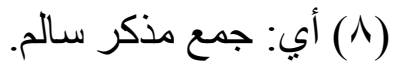

(9) هو إسحاق بن مرار الثيباني اللغوي، كان من أعلم الناس باللغة، جمع

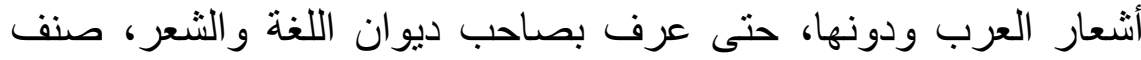

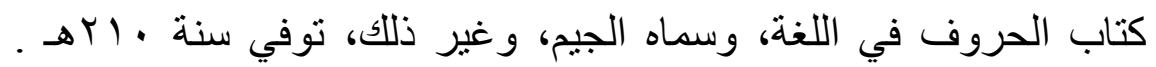

$$
\begin{aligned}
& \text { انظر: إنباه الرواة / / جه ب وما بعدها. } \\
& \text { ( • ( ) أي: جمعه بالواو و النون. }
\end{aligned}
$$




\section{الموفور من شرح ابن عصفور}

فُعْل: قليل جدَّا، لم يتجاوز فيه إن كان لأدمي حُلُوون ومُرُّونَ (1)، ويجمع

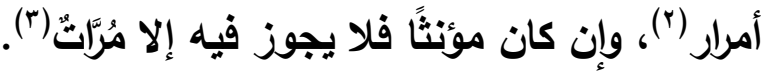

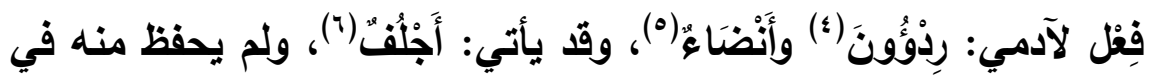

$$
\text { المؤنث شيء. }
$$

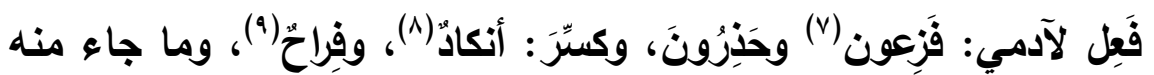
لمؤنث لا يتجاوز فيه جمع المؤنث بالألف والتاء.

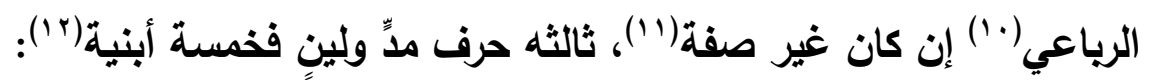

$$
\begin{aligned}
& \text { (1) أي: يجمع بالو او و النون. } \\
& \text { (Y) أي: على(أفعال). }
\end{aligned}
$$

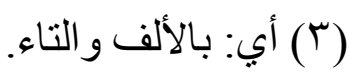

$$
\begin{aligned}
& \text { ( ) أي: يجمع بالو او والنون. بالاء } \\
& \text { (0) أي: يجمع في الكثير على (أفعال). } \\
& \text { (7) أي: بالألف والتع في التاء. } \\
& \text { ( أي: يجمع بالو او و النون. (V) } \\
& \text { (^) (أي: يُكسر على (أفعال). } \\
& \text { (9) أي: وكسروه على (فِعال). }
\end{aligned}
$$

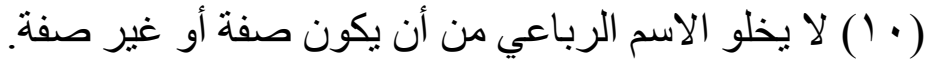

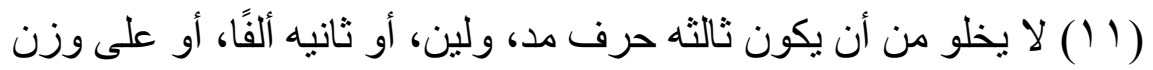

(أفعل)، أو على غير ذللك من الأوزان.

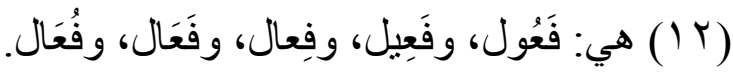


فِعال: أخمرة(') وخُمُر (ץ)، ويجوز تسكين العين (ז)، ومضاعفه ومعتل لامه

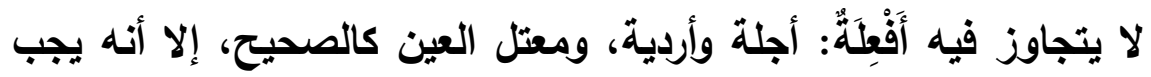
في فُعْلٍ الواويِّها تسكينُ العين: سورُ، وتُحَرَّك ضرورة، وفي اليائيّها التحريكُ والتسكينُ: عُيُنْ وعُيْنُ.

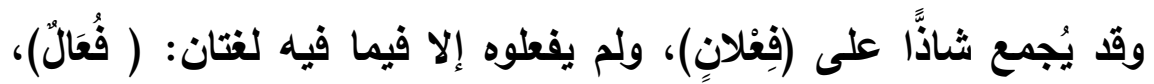
و (فِعال)، قُالوا: صُوار، وصِيرانٌ.

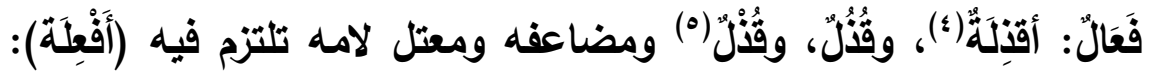

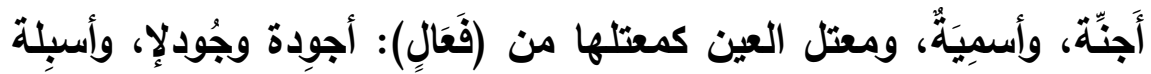
وسيُّبل وسبل.

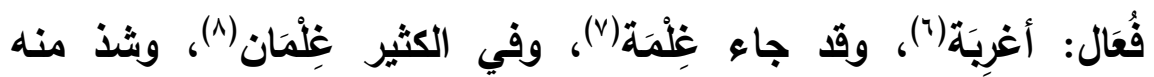

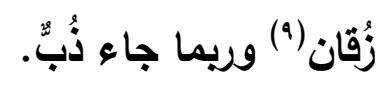

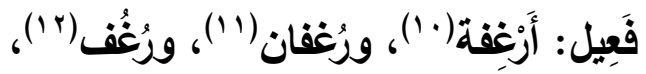

$$
\begin{aligned}
& \text { ( ( ) أي: يجمع في القلة على (أفعِلَة). }
\end{aligned}
$$

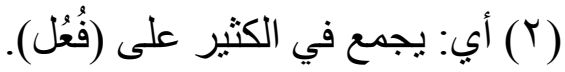

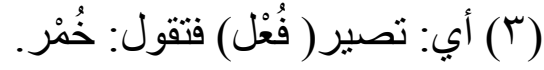

$$
\begin{aligned}
& \text { ( () أي: يجمع في القلة على (أفعِلَة). } \\
& \text { (0) أي: يجمع في الكثير على (فُعُل)، أو (فُعْلَ). } \\
& \text { (T) أي: يجمع في القلة على (أفحِلَة). } \\
& \text { ( أي: جاء على (فِعْلَة) قليًَا. } \\
& \text { (A) أبي: جاء على (فِعْلان) كثيرًا. } \\
& \text { (9) أب: جاء على (فُعْلان) كثيرًا. } \\
& \text { ( • ( ) فيجمع في القليل على (أفعلة). }
\end{aligned}
$$

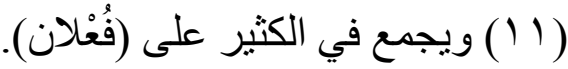

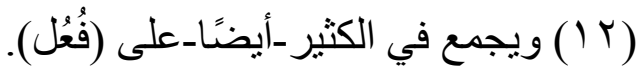


وقد يجمع قِضْبَان، وأنصِباء (').

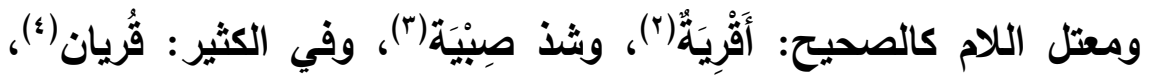

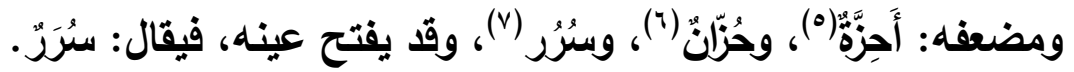

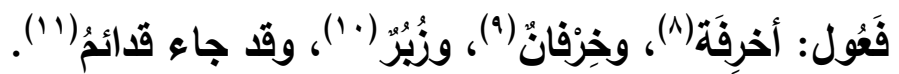

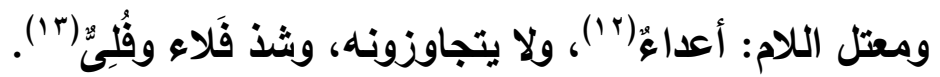

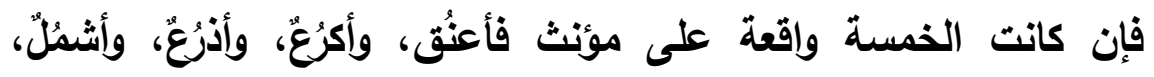

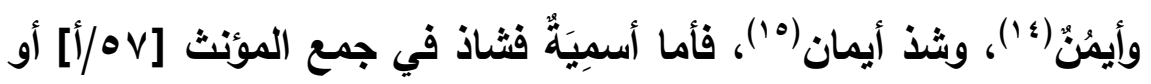
جمع سماء، وسماء مذكر، قولان.

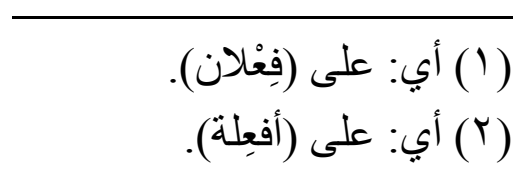

(Y) أي: شذ جمعه في القليل على (فِعلَة).

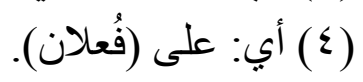

(0) أي: يجمع في القليل على (أفعِلة).

(T) أي: وفي الكثير على (فُعلان).

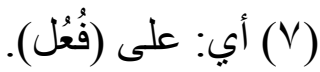

(^) أي: يجمع في القليل على (أفعِلة).

(9) أب: وفي الكثير على (فِعْلان).

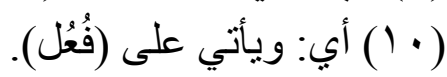

(1) (1) أي: على (فعائل).

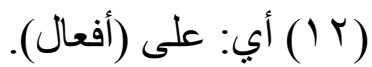

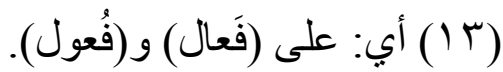

( ع ( ) أي: جمعت في القلة على (أفعُل).

(10) أي: جمع يمين، فجمعوه في القلة على (أفعال). 


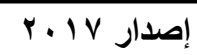

حولية كلية اللغة العربية بالمنوفية العدد الثاني والثلاثون

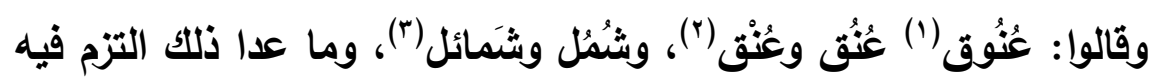

أفمُلْه.

وفَعُول: للمؤنتث كالمذكر لا فرق، نحو: قََُوم وقُُُم، فإن لحقت بهذه

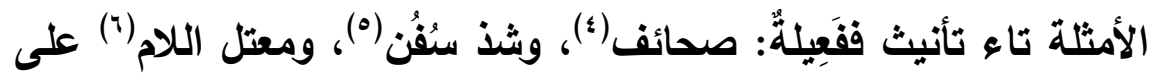
فعائل خاصة، ولا بد من تحويل الكسرة فتحة، وقلب الياء الأخيرة ألفًا، واللهمزةِ ياءًً، نحو: مَطِيّة ومطايا.

وغير فعائل من الأوزلن الأربعة: ذَوائب، ورسائل، وحَلائب، وعمائم(V)، ولا يتجاوز هذا في المصنوع، فإن كاتت لمخلوق فبحذفها(^)، أو بالألف والتاء(9)، وقد يجرى المخلوق كالمصنوع في الجمع والعكس، والمسموع:

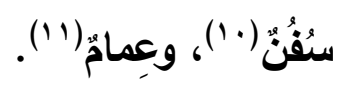

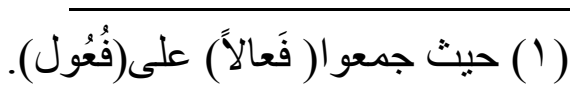

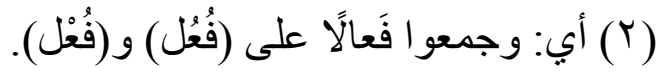

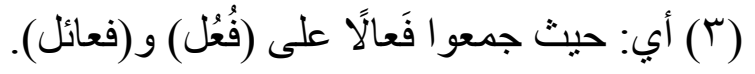
( ( ) أي: تجمع على (فعائل).

(0) أي: شذ جمع (فَعِيلة) على (فُعُل)، وهي جمع (سفينة)، وقالوا في صحيفة: صُحُف. (7) أي: من هذا. ( أي: تجمع على (فعائل). (V) (^) أي: يحذف التاء في الكثير. (1) (9) أي: في القليل. ( ( ) أي: في سفينة. (1) (1) (1) 


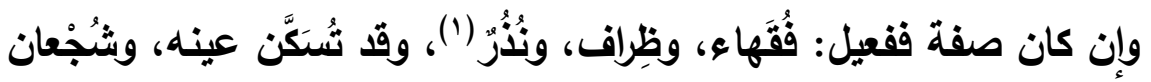

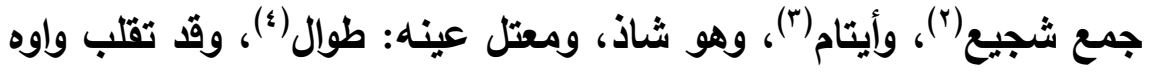

ياء)

ومعتل لامه: أغنياء(")، وشثذ تُقَواء وفيه شذوذان(V)، ولا يحفظ البصريون غيره.

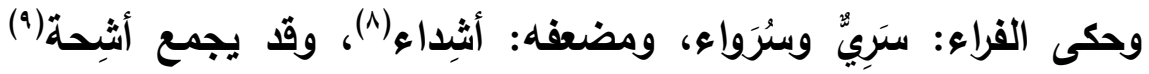

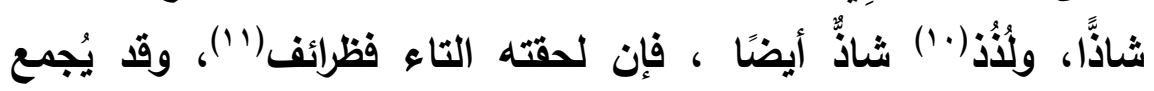
سُفَهاء وفُقَراء(r')، ولا يحفظ من ذلك إلا هذان، وظِراف، وهو القياس،

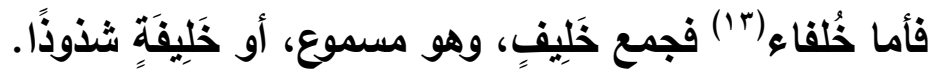

(1) أي: يجمع على (فُعَلاء) و و(فِعال) و(فُعُل).

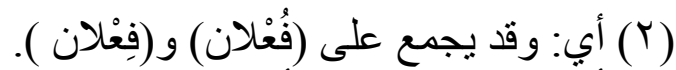

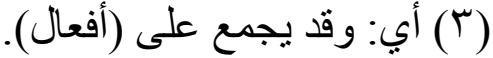

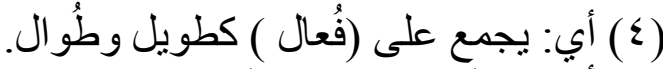

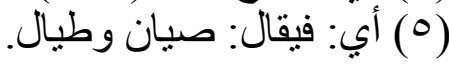

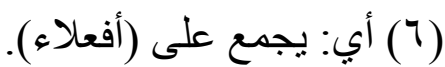

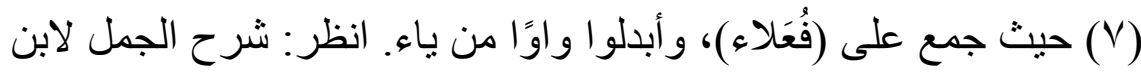
عصفور r/T)

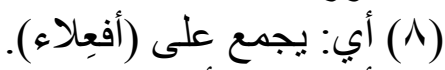

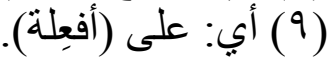

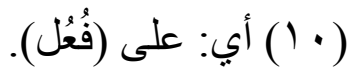

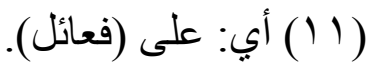

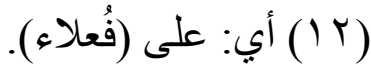

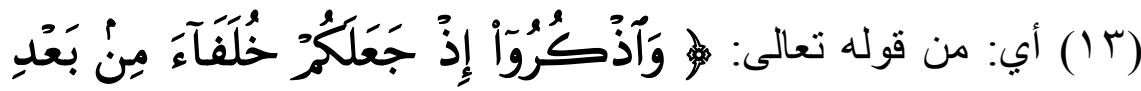

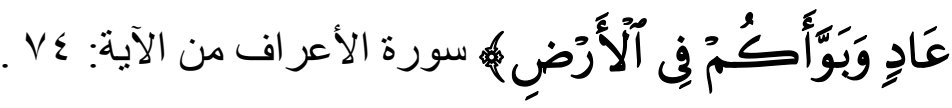


فَعُول: للمذكر والمؤنث بغير تاء، فللمذكر: صُبرُ (')، وللمؤنث: عُجُز (r)، وقد يجمع: عجائز ()، ومعتل اللام: أعداع(๕)، وذو التاء: حلائب(ْ). وما كان من هذه الصفات للمذكر فلا يمتعع جمعه بالواو والنون إذا كان

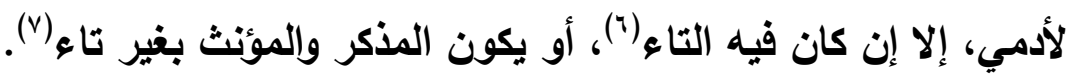

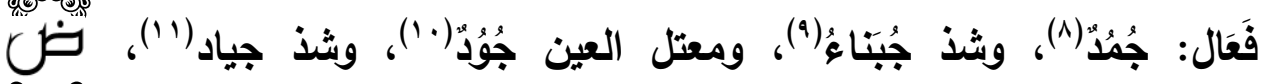

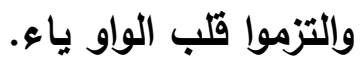

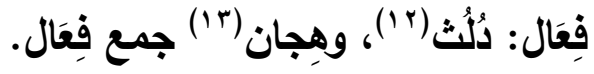

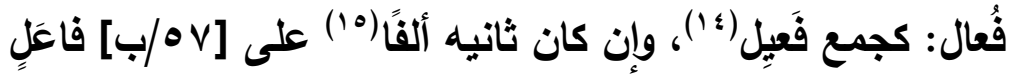

$$
\begin{aligned}
& \text { (1) أي: على (فُعُل). }
\end{aligned}
$$

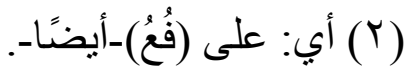

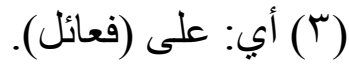

$$
\begin{aligned}
& \text { ( ( ) أي على (أفعال). } \\
& \text { (0) أي يجمع على (فعائل) كركوبة وركائب. } \\
& \text { (7) نحو: (خليفة). } \\
& \text { (V) نحو: (صبور ، وشكور). (V) } \\
& \text { (^) في جَماد، أي: يجمع على (فُعُعل). }
\end{aligned}
$$

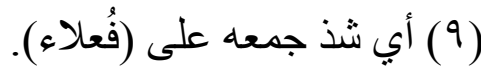

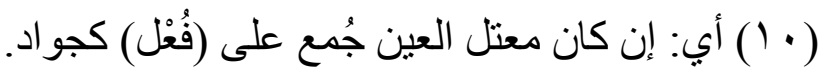

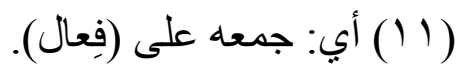

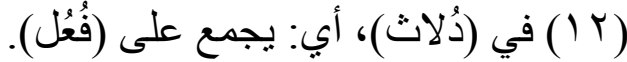

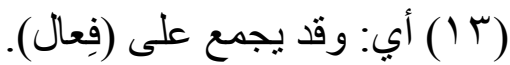

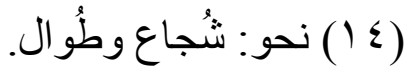

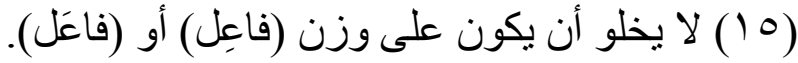




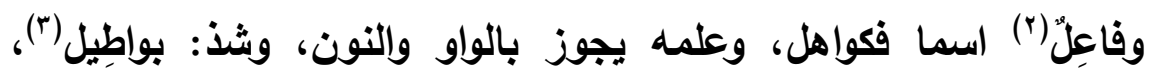
وزعم الفراء أنّها من كلام المولدين.

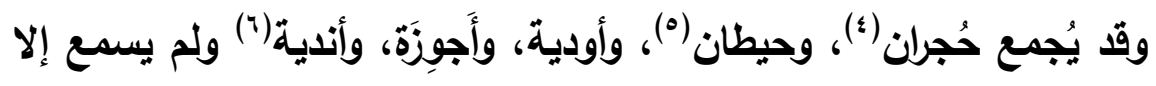
هذه الثلاثة.

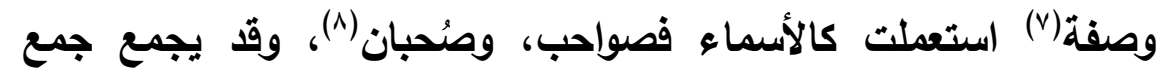

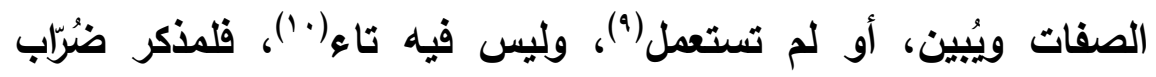

وضُرَّب، لعاقل وغير عاقل (1').

$$
\begin{aligned}
& \text { (1) أب: إن كان على وزن (فاعَل) جمع على (فو اعيل). }
\end{aligned}
$$

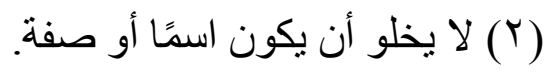

$$
\begin{aligned}
& \text { (r) أب: شذ جمعه على (فو اعيل). } \\
& \text { ( ) أي: يجمع على (فُعلان). } \\
& \text { (1) أي: وقد يجمع على (فِعلان). }
\end{aligned}
$$

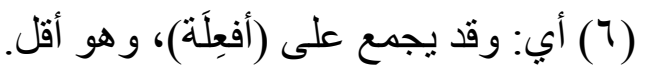

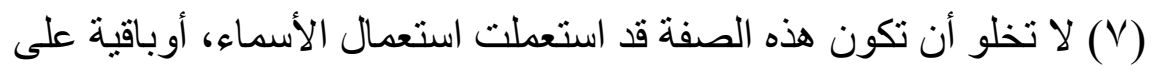

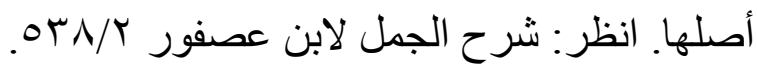

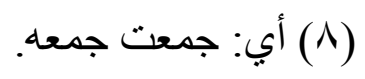

(9) أي: لا يخلو أن يكون فيه تاء التأنيث أو لا يكون. شرح الجمل لابن

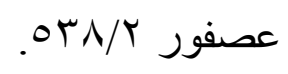

( • (1) أي: لا يخلو أن يكون لمذكر أو لمؤنّث، شرح الجمل لابن عصفور . Or N /

(11 (1) أي: جمعت على (فُعْال)، و(فُعْل). 


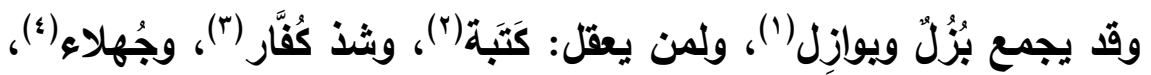

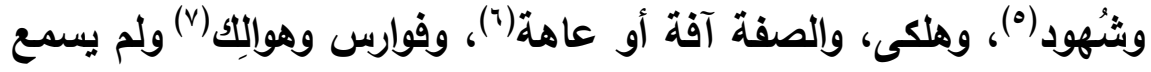
في الكلام غيرهما، وفي الثعر:

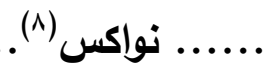

وكذا حكم المُضضَّفَ منه، والمعتل العين إلا أن فُمَّالا أفصح في المضعف

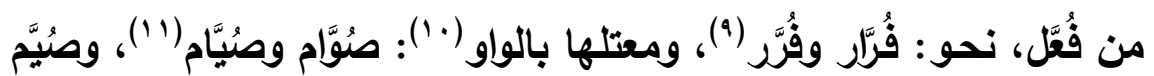

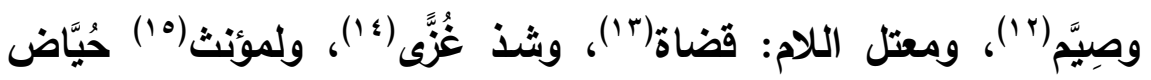

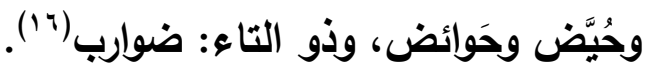

$$
\begin{aligned}
& \text { (1) أي: يجمع على (فُعْل) و(فو اعل ) لغير العاقل. }
\end{aligned}
$$

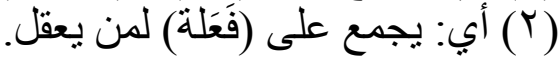

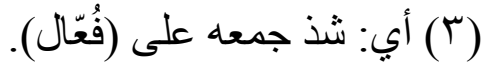

$$
\begin{aligned}
& \text { ( ) أي: شذ جمعه على (فُعلاء). } \\
& \text { (0) أي: شذ جمعه على (فُعول). } \\
& \text { (7) أي: وقد يجمع على (فَعْلَى). }
\end{aligned}
$$

( أي: وقد يجمع على (فو اعل) للعاقل. (V)

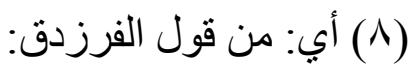

خُضُعَ الرقابِ نو اكِسَ الأبصـارِ

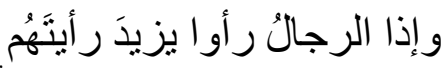

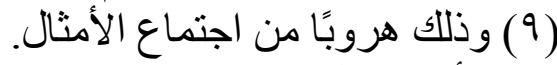

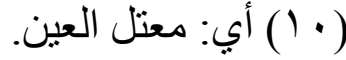

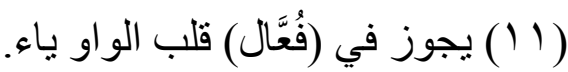

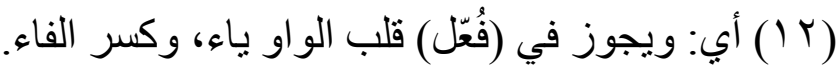

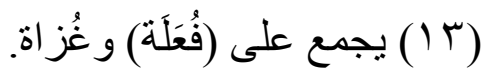

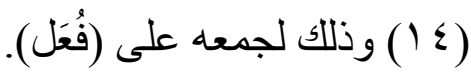

(0) (1) أي: إن كان مؤنثًا فحكمه حكم المذكر ، إلا أنه يجوز في جمعه فو اعل.

( 7 ( ) جمع ضاربة، أي: يجمع على (فو اعل). 


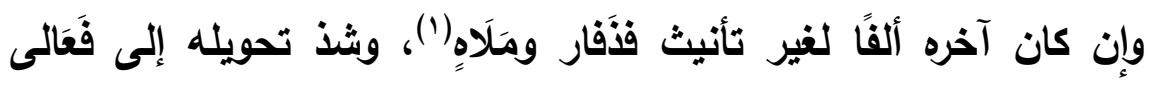
نحو: ذَفَارى ومَدَارى، أو لتأنيث ممدودة(َ) على فَعْلاع(َ) اسمًا فصحارٍ

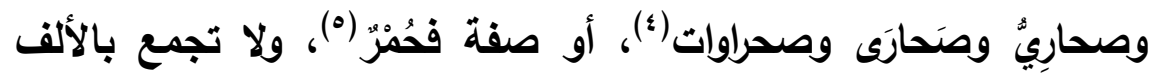
والتاء، ولا يقاس على الخضروات(")، ويطاح) (V)، أو على غير فعلاء

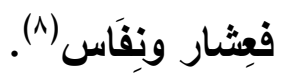

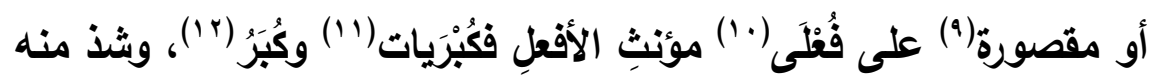

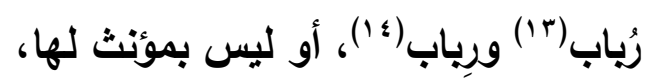

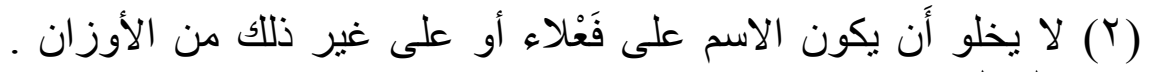

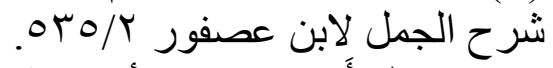

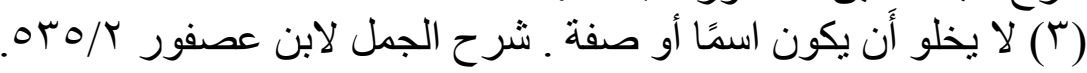

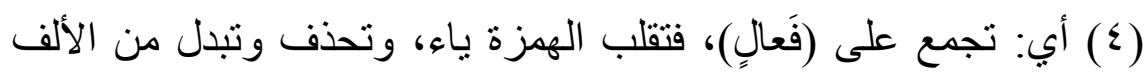

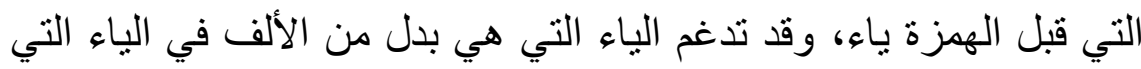

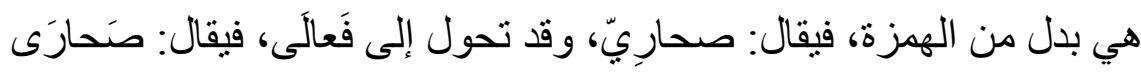

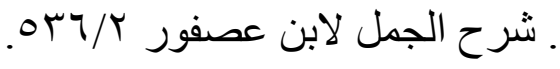

$$
\begin{aligned}
& \text { (0) أي: يجمع على (فُعْل). }
\end{aligned}
$$

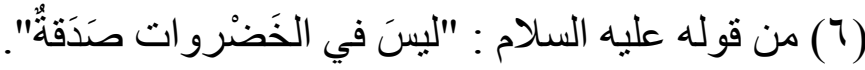

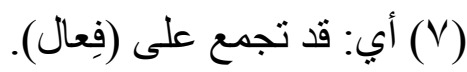

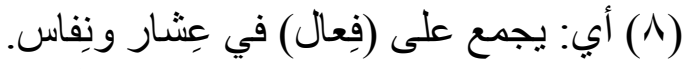

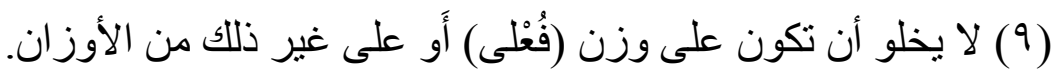

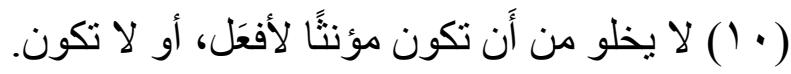

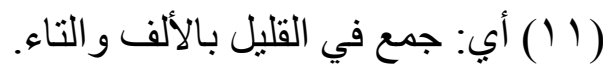
( ( I ) وجمع في القليل على (فُعَل).

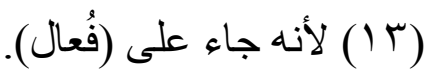

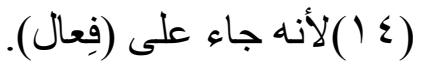




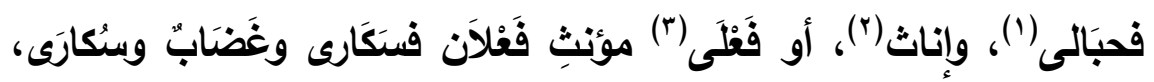

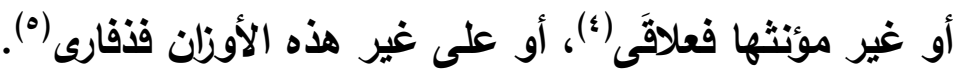

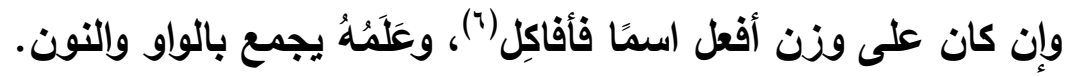

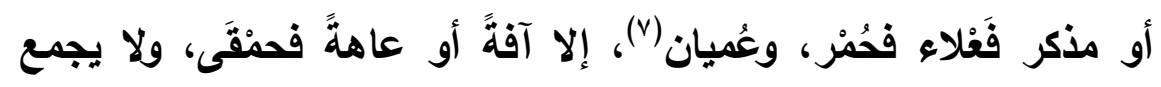

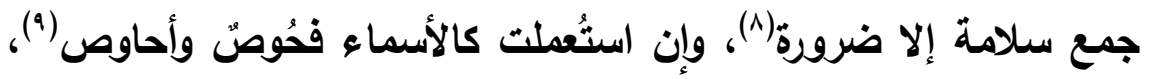

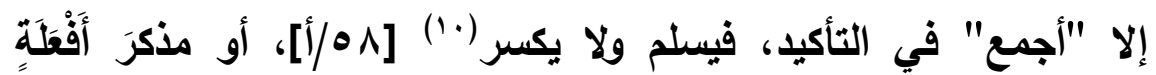

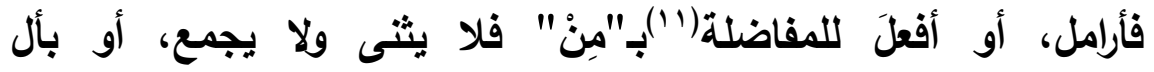

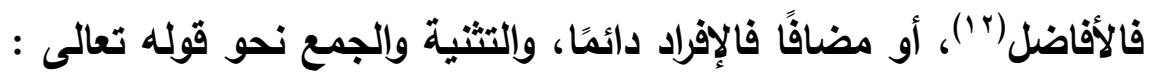

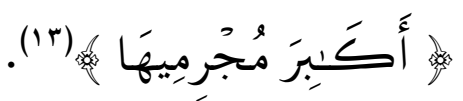

( ( ) أي: إذا لم يكن مؤنثًا لأفعل جُمع على (فَعالَى).

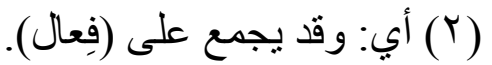

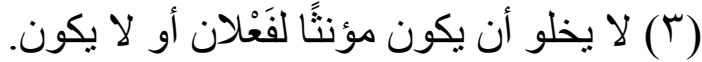

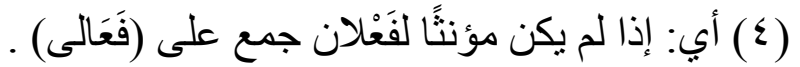

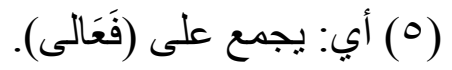

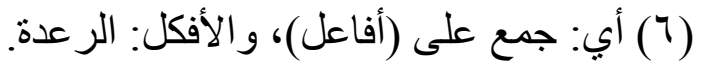

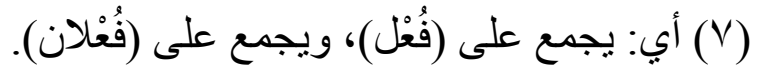
(^) كقول الكميت:

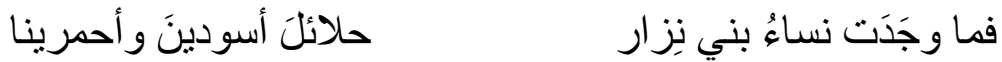
(9) أي جمعت تارة جمع الأسماء، وتارة جمع الصفات. (1) (1) أي: يجمع جمع مذكر ، و لا يجمع جمع تكسير. (1) (1) أي: لا يخلو أن يكون بـ"مِنْ" أو بالألف و اللام أو مضافًا.

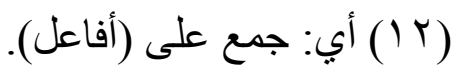

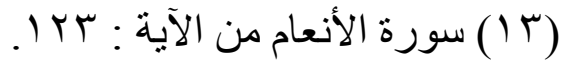


أو على غير ذلك من الأوزلن فعلى فَعالِلَ، نحو: دراهم، وهَجَارع إلا

مضاعف اللام فقراديد(')، أو على فَيْعِل فأموات ، وأجياد (؟).

الخماسي فصاعدا"َّ): إن كان في آخره ألف ونون، وهو خماسي اسمًا أو أو

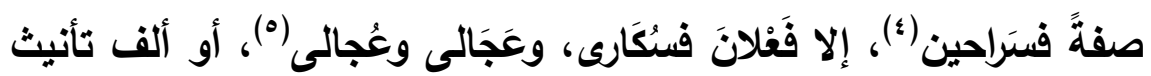

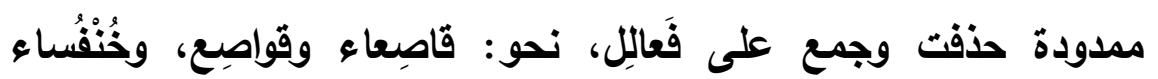

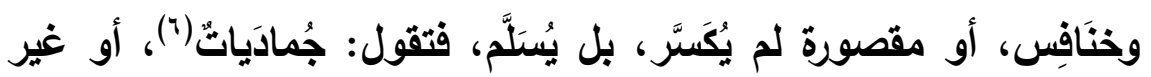
ذلك حذف حتى ييقى منه أربعة، وكُسِّر على مثال فَعالل أو فَعَالِيل، والِياء عوض (v) إلا أن يكون رابعه حرف مد ولين، فلا يحذف منه شيء، تقول: سَرَابِيلِ، وقَنَاديل. هذا حكم الجمع المبني على واحدة الملقوظ به، وشثذت جموع لم ينطق لها بواحد، نحو: عبَادِيد، وشَمَاطِيط(^)، وجاء من الجموع ما هو هو على غير لفظ واحده المنطوق به، فيحفظ.

( ( ) أي: يجمع على (فعاليل)، وهو جمع قَرْدَد.

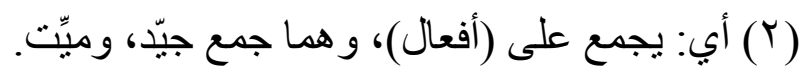

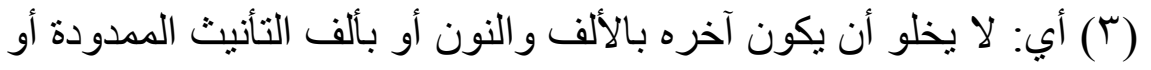

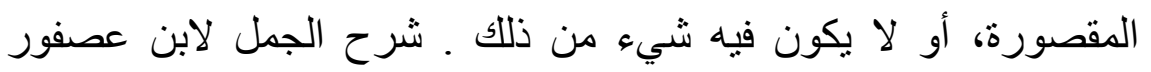
$0 \leqslant 1 / 4$

( ) أي: يجمع على (فَعالين)، وهما جمع: سِرْحان.

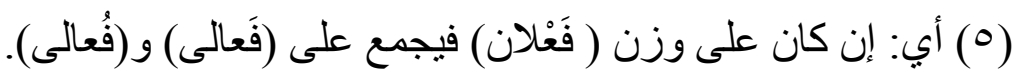

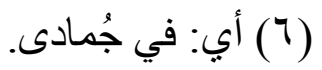

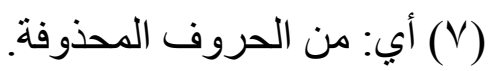

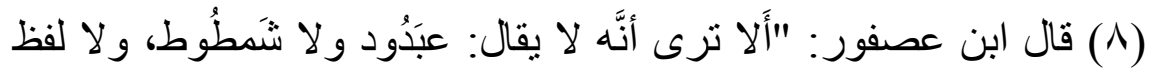
بثيء يمكن أن يكون مفردًا لهذه الجموع" ـ شرح النه الجمل لابن عصفور . $0 \leqslant Y / T$ 
والمسموع: مَلاميح جمع لَمْحَة، ومَذَاكِير جمع ذَكَرَ، وأراهط جمع رهط، وأراضٍ، وأحاديث جمع حديث، وأقاطيع، وأباطيل، وأطيار، وتُؤَم، وأَمْكُنْ، وأعاريض، وأهالٍ، وليالٍ وكِزْان، وَوِْشَان، في جمع: لمحة، وذَكر، ورهط، وأرض، وحديث، وقطيع، وياطل، وطائر، وتَوَأم، ومكان، وعَروض، وأهل، وليلة، وكَرَوانٍ، وَرَشَانِ، هذا ما شذ من الجموع من هذا النوع، إلا

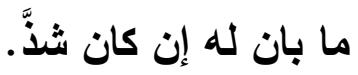

وأما فَعْل في جمع فاعل نحو: طائر وطَيَرِ، وراكب ورَكْبِ، فجعل الأخفش ذللك جمع تكسير(')، وجعل سيبويه ذللك اسم جمع، وهو الصحيح؛ باليل تصغيره على لفظه(r). وجمع الجمع شاذ يحفظ، ولا [^ه/ب] يقاس عليه، فمن ذلك: أيادٍ، وأواطِب، وأسمامٍ، وأساور، وأبِييت، وأناعِم، وأقاويل، ومصارين، وحَشَاشين، وجمائل، وأعطيات، وأسقيات، وبيُوتات، ومَواليات بني هاشم،

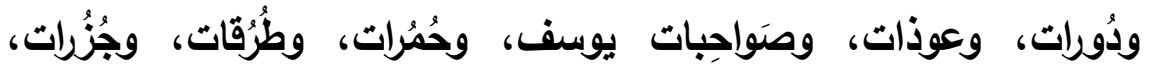

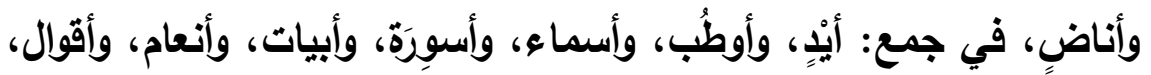
ومُصران، وحُشّان، وجمال، وأعطية، وأسقية، وييوت، وموال، ودور، وعُوذ، وصواحب، وحُمُر ، وطُرُق، وجُزُر، وأنضاء.

وفي آصال خلاف، قيل: جمع أُصُل الذي هو جمع أصيل، وقيل: جمع

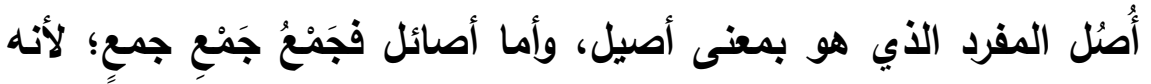

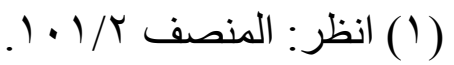

(Y) انظر: الكتاب س/Y (1). 
الموفور من شرح ابن عصفور

دالحمد محسمد الجندي

دا عبد الملك أحمد شثيوي

جمع آصال، وآصال جمع أُصُل، وأُصُل جمع: أصبل، وحكى يعقوب(1) أصِيلة في معنى أصيل، فعلى ذلك يكون أصائل جمعه.

هذا ما جمع من الجمع في الكلام وما عدا ذلك لا يجوز أن يستعمل إلا ضرورة، إلا أن يسمع من ذلك شيء، فيحفظَ ولا يقاس عليه.ومما جاء

(ץ) أعينُاتٍ ....... ضرورة:

(r) أيامِنينَا

(أ).................

وهو كثير في الثعر إلا الجمعَ المتناهيَ، فلا يجمع لا في ضرورة ولا غيرها، إلا أن يجمع جمع سلامة خاصة.

(1) هو أبو يوسف، يعقوب بن إسحاق بن السكيت البغدادي النحوي المؤدب، مؤلف كتاب إصلاح المنطق، حجة في العربية، أخذ عن أبي بوني

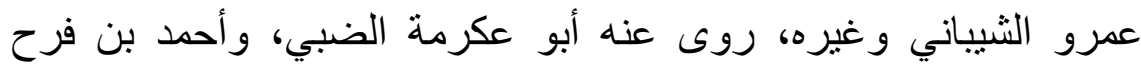
المفسر ، وجماعة، وبرع في النحو و اللغة، مات سنة أربع وأربعين ومائتين.

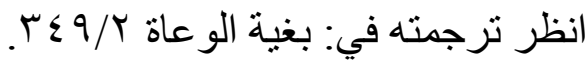
: (r)

بأعيُناتِ لم يُخِالِطْها قَذَى

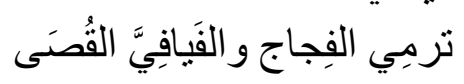
(r) أي في قول الثاعر :

قد جَرَتِ الطَيرُ أَيامِنينا ( ) أي في قول الراجز : أَشَكو إلى مولايَّ من مولاتي

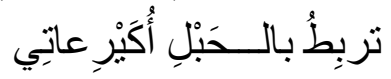


هذا حكم جمع المجموع ما لم يكن أعجميًّا، فإن كان أعجميًّا وافق العربي فيما ذكرنا، إلا أنّه يلزم جمع الرباعي منه تاء التأنيث، نحو: سنَّح وسنَبَابحَة، إلا أن يشذ من ذلك شيء، فيجمع بغير التاء، نحو: جَوْرَب

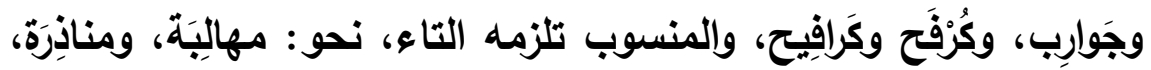
ومسامِعَة إلا ما شذَ كالََّّاسِمِ ، والمَعَاوِل لقبِيلتين. فأما أناسية في جمع إنسان فيحتمل وجهين. والمنقوص كغيره، نحو: أَخ وزنهـه فَعَلُ، فجمعه: آخاعُ، ووزنهـه أفعال، ويًَ

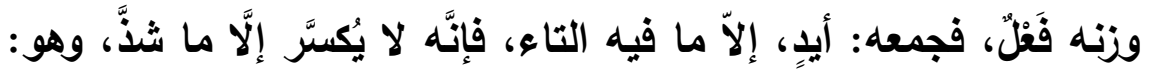

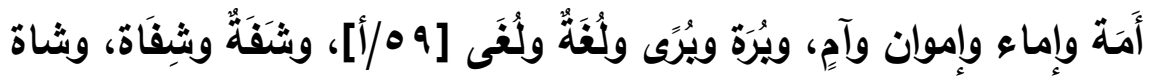
وشياهٌ، وياب هذا الجمع بالألف والتاء للقلة، أو بالواو والنون للكثرة، نحو: سنَّة وسَنَوات وبِنينينَ. وأسماء الأجناس(') إن لم تكن فيها علامة تأنيث، وأردت الواحدة، أدخلتها تاء التأنيث، نحو: تمر وتَمَرة، وليس تمر جمعًا لتمرة، بل هو اسم جنس مفرد، يصغر على لفظه، والباب فيه ألا يجمع، فإن جمع فلذهابه مذهب النوع.

أو كانت فيه لم تدخل التاء إن أردت الواحدة، بل الفارق بين الواحد والجنس الوصف، فتقول: شُكاعَى واحدة، وشُكاعى كثيرة، وحَلْفاء واحدة،

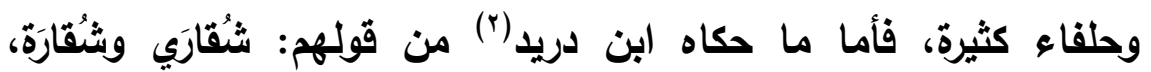

( ) (أي لا يخلو أن تكون فيها تاء التأنيث أو لا تكون.

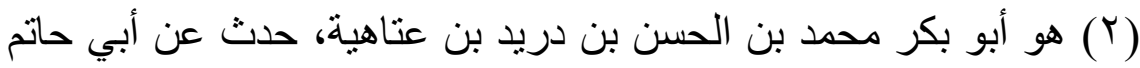

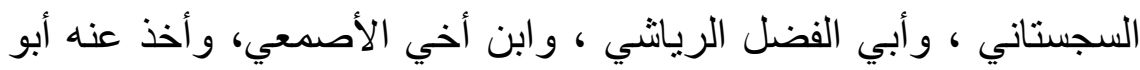

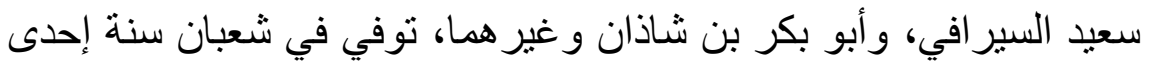

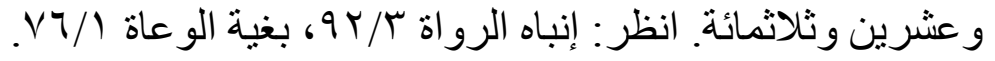


ولُصَيْفَي ولُصَيْقِات، فلا يُعَوَّل عليه؛ لأنَّ أهل الضبط كـ سيبويهه ، والخليل، وأبي زيا ، وأعلام النحويين لا يعرفونه ، فإن صح فالألف زائدة لغير

(1) تأنيث

\section{****** $* *$ \\ أبنية المصادر}

الفعل ثثلاثي ومزيد، الثلاثي علاج وغيره، العلاج متعدٍ وغيره، المتعدي:

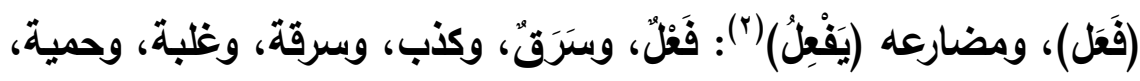

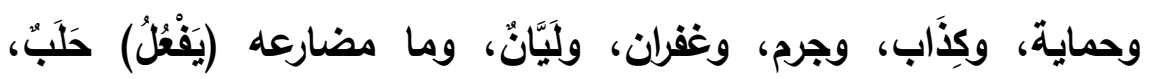

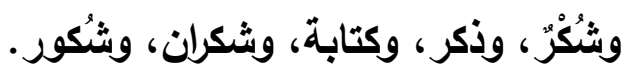

والمقيس من المتعدي سواء أكان صحيحًا أو مضاعفًا أو معتلَّاً: (فَعْلُ)

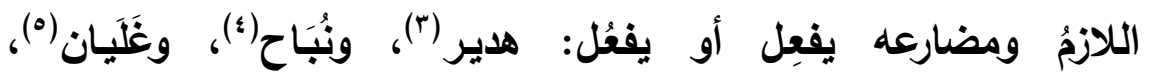

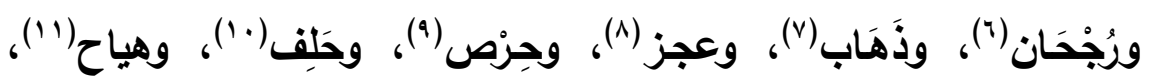

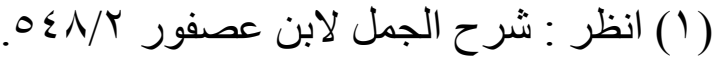

$$
\begin{aligned}
& \text { (Y) أب: أن مضار عاه بفتح العين أو كسر ها. }
\end{aligned}
$$

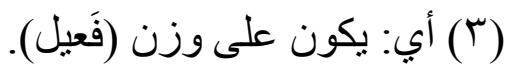

$$
\begin{aligned}
& \text { ( ) أي: يكون على وزن (فُعال). } \\
& \text { (0) أي: يكون على وزن (فَعَلان). } \\
& \text { (7) أي: يكون على وزن (فُعْلان). }
\end{aligned}
$$

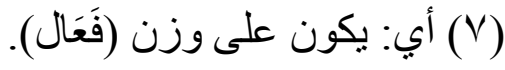

$$
\begin{aligned}
& \text { (^) أي: يكون على وزن (فَعْل). }
\end{aligned}
$$

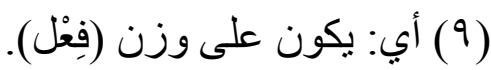

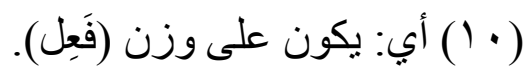

$$
\begin{aligned}
& \text { (1 (1) أي: يكون على وزن (فِعَال). }
\end{aligned}
$$




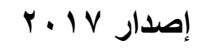

حولية كلية اللغة العربية بالمنوفية العدد الثاني والثلاثون

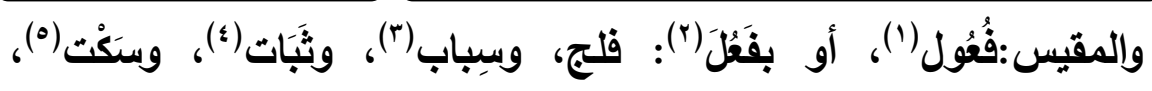

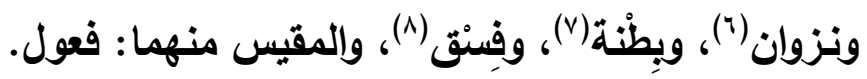

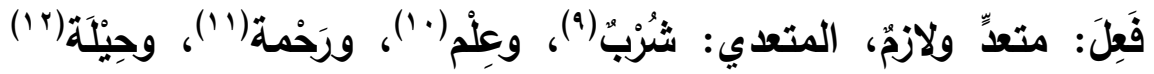

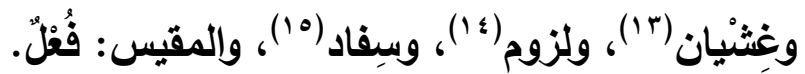

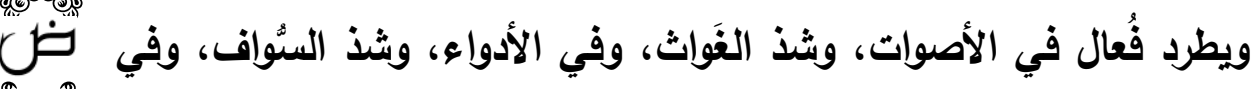
[9ه/ب] متفرق الأجزاء(1").

وفُعَالةُ في الفضلات نحو: النحاتة والنجارة والنفاية، هذه مصادر في الأصل وضعت موضع اسم المفعول.

$$
\begin{aligned}
& \text { (1) (1) كقعود. } \\
& \text { (Y) كرقص. }
\end{aligned}
$$

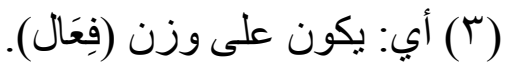

( (؛) أي: يكون على وزن (فَعَال).

(0) أي: يكون على وزن (فَعْل).

(T) أي: يكون على وزن (فَعَلان).

(l) أي: يكون على وزن (فْعْلة).

(^) أي: يكون على وزن (فِعْل).

(9) أي: يكون على وزن (فُُْل).

( • (1) أي: يكون على وزن (فِعْل).

(11) أي: يكون على وزن (1) (فَعْلة).

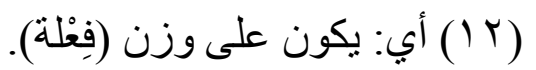

(T ( ) أي: يكون على وزن (فِعْلان).

( ع () أي: يكون على وزن (فُعُول).

(10) أي: يكون على وزن (فِعَال).

(7 (1) نحو: الدقاق، و الحُطام. 
الموفور من شرح ابن عصفور

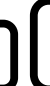

د / لحمدمحسمد لجنـدي

دا عبد الملك أحمد شمثيوي

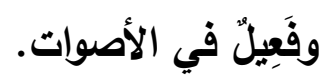

وفِعَال في الهياج وما جرى مجراه(')، ويكثر في الأصوات(؟)، ويطرد في

انقضاء أوان الشيع وَ").

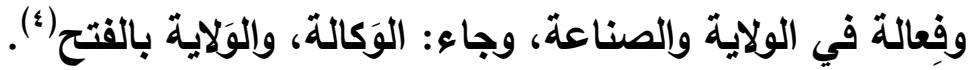

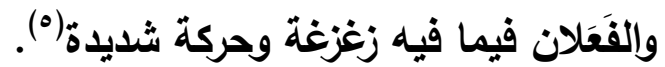

وفَعْلة في الهيئة.

اللازم ينقاس فيه فَعَّ في الأدواء وضدها، وفيما يتعذر ويعسر، وفي الامتلاء وضده.

وما عدا ذلك فيطرد فيه فعيل، إلا ما كان لونًا فيطرد فيه فُعْلة وفَعَل، نحو:

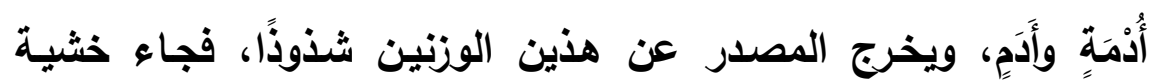

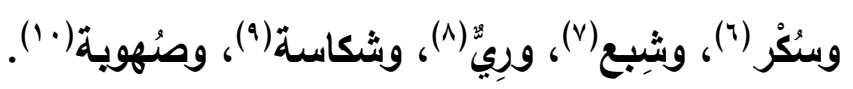

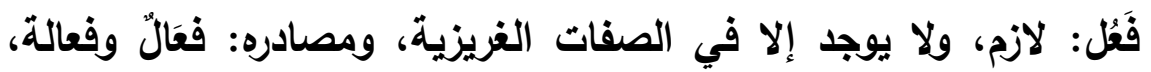

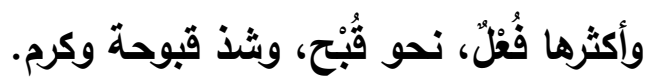

$$
\begin{aligned}
& \text { ( (1) نحو: النِكاح، و الوِداق، و الضِرِ اب. } \\
& \text { (r) كالصِياح و النِداء. } \\
& \text { (ז) كالحِداد، و الصِر ام. } \\
& \text { ( () أي: بفتح الفاء من (فَعَالة). } \\
& \text { (0) نحو: الغليان. } \\
& \text { (T) أي: على وزن (فُعْل). }
\end{aligned}
$$

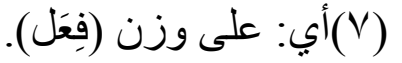

$$
\begin{aligned}
& \text { (1) أي: على وزن (فِعْل). } \\
& \text { (9) أي: على وزن (فَعالة). } \\
& \text { ( • (1أي: على وزن (فُعولة). }
\end{aligned}
$$


ومما يحفظ من المصادر ولا ينقاس: فَعول، وجاء منه: الوَضُوء والطَّهور

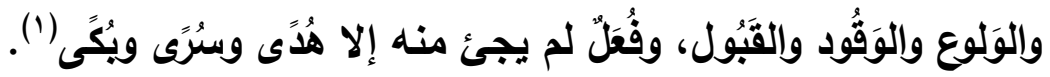
والذي جاء وفي آخره ألف التأنيث الممدودة: الكبرياء(؟) ليس إلا،

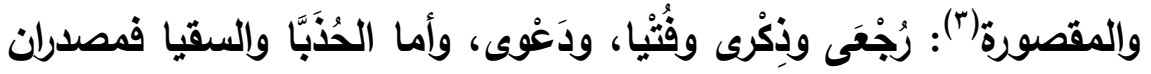
وضعا موضع الاسم، إلا للمبالغة فيطرد فيه الفعيلى، ولا يحفظ البصريون شيئًا من فعيلى ممدودًا إلا الخصيصاء، وقاس عليه الكسائي فأجاز الخليفاء والمكيثاء، والتفعال نحو التلعاب. المزيل: ما فى أوله همزة وصل، ومصدره على مثال الماضي، إلا أنك تزيل

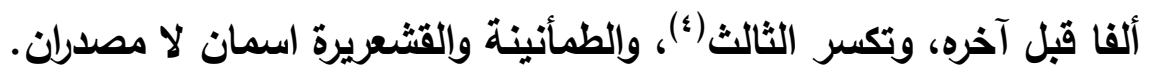

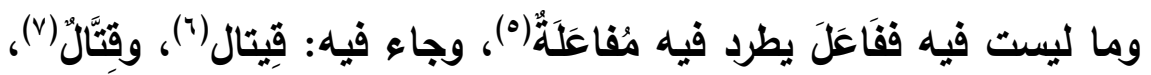
وفي فَعَّل تفعيل (^)، وجاء فيه نَكْرِمة وكِنَّابِّ.

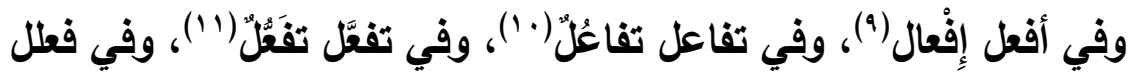

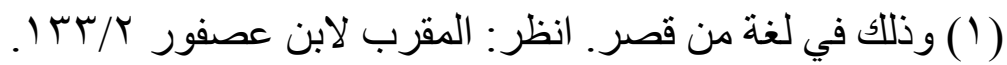

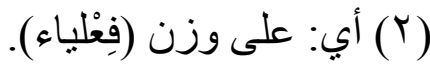

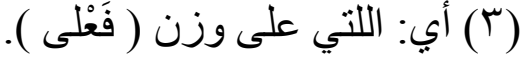

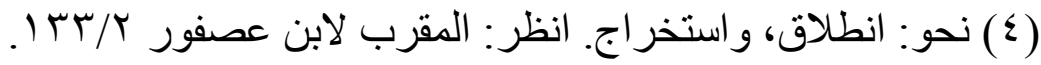

$$
\begin{aligned}
& \text { (0) (1) نحو: مُضناربة. }
\end{aligned}
$$

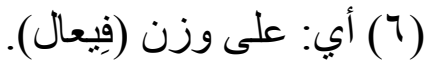

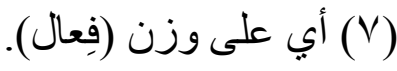

$$
\begin{aligned}
& \text { (^) نحو: تعذيب. } \\
& \text { (9) نحو: إكر ام. }
\end{aligned}
$$

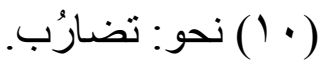

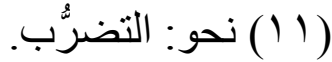




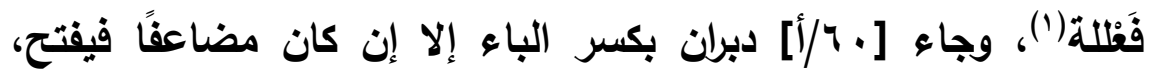

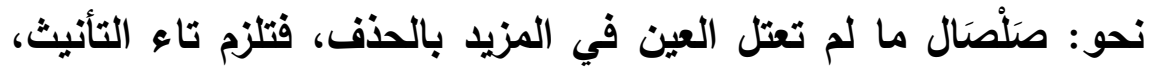

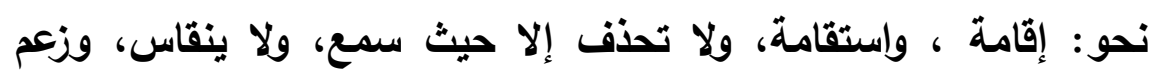

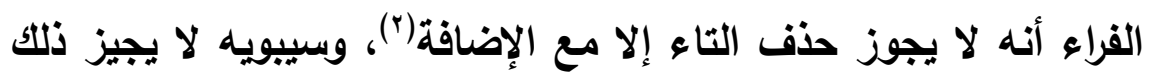

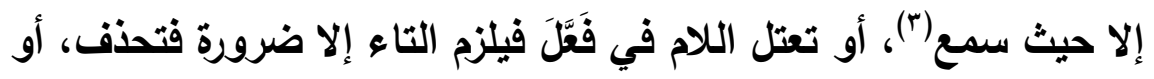

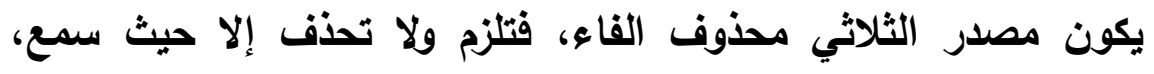
والفراء يجيز ذلكك لأجل الإضافة. وما ألحق من الثثلاثي بالرياعي جرى مجراه، وقد يجيء مصدر الفعل على الاضياءه

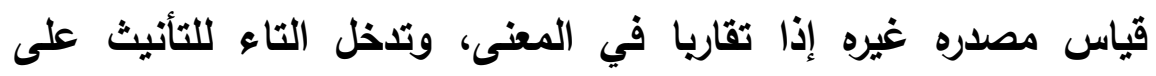
المصادر للمرة الواحدة من الأفعال المزيدة. \%***\%**

\section{اسم المصدر ، والزمان والمكان}

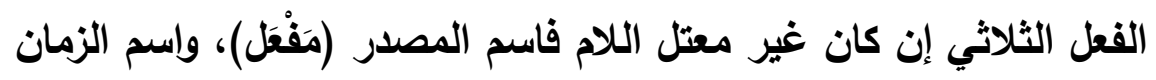

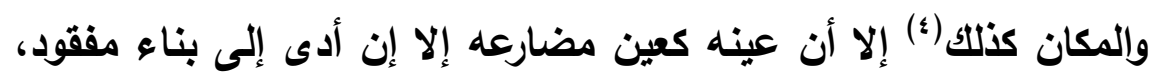

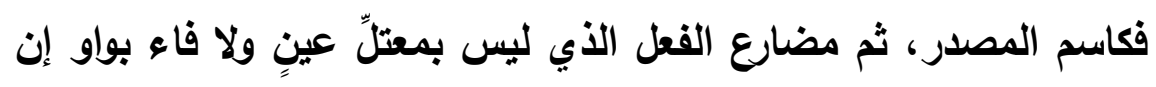

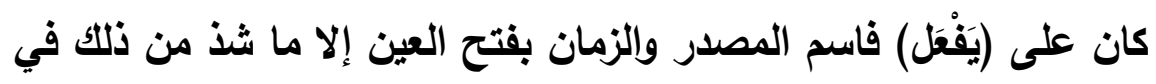

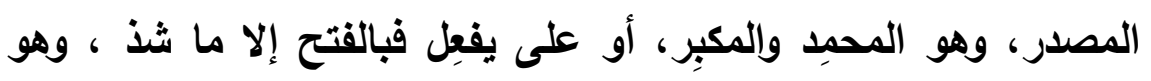

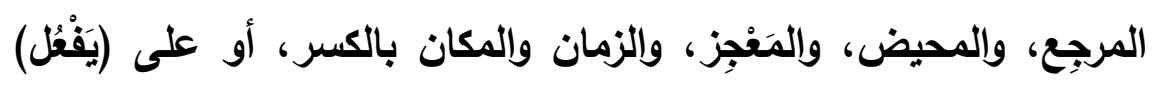

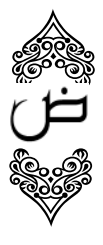


فالمصدر منه والزمان والمكان بقتح العين(')، إلا ما شذ في المكان،

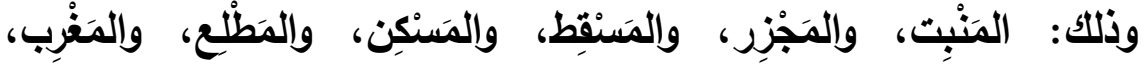

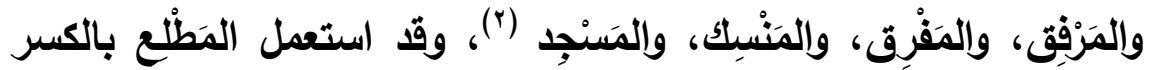
في معنى الطلوع.

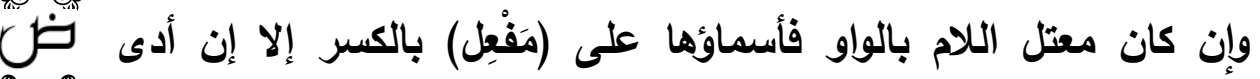
التصريف إلى تحريك فاء في مضارع فكالصحيح إلا ما شذ، وذلك: مَوْجل،

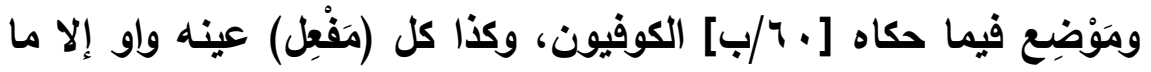
شَذ، وهو: مَوْهَبْ، ومَوْظَبْ، ومَوْرَقْ، وهو آلَة، أو بالياء فتثلاثتها: (مَفْعَل)

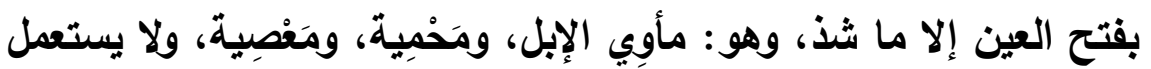

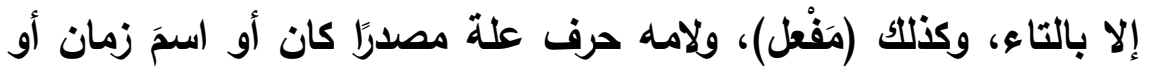

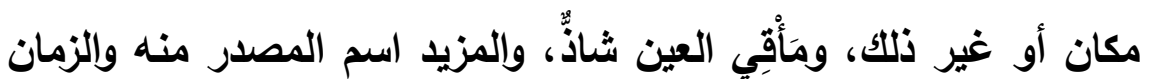
والمكان كاسم المفعول(َ).

****** $* *$

المقصور

سُمِي بذلك لأنه قصر عن الإعراب أو عن الغاية التي للمد، وهو مسموع، ومقيس.

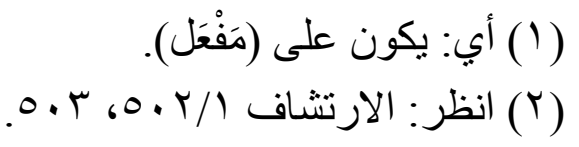

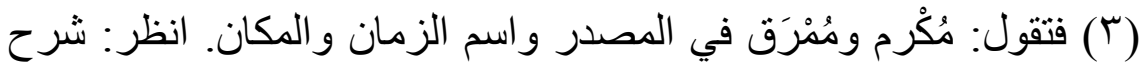

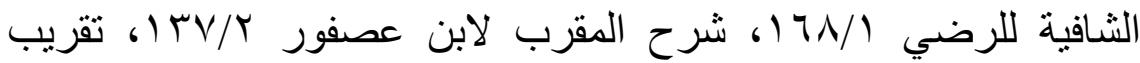

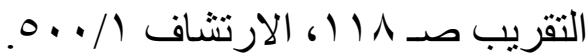


المقيس: مصدر لفعل لازم معتل اللام على (فَعَلَ)، واسم فَاعله (فَعِلٌ)، أو

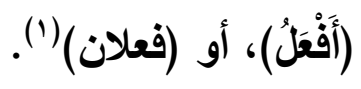

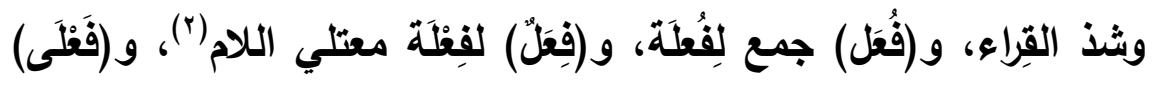
جمع (فَعِلِ) بمعنى (مفعول)(َّ)، أو جمع (أفعل) آفة أو علامة، وما وازن

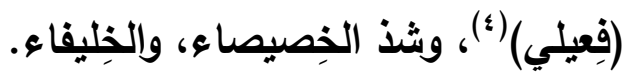

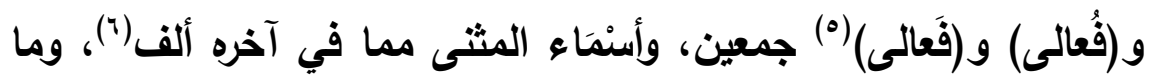

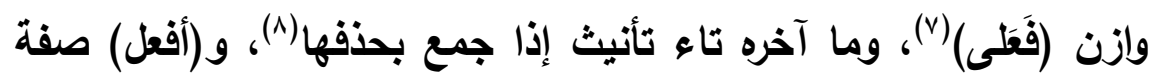

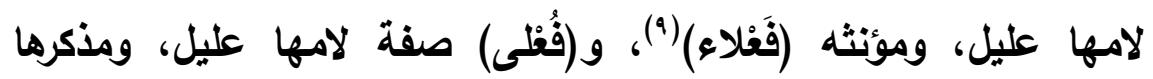
(الأفعل)(·")، ومصدر لفعل معتل اللام في أوله ميم زائدة(")، وكل فعل وموله

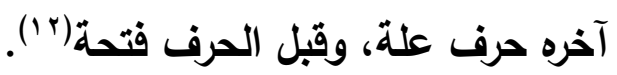

(1) نحو: عَمِى عَمَى، فهو أعمى، وصَدِي صندى فهو صندٍ، وطوِيَ طوى، فهو طيان.

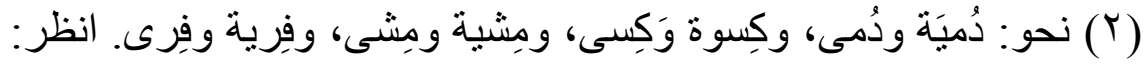

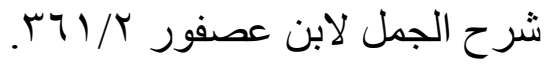

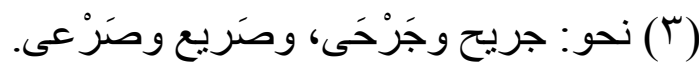
(乏) نحو: القبيلي. (0) نحو: سُكارى، وأسارى، فهو مقصور. (T) نحو: الخَوْزَّلى، و الهَيْدَبى.

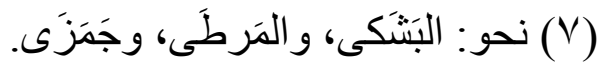

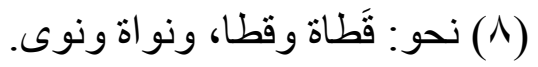

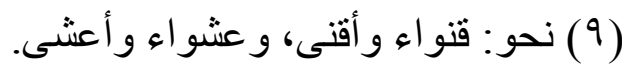

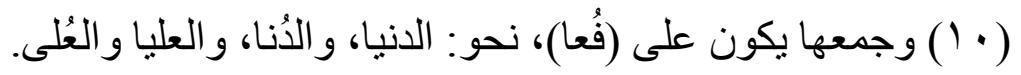

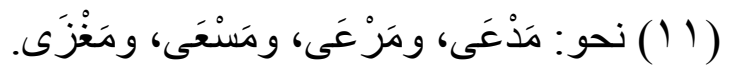

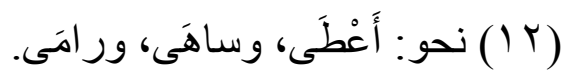


الممدود: مسموع ، ومقيس • المقيس: مصدر فعل معتل اللام، في أوله

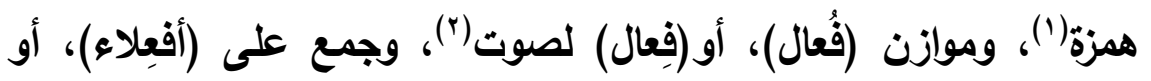

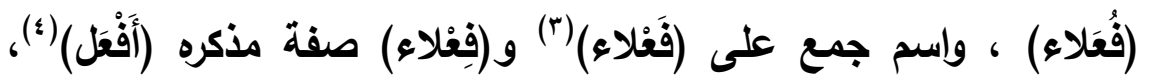
وموازن (فُقَلاء) غالبًا (ه). وقد جاء مقصورا: شُعَبَى (")، وأُرَبَى (v)، وجمع أسامٍ في آخره تاء التأنيث

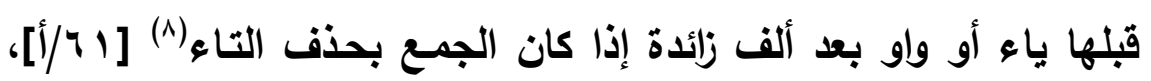

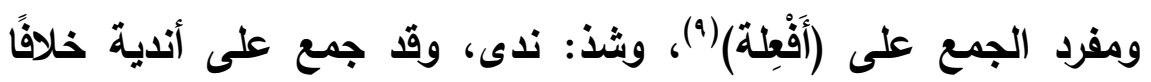
للمبرد (')؛ إذ زعم أنه جمع نداء الذع الذي هو جمـع نَدى.

(1) (1) نحو: انطوى انطو اء.

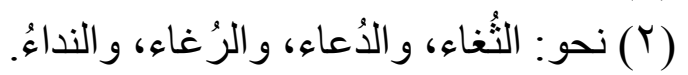

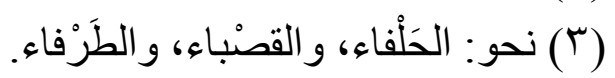

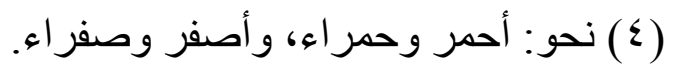
(1) نحو: عُشَرَ اءَ ونُفَسَاء.

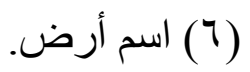

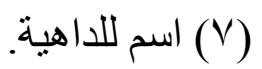

(^) نحو: عظايَة، وصَلايَة، وسماوَة تقول في جمعها: عظاء، وصِلاء، وسنماء. (9) نحو: أَرْثَيَة واحدها رِشَاء، و أكسية واحدها كِساء إلا أندية فإنه شـاذ، و الوجه منه: نداء.

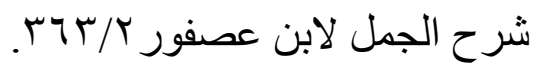

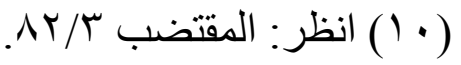




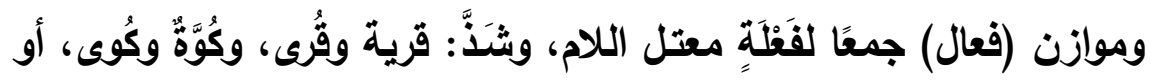

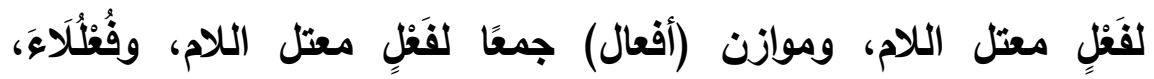

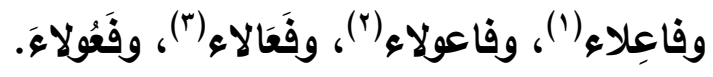

وألحق بعضهم بمقيس الممدود كلَّ مقصور أو ممدود له من الصحيح ما هو على وزنه ومعناه.

********

\section{اسما الفاعلِ والمفعول}

لا يبنى اسم الفاعل إلا من فعل متصرف(؛)، فمن (فَعَلَ): فَعِيل (ه)، ومن

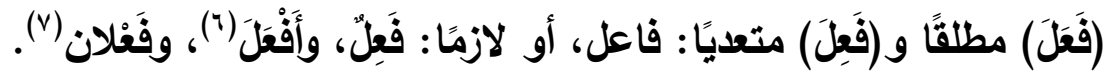
ومن زائد على الثلاثي يأتي على وزن المضارع إلا أن مكان حرف المضارعة ميمًا مضمومة، ويكسر ما قبل الآخر. ولا يبنى اسم المفعول إلا من فعل بني لما لم يسم فاعله، فمن الثلاثي ماني على وزن مفعول قياسنًا، ومن الزائد يأتي على وزن المني المضارع المبني للمفعول؛ إلا أن مكان حرف المضارعة ميمًا مضمومة. ****** $* *$

$$
\begin{aligned}
& \text { (1) نحو: السابياء، و القاصِعاء. } \\
& \text { (Y) نحو: عاشور اء. } \\
& \text { (ז) نحو: عجاساء وبر اكاء. }
\end{aligned}
$$

( ) اسم الفاعل لا يخلو أن يكون من فعل ثلاثي أو أزيد، فإن كان من فعل

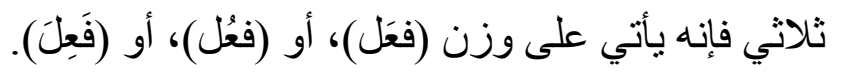$$
\text { (0) نحو: ظرُف فهو ظريف، وكرُم فهو كريم. }
$$

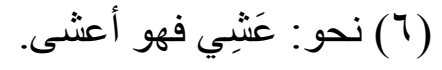$$
\text { نحو: صَدِي فهو صَديْان. }
$$ 
الإمالة: أن تنحو بالألف نحو الياء، ويالقتحة قبلها نحو الكسرة(')،

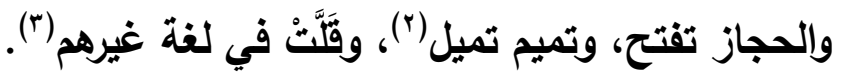
وهي لياء قبلها، وألف تليها، أو بينهما حرف(؛)، أو متحركان أحدهما الهاء، ولم يفصل بينهما بضمة(ه)، ولكسرة متأخرة تلي الألف(؟)، ومتقدمة فصل بينهما بحرف(v) أو بحرفين أولهما ساكن(^)، أو متحركين بشرطهما(9) قيل: أو بثلاثة أولها ساكن، ويذلك الشرط(·')، ولانقلاب عن التهن

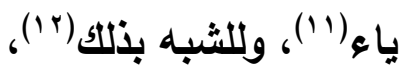

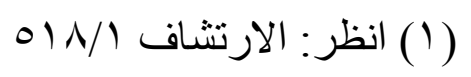

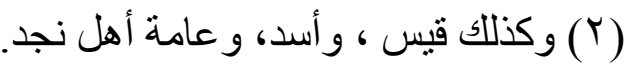

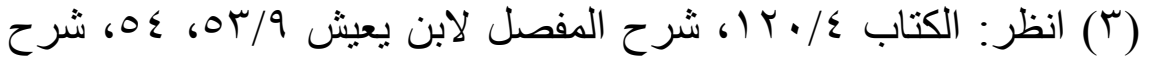

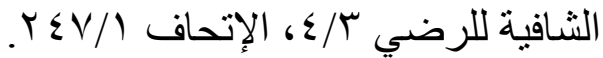

$$
\begin{aligned}
& \text { ( ) نحو: شيبان. } \\
& \text { (0) نحو: بينها. } \\
& \text { (T) نحو: عابد. } \\
& \text { نحو: عِماد. (V) } \\
& \text { (^) نحو: شِمْلال. }
\end{aligned}
$$

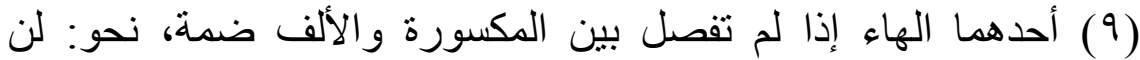

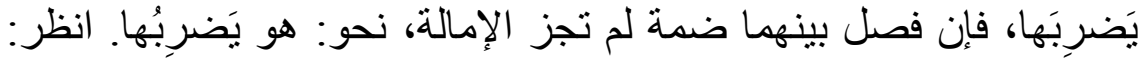

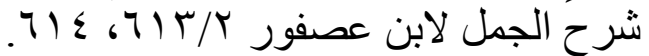

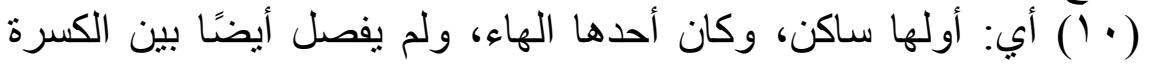

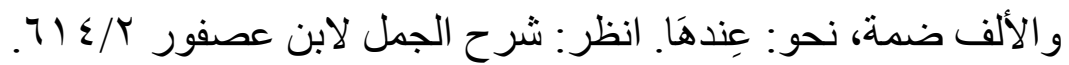

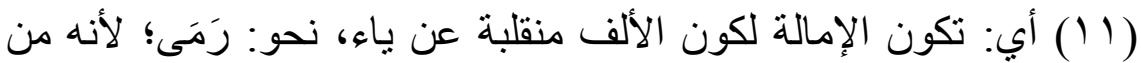

( I أب: أن الإمالة تكون لكون الألف مشبهةً بما انقلب عن ياء، نحو: حُبْلَى، فإن ألفها غير منقلبة عن شيء إلا أنها نتبه المنقلبة عن الياء من جهة 


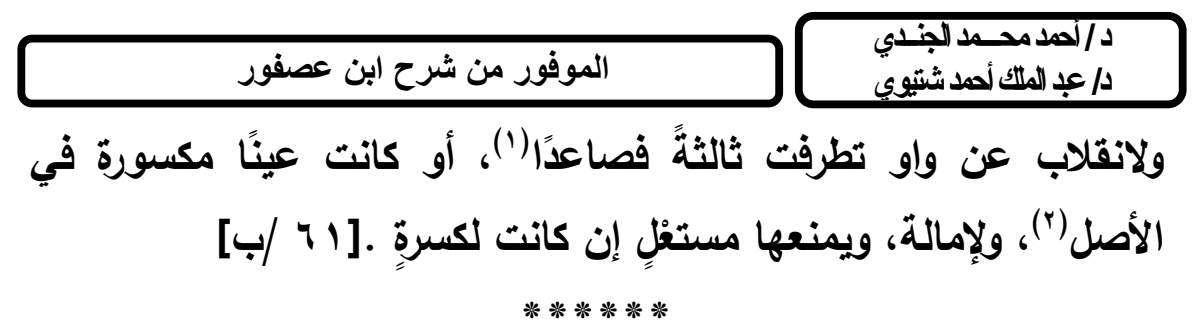

أنكا لو ثنيت حُبلى لقلت: حُبليان، فقلبت الألف ياء كما تفعل بالألف المنقلبة

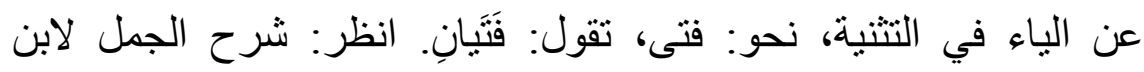

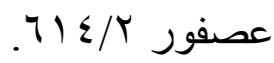

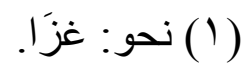
(Y) (1) نحو: خاف، فإن أصله: خَوِفَ. 


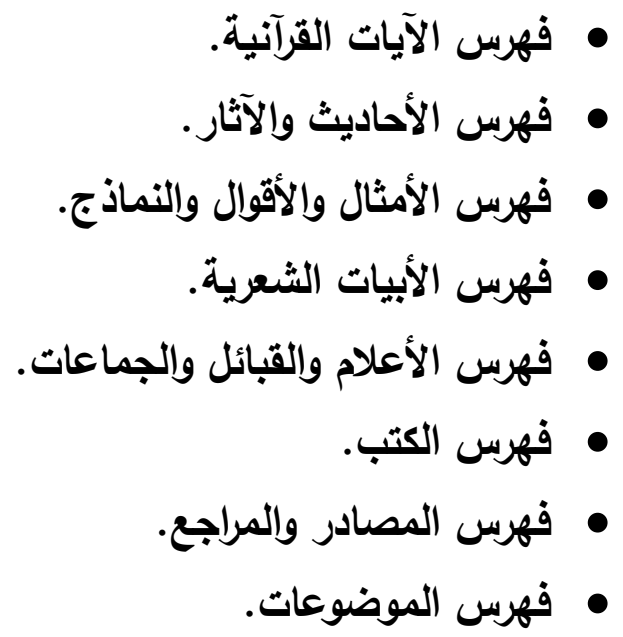




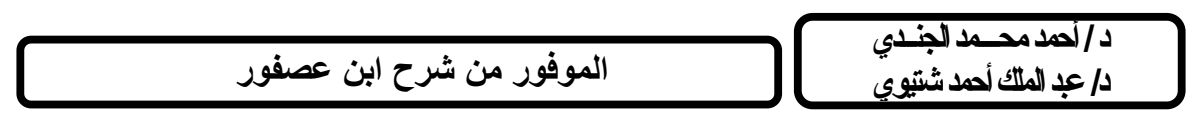

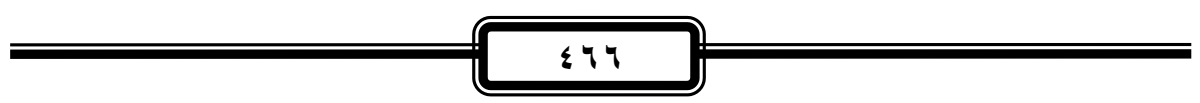




\begin{tabular}{|c|c|c|}
\hline \multicolumn{2}{|c|}{ 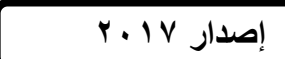 } & حولية كلية اللغة العربية بالمنوفية العدد الثاني والثلاثون \\
\hline \multicolumn{3}{|r|}{ فهرس الآيات القرآنية } \\
\hline الصفحة & رقمها & الآية \\
\hline & & 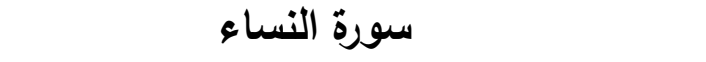 \\
\hline rqu & $\varepsilon$ & 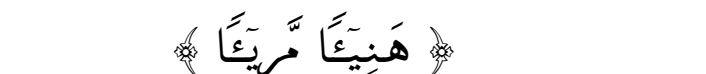 \\
\hline rqV & $|v|$ & 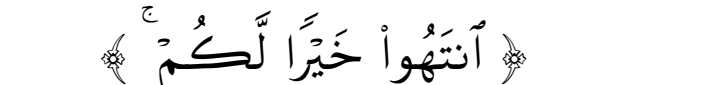 \\
\hline & & 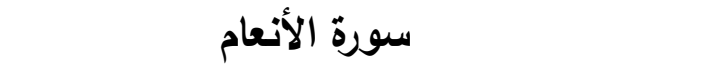 \\
\hline$\leqslant \leqslant \wedge$ & Irr & 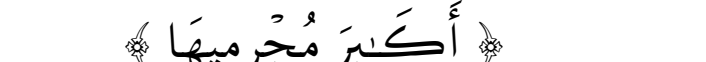 \\
\hline & & سورة الأعراف \\
\hline 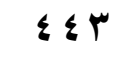 & $V \varepsilon$ & 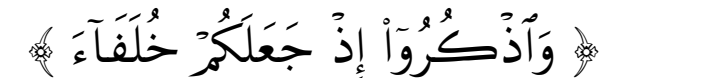 \\
\hline
\end{tabular}

فهرس الأحاديث والآثار

لا ها الله ذا: الجr.

فهرس الأمثال والأقوال والنماذج

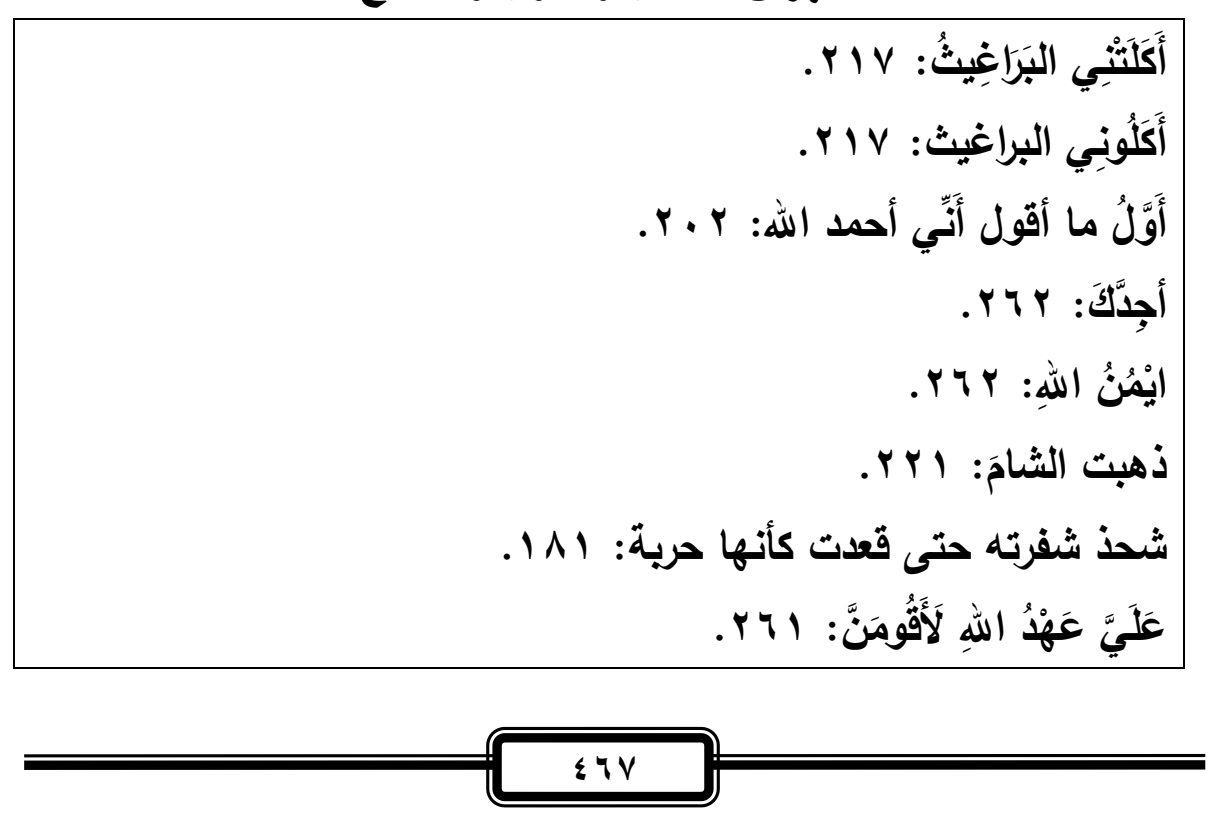




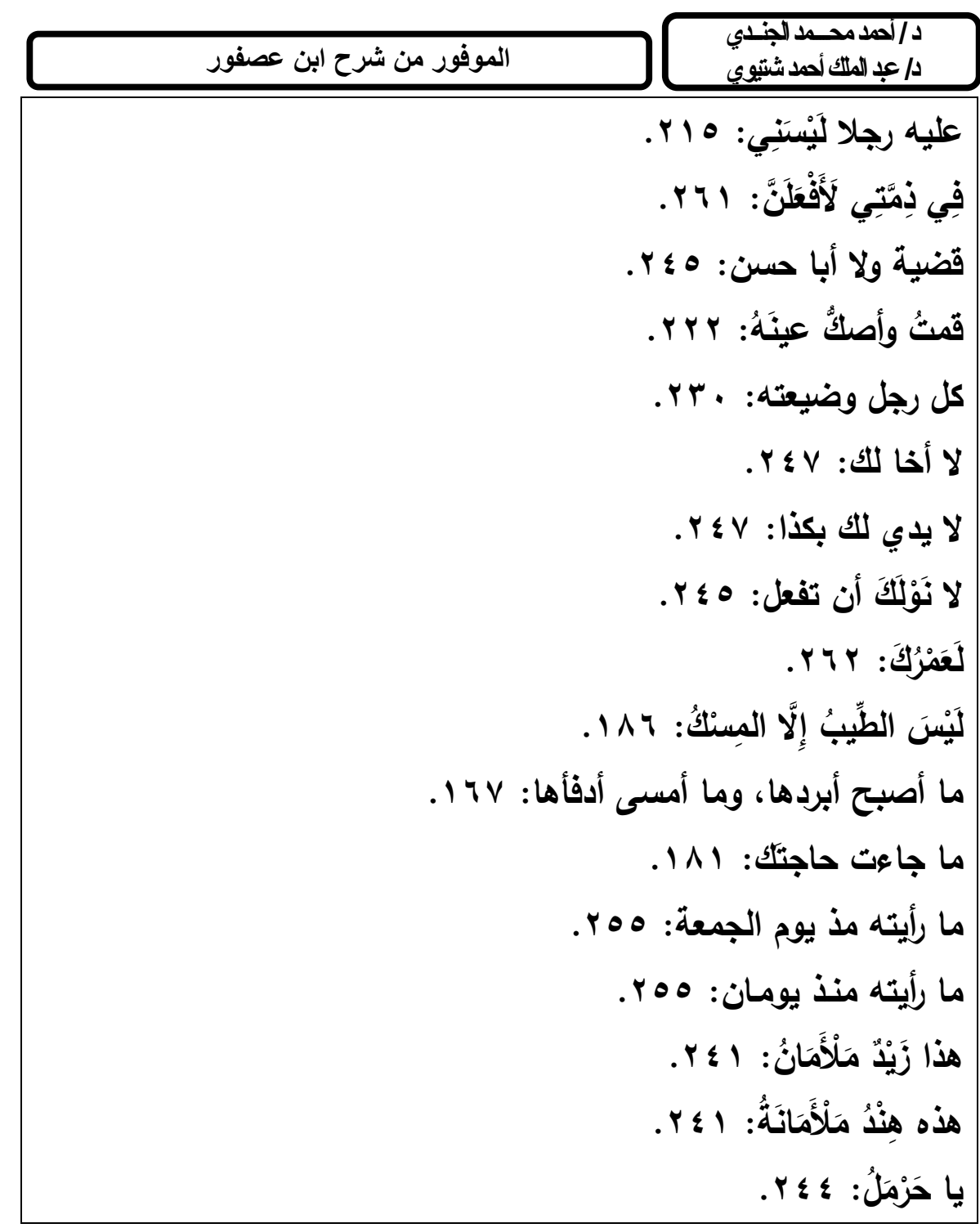




\begin{tabular}{|c|c|c|}
\hline \multicolumn{2}{|c|}{ 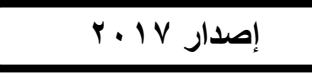 } & \multirow{2}{*}{ حولية كلية اللغة العربية بالمنوفية العدد الثاني والثلاثون } \\
\hline & & \\
\hline الصفحة & القائل & البيت \\
\hline 451 & - & تربِطِ بالحَبْلِ أُكَيْرِعِاتِي \\
\hline 189 & زالأعجم & كمن ليس غاد ولا رائحُ \\
\hline $1 \wedge 7$ & ذو الرمة & 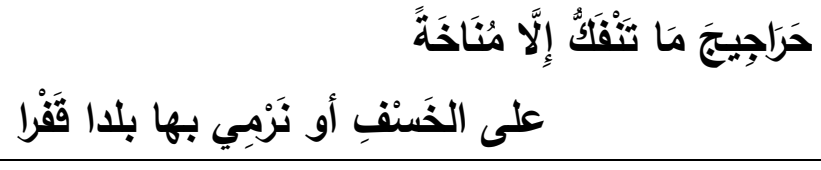 \\
\hline 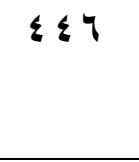 & الفرزدق & وإذا الرجالُ رأوا يزيََ رأيتَهُم \\
\hline$r \vee q$ & - & تَرَى الثَور فيها مُدخلَ الظل رأسََهُ \\
\hline IAr & ن بضل بني & 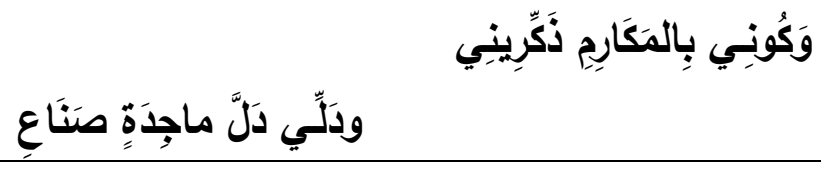 \\
\hline$r \wedge q$ & القيسو & فلو أنّ ما أسعى لأنسى معيشتة \\
\hline$\leqslant 01$ & - & قد جَرَتِ الطَيَرُ أَيامِنينا \\
\hline$\leq 01$ & - & 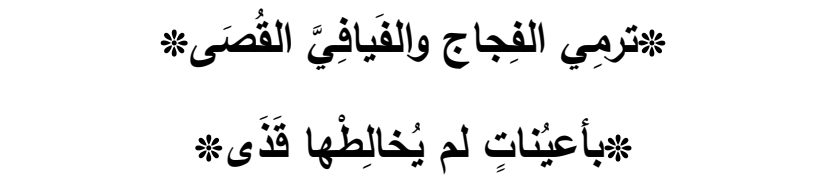 \\
\hline
\end{tabular}


الموفور من شرح ابن عصفور

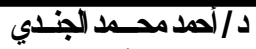

دا عبد الملك أحمد شنتئوي

فهرس الأعلام والقبائل والجماعات والطوائف

الأخفش الأوسط: IV

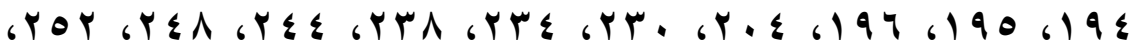
I الأخفش الأصغز : ع.r.

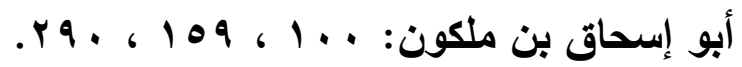

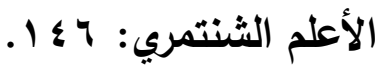

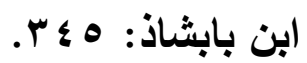

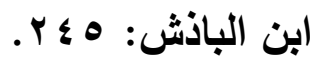

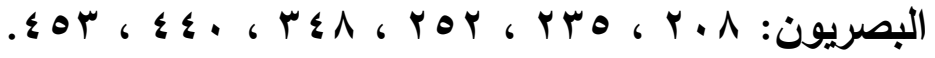

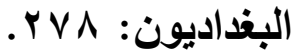

تميم (التميميون): . $\{09$, $r \leq \leqslant$, $r\{$.

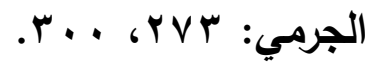

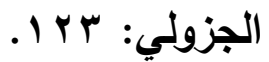

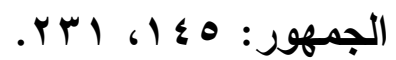

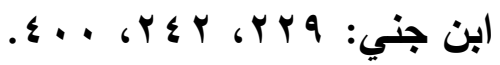

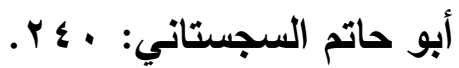

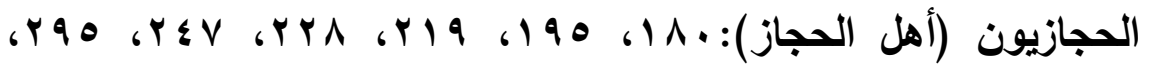




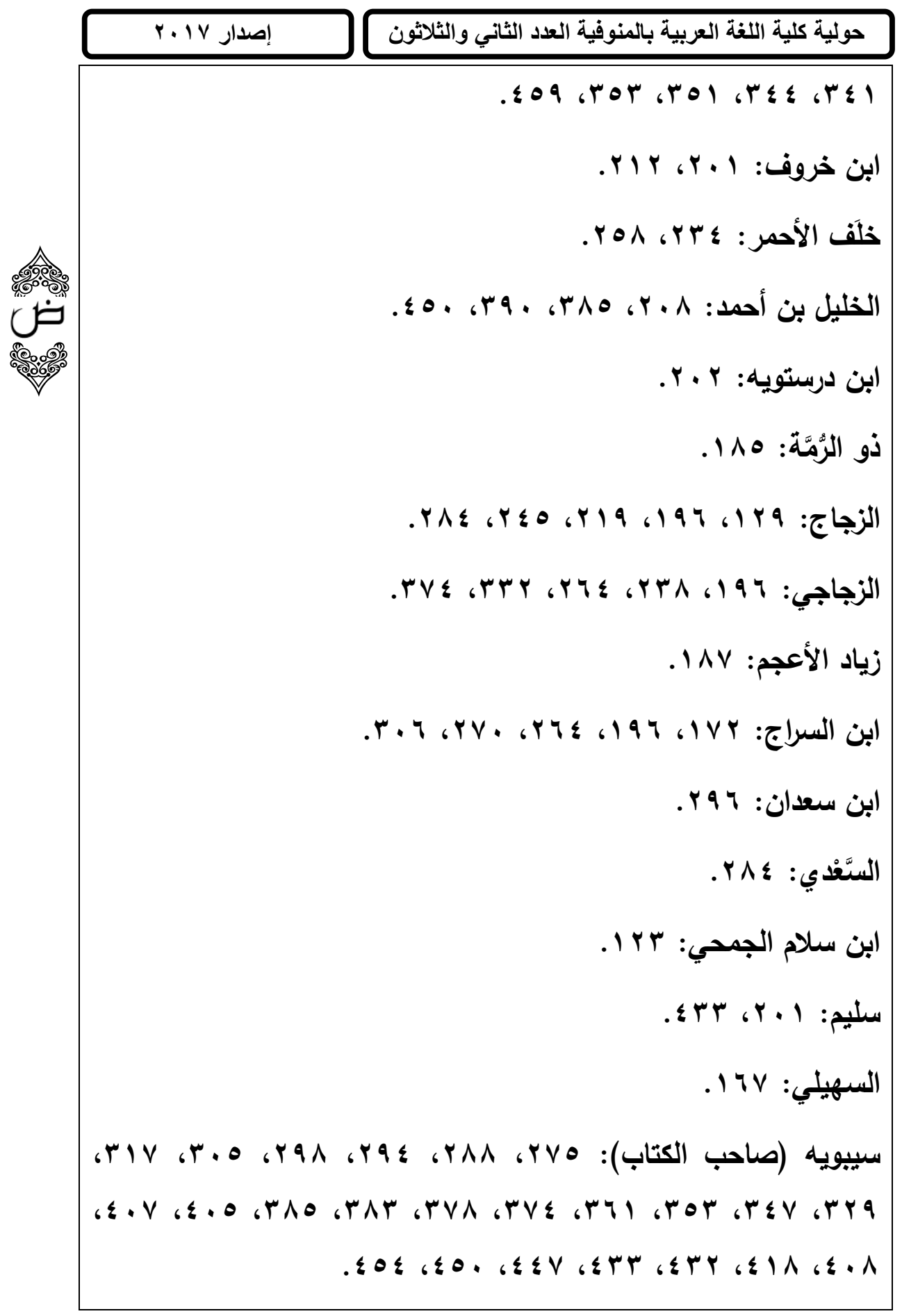




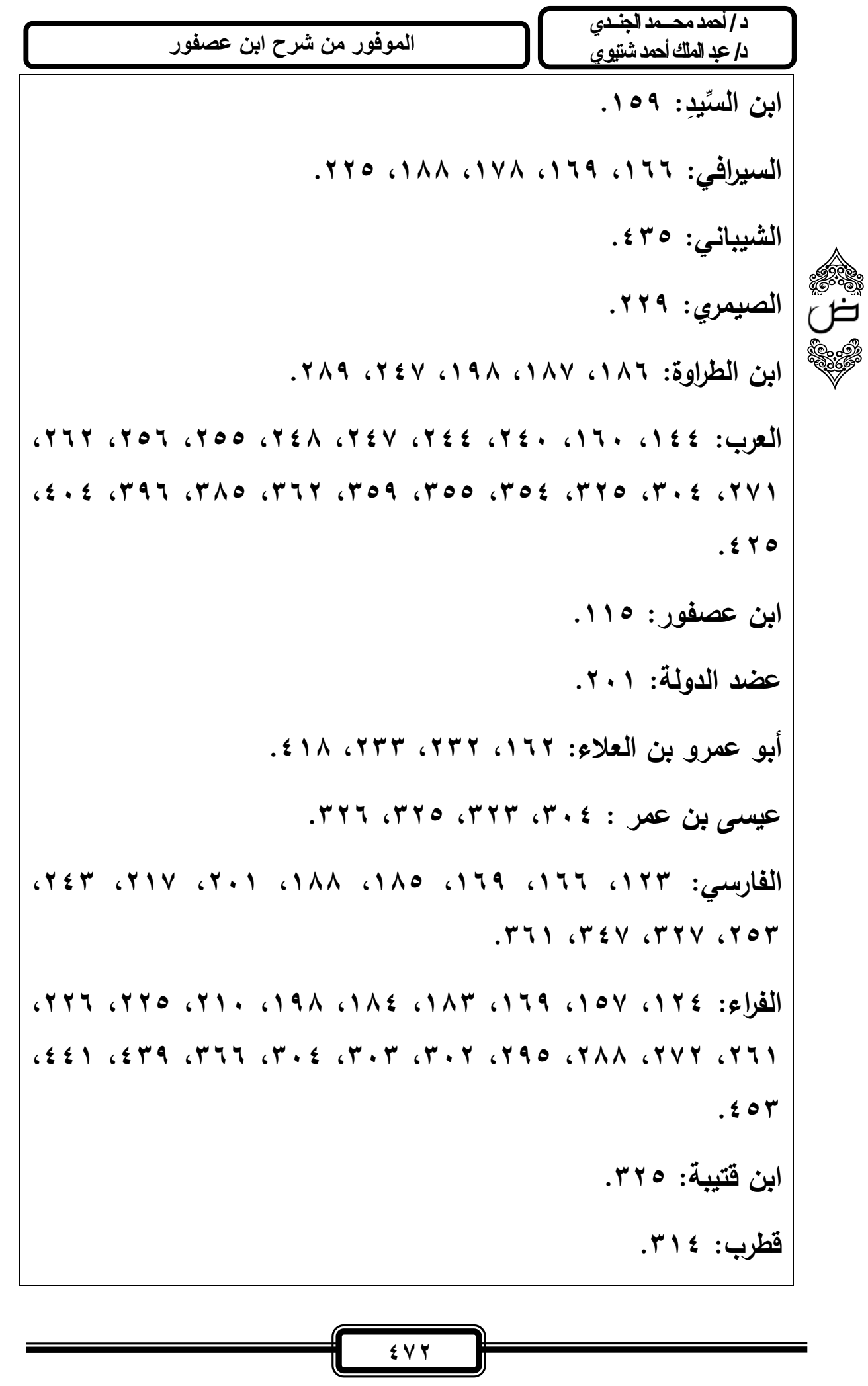




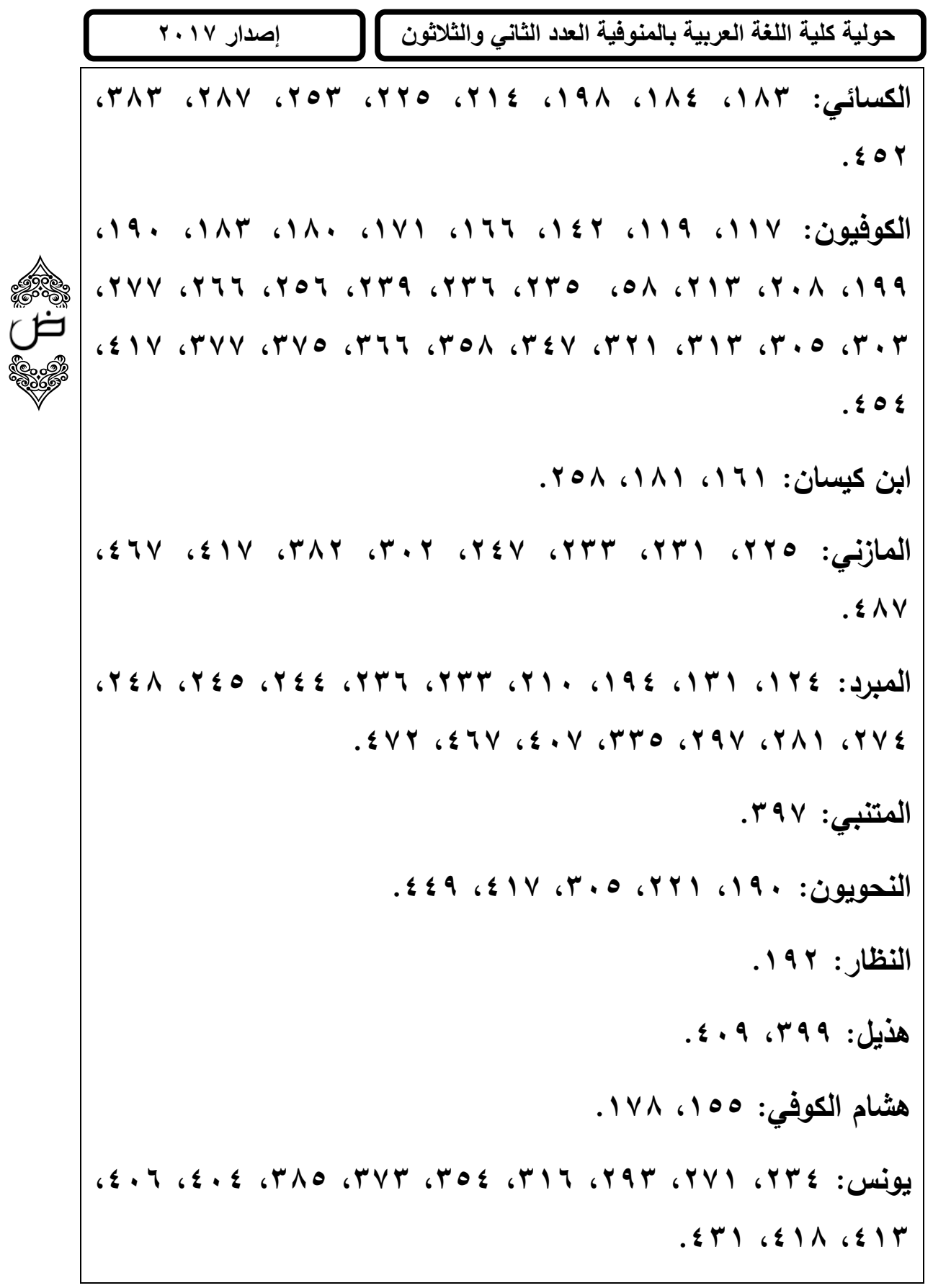




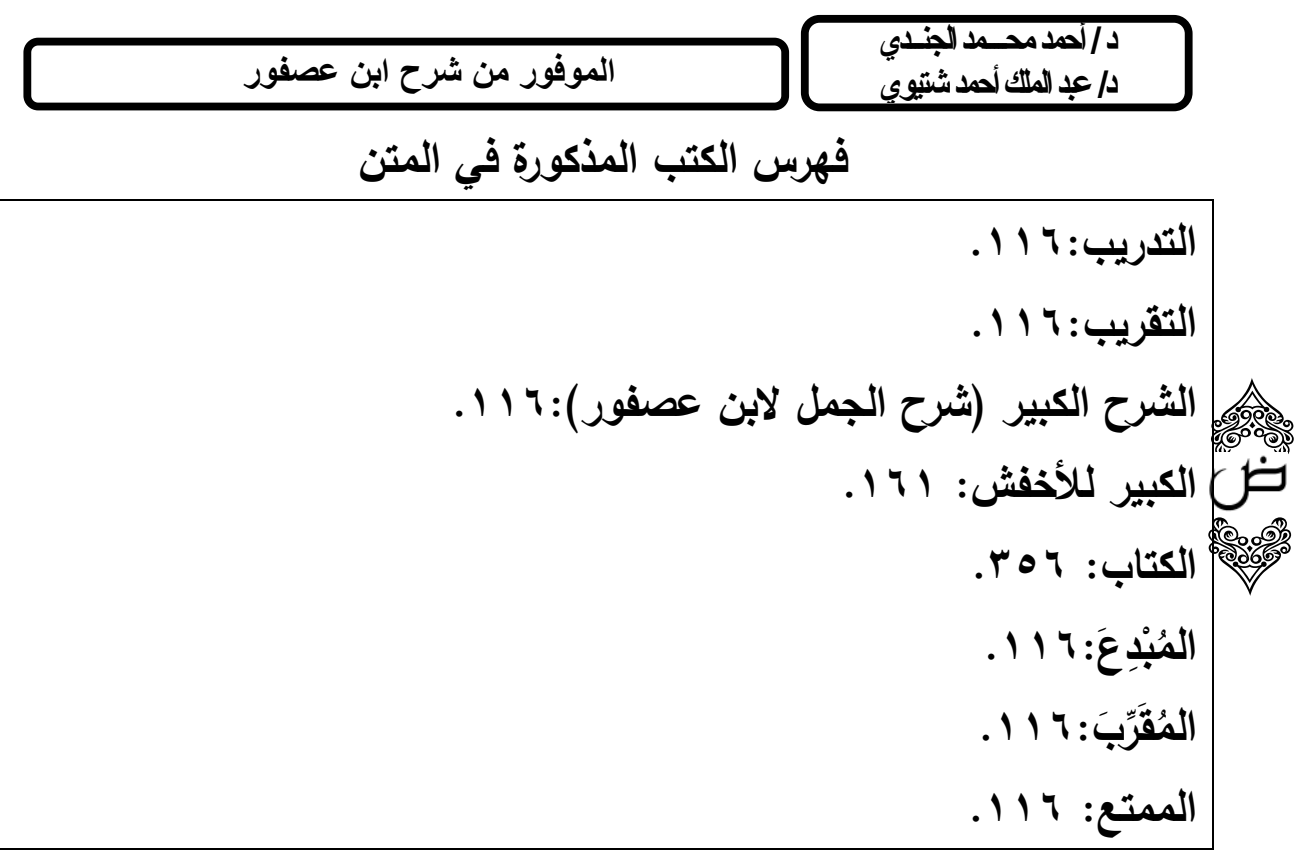




\section{المادر والمراجع}

- ائتلاف النصرة في اختلاف نحاة الكوفة والبصرة لعبد اللطيف بن أبى بكر الشرجي الزبيدي تحقيق د/ طارق الجنابي-عالم الكتب ومكتبة

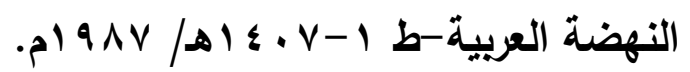
- الأبذي ومنهجه في النحو مع تحقيق السفر الأول من شرحه على الجزولية، إعداد/ سعد بن حدان الغامدي، إثراف أ.د/محمد إبراهيم

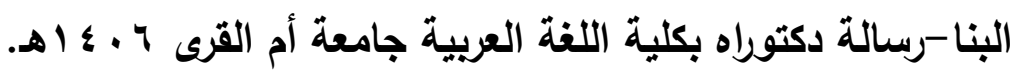
- أبو حيان النحوي -للاكتورة/ خديجة الحديثي -مكتبة النهضة بغداد-ط

$$
\text { . } 997 / \Delta 1 \% \wedge 0-1
$$

- - أبو عبد الله بن الفخار وجهوده في الدراسات النحوية مع تحقيق كتابه شرح الجمل، إعداد/ حمّاد بن محمد حامد الثمالي، رسالة دكتوراه في كلية

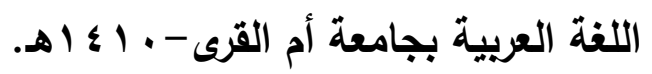

- إتحاف فضلاء البشر بالقراءات الأربعة عشر المسمى ( منتهى الأمانى والمسرات في علوم القراءات) تأليف/ أحمد بن محمد البنا

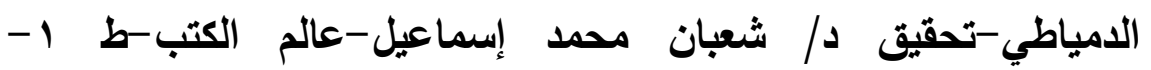

$$
\text { . } 9 \Lambda V / \Delta 1 \leq \cdot V
$$

- الإحاطة في أخبار غرناطة-لمحمد بن عبد الله بن سعيد السلماني اللوشي الأصل، الغرناطي الأندلسي، الثهير بلسان الدين ابن الخطيب

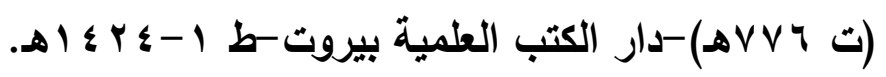
- أخبار النحويين البصريين ومراتبهم وأخذ بعضهم عن بعض، صنعه أبي سعيد الحسن بن عبد الله السيرافى -تحقيق د/ محمد إبراهيم البنا-دار

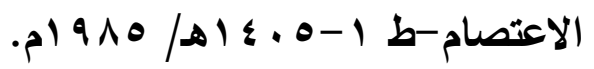


- أدب الكاتب لابن قتيبة-شرحه وقام لله أ/ علي فاعور -وزارة الشؤون الإسلامية بالمملكة العربية السعودية-بدون تاريخ. - أدب الكاتب أو أدب الكتّاب لابن قتيبة-تحقيق د/ محمد الداليمؤسسة الرسالة بيروت.

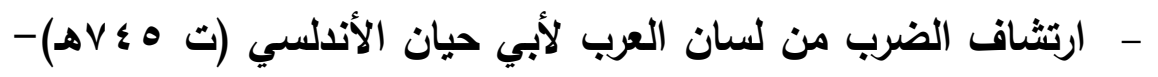

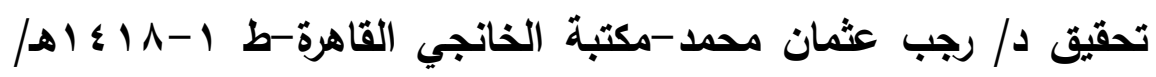
. $) 991$

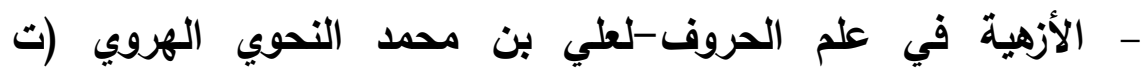
ه أهـ)-تحقيق/ عبد المعين الملوحي -مطبوعات مجمع اللغة العربية

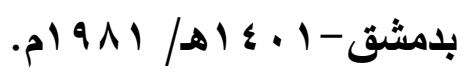

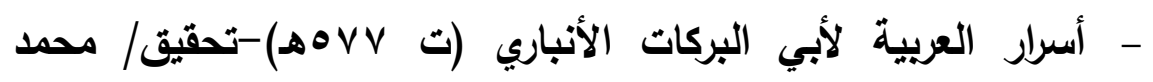
بهجة البيطار -دار الأقاق العربية دمثق -بدون.

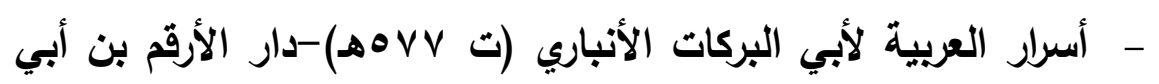

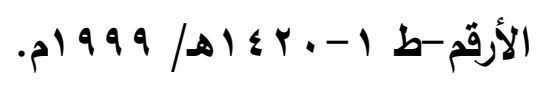

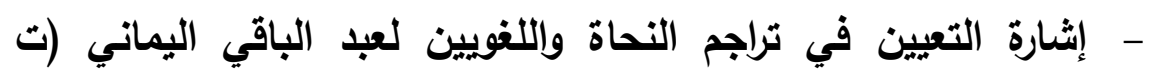
r ع Vه)-تحقيق د/عبد المجيد دياب-ط r-مركز الملك فيصل الرياض-p) $9 \wedge 7$

- إصلاح الخلل الواقع في الجمل للزجاجي-لابن السيد البطليوسي- التهي-

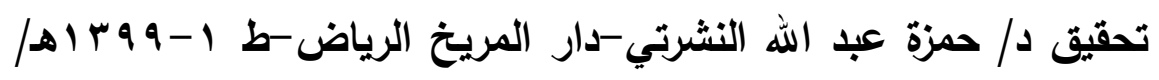
. $) 9 \vee 9$

- الأصول في النحو لأبي بكر بن السراج (ت آ اسهـ)-تحقيق د/ عبد

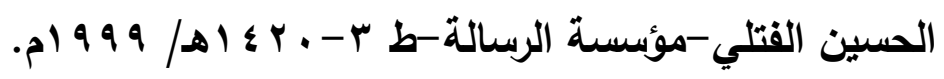




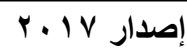

حولية كلية اللغة العربية بالمنوفية العدد الثاني والثلاثون

- إعراب القرآن للنحاس (ت ^rrهـ)-تحقيق د/ زهير غازي زاهد-عالم

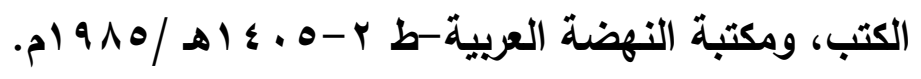

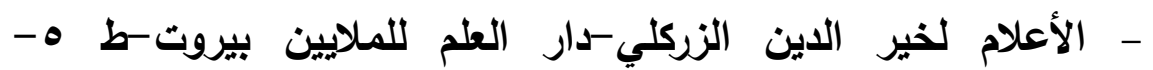
- 191 .

- أعيان العصر وأعوان النصر-لصلاح الدين الصفدي (ت ع ؟ ؟هـ)تحقيق د/ علي أبو زيد وآخرين-دار الفكر المعاصر بيروت، ودار الفكر

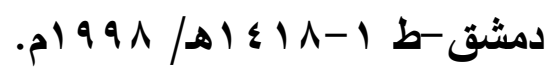

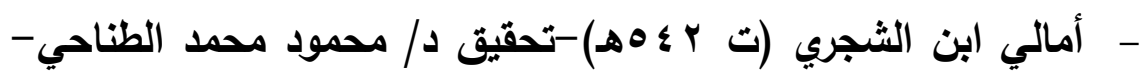

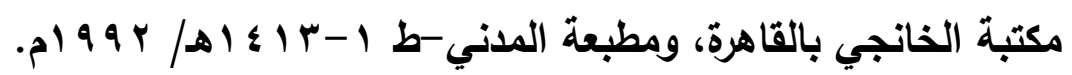
- إنباه الرواة علي أنباه النحاة-تأليف/ جمال الدين القفطي ل צ r 7هـ)-تحقيق/محمد أبي الفضل إبراهيم-دار الفكر العربي القاهرة،

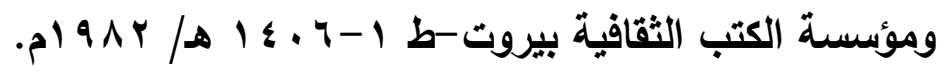
- الانتصار لسيبويه على المبرد-لأبي العباس أحمد بن محمد بن ولاد (ت ب rMه)-تحقيق د/ زهير عبد المحسن سلطان-مؤسسة الرسالة

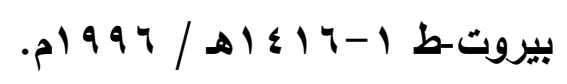

- الإنصاف فى مسائل الخلاف بين النحويين البصريين والكوفيين-لأبي البركات الأنباري (ت هAV هـ)، ومعه كتاب الانتصاف من الإنصاف للشيخ/ محمد محيي الدين عبد الحميد-المكتبة العصرية صيدا بيروت . $9 \wedge \mathrm{V} / \Delta 1 \varepsilon \cdot V$

- أوضح المسالك إلى ألفية ابن مالك لابن هثام الأنصاري -تحقيق|

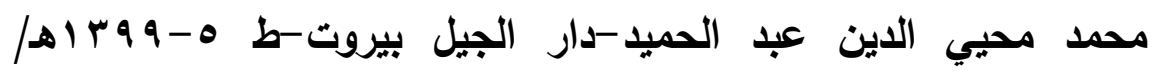


- الإيضاح-لأبي علي الفارسي (ت هـVVV)-تحقيق د/ كاظم بحر

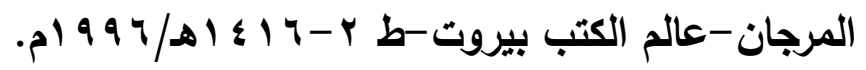
- الإيضاح العضدي لأبي علي الفارسي (ت هـVVV)-تحقيق: حسن

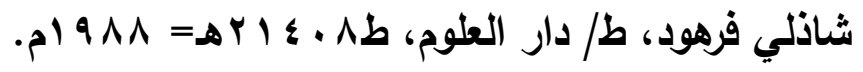
- الإيضاح في شرح المفصل لابن الحاجب النحوي (ت ؟ ؟ \هـ)-تحقيق

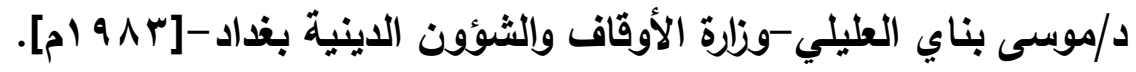

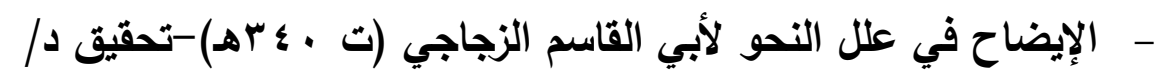

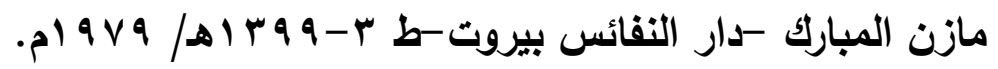
- البحر المحيط في التفسير لأبي حيان الأندلسي (ت ه ؛ \&هـ)-تحقيق|

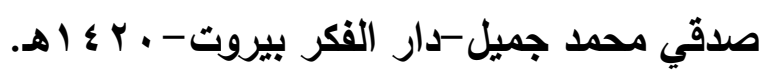
- البدر الطالع بمحاسن من بعد القرن السابع لمحمد بن علي بن محمد

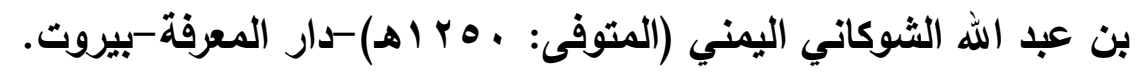

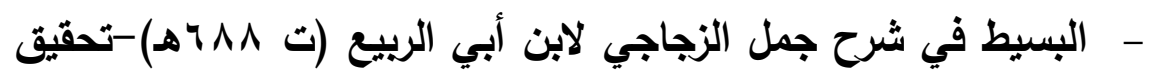

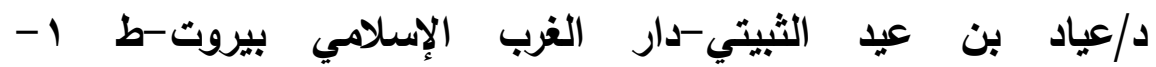
. 9 ( $9 \wedge 7 / \Delta 1 \varepsilon \cdot V$

- بغية الوعاة في طبقات اللغويين والنحاة-لجلال الدين السيوطي

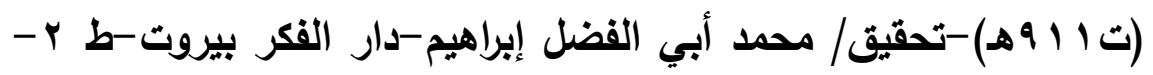
. 9 Q 9 / $/$ / 149

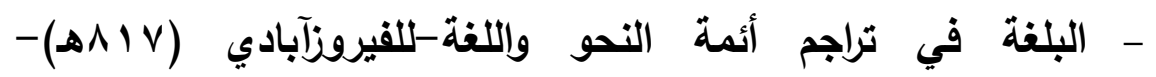

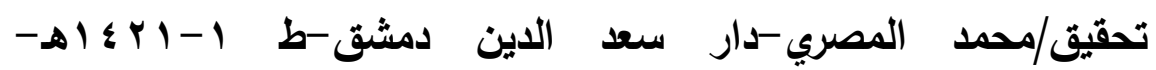
مr... 
- تاريخ الإسلام ووفيات المشاهير والأعلام لشمس الدين الأهبي (ت الدمات

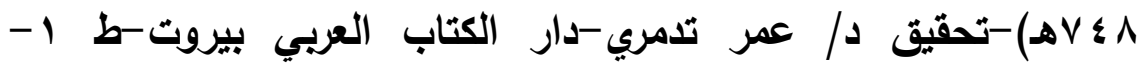
. $9 \wedge V / \Delta 1 \leq \cdot V$

- التبصرة والتذكرة، للصيمري -تحقيق د/ فتحي أحمد مصطفي -جامعة أم

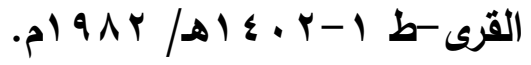

- - التبيين عن مذاهب النحويين البصريين والكوفيين -لأبي البقاء العكبري

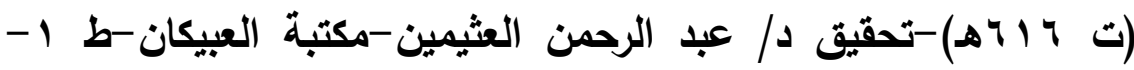
. $r$...

- التدريب في تمثيل التقريب لأبي حيان الأندلسي (ت 0 \& عه)-تحقيق د/ نهاد فليح حسن-مطبعة الإرشاد بيغداد-9 9 ام.

- التذييل والتكميل في شرح كتاب التسهيل لأبي حيان الأندلسي (تانيل

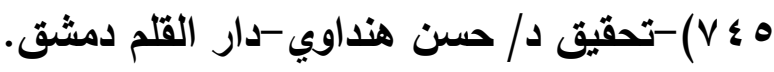

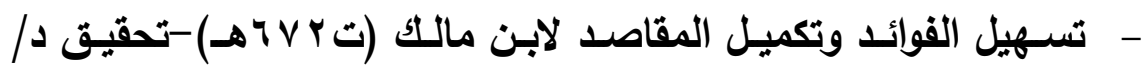
محمد كامل بركات-وزارة الثقافة بالجمهورية العربية المتحدة- I I I اهـ / - $197 \mathrm{~V}$ - التصريح بمضمون التوضيح للشيخ خالد الأزهري (ته ـ 9ه)-تحقيق

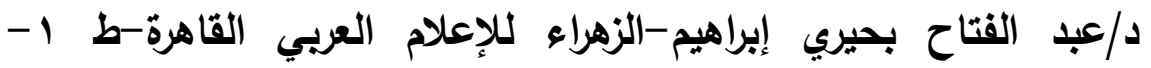
. $994 / \Delta 1 \leq 1 r$ - التصريح بمضمون التوضيح للشيخ خالد الأزهري (تهه. هـ)-دار

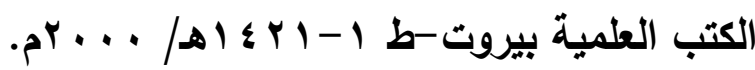

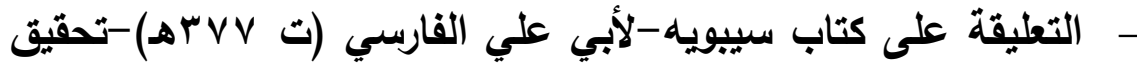

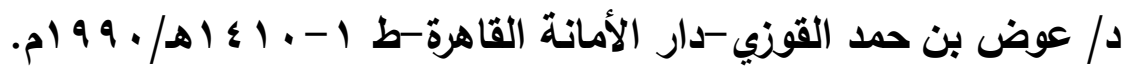


الموفور من شرح ابن عصفور

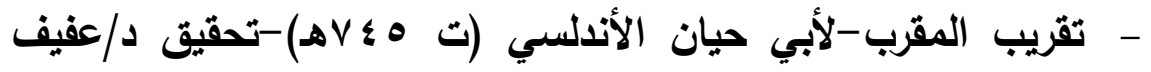

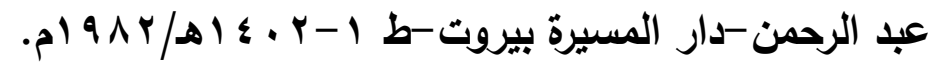

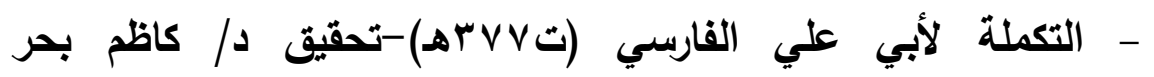

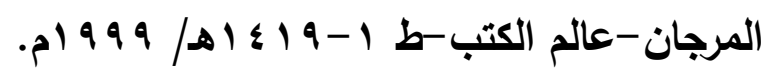

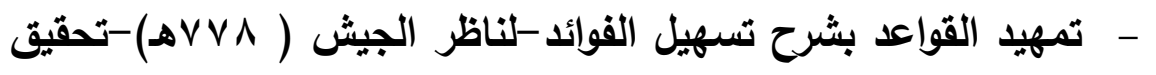

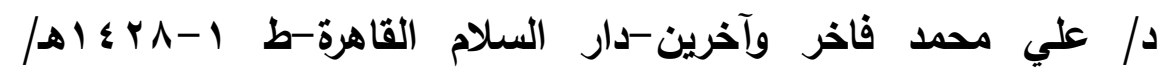
$\cdot p^{r} \cdot v$

- توجيه اللمع لابن الخباز ، تحقيق د/ فايز زكي دياب-دار السلام

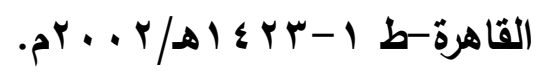
- توضيح المقاصد والمسالك بشرح ألفية ابن ماللك-للمرادي (9 \& \&ه)تحقيق د//عبد الرحمن علي سليمان -دار الفكر العربي القاهرة-ط ا-

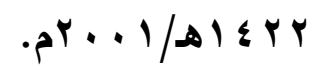
- الجمل في النحو-لأبي القاسم الزجاجي (ت ع عهـ)-تحقيق د/على

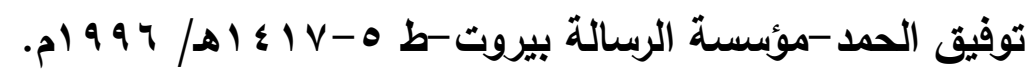

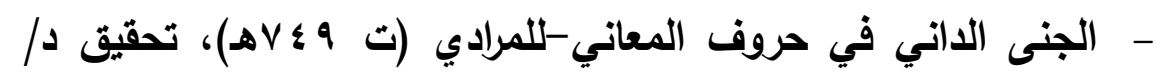
فخر الدين قباوة، أ/محمد نديم فاضل-دار الكتب العلمية بيروت-ط إسي جروفي - م) $99 r / \Delta 1 \leq 1 r$ - حاشية الخضري على شرح ابن عقيل على ألفية ابن مالك-دار الفكر للطباعة والنشر والتوزيع -بدون. - حاثية الصبان على شرح الأشثوني لألفية ابن مالك-دار الكتب

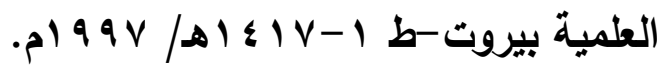


- الحجة للقراء السبعة-لأبي علي الفارسي (ت هـVV -

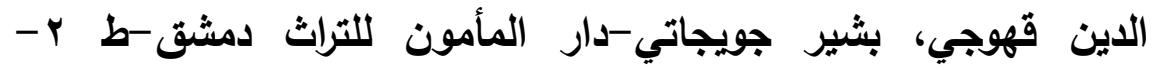

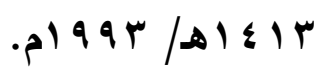
- حروف المعاني-لأبي القاسم الزجاجي (ت ـ ـ هـ)-تحقيق د/علي توفيق الحمد-مؤسسة الرسالة بيروت، ودار الأمل الأردن-ط ب r -

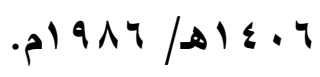

- خزانة الأدب ولب لباب لسان العرب-تأليف/عبد القادر بن عمر

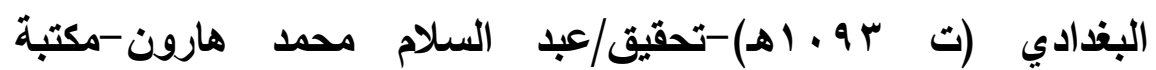

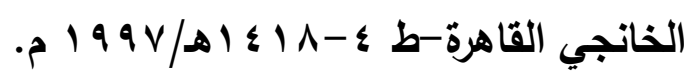
- الخصائص-لابن جني (ت r Y Y Mـ)-الهيئة المصرية العامة للكتابط - درة الحجال في أسماء الرجال لأبي العباس المكناسي الشهير بابن القاضي (ت ه • (1ه)-تحقيق/ محمد الأحمدي أبو النور-دار التراث بالقاهرة-بدون. - دقائق التصريف-لأبي القاسم المؤدب (ت ^بr)-تحقيق د/حاتم

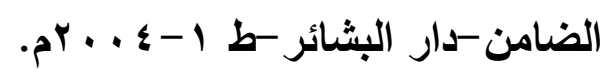
- ذيل التقييا في رواة السنن والأسانيا-لمحمد بن أحمد بن علي الفاسي (ت r rAه)-تحقيق/ كمال يوسف الحوت-دار الكتب العلمية

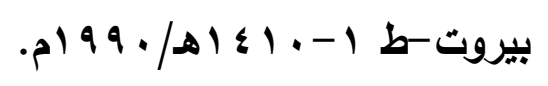

- الايل والتكملة لكتابي الموصول والصلة لأبي عبد الله الأنصاري الأوسي المراكثي (ت ب · Vه)-تحقيق/ إحسان عباس -ط ا-دار الثقافة

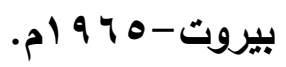




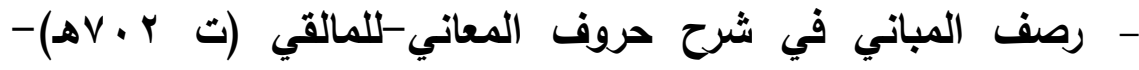
تحقيق/أحمد محمد الخراط-مطبوعات مجمع اللغة العربية بامشق - p) 9 V0 - روضات الجنات في أحوال العلماء والسادات-تأليف/ محمد باقر

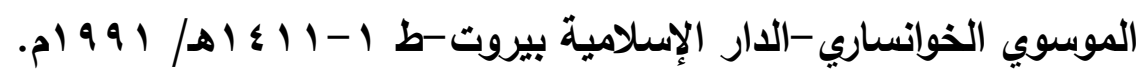
- الزجاجي حياته وآثاره ومذهبه النحوي من خلال كتابه (الإيضاح)

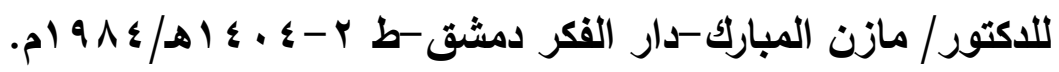

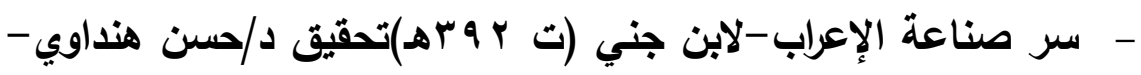

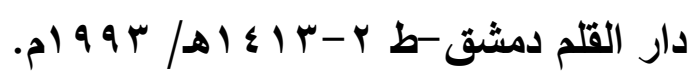
- سر صناعة الإعراب لابن جني (ت r r بهـ)-دار الكتب العلمية

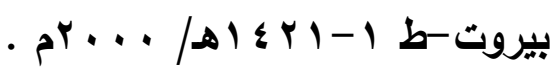
- السلوك لمعرفة دول الملوك لتقي الدين المقريزي (تمــهـ)-

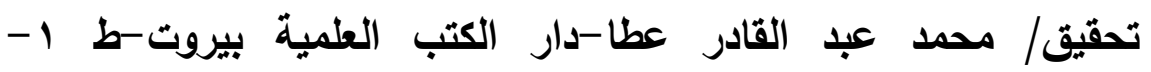
- $99 \mathrm{~V} / \mathrm{D} / \leq 11$

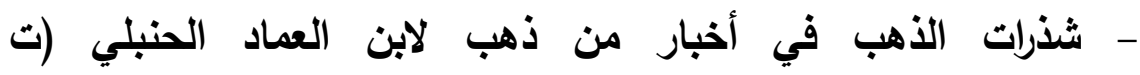
9 • ا (هـ)-تحقيق/ محمود الأرناؤوط-دار (بن كثير دمثق، وييروت-ط . $9194 / 81 \leq \cdot 7-1$

- شرح الأشموني علي ألفية ابن مالك المسمى منهج السالك إلى ألفية ابن مالكك-تحقيق/ محمد محيي الدين عبد الحميد-دار الكتاب العربي

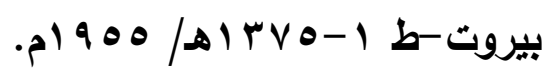

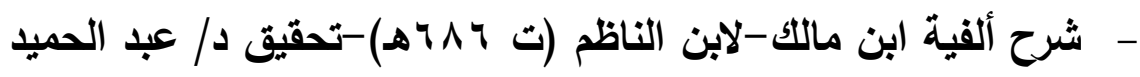

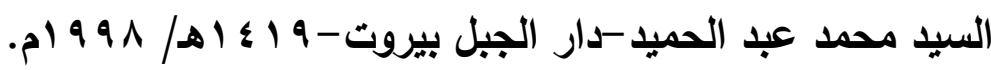


د/ محمد بدوي المختون -هجر للطباعة والنشر والتوزيع -ط 1- ـ 1 أهـ/ . p) 99 . - شرح جمل الزجاجي الثرح الكبير-لابن عصفور (ت 9 ؛ جهـ)-تحقيق

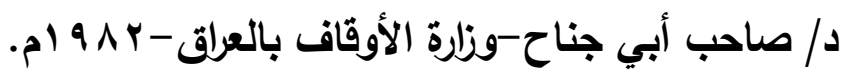
- شرح جمل الزجاجي لابن خروف الإثبيلي (ت 9 . د/سلوى محمد عرب-مطبوعات جامعة أم القرى -9 1 ـ الهـ.

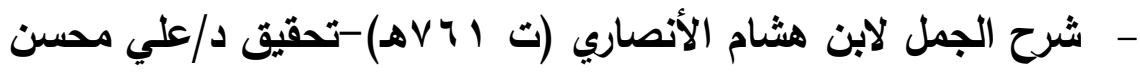

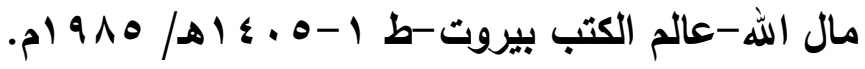

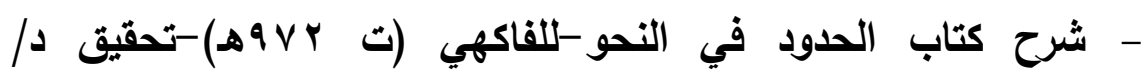

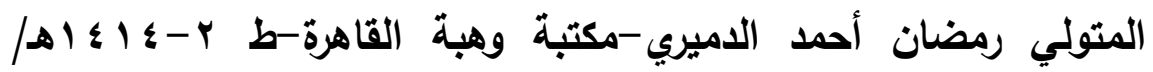
. 1994 - شرح حدود النحو-لابن قاسم-تحقيق د/ المتولي رمضان أحمد

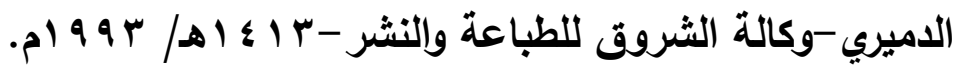
- شرح شافية ابن الحاجب لرضي الدين الأستراباذي (ت ؟1 \هـ) مع شرح شواهده لعبد القادر البغدادي (ت ب و ، اهـ)-تحقيق وضبط/ محمد

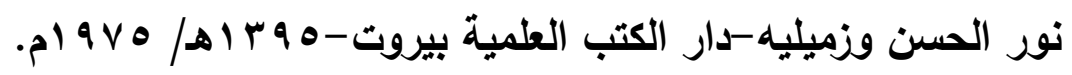

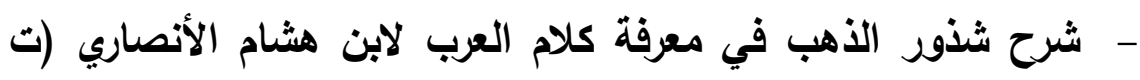

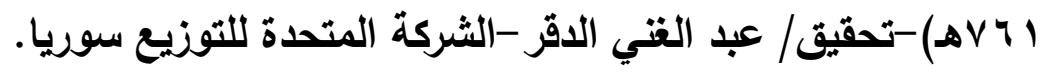
- شرح شواهد المغتي-لجلال الدين السيوطي (ت الهوهـ-منشورات دار مكتبة الحياة بيروت -بلون.

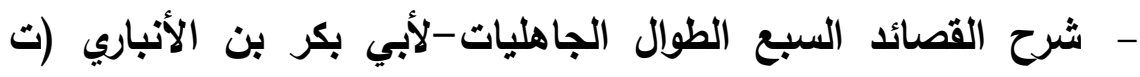

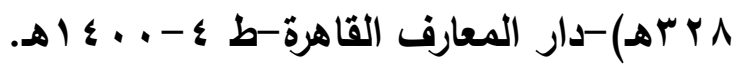


- شرح قطر الندى ويل الصدى -لابن هشام الأنصاري (ت الجVهـ)تحقيق/ محمد محيي الدين عبد الحميل-ط 1 |-المكتبة التجارية الكبرى

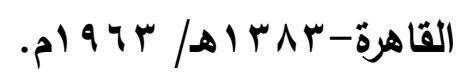

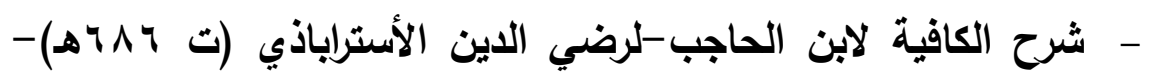
تصحيح وتعليق د/يوسف حسن عمر-منشورات جامعة قاريونس-

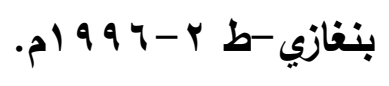

- شرح كافية ابن الحاجب-لابن جمعة الموصلي-تحقيق د د/علي

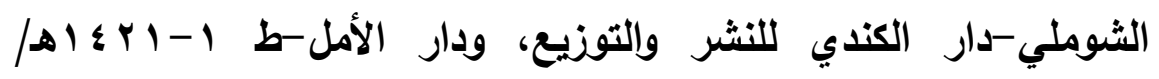
.

- شرح الكافية الموسوم بالبدور الضافية لابن الحاجب الصنعانيتحقيق/ محمد عبد الستار أبو زيلـرسالة دكتوراه بكلية اللغة العربية

$$
\text { بالزقازيق -جامعة الأزهر - V . . r م. }
$$

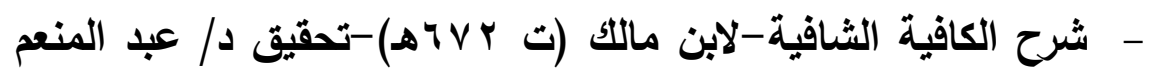

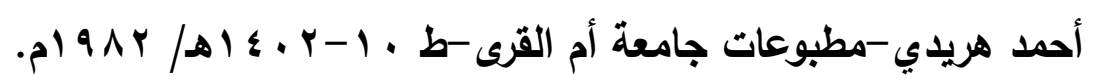
- شرح كتاب سييويه لأبي سعيد السيرافي (ت ^ ^rهـ)-تحقيق/ أحمد حسن مهدلي وعلي سيد علي-دار الكتب العلمية بيروت -ط ا-1 ـ . . بم. - شرح ابن عقيل (ت 9 - 9 (ته) على ألفية ابن مالك-ومعه كتاب منحة الجليل بتحقيق شرح ابن عقيل للشيخ/محمد محيي الاين عبد الحميد-دار

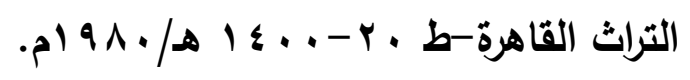
- شرح المفصل لابن يعيش (تبـ بهـ)-إدارة الطباعة المنيرية القاهرة-بدون. 
- شرح المفصل في صنعة الإعراب الموسوم بالتخمير-لصدر الأفاضل

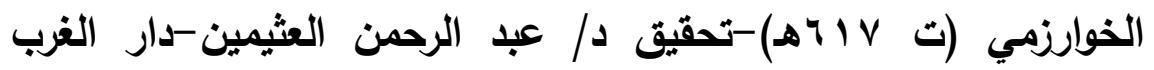

$$
\text { الإستلامي بيروت- - } 99 \text { ام. }
$$

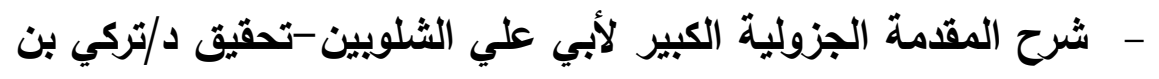

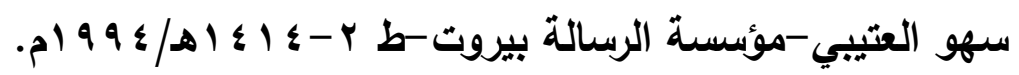
- شرح المقدمة المُحْسِبَةِ-لطاهر بن أحمد بن بابشاذ (ت 99 ؟ـهـ)-

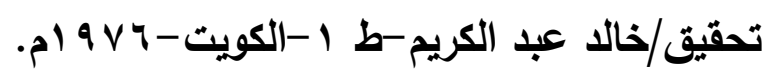

- شرح المقرب المسمى التعليقة للعلامة بهاء الدين بن النحاس مان

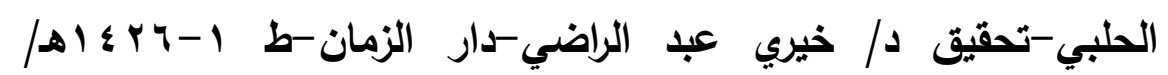

$$
\text { . م. م }
$$

- شرح المكودي (ت V • 1هـ) على ألفية ابن مالك-تحقيق د/ فاطمة الراجحي -جامعة الكويت بو 99 ام. - شعر زياد الأعجم-جمع وتحقيق ودراسة د / يوسف حسين بكار -دار

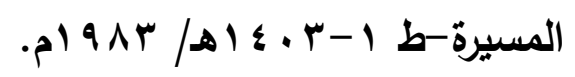
- شعر عمرو بن أحمر الباهلي-جمعه وحققه د د/ حسين عطوان مطبوعات مجمع اللغة العربية بدمشق.

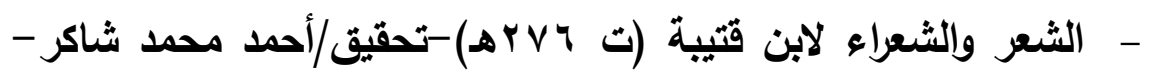
دار المعارف القاهرة-[ [ 9 امج]. - الثهادة الزكية في ثناء الأئمة على ابن تيمية-لمرعي بن يوسف الكرمي المقدسي الحنبلى (ت ب م ـ اهـ)-تحقيق/ نجم عبد الرحمن خلف-

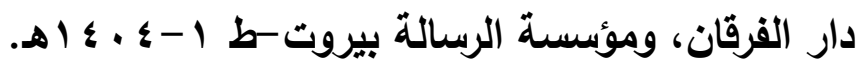




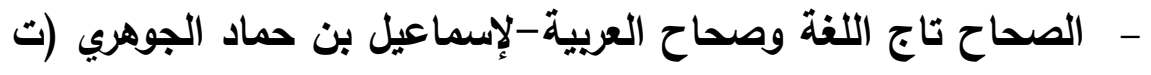
rq بهـ)-تحقيق/ أحمد عبد الغفور عطار-دار العلم للملايين بيروت-ط

$$
\text { . } 9 \wedge \varepsilon / \Delta 1 \leq \cdot \leq-r
$$

- صلة الصلة-لأبي جعفر الغرناطي (ت 1 •.Vه)-تحقيق/ شريف

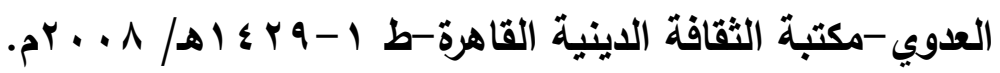
- - طبقات الشافعية لأبي بكر تقي الدين ابن قاضي شهبة (ت الهمهـ)-

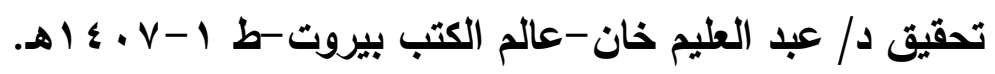
- طبقات الشافعية الكبرى لتاج الدين السبكي (ت IVV)-تحقيق د/ محمود محمد الطناحي، د// عبد القتاح محمد الحلو-هجر للطباعة

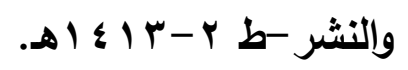

- طبقات المفسرين -للحافظ شمس الدين الداودي (ته ؛ هـ)-دار

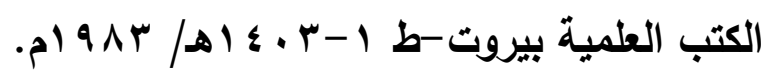

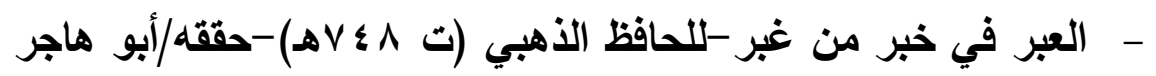

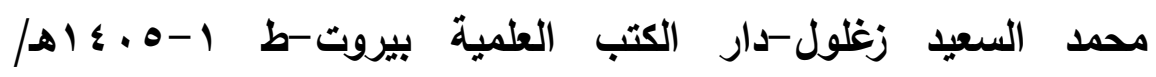
. 1910 - العقد المذهب في طبقات حملة المذهب لابن الملقن (ت ع . 1 هـ)

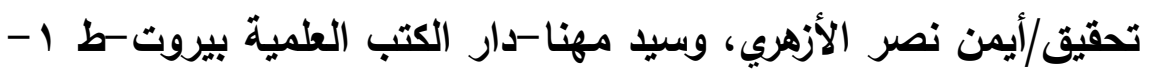
. $99 \mathrm{~V} / \mathrm{A} / \mathrm{s} 1 \mathrm{~V}$ - علل النحو لأبي الحسن الوراق (ت ه یrهـ)-تحقيق د/ محمود جاسم

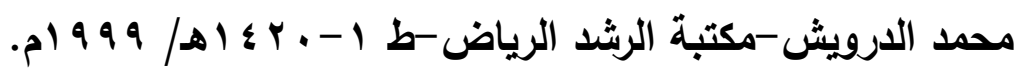
- عنوان الاراية فيمن عُرِفَ من العلماء في المائة السابعة ببجاية-لأبي

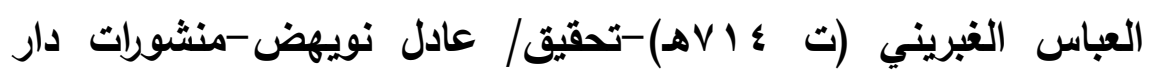

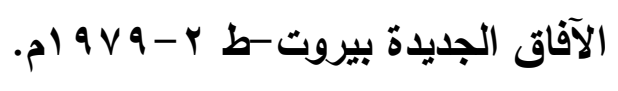




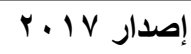

حولية كلية اللغة العربية بالمنوفية العدد الثاني والثلاثون

- غاية النهاية في طبقات القراء-لابن الجزري (ت بr^هـ)-عنى

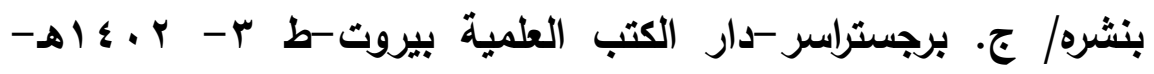
. $9 \wedge \mathrm{r}$

- الفاخر في شرح جمل عبد القاهر -لأبي الفتح البعلي (ت 9 ـ Vهـ)-

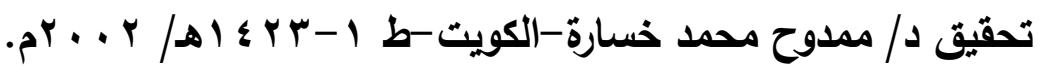
- فهرس الفهارس والأثبات ومعجم المعاجم والمشيخات والمسلسلات تأليف/ عبد الحي الكتاني-اعتناء د/ إحسان عباس-دار الغرب الإسدلامي

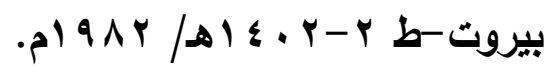
- فوات الوفيات لمحمد بن شاكر الكتبي (تع ؟Vه)-تحقيق/ إحسان

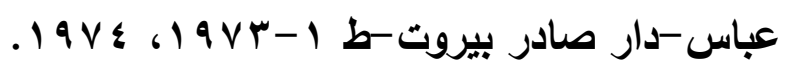
- الكامل في اللغة والأدب-لأبي العباس محمد بن يزيد المبرد (تال

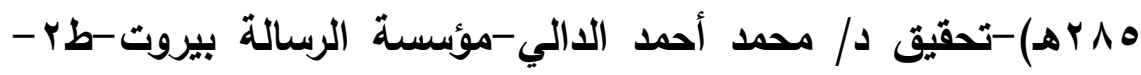
- $199 \mathrm{~V}$ - الكتاب لأبي بشر عمرو بن عثمان بن قنبر تحقيق وشرح الشيخ عبد السلام هارون ، دار الجيل بيروت ، الطبعة الأولى •

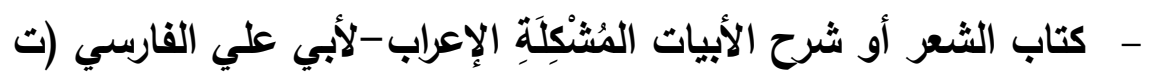

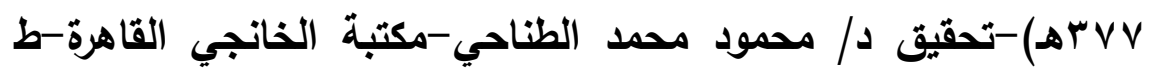

$$
\text { . } 9 \wedge \wedge / \$ 1 \varepsilon \cdot \Lambda-1
$$

- كثف الظنون عن أسامي الكتب والفنون-لحاجي خليفة اهن

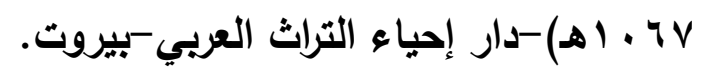
- الكليات معجم في المصطلحات والفروق اللغوية-لأبي البقاء الكفوي

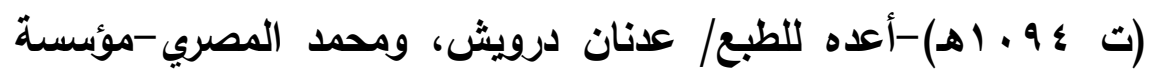

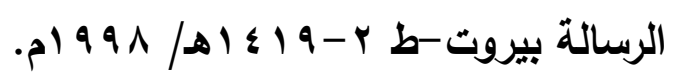


- اللباب في علل البناء والإعراب-لأبي البقاء العكبري (ت 19 (71)هـ)تحقيق د/ عبد الإله نبهان، وغازي مختار طليمات-دار الفكر المعاصر

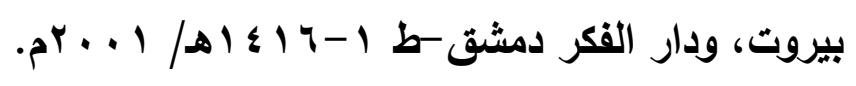

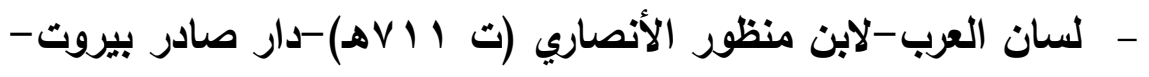
هـ

- ما ينصرف وما لا ينصرف-لأبي إسحاق الزجاج-ت المهـ-تحقيق د/ هدى محمود قراعة -مكتبة الخانجي القاهرة، ومطبعة المدني -ط ب. Pr...

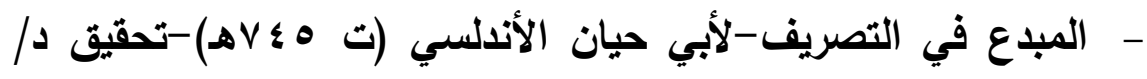

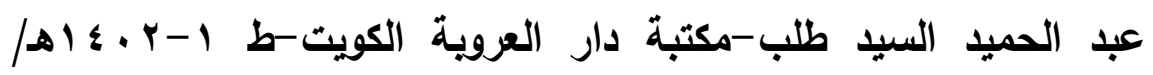
. $) 9 \wedge r$

- مجالس ثعلب-شرح وتحقيق/عبد السلام محمد هارون -دار المعارف القاهرة-الجزء الأول ط ع -... اهـ=.9 امه، والجزء الثاني طه [5) $9 \wedge \mathrm{s}]$ - مجالس العلماء-لأبي إسحاق الزجاجي (ت . ع بهـ-تحقيق/عبد

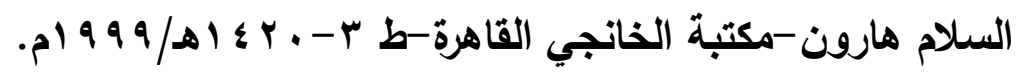
- مجمع الأمثال-لأبي الفضل الميداني (ت 1 ا 10 هـ)-تحقيق/ محمد أبي الفضل إبراهيم -مكتبة عيسي البابي الحلبي. - المحتسب في تبيين وجوه شواذ القراءات والإيضاح عنها-لابن جني (ت r r r r)-تحقيق/علي النجدي ناصف وزميليه-المجلس الأعلى

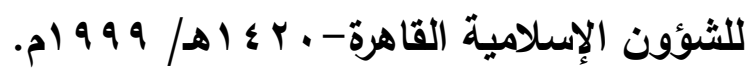


- المحرر الوجيز في تفسير الكتاب العزيز-لابن عطية الأندلسي (تابل 7 \هــ)-تحقيق/عبد السلام عبد الشافي محمد-دار الكتب العلمية

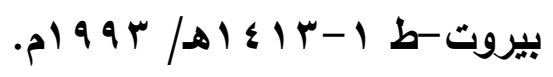

- المحكم والمحيط الأعظم لابن سيده (ت ^هـ هـ)-تحقيق/ عبد الحميد

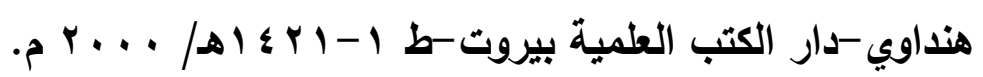
- المخصص لابن سيده (ت ^هـ هـ)-تحقيق/ خليل إبراهم جفال-دار هـ

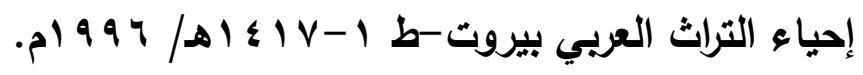
- المرتجل في شرح الجمل-لابن الخشاب (ت Vوهـ)-تحقيق/علي

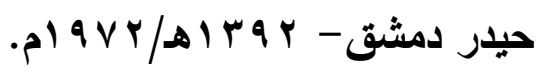
- المسائل البصريات-لأبي علي الفارسي (ت هـVV -

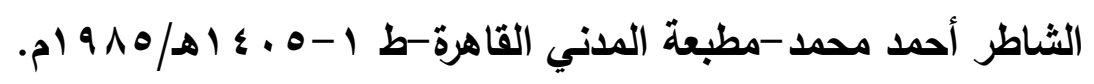
- المسائل الحلبيات-لأبي علي الفارسي (ت

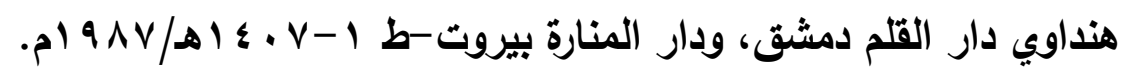

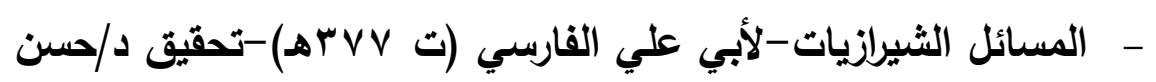

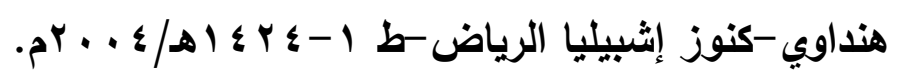

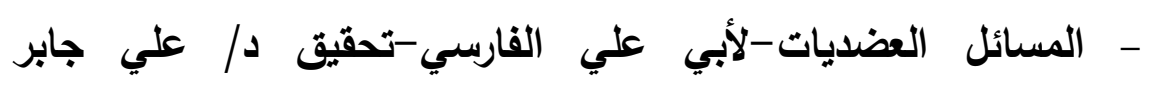
المنصوري-عالم الكتب ، ومكتبة النهضة بيروت - ط الميات

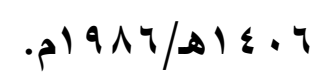

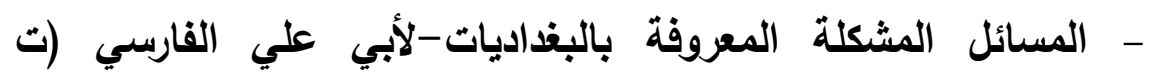

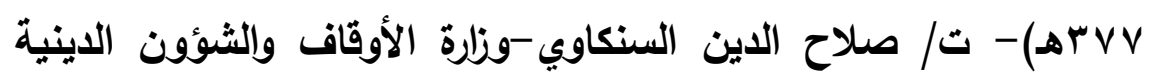

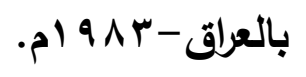

- المسائل المنثورة-لأبي علي الفارسي (ت PLVV)-تحقيق/شريف

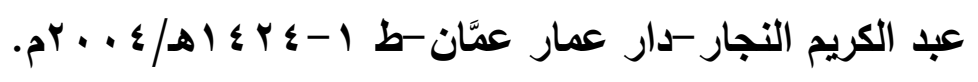


- المساعد على تسهيل الفوائد-لبهاء الدين بن عقيل (ت 99 (ته)تحقيق د/محمد كامل بركات-مطبوعات جامعة أم القرى . $9 \wedge \leq / \Delta 1 \leq$. . 0 - معاني القرآن للأخفش الأوسط (ت ه ا مهـ)-تحقيق د// هلى محمود

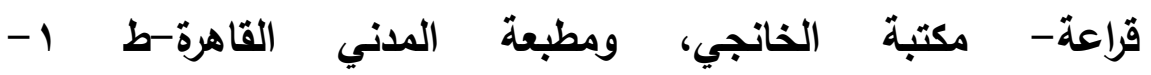
. $99 \cdot 9 \cdot / 211$ - معاني القرآن للفراء (ت V V. Vه)-تحقيق/ أحمد يوسف نجاتي،

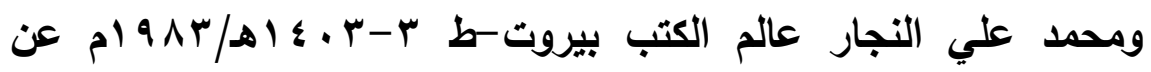
طبعة دار الكتب المصرية. - معاني القرآن وإعرابه-لأبي إسحاق الزجاج (ت ا استه)-تحقيق

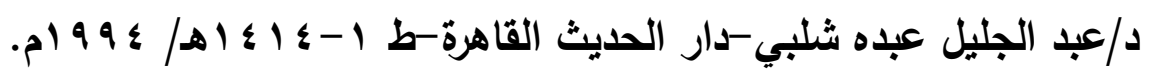
- معجم الأدباء إرشاد الأريب إلى معرفة الأديب-لياقوت الحموي

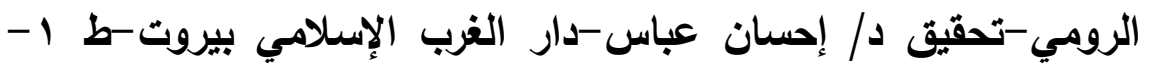
. 994 - معجم المؤلفين-تأليف/عمر رضا كحالة-مكتبة المثنى، ودار إحياء

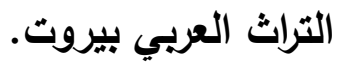

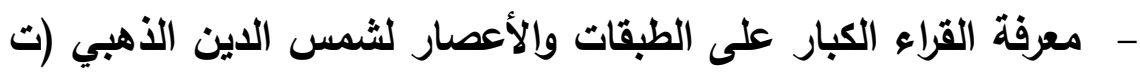

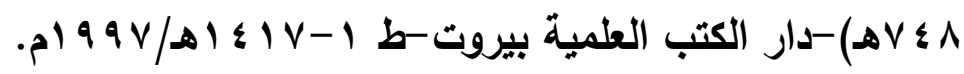
- المغني في النحو-لابن فلاح اليمني (ت . • بهـ)-تحقيق د/عبد

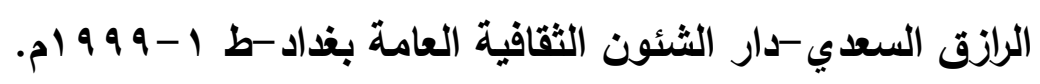
- مغتي اللبيب عن كتب الأعاريب-لابن هشام الأنصاري(ت IVIهـ)تحقيق د/ مازن المبارك، ومحمد علي حمد الله-دار الفكر-بيروت-طا . $99 r / \Delta 1 \leq 1 r$ 
- مغتي اللبيب عن كتب الأعاريب-لابن هشام الأنصاري (ت I Iهـ)تحقيق وشرح د/ عبد اللطيف محمد الخطيب-المجلس الوطني للثقافة

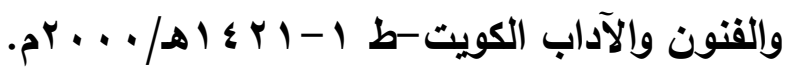
- المفصل في صنعة الإعراب-للزمخشري (ت ^ ^هـ)-تحقيق د/ علي

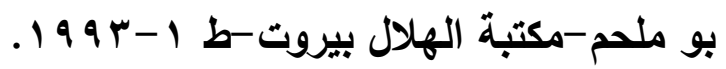
- المقاصد الشافية في شرح الخلاصة الكافية-للإمام أبي إسحاق الشاطبي (ت • Vوهـ)-تحقيق د/ عبد الرحمن العثيمين وآخرين -جامعة

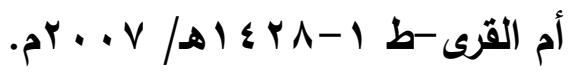

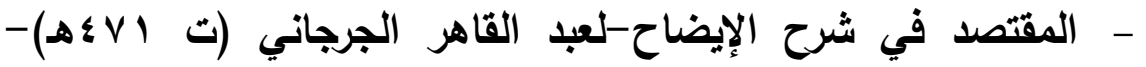
تحقيق د/ كاظم بحر المرجان -منشورات وزارة الثقافة والإعلام بالعرلق . 9 lar

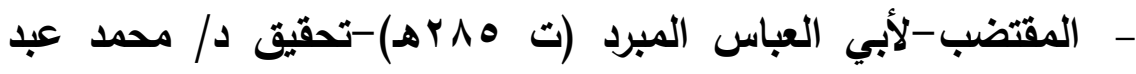
الخالق عضمية- المجلس الأعلى للثئون الإسلامية مصر -ط ب- المبردية . $199 \leq / 81 \leq 10$

- المقدمة الجزولية في النحو-لأبي موسى الجزولي (ت V • †ه)تحقيق د/ شعبان عبد الوهاب محمد-أم القرى للطبع والنشر القاهرة-ط

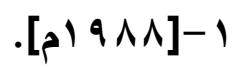
- المقرب لابن عصفور (ت 979 (7ه)-تحقيق د// أحمد عبد الستار

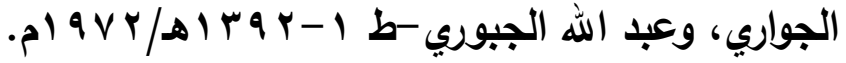

- الملخص في ضبط قوانين العربية-لابن أبي الربيع الإثبيلي (مهابئ

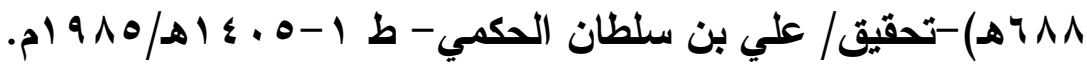


الموفور من شرح ابن عصفور

- المنصف شـرح تصسيف المـازتي_لابـن جني (ت r و بهـ)-تحقيق| إبراهيم مصطفى، وعبد الله أمين -مكتبة ومطبعة مصطفى البابي الحلبي

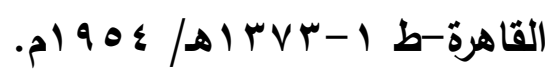

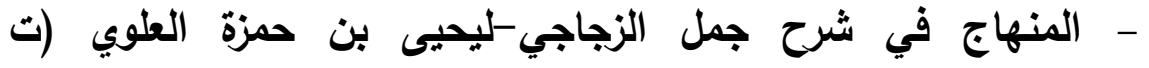

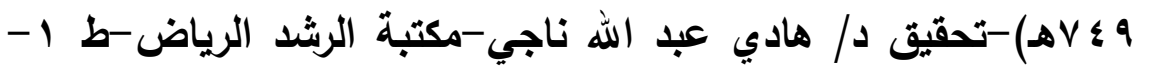

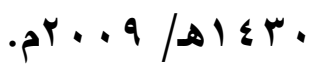

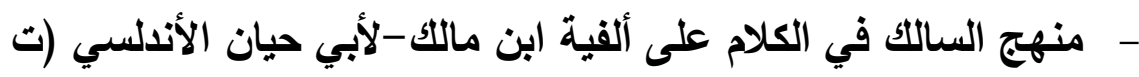

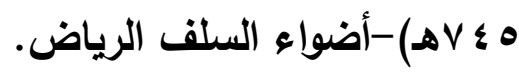

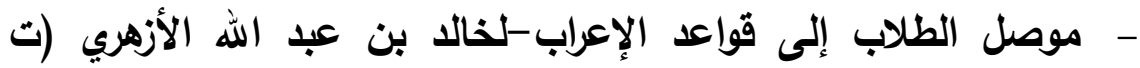

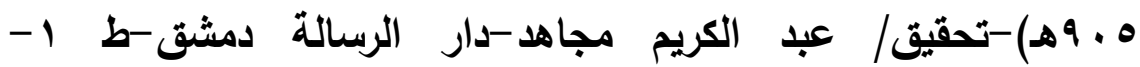

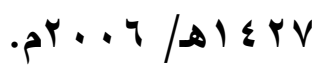

- نتائج الفكر في النحو-لأبي القاسم السهيلي (ت امهـه)-تحقيق د/ محمد إبراهيم البنا-دار الاعتصام القاهرة. - نزهة الألباء في طبقات الأدباء-لأبي البركات الأنباري (ت هـ -

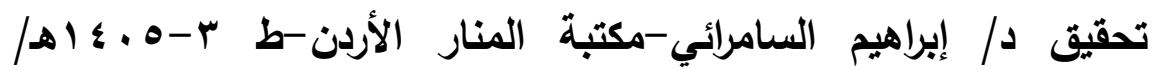
- p) 9 人० - نشأة النحو وتاريخ أثهر النحاة-تأليف الثيخ/محمد الطنطاوي -دار

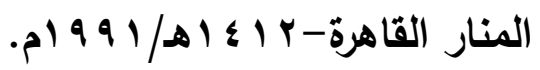
- - نفح الطيب من غصن الأندلس الرطيب-للشيخ أحمد بن محمد المَقَّرِيٍّ التلمساني (ت )-تحقيق د// إحسان عباس-دار صادر بيروت-ط إن. $9 \Lambda \Lambda / ه 1 \leq 1$ 


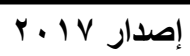

حولية كلية اللغة العربية بالمنوفية العدد الثاني والثلاثون

- النكت الحسان في شرح غاية الإحسان-لأبي حيان الأندلسي (تهان

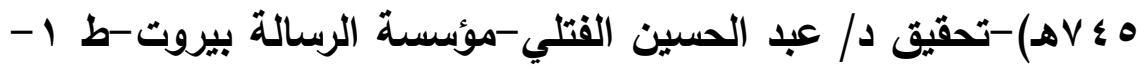

$$
\text { . } 1910 / \Delta 1 \leq \cdot 0
$$

- النكت في تفسير كتاب سيبويه-لأبي الحجاج الأعلم الشنتمري (تهابل

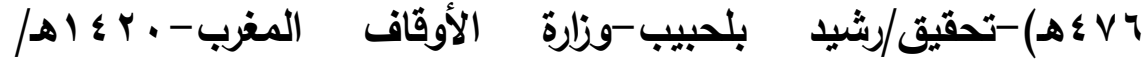
-p) 999

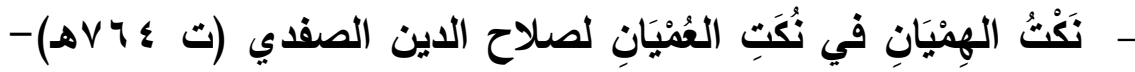

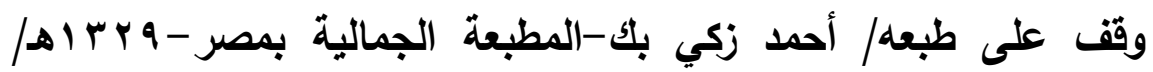
.01911

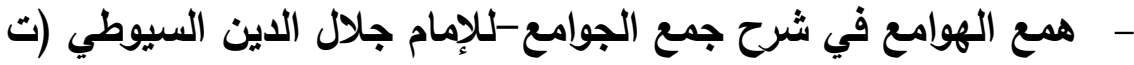
19 هـ) تحقيق/أحمد شمس الدين-دار الكتب العلمية بيروت-طا - $991 / \Delta 1 \leq 11$

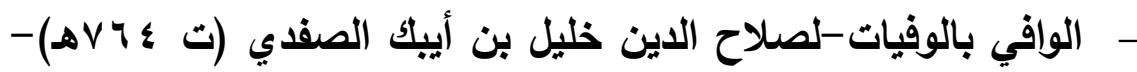
تحقيق/ أحمد الأرناؤوط، وتركي مصطفى -دار إحياء التراث بيروت-

$$
\text { . }
$$

-

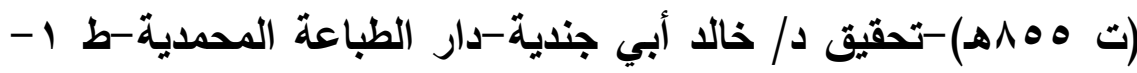
. $) 99 r / \Delta 1 \leqslant 1 r$ 


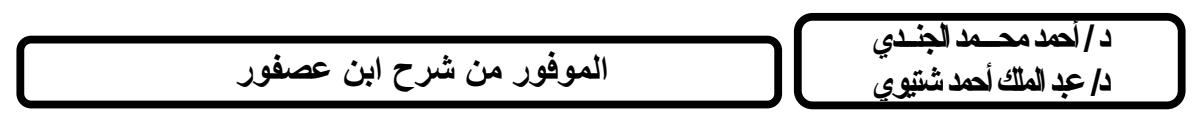

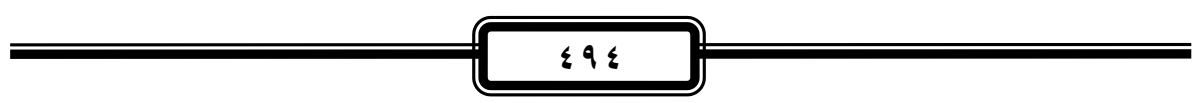




\begin{tabular}{|c|c|}
\hline 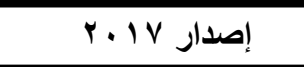 & حولية كلية اللغة العربية بالمنوفية العدد الثاني والثلاثون \\
\hline الصفحة & الموضوع \\
\hline$\leq 0$ & المقدمة . \\
\hline$\varepsilon 9$ & التمهيد. \\
\hline 0 . & المبحث الأول : ابن عصفور حياته ، وآثاره . \\
\hline OV & المبحث الثاني : الجمل وشروحه . \\
\hline 71 & المبحث الثالث : أبو حيان حياته ، وآثاره . \\
\hline vo & القسم الأول : ( دراسة المخطوط ): \\
\hline$\vee 7$ & المبحث الأول : شرح الجمل الكبير لابن عصفور \\
\hline$\vee 9$ & المبحث الثاني : منهج الموفور. \\
\hline 99 & (الموفور) الثالث:أصول النحو عند أبي حيان من خلال \\
\hline 1.0 & القسم التثاني : التحقيق. \\
\hline $1 \cdot 7$ & وصف نسخة المخطوط \\
\hline $1 \cdot v$ & توثيق نسبة الموفور لأبي حيان \\
\hline $11 \cdot$ & منهج التحقيق \\
\hline $11 r$ & صور من المخطوط \\
\hline 110 & النص المحقق \\
\hline 117 & مقدمة أبي حيان \\
\hline $11 \mathrm{~V}$ & الكلام وأققامه \\
\hline 119 & الإعراب وعلاماته \\
\hline Irr & الباب الأول: باب النكرة والمعرفة \\
\hline
\end{tabular}




\begin{tabular}{|c|c|c|}
\hline \multicolumn{2}{|c|}{ الموفور من شرح ابن عصفور } & 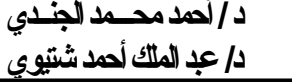 \\
\hline الصفحة & الموضوع & \\
\hline Iro & & المضمر \\
\hline 14 & & 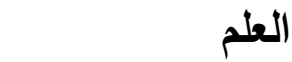 \\
\hline Irr & & اسم الإشارة \\
\hline $1 T \leq$ & & المعرف بـ"أل" \\
\hline $1 \%$ & & المعرف بالإضافة \\
\hline 1 & & المخاطبة \\
\hline ITV & & 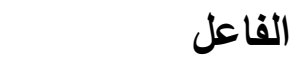 \\
\hline Irk & & المفعول \\
\hline $1 \leq 1$ & & قلب الإعراب \\
\hline $1 \leqslant r$ & & الموصول \\
\hline $10 \leqslant$ & & الإخبار \\
\hline 101 & & نعم ويئس \\
\hline $19 r$ & & حَبًََّا \\
\hline $17 \varepsilon$ & & التعجب \\
\hline 171 & & النائب عن القاعل \\
\hline$|V|$ & & المبتدأ والخبر \\
\hline 187 & & أدوات الابتداء \\
\hline$I V V$ & & الاشتفال \\
\hline $1 \wedge 1$ & & النواستخ \\
\hline 111 & & "كان" وأخواتها. \\
\hline $19 \varepsilon$ & & أفعال المقارية \\
\hline
\end{tabular}




\begin{tabular}{|c|c|}
\hline 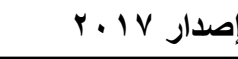 & حولية كلية اللغة العربية بالمنوفية العدد الثاني والثلاثون \\
\hline الصفحة & الموضوع \\
\hline 190 & ما النافية \\
\hline $19 V$ & "إنَّ" وأخواتها \\
\hline$r \cdot r$ & الأفقعال المتعدية \\
\hline$r \cdot q$ & الفصل \\
\hline r. & اسم القاعل \\
\hline rir & الأمثلة \\
\hline rir & 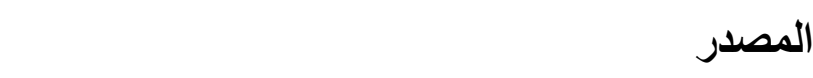 \\
\hline Yio & 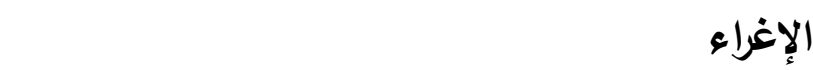 \\
\hline Y17 & الصفة المشبهة باسم القاعل \\
\hline Y^ & المفعول المطلق والظرفان والحال والتمييز والاستثناء \\
\hline Yイ & المفعول المطلق \\
\hline Y 9 & ظرف الزمان \\
\hline rr. & ظرف المكان \\
\hline rrr & 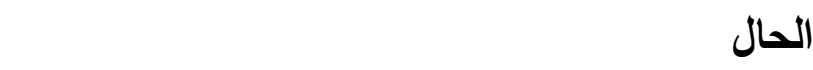 \\
\hline rrr & التمييز \\
\hline rrs & الاستثناء \\
\hline$r r$. & المفعول معه \\
\hline ו & المفعول من أجله \\
\hline r l & أبواب النداء \\
\hline Q & الندبة \\
\hline
\end{tabular}




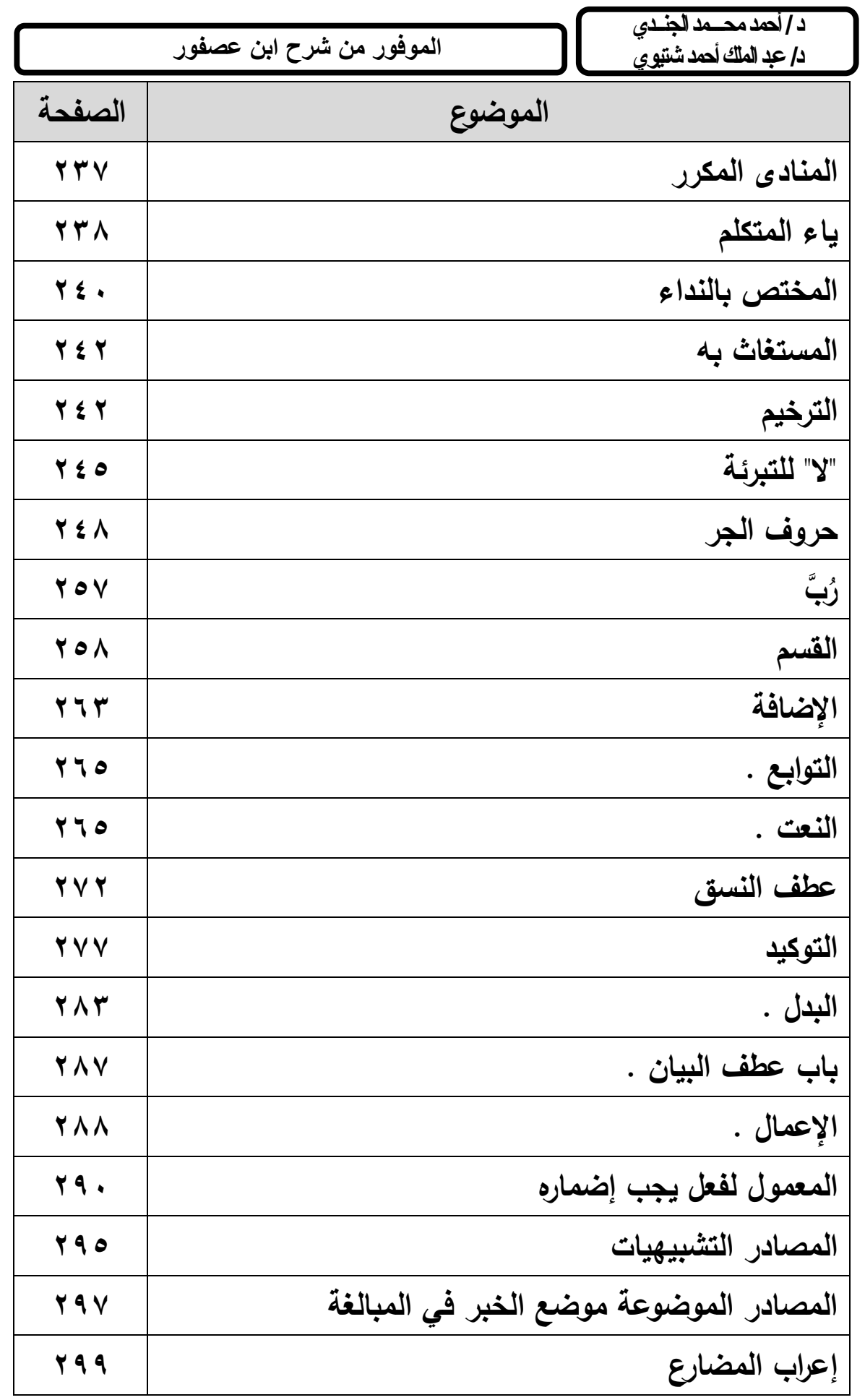




\begin{tabular}{|c|c|}
\hline 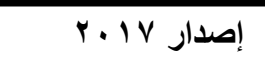 & حولية كلية اللغة العربية بالمنوفية العدد الثاني والثلاثون \\
\hline الصفحة & الموضوع \\
\hline r.. & 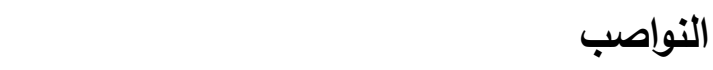 \\
\hline M & الجوازم لفعل واحد \\
\hline riv & كلم الجزاء \\
\hline mrt & الاسم المنصرف \\
\hline rrm & التنوين \\
\hline r p & غير المنصرف \\
\hline$r \leq 1$ & اسم القبيلة \\
\hline$r \leq r$ & الأماكن \\
\hline$r \leq \varepsilon$ & 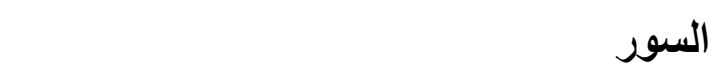 \\
\hline$r \leq q$ & فَعَالِ \\
\hline$\Gamma \leq \wedge$ & البناء - اء \\
\hline ror & الحكاية \\
\hline ros & القول \\
\hline roq & حكاية الاسم المفرد \\
\hline rov & الاستقهام عن نكرة بـ"مَنْ" \\
\hline roq & حكاية الجمل \\
\hline rq & التذكير والتأنيث \\
\hline rqv & 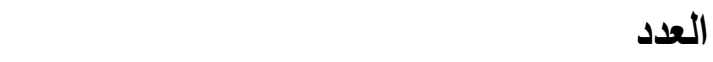 \\
\hline rvr & اسم الفاعل من العدد \\
\hline$r v \varepsilon$ & التأريخ \\
\hline rVq & 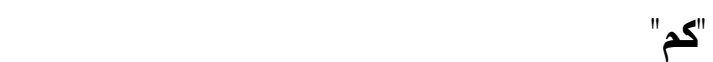 \\
\hline
\end{tabular}




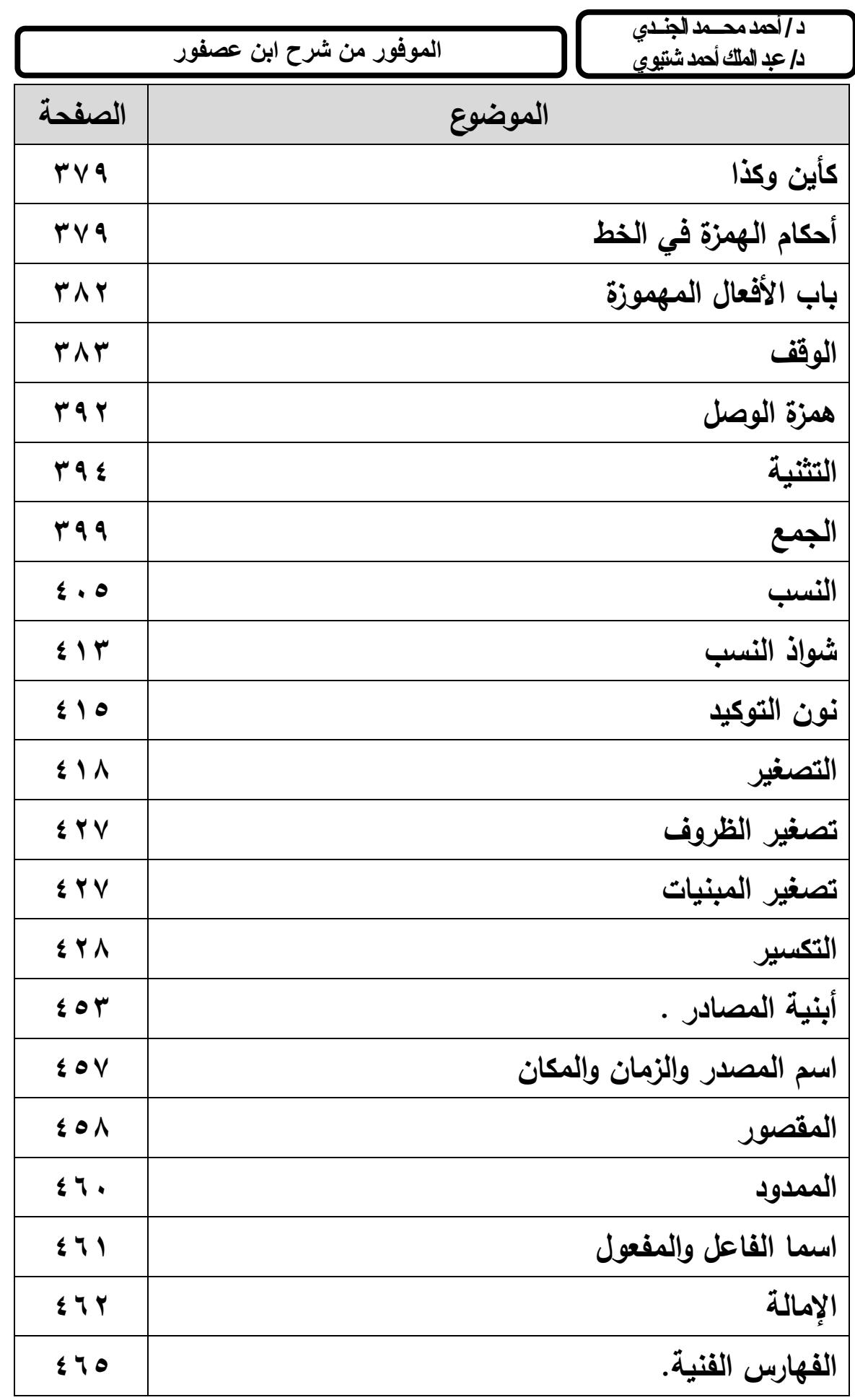




\begin{tabular}{|c|c|}
\hline$r+1$ & حولية كلية اللغة العربية بالمنوفية العدد الثاني والثثلاثون \\
\hline الصفحة & الموضوع \\
\hline$\leqslant 97$ & فهرس الآيات القرآنية . \\
\hline ะ77 & فهرس الأحاديث والآثار \\
\hline 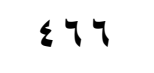 & فهرس الأمثال والأقوال والنماذج. \\
\hline$\varepsilon \neg \wedge$ & فهرس الأبيات الشعرية . \\
\hline$\leqslant 79$ & فهرس الأعلام والقبائل والجماعات والطوائف. \\
\hline$\varepsilon \vee Y$ & فهرس الكتب المذكورة في المتن \\
\hline$\varepsilon \vee \bullet$ & المصادر والمراجع \\
\hline
\end{tabular}




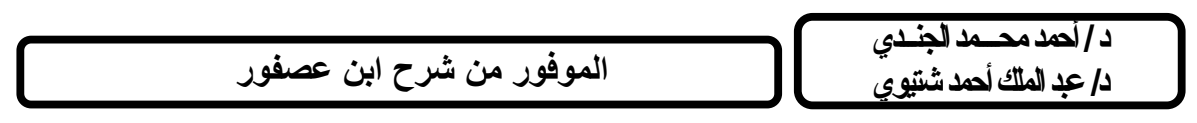

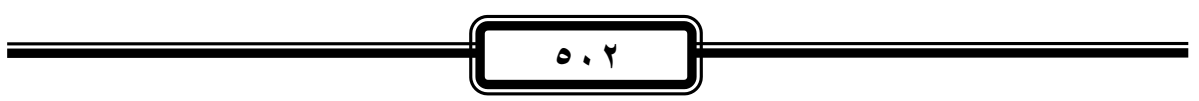

